\begin{abstract}
UNIVERSIDADE DE SÃO PAULO
FACULDADE DE FILOSOFIA, LETRAS E CIÊNCIAS HUMANAS DEPARTAMENTO DE HISTÓRIA

PROGRAMA DE PÓS-GRADUAÇÃO EM HISTÓRIA ECONÔMICA
\end{abstract}

RONALD LEÓN NÚÑEZ

EL CARÁCTER DE LA INDEPENDENCIA PARAGUAYA EN EL CONTEXTO
DE LAS REVOLUCIONES ANTICOLONIALES HISPANOAMERICANAS

Versão corrigida

São Paulo

2021 
RONALD LEÓN NÚÑEZ

\title{
EL CARÁCTER DE LA INDEPENDENCIA PARAGUAYA EN EL CONTEXTO DE LAS REVOLUCIONES ANTICOLONIALES HISPANOAMERICANAS
}

\begin{abstract}
Versão corrigida da tese apresentada ao Programa de Pós-Graduação em História Econômica do Departamento de História da Faculdade de Filosofia, Letras e Ciências Humanas da Universidade de São Paulo, para a obtenção do título de Doutor em História Econômica.
\end{abstract}

Orientador: Prof. Dr. Rodrigo Ricupero

São Paulo 
Autorizo a reprodução e divulgação total ou parcial deste trabalho, por qualquer meio convencional ou eletrônico, para fins de estudo e pesquisa, desde que citada a fonte.

Catalogação na Publicação

Serviço de Biblioteca e Documentação

Faculdade de Filosofia, Letras e Ciências Humanas da Universidade de São Paulo

Núñez, Ronald León

El carácter de la independencia paraguaya en el contexto de las revoluciones anticoloniales

hispanoamericanas / Ronald León Núñez; orientador Rodrigo Ricupero - São Paulo, 2021.

$329 \mathrm{f}$.

Tese (Doutorado)- Faculdade de Filosofia, Letras e Ciências Humanas da Universidade de São Paulo. Departamento de História. Área de concentração: História Econômica.

1. América colonial. 2. América independente. 3. História da América. 4. Paraguaios. 5. Estrutura social. I. Ricupero, Rodrigo, orient. II. Título. 


\section{ENTREGA DO EXEMPLAR CORRIGIDO DA DISSERTAÇÃO/TESE}

\section{Termo de Ciência e Concordância do (a) orientador (a)}

Nome do (a) aluno (a): Ronald León Núñez

Data da defesa: 14/05/2021

Nome do Prof. (a) orientador (a): Prof. Dr. Rodrigo Ricupero

Nos termos da legislação vigente, declaro ESTAR CIENTE do conteúdo deste EXEMPLAR CORRIGIDO elaborado em atenção às sugestões dos membros da comissão Julgadora na sessão de defesa do trabalho, manifestando-me plenamente favorável ao seu encaminhamento e publicação no Portal Digital de Teses da USP.

São Paulo, 24/06/2021

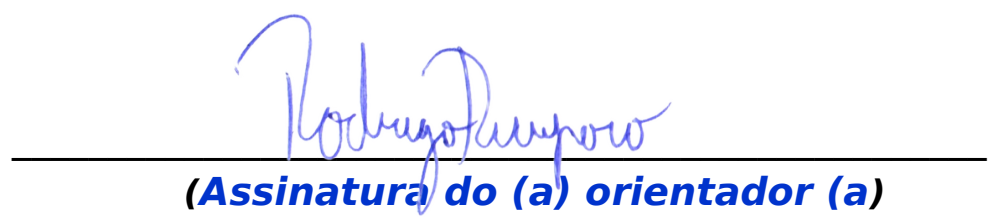




\section{AgRADECIMIENTOS}

Agradezco, en particular, al Prof. Dr. Rodrigo Monteferrante Ricupero por la confianza, paciencia y dedicación con que orientó esta investigación.

Al auxilio financiero de la CAPES (Coordenação de Aperfeiçoamento de Pessoal de Nível Superior), que posibilitó una dedicación todavía mayor a este trabajo.

A los profesores que participaron de la mesa de calificación y de la Comisión Juzgadora: Prof. Dra. Gabriela Pellegrino Soares, Prof. Dr. Lincoln Ferreira Secco, Prof. Dr. Alberto Luiz Schneider y Prof. Dr. José Carlos Vilardaga, por sus valiosos aportes a la elaboración de esta tesis doctoral.

Al Prof. Dr. Antonio Carlos Mazzeo, por los conocimientos acerca de la Historia Económica que nos brindó durante la disciplina cursada en este periodo.

A los trabajadores y trabajadoras del Archivo Nacional de Asunción, por su colaboración paciente y gentil.

Asimismo, a los trabajadores y trabajadoras de la Biblioteca Florestan Fernandes de la FFLCH/USP.

A mi familia, por su apoyo constante. 


\section{RESUMEN}

NÚÑEZ, Ronald León. El carácter de la independencia paraguaya en el contexto de las revoluciones anticoloniales hispanoamericanas. Tese (Doutorado) - Curso de História Econômica, Faculdade de Filosofia, Letras e Ciências Humanas, Universidade de São Paulo, São Paulo, 2020.

El proceso de crisis y desintegración de los antiguos imperios ibéricos, principalmente el español, que derivó en las revoluciones de independencia y, paralelamente, en la conformación de nuevos Estados nacionales durante el siglo XIX es, además de una materia apasionante, un laberinto historiográfico cargado de controversias. Este trabajo tiene la finalidad de aproximarse a la comprensión general de este periodo trascendental del subcontinente latinoamericano, examinando las interpretaciones que juzgamos más influyentes o relacionadas con nuestra perspectiva metodológica. En particular, nuestro propósito es analizar con detenimiento el caso de la antigua Provincia del Paraguay, desde el inicio de su colonización hasta los prolegómenos de la Guerra contra la Triple Alianza. Así, el hilo conductor de esta tesis es la definición del carácter o contenido esencial de la revolución de independencia paraguaya, específicamente, si fue social o política. En otros términos, en cuál de estas esferas -que no concebimos como compartimentos estancos, por supuesto- se expresaron con mayor nitidez las rupturas y continuidades con el antiguo orden colonial. La atención, en el contexto de nuestra hipótesis, estará puesta en los cambios en el terreno de la producción, concretamente en las distintas relaciones sociales que coexistieron y se combinaron de manera desigual durante el período independiente. Sin renegar del relato político ni dejar de apuntar aspectos de la vida cultural, siempre relacionados con el contexto económico de cada período, el objeto principal de este estudio son aquellos sectores explotados, discriminados, marginados por la sociedad de ayer y de hoy.

Palabras-clave: Independencias hispanoamericanas; Independencia del Paraguay; Estructura social; Superestructura; Historia de América. 


\section{RESUMO}

NÚÑEZ, Ronald León. O caráter da independência paraguaia no contexto das revoluções anticoloniais hispano-americanas. Tese (Doutorado) - Curso de História Econômica, Faculdade de Filosofia, Letras e Ciências Humanas, Universidade de São Paulo, São Paulo, 2020.

O processo de crise e desintegração dos antigos impérios ibéricos, principalmente o espanhol, que derivou nas revoluções de independência e, paralelamente, na conformação de novos Estados nacionais durante o século XIX é, além de um assunto apaixonante, um labirinto historiográfico carregado de controvérsias. Este trabalho tem a finalidade de aproximar-se à compreensão geral deste período transcendental do subcontinente latinoamericano, examinando as interpretações que julgamos mais influentes ou relacionadas com nossa perspectiva metodológica. Em particular, nosso propósito é analisar em detalhes o caso da antiga Província do Paraguai, desde o início de sua colonização até os prolegômenos da Guerra contra a Tríplice Aliança. Assim, o fio condutor desta tese é a definição do caráter ou conteúdo essencial da revolução de independência paraguaia, especificamente se foi social ou política. Dito de outro modo, em qual destas esferas - que não concebemos como compartimentos estaques, naturalmente - foram expressas com maior nitidez as rupturas e continuidades com a antiga ordem colonial. A atenção, no contexto de nossa hipótese, estará posta nas mudanças no terreno da produção, concretamente nas distintas relações sociais que coexistiram e se combinaram de modo desigual durante o período independente. Sem evitar

o relato político nem deixar de apontar aspectos da vida cultural, sempre relacionados ao contexto econômico de cada período, o objeto central deste estudo são aqueles setores explorados, discriminados, marginalizados pela sociedade de ontem e de hoje.

Palavras-chave: Independências hispano-americanas; Independência do Paraguai; Estrutura social; Superestrutura; História da América. 


\begin{abstract}
NÚÑEZ, Ronald Léon. The nature of Paraguayan independence in the context of the Spanish American anti-colonial revolutions. Tese (Doutorado) - Curso de História Econômica, Faculdade de Filosofia, Letras e Ciências Humanas, Universidade de São Paulo, São Paulo, 2020.
\end{abstract}

The process of crisis and disintegration of the old Iberian empires, mainly the Spanish, which resulted in the independence revolutions and, in parallel, in the formation of new national states during the nineteenth century is, in addition to an exciting subject, a historiographic labyrinth marked by controversies. The purpose of this work is to come nearer to a general understanding of that extraordinary period on the Latin American subcontinent, examining the interpretations we deem most influential or related to our methodological perspective. Our purpose is to analyze in detail the case of the former Province of Paraguay, from the beginning of its colonization to the eve of the war against the Triple Alliance. Thus, the main thread of this thesis is the definition of the essential nature or content of the Paraguayan independence revolution, specifically, whether it was of social or political nature. In other words, in which of these areas - which we do not conceive of as watertight compartments, of course - the ruptures and continuities with the old colonial order were expressed more clearly. The focus, in the context of our hypothesis, will be on the changes in the field of production, specifically in the different social relationships that coexisted and combined unevenly during the independence period. Without neglecting the political stories or aspects of cultural life, always related to the economic context of each period, those exploited, oppressed, marginalized sectors by yesterday and today societies are the main subject of this study.

Keywords: Latin American independence; Independence of Paraguay; Social structure; Superstructure; History of America. 


\section{LISTAS}

\section{MAPAS}

Mapa 1. Ubicación de las Misiones jesuíticas de Sudamérica y el plano de detalle de las del

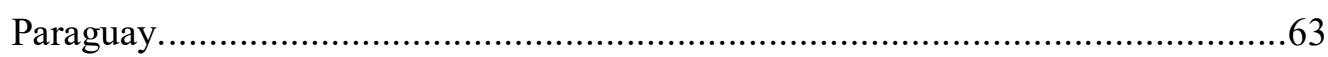

\section{TABLAS}

Tabla 1. Indígenas originarios (yanaconas) sobre el total de la población sometida a la

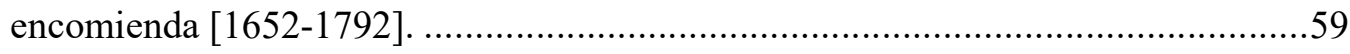

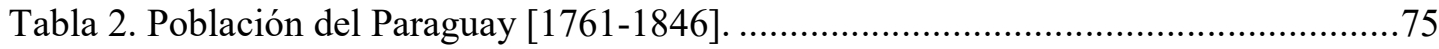

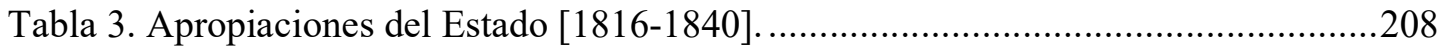

Tabla 4. Poder económico y militar de los países beligerantes hacia $1860 \ldots \ldots \ldots \ldots \ldots \ldots \ldots \ldots . . .262$

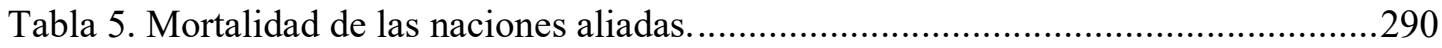




\section{ÍNDICE}

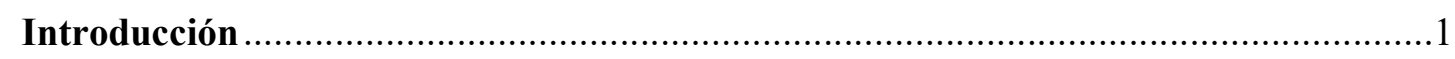

Capítulo I - Apuntes sobre el carácter de la colonización hispano-lusitana ...............11

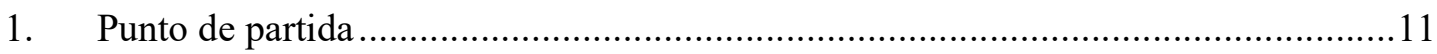

2. El carácter de la empresa conquistadora y colonizadora europea en América ..........12

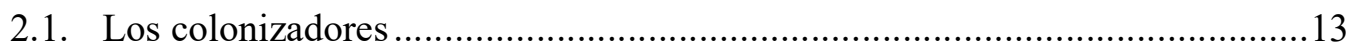

2.2. La esencia de la empresa colonizadora: ¿feudal o capitalista? .......................17

2.3. La forma de la colonización: el debate sobre las relaciones de producción .....30

3. Notas sobre el enfoque marxista y de izquierdas del caso brasileño........................36

3.1. Las críticas al modelo de Caio Prado Júnior: el "esclavismo colonial” ...........40

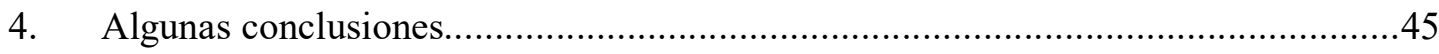

Capítulo II - Una aproximación sobre la inserción del Paraguay en el sistema colonial y el debate sobre las relaciones de producción .........................................................49

1. Ubicación periférica en el sistema colonial ...................................................49

2. Economía exportadora y relaciones de producción..........................................53

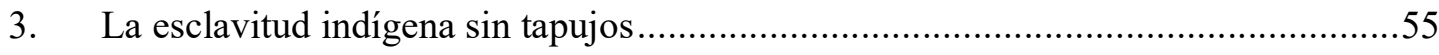

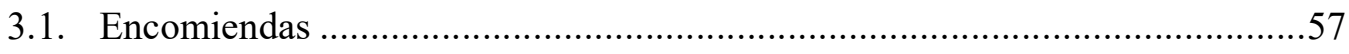

3.2. Los "pueblos de indios" y las Misiones jesuíticas......................................61

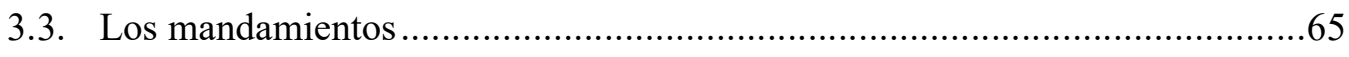

3.4. El campesinado pobre, libre, mestizo y de habla guaraní..............................66

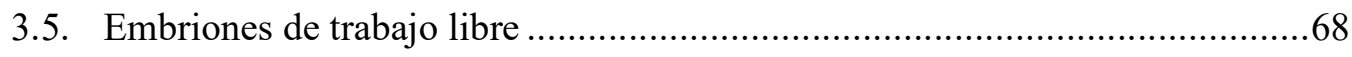

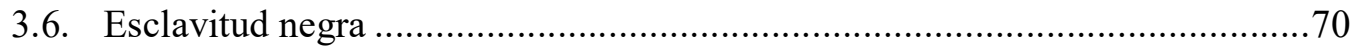

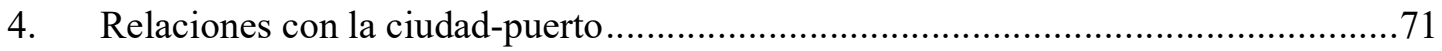

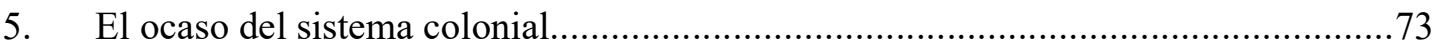

6. Un análisis-justificación de la visión eurocéntrica y etapista ................................79 
Capítulo III - El contenido de las independencias en debate .......................................81

Capítulo IV - Independencia y República ...................................................................110

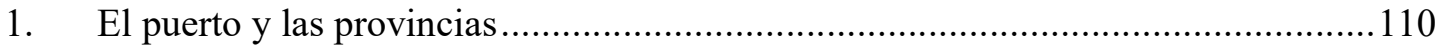

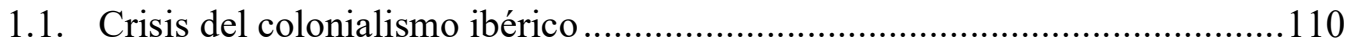

1.2. Alboroto en la capital: la revolución de Mayo en Buenos Aires.....................117

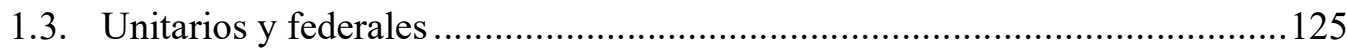

1.4. Limitaciones y contradicciones de Mayo..................................................... 128

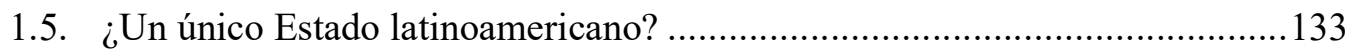

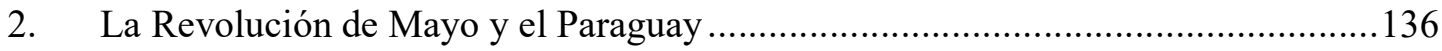

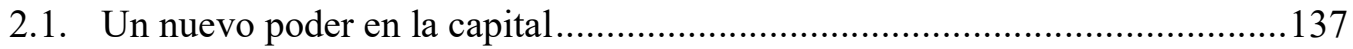

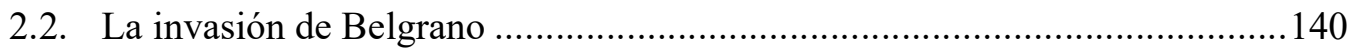

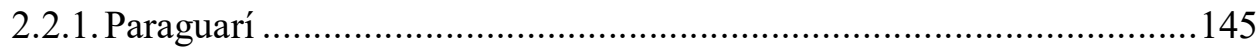

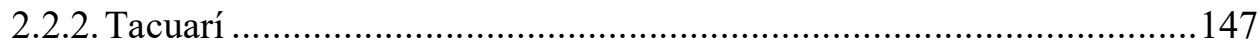

2.3. Consideraciones para el estudio y el debate.............................................. 150

3. La revolución paraguaya, Buenos Aires y la idea de la Confederación ...................152

3.1. El plan contrarrevolucionario hispano-portugués .................................... 153

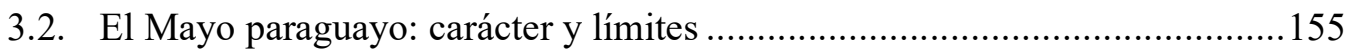

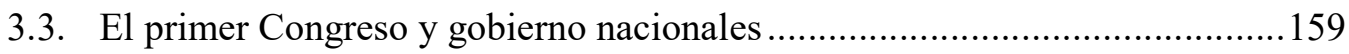

3.4. La nota del 20 de julio: el primer llamado a la Confederación ....................... 162

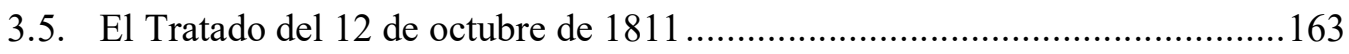

3.6. Ruptura definitiva con Buenos Aires................................................... 166

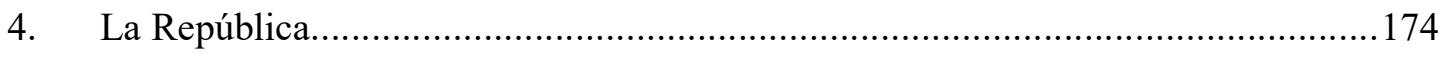

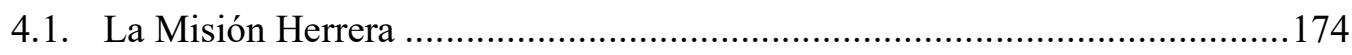

4.2. El Congreso de 1813: los mil diputados y la proclamación de la República..176

Capítulo V - El carácter histórico y los límites del régimen de EI Supremo [1814$1840]$..................................................................................................................185 
1. El marco histórico: la revolución democrático-burguesa anticolonial

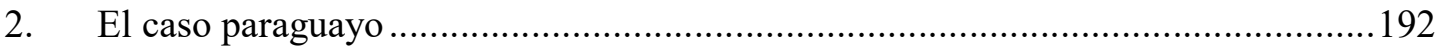

2.1. José Gaspar en el período prerrevolucionario ........................................... 193

2.2. El proceso social y político …......................................................... 197

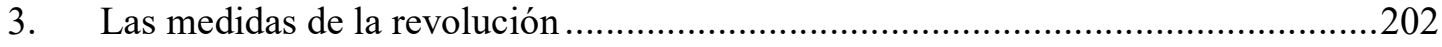

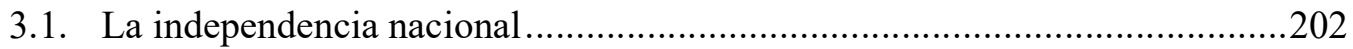

3.2. La expropiación y el terror del nuevo régimen contra las fuerzas

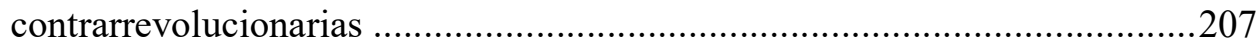

3.3. La política mercantilista: prohibición de la exportación de metales preciosos y control del comercio exterior .............................................................211

3.4. El problema de la tierra: nacionalización y arrendamientos .......................214

3.5. El debate sobre la nacionalización de las tierras: ¿medida burguesa o

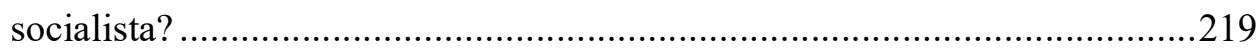

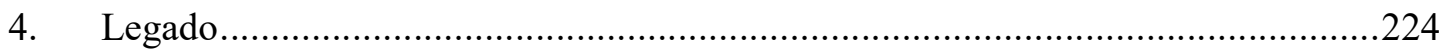

5. Tres debates sobre el régimen del dictador Francia.......................................225

5.1. ¿Era "igualitarista" el régimen de Francia? ............................................225

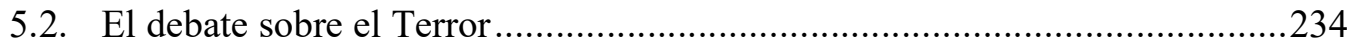

5.3. El principio de "no intervención" y la causa americana .............................2240

Capítulo VI - El Paraguay de los López [1842-1870] ............................................245

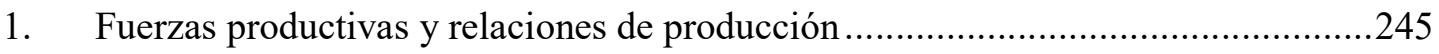

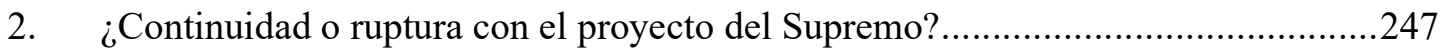

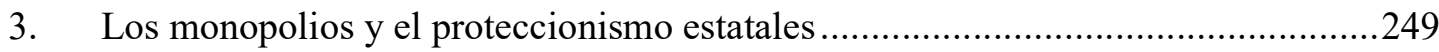

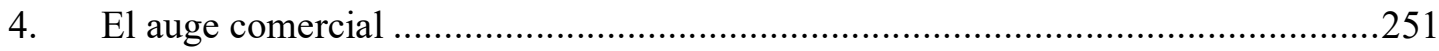

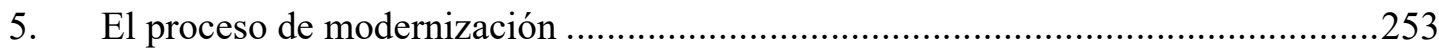

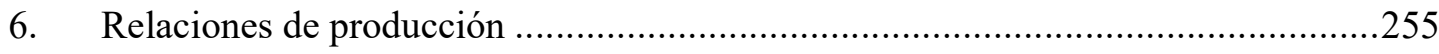

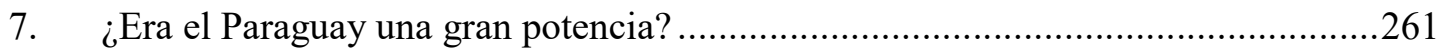


8. Superestructura política: la dictadura de una familia.

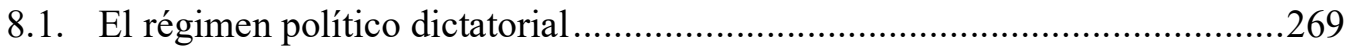

9. Nubes de tormenta en el Plata: la crisis internacional y el ascenso de Solano López

9.1. Notas sobre las relaciones con el Imperio del Brasil................................276

9.2. El problema de límites con la Confederación Argentina ............................279

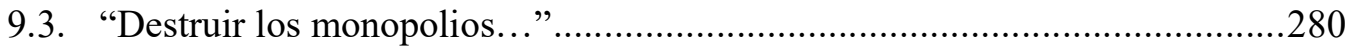

9.4. Una escuadra norteamericana en el Plata..................................................283

9.5. El Tacuarí es cañoneado por la escuadra inglesa en Buenos Aires...............283

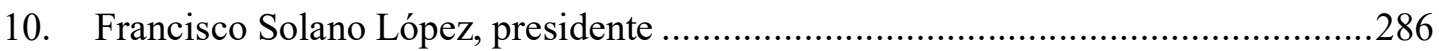

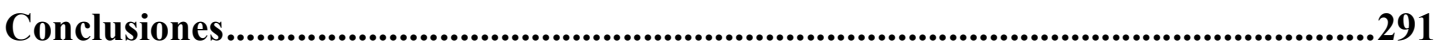

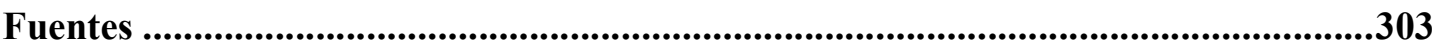

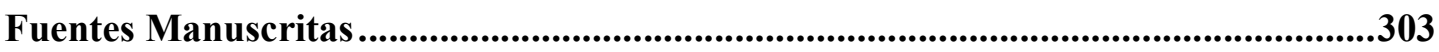

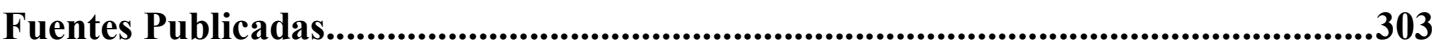

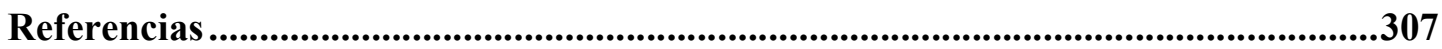




\section{INTRODUCCIÓN}

No obstante las más de tres décadas de un intento de renovación historiográfica en el mundo académico acerca del estudio del Paraguay decimonónico y de la guerra contra la Triple Alianza - con expresiones concretas en medios políticos, periodísticos y materiales de divulgación accesibles al público en general-, los principales postulados del nacionalismo paraguayo y del llamado revisionismo histórico argentino mantienen un notable influjo en el sentido común y el imaginario popular de los paraguayos.

La cristalización de este relato -apoyado en una sensibilidad y demanda social real surgida tras la derrota histórica del país en la Guerra Grande [1864-1870]-condiciona trabajos de investigación y continúa permeando el discurso de actores políticos principales, no solo de los tradicionales partidos de derechas ${ }^{1}$ sino también de los pertenecientes a un amplio arco de las izquierdas en Paraguay. El puente que parece unir ambos extremos no puede ser otro que la ideología nacionalista y su conocida producción historiográfica aunque asumida en grados y formas diferentes, por supuesto-. Ese punto en común a menudo se expresa en una disputa por quién representa de manera más fiel el legado de tal o cual prócer o héroe nacional, o quién es realmente patriótico.

Uno de los pilares que cimienta este relato es la propuesta de que, desde el inicio de la colonización europea hasta el fin de la Guerra Grande, el devenir histórico del Paraguay actual es un caso aparte, explicado en sí mismo y sin relación con el contexto global. Fue una "isla" en todo sentido: económico, social, cultural, étnico, moral. En definitiva, el fruto de un proceso histórico esencialmente -o exclusivamente- endógeno.

Así, las particularidades, inherentes a cualquier región, se extrapolan y agrupan para construir una totalidad contenida en el controvertido concepto de nación. El problema de esa lógica es que el todo se desdibuja en medio de una enmarañada suma de partes. Además, la "nación" es entendida como una unidad monolítica de pasado y predestinación, no como una formación histórica con las implicaciones que esa noción conlleva: transitoriedad e historicidad.

Entre las muchas singularidades realzadas por esta perspectiva -particularidades que no pretendemos negar-, está la afirmación de que la revolución de independencia de Paraguay fue la primera y más radical del continente; en otros términos, la única que avanzó

\footnotetext{
${ }^{1}$ Principalmente en el de representantes del Partido Colorado (ANR), aunque también está presente en muchas figuras e incluso historiadores ligados al otro partido tradicional paraguayo, el Partido Liberal (PLRA).
} 
hasta alcanzar un contenido social, no terminando, como los demás casos, en un mero cambio de amos ${ }^{2}$.

De esta premisa surge la representación del doctor Francia no solo como padre de la nacionalidad, como un individuo que cumplió un papel de primera importancia para consolidar el Estado nacional en sus horas más difíciles, sino como benefactor de los pobres -cuando no un igualitarista o nivelador social-; o bien el retrato de los dos López como incorruptibles estadistas y modernizadores que elevaron la nación al estatus de potencia económica -para muchos, industrial- y militar en la región del Río de la Plata, pero con suficiente éxito para que ese proceso de desarrollo llegara a poner en guardia nada menos que a las naciones más industrializadas del mundo, comenzando por el Imperio británico.

La principal cuestión abordada en este trabajo es si el presupuesto de que la revolución paraguaya de independencia tuvo un carácter económico-social -es decir, si modificó estructuralmente las relaciones sociales de producción y propiedad heredadas de la Colonia-, con las derivaciones políticas sostenidas por el relato descripto más arriba, está justificada o no. Nuestra hipótesis es que no.

Por consiguiente, intentaremos fundamentar que, del mismo modo que en el resto de Iberoamérica, el proceso de emancipación fue esencialmente político, es decir, producto de una disputa superestructural entre dos facciones de la clase propietaria en la sociedad colonial por el control del aparato estatal: de un lado, los realistas que pretendían perpetuar el carácter colonial de la provincia; $y$, de otro, distintas facciones de criollos que, con mayor o menor base social entre los sectores populares, llegaron a la conclusión de que lo mejor para sus intereses era luchar para romper con la metrópoli, con la ex capital virreinal, e iniciar el dilatado proceso de construcción de un Estado nacional soberano. Derrotado el españolismo, como se sabe, la lucha política continuará entre facciones de criollos propietarios de distinto porte- acerca del modelo de acumulación a ser implementado, si librecambista o basado en el control estatal de la economía.

Si bien este enfoque en el caso de Iberoamérica no es nuevo -el de una revolución que no pretendió cambios sociales, o que estos se dieron de manera lenta, ordenada y gradual luego de sobreponerse a la inercia de atrasadas tradiciones-, estamos convencidos de que el caso de la independencia de Paraguay amerita una profundización del estudio que justifique

\footnotetext{
${ }^{2}$ Una obra que sintetiza esa visión y alcanzó una amplia difusión en Paraguay, sobre todo en ámbitos de las izquierdas, es: WHITE, Richard Alan [1984]. La Primera Revolución Popular en América: Paraguay 18101840. 2. ed. Asunción: Carlos Schauman Editor, 1989.
} 
esta premisa. No solo por lo problemático de la influencia nacionalista que apuntamos al comienzo, sino porque ese proceso que propició el nacimiento de la República en 1813 y su derrotero no cuenta con el calado historiográfico destinado a otras revoluciones hispánicas. El examen de la cuestión paraguaya, probablemente debido a su marginalidad en distintos terrenos, con frecuencia aparece como un aspecto secundario en abordajes más generales del proceso independentista en la región del Río de la Plata, sin contar en el de las Américas. El estudio concienzudo de este caso, por lo tanto, no puede sino contribuir a un conocimiento y una comprensión más completos de las revoluciones de independencia en Hispanoamérica.

En otros términos, el hilo conductor de esta tesis es la definición del carácter o contenido esencial de la revolución de independencia paraguaya, específicamente, si fue social o política, aunque tomando el recaudo necesario para no caer en la simplificación de concebir ambas esferas como compartimentos estancos.

Sin dejar de lado el relato político y el detenimiento en determinados aspectos culturales, la atención, en el contexto de nuestra hipótesis, estará puesta en los cambios en el terreno de la producción, concretamente en las relaciones sociales de producción que moldearon el período independiente.

Esto obliga a poner empeño en desenmarañar la compleja combinación de diversas relaciones económico-sociales que coexistieron durante ese período y sirvieron a las clases dominantes para apropiarse, por medio de la coerción, del excedente social de los productores directos de valor: reducciones o pueblos de indios; indígenas encomendados o semiesclavizados; esclavos negros o libertos; jornaleros de estancias o peones yerbateros, que constituyeron embriones del trabajo libre, etc. En definitiva, nuestra intención es que los protagonistas de esta obra sean aquellos sectores explotados, discriminados, marginados por la sociedad de ayer y de hoy.

Nos intrigó aproximarnos a la cuestión de cuánto en las condiciones de vida de la plebe cambió con el advenimiento de la República independiente; cómo operó la relación dialéctica entre lo superestructural y lo económico-social en el cotidiano del común. Solo después de establecer esa base estructural es que, según nuestra mirada, el andamiaje del relato ofrecerá la consistencia necesaria para señalar las particularidades económicas y políticas del caso paraguayo.

El cuerpo de esta investigación fue tomando nuevas dimensiones a medida que escudriñábamos textos y más cuestiones requerían nuestra atención. Luego de nuestra disertación de maestría, que abordó el pensamiento económico y político de José Gaspar 
Rodríguez de Francia contrastado con sus principales medidas de gobierno ${ }^{3}$, el interés inicial consistió en comprender cuál fue la mecánica de la independencia paraguaya y detener el estudio en 1813, momento axial de ese proceso, puesto que un congreso nacional de "mil diputados" de todos los rincones de la ex provincia proclamó la República del Paraguay. La relación con el trabajo anterior parecía no solo coherente sino obvia, dado que ese mismo congreso significó el ascenso definitivo de El Supremo y su facción a la cúspide del poder absoluto. Para establecer los antecedentes, pretendíamos partir, como mínimo, del último tercio del siglo XVIII, signado por la expulsión de los jesuitas y el impacto de las conocidas reformas borbónicas en la ex provincia paraguaya. Esa sería la puerta de entrada a nuestro tema.

Sin embargo, ese recorte temporal no sería suficiente para ofrecer un sostén documental para una sólida interpretación del contenido de la independencia paraguaya: si política o social. No sería suficiente para aproximarnos a un problema que la historiografía moderna discute con énfasis: si lo que primó en las independencias iberoamericanas fueron los cambios o las continuidades con el viejo orden colonial. Sobre todo, si consideramos el problema que plantea la diferencia de ritmos entre cambios políticos "por arriba" y cambios económico-sociales "por abajo". Detener la investigación en 1813 ofrece la posibilidad de un buen análisis político del proceso anticolonial, de reconstruir un período intenso y apasionante, lleno de contradicciones, pero ciertamente queda corto si lo que se pretende es arrojar luz sobre lo que pasaba en la base de la sociedad.

La pervivencia o no de relaciones de producción no capitalistas -con sus expresiones políticas, jurídicas, culturales- en el contexto de la institucionalización del Estado nacional y de un relativamente breve pero intenso proceso de modernización entre la década de 1850 y el inicio de la guerra, exigió el estudio de un período más prolongado. Esta comprensión justificó dos incorporaciones: a) la discusión sobre el carácter de la colonización hispánica, concibiéndola como punto de partida para comprender el sistema que se fracturaría en el siglo XIX; b) el abordaje de los problemas planteados por los gobiernos del doctor Francia y de los López, padre e hijo. El final de este recorte será el período inmediato al estallido de la guerra en 1864. Esperamos que la ampliación del campo de visión sobre nuestro objeto de estudio contribuya a comprender mejor no solo qué cambió y qué perduró sino la relación

${ }^{3}$ NÚÑEZ, Ronald León. El pensamiento político y económico de José Gaspar Rodríguez de Francia: 18141840. 248 f. Dissertação (Mestrado) - Curso de História Econômica, Faculdade de Filosofia, Letras e Ciências Humanas, Universidade de São Paulo, São Paulo, 2015. Disponible en: <doi:10.11606/D.8.2015.tde05112015-144136>. Consultado el: 22/01/2020. 
entre lo progresivo y lo retrógrado, y que ese proceso, tomado como una totalidad, poseía una dinámica dictada por la época histórica global.

Todo lo anterior implica, inevitablemente, una revisión de las principales interpretaciones de los procesos revolucionarios en Iberoamérica, especialmente en los territorios de las ex colonias españolas. Huelga decir que la complejidad que supone el estudio de uno de los acontecimientos más importantes del siglo XIX es todo un desafío; un hecho poliédrico, cargado de contradicciones, que marca un antes y un después en la historia de las sociedades latinoamericanas.

Sin menospreciar aspectos de la cronología político-militar -que surgen aquí y allá cuando consideramos que tales elementos contribuyen a una mejor comprensión de nuestra tesis-, el interés estuvo puesto en las conclusiones acerca del contenido de ese proceso que impactó ambos lados del Atlántico: la desintegración del antiguo Imperio colonial español, de la cual los sucesos de Bayona fueron simplemente el detonador de una crisis estructural que se profundizó en el último tercio del siglo XVIII; y el proceso de conformación de los Estados nacionales modernos iberoamericanos, que se desarrolló paralelamente a la guerra de independencia contra los ejércitos realistas y continuó tras la victoria emancipadora.

Cuando decimos que nos centramos en la caracterización del proceso, no lo hacemos con la intención de sentenciar un supuesto agotamiento del debate -algo así sería imposible dada la magnitud de hechos, sobre los cuales se han escrito bibliotecas enteras- sino con la de aproximarnos con más claridad y rigor a la materia. Este enfoque nos resultó motivante.

Uno de los interrogantes que rondó la orientación de nuestra tesis es si, en medio de tanta particularidad regional y cabos sueltos, era posible encontrar un hilo conductor, una esencia de la cosa misma, un carácter general que sirva de pórtico para comprender el proceso anticolonial americano. Y, a partir de la resolución de ese problema, ¿cómo aplicar esas reglas generales -si es que las hay- al caso paraguayo, en el que no pocos identifican una excepción a la norma?

Sobre nuestras fuentes. El material fundamental para la elaboración de esta tesis se encuentra en el Archivo Nacional de Asunción (ANA), acervo que tuvimos ocasión de visitar $\mathrm{y}$, cuando fue necesario, de poder consultarlo a distancia, merced al meritorio avance en su proceso de digitalización. En nuestro caso, la parte más rica de la documentación original a la que tuvimos acceso es aquella relacionada con la revolución de independencia y los materiales escritos por el propio doctor Francia. En ese archivo se guardan los manuscritos de su correspondencia personal, los decretos y las órdenes que dictaba a sus subalternos, así 
como los valiosos libros de la contabilidad del Estado. Los casos judiciales y administrativos completan ese caudal de fuentes primarias. Lo mismo para el caso de los gobiernos de los López: decretos, acuerdos internacionales, proclamas y los conocidos Mensajes a la nación de don Carlos están registrados en ese trabajo. Por otra parte, es útil resaltar, puesto que iniciativas de esta índole facilitan el trabajo del historiador o historiadora, que parte considerable de los documentos de los primeros años de vida independiente de Paraguay, así como sobre el doctor Francia también están disponibles en formato impreso, y enriquecidos con la revisión y los comentarios de reconocidos historiadores ${ }^{4}$.

Hemos subdividido este trabajo en cinco capítulos. En el primero, como adelantamos, abordaremos el espinoso problema del carácter o sentido de la colonización europea en las Américas: ¿cuál fue el contenido esencial de la colonización europea que se inició en el siglo XVI?; ¿qué relaciones de producción engendró esa empresa en nuestro continente?, lo que implica entrar en la añeja discusión entre circulacionistas y produccionistas; ¿cuáles fueron las bases objetivas de la crisis de los reinos ibéricos a inicios del siglo XIX?; ¿cuáles han sido las consecuencias prácticas de las principales interpretaciones acerca del período colonial, necesarias para comprender el presente?

En el segundo capítulo nos centraremos en analizar la imbricación de las características de ese proceso en el Paraguay colonial: ¿cuál era la ubicación de la ex provincia en el sistema colonial hispánico?; ¿cuál fue el motor de su colonización?; y, una vez más, ¿cuáles fueron las relaciones de producción durante ese período?

En la tercera parte ensayamos una síntesis y una lectura crítica, sin ninguna pretensión de exhaustividad, de las interpretaciones más significativas sobre el proceso de independencia en Hispanoamérica. Intentamos abordar no solo las lecturas clásicas sino

\footnotetext{
${ }^{4}$ CABAllero CAMPOS, Herib. Los Bandos del Buen Gobierno de la Provincia del Paraguay, 1778-1811. Asunción: FONDEC/Arandurã, 2007; VELILLA, Margarita (Org.). Autos de la Revolución del Paraguay del 15 de mayo de 1811: Archivo Nacional de Asunción, Sección Historia, vols. 213 A y B. Asunción: Servilibro, 2011; RODRÍGUEZ ALCALÁ, Guido; DURÁN, Margarita; ROMANO, Martín (Org.). FRANCIA: [17621816]. Edición comentada, aumentada y corregida de la Colección Doroteo Bareiro del Archivo Nacional de Asunción. v. 1. Asunción: Editorial Tiempo de Historia, 2009; RODRÍGUEZ ALCALÁ, Guido; DURÁN, Margarita; ROMANO, Martín (Org.). FRANCIA: [1817-1830]. Edición comentada, aumentada y corregida de la Colección Doroteo Bareiro del Archivo Nacional de Asunción. v. 2. Asunción: Editorial Tiempo de Historia, 2009; RODRÍGUEZ ALCALÁ, Guido; DURÁN, Margarita; ROMANO, Martín (Org.). FRANCIA: [18311840]. Edición comentada, aumentada y corregida de la Colección Doroteo Bareiro del Archivo Nacional de Asunción. v. 3. Asunción: Editorial Tiempo de Historia, 2010; LÓPEZ, Carlos A. Mensajes de Carlos Antonio López. Asunción: Imprenta Nacional, 1931; RODRÍGUEZ ALCALÁ, Guido; ALCÁZAR, José. Paraguay y Brasil: documentos sobre las relaciones binacionales 1844-1864. Asunción: Editorial Tiempo de Historia, 2007; entre otros.
} 
también el enfoque sobre el tema que consideramos más aceptado en ámbitos académicos, señalando sus méritos y aquello que nos parece necesario problematizar.

En la cuarta sección nos detenemos en el Río de la Plata y, en ese contexto, en el caso de la Intendencia del Paraguay, conformada en 1782 como parte de las reformas administrativas establecidas por Madrid. Este apartado es, quizás, el más narrativo, en el sentido que intenta seguir, por lo menos en parte, el ritmo de los intensos acontecimientos políticos. Esto se debe al periodo que abarca: el periodo de la revolución independentista. Sin embargo, la abundancia de hechos, personajes, citas y comentarios no está en contradicción con una lógica ordenada sobre la base de abordar problemas de fondo.

Si concentramos nuestro foco en los sucesos posteriores a 1810, ¿cuál fue el papel de Buenos Aires en la región luego de negar la autoridad del Consejo de Regencia?; ¿cuáles son los antecedentes que llevaron a que los paraguayos negaran la autoridad de la Junta porteña?; en ese sentido, ¿qué motivó la movilización general que enfrentó el ejército de Belgrano en suelo paraguayo?; ¿la declaración de la independencia era la única e inevitable alternativa? Si no es así, ¿fue correcto proclamar la independencia y crear el Estado nacional paraguayo, o esa medida fue más bien reaccionaria porque habría contribuido a la desunión de los pueblos en la llamada causa común contra España?, dicho de otra manera, ¿fue un acto de autodeterminación nacional o fue una secesión mezquina?; ¿cómo reaccionó Buenos Aires ante la proclamación de la independencia del Paraguay?; ¿por qué la nueva República no participó de la campaña militar continental contra los intentos españoles de reconquista de América?; ¿cuál fue el telón de fondo de las sangrientas disputas interburguesas en el proceso de conformación de los Estados platenses?

En ese sentido, el estudio del proceso de conformación de los Estados nacionales nos llevó inevitablemente a la discusión sobre la pertinencia y sobre las posibilidades, en el siglo XIX, de un único Estado americano, la conocida idea de la "Patria Grande". De la misma forma, ese asunto hizo obligatorio tocar el áspero tema del nacionalismo o de los nacionalismos; sus orígenes y su dinámica durante ese doble proceso de ruptura con la metrópoli y conformación de los Estados nacionales. Nos preguntamos: ¿los nacionalismos son todos iguales?, ¿cumplen el mismo rol en cualquier circunstancia histórica? ¿son execrables en sí mismos? ¿No es aconsejable que, en medios académicos, se profundice más la concepción de naciones opresoras y oprimidas, y su relación con el derecho o no a la autodeterminación nacional? 
El quinto y el sexto capítulos se proponen analizar los gobiernos posteriores a la declaración de la República en 1813: la dictadura de José Gaspar Rodríguez de Francia y los gobiernos de los López. Un período de casi seis décadas, repleto de interrogantes y polémicas entre distintas corrientes historiográficas.

¿Cuál fue el carácter de clase y el sentido histórico de las medidas adoptadas por José Gaspar Rodríguez de Francia?; ¿su obra fue dictada por un programa político que el antiguo abogado tenía predeterminado o fue una suma de respuestas a los peligros que provenían del exterior y de la oposición interna?; independientemente de lo anterior, ¿su régimen fue una tiranía bárbara, basada en el terror, que aisló al Paraguay del progreso económico y de las luces que emanaban del libre comercio reinante en el resto de la Cuenca del Plata, como defiende el liberalismo, o fue un régimen igualitario, casi socialista, como sostienen algunos nacionalistas o revisionistas de izquierdas?; ¿fue acaso una dictadura para la oligarquía y un reino de libertad y prosperidad para los pobres? En suma: ¿cuáles fueron las contradicciones y los límites históricos de El Supremo?

Luego de 1840, ¿cuál fue el régimen de sus sucesores, los López? ¿Fueron continuadores de la obra del doctor Francia o una especie de Termidor que, en dinámica, liquidaría lo esencial de aquel modelo económico y social?

Después de Caseros y del incremento del comercio exterior que propició la anhelada abertura de los ríos, ¿el Paraguay de los López se transformó en una gran potencia industrial, como sugieren ciertos autores revisionistas, o al menos en una nación en vías de serlo?; ¿realmente estaba en condiciones de competir o amenazar la industria y el comercio británicos en la región?; ¿era superior en algún sentido al desarrollo de Buenos Aires o del Imperio del Brasil? En otros términos, ¿cuál era el grado de desarrollo de las fuerzas productivas del Paraguay en 1864?; ¿sobre qué relaciones de producción se establecieron los regímenes políticos de Francia y de los dos López?; ¿cómo se extraía el sobretrabajo de las clases explotadas que sirvió de sostén y palanca a la conocida modernización que experimentó el Paraguay quince años antes del comienzo de la guerra? Sintetizando: ¿cuál fue la estrategia económica y política de los gobiernos y regímenes que controlaron el Estado nacional paraguayo entre 1813 y 1870 ?

En el último apartado derivamos algunas conclusiones.

La investigación asumirá el desafío de adentrarse más en el laberinto de estas cuestiones, para así poder desamarrar el nudo principal de la polémica historiográfica sobre el Paraguay decimonónico: si la independencia, de la forma como se dio desde 1813 y 
concebida no como punto de llegada sino como un proceso lento que pasó por altibajos hasta poder consolidarse y que debió ser defendida en la Guerra Grande, fue un hecho progresivo o retrógrado. En otras palabras, si esa Primera República fue un paso adelante o un retroceso en términos históricos.

Ese es el debate principal, por ejemplo, con la literatura historiográfica liberal, hegemónica hasta la década de 1930 y que aún mantiene un peso nada despreciable entre la intelectualidad paraguaya y regional. Una discusión que su contraparte, el nacionalismo populista de derechas o de izquierdas, no pudo ni podrá resolver dadas las limitaciones inherentes a su carácter igualmente conservador.

Esto nos lleva a la cuestión de nuestro enfoque metodológico: ¿desde qué perspectiva entablamos estas discusiones? El punto de vista del análisis y la interpretación de los hechos será el del materialismo histórico-dialéctico, el método marxista. Pero nada está más alejado de nuestras pretensiones que cerrar el estudio o la discusión, ni siquiera en el terreno del socialismo científico. No solo debido a nuestras propias limitaciones sino porque estamos convencidos de que el marxismo paraguayo y, en general, el sudamericano, aún tienen mucho que investigar, problematizar y polemizar sobre un tema tan vasto y que involucra muchas particularidades nacionales y culturales. Y esta tarea posee una envergadura tal que, por más significativos que los aportes individuales puedan resultar, necesariamente debe ir construyéndose sobre la base de una acumulación colectiva.

El aporte del marxismo debe considerarse inicial. Hay mucha tela que cortar. Por eso, esta obra debe tomarse como un intento de aproximarnos un poco más a la materia. Ni más ni menos. Si bien planteamos propuestas o extraemos conclusiones más sólidas en algunos aspectos de este estudio, en muchos otros nuestro propósito consiste en encontrar cuáles serían las preguntas adecuadas que puedan servir de guía para posibles investigaciones futuras.

Para alcanzar este objetivo, sostenemos que no existe mejor camino que acometer un estudio riguroso de los hechos, fundamentado en el análisis de documentos, y, sobre ese cimiento, entablar un debate lo más nítido posible entre corrientes historiográficas, partiendo de la premisa de que ninguna interpretación de la historia es o podrá ser neutra o imparcial -ni social ni políticamente -, es decir, ajena a la subjetividad de quien escribe ${ }^{5}$.

\footnotetext{
${ }^{5}$ Sobre el problema de la pretendida neutralidad en el estudio de las ciencias sociales, consultar: LOWY, Michael. Método dialético e teoria política. 2. ed. Rio de Janeiro: Paz e Terra, 1978; GOLDMANN, Lucien. Sciences Humaines et Philosophie. París: Gontier, 1966; NOVACK, George. Los orígenes del materialismo. Buenos Aires: Ediciones Pluma, 1975.
} 
Según nuestro criterio, ese debate de ideas debe ser más enfático con la corriente liberal, en sentido amplio, encarnada en la clásica lectura mitrista que llegan hasta la actualidad con distintos matices. En otras palabras, la polémica histórica debe enfocarse en aquellos autores y autoras que, de una forma u otra, identifican el período independiente como un retroceso hacia el atraso y la barbarie y, por ende, justifican en alguna medida a la Triple Alianza. Pero estamos igualmente convencidos de que la tarea de cuestionar la llamada historia escrita por los vencedores sobre el Paraguay de preguerra, de modo alguno autoriza a hacer concesiones teóricas a las conocidas exageraciones y desvaríos políticos del nacionalismo y de la amplia corriente que se denomina revisionista, tanto en su variante de derecha como de izquierda. 


\title{
CAPÍTUlo I - APUNTES SOBRE El CARÁCTER DE LA COLONIZACIÓN HISPANO-LUSITANA
}

\author{
"En la ciencia no hay caminos reales, y solo tendrán esperanzas de acceder a sus cumbres \\ luminosas aquellos que no teman fatigarse al escalar la montaña por senderos escarpados".
} KARL MARX, prólogo a la edición francesa del tomo I de El Capital, 1872.

\section{Punto de partida}

Huelga decir que la discusión acerca del carácter de la colonización y sobre las relaciones de producción originadas en América tras la llegada de los europeos es tan añeja como espinosa.

Existe un amplio abanico de aproximaciones a este objeto de estudio, que se desarrolló sobre la base de las más diversas matrices teóricas y sus matices. El alcance del debate no fue ni es estrictamente académico -aunque, evidentemente, muchos académicos hayan intervenido-, sino que se instaló en la arena política. Y esto no podía ser de otra manera, puesto que las conclusiones de los análisis sobre el período revisten consecuencias prácticas en el terreno programático. Si bien la polémica sobre este asunto pasó a segundo plano hace décadas, sería poco cauteloso y hasta superficial considerar que el estudio sobre un problema tan amplio -que tuvo una génesis y un impacto mundial $\mathrm{y}$, al mismo tiempo, adquirió tantas ramificaciones de acuerdo con las complejas particularidades regionalesestá superado.

Por el contrario, no debe sorprender que el tema continúe despertando tanto interés como pasiones ideológicas, por supuesto, con distintos niveles de fundamentación. En suma, una cosa es reconocer que el auge de este debate puede situarse en las décadas del sesenta y setenta del siglo XX y, otra, que las polémicas que devienen de su estudio estén agotadas.

La irrupción de los conquistadores europeos en territorio americano es el punto de partida para comprender nuestro proceso histórico, esto es, el origen de las distintas formaciones económico-sociales y de las superestructuras políticas del continente. Un proceso que, por descontado, no fue lineal sino cargado de contradicciones y singularidades propias de un mundo en vertiginosa transformación. 
Puede afirmarse que, del enfoque metodológico y, consecuentemente, de la visión global que se tenga de este período histórico, dependerá la coherencia de la caracterización del problema que ocupa el grueso del esfuerzo investigativo de esta tesis: el carácter, el contenido de las independencias americanas, específicamente el del caso paraguayo.

En este apartado, además de reseñar las tesis fundamentales sobre el asunto y apoyándonos en el pensamiento de determinados autores que -en nuestra opinión, por supuesto- se aproximaron al tema de manera más coherente y acertada, abordaremos: 1) el carácter o, si se prefiere, el sentido de la colonización europea; 2) los modos de producción engendrados por esa conquista y colonización; 3) el papel de las clases sociales del período en ese proceso.

Como se ha sugerido, de las nociones parciales acerca de estos tres aspectos generales devendrá una caracterización de la época histórica, del carácter de clase y, lo más importante, de las tareas planteadas por la crisis de las independencias en los inicios del siglo XIX, objeto de los próximos capítulos.

\section{El CARÁCTER de LA EMPRESA CONQUISTAdORA Y COLONIZAdORA EUROPEA EN AMÉRICA}

¿Fue feudal, fue capitalista, fue híbrida, no fue ninguna de las opciones anteriores? La polémica es compleja, puesto que a menudo se enmaraña en la propia definición de conceptos y está atravesada por el debate sobre la transición del feudalismo al capitalismo en Europa ${ }^{6}$, un callejón tortuoso en el que no pretendemos incursionar más que lo estrictamente necesario.

Valiéndonos de la metáfora propuesta por Marx, ciertamente no nos proponemos escalar una montaña alta y harto escabrosa. Por supuesto, no podemos asegurar que alcanzaremos las "cumbres luminosas" de la ciencia en un asunto tan complicado -de aquellos en que la calidad de los polemistas y la guerra de citas de tanto en tanto parecen dar la razón a las principales y diferentes posiciones por igual-, y que seguirá siendo largamente estudiado y discutido. El objetivo es más modesto: quizá subir algunos peldaños y aproximarnos un poco más a la materia. En otras palabras: contextualizar el abordaje de los problemas que nos ocuparán más adelante.

\footnotetext{
${ }^{6}$ SWEEZY, Paul; DOOB, Maurice, et al. Do feudalismo ao capitalismo. Lisboa: Publicações Dom Quixote, 1971; ANDERSON, Perry. Tras las huellas del materialismo histórico. México D.F.: Siglo XXI Editores, 1986.
} 
En principio, haremos una revisión sucinta de las posiciones de algunos autores, principalmente marxistas latinoamericanos, que se dedicaron al estudio teórico de la cuestión. Así, sistematizaremos y discutiremos -aunque no únicamente, por supuesto- las elaboraciones de los trotskistas argentinos Nahuel Moreno ${ }^{7}$ y Milcíades Peña ${ }^{8}$, al igual que las del estadounidense George Novack ${ }^{9}$, comparándolas con algunos escritos de Marx y Engels que nos parecieron pertinentes.

\subsection{Los colonizadores}

Primero: ¿cuál era la estructura económica interna y la ubicación en el naciente mercado mundial del Imperio español cuando conquistó y emprendió la colonización de una parte de América desde el siglo XVI?

Nahuel Moreno aborda este problema, aunque con su preocupación puesta en caracterizar el Imperio español en su ocaso:

El español, igual que el austrohúngaro o el ruso, eran imperios atrasados que sufrían la influencia del desarrollo capitalista en el occidente europeo. Justamente por su atraso y por limitar con esos países capitalistas, a diferencia de China o la India, sus gobiernos absolutistas hacían esfuerzos denodados por provocar un desarrollo de sus países, industrializándolos. Trataban de perpetuar el feudalismo pero, al mismo tiempo, lograr por todos los medios un desarrollo capitalista impulsado desde arriba, burocráticamente, controlado por sus gobiernos $[\ldots]^{10}$.

Él ubica este impulso capitalista tardío y "desde arriba" en el siglo XVIII, durante los reinados de Carlos II y Carlos III. Estos monarcas, según su análisis, contradictoriamente lideraban un "inmenso aparato gubernamental burocrático y feudal que, por un lado,

\footnotetext{
${ }^{7}$ Nahuel Moreno [1924-1987]: Dirigente y teórico trotskista argentino, con destacada participación en diversos intentos de reagrupamiento y reconstrucción de la llamada Cuarta Internacional.

${ }^{8}$ Milcíades Peña [1933-1965]: Historiador trotskista argentino. En 1947 ingresó al Grupo Obrero Marxista (GOM), dirigido por Nahuel Moreno. Abandonó la militancia en el partido entre 1952 y finales de 1955, cuando se reincorporó. Entre 1955 y 1957 escribió lo que hoy se conoce como Historia del pueblo argentino [Emecé, 2012]. Entre 1957 y 1958 editó, junto con Moreno, la revista teórico-marxista Estrategia. Su alejamiento definitivo del partido de Moreno, entonces llamado Palabra Obrera, se dio en 1959. En los años de 1960 publicó, de manera independiente, Fichas de Investigación Económico Social. Peña se suicidó el 29 de diciembre de 1965, a los 32 años. Para una reseña de su obra, consultar: CAMARERO, Hernán. El período formativo de un intelectual: Milcíades Peña y el trotskismo en las décadas de 1940-1950. Archivos de historia del movimiento obrero y la izquierda, Buenos Aires, n. 3, pp. 9-33, 2013.

${ }^{9}$ George Novack [1905-1992]: Intelectual e historiador trotskista, dirigente del antiguo SWP estadounidense. 10 MORENO, Nahuel. Método de interpretación de la historia argentina. 1975. Disponible en: $<$ http:/www.litci.org/es/wp-content/uploads/14_metodo_historia argentina_1.pdf $>, \quad$ consultado el 17/11/2016. Todos los destacados y traducciones a lo largo de esta tesis son nuestros, salvo indicación contraria.
} 
favorecía las tendencias capitalistas en germen y, por el otro, perpetuaba los privilegios de los señores de la tierra y el atraso" $" 11$.

Moreno concluirá que la crisis de la independencia americana no se debió, como se plantea comúnmente, simplemente a la "decadencia" de España sino a la combinación dialéctica con una dinámica opuesta: las “tendencias centrífugas que produjo el importante desarrollo capitalista que se dio durante fines del siglo XVIII en el Imperio español"12. En otras palabras, lo moderno habría acelerado la decadencia de un sistema anticuado y caduco.

Al mismo tiempo, apunta que en ese período España había acumulado un atraso y una enorme desventaja en cuanto a la industrialización de su economía con relación a sus competidores [Inglaterra, Francia, Holanda], principalmente en la industria naviera, decisiva para mantener el monopolio del comercio colonial y la centralización misma del Imperio.

Para entender la importancia de este aspecto y su relación con el desarrollo de la industria es útil una cita de Marx y Engels acerca de la puja entre las potencias coloniales europeas y la ventaja inglesa en ese terreno:

La nación que tuvo la supremacía en el comercio marítimo y poseía el mayor
poderío colonial se aseguró, como es natural, el más amplio desenvolvimiento,
tanto en el aspecto cuantitativo como en el cualitativo, de la manufactura... ${ }^{13}$.

De esta suerte, a comienzos del siglo XIX, España intenta revertir siglos de atraso económico impulsando un vacilante proyecto de desarrollo capitalista que, al contrario de lo que la burocracia metropolitana esperaba, azuza tendencias centrífugas que a la larga serán incontenibles.

Por su parte, Milcíades Peña analiza el carácter del antiguo Imperio español partiendo de más atrás. Más tajante, escribe: "El binomio grandeza-decadencia de España es un mito puro [...] en España no hay ninguna decadencia, sino un permanente 'raquitismo' de su desarrollo económico"14.

Desde esa perspectiva, sentencia:

Ni en España ni en América hubo nada comparable [a las revoluciones burguesas en Francia, EEUU, Alemania]. De allí proviene la esencial identidad entre España y América Latina. En el mundo moderno, la exmetrópoli y las excolonias se caracterizan por su atraso y dependencia respecto [de] otras potencias. Ni una ni otras pudieron desarrollarse hasta hoy como naciones capitalistas industriales, vale decir, no han podido realizar lo fundamental de la revolución democráticoburguesa $^{15}$.

\footnotetext{
${ }^{11}$ Ibídem.

12 Ibídem.

${ }^{13}$ MARX, Karl; ENGELS, Friedrich. Acerca del colonialismo. Artículos y cartas. Moscú: Editorial Progreso, 1981, p. 6.

${ }^{14}$ PEÑA, Milcíades. Historia del pueblo argentino. Buenos Aires: Emecé, 2012, p. 42.

15 Ídem, p. 41.
} 
Acentúa, además, que en la España imperial no existía una economía unificada, requisito básico para el desarrollo del capitalismo industrial, sino una "federación de cinco reinos -Aragón, Castilla, Cataluña, Navarra y Valencia- dotados de parlamentos, constituciones, sistemas monetarios y aranceles aduaneros separados"16.

Esta definición está tomada de Marx:

España, como Turquía, siguió siendo una aglomeración de repúblicas mal administradas con un soberano nominal a su cabeza [...] si bien el gobierno era despótico, no impidió que subsistiesen las provincias con sus diferentes leyes y costumbres, con diferentes monedas, con banderas militares de colores diferentes y con sus respectivos sistemas de contribución ${ }^{17}$.

Peña sostiene, como otros autores de corte marxista y hasta dependentista, que el Imperio español siempre dependió de la industria extranjera. La política económica de los Reyes Católicos impuso a España la función era ser abastecedora de lana para la industria textil inglesa, que implicó el estímulo del latifundio y de la ganadería en detrimento de la agricultura $\mathrm{y}$, en última instancia, de la manufactura. Por otra parte, el grueso de las transacciones comerciales y los movimientos financieros de Sevilla y Cádiz estaban controlados por banqueros franceses, italianos y flamencos ${ }^{18}$.

En España -siempre de acuerdo con la visión de Peña- nunca existió una política mercantilista, entendida en última instancia como una política industrial: "El mercantilismo no solo buscaba acumular metales; explicaba que para lograrlo había que exportar más de lo que se importaba y, para ello, era preciso vender artículos manufacturados e importar materias primas"19.

Al contrario de otras monarquías absolutas, la Corona hispánica se contentó con una política metalista [acumular el oro por el oro], que, como se señaló, acompañó el incentivo al pastoreo, supeditando el reino a la industria extranjera ${ }^{20}$.

Finalmente, Peña explica la contradicción de que un Imperio "atrasado", que según su interpretación sufría de un "raquitismo estructural", haya sido el que descubrió y conquistó América:

Fue España quien por una combinación de procesos superestructurales descubrió América, lo que no es sino una temprana manifestación de la ley del desarrollo desigual, común a toda la historia, y particularmente visible en el capitalismo. Pero a la larga, la estructura económica hizo sentir su acción y España perdió bien

\footnotetext{
16 Ídem, p. 42.

17 MARX, Karl. La España revolucionaria. 1854. Disponible en: <https://www.marxists.org/espanol/me/1850s/9-ix-54.htm>, consultado el 15/01/2020. Sobre la historia de España, conviene consultar: VILAR, Pierre [1947]. Historia de España. Barcelona: Crítica, 2014.

${ }^{18}$ PEÑA, Milcíades. Historia del pueblo argentino..., op. cit., p. 43-45.

19 Ídem, p. 48.

${ }^{20}$ Ibídem.
} 
pronto el monopolio de sus colonias y se transformó en agente intermediario de Inglaterra y Francia, que luego habrían de heredarlas como metrópolis económicas de América Latina ${ }^{21}$.

Pueden reconocerse matices importantes entre las lecturas de Moreno y Peña -los teóricos trotskistas latinoamericanos que más se adentraron en este laberinto historiográficosobre el Imperio español.

El primero, si bien caracteriza a España como un Imperio "atrasado" y "semifeudal", no deja de señalar, al menos a partir del siglo XVIII, una política -aunque vacilante e insuficiente- proteccionista y de "impulso" a la industrialización en algunas regiones. Peña, por su parte, acentúa el atraso y la incapacidad permanentes de la burguesía hispana para acometer la tarea de industrializar y unificar la nación, asumiendo, por el contrario, el papel subordinado de actuar, a lo sumo, como intermediaria de la penetración de las manufacturas del norte de Europa en sus posesiones coloniales. La sentencia de Peña es lapidaria. La herencia española en el continente sería: "una función periférica en la platea del capitalismo mundial, un raquitismo insuperable del capitalismo industrial interno. Y, por lo tanto, atraso, dependencia, estancamiento"22.

Sin embargo, más allá de las diferencias en supuestos y matices, ambos autores coinciden en algo que parece central: señalar el atraso económico del capitalismo y del liberalismo español en Europa como el trazo principal de su formación histórica.

Para ahondar en este problema, resulta interesante incorporar la visión sobre el tema escrita en 1931 por León Trotsky. Si bien él ubica a España como perteneciente "al grupo de los países más atrasados de Europa", no dejó de reconocerle un "gran pasado histórico":

España conoció períodos de gran florecimiento, de superioridad sobre el resto de Europa y de dominio sobre la América del Sur. El poderoso desarrollo del comercio interior y mundial iba venciendo el aislamiento feudal de las provincias y el particularismo de las regiones nacionales del país ${ }^{23}$.

Puede decirse que el marxista ruso contradice la unilateralidad de Peña al identificar un innegable período de auge del Imperio español, aunque este haya sido relativamente corto:

El descubrimiento de América, que en un principio fortaleció y enriqueció a España, se volvió contra ella. Las grandes vías comerciales se desviaron de la península ibérica. La Holanda enriquecida se desgajó de España. Después de Holanda fue Inglaterra la que se elevó por encima de Europa a una gran altura y por largo tiempo. Y a partir de la segunda mitad del siglo XVI la decadencia de España es evidente. Después de la destrucción de la Armada Invencible

\footnotetext{
${ }^{21}$ Ídem, p. 59.

22 Ídem, p. 41.

23 TROTSKY, León. La revolución española y la táctica de los comunistas. 1931. Disponible en: $<$ http://www.ceip.org.ar/La-revolucion-espanola-y-la-tactica-de-los-comunistas $>$, consultado el 17/11/2016.
} 
(1588) esta decadencia toma, por decirlo así, un carácter oficial. Es el advenimiento de este estado de la España feudal-burguesa que Marx calificó de "putrefacción lenta e ingloriosa"24.

En efecto, aproximadamente entre 1500 y 1650, la superioridad colonial y militar hispánica, con su poderosa armada y su temida infantería -los eficientes tercios españoles-, era una realidad en Europa y el sostén de su dominio sobre otros pueblos en el contexto de llamado "imperio donde nunca se pone el sol".

Pero iniciada la decadencia durante la Guerra de los Ochenta Años [1566-1648] y la consecuente independencia de los Países Bajos del dominio español, Trotsky subraya que "el retraso del desarrollo económico de España ha debilitado inevitablemente las tendencias centralistas inherentes al capitalismo" 25 , hecho que fundamenta el proceso de disolución de su maltrecho Imperio en el siglo XIX y las propias tendencias centrífugas internas.

\subsection{La esencia de la empresa colonizadora: ¿feudal o capitalista?}

El contenido de la colonización es el principal nudo de todo este debate. Es una cuestión compleja y plagada de peligros, principalmente el de caer en la unilateralidad. En ese sentido, son comunes las interpretaciones que universalizan elementos que en realidad constituyen una particularidad del proceso, o bien terminan cometiendo el error opuesto: omiten o diluyen las particularidades en una supuesta totalidad monocromática.

El debate puede esquematizarse en tres posiciones principales: 1) la colonización fue lisa y llanamente feudal, producto de un trasplante de ese modo de producción en América realizado por los conquistadores europeos. Esta es la posición clásica del liberalismo que, en el terreno de las izquierdas, terminó siendo asumida, con otra terminología, por el estalinismo, por motivos políticos que ahondaremos después; 2) la colonización fue directamente capitalista, en todos los sentidos, existiendo casi una continuidad desde Colón hasta los gobiernos y regímenes modernos. Un enfoque circulacionista que fue defendido por los adictos a la influyente Teoría de la Dependencia, con mucho peso durante las décadas de 1960 y 1970, y que encontró uno de sus voceros más altisonantes en el intelectual alemán André Gunder Frank; 3) la tesis de que el sentido de la colonización fue capitalista, producto del proceso de conformación del mercado mundial, aunque se basó en una combinación de modos de producción preexistentes, esto es, no capitalistas. Es la conclusión fundamental a

\footnotetext{
${ }^{24}$ Ibídem.

${ }^{25}$ Ibídem.
} 
la que llegó Nahuel Moreno y, hasta cierto punto y con matices, también es sostenida por intelectuales como Caio Prado Júnior o Fernando Novais en el caso del Brasil. Proponemos analizar más de cerca esta tercera alternativa.

Según Moreno, que en 1948 escribió el texto Cuatro tesis sobre la colonización española y portuguesa en América" "la colonización tiene objetivos capitalistas, obtener ganancias, pero se combina con relaciones de producción no capitalistas" 27 . Dicho de otra manera: una empresa que poseía un sentido dictado por las leyes de la acumulación originaria de capital en Europa, pero que se abría paso apelando a los más diversos modos de extracción de excedente social para alcanzar ese fin.

Una paradoja de la historia que, desde nuestra perspectiva, solo la lógica dialéctica puede explicar: la empresa colonizadora fue parte importante del largo proceso que derivó en la hegemonía del modo de producción capitalista -un proceso que solo cristalizó en el siglo XIX en Europa y más tardíamente en las Américas-, pero el capitalismo se engendró y se fue moldeando mediante relaciones sociales de producción no capitalistas.

Así, desde el punto de vista del marxismo latinoamericano, la importancia de las cuatro tesis de Moreno no reside solamente en su contenido, inserto en la polémica teórica del autor con el estalinismo y con "la influencia de un seudo marxismo que había abrevado en las fuentes de los historiadores liberales", sino en el carácter pionero de su tesis principal:

La colonización española, portuguesa, inglesa, francesa y holandesa en América, fue esencialmente capitalista. Sus objetivos fueron capitalistas y no feudales: organizar la producción y los descubrimientos para efectuar ganancias prodigiosas y para colocar mercancías en el mercado mundial. No inauguraron un sistema de producción capitalista porque no había en América un ejército de trabajadores libres en el mercado. Es así como los colonizadores, para poder explotar en forma capitalista a América, se ven obligados a recurrir a relaciones de producción no capitalistas: la esclavitud o una semiesclavitud de los indígenas. Producción y descubrimiento por objetivos capitalistas; relaciones esclavas o semiesclavas; formas y terminologías feudales (al igual que el capitalismo mediterráneo), son los tres pilares en que se asentó la colonización de América $^{28}$.

Esta definición, a su vez, se cimienta en un enfoque metodológico: estudiar la historia de un determinado país o región considerando sus peculiaridades, pero, principalmente, "como parte de ese todo que es la economía y la política mundial[es]"29, que surge en el siglo XVI. En otros términos: lo que no debe perderse de vista es que la colonización fue

\footnotetext{
${ }^{26}$ MORENO, Nahuel. Cuatro tesis sobre la colonización española y portuguesa en América. 1948. Disponible en: <https://www.marxists.org/espanol/moreno/obras/01_nm.htm>, consultado el 18/11/2016.

${ }^{27}$ Ibídem.

${ }^{28}$ Ibídem.

${ }^{29}$ MORENO, Nahuel. Método de interpretación de la historia argentina..., op. cit.
} 
parte de una totalidad. La riqueza y complejidad de cada parte emergen de forma nítida, y solo pueden ser aprehendidas cabalmente, comprendiendo la esencia del todo que las contiene.

Milcíades Peña, que comenzó a escribir sus ensayos sobre historia argentina en 1955, aunque no cita a Moreno, llega a la misma conclusión: “El objetivo de la colonización y conquista fue eminentemente capitalista: producir en gran escala para vender en el mercado y obtener una ganancia"30. Identifica un fenómeno diferente a los procesos de colonización acontecidos durante el feudalismo europeo, como es el caso de los germanos desplazándose en dirección al este, puesto que el único propósito de estos era conquistar tierras para subsistir.

Aunque más adelante ahondaremos en la cuestión, merece la pena retomar, por lo menos en líneas generales, el contexto de esta discusión en ámbitos marxistas. Es nítido que tanto Moreno, como Peña y otros autores trotskistas o en proceso más o menos completo de alejamiento de los partidos comunistas tradicionales, se empeñaron en polemizar con la teoría de la colonización feudal, supuestamente trasplantada desde Europa en las Américas. No por mero ejercicio intelectual sino por las consecuencias prácticas que esa interpretación supone. El problema estribaba en que esta tesis, propia del liberalismo, poseía hábiles portavoces entre los intelectuales de los partidos estalinistas, entonces con peso considerable entre la clase obrera organizada.

Uno de ellos era el argentino Rodolfo Puiggrós ${ }^{31}$. En 1965, Puiggrós mantuvo un interesante debate con André Gunder Frank sobre los modos de producción y las causas del subdesarrollo en Latinoamérica, que ilustra en parte el contenido de la discusión.

En determinado momento del debate, Puiggrós afirma, correctamente, que los conquistadores españoles del siglo XVI no vinieron a América a organizar sociedades capitalistas, en el sentido de que ese modo de producción no existía como tal en ninguna parte del mundo. También escribió, con justicia, que "el desarrollo desigual de las sociedades indígenas de nuestro continente, al momento de la colonización hispánica, determinó notables diferencias entre las regiones durante la Colonia"; y, por ende, "el modo de

\footnotetext{
${ }^{30}$ PEÑA, Milcíades. Historia del pueblo argentino..., op. cit., p. 65.

31 Rodolfo Puiggrós [1906-1980]: Historiador, periodista y profesor universitario. Militó en el Partido Comunista argentino entre 1933-1946, cuando fue expulsado. Adhirió luego al peronismo "de izquierda".
} 
producción que se organizó en nuestra América en el siglo XVI derivó de la simbiosis del orden social de los conquistadores con el orden social de las comunidades precolombinas" ${ }^{2}$.

Puiggrós incluso admitió que el descubrimiento de América fue obra de la burguesía comercial: "La contradicción entre el descubrimiento de América por la burguesía comercial mediterránea y la conquista colonizadora de América por el decadente feudalismo ibérico es el quid de mi tesis"33.

A partir de la separación -arbitraria, según nuestro modo ver- entre el carácter del descubrimiento y el de la colonización, concluye:

¿Qué orden social, o qué modo de producción, trasplantaron los españoles de la península al Nuevo Mundo? [...] se trataba de un feudalismo en decadencia, de un feudalismo al que la conquista colonizadora de América rehabilitó para desatar la reacción que aniquiló el amanecer del capitalismo en España [...] América salvó de la muerte al feudalismo en España [...] América abrió a los señores una perspectiva que no tenían. España derramó en los territorios transatlánticos los elementos de su régimen feudal en descomposición [...] Decimos que los modos de producción de las sociedades creadas en nuestra América en el siglo XVI eran, en general, formas singulares del feudalismo ${ }^{34}$.

En definitiva, Latinoamérica se transformó en un "inmenso feudo español"35. El papel de la burguesía comercial se limitó, sin más, a "tender el puente a través del cual el feudalismo español se trasplantaría a América"36.

En ese sentido, hay que subrayar que la perspectiva de Ernesto Laclau, otro teórico de la tesis feudal y que también combatió las posiciones de Gunder Frank. Laclau afirma de manera clara que:

El régimen feudal de las haciendas [de la América colonial, nda.] tendió a incrementar las exacciones serviles sobre el campesinado a medida que las crecientes demandas del mercado mundial impulsaron a maximizar el excedente. De tal modo, lejos de constituir el mercado externo una fuerza desintegradora del feudalismo, tendió a acentuarlo y consolidarlo $[\ldots]^{37}$.

32 PUIGGRÓS, Rodolfo. Los modos de producción en Iberoamérica. 1965. Disponible en:

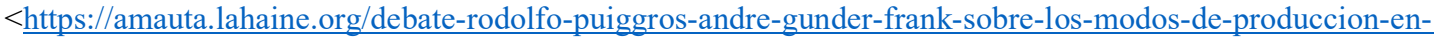
america-latina/>, consultado el 19/03/2019. Este texto es parte de la polémica entre Rodolfo Puiggrós, entonces exiliado en México, y el historiador alemán André Gunder Frank sobre el carácter de la colonización en América. Se publicó inicialmente en 1965 en el "Gallo Ilustrado", suplemento cultural semanal del diario mexicano El Día.

${ }^{33}$ PUIGGRÓS, Rodolfo. ¿Diálogo entre sordos?. 1965. Disponible en: <https://amauta.lahaine.org/debaterodolfo-puiggros-andre-gunder-frank-sobre-los-modos-de-produccion-en-america-latina/>, $\quad$ consultado el 19/03/2019.

${ }^{34}$ PUIGGRÓS, Rodolfo. Los modos de producción en Iberoamérica..., op. cit.

35 PUIGGRÓS, Rodolfo. Historia económica del Río de la Plata. Buenos Aires: Siglo XX, 1948, p. 21.

36 Ídem, p. 9.

${ }^{37}$ LACLAU, Ernesto. Feudalismo y capitalismo en América Latina. In: ASSADOURIAN, Carlos; CARDOSO, Ciro; CIAFARDINI, Horacio, et al. Modos de producción en América Latina. 2. ed. Córdoba: Cuadernos Pasado y Presente, 1974, p. 36. 
Y remata diciendo, en pleno año 1971, que "las condiciones feudales son aún predominantes, en gran medida, en las áreas rurales de América Latina..."38.

Stern, que sistematiza la cuestión, afirma que los teóricos de la escuela feudal muchas veces tuvieron que presentar el supuesto feudalismo decimonónico en Latinoamérica refiriéndose "[...] menos a relaciones económicas que a padrones políticos, sociales y jurídicos"39. En el siglo XX, las dificultades para sostener esa premisa hicieron que las elaboraciones se volviesen más sofisticadas -0 forzadas-, pero la tipificación feudal permaneció, como muestra el caso de Laclau ${ }^{40}$.

Peña, polemizando con Puiggrós y otros teóricos de esta tesis planteó: "El régimen feudal supone la pequeña propiedad de la tierra. De ahí sale la pequeña escala de la producción disponible para el mercado y el reducido volumen de intercambio" 41 .

En esa dirección, el argumento que se sostendrá aquí es que la producción de valores de cambio a gran escala y orientados al mercado mundial o regional, no la creación de feudos cerrados, fue el motor de la colonización ${ }^{42}$.

Es evidente que la colonización europea en América se asentó en relaciones de producción no capitalistas. La discusión no es esa. El plustrabajo se extraía por medio de variantes de servidumbre, como las encomiendas mitarias; variantes de esclavitud, como las encomiendas indígenas yanaconas; o de la pura y simple esclavitud negra.

Pero esta realidad, en sí misma, no autoriza a concluir que el feudalismo europeo fue simplemente trasplantado en América. Este es un planteamiento salido de un razonamiento simplista y eurocéntrico. En el campo de las izquierdas, está al servicio del armazón políticoprogramático etapista, que el estalinismo heredó de los viejos mencheviques rusos y lo elevó a la categoría de dogma universal en el movimiento comunista.

\footnotetext{
38 Ídem, p. 37.

${ }^{39}$ STERN, Steve. Feudalism, Capitalism, and the World-System in the Perspective of Latin America and the Caribbean. The American Historical Review, v. 93, n. 4, pp. 829-872, 1988.

${ }^{40} \mathrm{Jacob}$ Gorender, que podemos decir que entiende del tema, en su libro sobre el Esclavismo colonial, clasificó los trabajos de Oliveira Vianna y Gilberto Freyre dentro de la tesis feudalista "imprecisa". Ya los estudios de Alberto Passos Guimarães y Nelson Werneck Sodré constituían una "teoría categórica de la sociedad feudal en el Brasil". Stern, por su parte, clasifica como autores adictos a la tesis feudal a José Carlos Mariátegui y Lesley B. Simpson en la década de 1920; Luís Chávez Orozco, Gilberto Freyre, George McBride, Rodolfo Puiggrós, y Silvio Zavala entre 1930-1940; Woodrow Borah, François Chevalier, y Jacques Lambert entre 1950-1960, todos considerados "figuras preminentes y diversas que invocaron un pasado de tipo feudal para entender características perdurables de la vida y la historia latinoamericana”, citado en: Ídem, p. 832.

${ }^{41}$ PEÑA, Milcíades. Historia del pueblo argentino..., op. cit., p. 65.

${ }^{42}$ NÚÑEZ, Ronald León. Apuntes sobre el carácter de las independencias americanas. ABC Color. Asunción, 15/12/2019. Disponible en: <https://www.abc.com.py/edicionimpresa/suplementos/cultural/2019/12/15/apuntes-sobre-el-caracter-de-las-independencias-americanas/>, consultado el 02/01/2020.
} 
Es verdad que la encomienda de los indígenas, por ejemplo, poseía elementos de servidumbre, pero no en los mismos moldes del modo de producción feudal tal como imperó en la Europa medieval. Incluso porque no es lícito confundir cualquier tipo de relación servil con feudalismo.

El feudalismo europeo, como se sabe, se asentaba principalmente en la servidumbre. Por medio de esta forma de organización del trabajo se realizaba la transferencia para el terrateniente del excedente producido por la familia campesina, es decir, de aquello que excedía lo necesario para su subsistencia y reproducción. Este producto excedente podía ser transferido al señor feudal, por parte de la familia sierva, en la forma de trabajo, renta en especie, o incluso en dinero. La diferencia con el modo de producción capitalista radica en que el siervo no precisaba alienar su fuerza de trabajo para sobrevivir, sino que detentaba los medios productores de sus bienes de subsistencia. Así, el excedente social del que se apropiaba el señor feudal europeo debía ser extraído de manera coercitiva, o sea, forzada por medio de leyes o de la violencia.

Esta definición es importante como forma de caracterización general del período, pero no debe tomarse a secas, en detrimento de considerar que, en la vida real, se dieron muchas variantes jurídicas -distintos tipos de impuestos, instituciones y prerrogativas de la aristocracia militar terrateniente, etc.-, dependiendo de las regiones a ser estudiadas.

En auxilio de nuestra tesis, citamos una misiva que Engels escribió a Marx asegurando que servidumbre no necesariamente significaba feudalismo:

Estoy contento de que en lo que respecta a la historia de la servidumbre hayamos "procedido de acuerdo", como se dice en el lenguaje de los negocios. Es seguro que la servidumbre y la prestación de servicios no son una forma exclusiva del medioevo feudal; las encontramos en o casi en todas partes donde los conquistadores hacen que los antiguos habitantes cultiven la tierra ${ }^{43}$.

De la misma forma, ni latifundio y ni siquiera un régimen monárquico son, indefectiblemente, sinónimos de una estructura económica feudal. Esta es una interpretación vulgar de la cuestión.

De cualquier manera, como apuntamos, de acuerdo con la lectura de Marx, la servidumbre feudal en Europa occidental estaba en decadencia desde el siglo XIV:

En Inglaterra la servidumbre de la gleba, de hecho, había desaparecido en la última parte del siglo XIV. La inmensa mayoría de la población se componía entonces y aún más en el siglo XV-de campesinos libres que cultivaban su propia tierra, cualquiera que fuere el rótulo feudal que encubriera su propiedad ${ }^{44}$.

43 ENGELS, Friedrich. Carta a Marx del 22 de diciembre de 1882. Disponible en: $<$ https://www.marxists.org/espanol/m-e/cartas/e1882-12-22.htm>, consultado el 19/03/2019.

${ }^{44}$ MARX, Karl. El Capital. Tomo I, v. 3. $8^{\text {a }}$. reimp. México: Siglo XXI, 2009, p. 896. 
A finales de 1882 Engels indicó que ese proceso había comenzado incluso antes, resaltando el acuerdo que había alcanzado con Marx acerca de esa cuestión:

La cuestión de la desaparición casi total de la servidumbre - de hecho o de derecho- en los siglos XIII y XIV me parece importantísima, ya que anteriormente expresaste una opinión opuesta al respecto ${ }^{45}$.

Entonces, vale insistir: si es cierto que el feudalismo se basó en la servidumbre, no toda variante de servidumbre puede ser consideraba, a priori, feudalismo. También merece cautela la relación desigual entre cambios en la estructural social y la superestructura política, en ocasiones más "atrasada" que los cambios económicos. Aun cuando no existe un acuerdo sobre el período de transición del feudalismo al capitalismo en Europa, nos inclinamos a creer que, en la Europa de finales del siglo XVIII, incluso con la servidumbre en decadencia desde el siglo XIII, la superestructura continuaba siendo, básicamente, un Estado feudal.

En esto compartimos la opinión del historiador inglés Christopher Hill, que argumentó que si en 1789 el Estado francés no era feudal "nunca habría existido una revolución burguesa, en el sentido de una revolución que derriba el Estado feudal"46.

Lo determinante no es negar la existencia en la América colonial de relaciones de producción precapitalistas, expresadas en forma de servidumbre y esclavitud, sino entender que aquello no estaba al servicio de reproducir pequeños feudos destinados a la subsistencia sino a producir valores de cambio para un mercado mundial ya regido por las leyes del capital. Ese mundo en transición al capitalismo era la fuente inagotable de la cual surgía la voracidad del colonizador por la ganancia y por el trabajo excedente:

Es evidente, con todo, que cuando en una formación económico-social no prepondera el valor de cambio sino el valor de uso del producto, el plustrabajo está limitado por un círculo de necesidades más estrecho o más amplio, pero no surge del carácter mismo de la producción una necesidad ilimitada de plustrabajo $^{47}$.

Enfocando el problema desde otro ángulo, en el feudalismo medieval "clásico" no existía una presión incontenible por mejorar los medios de producción, como sí ocurriría en el proceso de formación y auge del capitalismo. La producción de las colonias para el mercado exterior, por el contrario, estuvo sin duda caracterizada por la "necesidad ilimitada de plustrabajo" extraído de los pueblos colonizados y esto, ininterrumpidamente, estimuló

\footnotetext{
${ }^{45}$ Carta de Engels a Marx, citada en: SWEEZY, Paul. Uma crítica. In: SWEEZY, Paul; DOOB, Maurice, et al. Do feudalismo ao capitalismo..., op. cit., p. 43.

${ }^{46}$ HIIL, Christopher. Comentário. In: SWEEZY, Paul; DOOB, Maurice, et al. Do feudalismo ao capitalismo..., op. cit., p. 165.

${ }^{47}$ MARX, Karl. El Capital. Tomo I, vol. 1. 28. reimp. México: Siglo XXI, 2008, pp. 282-283. Destacados en el original.
} 
el uso de nuevas técnicas y tecnologías. Esta lógica de acumulación es explicada por T. J. Dunning, que es citado por Marx en un pasaje de El Capital:

El capital tiene horror a la falta de ganancias o las ganancias pequeñas, como la naturaleza aborrece el vacío. Con ganancias adecuadas, el capital se hace muy audaz. Un 10 por 100 y acudirá a donde sea; un 20 por 100 , y se sentirá ya animado; con un 50 por 100, positivamente temerario; al 100 por 100, es capaz de saltar por encima de todas las leyes humanas; el 300 por 100 , y no hay crimen a que no se arriesgue, aunque arrostre el patíbulo. Si el tumulto y las riñas suponen ganancia, allí estará el capital encizañándolas. Prueba: el contrabando y el comercio de esclavos $^{48}$.

Retornando a los círculos marxistas de la Argentina, otro autor frecuentemente citado es Sergio Bagú 49 , que en 1949 escribió: "El régimen económico luso-hispano del período colonial no es feudalismo. Es capitalismo colonial. [...]"50. El uso de la categoría capitalismo, como veremos, está equivocada. Pero la intención de Bagú, aunque adolecía de imprecisiones, también consistía en refutar la interpretación feudal, entonces tan poderosa que era aceptada incluso por Liborio Justo, intelectual proveniente del trotskismo que defendía la tesis del "feudalismo colonial"51.

Pero, como abordaremos seguidamente, los intelectuales latinoamericanos que mencionamos no estaban sino dando continuidad a las elaboraciones clásicas de Marx y Engels sobre el contexto y el propósito de la empresa colonizadora ${ }^{52}$.

En primer lugar, para Marx y Engels, el marco histórico del descubrimiento y la colonización de América no se inscribía en un "proceso de expansión del feudalismo" con capacidad para "trasplantarse" a lugar alguno, sino todo lo contrario: se asentaba en la creación del mercado mundial capitalista, que atizaba "el elemento revolucionario que se

\footnotetext{
${ }^{48}$ MARX, Karl. La acumulación originaria de capital. México D.F.: Editorial Grijalbo, 1969, p. 107.

49 Sergio Bagú [1911-2002]: Abogado y periodista argentino. En 1949 publicó Economía de la sociedad colonial, su obra más conocida y discutida.

50 BAGÚ, Sergio. Economía de la sociedad colonial: Ensayo de Historia comparada de América Latina. Buenos Aires: El Ateneo, 1949, pp. 142-143.

${ }^{51}$ Liborio Justo [1902-2003] polemizó con Bagú argumentando que hablar de "capitalismo colonial" sería atribuir a América Latina un grado de desarrollo de fuerzas productivas inexistente. Sobre el debate entre Justo y otros marxistas latinoamericanos, consultar: BOSCH ALESSIO, Constanza. El debate marxista sobre los modos de producción coloniales latinoamericanos en el seno de la intelectualidad argentina [1890-1973]. 2016. Disponible en: <http://www.aacademica.org/constanza.bosch/27>, consultado el 23/11/2016.

${ }^{52}$ De la extensa bibliografía de Marx y Engels dedicada a la cuestión colonial, me restrinjo a indicar: MARX, Karl; ENGELS, Friedrich. Acerca del colonialismo..., op. cit... Consultar también escritos de los siguientes comentaristas: COSTA NETO, Pedro. Notas preliminares sobre o conceito de progresso em Karl Marx e Friedrich Engels. Germinal: Marxismo e educação em debate, Salvador, v. 10, n. 1, pp. 43-52, 2018; COSTA NETO, Pedro. Forças produtivas, progresso e expansão colonial em Marx e Engels (1845-1853). Disponible en:

$<$ https://www.unicamp.br/cemarx/ANAIS\%20IV\%20COLOQUIO/comunica\%e7\%f5es/GT4/gt4m4c4.PDF >, consultado el 03/01/2020; sobre América Latina: ARICÓ, José. Marx e a América Latina. Rio de Janeiro: Paz e Terra, 1982.
} 
escondía en el seno de la sociedad feudal en descomposición" ${ }^{53}$ y abría paso -asumiendo la forma de "cruzada de exterminio, esclavización y sepultamiento en las minas de la población aborigen"54 - a la victoria final del modo de producción capitalista en Europa.

La manufactura y en general el movimiento de la producción recibieron un enorme impulso gracias a la expansión del comercio, ocasionada por el descubrimiento de América y de la ruta marítima hacia las Indias Orientales. Los nuevos productos, importados de esas regiones y, en particular, las grandes cantidades de oro y plata que entraron a la circulación modificaron totalmente la posición recíproca de las clases y asestaron un rudo golpe a la propiedad feudal de la tierra [...] la colonización y ante todo la expansión de los mercados hacia el mercado mundial, ahora posible y en vías de realización día tras día, inauguraron una nueva fase del desarrollo histórico $[\ldots]^{55}$.

Y agregan:

No cabe duda alguna [de que en] la súbita expansión del mercado mundial, la multiplicación de las mercancías circulantes, la emulación entre las naciones europeas, afanosas por apoderarse de los productos asiáticos y de los tesoros de América, el sistema colonial, coadyuvaron esencialmente a derribar las barreras feudales que obstaculizaban la producción ${ }^{56}$.

Así, al contrario de lo que opinaba Puiggrós, el capital y la burguesía comercial del siglo XVI, lejos de servir de "puente" para una supuesta expansión del feudalismo, engendraban los elementos centrales que contribuían a su disolución. Los fundadores del socialismo científico son categóricos cuando sostienen que el sistema colonial, advenido de la expansión del comercio mundial, significó una modificación total que coadyuvó para destruir -con distintos ritmos, obviamente- las barreras feudales en el terreno de la producción.

En 1884, Engels es enfático al definir los objetivos de la colonización europea en América. Sentencia que la época "del joven al que encandilaban las riquezas de las Indias, las minas de oro y plata de México y Potosín" fue "la época de la caballería andante de la burguesía [pero] sobre una base burguesa y con fines en último término burgueses" ${ }^{\text {57 }}$.

Hasta qué punto -reflexiona Engels- el feudalismo, a fines del siglo XV, estaba ya socavado y carcomido en sus entrañas por el dinero, se pone patentemente manifiesto en la sed de oro que por esa época se enseñorea de Europa. Oro era lo que buscaban los portugueses en las costas africanas, en la India, en todo el Lejano Oriente; oro era la palabra mágica que impulsaba a los españoles a cruzar el Atlántico rumbo a América; oro era lo primero por lo que preguntaba el blanco cuando hollaba una playa recién descubierta. Pero ese afán de salir hacia lo lejos

53 MARX, Karl; ENGELS, Friedrich. Manifiesto del Partido Comunista. 1848. Disponible en: $<$ https://www.marxists.org/espanol/m-e/1840s/48-manif.htm>, consultado el 18/11/2016.

${ }^{54}$ MARX, Karl. El Capital. Tomo I. Buenos Aires: Editorial Cartago, 1956, p. 601.

${ }^{55}$ MARX, Karl; ENGELS, Friedrich. La ideología alemana. In: MARX, Karl; ENGELS, Friedrich. Materiales para la historia de América. Córdoba: Cuadernos Pasado y Presente, 1972, p. 39.

${ }_{56}$ MARX, Karl. El Capital. Tomo III. In: MARX, Karl; ENGELS, Friedrich. Materiales para la historia de América..., op. cit., p. 45.

${ }^{57}$ ENGELS, Friedrich [1884]. El origen de la familia, la propiedad privada y el Estado. In: MARX, Karl; ENGELS, Friedrich. Materiales para la historia de América..., op. cit., pp. 45-46. 
en busca de aventuras para buscar oro, por más que en sus principios se realizara bajo formas feudales y semifeudales, en sustancia era ya incompatible con el feudalismo, que se fundaba en la agricultura y cuyas expediciones de conquista apuntaban esencialmente a la adquisición de tierras. Fuera de ello, la navegación era un quehacer decididamente burgués, que ha impreso su carácter antifeudal también a todas las flotas de guerra modernas ${ }^{58}$.

A propósito, Antonio Mazzeo señala que ese proceso de desagregación del modo de producción feudal tiene su punto crucial en la crisis europea que se desarrolla a partir del siglo $\mathrm{XII}^{59}$. Esa decadencia expresaba una crisis estructural, debida a su inoperancia e incapacidad de autorreproducción, un proceso "que se realiza por elementos inmanentes al propio feudalismo, que actúan simultáneamente como fuerza de perpetuación del mismo y como fuerza propulsora de su disolución" ${ }^{60}$. Mazzeo, además, anota:

El fundamento de las contradicciones en el seno del feudalismo debe ser buscado en lo que se potenció como su negación, como contrario antagónico, donde el conflicto mayor entre fuerzas productivas y relaciones de producción determina alteraciones en la identidad anterior, permitiendo el surgimiento de una particularidad que inició su camino en la dirección de tornarse universalidad ${ }^{61}$.

Por su parte, las formas político-ideológicas superestructurales fueron acompañando, con distintos ritmos, los cambios estructurales: "El mercantilismo, el real determinante del Estado absoluto, fue una actividad reglamentada por el Estado y efectivizada por las acciones del mercado de la burguesía, realizando objetivamente la política económica de una era de acumulación primitiva" ${ }^{62}$.

En suma:

Tenemos, así, una expansión capitalista mercantil buscando formas de ampliar su producción. A partir del siglo XVI, el gran centro productor se instalará en América, donde los capitalistas europeos invertirán sus capitales acumulados, pasando, efectivamente, a la producción ampliada de mercaderías. El capital comercial sale, entonces, de los restrictos límites de la distribución, entrando definitivamente para el sector de la producción. Y será con el objetivo de crear una amplia producción para el mercado capitalista que la burguesía comercial implantará, aquí en América, la gran empresa mercantil [...] Los capitales antes acumulados en el comercio oriental de las especias son ahora aplicados en el más vasto emprendimiento comercial jamás visto hasta entonces; tendremos así la colonización de América y el surgimiento del sistema colonial. Y, sobre el sistema colonial prosperaron el comercio, la navegación y la producción de mercaderías ${ }^{63}$.

Por otro lado, elaboraciones más recientes, como las de João Paulo Pimenta, también puntualizan que:

\footnotetext{
${ }^{58}$ Ídem, p. 46.

${ }^{59}$ MAZZEO, Antonio Carlos. Estado e burguesia no Brasil: origens da autocracia brasileira. 2. ed. São Paulo: Cortez Editora, 1997, pp. 26-27.

${ }^{60}$ Ídem, pp. 28-29.

61 Ídem, p. 30.

62 Ídem, p. 53.

63 Ídem, pp. 55-56.
} 
[...] foi nos marcos do desenvolvimento e difusão de uma verdadeira globalização, em boa medida assentada na expansão do comércio mundial e em formas capitalistas de produção que, ao longo da Idade Moderna, Estados monárquicos da Europa ocidental se expandiram para além-mar, configurando-se impérios coloniais $^{64}$.

Es nítido cómo el marxismo aborda la cuestión en su totalidad y dinámica sin perderse en los laberintos de las "formas". Nos referimos a la categoría metodológica de totalidad, que no significa, evidentemente, el estudio de toda la realidad objetiva, un propósito que sería imposible de realizar puesto que la realidad, por su naturaleza, es infinita y está en permanente transformación. Hablamos de totalidad en el sentido de un todo orgánico, estructurado, en el cual no se puede comprender un elemento, una dimensión, aislándolo de su relación con el conjunto. Desde esa perspectiva, el marxismo define una primera y determinante ubicación del problema: el descubrimiento y colonización de América fueron parte fundamental del proceso de acumulación originaria de capital y cumplieron un papel disolvente, no estimulante o fortalecedor, de lo que quedaba de feudalismo en Europa. Este planteamiento es opuesto a la propuesta del estalinismo, en el campo de las interpretaciones de izquierdas.

En la visión de Marx y Engels, la conformación del mercado mundial y la colonización americana "aunque se realizaran bajo formas feudales eran ya incompatibles con el feudalismo". Esta es la definición esencial, profundamente dialéctica, que es necesario entender. Los adelantos en la navegación, la expansión del comercio, el mundo colonial, el tráfico de esclavos... todo esto poseía un sentido "decididamente burgués", que aceleró el advenimiento del capitalismo como modo de producción hegemónico.

Esto queda más claro en este corto pasaje escrito en 1858, en el que Marx expone su criterio sobre la relación mercado mundial-modos de producción:

El que a los dueños de las plantaciones en América no solo los llamemos ahora capitalistas, sino que lo sean, se basa en el hecho de que ellos existen como una anomalía dentro de un mercado mundial basado en el trabajo libre ${ }^{65}$.

En Historia Crítica de la Plusvalía, Marx hace alusión a las colonias basadas en las grandes plantaciones - como el sur de los actuales EEUU o el Brasil-. Dice que estas fueron:

[...] desde el momento mismo de crearse [las plantaciones, nda.] son especulaciones comerciales, centros de producción para el mercado mundial, existe un régimen de producción capitalista, aunque solo de un modo formal, puesto que la esclavitud de los negros excluye el libre trabajo asalariado, que es la base sobre la que descansa la producción capitalista. Son, sin embargo,

${ }^{64}$ PIMENTA, João Paulo. A independência do Brasil e a experiência hispano-americana (1808-1822). São Paulo: Hucitec/Fapesp, 2015, p. 16.

${ }^{65}$ MARX, Karl. Elementos fundamentales para la crítica de la economía política: Grundrisse [1857-1858]. In: MARX, Karl; ENGELS, Friedrich. Materiales para la historia de América..., op. cit., p. 164. 
capitalistas los que manejan el negocio de la trata de esclavos. El sistema de producción introducido por ellos no proviene de la esclavitud, sino que se injerta en ella. En este caso, el capitalista y el terrateniente son una sola persona ${ }^{66}$.

Notemos que para definir las plantaciones esclavistas el criterio decisivo era su inserción en el mercado mundial, no la "forma" como se producía en ellas; de ahí que Marx denomina capitalistas a los plantadores, aunque produzcan por medio del trabajo esclavo y no del trabajo "libre" asalariado.

Esta definición es importante, puesto que muchos autores se oponen a referirse a las clases propietarias nativas durante el período colonial como capitalistas o burgueses. Incluso algunos que se reivindican marxistas optan por utilizar categorías más amplias, como oligarquía y hasta elite, argumentando la evidente complejidad del asunto. Estas definiciones, aunque sean de uso común y puedan servir para efectos de difusión, no son precisas. La justificación más habitual es que, como mínimo hasta mediados del siglo XIX, no existían aún trabajadores libres ni régimen capitalista de producción puro e industrial. Eso es correcto. Pero eso no hacía menos capitalistas a los encomenderos, a los esclavistas coloniales, a los comerciantes, todos agentes directos del capital comercial y usurario, según el criterio de Marx.

Puede resumirse, a partir del recorrido que hemos hecho, que la esencia de la colonización fue "capitalista" no porque en América existió "trabajo libre" y asalariado desde el siglo XVI, sino porque esa empresa estuvo dictada por el proceso de conformación del mercado mundial, regido por la implacable ley de acumulación originaria de capital en Europa. Esta nueva división internacional del trabajo en escala mundial asignó a las colonias un doble papel desde el siglo XVI: proveedoras de metales preciosos, materias primas y fuerza de trabajo esclavizada; consumidoras de manufacturas producidas por las naciones más adelantadas del norte de Europa, de las cuales los reinos de España y Portugal, por su crónico atraso industrial, pasaron a actuar como intermediarios ${ }^{67}$.

Para terminar este apartado sobre el análisis marxista del sentido de la colonización, no podemos dejar de mencionar que en relación con la cuestión colonial hubo dos fases en el pensamiento de Marx y Engels. Hasta 1867, los fundadores del socialismo científico sostuvieron que el avance del capitalismo, aunque brutal, cumplía casi invariablemente un papel “civilizador” de pueblos bárbaros, semibárbaros, o sin historia.

\footnotetext{
${ }^{66}$ MARX, Karl. Historia crítica de la teoría de la plusvalia. Tomo II. México: Fondo de Cultura Económica, 1944, pp. 331-333.

${ }^{67}$ NÚÑ̃EZ, Ronald León. Apuntes sobre el carácter de las independencias..., op. cit.
} 
Por consiguiente, la colonización o semicolonización de los países "atrasados”, como el caso de China o la invasión de los EEUU al territorio mexicano, era progresiva.

Esta concepción del problema colonial merece ser criticada. El error de esta visión eurocéntrica derivaba de una interpretación mecánica, expresada en el propio Manifiesto Comunista, de que el desarrollo capitalista que se dio en las potencias centrales se repetiría en los países colonizados por medio de la penetración del imperialismo en formación ${ }^{68}$.

En las décadas de 1840 y 1850, ambos pensadores alemanes suponían que la cuestión colonial y la independencia de los países atrasados serían resueltas como subproducto de la toma del poder por parte del proletariado en los países avanzados: "En la medida y a la par que vaya desapareciendo la explotación de unos individuos por otros, desaparecerá también la explotación de unas naciones por otras"69.

En 1914, Lenin confirmó esa noción y explicó que: “Al principio, Marx creía que el movimiento que liberaría a Irlanda era el movimiento obrero de la nación opresora y no el nacional de la nación oprimida" ${ }^{70}$.

Sin embargo, a partir de observar la experiencia de Irlanda, Marx y Engels llegaron a la conclusión opuesta: el papel colonizador del Imperio británico en ese país y en la India no era progresivo sino regresivo, toda vez que destruía su economía, su industria, y así impedía el desarrollo capitalista normal de esos países. Dicho de otra manera, comprendieron que el desarrollo de los países atrasados no se daría a través del intercambio comercial desigual con los países avanzados.

Por otra parte, también identificaron que la dominación de la burguesía inglesa en Irlanda era un motivo de corrupción para la clase obrera de la "nación opresora", que en parte se beneficiaba de la explotación colonial. Por ende, la liberación de Irlanda pasó a ser considerada precondición para la propia liberación de clase obrera inglesa. En ese sentido, Marx escribió en abril de 1870 sobre cuál debería ser la posición de la Primera Internacional sobre este problema:

Inglaterra, como metrópoli del capital, como potencia que domina el mercado mundial actual, es por el momento el país más importante para la revolución obrera, y el único país donde las condiciones materiales de esta revolución se encuentran desarrolladas hasta cierto grado de madurez. Acelerar la revolución social en Inglaterra, por lo tanto, es el objetivo principal de la Asociación Internacional de los Trabajadores. La única forma de acelerarla es conseguir la

68 GODEIRO, Nazareno. O marxismo e a questão nacional e colonial. 2017. Disponible en: < https://teoriaerevolucao.pstu.org.br/o-marxismo-e-a-questao-nacional-e-colonial/>, consultado el 03/02/2020.

${ }^{69}$ MARX, Karl; ENGELS, Friedrich. Manifiesto del Partido Comunista..., op. cit.

70 LENIN, V. I. El derecho de las naciones a la autodeterminación. 1914. Disponible en: $<$ https://www.marxists.org/espanol/lenin/obras/1910s/derech.htm>, consultado el 04/12/2020. 
independencia de Irlanda. De ahí la tarea de la "Internacional" de poner el conflicto entre Inglaterra e Irlanda en primer plano en todas partes, de tomar partido abiertamente por Irlanda en todas partes. La tarea especial del Consejo Central de Londres es despertar la conciencia de la clase obrera inglesa de que la emancipación nacional de Irlanda no es para ellos una cuestión de justicia abstracta o de sentimiento humanitario, sino la primera condición de su propia emancipación social $^{71}$.

El 24 de octubre de 1869, Engels ya había escrito a Marx que: "la historia irlandesa le recuerda a uno lo desastroso que es para una nación el haber subyugado a otra nación"72. De esta suerte, adoptó la máxima de que "un pueblo que oprime a otro no puede ser libre"73. En abril de 1917, por ejemplo, Lenin exhortaba: "No, pueblo ruso, no te atrevas a avasallar

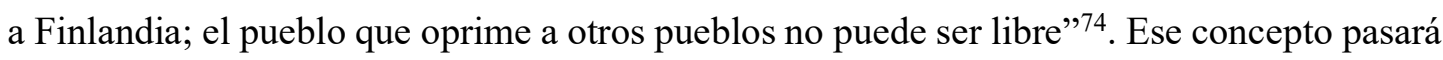
a ser una piedra angular del pensamiento socialista principista. Identificar la evolución del pensamiento de Marx y Engels sobre la cuestión colonial reviste importancia, sobre todo, para rechazar la idea de que el marxismo es un dogma infalible. El marxismo no ofrece recetas ni esquemas estáticos. La elaboración teórica, como muestra el caso del abordaje de esta espinosa cuestión, fue contrastada con la realidad y convenientemente corregida.

\subsection{La forma de la colonización: el debate sobre las relaciones de producción}

La inserción de la colonización americana en el proceso de expansión del mercado mundial no agota la discusión sobre las relaciones de producción en los espacios coloniales: ¿cómo se producían esas mercancías destinadas al mercado mundial capitalista? ${ }^{75}$

Es un error confundir la producción para el naciente mercado mundial, o bien el proceso de acumulación originaria de capital, con capitalismo, entendido como un determinado modo de producción.

Esto es importante, pues la mera producción de valores de cambio y la expansión de su circulación, si bien fue premisa para el modo de producción capitalista, no necesariamente significa que el modo de producir esas mercancías sea capitalista. La "producción para el

71 MARX, Karl. Carta a Sigfrid Meyer y August Vogt. 1870. Disponible en: $<$ https://www.marxists.org/espanol/m-e/1870/abril/09.htm>, consultado el 04/02/2020.

72 MARX, Karl; ENGELS, Friedrich. Correspondencia. Buenos Aires: Editorial Cartago, 1957, p. 181.

${ }^{73}$ Originalmente esa frase corresponde a un diputado americano ante las Cortes de Cádiz, llamado Yupanqui. El texto de su discurso figura en: ABELARDO, Jorge. La historia de la nación latinoamericana. Tomo I. Buenos Aires: Editorial Peña y Lillo, 1973, pp. 132-134.

${ }^{74}$ LENIN, V.I. Obras escogidas. Tomo 2. Moscú: Editorial Progreso, 1966, p. 132.

${ }^{75}$ Para la discusión sobre modos de producción existe abundante bibliografía. Destaco, entre otras: SOFRI, Giani. O modo de produção asiático: História de uma controvérsia marxista. Rio de Janeiro: Paz e Terra, 1977; HINDESS, Barry; HIRST, Paul. Modo de produção e formação social. Rio de Janeiro: Zahar Editores, 1978; GEBRAN, Philomena (Org.). Conceito de modo de produção. Rio de Janeiro: Paz e Terra, 1978; CARDOSO, Ciro; PÉREZ, Héctor. História econômica da América Latina. 3. ed. Rio de Janeiro: Edições Graal, 1983. 
mercado" y el capital mercantil existen desde tiempos remotos y coexisten con distintos modos de producción anteriores al capitalismo, como el esclavismo y el feudalismo.

Lo que define al capitalismo, hablando con propiedad, es la expropiación total de los medios de producción a la clase trabajadora y la transformación de su propia fuerza de trabajo en mercancía. Capitalismo presupone un mercado de trabajo "libre". Según Marx:

[...] el proceso que engendra el capitalismo solo puede ser uno: el proceso de disociación entre el obrero y la propiedad de las condiciones de su trabajo, proceso que, de una parte, convierte en capital los medios sociales de vida y de producción, mientras, de otra parte, convierte a los productores directos en obreros asalariados. La llamada acumulación originaria no es, pues, más que el proceso histórico de disociación entre el productor y los medios de producción ${ }^{76}$.

Es decir, debe existir la proletarización y la liberación jurídica de los productores directos. Lenin confirmará esta definición:

El capitalismo es la fase de desarrollo de la producción mercantil en la que también la fuerza de trabajo se transforma en mercancía. La tendencia fundamental del capitalismo consiste en que toda la fuerza de trabajo de la economía nacional se aplica a la producción únicamente después de haber sido negociada su venta y compra por los patronos ${ }^{77}$.

Por este motivo, Nahuel Moreno acierta cuando al mismo tiempo que define correctamente que el carácter, esencia, sentido, signo de la colonización europea en América Latina fue capitalista, precisa que las relaciones de producción con las cuales se extraía el excedente social de las clases explotadas eran precapitalistas, "la esclavitud o una semiesclavitud de los indígenas $[\ldots]^{\text {"78. }}$.

Milcíades Peña, siguiendo a Bagú, propone una definición muy imprecisa cuando asume la existencia de un tipo de capitalismo, aunque haga la salvedad de que se trataba de algo distinto del "capitalismo industrial":

No se trata de un capitalismo industrial. Es un capitalismo de factoría,
'capitalismo colonial' [... que produce] en gran escala para el mercado [...] estas
son características decisivamente capitalistas, aunque no del capitalismo
industrial, que se caracteriza por el salario libre ${ }^{79}$.

En ese sentido, enfatiza las "concentraciones de mano de obra semiasalariada" ${ }^{\circ 0}$, que, si bien existían, no pueden atenuar el hecho de que el trabajo "libre" era marginal y deformado. Por lo tanto, la utilización de la categoría capitalismo, aunque diferencie este del industrial se presta a confusiones.

\footnotetext{
${ }^{76}$ MARX, Karl. El Capital. Tomo I. Buenos Aires..., op. cit., p. 574. Destacado en el original.

${ }^{77}$ LENIN, V. I. [1899]. El desarrollo del capitalismo en Rusia: El proceso de la formación del mercado interior para la gran industria. Moscú: Editorial Progreso, 1974, p. 636.

${ }^{78}$ MORENO, Nahuel. Cuatro tesis sobre la colonización española y portuguesa en América..., op. cit.

${ }^{79}$ PEÑA, Milcíades. Historia del pueblo argentino..., op. cit., p. 67.

80 Ídem, p. 69.
} 
Hasta aquí, hemos enfocado el análisis en los esfuerzos que hizo el marxismo para contraponer su visión a la tesis de la colonización feudal con la que el estalinismo desarrollaba su enfoque etapista de la historia. Cuestionar ese esquema era necesario, dadas sus consecuencias programáticas y políticas.

Sin embargo, frente a ese problema, poco o nada ayudaba sostener, como hicieron André Gunder Frank y otros intelectuales, que la colonización de América Latina fue enteramente capitalista desde el comienzo: "el capitalismo comienza a penetrar, a formar, a caracterizar por completo a Latinoamérica y a la sociedad chilena ya en el siglo XVI"81, escribió en uno de sus textos más referenciados.

Moreno criticó duramente ese planteamiento, diciendo que, aunque opuesto a la tesis estalinista, el esquema era políticamente "tan peligroso como el anterior [la tesis feudal]" 82 .

En su polémica con Puiggrós, Gunder Frank respondió que “el enfoque preciso para solucionar la problemática latinoamericana tiene que partir del sistema mundial que la crea y salir de la autoimpuesta ilusión óptica y mental del marco iberoamericano o nacional"83. En esto llevaba razón.

También insistió, acertadamente, en que el raquitismo económico y el subdesarrollo de América Latina debían ser explicados "no como la sobrevivencia feudal que sigue esperando su superación por el desarrollo capitalista sino como el producto histórico y aun continuado del mismo desarrollo capitalista de un sistema mundial único"84. En otras palabras, a partir de su incorporación dependiente desde el comienzo en la formación del mercado mundial capitalista.

Salta a la vista, entonces, que a Gunder Frank no se le puede negar el mérito de haber combatido a aquellos que, para enfrentar la atrofia capitalista latinoamericana producto de un supuesto feudalismo perenne, proponían una estrategia y una política de conciliación de clases para abrir las puertas a un pretendido capitalismo nacional y democrático ${ }^{85}$.

81 GUNDER FRANK, André. Capitalismo y subdesarrollo en América Latina. 1965. Disponible en: $<$ http://www.eumed.net/cursecon/textos/Frank/index.htm>, consultado el 19/11/2016.

${ }^{82}$ MORENO, Nahuel. Cuatro tesis sobre la colonización española y portuguesa en América..., op. cit.

${ }^{83}$ GUNDER FRANK, André. ¿Con qué modos de producción convierte la gallina ..., op. cit.

${ }^{84}$ Ibídem.

${ }^{85}$ Entre los pensadores influenciados por la teoría de la dependencia o sus matices, además de Gunder Frank, podemos mencionar, en Brasil: Ruy Mauro Marini, Vânia Bambirra, Roger Bastide, Florestan Fernandes, Fernando Henrique Cardoso, Celso Furtado, Emília Viotti da Costa; en México, Pablo González Casanova, Rodolfo Stavenhagen, Alejandro Marroquín, y Carlos Fuentes; en Perú, Jorge Bravo Bresani, Carlos Malpica, José Matos Mar, y Aníbal Quijano Obregón, entre muchos otros y otras. 
Pero ese acierto metodológico, que ubicaba el problema en dimensión global, al igual que su combate al discurso histórico etapista, se diluía en el error de absolutizar el elemento "sistema mundial único" y, a partir de ello, sentenciar: “[...] declaramos Iberoamérica capitalista no solo desde la cuna sino desde su concepción" ${ }^{\prime 86}$.

Efectivamente, Gunder Frank terminaba confundiendo economía mercantil y sed de lucro con el modo de producción capitalista propiamente dicho y, a raíz de este craso error, abría a sus adversarios un flanco indefendible. Su análisis prescindía de los modos de producción y se reducía a la existencia mayor o menor de relación con el mercado; en otros términos, estaba encapsulado en el proceso de circulación de mercaderías. De ahí que en medios marxistas haya sido acusado, con justeza, de circulacionista.

Puiggrós, por ejemplo, le respondió:

El error más cultivado es el de confundir economía mercantil con capitalismo. Como la producción y la circulación de mercancías son las premisas del modo de producción capitalista, no hay capitalismo sin economía mercantil, pero el modo de producción capitalista comienza al llegar la economía mercantil a determinada etapa de desarrollo, al universalizarse la producción de mercaderías y la mercadería misma, al extremo de ser mercadería también la fuerza de trabajo. Desde los tiempos más remotos existe la economía mercantil en convivencia con los distintos modos de producción: la hubo durante la esclavitud y durante el feudalismo ${ }^{87}$.

Desde nuestra perspectiva, Puiggrós y otros utilizaban esas verdades al servicio de una gran falsedad: demostrar el supuesto pasado feudal de Latinoamérica, universalizando el elemento contradictorio, esto es, el hecho de que durante la Colonia efectivamente existieron relaciones de producción no capitalistas. En ese sentido, una de las pruebas de que en estas tierras se había trasplantado el feudalismo europeo era la inexistencia, en el siglo XVI, de la "jornada de 8 horas, el pago semanal en dinero contante y sonante, el servicio médico, el seguro de enfermedades y accidentes, las mercaderías a precios irrisorios, etcétera"88; ciertamente una exageración polémica, pero que hacía mella en los débiles pilares con los que Gunder Frank y los dependentistas sostenían su construcción teórica.

A todo esto, es útil recordar que Marx afirma en El Capital que "la biografía moderna del capital se abre en el siglo XVI con el comercio y el mercado mundiales" ${ }^{\text {, }}$, pero nunca dijo, pues no sería verdadero, que eso generó mecánicamente un modo de producción capitalista en el continente americano. Pasarían siglos para que eso ocurriese. En el siglo

\footnotetext{
${ }^{86}$ GUNDER FRANK, André. ¿Con qué modos de producción convierte la gallina ..., op. cit.

${ }^{87}$ PUIGGRÓS, Rodolfo. Los modos de producción en Iberoamérica..., op. cit.

${ }^{88}$ Ibídem.

${ }^{89}$ MARX, Karl. El Capital. Tomo I. Buenos Aires..., op. cit., p. 121.
} 
XVI, en América, en África y en Asia, los europeos se depararon inevitablemente con modos de producción preexistentes, que no eran ni podían ser capitalistas, aunque se hayan servido de ellos para "acumular" capital que, solo después, redundaría en la victoria final del capitalismo.

En ese sentido, en Las formaciones híbridas y la revolución permanente en Latinoamérica $^{90}$, el trotskista estadounidense George Novack criticó los errores metodológicos y la definición de Gunder Frank. Un texto poco conocido del que consideramos útil transcribir algunos alegatos:

I. "En el siglo XVI el capitalismo recién comenzaba a tomar forma en Europa occidental. La revolución industrial, que estableció el modo específicamente capitalista de producción, no despegó hasta el siglo XIX. ¿Cómo podía entonces la atrasada Latinoamérica haberse convertido en 'completamente' capitalista tan pronto?";

II. "La principal potencia colonial, España [...] era todavía tan feudal como burguesa [...] Se apoyaba en una economía decadente cuyas relaciones con el Nuevo Mundo servían mucho más para enriquecer a las potencias más avanzadas del otro lado de los Pirineos que para revolucionar su propia estructura social";

III. "Los comerciantes españoles servían como agentes intermediarios de los productores franceses, ingleses y holandeses, y las potencias. ¿Cómo podían los españoles y los portugueses haber instituido formas de organización económica en Latinoamérica superiores a la suya propia entre los siglos XVI y XIX?"91.

En cuanto a la estructura económica colonial, que entrelazaba distintas relaciones de producción, Novack sostiene que:

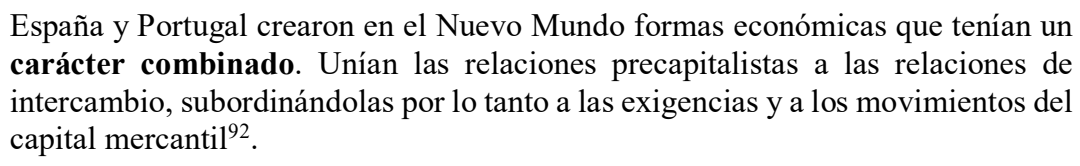
carácter combinado. Unían las relaciones precapitalistas a las relaciones de intercambio, subordinándolas por lo tanto a las exigencias y a los movimientos del capital mercantil ${ }^{92}$.

Así, el teórico estadounidense explicará el peso de las formas precapitalistas en el terreno de la producción:

Durante el período colonial, fueron más predominantes diversas formas de trabajo forzado que el trabajo libre en las principales áreas de producción tales como las empresas mineras, ganaderas y agrícolas. La población nativa sojuzgada trabajaba duramente bajo la servidumbre (mita), la esclavitud lisa y llana, el peonazgo o la

\footnotetext{
90 NOVACK, George. Para comprender la historia. Buenos Aires: Ediciones Pluma, 1975; NOVACK, George. O desenvolvimento desigual e combinado na história. São Paulo: Editora Sundermann, 2008.

${ }^{91}$ NOVACK, George. O desenvolvimento desigual e combinado na história ..., op. cit., pp. 89-90.

92 Ídem, p. 90.
} 
servidumbre por deudas, y la aparcería. EI trabajo asalariado surgía aquí y allá, pero era una excepción, marginal y débil ${ }^{93}$.

Desde el punto de vista metodológico, la crítica de Novack a Gunder Frank puede ser resumida de esta forma:

No comprende el rol de las formaciones combinadas en el período de transición de una economía precapitalista a una economía capitalista [ni entiende] la explotación en condiciones precapitalistas de producción por parte de las potencias coloniales para beneficio del sistema capitalista naciente ${ }^{94}$.

Esto se debería a que Gunder Frank "ignora la ley dialéctica de la unidad o la interpenetración de los opuestos que, en términos sociohistóricos, presupone la posibilidad de coexistencia, al menos durante un cierto tiempo, de relaciones feudales y capitalistas en la evolución de las sociedades de clase" $" 95$.

En efecto, la cuestión de la coexistencia de objetivos capitalistas y relaciones de producción no capitalistas en una determinada formación económico-social -algo imposible de comprender si se sigue la lógica estalinista unilineal de "los cinco estadios" (comunismo primitivo, esclavismo, feudalismo, capitalismo, socialismo), que supone una sucesión infranqueable de modos de producción aplicada de manera mecanicista a la historia de todos los pueblos- solo puede ser entendida plenamente a través de la perspectiva de la ley del desarrollo desigual y combinado.

Novack explica que la instauración del capitalismo no fue, ni podía ser, lineal. En su avance para conformar el mercado mundial, el capital mercantil se deparó con todo tipo de modos de producción y relaciones sociales precapitalistas, en las cuales penetró. Si bien es correcto que su objetivo último era disolverlas, eso no significa que no haya utilizado $-\mathrm{y}$ hasta estimulado- instituciones y relaciones de producción no capitalistas mientras esto le fue provechoso. Basta analizar el caso de la esclavitud:

Los elementos mercantiles fueron tan lejos que recrearon en las colonias modos anticuados de producción que ellos ya habían descartado en su patria. El caso más notorio fue la implantación de la esclavitud en gran escala en el Nuevo Mundo [...] Sin embargo - explica Novack- la esclavitud introducida en las Américas no fue una mera réplica de la esclavitud clásica. Aunque tenía la misma forma económica, adquirió características y funciones muy distintas [...] Desde sus orígenes, fue una esclavitud comercializada y aburguesada. La trata de esclavos fue en sí misma una de las formas principales de empresa comercial ${ }^{96}$.

\footnotetext{
${ }^{93}$ Ibídem.

94 Ídem, pp. 91-92.

95 Ídem, p. 93.

96 Ídem, pp. 86-87.
} 


\section{NOTAS SOBRE EL ENFOQUE MARXISTA Y DE IZQUIERDAS DEL CASO BRASILEÑO}

El caso de la colonia portuguesa en Sudamérica, con sus particularidades, es parte del mismo debate y, por su papel histórico, reviste enorme importancia para comprender el proceso en su conjunto.

Aquí haremos un repaso de las principales posiciones de algunos intelectuales que se identificaron con el marxismo, ligados o no al estalinismo, sobre el sentido de la colonización y las relaciones de producción engendradas por esta empresa, principalmente el caso de la esclavitud negra. Pero insistimos al lector o lectora que se trata de apuntes, pinceladas de un elemento muy importante y por ello imposible de ser simplemente desconsiderado, pero sobre el cual este trabajo no pretende ahondar con la exhaustividad que merece ni alcanzar conclusiones definitivas.

En 1942, el intelectual brasileño Caio Prado Júnior ${ }^{97}$ publicó su obra Formação do Brasil contemporâneo, en la que planteó su polémica idea acerca del "sentido de la colonización tropical":

En su conjunto, y vista en el plano mundial e internacional, la colonización de los trópicos adquiere el aspecto de una vasta empresa comercial $[\ldots]$ destinada a explotar los recursos naturales de un territorio virgen en provecho del comercio europeo. Este es el verdadero sentido de la colonización tropical, de la que el Brasil es una de sus resultantes [...] Si vamos a la esencia de nuestra formación, veremos que en realidad nos constituimos para proveer azúcar, tabaco, algunos otros géneros; más tarde oro y diamantes; después algodón, y seguidamente café, para el comercio europeo. Nada más que esto [...] Todo se dispondrá en aquel sentido: la estructura, así como las actividades del país [...] Con tales elementos, articulados en una organización puramente productora, industrial, se constituirá la colonia brasileña ${ }^{98}$.

\footnotetext{
${ }^{97}$ Caio Prado Júnior [1907-1990]. Intelectual brasileño, miembro del Partido Comunista Brasileño [PCB] desde 1931 hasta su muerte. Hijo de una de las familias más ricas y tradicionales de San Pablo, fue electo diputado de la Asamblea Constituyente Estadual paulista en 1947. Su mandato, no obstante, fue cancelado en virtud de la ilegalización del PCB. Fue admirador de la URSS, que visitó en dos ocasiones, la primera en 1933. A su regreso escribió su primer ensayo historiográfico: Evolução Política do Brasil - Ensaio de Interpretação Materialista do Brasil. En 1934 escribió otro texto: URSS, um novo mundo. Elogió los regímenes de Polonia, la ex Checoslovaquia, China y Cuba, donde fue recibido por Fidel Castro. En su papel de empresario, fundó en 1943 la Editora Brasiliense y en 1955 la Revista Brasiliense, esta última clausurada por la dictadura militar en 1964. En el terreno historiográfico, criticó la teoría del PCB sobre el "pasado feudal” del Brasil, aunque sin romper con la lógica etapista del estalinismo. Entre sus principales obras se encuentran: Formação do Brasil contemporâneo (1942) y A Revolução Brasileira (1966), estudios históricos orientados al debate político de su tiempo. Sobre la vida y obra política de Caio Prado Júnior, entre otros, consultar: PERICÁS, Luiz. Caio Prado Júnior. Uma biografia política. São Paulo: Boitempo, 2016; SECCO, Lincoln. Caio Prado Júnior: o sentido da revolução. São Paulo: Boitempo, 2008.

${ }^{98}$ PRADO Jr., Caio [1942]. Formação do Brasil contemporâneo. 12. ed. São Paulo: Brasiliense, 1972, pp. 3132. Ver también: PRADO Jr., Caio [1945]. História econômica do Brasil. 43. ed. São Paulo: Brasiliense, 2012. Un autor que continúa la línea de Caio Prado y que incluso la amplía es Fernando Novais. Ver: NOVAIS, Fernando. Portugal e Brasil na crise do Antigo Sistema Colonial [1777-1808]. São Paulo: Hucitec, 1979.
} 
Así, sostuvo que la estructura económica y social de la colonia brasileña -con sus pilares de "grandes plantaciones, monocultivo y el trabajo esclavo"- estuvo indisolublemente ligada y al servicio de abastecer el mercado europeo. Esa producción para el mercado mundial, según Caio Prado Jr., será el motor de la colonización portuguesa en América, que para ello recurrirá a la "mano de obra que necesita: indígenas o negros importados". Ese carácter colonial o subordinado, a su vez, no terminaría con la independencia política declarada formalmente en 1822 sino que se prolongaría en el tiempo: “él explicará los elementos fundamentales, tanto en lo económico como en lo social, de la formación y evolución históricas de los trópicos americanos"99.

Caio Prado no solo acertó en esa definición general sino que presentó una tesis que colisionaba con la visión estalinista que sostenía la existencia de feudalismo tanto en el Brasil como en el resto de América Latina ${ }^{100}$. Este era el análisis-justificación del programa etapista que los partidos comunistas tradicionales promovían en los países semicoloniales: primero la revolución "democrática" y "antifeudal", concebida como una "etapa" infranqueable en la que el proletariado debería subordinarse a la burguesía "progresista", y sin la cual se hacía imposible abrir las compuertas al capitalismo industrial y nacional; solo después podría plantearse el programa socialista.

La resolución del VI Congreso Mundial de la Internacional Comunista estableció las distintas "graduaciones de madurez en los distintos países", que imponían "etapas intermediarias para llegar a la dictadura del proletariado"101.

Los países coloniales y semicoloniales (China, India, etc.) y los países dependientes (Argentina, Brasil, etc.) con gérmenes de industria y, a veces, con un desarrollo industrial considerable, insuficiente, sin embargo, para la edificación socialista independiente; con predominio de las relaciones feudal-medioevales o relaciones de "modo asiático de producción" [...En estos países...] la transición a la dictadura del proletariado es aquí posible, como regla general, solamente a

\footnotetext{
${ }^{99}$ PRADO Jr., Caio [1942]. Formação do Brasil contemporâneo..., op. cit., pp. 31-32.

${ }^{100}$ La cuestión del pasado feudal en América Latina se incorporó formalmente en 1928, durante el VI Congreso de la III Internacional Comunista, ya controlada por el estalinismo. En esa línea, entre 1929 y 1931, la burocracia de la ex URSS decidió eliminar el concepto marxista de modo de producción asiático - sin propiedad privada, pero con explotación de los campesinos aldeanos por una casta dirigente y administradora de los trabajos públicos y los canales de irrigación-, debido a que esa categoría podía contribuir a elucidar el carácter del propio régimen burocrático estalinista. En 1938, Stalin sanciona la teoría de los cinco modos de producción: "La historia conoce cinco tipos fundamentales de relaciones de producción: el comunismo primitivo, la esclavitud, el feudalismo, el capitalismo y el socialismo", plasmada en su libro Materialismo dialéctico $\quad y \quad$ el materialismo histórico, disponible $<$ http://www.marx2mao.com/M2M(SP)/Stalin(SP)/DHM38s.html>. Estos cinco estadios, sucedidos linealmente, eran considerados "etapas" comunes al desarrollo histórico de todos los pueblos. Desde esta perspectiva, por ejemplo, Stalin caracterizaba como esclavistas las sociedades incas, mayas y aztecas.

${ }_{101}$ COMINTERN. Programa y estatutos de la Internacional Comunista: Adoptados por el VI Congreso Mundial en Moscú el 1 de setiembre de 1928. Bruselas: Ediciones Adelante, s/f, p. 52.
} 
través de una serie de etapas preparatorias, como resultado de todo un período de transformación de la revolución democrático-burguesa en revolución socialista ${ }^{102}$.

La traducción de esta tesis al caso brasileño puede leerse, entre otros documentos, en la resolución política del V Congreso del PCB en 1960:

El Partido Comunista del Brasil, partido de la clase obrera, tiene como objetivo supremo el establecimiento de la sociedad socialista [...] En las condiciones actuales, no obstante, Brasil tiene su desarrollo entrabado por la explotación del capital imperialista internacional y por el monopolio de la propiedad de la tierra en manos de la clase de los latifundistas. Las tareas fundamentales que se plantean hoy delante del pueblo brasileño son la conquista de la emancipación del País del dominio imperialista y la eliminación de la estructura agraria atrasada, así como el establecimiento de amplias libertades democráticas y la mejora de las condiciones de vida de las masas populares. Los comunistas se empeñan en la realización de estas transformaciones, al lado de todas las fuerzas patrióticas y progresistas, ciertos de que ellas constituyen una etapa previa y necesaria en el camino para el socialismo ${ }^{103}$.

Caio Prado tuvo la osadía intelectual de calificar esa tesis como "obsoleta" para el Brasil, aunque la consideró acertada para los países asiáticos. Ya en 1933, refiriéndose al carácter de propiedad jurídica de la tierra en los primeros años de la colonización brasileña, refutó la cuestión del pasado feudal: "No manifiesta, sin embargo, ninguna relación de carácter feudal, vasallaje u otra. Las tierras eran alienables por libre disposición de los propietarios y no creaban lazo alguno de dependencia personal"104.

En su interpretación histórica, Caio Prado Jr. opuso el concepto de "economía colonial" al de "economía nacional", entendida esta última como un modelo enfocado en atender las necesidades de la población de su país en detrimento de los negocios foráneos. Sintetizó esa visión teórica de esta manera: "En una palabra, no completamos aún hoy nuestra evolución de la economía colonial a la nacional”105.

A pesar de la lucidez de su análisis sobre el período colonial, no es posible omitir críticas a su pensamiento político. Incluso porque, según él mismo reconocía, su prolífico trabajo intelectual nunca estuvo subordinado a un interés académico, sino que servía de coadyuvante a su militancia política, que estuvo siempre ligada al PCB: "é por acão que os homens se definem", dijo en cierta oportunidad ${ }^{106}$.

\footnotetext{
102 Ídem, p. 54. Destacado en el original.

103 PCB. Resolução politica do $V$ Congresso do PCB. 1960. Disponible en: $<$ https://pcb.org.br/fdr/index.php?option=com content\&view=article\&id=149:resolucao-politica-do-vcongresso-do-pcb\&catid=1:historia-do-pcb>, consultado el 02/12/2016.

${ }_{104}$ PRADO Jr., Caio [1933]. Evolução política do Brasil. 15. ed. São Paulo: Brasiliense, 1986, p. 15.

105 PRADO Jr., Caio [1942]. Formação do Brasil contemporâneo..., op. cit., p. 7.

106 SECCO, Lincoln. Caio Prado Júnior ..., op. cit., pp. 11-15.
} 
Aunque no exista un acuerdo sobre el tema, desde nuestra perspectiva, el alejamiento de este intelectual brasileño con la concepción etapista de la historia propuesta por el estalinismo, en el terreno de la estrategia y de la política concreta, fue incompleta.

Como adelantamos, a partir de identificar una contradicción principal: la oposición entre economía “colonial” y economía "nacional”, Caio Prado Júnior propuso desarrollar, como primer paso al socialismo, esa economía nacional "dentro de las relaciones capitalistas de producción"107.

Si bien no descartaba el socialismo "a largo plazo", lo consideraba prematuro para las condiciones históricas concretas del Brasil y otros países semicoloniales. Existen distintos pasajes en sus obras que insisten sobre este tema. Para no dar largas al asunto, baste aquí con destacar algunas de ellas.

En 1957, planteó: "La socialización de los medios de producción, premisa de esa transformación, es ciertamente prematura en los países subdesarrollados con su bajo nivel industrial y la larga fragmentación y dispersión de las actividades económicas" ${ }^{108}$.

En 1966, Caio Prado publicó su libro A revolução brasileira, un clásico dentro de la literatura de izquierdas en el Brasil, que reafirmó su concepción general de que la línea esencial del desarrollo histórico brasileño no apuntaba al socialismo sino, más precisamente, a la consolidación de una economía nacional soberana.

Según su interpretación, el socialismo no debía pasar de una "previsión histórica" que no debía interferir necesariamente en la formulación de la política cotidiana, puesto que, según sus propias palabras, el socialismo era irrealizable en el Brasil:

La eliminación de la iniciativa privada solamente es posible con la implantación del socialismo, lo que en la situación presente es desde luego irrealizable en el Brasil por faltar, si no hubiese otros motivos, las condiciones mínimas de consistencia y estructuración económica, social, política e incluso simplemente administrativa $^{109}$.

De esta manera, aunque por otra vía, su elaboración paró en la misma "estación” que la dirección del PCB:

La contradicción antagónica entre el proletariado y la burguesía, inherente al capitalismo, es también una contradicción fundamental de la sociedad brasileña. Pero esta contradicción no exige solución radical y completa en la actual etapa de la revolución, una vez que, en la presente situación del País, no hay condiciones para transformaciones socialistas inmediatas $[\ldots]^{110}$.

\footnotetext{
${ }^{107}$ PRADO Jr., Caio. Diretrizes para uma política econômica brasileira. São Paulo: Gráfica Urupês, 1954, pp. 227-228.

${ }^{108}$ PRADO Jr., Caio [1957]. Esboço dos fundamentos da teoria econômica. 3. ed. São Paulo: Brasiliense, 1961, p. 222.

${ }^{109}$ PRADO Jr., Caio [1966]. A revolução brasileira. 3. ed. São Paulo: Brasiliense, 1968, p. 250.

${ }^{110}$ PCB [1960]. Resolución política del V Congreso del PCB..., op. cit.
} 
En apretada síntesis, en la propuesta política de Caio Prado existe una etapa previa sin la cual el socialismo es "irrealizable": la eliminación de los trazos coloniales de la economía brasileña y el paso hacia una economía nacional -capitalista, "regulada" y enfocada en el desarrollo del mercado interno- que él denominó “organización económica nacional, a saber, estructurada en función y para el fin precipuo del atendimiento de las necesidades del propio país"111.

Puede notarse, en su formulación de las tareas políticas cotidianas, una separación entre tareas democráticas y propiamente socialistas, que son concebidas como parte de "etapas", "situaciones" o "fases" distintas. El proceso de transformaciones que el autor propone, en definitiva, sería impulsado por un sector de la iniciativa privada y tendría como sujeto social un abanico policlasista de "fuerzas anticoloniales".

\subsection{Las críticas al modelo de Caio Prado Júnior: el "esclavismo colonial"}

Entre las principales críticas teóricas al planteamiento de Caio Prado Jr. sobre el "sentido de la colonización", se destaca la tesis del modo de producción esclavista colonial. Posiblemente, la obra más conocida y consistente sobre el tema sea $O$ escravismo colonial, escrita por Jacob Gorender ${ }^{112}$ y publicada en 1978, aunque ese concepto fue propuesto anteriormente por el intelectual Ciro F. Cardoso ${ }^{113}$.

Ambos autores enfocan su análisis en la discusión sobre modos de producción, especialmente en el Brasil, impugnando el enfoque de Caio Prado, que enfatiza la relación colonial con el mercado europeo como circulacionista, una crítica injusta según nuestro parecer, puesto que lo central para Caio Prado era la relación colonial, no simplemente la mayor o menor participación en el mercado. En palabras de Gorender, una visión basada en

${ }^{111}$ PRADO Jr. Caio [1966]. A revolução brasileira..., op. cit., p. 144.

112 Jacob Gorender [1923-2013]. Intelectual brasileño y dirigente del PCB. Ingresó al PCB en 1942, llegando a componer su CC en 1960. Se destacó en la redacción del órgano central del partido, Classe Operária, al igual que en la tarea de formación de militantes en los llamados Cursos Stalin. Estudió en la Escuela Superior del PC de la URSS, entre 1955 y 1957. A su regreso, fue parte de la redacción de la "Declaración de marzo de 1958”, que cambió la orientación "izquierdista” del PCB para adoptar una línea más adaptada a la legalidad democrática. Tras la instauración de la dictadura militar en 1964, surgieron diferencias internas sobre cómo enfrentar ese régimen y Gorender rompió con el PCB para fundar, en 1967, el Partido Comunista Brasileiro Revolucionário (PCBR), que proponía una lucha abierta, incluso armada, contra el régimen militar. Entre 1970 y 1972 fue preso y torturado por la dictadura brasileña. Su principal obra, O escravismo colonial, fue escrita en 1978. Por muchos años se alejó de la militancia partidaria, hasta que en la década de 1990 ingresó al PT brasileño.

${ }^{113}$ Ciro Flamarion Cardoso [1942-2013]. Intelectual brasileño. Escribió sobre historia y metodología, pero sus principales estudios se centraron en los modos de producción coloniales, a los que atribuía carácter específico. Fue pionero en el concepto del modo de producción esclavista colonial. Posteriormente, se transformó en egiptólogo. 
"manifestações sequenciais de algo mais profundo, de uma realidade permanente e imanente - a estructura exportadora da economia colonial"114.

Gorender planteará que la esclavitud es la categoría central, el "punto de partida" para comprender el Brasil colonial:

Tal diferencia consiste en que [Fernando] Novais y [João Manuel] Cardoso de Mello parten del sistema colonial mundial como totalidad que determina el contenido de la formación social en el Brasil, al paso que yo inicio mi análisis con el modo de producción esclavista colonial, a cuya dinámica propia atribuyo una determinación fundamental ${ }^{115}$.

Según esta interpretación, la estructura económica interna habría alcanzado tal autonomía que engendró un modo de producción original, distinto de los que surgieron antes:

Se impone, por consiguiente, la conclusión de que el modo de producción esclavista colonial es inexplicable como síntesis de modos de producción preexistentes, en el caso del Brasil [...] El esclavismo colonial emergió como un modo de producción de características nuevas, antes desconocidas en la historia humana ${ }^{116}$.

En oposición a la propuesta de Prado Jr., sus críticos sostuvieron que la colonia tenía un "sentido" propio, no subordinado a la metrópoli. Gorender propuso, entonces, que "las relaciones de producción de la economía colonial necesitan ser estudiadas de dentro para fuera" ${ }^{17}$. Ciro Cardoso, a su turno, criticó el modelo interpretativo de Prado Jr. achacándole una "obsesión plantacionista", que consideró simplificadora118.

Es justo destacar que estos autores no dejaron de criticar el dogma estalinista de los "cinco estadios". Argumentaron, correctamente, que tanto el desarrollo de las fuerzas productivas como los modos de producción en América no seguían -ni podían seguir- el "esquema" europeo. Sin embargo, en el afán por negar la dicotomía "pasado feudal-pasado capitalista", se adentraron en la senda de elaborar una "teoría general"119 sobre la complejidad de la particularidad del caso americano. Así, haciendo un llamado a "renunciar

\footnotetext{
114 GORENDER, Jacob [1978]. O escravismo colonial. 3. ed. São Paulo: Ática, 1980, p. 51. Destacado en el original. Gorender identifica a Caio Prado Júnior como fundador de la "ideia da economia de estrutura exportadora" no Brasil, que en su opinión sería abrazada también por Celso Furtado, Alice Canabrava, Fernando Novais, Fernando Henrique Cardoso, además de Eric Williams.

115 GORENDER, Jacob [1981]. A burguesia brasileira. 3. ed. 2. reimp. São Paulo: Brasiliense, 2004, p. 7. Sobre la esclavitud negra como modo de producción en el Brasil ver, entre otras: CASTRO, Antonio Barros de. A economia política, o capitalismo e a escravidão. In: AMARAL LAPA, José Roberto do (Org.). Modos de produção e realidade brasileira. Petrópolis: Vozes, 1980; FRAGOSO, João Luís. Novas perspectivas acerca da escravidão no Brasil. In: CARDOSO, Ciro (Org.), Escravidão e abolição no Brasil: novas perspectivas. Rio de Janeiro: Jorge Zahar, 1988, pp. 67-107.

${ }^{116}$ GORENDER, Jacob [1978]. O escravismo colonial..., op. cit., p. 54. Destacado en el original.

117 Ídem, p. 21.

${ }^{118}$ CARDOSO, Ciro. O trabalho na colônia. In: LINHARES, Maria (Org.). História geral do Brasil. 5. ed. Rio de Janeiro: Campus, 1990, p. 69. Ver también: COSTA, Iraci del Nero da. Repensando o modelo interpretativo de Caio Prado Júnior. Cadernos NEHD, São Paulo, v. 3, 1995.

${ }^{119}$ GORENDER, Jacob [1978]. O escravismo colonial..., op. cit., p. 22.
} 
a la importación de esquemas interpretativos elaborados a partir de otros procesos de evolución”, Ciro F. Cardoso exhortó:

[Hay que reconocer] la especificidad de los modos de producción coloniales de América. Pero especificidad en serio, en el sentido fuerte de la palabra: ellos existieron como estructuras dependientes (es decir, la dependencia constituye un elemento esencial de su definición y de su modelo), pero irreductibles a los esquemas eurocéntricos [...] Desde 1968, he defendido la necesidad de reconocer el carácter específico e irreductible de los modos de producción coloniales $^{120}$.

Para demostrar la especificidad del "esclavismo colonial", la contribución de Cardoso sistematizó las diferencias entre el esclavismo de la Antigüedad y su versión moderna $^{121}$.

A nuestro juicio, las diferencias entre ambos tipos de esclavismo resultan evidentes, fundamentalmente porque el esclavismo antiguo y el moderno se asentaron sobre distintos grados de desarrollo de las fuerzas productivas. Sin embargo, tomadas en su conjunto, ambas formas de trabajo forzado mantuvieron una característica fundamental, común a toda sociedad esclavista: el esclavo era al mismo tiempo capital fijo y mercancía; el mercado de trabajo era abastecido por robos que "constituyen pura y simplemente actos de apropiación de la fuerza de trabajo por medio de la violencia física descarada"122.

Desde esta perspectiva, la esclavitud moderna no deja de ser una forma de producción precapitalista. Por lo tanto, no es consistente presentar el "esclavismo colonial" como un modo de producción completamente nuevo para luego absolutizar las particularidades que presentó en Brasil y las Américas.

No se trata de discutir si existían o no diferencias entre el esclavismo moderno y el antiguo, o con el feudalismo y el capitalismo. Eso es así. También es un hecho que, en América, el capital comercial en expansión se sirvió de las más diversas relaciones de producción precapitalistas, que se combinaron entre sí y dieron origen a formaciones económico-sociales "híbridas", aunque siempre con hegemonía de una u otra forma de producción en un determinado período. Así, es cierto que, en esa combinación de formas de

\footnotetext{
${ }^{120}$ CARDOSO, Ciro. Severo Martínez Peláez y carácter del régimen colonial. In: ASSADOURIAN, Carlos; CARDOSO, Ciro; CIAFARDINI, Horacio, et al. Modos de producción en América Latina..., op. cit., p. 102. Ver también: CARDOSO, Ciro. Escravo ou camponês? O protocampesinato negro nas Américas. São Paulo: Brasiliense, 1987.

${ }^{121}$ CARDOSO, Ciro. El modo de producción esclavista colonial en América. In: ASSADOURIAN, Carlos; CARDOSO, Ciro; CIAFARDINI, Horacio, et al. Modos de producción en América Latina ..., op. cit., p. 224.

${ }^{122}$ MARX, Karl [1859]. Contribución a la crítica de la economía politica. Buenos Aires: Estudio, 1970, p. 210 .
} 
producción, la predominante en el Brasil, las Antillas, las Guayanas, el sur de EEUU, etc. fue la esclavista.

La polémica estriba en cuál era el objetivo, para qué se organizaba esa producción; si el esclavismo en la América colonial estaba subordinado, o no, al proceso de acumulación originaria de capital por la vía de la producción en gran escala para el mercado mundial, regido por leyes capitalistas.

Las contribuciones de Cardoso y Gorender son acertadas al cuestionar la deformación estalinista de los "cinco estadios", pero ese acierto termina con la opción equivocada de crear una categoría en cierta medida "autónoma" del proceso de conformación del capitalismo americano y mundial; según lo vemos, un pretendido modo de producción esencialmente "desconocido" por la historia.

Mantenemos la definición de que el esclavismo en las colonias fue una de tantas relaciones de producción precapitalistas que el capital comercial y usurario "explotaba" para extraer excedente social de los pueblos colonizados, pero siempre en aras de fortalecer la acumulación originaria de capital.

En el terreno metodológico, el error de Cardoso y de Gorender radica en sobredimensionar el fenómeno, perdiendo de vista la totalidad y universalizando la particularidad. Existen autores que van más lejos en esto de extrapolar las particularidades, y crean categorías como "capital esclavista mercantil"123.

La esclavitud, así como la encomienda mitaria o yanacona, y otras formas de trabajo que en la América colonial se asentaban en la coerción extraeconómica, eran particularidades insertas en una totalidad: el capital comercial avanzando, con distintos ritmos, sobre formas de producción preexistentes, sin perjuicio de haberlas utilizado durante siglos en provecho propio. El esclavismo en las colonias se desarrolló, entonces, como una particularidad dentro de la universalidad del proceso de acumulación originaria de capital.

Si bien los autores que mencionamos señalan que el "esclavismo colonial" era “dependiente", exactamente debido a la relación colonial, ese elemento es luego abstraído de sus conclusiones. Una lectura crítica de sus textos sugiere que terminan menospreciando la relación metrópoli-colonia y la ligazón con el mercado mundial capitalista. Pierden de

${ }^{123}$ PIRES, Júlio Manuel; COSTA, Iraci del Nero da. O capital escravista-mercantil. Cadernos NEHD, São Paulo, v. 3., n. 1., 1995; DE SOUZA, João Paulo. Entre o Sentido da Colonização e o Arcaísmo como Projeto: A Superação de um Dilema através do Conceito de Capital Escravista-Mercantil. Revista Estudos Econômicos, São Paulo, v. 1., n. 38, 2008, pp. 173-203; TEIXEIRA, Rodrigo. Capital e Colonização: A Constituição da Periferia do Sistema Capitalista Mundial. Revista Estudos Econômicos, São Paulo, v. 3, n. 36, 2006, pp. 539591. 
vista que el grueso de la producción extraída de las colonias americanas, con todas sus particularidades, no era mayormente realizada en las colonias sino fuera de ellas, dado que estaban vinculadas a las metrópolis y, por esa vía, al desarrollo desigual del capitalismo europeo.

En medio de este proceso general, el esclavismo - con su odiosa brutalidad- fue una necesidad económica -altamente lucrativa- derivada tanto del interés por ampliar la producción para un mercado que había dejado de ser solo "europeo", como de la escasez de mano de obra en América. Fue un proceso similar a la "segunda servidumbre europea" de la que habló Engels ${ }^{124}$. El trabajo forzado se transformó en algo imperioso en el proceso de acumulación originaria de capital.

Marx señala este papel económico de la esclavitud moderna: "En general, la esclavitud disfrazada de los trabajadores asalariados en Europa exigía, a modo de pedestal, la esclavitud 'sans phrase'125 en el Nuevo Mundo"126. En otras palabras, para garantizar el desarrollo capitalista europeo, las colonias debían producir en gran escala, incluso con relaciones de producción que las propias metrópolis habían superado.

Apunta Marx sobre el "sentido" capitalista de la moderna esclavitud:

La esclavitud es una categoría económica como cualquier otra. Por ende, tiene también sus dos lados. Dejemos el lado malo de la esclavitud y hablemos del lado bueno: quede claro que hablamos tan solo de la esclavitud directa, de la esclavitud de los negros en Surinam, en Brasil, en las comarcas meridionales de Norteamérica. La esclavitud directa es el fundamento de la industria burguesa, al igual que las máquinas, el crédito, etc. Sin esclavitud, no tendríamos el algodón; sin el algodón, no tendríamos la industria moderna. Es la esclavitud lo que ha dado valor a las colonias; son las colonias las que han creado el comercio universal; es el comercio universal lo que constituye la condición de la gran industria. La esclavitud, pues, es una categoría económica de enorme importancia [...] Los pueblos modernos no han hecho más que encubrir la esclavitud en su propio país, y la han impuesto sin disfraz en el Nuevo Mundo ${ }^{127}$.

No es consistente explicar la "estructura interna" de las economías coloniales americanas por fuera de este proceso de expansión del sistema capitalista.

\footnotetext{
${ }^{124}$ Engels explicó que en el siglo XVI hubo un "rebrote" feudal en gran parte de Europa Oriental, con el objetivo de producir lana y otras materias primas para el desarrollo manufacturero de Europa Occidental. Así, el siervo vio reforzada su sujeción a la tierra por la fuerza, para producir en gran escala para el mercado occidental. Ese proceso sería un preanuncio de lo que ocurriría, de manera ampliada, en el Nuevo Mundo. Consultar: MAZZEO, Antonio. O escravismo colonial: modo de produção ou formação social? Revista Brasileira de História. São Paulo, v. 6, n. 12, 1986, p. 211.

${ }^{125}$ Desembozada.

${ }^{126}$ MARX, Karl. El Capital. Tomo I. In: MARX, Karl; ENGELS, Friedrich. Materiales para la historia de América..., op. cit., p. 166. Destacado en el original.

${ }^{127}$ MARX, Karl. Miseria de la Filosofía. In: MARX, Karl; ENGELS, Friedrich. Materiales para la historia de América..., op. cit., p. 153.
} 
De la misma forma que resulta imposible pasar por alto el aporte de esta vertiente "produccionista" que se rige por el estudio de las particularidades de los modos de producción locales, no sería posible discutir en su totalidad la obra de Gorender en los límites de este trabajo. Mucho menos dirimir todos los problemas que plantea. Considérense nuestros comentarios como una primera aproximación a un problema que está lejos de ser resuelto.

\section{Algunas Conclusiones}

I. El punto de partida para determinar el carácter de la colonización europea en América Latina es la relación metrópoli-colonia. Nuestro devenir histórico no puede ser encasillado en ningún esquema del desarrollo económico europeo. Fueron procesos históricos esencialmente distintos. Europa cumplió el papel de colonizador y los americanos el de pueblos colonizados y subyugados.

II. La esencia o contenido de esta empresa está determinada por la división internacional del trabajo, que desde el siglo XVI impuso el proceso de conformación del mercado capitalista mundial a los espacios coloniales: proveedores de metales preciosos, materias primas, y fuerza de trabajo esclavizada para un mercado que se expandía de manera agresiva; consumidores de las manufacturas producidas por las naciones más adelantadas del norte de Europa, de las cuales los reinos de España y Portugal, por su crónico atraso industrial, pasaron a actuar como intermediarios.

III. Las colonias americanas no fueron unidades económicas naturales, de estricta subsistencia. Desde su origen fueron productoras de valores de cambio en gran escala y orientadas al mercado mundial, o, como mínimo, regional. Ese fue el motor de la colonización. La producción para el mercado interno y otros fenómenos endógenos surgieron subordinados a la dinámica del comercio externo, pautada por la demanda del mercado europeo y la fluctuación de los precios internacionales de los productos tropicales. Ese es el elemento esencial que marcaría a fuego tanto la sociedad colonial como la contemporánea. En palabras del historiador trotskista Luis Vitale:

[...] de esa época arranca el carácter deformado de nuestra economía monoproductora [...] Durante la Colonia se origina la propiedad privada de los medios de producción y el fenómeno de concentración de la tierra [...] De aquella época, en fin, data esa burguesía criolla que por su carácter dependiente será 
incapaz de realizar las tareas democrático-burguesas durante los siglos XIX y $\mathrm{XX}^{128}$

IV. Por lo tanto, las razones del "atraso" económico latinoamericano no hay que buscarlas en el supuesto "pasado feudal" o "esclavista colonial" sino en la incorporación, desde el inicio dependiente y deformada por la explotación metropolitana, al largo proceso de génesis del capitalismo mundial.

V. La relación colonial - parte integrante del proceso de conformación del mercado mundial ya capitalista- es el hecho decisivo para determinar que el sentido de esa empresa fue capitalista, y no tal o cual modo de producción nativo. Para el capitalismo naciente, lo fundamental era la producción de mercaderías en gran escala; el cómo producirlas era secundario.

VI. Es la relación colonial -y el grado de desarrollo de las fuerzas productivas de la metrópoli, que en el caso de la Península Ibérica estaba en transición entre el feudalismo decadente y un capitalismo que no conseguía hegemonizar la sociedad-, la que se impondrá sobre un espacio particular -con determinadas condiciones climáticas, geográficas, fuerza de trabajo más o menos disponible, modos de producción preexistentes, cultura y costumbres propias, etc.-, haciendo que las relaciones de producción originadas en ese espacio colonial adquieran las características más diversas, híbridas y combinadas, aunque insertas, en el caso que estudiamos, en el proceso general de la acumulación originaria de capital en Europa.

VII. De acuerdo con Marx:

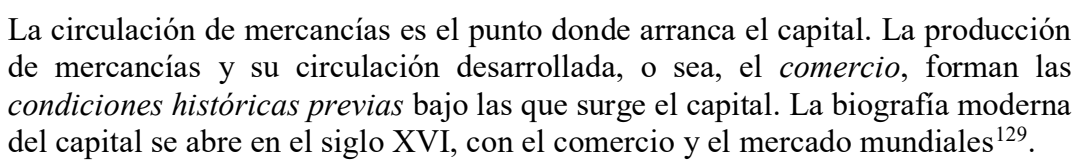

Es decir, la expansión del comercio mundial, en la cual se inserta la colonización americana, fue fundamental para la acumulación originaria, "una acumulación según Marx- que no es fruto del régimen capitalista de producción sino punto de partida de él"130.

128 VITALE, Luis. Interpretación marxista de la historia de Chile: La Colonia y la Revolución por la independencia [1540-1810]. Tomo $\quad$ II. $1967 . \quad$ Disponible $<$ http://www.archivochile.com/Historia_de_Chile/trab_gen/HCHtrabgen0005.pdf>, consultado el 06/01/2017. ${ }^{129}$ MARX, Karl. El Capital. Tomo I. Buenos Aires..., op. cit., p. 121. Destacado en el original.

130 Ídem, p. 573. Destacado en el original. 
VIII. Esto significa que el capital comercial -así como el capital usurario-, que es previo al capital industrial y al propio modo de producción capitalista, coexiste y explota los más diversos modos de producción y sus combinaciones. Marx llama al capital comercial y al capital usurario "formas derivadas" del capital. Las consideraba "manifestaciones vulgares y antediluvianas, por así decirlo"131 del capital, que son históricamente anteriores a su "forma básica" moderna, esto es, al capital productivo o industrial. Marx es categórico:

El capital industrial es la única modalidad del capital en la que el capital tiene como función no solo la apropiación de plusvalía o de producto excedente sino también su creación. Es, por tanto, el capital industrial el que condiciona el carácter capitalista de la producción ${ }^{132}$.

IX. En ese sentido, el capital comercial llegó a América con apetito insaciable de trabajo excedente. Su papel fue vehiculizar el excedente generado por los productores directos valiéndose, para ello, de distintas relaciones de producción no capitalistas: la esclavitud de los negros y de los indígenas originarios yanaconazgo-; la mita potosina y asunceña -similar a una relación más "servil" -; hasta la posterior papeleta de conchabo de los gauchos, etc.

X. En el espacio colonial americano, el capital comercial, a través de los plantadores esclavistas, encomenderos, comerciantes, etc. -que eran esencialmente capitalistas, participando no solo del proceso de circulación de mercancías sino también invirtiendo en una producción regulada por las necesidades del mercado externo-, dominará a los productores directos -indígenas, mestizos, negros esclavizados-, de los cuales extraerá excedente social por medio de todo tipo de coerciones extraeconómicas, esto es, usando la violencia sin tapujos. El capital vino al mundo, en palabras de Marx, "[...] chorreando sangre y lodo por todos los poros, desde los pies hasta la cabeza [...]"133.

Esto se debió a que, como apunta Nahuel Moreno, no existía en América colonial un mercado de trabajadores libres. Preexistían sociedades con un grado de desarrollo de las fuerzas productivas muy atrasado, que en general no producían valores de cambio sino de uso. Por ese motivo, la única manera de lograr que produjeran excedente social era por medio de la coerción y la represión más brutal.

131 Ídem, pp. 134-135.

${ }^{132}$ MARX, Karl. El Capital. Tomo II. Buenos Aires: Editorial Cartago, 1956, p. 47.

${ }^{133}$ MARX, Karl. La acumulación originaria de capital..., op. cit., p. 107. 
XI. En otras palabras, el capital comercial en América penetró y actuó como disolvente de las viejas formas productivas, pero no llegó a elevarse, durante la época colonial, al modo de producción capitalista -ni podría haberlo hecho, pues en la misma Europa existía una transición entre el modo feudal y el capitalista propiamente dicho-. Solo después, bien entrado el siglo XIX, preponderó el mercado de trabajo "libre" sobre la coerción extraeconómica.

XII. La disyuntiva, planteada en sentido extremo y puro entre colonización "feudal" -liberalismo y estalinismo- o directamente "capitalista" - Gunder Frank y otroses imprecisa y, por lo tanto, tramposa. Desde nuestra perspectiva, la mejor definición continúa siendo la que ofreció Nahuel Moreno en 1948: colonización esencialmente capitalista sobre la base de relaciones de producción precapitalistas. Esta formulación no cae en el llamado circulacionismo, que rige su análisis por el mayor o menor vínculo de esas sociedades con el mercado, ni en el produccionismo, que absolutiza las peculiaridades de los distintos modos de producción surgidos en América perdiéndose en los rasgos de cada región y creando innumerables categorías, desconectando las inevitables singularidades del fenómeno global de la acumulación originaria de capital, de la totalidad que, en última instancia, condiciona las partes. La síntesis de Moreno da cuenta tanto de la definición de las relaciones de producción como de su nexo y papel en la economía mundial naciente. Su posición, que es esencialmente la de Marx y Engels, fue posteriormente incorporada por Milcíades Peña y George Novack, entre otros.

XIII. En cuanto a la interpretación de este período de la historia de América Latina, como ahondaremos en otros apartados, la principal consecuencia que se desprende de lo anterior y que interesa a esta investigación es: las revoluciones de independencia latinoamericanas de inicios del siglo XIX no fueron revoluciones sociales -burguesas "antifeudales"-, sino políticas -burguesas anticoloniales-, en las cuales la todavía embrionaria burguesía nativa enfrentó a la metrópoli europea pretendiendo realizar la extracción de excedente social en el mercado internacional sin las trabas coloniales. 


\title{
CAPÍtulo II - UNA APROXimación SObRe la INSERCión DEL PARAGUAY EN EL SISTEMA COLONIAL Y EL DEBATE SOBRE LAS RELACIONES DE PRODUCCIÓN
}

\begin{abstract}
“Esta provincia está poblada por la más pobre gente que conozco en cuanto tengo paseado del reino. No es laboriosa y mucho menos industriosa. Esta natural desidia y la continua carga de guardias y destacamentos que de unas y otros hay treinta y dos en el país, rodeado de enemigos por todos sus costados, no les permite salir a los más de la mendicidad". Marcos José LARrazÁBAL, gobernador de la Provincia del Paraguay, 1747.
\end{abstract}

$\mathrm{Si}$ aceptamos el marco histórico general de la colonización europea, que analizamos en el capítulo anterior, entendiéndola como una empresa con fines esencialmente capitalistas basados en relaciones de producción precapitalistas, en la cual, dependiendo de las particularidades de las distintas regiones colonizadas, en algún momento esas relaciones de producción no capitalistas se combinaron desigualmente con embriones de trabajo "libre"; si hacemos de esa totalidad el punto de partida de nuestro análisis, no es difícil advertir que, con todas sus contradicciones y características propias, la región de la Cuenca del Plata y, específicamente, la antigua Provincia del Paraguay no podían estar esencialmente ajenas a ese proceso general.

En ese sentido, nos adelantamos a decir que Oscar Creydt -exdirigente del Partido Comunista paraguayo y autor de un trabajo pionero que tiene el mérito de intentar hacer un análisis histórico estructural-se equivoca cuando define que "no hay duda sobre el carácter esencialmente feudal del Paraguay como colonia hispana"134.

Pero antes de profundizar más sobre la cuestión de las relaciones de producción del Paraguay colonial, se hace necesario definir cuál era su ubicación en la relación metrópolicolonias.

\section{UBICACIÓN PERIFÉRICA EN EL SISTEMA COLONIAL}

La geografía impuso al Paraguay una ubicación periférica dentro del sistema colonial que los españoles impusieron en América. Si bien nunca estuvo ni podría haber estado

${ }^{134}$ CREYDT, Oscar [1963]. Formación histórica de la nación paraguaya. 2. ed. Asunción: Servilibro, 2004, p. 126. 
completamente "aislada" - como la corriente historiográfica nacionalista gusta de enfatizar, dado que existieron lazos comerciales con otras áreas de la región, tampoco se puede negar que la importancia de Asunción en el entramado de rutas comerciales y flujos migratorios y/o culturales siempre fue secundaria.

A más de mil kilómetros del mar, enclaustrados en una tierra sin metales preciosos ni productos tropicales que tuvieran alta demanda en el mercado europeo, los habitantes de esa provincia tuvieron en el aislamiento geográfico, económico y cultural, un elemento fundamental en el proceso de su formación histórica como nación.

La "fiebre del oro" desatada por las noticias de la existencia de la "sierra de la plata", que no era sino el Imperio inca, motivó la expedición militar de Pedro de Mendoza en 1536, una empresa financiada por él mismo y, en parte, por banqueros alemanes ${ }^{135}$. A su llegada, los conquistadores fundaron el fuerte de Buenos Aires, pero al poco tiempo debieron abandonarlo por la escasez de alimentos y por la abierta hostilidad indígena.

En medio de las expediciones en busca de El Dorado, los españoles fundaron el fuerte de Asunción en 1537, comenzando el proceso de colonización de lo que hoy es el Paraguay. Los carios-guaraníes que poblaban la región eran agricultores, al contrario de los querandíes que habitaban el área de Buenos Aires. Eso abrió a los expedicionarios mejores posibilidades de abastecerse de alimentos y de todo lo necesario para sus viajes rumbo al Alto Perú, actual Bolivia.

Pero en 1548, los españoles liderados por Domingo Martínez de Irala descubrieron que el Imperio inca había sido conquistado por las huestes de Pizarro. Enorme frustración. No les quedó más alternativa que transformar a Asunción en asentamiento definitivo, sitio que hasta entonces no pasaba de un puesto intermedio para la conquista del actual Perú.

Lo cierto es que, alejado del mar y en medio de la selva, sin oro ni plata, y rodeado por tribus nativas hostiles, el fuerte -y la posterior ciudad de Asunción-quedó prácticamente olvidado por la metrópoli. En rigor, España perdió interés por toda el área del Río de la Plata que no poseía metales preciosos. La Corona siguió empeñada en buscar oro en el Amazonas, el Itatín y el Guairá, aunque sin éxito.

\footnotetext{
135 Pedro de Mendoza firmó la capitulación para la conquista del Río de la Plata el 21 de mayo de 1534, en Toledo. La Corona le confirió el título de Adelantado, Gobernador, Capitán y Alguacil Mayor de las tierras que descubriera y colonizase. También le concedió la doceava parte de todos los quintos reales; la exención vitalicia del pago del almojarifazgo para el aprovisionamiento de su casa; el transporte desde Brasil, Cabo Verde o Guinea de 200 esclavos negros, libre de todo impuesto; la facultad de repartir solares y tierras; y, por supuesto, de encomendar indios.
} 
Los colonos hispanos anclados en Asunción pronto se vieron a contramano del Potosí, entonces el centro productivo y comercial más dinámico. El gobierno de Irala, en un intento de romper el aislamiento, dispuso buscar un puerto sobre el Atlántico abriendo "las puertas a la tierra". Trazó un osado plan de expansión hacia zonas más cercanas a la embocadura del Río de la Plata y las costas del actual Brasil.

Así, de Asunción salieron expediciones en tres sentidos principales: a) buscando ligazón directa con el Alto Perú, que resultó en la fundación de Santa Cruz de la Sierra [1561]; b) rumbo al Brasil: Ontiveros [1554], Ciudad Real [1557], y la primera Villa Rica del Espíritu Santo, en el Guairá [1570]; c) Paraná abajo rumbo al Atlántico: Santa Fe [1573] -fundamental para el tráfico con el Perú vía Tucumán-, Buenos Aires, por segunda vez [1580], y Corrientes [1588]. Asunción, ahora "madre de ciudades", quedó como capital de estas villas hasta 1620 , y se le abrieron mejores condiciones de comercio ${ }^{136}$. Pero esa “expansión" no era sustentable y, por lo tanto, no solucionó el problema de la marginalidad. En primer lugar, en pocas décadas las economías de las nuevas poblaciones cayeron en la órbita de los polos de atracción más poderosos -la producción minera altoperuana y el contrabando atlántico-. En segundo lugar, la Corona, presionada por los comerciantes de Lima, clausuró el puerto bonaerense en 1594 y obligó al Paraguay a comerciar por tierra a través del puerto del Callao, en el Perú. Asimismo, entre 1617 y 1620, la metrópoli dividió la entonces Provincia Gigante de las Indias y erigió a Buenos Aires como capital de Santa Fe y Corrientes. Asunción, por su parte, quedó como cabecera de Villa Rica, Santiago de Jerez y Ciudad Real ${ }^{137}$. En suma, por su aislamiento geográfico, la provincia del Paraguay perdió cualquier posibilidad de establecer un puerto directo sobre el océano, elemento indispensable para dinamizar el comercio y las comunicaciones. Esto tendría un impacto no solo económico sino también social y cultural. Asunción tuvo que relacionarse con la ruta peruana por medio de Santa Fe y, desde finales del siglo XVIII, a través de Buenos Aires. Y ambas plazas comerciales y de redistribución cobraron un alto precio por ese papel de intermediarias entre la producción paraguaya y los mercados consumidores más importantes ${ }^{138}$.

\footnotetext{
${ }^{136}$ CARDOZO, Efraím [1965]. Breve historia del Paraguay. Asunción: El Lector, 1996, p. 31; PERUSSET, Macarena. Conductas y procedimientos fuera de la ley: comercio ilícito, líderes y prácticas. 2017. Disponible en: <http://www.scielo.org.co/pdf/unih/n63/n63a11.pdf>, consultado el 13/02/2015.

${ }^{137}$ CHAVES, Julio [1958]. Compendio de historia paraguaya. Asunción: Carlos Schauman Editor, 1991, p. 84.

${ }^{138}$ GARAVAGLIA, Juan. [1983]. Mercado interno y economía colonial: tres siglos de historia de la yerba mate. 2. ed. Rosario: Prohistoria ediciones, 2008, p. 108.
} 
Luego de su segunda fundación, Buenos Aires no tardó en convertirse en un puerto de tráfico legal o ilegal entre el Atlántico y el camino de Potosí. El motor del desarrollo de lo que, al comienzo, no pasaba de una pequeña aldea fue esta ligazón con la economíamundo. Por otra parte, la dificultad de explotar a los indígenas de la zona, los pampas y querandíes, hizo que la esclavitud africana apareciera de manera temprana tanto en la ciudad como en sus estancias y chacras. En efecto, la primera mercadería que la ciudad recibía eran africanos esclavizados, que llegaban desde las costas del Brasil. El primer producto de exportación fue la plata: alrededor de $85 \%$ de lo que salía por el puerto eran metales preciosos. El restante $15 \%$ estaba compuesto por harina, sebo, cecinas, cueros y tejidos. En el Interior, el crecimiento de la ciudad impulsó la cría de ganados y el cultivo de cereales, actividades beneficiadas por las condiciones de una pradera con abundante tierra fértil y un clima excepcionalmente propicio. Esto hizo que la región participara activamente en los envíos de ganado hacia el Alto Perú y Chile, alcanzado picos de 10.000 vacas a mediados del siglo XVII ${ }^{139}$. Esta situación no tardó en generar una burguesía mercantil y burocrática -con distinción de roles difíciles de diferenciar-, muchas veces unida por lazos de parentesco, propietaria de tierras, estancias ganaderas, y esclavos.

De esta suerte, desde 1617 hasta la expulsión de la Compañía de Jesús en 1767, la jurisdicción a cargo del gobernador del Paraguay quedó reducida a su menor expresión territorial, con todas sus fronteras amenazadas. Hacia 1680, la provincia se limitaba a una estrecha franja de tierra comprendida entre el río Manduvirá al norte y el río Tebicuary al sur, separados entre sí por una distancia de no más de doscientos kilómetros ${ }^{140}$. Al norte del río Manduvirá, el control pertenecía a los indios mbayás, chanés y guanás, que hostilizaban permanentemente las poblaciones "españolas". Al sur del Tebicuary, el territorio estaba

\footnotetext{
${ }^{139}$ Por otra parte, a partir de 1631 la Corona estableció en Buenos Aires una guarnición militar de alrededor de un millar de soldados - como ocurría en el Caribe-, asignándole un "situado" (dinero para mantener a las tropas) de aproximadamente 120.000 pesos, que era enviado desde Potosí. Esta circulación de metálico se sumaba al creciente movimiento comercial legal e ilegal entre Potosí y el Atlántico, que giraba especialmente en el intercambio de esclavos y mercancías europeas por plata. El clímax del puerto bonaerense, en este período, puede situarse entre 1605 y 1625 , cuando se registró oficialmente el arribo de más de 230 naves, cifra que no incluye el comercio ilegal; por lo tanto, indica que el tráfico efectivo fue muy superior. Hasta mediados de siglo entrarían por la rada de Buenos Aires entre 25.000 y 40.000 africanos esclavizados; luego de 1640, ese volumen caería para aproximadamente 10.000. Entre 1648 y fines de ese siglo, la ciudad recibirá más de 158 naves, de las cuales casi $40 \%$ eran holandesas, un tercio españolas, un cuarto portuguesas. A su vez, la relativa facilidad de alimentar a su población con trigo y carne, cooperaría con el despegue de la ciudad porteña como uno de los principales centros urbanos y comerciales del Plata. Consultar: FRADKIN, Raúl; GARAVAGLIA, Juan. La Argentina Colonial: el Río de la Plata entre los siglos XVI y XIX. Buenos Aires: Siglo XXI Editores, 2009 , pp. 37,39, 60, 61 .

${ }_{140}$ TELESCA, Ignacio. La Provincia del Paraguay: revolución y transformación [1680-1780]. Asunción: El Lector, 2010, p. 13. Sobre este asunto, ver también: TELESCA, Ignacio. Tras los expulsos: cambios demográficos y territoriales después de la expulsión de los jesuitas. Asunción: CEADUC, 2009.
} 
controlado por la Compañía de Jesús - con sus treinta Misiones de indios-, espacio que la Orden llegó a desanexar de la jurisdicción de la provincia ${ }^{141}$. Al oeste del río Paraguay, los payaguás, mocovíes y abipones también eran un peligro constante. Al este, señoreaban los guaraní-monteses, otra parcialidad de naturales “infieles"142. Esto, sin contar que hasta 1641 las temibles incursiones de bandeirantes paulistas ${ }^{143}$, por el este, asolaron pueblos enteros ${ }^{144}$.

Así, el Paraguay se encontraba entre los eslabones más débiles de la cadena de dominación colonial. La dificultad para ligarse al mercado externo, que no se debió fatalmente a la geografía, como afirma la historiografía tradicional, sino a lo que denominamos doble dependencia tanto de la metrópoli peninsular como de las submetrópolis locales -Lima, primero; Buenos Aires, después-, moldearon una de las provincias más pobres y marginales en la región.

\section{ECONOMÍA EXPORTADORA Y RELACIONES DE PRODUCCIÓN}

Sobre el objetivo esencial de la colonización, está claro que los españoles que se asentaron en Asunción no lo hicieron para recrear los "feudos" europeos. Llegaron obsesionados con la idea de encontrar una ruta hacia las minas de metales preciosos del Alto Perú. El fracaso de ese proyecto no les impidió seguir buscando oro y plata en otras regiones, siempre de manera infructuosa.

Llegó entonces el momento en que el conquistador europeo entendió que la única riqueza en Asunción y sus alrededores era la tierra fértil. Así, no descansó hasta encontrar alguna mercancía agrícola o forestal que pudiera ser exportada al Alto Perú o "espacio peruano" - un inmenso territorio que se extendía desde Quito hasta el Paraguay y se regía

141 TELESCA, Ignacio. La Provincia del Paraguay..., op. cit., p. 25. Los jesuitas llegaron al Paraguay en 1588, solicitados por el gobernador Hernandarias. En 1604 se establecieron definitivamente, creando la Provincia Jesuítica del Paraguay, unidad administrativa que tenía su sede principal en la ciudad de Córdoba. Los dominios jesuitas funcionaban prácticamente al margen del gobierno en Asunción.

142 Ídem, pp. 71-72.

${ }^{143}$ Los Bandeirantes eran grupos armados que, partiendo de São Paulo, penetraban territorios interiores que, según el Tratado de Tordesillas, correspondían a la Corona española. Comportándose como "piratas de la tierra", atacaban villas y secuestraban indígenas para transformarlos en esclavos, destinados luego a las regiones productoras de azúcar y otros géneros. Además, cumplieron un papel fundamental para ampliar las fronteras de los dominios portugueses en Sudamérica.

${ }^{144}$ MONTEIRO, John Manuel. Negros da terra: índios e bandeirantes nas origens de São Paulo. São Paulo: Companhia das Letras, 1994. Sobre las incursiones bandeirantes en el Paraguay, ver también: BANDEIRA, Luiz Alberto M. [1985]. O expansionismo brasileiro e a formação dos Estados na Bacia do Prata: Argentina, Uruguai e Paraguai, da colonização à Guerra da Tríplice Aliança. 3. ed. Rio de Janeiro: Revan, 1998, pp. 2225; BOCCIA ROMAÑACH, Alfredo. Paraguay y Brasil, crónica de sus conflictos. Asunción: El Lector, 2000, pp. 123-144; TEIXEIRA, Fabiano. A Primeira Guerra do Paraguai: A expedição do Império do Brasil a Assunção [1854-1855]. Passo Fundo: Editora Méritos, 2012, pp. 19-30. 
por la minería, polo productivo que generó un dinámico mercado interno colonial marcado por la especialización de las regiones en una o dos mercancías destinadas a abastecer la región minera- o bien a la propia España. Primero fueron el vino y los derivados de la caña de azúcar: aguardiente y miel. También ganados, lienzos de algodón y tabaco. Desde 1630 hasta la crisis de la independencia, el producto por excelencia que ligó el Paraguay con el mercado interno colonial fue la yerba mate ${ }^{145}$. La infusión derivada de este arbusto fue lo que permitió a la provincia un contacto más fluido con el exterior. La yerba mate alcanzó, siempre por el costoso intermedio de Santa Fe y luego de Buenos Aires, no solo el mercado potosino sino el de Lima, el de Santiago de Chile, y hasta el de Quito. Si entre 1660 y 1680 se produjeron en promedio 25.000 arrobas $^{146}$ anuales, entre 1781 y 1789 , el promedio de entrada de yerba mate a Buenos Aires alcanzó 140.000 arrobas anuales ${ }^{147}$. En términos de ventaja comparativa, ningún otro producto comercializable tendría las condiciones favorables que tuvo la yerba mate -exceptuando tal vez el tabaco- para relacionar la economía de la región paraguaya tanto con las corrientes mercantiles del Alto Perú minero como con las del espacio rioplatense.

De esa suerte, la columna vertebral de la economía provincial, que internamente satisfacía un consumo elemental por medio de cultivos de subsistencia, fue la producción destinada a la exportación. En la escala de productos exportables, después del llamado "té del Paraguay", seguían el tabaco y las maderas aptas para la construcción. En la segunda mitad del siglo XVIII, la ganadería fue ganando más peso de la mano de una expansión territorial de la provincia luego de la expulsión de los jesuitas. Pero la cría de ganado, aunque en ascenso en el período que antecede a la crisis de la independencia, siguió subordinada a los rubros anteriormente mencionados.

Por su parte, la producción de subsistencia respondía por casi $60 \%$ de la superficie sembrada. La producción comercializable se basaba en el azúcar, el tabaco, el algodón. Sin embargo, como alerta Garavaglia, ambos sectores no pueden considerarse estancos. Una

\footnotetext{
${ }^{145}$ La yerba mate (ilex paraguariensis) es un arbusto que crece espontáneamente en los bosques, y es usado, desde los tiempos precolombinos, en una infusión con notables efectos energéticos. Durante la época colonial era considerado un "mineral", y el monarca era el propietario absoluto de los yerbales. No obstante, el producto podía ser explotado también por particulares, a partir de un sistema de licencias (beneficios). Todo el proceso de producción y transporte de la yerba, además de rudimentario, era sumamente penoso para miles de trabajadores que se internaban en los montes, sobre todo en las zonas de Concepción y Villa Rica, donde solían permanecer más de seis meses. Ver: WHIGHAM, Thomas. La economía de la independencia. Asunción: Intercontinental, 2010.

${ }^{146}$ Una arroba equivalía, aproximadamente, a 11,5 kilos.

${ }^{147}$ GARAVAGLIA, Juan. [1983]. Mercado interno y economía colonial..., op. cit, pp. 75-84.
} 
parte de la producción llamada de "subsistencia": el maíz, el maní, las chipas (panecillos de harina de maíz), circunstancialmente podían llegar al mercado local. De la misma forma, aquellos productos comúnmente "comercializables" también eran consumidos en los hogares campesinos ${ }^{148}$.

La historiadora alemana Barbara Potthast, citando a Daniel Torner y otros autores, describe este modelo interno como un clásico ejemplo de "economía campesina": las unidades domésticas producen, mediante el trabajo manual de los miembros de la familia, lo necesario para su propio sustento. Por su parte, esta producción de subsistencia se vincula con una orientación hacia el mercado local, combinándose con actividades artesanales rudimentarias, por medio del pequeño comercio o el trueque ${ }^{149}$.

En otras palabras, la economía de subsistencia y la orientada a la comercialización integraban una totalidad, aunque dominada por el polo exportador, actividad que concentraba más capital invertido.

$\mathrm{Y}$, en esa dinámica de producir valores de cambio en la mayor escala posible, el europeo debió hacerse con la mayor cantidad de brazos de los cuales pudiera extraer el plustrabajo necesario no solo para "subsistir" sino, principalmente, para apropiarse del excedente que le permitiera enriquecerse. Esto nos lleva al análisis de las distintas relaciones de producción.

\section{LA ESCLAVITUD INDÍGENA SIN TAPUJOS}

En la fase inicial de la colonización del Paraguay predominó la esclavitud desembozada de la mano de obra indígena. Los colonizadores aprovecharon la lucha interna entre los carios-guaraníes y las tribus nómadas guaicurúes del Chaco para hacerse con la fuerza de trabajo de los primeros. A cambio de cooperación militar y algunos utensilios de hierro, los carios colaboraron con los españoles en sus primeras marchas rumbo al Perú. Sin embargo, no se puede soslayar que el apoyo de los carios-guaraníes fue precedido por una derrota militar.

El mestizaje étnico, característico de la mayoría de la población paraguaya, fue casi inmediato. Consistió en una política de uniones forzadas y poligámicas entre mujeres carios

\footnotetext{
148 Ídem, p. 239.

${ }^{149}$ POTTHAST, Barbara. Entre lo invisible y lo pintoresco: las mujeres paraguayas en la economía campesina [siglo XIX]. Jahrbuch für Geschichte Lateinamerikas, Köln, n. 40, pp. 203-220, 2003.
} 
y varones europeos. De ahí surgió el llamado cuñadazgo, mecanismo por el cual el blanco estableció relaciones de parentesco con caciques guaraníes.

Esto sirvió a los españoles para acumular mujeres carios. Esto implicaba, en realidad, una apropiación de fuerza de trabajo, puesto que las indígenas no solo trabajaban para los europeos como también lo hacían para los hombres carios, hilando, cargando bultos en las expediciones, o labrando la tierra; y esas mujeres representaban, además, una vía de acceso a la fuerza de trabajo de sus parientes masculinos -padres y hermanos- que culturalmente quedaban obligados a "ayudar" a sus "yernos"y "cuñados"150.

Inevitablemente, la coerción para obtener más trabajo excedente de los "parientes" indígenas fue aumentando. Las mujeres, en la práctica, fueron esclavizadas y comenzaron a ser intercambiadas por caballos o ropas, entre los propios españoles. Esto generó los primeros levantamientos indígenas, todos ahogados en sangre ${ }^{151}$. El proceso de esclavización dio un salto luego del fracaso de la conquista del Perú, que supuso la necesidad de convertir a Asunción en asentamiento definitivo. Los españoles, entonces, se lanzaron a la caza y la esclavización indiscriminada de los guaraníes. En incursiones militares conocidas como rancheadas, correrías, malocas, auténticas cacerías humanas, que duraron hasta 1555 como mínimo, arrasaron aldeas enteras, robaron tierras, y sometieron a los nativos a mansalva ${ }^{152}$.

En otras regiones, como el Tucumán y Santa Fe ocurriría lo mismo. Tras derrotar un levantamiento de calchaquíes que se extendió entre 1656 y 1664, los prisioneros fueron repartidos por el gobernador Mercado y Villacorta entre los vecinos encomenderos, que, de acuerdo con las crónicas del padre Lozano, quedaron satisfechos con sus "despojos": “[...] que fueron principalmente indios para su servicio, premio más apetecido en esta provincia, pues de él dependen las demás conveniencias temporales, que sin indios es imposible gozar"153.

Las rancheadas iban en busca de nuevas "piezas de indios", principalmente niños, adolescentes y mujeres, que según escribió el padre Pedro de Oñate en 1616 “... en buen

\footnotetext{
${ }^{150}$ FRADKIN, Raúl; GARAVAGLIA, Juan. La Argentina Colonial...op. cit., p. 18.

${ }^{151}$ La primera rebelión indígena fue la encabezada por el cacique Lambaré, en 1539. Fue derrotada debido a la superioridad militar y tecnológica de los españoles. Hubo otros levantamientos en 1543, 1561, 1562, 1575 1579,1660 , pero todos corrieron la misma suerte.

152 PASTORE, Mario. Trabalho forçado indígena e campesinato mestiço livre no Paraguai: uma visão de suas causas baseada na teoria da procura de rendas econômicas. Revista brasileira de história, São Paulo, v. 11, n. 21, p. 152, set.1990-fev.1991.

${ }^{153}$ FRADKIN, Raúl; GARAVAGLIA, Juan. La Argentina Colonial...op. cit., p. 44.
} 
romance son esclavos..."154. Los indígenas resistieron cuanto pudieron, pero fueron derrotados debido a la superioridad militar de los invasores hispanos.

No pasó mucho tiempo para que la cacería, la explotación brutal, y las enfermedades hicieran disminuir drásticamente la población nativa ${ }^{155}$. Alarmada por la posibilidad de liquidar la mano de obra existente, la propia Corona debió intervenir y presionar para atenuar o abolir la esclavitud directa e implementar el mecanismo conocido como encomienda, que en el Paraguay se concretó en 1556 cuando el gobernador Irala "repartió" más de 27.000 nativos entre 300 a 400 conquistadores de la región asuncena ${ }^{156}$. Sin embargo, en la práctica, la línea divisoria entre la esclavitud lisa y llana y las encomiendas era muchas veces formal.

\subsection{Encomiendas}

Hasta inicios del siglo XIX, el mecanismo predominante de apropiación del excedente producido por la fuerza de trabajo nativa fue la encomienda. Proseguir con la esclavitud "pura" habría significado un rápido agotamiento de la mano de obra, fuente de riqueza apropiada principalmente por la metrópoli.

Este "derroche" debía ser "regulado", pues afectaba la productividad y la recaudación fiscal. La Corona, entonces, vio en la encomienda una salida para dos problemas: 1) afirmar sus derechos de propiedad sobre los recursos de las colonias, incluida la fuerza de trabajo nativa; 2) limitar el poder de los conquistadores con los que se había asociado para dominar esos territorios ${ }^{157}$.

España dispuso formalmente que los indígenas no podían ser vendidos ni alquilados. Los declaró "súbditos" y, como tales, quedaron sujetos a tributo real.

Las encomiendas fueron "mercedes" o concesiones reales del trabajo indígena a conquistadores "destacados" -los encomenderos-, a quienes la Corona autorizó a recaudar, en forma de trabajo, en servicio personal, los tributos que, de no ser así, los indígenas hubieran debido pagar directamente al monarca. A cambio de ello, los encomenderos se comprometían a pagar anualmente a la metrópoli, por cada indio "encomendado" a su

\footnotetext{
${ }^{154}$ GARAVAGLIA, Juan. [1983]. Mercado interno y economía colonial..., op. cit., pp. 266- 267.

${ }^{155}$ PASTORE, Mario. Trabalho forçado indígena e campesinato mestiço..., op. cit., p. 152.

${ }^{156}$ GARAVAGLIA, Juan. [1983]. Mercado interno y economía colonial..., op. cit., p. 157.

${ }^{157}$ PASTORE, Mario. La hipótesis de Domar sobre las causas de la servidumbre o la esclavitud en una colonia hispanoamericana: contraste y reformulación. Revista de Historia Económica, Madrid, v. 8, n. 3, p. 583, 1990. En ese sentido, existieron legislaciones como las Leyes de Burgos (1512) y las Nuevas Leyes (1542), aunque todas mantenían el carácter hereditario de la encomienda. En 1547, el monarca Carlos I otorga a los indios el estatus de "súbditos" de la Corona.
} 
servicio, la suma de 16 pesos con cuatro reales huecos; evangelizarlos, y asumir la defensa militar de la comarca o provincia por medio de milicias locales, puesto que España no consideraba rentable costear un ejército regular en esa región. Las encomiendas valían generalmente por "dos vidas", esto es, durante la del beneficiado y la de su heredero. Terminado ese período, o bien por otro motivo, las encomiendas "retornaban" a la Corona, su propietaria. Si bien existían elementos de servidumbre, no es difícil advertir que, en los hechos, la encomienda no pasó de una esclavitud más o menos velada ${ }^{158}$.

Existieron dos tipos de encomiendas: la mitaria y la yanacona, también llamada originaria. En la primera, los indígenas estaban confinados en pueblos o reducciones -que en una primera fase estuvieron controlados por religiosos- y debían "pagar" su tributo trabajando para el encomendero, en teoría, por turnos y durante dos meses al año. Pero eso casi nunca era así.

La encomienda originaria, a su vez, era la variante jurídica más semejante a la esclavitud pura, puesto que los indios y sus familias trabajaban permanentemente para el encomendero hispano, en su casa o en sus cultivos. Es decir, completamente desarraigados de sus comunidades reales o artificiales -los "pueblos de indios"-, al igual que los naborías de las Antillas ¿Cuál era la condición social de los indios yanaconas? Debían trabajar durante toda su vida desde la más tierna edad. De hecho, la noción de "edad tributaria" no existía, al menos durante los siglos XVI y XVII.

Tampoco existían determinaciones claras sobre los límites de tiempo para el trabajo de los indios originarios y mitarios. Esto sugiere que el tiempo de explotación de la fuerza de trabajo nativa duraba tanto como el señor encomendero lo determinara. En las primeras ordenanzas sobre encomiendas, dictadas por el gobernador Martínez de Irala en 1556, solo se establece que el encomendero podía disponer de la cuarta parte de sus tributarios por cada turno [mita], sin bien esto se flexibilizaría disponiendo que "a conocida necesidad" podía servirse de hasta la mitad de sus indios.

En Asunción, según el censo de 1682, los indígenas originarios llegaban a 20\% de la población total; en Villa Rica, representaban 40\%. En promedio, cada "vecino feudatario" poseía dos encomiendas, siendo que cada encomienda mitaria contaba con diez indígenas

${ }^{158}$ Sobre las encomiendas y otras formas de extracción de excedente social de los indígenas, recomendamos dos trabajos de Mario Pastore: PASTORE, Mario. La hipótesis de Domar..., op. cit., pp. 577-578; PASTORE, Mario. Trabalho forçado indígena e campesinato mestiço..., op. cit., pp. 155-175. 
encomendados; en las originarias, el promedio era de cuatro ${ }^{159}$. En el siguiente cuadro, podemos observar la evolución de la población encomendada y, específicamente, de la yanacona.

Tabla 1. Indígenas originarios (yanaconas) sobre el total de la población sometida a la encomienda [1652-1792].

\begin{tabular}{llllll}
\hline & 1652 & 1682 & 1726 & $1754 / 61$ & 1792 \\
\hline Total población encomendada & 14.360 & 11.254 & 6.838 & 6.084 & 7.950 \\
\hline Originarios (yanaconas) & 3.381 & 2.517 & 1.057 & 756 & 509 \\
\hline$\%$ sobre el total & $23,5 \%$ & $22,4 \%$ & $15,5 \%$ & $12,4 \%$ & $6,4 \%$ \\
\hline
\end{tabular}

Fuente: GARAVAGLIA, Juan Carlos. Mercado Interno y economía colonial..., op. cit., p. 270.

Los encomenderos reclamaban constantemente la falta de encomiendas; que estas no eran perpetuas; que no podían negociarlas sin intermediación de la Corona. Y siempre que podían, convertían a los mitayos en yanaconas, o bien vendían a los indígenas ${ }^{160}$.

Lo cierto es que el peso principal de la extracción de yerba mate recayó principalmente sobre los indígenas encomendados. En 1629, el gobernador Céspedes Xería dictó unas Ordenanzas en Mbaracayú, para organizar los beneficios yerbateros. El teniente de gobernador tenía la potestad de abrir oficialmente la época del beneficio general y disponer el reparto de la fuerza de trabajo de los pueblos de indios concernidos -en ese tiempo, los del Guairá y Mbaracayú- entre los encomenderos y empresarios no encomenderos interesados en el negocio. El servicio de los indígenas debía durar seis meses: cuatro de trabajo en los yerbales y dos en el acarreo del producto hasta los puertos fluviales. A los montes no solo acudían indígenas mitayos sujetos a algún encomendero, sino también aquellos que trabajaban para empresarios no encomenderos. En ocasiones, también podía verificarse la concurrencia de nativos "enganchados", es decir, semiasalariados, que iban enviados por sus encomenderos -que después se adueñaban de sus "salarios"-, o bien porque eran realmente libres.

Tenía razón el virrey Toledo cuando afirmó, en 1572, que todo el poder del encomendero "ha sido a costa de los indios, de cuyo cuero salen todas las correas..."161. No tardó mucho para que esta actividad económica sea conocida como el "trabajo de la muerte".

\footnotetext{
159 TELESCA, Ignacio. La Provincia del Paraguay..., op. cit., pp. 20-28.

${ }^{160}$ PASTORE, Mario. Trabalho forçado indígena e campesinato mestiço..., op. cit., pp. 155-156.

${ }^{161}$ GARAVAGLIA, Juan. [1983]. Mercado interno y economía colonial..., op. cit., p. 289.
} 
Las condiciones de explotación causaron una gran mortandad entre la población originaria. Garavaglia calcula que, sobre un total de aproximadamente 100.000 indígenas reducidos en las regiones de Asunción y Jerez, existió una disminución superior a 50\% desde 1555 hasta la entrada masiva de los bandeirantes en $1632^{162}$. En términos generales, si se acepta que en el momento de los primeros contactos con los conquistadores existía una población de medio millón de guaraníes, hacia 1652, cuando se realiza la visita-entiéndase, inspección- de Andrés Garabito, se estima que entre nativos encomendados y aquellos sometidos por los jesuitas, el poder colonial español llegaba a treinta mil individuos como máximo. Es decir, en poco más de un siglo, si suponemos que todavía existían guaraníes que escapaban al control directo de los colonos, estamos delante de una cifra que se había reducido a una décima parte de la población indígena previa a la invasión europea.

Los encomenderos intentaron entonces extender la encomienda a los mestizos. También intentaron introducir esclavos africanos. La Corona se opuso. La esclavitud negra era más insegura y costosa que la explotación indígena. Someter a los mestizos pobres provocaba mucha incertidumbre acerca de las posibles consecuencias políticas y militares. Así, la escasez de fuerza de trabajo hizo que la metrópoli, como hiciera antes con la esclavitud "pura" inicial, intentara regular el sistema de encomiendas.

Una de las medidas para garantizar la reproducción -y reorganizar la apropiación de la fuerza de trabajo indígena-, fue el impulso de los llamados pueblos o reducciones de indios, tanto de los administrados por religiosos como por funcionarios civiles.

De este modo, es posible notar que, lejos de permitir que se consolidara y fortaleciera una "clase feudal" trasplantada desde Europa, la Corona española no dudó en dictar leyes para limitar el poder de los encomenderos -asuncenos, tucumanos, cuyanos, etc.-, por supuesto en virtud de sus intereses mercantilistas y metropolitanos. Los intereses inmediatos de los colonos no siempre coincidían con las políticas del centro imperial.

En la suma, sostiene Pastore, las encomiendas fueron concesiones temporales de derechos sobre la fuerza de trabajo indígena a empresarios particulares -los conquistadores, con los cuales la metrópoli se había aliado para llevar adelante la colonización de sus posesiones $^{163}$. Este autor advierte:

162 Ídem, pp. 160-161. Sobre la región del Tucumán, Fradkin y Garavaglia recogen a los cálculos de Roberto Pucci, que estimó una población cercana al medio millón en el momento del contacto con el europeo y que, un siglo más tarde, no llegaría a quince por ciento de esa cantidad. Ver: FRADKIN, Raúl; GARAVAGLIA, Juan. La Argentina Colonial..., op. cit., p. 30.

${ }^{163}$ PASTORE, Mario. Trabalho forçado indígena e campesinato mestiço..., op. cit., p. 175. 
[...] la encomienda no era una concesión de tierra ni implicaba en eso, simultánea o subsecuentemente. De hecho, el uso más rentable de las encomiendas no implicaba en la propiedad privada de ninguna tierra. Teniendo encomiendas, los particulares podían extraer la yerba mate de tierras de la Corona, para lo cual debían simplemente obtener una licencia que les permitiera esa explotación ${ }^{164}$.

En el mismo sentido, Carlos S. Assadourian apunta:

[El encomendero] no era propietario de la encomienda ni podía disponer de ella en tratos con personas vivas o jurídicas ni darles destinatarios en su testamento, ya que era un beneficiario temporal y limitado de la Corona ${ }^{165}$.

La encomienda ciertamente contenía elementos de servidumbre, pero combinados con características de una relación esclavista - pues la Corona actuaba como "propietaria" de la mano de obra indígena, que además podía ser "heredada"-. Pero no hay nada -si excluimos, por supuesto, la terminología, los modos o los títulos, que no implicaban necesariamente la existencia de un linaje "noble" sino que también podían ser comprados con dinero- que autorice a caracterizar las encomiendas como el feudalismo tal como se conoció en Europa.

\subsection{Los "pueblos de indios" y las Misiones jesuíticas}

La constante escasez de fuerza de trabajo hizo que la metrópoli intentara regular también el sistema de encomiendas. Para garantizar la reproducción y hacer más eficaz el control y la apropiación de la fuerza de trabajo indígena se crearon hacia 1580 los primeros pueblos o reducciones de indios. Es posible señalar, como antecedente, la inestabilidad política que se hizo sentir entre los colonos europeos a fines de la década de 1570. El propio mecanismo de la encomienda tambaleó por causa de una fuerte rebelión indígena -liderada por el carismático líder Overá entre 1575 y 1579-, que abarcó casi todo el territorio conquistado. La revuelta había adquirido un cariz profético y religioso. Los guaraníes seguidores de Overá fueron finalmente derrotados y duramente reprimidos, pero su lucha dejó claro que las cosas no podían continuar como antes. Es en este momento crítico que aparecen los franciscanos, pioneros en la tarea de crear y organizar las reducciones. Pero esos campos de trabajo podían estar dirigidos tanto por religiosos como por autoridades laicas.

Al contrario de la América andina, donde el europeo se deparó con una mano de obra nativa mejor organizada para el trabajo en gran escala, más al sur el conquistador debió

\footnotetext{
164 Ídem, p. 155.

165 ASSADOURIAN, Carlos; BEATO, Guillermo; CHIARAMONTE, José. Argentina, de la conquista a la independencia. Buenos Aires: Editorial Paidós, 1972, p. 229.
} 
"crear", adecuándose a las condiciones preexistentes, nuevas formas para facilitar la apropiación del excedente social. De ahí el mecanismo explotador de los "pueblos" o “comunidades" indígenas.

Aquí es ineludible referirse a los jesuitas y sus célebres Misiones. En la medida en que eran una forma de explotación distinta de la encomienda desenfrenada, la política de las reducciones suscitó serios enfrentamientos entre los encomenderos asuncenos y el sistema basado en los "pueblos", sobre todo aquellos administrados por la Compañía de Jesús. Estas crisis no pocas veces derivaron en conflictos con la propia Corona, que por más de 150 años respaldó la tarea de los "soldados del Papa” en el llamado Nuevo Mundo.

Los jesuitas habían llegado a Asunción en 1587. En 1604 crearon la Provincia Jesuítica del Paraguay, unidad administrativa que, en la práctica, se separó de la autoridad que ejercían los gobernadores españoles del Paraguay. Después de retirarse de la zona del Guairá y Jerez ante al avance de los bandeirantes entre 1628 y 1632, los jesuitas concentraron sus principales reducciones en las márgenes de los ríos Paraná y Uruguay.

La Corona estimuló claramente las reducciones jesuíticas, que cumplirían, además de una tarea reguladora de la fuerza de trabajo, un rol defensivo en una difícil zona fronteriza entre los dos imperios ibéricos y hasta en algunos conflictos entre los colonos y la metrópoli. Así, Madrid eximió de la encomienda a los indígenas de sus Misiones. Estableció un tributo de un peso por cada indio varón entre 18 y 50 años, monto inferior al de los indios en manos de los encomenderos del resto de la provincia. Este tributo solo podía ser pagado en plata, no en mitas de trabajo. Los intermediarios entre las arcas reales y los indios eran, por supuesto, los bienintencionados sacerdotes. Para ello, la Corona les autorizó a remitir hasta 12.000 arrobas de yerba mate a Santa Fe y Buenos Aires ${ }^{166}$. Si en 1673 las Misiones exportaron, vía Santa Fe, 10.531 arrobas de este arbusto, para 1734, por la misma ruta, el volumen había aumentado a 44.000 arrobas $^{167}$.

Las dimensiones geográficas y demográficas de los dominios jesuitas se hicieron enormes. Desde 1720, las Misiones sumaron 30 pueblos. Las Misiones no eran el "paraíso" que algunos autores intentan hacer creer. Eran centros de segregación y explotación indígena en gran escala. En 1732, su población alcanzó 141.182 indígenas ${ }^{168}$. El Colegio de la Orden en Asunción se erigió como un agente económico poderoso. Los religiosos poseían tierras y

${ }^{166}$ MAEDER, Ernesto. Las Misiones jesuíticas. In: TELESCA, Ignacio (Org.). Historia del Paraguay. 4. ed. Asunción: Taurus, 2014, p. 122.

${ }^{167}$ WHIGHAM, Thomas. La economía de la independencia..., op. cit., p. 17.

${ }^{168}$ MAEDER, Ernesto. Las Misiones jesuíticas..., op. cit., p. 124. 
estancias ganaderas, donde explotaban el trabajo de negros esclavizados. En 1753, los jesuitas poseían 636 esclavos, de los cuales 380 trabajaban en su estancia de Paraguarí1 ${ }^{169}$. Recordemos que la Iglesia católica, por medio de sus distintas congregaciones, era la principal propietaria de esclavos negros en el Paraguay.

Mapa 1. Ubicación de las Misiones jesuíticas de Sudamérica y el plano de detalle de las del Paraguay.

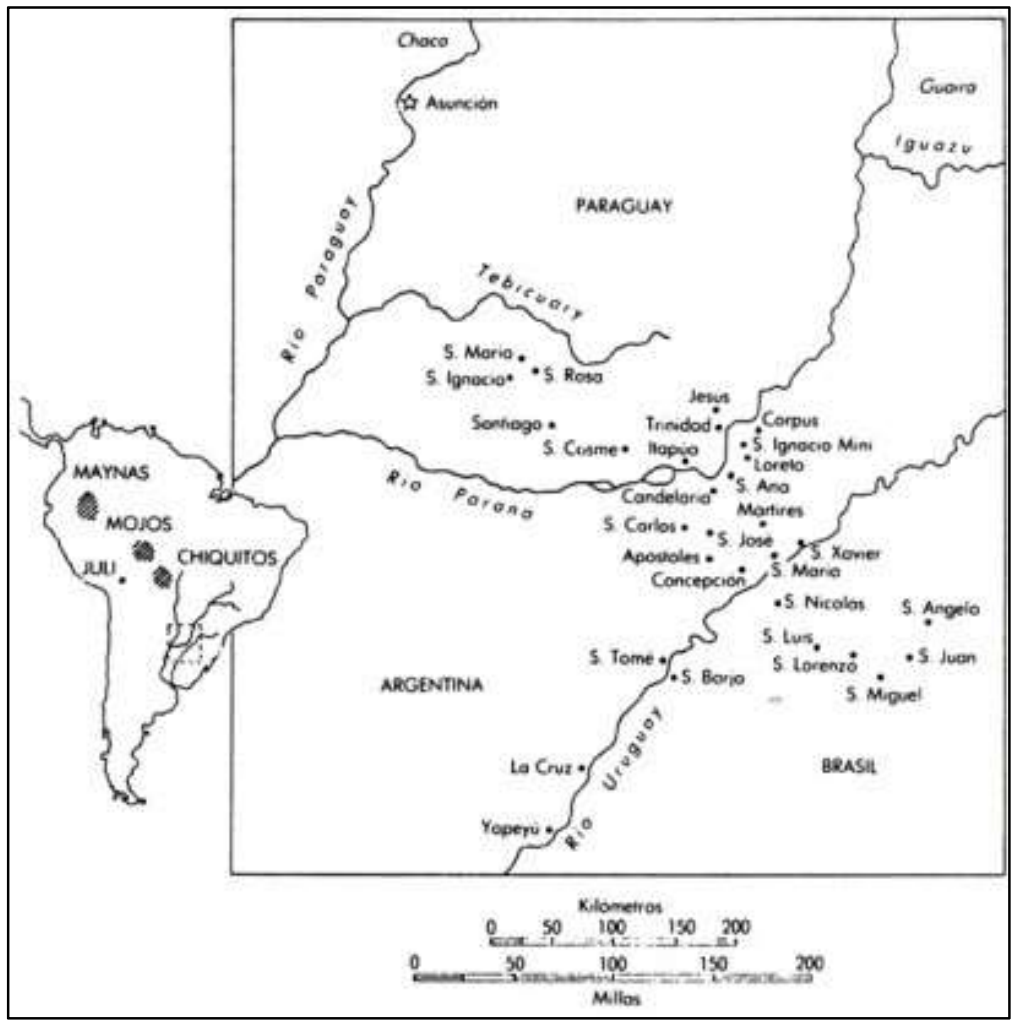

Los privilegios comerciales, la exención de gabelas y, por encima de todo, la disponibilidad de trabajo gratuito de decenas de miles de indígenas "evangelizados" -cuyo excedente era apropiado y realizado por los curas-, ciertamente hicieron de la Compañía de Jesús el agente económico más poderoso del Paraguay entre los siglos XVII y XVIII ${ }^{170}$. Para dominar a los nativos, debe decirse, los jesuitas estimularon y se apoyaron en una capa

169 TELESCA, Ignacio. La Provincia del Paraguay..., op. cit., p. 97.

${ }^{170}$ Una Cédula Real de 1743 quizá marca el auge de esta influencia cortesana, concediendo privilegios tributarios y organizativos en las Misiones. 
burocrática indígena, que participó en el control de la producción a cambio de ciertos privilegios ${ }^{171}$.

Todo esto hizo que los encomenderos y mercaderes asuncenos y de otras villas consideraran a los jesuitas una competencia comercial desleal y odiosa. Ese sector codiciaba la enorme masa de mano de obra que los religiosos controlaban para beneficio de su corporación y de la Corona.

El punto más alto de la crisis entre los colonos dependientes del gobierno de Asunción y los jesuitas fueron las rebeliones comuneras [1721-1735] ${ }^{172}$. Durante ese proceso, existieron dos etapas. La primera, desde 1721 hasta 1725, expresó una lucha en el interior de la clase propietaria asuncena, y de esta con los jesuitas, para hacerse con la mano de obra de los indios misioneros. La segunda etapa, entre 1730 y 1735, se diferenció en que los protagonistas no fueron los encomenderos sino un sector que se denominó el común, fundamentalmente oficiales y campesinos mestizos que servían como soldados en las fronteras. El reclamo principal de la rebelión fue un mayor acceso a la tierra ${ }^{173}$. Ambas etapas fueron derrotadas por la acción combinada de tropas reales y milicias indígenas comandadas por padres jesuitas.

Las consecuencias económicas fueron graves, sobre todo para el tráfico yerbatero. Si a principios de siglo se exportaba un promedio de 50.000 arrobas, esta cifra caería para 15.000 hacia 1730. Sin embargo, otro resultado del período de rebeliones del común fue el cambio en el proceso de extracción de yerba. La utilización de fuerza de trabajo indígena disminuyó para dar paso al concurso de campesinos mestizos que, sin abandonar completamente sus chacras, acudieron a los yerbales del Mbaracayú endeudándose en mercancías a cambio de trabajo futuro, como explicaremos más adelante.

La cuestión es que, en la disputa entre encomenderos y jesuitas, la Corona no tenía motivos para ceder ante los asuncenos y reimponer la encomienda a los indígenas sometidos por la Orden. Mario Pastore explica que, bajo el control y organización jesuita, el trabajo indígena produjo rendimientos mucho más elevados que cuando se hallaban encomendados

\footnotetext{
${ }^{171}$ GARAVAGLIA, Juan. Un modo de producción subsidiario: la organización económica de las comunidades guaranizadas en la formación regional altoperuana-rioplatense. In: ASSADOURIAN, Carlos; CARDOSO, Ciro; CIAFARDINI, Horacio, et al. Modos de producción en América Latina ..., op. cit., p. 164.

172 Sobre las rebeliones comuneras, ver: TELESCA, Ignacio. La Provincia del Paraguay..., op. cit., pp. 143168; GARAVAGLIA, Juan. [1983]. Mercado interno y economía colonial..., op. cit., pp. 317-322.

173 TELESCA, Ignacio. La Provincia del Paraguay..., op. cit., pp. 127-128.
} 
a particulares, o bien confinados en otros pueblos dirigidos por franciscanos, mercedarios o dominicos ${ }^{174}$.

A pesar de haber triunfado sobre las rebeliones comuneras, el poder jesuítico no duraría mucho tiempo. La participación de sectores de la Orden en la llamada Guerra Guaranítica [1753-1756], en la que siete pueblos resistieron las determinaciones de límites del Tratado de Madrid de 1750 y fueron derrotados por fuerzas coligadas de los reinos de España y Portugal, marcó el comienzo de la ruina de los jesuitas. A pesar de que, aparentemente, los jesuitas intentaron más bien contener la resistencia-que fue encabezada por el cacique Nicolás Ñeenguirú-, el impacto de la misma demostró que, en cierta medida, la Compañía se había convertido en un poder con dinámica propia, donde los indígenas eran más leales a ella que a la Corona.

El poder económico y el control de las poderosas milicias guaraníes, que se atrevieron a cuestionar un dictamen real, mermó la confianza metropolitana en la Orden. Estos fueron acusados de conspirar contra la Corona para instalar un "reino jesuítico" en el Paraguay. Carlos III, como parte de las conocidas reformas borbónicas, decretó en 1767 la expulsión de los jesuitas ${ }^{175}$. Esto se enmarcó, además, en un proceso más profundo de expansión de la ganadería en el Río de la Plata, donde las tierras y los indígenas controlados por los sacerdotes serían más rentables en ese tipo de $\operatorname{actividades}^{176}$.

\subsection{Los mandamientos}

Fueron un recurso exclusivo de los gobernadores y otras autoridades reales para hacerse con la mano de obra gratuita de los indígenas. En general era utilizado para obras públicas, el transporte de yerba mate por el río, etc. Sin embargo, siempre que podía, el gobernador echaba mano de los mandamientos para beneficio personal, sea para recuperar la inversión que realizara para comprar su puesto, sea para administrar los conflictos dentro de la clase dominante, compensando con mandamientos a aquellos que no tenían "suficientes" encomiendas.

El mecanismo, en síntesis, consistía en la asignación, por parte del gobernador o de su teniente, de un grupo de indígenas de los pueblos al servicio de un empresario -

\footnotetext{
174 PASTORE, Mario. La hipótesis de Domar..., op. cit., p. 587.

175 Tres Cédulas Reales relativas a la expulsión de la Compañía de Jesús. Archivo Nacional de Asunción Sección Histórica (ANA-SH), v. 60, n. 5.

${ }^{176}$ MAEDER, Ernesto. Las Misiones jesuíticas..., op. cit., p. 130.
} 
encomendero o no- para una determinada tarea y por un período especial. El transporte terrestre $\mathrm{y}$, sobre todo, fluvial de los productos paraguayos -sin el cual hubiera sido imposible que llegasen a los centros de redistribución o consumo- se basó, durante buena parte de la época colonial, en el recurso de mandamientos gubernamentales.

En apretado resumen: ser indígena durante la Colonia implicaba una doble y hasta triple explotación: la del encomendero; la de la comunidad o pueblo, cuando no estaba trabajando para el encomendero; la del Estado, cuando este requería mandamientos para el "bien común" o el particular de los gobernadores, cabildantes, y otros empresarios.

\subsection{El campesinado pobre, libre, mestizo y de habla guaraní}

Ya señalamos que el proceso de mestizaje comenzó al poco tiempo de iniciada la conquista europea. Debido a la condición marginal de la provincia, hubo poca inmigración desde la metrópoli. Esto posibilitó que los mestizos -que fueron uniéndose con otros mestizos, indígenas, e incluso con afrodescendientes- rápidamente se transformaran en la mayoría de la población ${ }^{177}$. La población mestiza adoptó el guaraní como idioma principal, un elemento cultural hasta la actualidad profundamente arraigado en la sociedad paraguaya.

La Corona reconoció a los mestizos la categoría jurídica de españoles americanos, diferenciándolos de los españoles europeos, que siempre representaron una minoría en el Paraguay.

Al ser jurídicamente españoles, los mestizos no estuvieron sujetos a tributo. Una parte minoritaria de mestizos, principalmente aquellos descendientes de los primeros conquistadores ibéricos, fueron beneficiados con encomiendas $\mathrm{y}$, con el tiempo, constituyeron una fracción de la clase propietaria y explotadora, pero siempre de manera subordinada a los españoles, que detentaban los principales cargos públicos y concentraban las mejores encomiendas y tierras. El resto de los mestizos, pobres y sin encomiendas, no tuvo más salida que dedicarse al duro trabajo de la tierra. Así se fue conformando un campesinado pobre, libre, mestizo, y guarani hablante, que producía principalmente para su subsistencia y destinaba alrededor de $30 \%$ de su cosecha al mercado interno ${ }^{178}$.

177 TELESCA, Ignacio. La Provincia del Paraguay..., op. cit., p. 22.

${ }^{178}$ GARAVAGLIA, Juan. [1983]. Mercado interno y economía colonial..., op. cit., p. 366-367. En el Archivo Nacional de Asunción existen registros de los precios oficiales de los principales productos agrícolas que se comercializaban en el mercado, en las pulperías, como el maní, maíz o la chipa. Consultar: Cabildo fija precio para venta de artículos comestibles, 1786. ANA-SH, v. 149, n. 16. 
Según el historiador Garavaglia, 67\% de ese campesinado mestizo no poseía tierra propia y vivía en propiedades ajenas, incluso aquellos que tenían bueyes, vacas y caballos. De este porcentaje, las dos terceras partes tampoco pagaba arriendo, y posiblemente era "tolerado" a cambio de una parte de su pequeña producción o porque realizaba algún trabajo para el propietario ${ }^{179}$.

En las comunidades agrarias se producían también artesanías y manufacturas caseras, como el enrollado de cigarros, que se vendían en las villas y ciudades, aunque estas actividades fueron siempre marginales en la economía rural. El artesanado, que no confería distinción ni estatus, era preferentemente desempeñado por indios, mestizos, negros y mulatos y, en menor medida, por algunos extranjeros pobres ${ }^{180}$.

Este campesinado pobre, por otro lado, tenía la pesada carga del servicio militar obligatorio dentro o fuera de la provincia. Esto se debía a que la Corona no costeó el mantenimiento de tropas profesionales en el Paraguay sino hasta el siglo XIX. Los campesinos varones podían pasar no menos de cinco meses al año alejados de sus cosechas y familias, sirviendo en los distintos "presidios" o fuertes de frontera. Hacia 1760, alrededor de $30 \%$ del total de varones paraguayos no indígenas estaba obligado a servir en la frontera ${ }^{181}$.

El gobernador español Lázaro de Ribera escribió en 1798 una nota sobre las consecuencias económicas del alto grado de militarización:

No hay un hombre en toda la Provincia que esté libre de la esclavitud militar y no hay ninguno que pueda contar con su trabajo, ni dedicarse a los que pudieran asegurar su subsistencia. Todos sufren la dura ley de estar todo el año con las armas en la mano, sirviendo en los Cuerpos de Guardia, en guarnecer los Fuertes, en cubrir los pasos, en destacamentos, y en todas las fatigas militares, y lo poco que adquieren lo disipan y consumen en este Servicio, que, como ya se ha dicho, lo hacen a su costa y con total abandono de sus familias: viendo de más a más arruinadas sus haciendas, ganados, y labores cuando vuelven de alguna expedición $^{182}$.

Estos campesinos-soldados, como confirma el propio gobernador, no solo no recibían remuneración alguna, sino que debían costearse su alimentación, los caballos, y hasta sus armas. Esta era una de las principales causas de la evidente pobreza de la provincia,

${ }^{179}$ GARAVAGLIA, Juan. Economía, sociedad y regiones. Buenos Aires: Ediciones de la Flor, 1987, p. 209.

${ }^{180}$ ARECES, Nidia. La economía paraguaya en los primeros años revolucionarios. In: TELESCA, Ignacio; BREZZO, Liliana; CABALLERO CAMPOS, Herib (Org.). Paraguay 1813: La proclamación de la República. Asunción: Taurus, 2013, p. 65.

${ }^{181}$ GARAVAGLIA, Juan [1983]. Mercado interno y economía colonial..., op. cit., p. 145.

182 RIBEIRO, Ana. Gaspar Rodríguez de Francia: El hombre de la independencia y el aislamiento paraguayo. Asunción: El Lector, 2011, p. 87. Ver: Informe presentado por el Gobernador del Paraguay Lázaro de Ribera, sobre el estado miserable de los pueblos de indios. ANA-SH, v. 172, n. 16; Informe sobre el estado ruinoso de la Casa de Gobierno y la necesidad urgente de su reparación. ANA-SH, v. 198, n. 4. 
hecho comprobado por casi todos los gobernadores, eclesiásticos, y otros cronistas de la época.

La actividad económica del campesinado pobre y mestizo, en suma, podría describirse como una producción agrícola, en la que las artesanías ocupaban un lugar secundario, orientada en sus dos terceras partes a la subsistencia y el resto a la comercialización en el mercado local ${ }^{183}$. A finales del siglo XVIII, cerca de $25 \%$ del total de las exportaciones paraguayas hacia Buenos Aires estaba compuesto por mercancías de origen campesino ${ }^{184}$.

En las últimas décadas del sistema colonial, el campesinado pobre y libre mestizo experimentaría un fortalecimiento social con el fin de las Misiones jesuíticas y la consecuente unificación territorial de la provincia. El peso sociopolítico de esta mediana y pequeña burguesía rural, evidentemente todavía en estado incipiente, sería decisivo en la crisis de la independencia en 1811-1813.

\subsection{Embriones de trabajo libre}

En los últimos 40 años del colonialismo, la economía de exportación se potenció y, con ello, la dependencia de la yerba mate, que permeaba todos los poros de la provincia. Para hacerse una idea del peso de este rubro, es interesante un informe al Rey del gobernador Agustín Fernando de Pinedo, escrito en 1775:

[...] tres objetos son, a los que por inclinación o necesidad, se aplican todos los habitantes de esta provincia. Unos al beneficio de la yerba en los montes donde se cría; otros a la conducción por el río de las embarcaciones del tráfico a Buenos Aires, y otros al cultivo de la tierra ${ }^{185}$.

Dos años antes, en otro informe, el mismo gobernador ponderó que casi la mitad de los hombres del Paraguay se ocupaban en el proceso productivo de la yerba ${ }^{186}$.

En el ocaso del siglo XVIII, en el beneficio de la yerba no solo trabajaban indios encomendados sino también peones jurídicamente "libres". Entre esos trabajadores se contaban peones de las estancias, marineros de los ríos, carpinteros navales y jornaleros en general. Garavaglia calculó que en los yerbales al menos 35\% eran trabajadores libres ${ }^{187}$. En realidad, puede decirse con más propiedad que constituían un incipiente semiproletariado,

183 GARAVAGLIA, Juan. [1983]. Mercado interno y economía colonial..., op. cit., p. 367.

184 Ídem, p. 479.

185 TELESCA, Ignacio. La Provincia del Paraguay..., op. cit., p. 91.

${ }^{186}$ WHITE, Richard Alan [1984]. La Primera Revolución Popular en América ..., op. cit., p. 21.

${ }^{187}$ GARAVAGLIA, Juan [1983]. Mercado interno y economía colonial..., op. cit., pp. 372-374. 
es decir, campesinos pobres que complementaban lo obtenido del cultivo de sus parcelas, propias o arrendadas, vendiendo durante un tiempo su fuerza de trabajo.

La extracción de la yerba mate, como motor de la economía de la provincia, fue la actividad de la que surgieron las primeras manifestaciones de trabajo libre. No solo se necesitaban hombres dispuestos a internarse en montes alejados e inhóspitos. Cerrar el ciclo de producción-realización del negocio de la yerba exigía, además, marineros que transportasen el producto desde la selva hasta Asunción y, después, hasta Buenos Aires; artesanos calificados para la fabricación de embarcaciones (barcazas); criadores de ganado para obtener la carne y el cuero necesarios para alimentar a los peones y confeccionar los sacos que envolvían la mercancía. La dinámica exportadora fue minando formas de explotación caducas, como las encomiendas.

En efecto, durante ese período es posible advertir una política anti-encomendera, es decir, de cierta facilitación de la contratación del indígena como “jornalero". El gobernador español Lázaro de Ribera [1796-1806], sin abandonar la explotación convencional del indio, trató de reorientarlo hacia una relativa libertad de contratación como peones agrícolaganaderos. Esto coincide con un amplio proceso en el que las autoridades coloniales y los estancieros en ascenso fueron apropiándose de las tierras, de la fuerza de trabajo y del ganado de los antiguos pueblos jesuíticos, por entonces en decadencia completa. Con el paso de los años, la mano de obra barata en las estancias o en los yerbales se hizo más codiciada y lucrativa que mantener a los indios confinados y sujetos a tributo ${ }^{188}$.

Esta política se aplicaba en el contexto de la serie de disposiciones promulgadas por la Corona para suprimir la encomienda, concretadas en distintas Cédulas reales: 1720, 1735, $1776,1777,1801,1802$, y $1803^{189}$.

Sin embargo, por más caducas que se mostraran ya hacia finales del siglo XVIII, formas de explotación como los pueblos de indios todavía tardarían en desaparecer jurídicamente. Su disolución formal llegaría en el tardío año 1848. Pero de esto hablaremos en otro capítulo.

A finales del siglo XVIII puede decirse que estaba en marcha un proceso sui géneris -y muy incipiente- de acumulación originaria, esto es, de proletarización del productor directo. Un proceso de desposesión de quienes producían riquezas. Pero insistimos que este

\footnotetext{
${ }^{188}$ GARAVAGLIA, Juan. Un modo de producción subsidiario..., op. cit., p. 172.

${ }^{189}$ ASSADOURIAN, Carlos; BEATO, Guillermo; CHIARAMONTE, José. Argentina: de la conquista..., op. cit., p. 238. Ver también el Bando del gobernador Bernardo de Velasco ordenando a los pueblos de la provincia el cese inmediato del castigo y maltrato a los indios en 1806. ANA-SH, v. 200, n. 6.
} 
era un proceso embrionario. Si bien esos peones mestizos o indígenas eran "libres", no necesariamente percibían un "salario" en metálico. En el caso del proceso de extracción y beneficio de la yerba mate, los trabajadores recibían, siempre a precios sobrevaluados, una partida de provisiones, herramientas y otros géneros por lo que quedaban "debiendo" a los empresarios o beneficiadores desde antes de internarse en los montes. Como la diferencia entre lo que recibían por la producción y el monto de sus "deudas" siempre era enorme e insalvable, resultaba que los peones permanecían "enganchados" a los beneficiadores en un ciclo infernal de explotación. Los empresarios locales de la yerba mate, por su parte, operaban en general con créditos otorgados por financistas porteños. Garavaglia muestra que los precios de las mercaderías que eran "fiadas" a los peones aumentaban alrededor de $60 \%$ entre Buenos Aires y Asunción, mientras que de la capital paraguaya a los "beneficios" del arbusto la diferencia podía llegar a 308\%. Al mismo tiempo, entre el precio "por arroba" producida que se pagaba a los peones en los montes de yerbales y el precio de venta de esa misma yerba mate en Asunción existía un margen de ganancia de cerca de $150 \%{ }^{190}$.

\subsection{Esclavitud negra}

Existe una falsa creencia de que en el Paraguay no hubo esclavitud negra, o bien que esta no fue "tan cruel" como en el Brasil, EEUU o el Caribe. Lo que no hubo en el Paraguay fue una economía de plantación intensiva ni, por esa razón, la esclavitud negra fue el sostén de la producción local. Pero sí existió esclavitud negra, y su peso social fue mayor de lo que usualmente se supone.

Los africanos esclavizados eran explotados principalmente en las estancias de las órdenes religiosas - particularmente, las jesuitas- y en los servicios domésticos. Y no eran "pocos". Los censos muestran que la población negra representó alrededor de $11 \%$ desde el último cuarto del siglo XVIII ${ }^{191}$. La esclavitud de los afrodescendientes, por su parte, abarcó entre 4 y $5 \%$ de la población total ${ }^{192}$. Los negros "libres", mejor dicho "no esclavizados", estaban sujetos a un tributo anual de tres pesos a la Corona por el simple hecho de ser negros

\footnotetext{
${ }^{190}$ GARAVAGLIA, Juan [1983]. Mercado interno y economía colonial..., op. cit., pp. 481-482. El cálculo se basa en 2.651 arrobas de yerba beneficiadas por 23 peones, que tuvo un costo de mano de obra de 800 pesos (más otros gastos de transporte, impuestos, etc.) y se vendieron en Asunción por 3.300 pesos.

191 TELESCA, Ignacio. La historiografia paraguaya y los afrodescendientes. 2008. Disponible en: $<$ http://bibliotecavirtual.clacso.org.ar/ar/libros/sursur/AFRICAN/10tele.pdf>, consultado el 27/03/2019.

${ }^{192}$ Para un estudio más profundo de la esclavitud, ver: PLÁ, Josefina. La esclavitud en el Paraguay. Asunción: Editora Intercontinental, 2010.
} 
o negras. El proceso de liquidación de esta relación de producción precapitalista fue lento ${ }^{193}$. Solo en 1842 se decretó la limitada libertad de vientres y la abolición formal debió esperar el final de la Guerra contra la Triple Alianza y la Constitución promulgada en 1870.

\section{RELACIONES CON LA CIUDAD-PUERTO}

La condición mediterránea de la provincia del Paraguay, ubicada en el centro de Sudamérica, hacía de la libre navegación de los ríos interiores una condición vital para ligarse al mercado regional y mundial.

Durante el período colonial y debido a su condición periférica, las exportaciones paraguayas estuvieron sujetas a una serie de gravámenes y trabas que la Corona impuso en Santa Fe y Buenos Aires. Esta situación profundizó la asfixia económica de la provincia en general.

Entre 1680 y 1779, las mercancías salidas de Asunción debían parar obligatoriamente en el "Puerto Preciso" de Santa Fe, donde las embarcaciones eran descargadas y los productos tasados. El producto principal, como sabemos, era la yerba mate. En el camino de retorno, las pesadas barcas que remontaban el Paraná rumbo al tosco muelle de Asunción iban, por lo general, cargadas con mercaderías importadas de Europa, vino y aguardiente cuyano, ropa peruana, añil salvadoreño, pailas de cobre chileno, entre otros enseres. Santa Fe se consolidó como nexo inevitable y funcionó como llave de paso del comercio desde y hacia la antigua Asunción que, como señalamos, había pasado a un segundo plano desde 1620. Para llegar a Buenos Aires, las mercaderías debían continuar por tierra.

La yerba mate destinada al Alto Perú o al Tucumán pagaba gabelas de más de 50\% de su valor original ${ }^{194}$. El propio gobernador Agustín Fernando de Pinedo protestó en 1778 diciendo que la yerba paraguaya rendía a la Real Hacienda más que el oro, que pagaba un quinto $^{195}$.

Ese circuito comercial impuesto hacía que los productos paraguayos pagasen, por ejemplo, tres veces en concepto de alcabala, el impuesto a las ventas. Primero en Asunción; luego en Santa Fe; por último, en Buenos Aires.

\footnotetext{
193 Sobre la esclavitud negra en América, véase: PRADO, Maria; PELLEGRINO, Gabriela. História da América Latina. 1. ed. 2. reimp. São Paulo: Contexto, 2016, pp. 35-36.

194 MORENO, Fulgencio [1912]. Causas de la independencia del Paraguay. Asunción: Editora Intercontinental, 2011, p. 42.

${ }^{195}$ CARDOZO, Efraím [1955]. El Paraguay Colonial. Asunción: E1 Lector, 1996, p. 97.
} 
Esta cadena de impuestos e intermediarios hacía, según informaba Pinedo, que la yerba mate, que en los montes no valía un peso por arroba, "asciende su estimación en Provincias más distantes donde se consume a veinte, veinte y cinco, y treinta pesos más o menos"196.

Existía, ya durante la Colonia, una relación de dependencia y desconfianza con Buenos Aires. Eso no se atenuó en 1776 con la creación del virreinato del Río de la Plata, que estableció la ciudad-puerto como capital. Todo lo contrario. Buenos Aires pasó a ser la nueva submetrópoli a la cual el Paraguay, como todo el Interior platense, quedó sujeto. En poco tiempo, la capital porteña se consolidó como el principal puerto marítimo, mercado consumidor, plaza financiera, y centro de redistribución de mercaderías de toda región ${ }^{197}$. No pasó mucho tiempo para que Buenos Aires se convirtiera en el tercer puerto del Imperio español, detrás de Veracruz y el Callao ${ }^{198}$. En realidad, la creación del Virreinato platense solo consolidó un proceso de preeminencia que se desarrollaba en Buenos Aires hacía décadas, a partir de la concentración del circuito comercial interno y la circulación de buena parte de la plata producida en las regiones del Alto Perú, cuya minería había experimentado una recuperación desde 1730. A esto se sumó el prometedor comercio con el Pacífico Sur, por medio de la habilitación de la ruta del Cabo de Hornos en la década de 1740. En Asunción, “ciudad subalterna”, el auge bonaerense se expresó en el peso preponderante que los financistas porteños pasaron a detentar en el proceso de extracción y transporte de la yerba mate paraguaya.

El poderío regional de la capital virreinal platense se incrementó aún más con el Reglamento y Aranceles Reales para el Comercio Libre de España e Indias (12 de octubre de 1778) ${ }^{199}$ y el establecimiento del Real Consulado (1794), institución que desembarazaba a los comerciantes porteños de la regulación comercial impuesta desde Lima ${ }^{200}$. En 1785,

\footnotetext{
${ }^{196}$ MORENO, Fulgencio [1912]. Causas de la independencia del Paraguay..., op. cit., pp. 105-106.

${ }^{197}$ En 1810, Buenos Aires contaba con 42.872 habitantes, Montevideo con 15.000 y Asunción con 7.000. El mayor crecimiento demográfico ocurrió entre 1744 y 1778, cuando la población porteña aumentó $110 \%$. Esto incrementó el peso de la capital virreinal también como potencial mercado de consumo.

198 GARAVAGLIA, Juan [1983]. Mercado interno y economía colonial..., op. cit., p. 420.

${ }^{199}$ El Reglamento de Libre Comercio con América de 1778 fue promulgado por el rey Carlos III de España el 12 de octubre de 1778, en el marco de las reformas borbónicas, a fin de permitir el librecambio comercial entre España e Hispanoamérica, flexibilizando el monopolio existente, para lo cual se conectaron 13 puertos de España con 27 de Indias. La liberación, aunque sentó un precedente importante, fue solo relativa, y la expresión no se justificaba más que en comparación con los monopolios y las prohibiciones totales del período precedente.

${ }^{200}$ El Consulado de Comercio de Buenos Aires fue una de las principales instituciones oficiales del virreinato del Río de la Plata, junto con el virrey, el Cabildo, y las de orden religioso. Fue erigido en 1794, a pedido de comerciantes locales. Se trataba de un cuerpo colegiado que funcionaba como tribunal comercial y como sociedad de fomento económico (llamada Junta de Gobierno). El Consulado dependía directamente de la
} 
Buenos Aires volvió a contar con el máximo tribunal de justicia, una Audiencia. Además, la ciudad se benefició de la constante afluencia de inmigrantes y comerciantes extranjeros, adquiriendo una fisonomía mucho más cosmopolita.

Halperin Donghi señala que, en los últimos años del siglo XVIII, Buenos Aires bien podía ser comparada con una ciudad española de las de segundo orden. Y acota:

\begin{abstract}
Buenos Aires es entonces, básicamente, una ciudad comercial y burocrática, con actividades complementarias (artesanales y primarias) destinadas a atender la demanda alimentada en primer término por quienes viven de la administración y el comercio. La importancia comercial de Buenos Aires es anterior a las reformas de la década del 70 (libre internación a Chile y [al] Perú; comercio libre con los más importantes puertos peninsulares) [...] pero es indudable que esas reformas consolidan y aceleran el ascenso comercial de Buenos Aires; facilitan el establecimiento de un núcleo de grandes comerciantes que adquieren bien pronto posición hegemónica en la economía de todo el virreinato ${ }^{201}$.
\end{abstract}

Las nuevas familias de acaudalados comerciantes, de hecho, provenían de la metrópoli: los catalanes Larrea y Matheu; los vasconavarros Anchorena, Álzaga, Santa Coloma, Lezica, Beláustegui, Azcuénaga; los gallegos Llavallol y Rivadavia, etc. La mayor parte de los comerciantes porteños eran consignatarios de casas españolas, cuando no directamente parientes de los comerciantes peninsulares ${ }^{202}$.

En este contexto, desde la segunda mitad del siglo XVIII la explotación y opresión colonial en el Paraguay pasó a ser instrumentada de manera más directa y sentida desde Buenos Aires. En aquella floreciente ciudad, a la sombra del poder del Virrey y de la burocracia colonial, se consolidaba una fuerte burguesía comercial y terrateniente local, entrelazada con la burocracia colonial de diversas maneras. El control del puerto y de la aduana en Buenos Aires, que intermediaba casi todo el comercio regional, impuso al Paraguay y al resto del Interior platense una situación de doble dependencia, metropolitana y submetropolitana.

\title{
5. El OCASO DEL SISTEMA COLONIAL
}

Las últimas décadas de dominio español estuvieron marcadas por importantes cambios económicos, territoriales y demográficos. En pocas décadas, la expulsión de los

Corona española. Era, en gran medida, un gremio de comerciantes con facultades delegadas por el rey, en materia comercial. Podía dirimir pleitos y demandas presentadas por comerciantes, y se financiaba mediante el cobro del impuesto. Con el pasar de los años aumentaría su poder de control sobre la aduana. Su primero y único secretario fue Manuel Belgrano.

${ }^{201}$ HALPERIN DONGHI, Tulio. Revolución y guerra. Formación de una élite dirigente en la Argentina criolla. 2. ed. Buenos Aires: Siglo XXI Editores Argentina, 2005, p. 41; HALPERIN DONGHI, Túlio. História da América Latina. São Paulo: Editora Paz e Terra, 2001.

${ }^{202}$ HALPERIN DONGHI, Tulio. Revolución y guerra ..., op. cit., p. 42. 
jesuitas y las reformas borbónicas habían modificado el panorama de la provincia. Durante el siglo XVIII, la monarquía española introdujo una serie de modificaciones en sus dominios coloniales con el objetivo de incrementar su control, su defensa e impulsar un crecimiento económico que permitiera, en primer lugar, aumentar la recaudación fiscal. La implementación de estas reformas, como es sabido, tuvo impactos diferentes en cada región, pero en casi todas tensionó las relaciones entre la metrópoli y las distintas clases sociales en las Américas. No podía haber sucedido de otra manera, puesto que se trató de la mayor reorganización económica y política del imperio colonial hispano desde el siglo XVI. La Corona buscó una mayor centralización política sobre la base de una burocracia más profesional, que ejerciera una autoridad más firme, es decir, menos dependiente de la tradicional negociación y renegociación con las élites americanas y el resto del entramado local. Para ello, creó nuevos virreinatos -el de Nueva Granada y el del Río de la Plata, además del estatus especial que adquirió la Capitanía de Chile, que mantuvo un considerable margen de autonomía con relación al virreinato del Perú- y designó como virreyes e intendentes a oficiales de los Reales Ejércitos y la Real Armada, el núcleo duro de la máquina estatal imperial.

En ese periodo, la población paraguaya aumentó, pasando de 85.138 habitantes en 1761 -donde el Paraguay no jesuítico no alcanzaba 50\% del total de la provincia-, a 108.070 en 1799, esparcida principalmente en villas o pueblos rurales. Asunción, por entonces, contaba con poco más de 7.000 habitantes $^{203}$.

En la capital, siempre de acuerdo con el criterio de los censistas de 1799, 53,5\% era considerado español; 3,8\% indígenas; y 43,6\% negros o pardos, en tanto que los esclavizados representaban $17,6 \%$ del total de la población ${ }^{204}$. Esto demuestra que la población afrodescendiente, casi invisible en los libros de la historia oficial como en los relatos asociados a determinadas corrientes de izquierdas, tenía un peso social enorme.

Por otra parte, si en 1761 la población considerada indígena representó 61\%, en el censo de 1799 ese sector cayó a 29,6\% ${ }^{205}$. Esta inversión se debió, en realidad, a que más de la mitad de la antigua población indígena de las ex reducciones jesuitas, que entraron en

${ }^{203}$ COONEY, Jerry. El fin de la colonia en el Paraguay: 1810-1811. Asunción: Editora Intercontinental, 2010, p. 21.

${ }^{204}$ TELESCA, Ignacio [2008]. La historiografia paraguaya y los afrodescendientes..., op. cit. Sobre el censo de 1782 y 1799, ver también: MAEDER, Ernesto. La población en el Paraguay en 1799: el censo del gobernador Lázaro de Ribera. Estudios Paraguayos, Asunción, v. 3, n. 1, pp. 63-86, 1975; GARAVAGLIA, Juan. La demografía paraguaya: aspectos sociales y cuantitativos (siglos XVI-XVIII). Suplementos Antropológico, v. 19, n. 2, pp. 19-85, 1984.

${ }^{205}$ GARAVAGLIA, Juan [1983]. Mercado interno y economía colonial..., op. cit., pp. 221-227. 
decadencia tras la expulsión de los Padres, se integró a la fuerza laboral del resto de la población considerada española -que, en rigor, eran mestizos-, engrosando el campesinado pobre y, en alguna medida, el sector jornalero libre.

Los españoles europeos siempre fueron una minoría en la provincia. En 1782 eran 212 individuos y en 1785 , tan solo $193^{206}$.

Tabla 2. Población del Paraguay [1761-1846].

\begin{tabular}{lcccccccc}
\hline & \multicolumn{2}{c}{$\mathbf{1 7 6 1}$} & \multicolumn{2}{c}{$\mathbf{1 7 8 2}$} & \multicolumn{2}{c}{$\mathbf{1 7 9 9}$} & \multicolumn{2}{c}{$\mathbf{1 8 4 6}$} \\
\hline & Total & $\%$ & Total & $\%$ & Total & $\%$ & Total & $\%$ \\
\hline Españoles & 29.747 & 34,9 & 55.920 & 57,9 & 63.506 & 58,8 & 220.450 & 92,3 \\
\hline Afrodescendientes & 3.470 & 4,1 & 10.846 & 11,2 & 12.546 & 11,6 & 17.212 & 7,2 \\
\hline Indígenas & 51.921 & 61 & 29.798 & 30,9 & 32.018 & 29,6 & 1.200 & 0,5 \\
\hline Total & $\mathbf{8 5 . 1 3 8}$ & $\mathbf{1 0 0}$ & $\mathbf{9 6 . 5 6 4}$ & $\mathbf{1 0 0}$ & $\mathbf{1 0 8 . 0 7 0}$ & $\mathbf{1 0 0}$ & $\mathbf{2 3 8 . 8 6 2}$ & $\mathbf{1 0 0}$ \\
\hline
\end{tabular}

Fuente: TELESCA, Ignacio. Antes y después. Del amor al espanto. Construcciones históricas e historiográficas del Paraguay del siglo XIX. In: GARAVAGLIA, Carlos; FRADKIN, Raúl. A 150 años de la Guerra de la Triple Alianza contra el Paraguay. Buenos Aires: Prometeo Libros, 2016, p. 176. Las cifras se basan en una compilación y comparación de censos oficiales y en los análisis de varios autores sobre los mismos. En los censos gubernamentales, la categoría “españoles”, en general incluía europeos y mestizos libres.

La expulsión de los jesuitas significó también una expansión y unificación territorial sobre el control de Asunción. La expansión pobladora, a su vez, incentivó la multiplicación de grandes estancias ganaderas, estimulando el latifundio especialmente alrededor de Concepción, al norte, y de Pilar, al sur ${ }^{207}$. En 1792 se repartieron 4.442 .079 hectáreas entre 52 estancias de Concepción. En Ñeembucú, fueron 169.096 hectáreas que originaron 66 estancias $^{208}$. Huelga decir que esa repartición, por medio de mercedes de tierras concedidas por los gobernadores coloniales, no benefició a los campesinos pobres sino a empresarios yerbateros, ganaderos, comerciantes, oficiales militares tanto españoles como nativos.

De esta forma, hacia finales del siglo XVIII comenzó a tomar forma un sector capitalista-latifundista más dedicado a la ganadería, en un contexto en el que la encomienda había entrado en decadencia y los pueblos de indios también se disgregaban ${ }^{209}$.

206 CABAllero CAMPOS, Herib. Proceso de la Independencia paraguaya [1780-1813]. Asunción: El Lector, 2010, p. 30.

${ }^{207}$ Sobre este proceso en el Norte, ver: ARECES, Nidia. La expansión criolla en la frontera norte del Paraguay: Estancieros y chacreros en Concepción [1773-1840]. Revista Europea de Estudios Latinoamericanos y del Caribe, Ámsterdam, n. 62, pp. 54-69, 1997. Disponible en: $<$ https://www.jstor.org/stable/25675731?seq=1\#page_scan_tab_contents>, consultado el 14/03/2019; ARECES, Nidia. Concepción "peligrosa" y "descubierta" de la frontera norte paraguaya: Espacio étnico y sociopolítico. Revista de História, São Paulo, n. 133, pp. 59-74, 1995.

${ }^{208}$ CABALLERO CAMPOS, Herib. El Virreinato del Río de la Plata [1776-1810]. In: TELESCA, Ignacio (Org.). Historia del Paraguay..., op. cit., p. 145.

209 TELESCA, Ignacio. La Provincia del Paraguay..., op. cit., p. 128. 
Sin embargo, la yerba mate siguió siendo el principal producto de exportación. La relativa liberalización del comercio dinamizó la extracción y el comercio de la yerba mate, que pasó de 27.000 arrobas en 1776 a 330.480 arrobas en $1798^{210}$. Lo mismo pasó con la exportación de maderas, que creció de 11.508 varas $^{211}$ en 1781 a 70.725 en $1809^{212}$. La Corona creó en 1779 la Real Renta de Tabacos y Naipes, con el fin de monopolizar la comercialización del tabaco, que pasó a ser producido casi exclusivamente en el Paraguay. Esto quedó conocido como el "Estanco del Tabaco", que obligaba a los productores directos -sobre todo campesinos pobres- a vender sus cosechas únicamente a la metrópoli.

A pesar de su atractivo inicial - pues con el Estanco se introdujo la moneda metálica y se prometió que los productores serían exonerados del servicio militar obligatorio- no pasó mucho tiempo para que esta institución se volviese particularmente odiosa entre los cosecheros. La cuestión es que el Estanco compraba por dos pesos cada arroba de tabaco de primera calidad, para revenderlo a nueve pesos y medio ${ }^{213}$. No por azar, cuando estalló el proceso de la independencia, la abolición del Estanco y el libre comercio de tabaco y otros géneros fueron reivindicaciones sentidas tanto por los grandes propietarios como por el campesinado mestizo pobre.

La Carrera del Paraguay, como era conocido el tráfico comercial a través de los ríos Paraguay y Paraná, se intensificó. Si en 1776 partieron de Asunción dos barcos y dieciocho embarcaciones menores, en 1793 esos números eran trece y ciento trece, respectivamente ${ }^{214}$. Yerba mate, tabaco y maderas eran transportados rumbo a Corrientes, Santa Fe y el estuario del Río de la Plata. Las nuevas condiciones políticas y el crecimiento promisor del comercio propiciaron un nuevo flujo migratorio de españoles peninsulares, que no tardaron en dominar ese intercambio comercial, el transporte, y establecer una compleja red de crédito. Además, dominaron el Cabildo de Asunción. Los europeos eran, sin duda, la facción más poderosa entre las clases propietarias.

Pero, a la sombra de los colonizadores europeos existía una incipiente burguesía criolla. Eran familias de terratenientes, tradicionales encomenderos cuyo linaje provenía de los primeros conquistadores. Hacia finales del siglo XVIII se dedicaban principalmente a sus estancias ganaderas en el interior, donde también poseían plantaciones de tabaco y

${ }^{210}$ CABALLERO CAMPOS, Herib. El Virreinato del Río de la Plata..., op. cit., p. 138.

${ }^{211}$ Una vara correspondía a aproximadamente 84 centímetros.

${ }^{212}$ CABALlERO CAMPOS, Herib. El Virreinato del Río de la Plata..., op. cit., p. 141.

${ }^{213}$ WHIGHAM, Thomas. La economía de la independencia..., op. cit., p. 62.

${ }^{214}$ CABALlERO CAMPOS, Herib. El Virreinato del Río de la Plata..., op. cit., p. 141. 
controlaban una parte de la extracción de yerba mate. Esta embrionaria burguesía nacional estaba íntimamente ligada, por negocios y lazos matrimoniales, con las autoridades metropolitanas. También tenían relaciones de negocios con financistas radicados en Buenos Aires, sobre todo en el ramo de la yerba mate.

Muchos de estos terratenientes nacidos en la provincia componían la oficialidad intermedia del ejército colonial. Las reformas militares en el marco del Virreinato crearon un núcleo de oficiales criollos, seleccionados entras las familias más acaudaladas y propietarias de tierras: Yegros, Montiel, Cabañas, Iturbe, entre otros. Además de su posición social privilegiada, los rangos militares garantizaban prestigio y una considerable autoridad política local. También gozaban de otros privilegios que los diferenciaban aún más del resto de la población, como el fuero militar vitalicio que los eximía de las actuaciones de la justicia ordinaria. Estas prerrogativas, otorgadas a oficiales que además actuaban como hacendados y comerciantes, concedían a este sector de clase una parte nada desdeñable de ventajas y protección a la hora de hacer negocios ${ }^{215}$.

Sin embargo, existía una contradicción que el crecimiento económico y comercial acelerado por las reformas borbónicas acentuaría al máximo: a pesar de su importante poder económico, estos criollos ricos estaban desplazados del poder político efectivo y del control directo del comercio exterior, todavía acaparado por los europeos y, en menor medida, por los comerciantes porteños.

En el campo, como expusimos, existía el mediano y pequeño campesino mestizo jurídicamente libre. Sin embargo, como mostramos, la mayoría de la población rural no poseía tierras y trabajaba en parcelas ajenas para satisfacer su alimentación básica, colocando una parte de sus cosechas en el mercado interno. El campesino rico, que explotaba mano de obra de indios encomendados o de esclavos negros, era minoritario.

En la capital, además, existía una clase media urbana de criollos que, como los campesinos pobres, no dependía directamente del comercio exterior -doctores, abogados, una reducida intelectualidad, oficiales y prelados de rangos inferiores, pequeños artesanos, comerciantes, tenderos, etc.-, que también se sentía oprimida por la Corona y estaba deseosa de ascender social y políticamente.

En suma, el final de la Colonia estuvo marcado por un relativo cambio en el panorama de marginalidad comercial, propiciado por las medidas borbónicas. La creación

215 ARECES, Nidia; GONZALEZ DE BOSIO, Beatriz. El Paraguay durante los gobiernos de Francia y de los López. Asunción: El Lector, 2010, p. 41. 
del Virreinato del Río de la Plata en 1776; el Reglamento de Libre Comercio en 1778; la supresión del Puerto Preciso de Santa Fe en 1779; el Estanco del Tabaco en ese mismo año, que introdujo por primera vez la circulación y los intercambios en metálico en el mercado interno; la creación en 1782 de la Gobernación Intendencia del Paraguay-que reincorporaba los treinta pueblos de las Misiones guaraníes- ${ }^{216}$ fueron todas medidas que hacían parte de un reordenamiento comercial y fiscal que no solo benefició a la metrópoli sino que, de manera secundaria, también enriqueció a sectores de las clases propietarias nativas, que exactamente por ese motivo potenciaron sus aspiraciones de sacarse de encima el peso del monopolio político y comercial del Imperio español. La expansión comercial creó una presión centrífuga, no al contrario ${ }^{217}$.

Pero no se debe exagerar el impacto de las medidas borbónicas - una tentación típica de la historiografía liberal-, puesto que este fue relativo a la ubicación de la provincia en el sistema colonial hispánico. A pesar del mayor flujo comercial, la provincia paraguaya siguió siendo marginal y sometida a la doble dependencia de la metrópoli y del puerto de Buenos Aires, ciudad que se benefició más que ninguna otra con la relativa liberalización del comercio.

Siglos de marginalidad en un territorio constantemente amenazado y que se unificó solo hacia finales del siglo XVIII; el amplio mestizaje étnico; y, sobre todo, el uso extendido del idioma guaraní, confluían en el proceso histórico de conformación de la nacionalidad paraguaya $^{218}$. Una nación que nació pobre y oprimida; doblemente oprimida.

Al despertar el siglo XIX, los españoles europeos y unas pocas familias de terratenientes criollos -que, a lo largo de tres siglos, y de manera deformada y subordinada a la dominación colonial, se habían incorporado a la clase propietaria de los medios de

\footnotetext{
216 El territorio del Virreinato se dividió en ocho intendencias y dos gobiernos militares: Buenos Aires (superintendencia), Paraguay, Tucumán (con Córdoba), Santa Cruz de la Sierra (con Cochabamba), La Paz, Mendoza, Charcas y Potosí.

${ }^{217}$ Sobre los cambios del siglo XVIII, ver: ROMERO DE VIOLA, Blanca Rosa. Paraguay siglo dieciocho: Período de transición. Asunción: Ediciones Comuneros, 1987. Sobre la era de la Intendencia: ACEVEDO, Edberto Oscar. La Intendencia del Paraguay en el Virreinato del Río de la Plata. Buenos Aires: Ediciones Ciudad Argentina, 1996; COONEY, Jerry. Economía y sociedad en la Intendencia del Paraguay. Asunción: CEPES, 1990. Sobre el ocaso del sistema colonial, ver: MONTE DE LÓPEZ MOREIRA, Mary. Ocaso del colonialismo español: El gobierno de Bernardo de Velasco y Huidobro, su influencia en la formación de Estado paraguayo [1803-1811]. Asunción: Fondec, 2006.

${ }^{218}$ El idioma guaraní sigue siendo la lengua materna de la mayor parte de la población. Resistió a muchos intentos de erradicarla. El más conocido es su prohibición tras la derrota del Paraguay en la guerra contra la Triple Alianza, pero también encontramos ese tipo de medidas en la Colonia. Ver: Real Cédula que ordena que en los Reinos de Indios y Filipinas se ponga en práctica una propuesta del Arzobispo de México para que se destierren los idiomas locales y solo se hable el castellano. ANA-SH, v. 62, n. 5.
} 
producción, transporte y circulación dentro de la provincia- continuaban controlando la economía, en detrimento de las clases trabajadoras, amplia mayoría de la nación.

El relativo auge económico solo aumentará las contradicciones entre esa incipiente burguesía nacional y el monopolio colonial español, que controlaba el comercio, la política, el sistema impositivo y, principalmente, el aparato estatal con sus fuerzas armadas.

En contraposición, decenas de miles de pequeños campesinos pobres, jornaleros, indígenas encomendados y negros esclavizados, intentaban ganarse el sustento diario por medio de la combinación de distintas relaciones de producción.

\section{UN ANÁLISIS-JUSTIFICACIÓN DE LA VISIÓN EUROCÉNTRICA Y ETAPISTA}

Si el análisis anterior es correcto, la formación económico-social del período colonial no puede definirse como "régimen de explotación feudal de casta", "método de explotación feudal de tipo esclavista", o bien "método feudal-patriarcal" 219 , todas ellas categorías creadas y entre las cuales oscila Oscar Creydt, sino como un entrelazamiento desigual y combinado de formas de extracción del excedente social al servicio de una lenta acumulación originaria de capital.

Esta definición tiene importancia y consecuencias programáticas que llegan hasta la actualidad. En el siglo XX, con la premisa de que el Paraguay no había superado su etapa "feudal", tanto Creydt como todos los partidos comunistas orientados desde Moscú, justificaron la concepción etapista de que no estaban planteadas las condiciones objetivas para la revolución socialista ni en el Paraguay ni en los demás países atrasados en el sentido capitalista.

Según este relato, la gran tarea consistía en impulsar una revolución burguesa democrática y antifeudal que, primero, desarrollara el capitalismo y las instituciones parlamentarias liberales. La lucha por un programa socialista solo podría plantearse después de superar esa primera etapa burguesa. Para esto, establecer alianzas que se concretaran por medio de los llamados frentes populares, o bien dar apoyo político a sectores o gobiernos capitalistas supuestamente "progresistas", no solo se hizo lícito, sino que se planteó como condición indispensable.

Creydt, por ejemplo, sostuvo que "la burguesía continúa siendo una fuerza objetivamente revolucionaria por sus intereses de clase, y participa de la lucha en cierta

${ }^{219}$ CREYDT, Oscar [1963]. Formación histórica de la nación paraguaya..., op. cit., pp. 61-63. 
medida y forma"; y que, por consiguiente, "puede apoyar la revolución en cierta medida y colaborar con el desarrollo de la industria nacional" ${ }^{220}$. En otras palabras, para el histórico dirigente del PCP, la burguesía o sectores de ella todavía podían cumplir un papel progresivo $\mathrm{y}$ hasta revolucionario en pleno siglo XX.

Esto explica el apoyo político del PCP a los más diversos gobiernos burgueses, incluso algunas dictaduras militares, como la del coronel Rafael Franco en 1936.

Este es solo un ejemplo de que los análisis históricos tienen consecuencias prácticas en el presente. En su afán de "desarrollar el capitalismo", el PCP, como todo el estalinismo latinoamericano con sus variantes, se empeñaron en la búsqueda de algún sector de la elite empresarial patriota o progresiva a quien ofrecer apoyo o concretar alianzas permanentes con la mira puesta en gestionar Estados capitalistas. Evidentemente, un abandono de los postulados básicos del marxismo tradicional.

En nuestra opinión, a partir una reflexión teórica concienzuda sobre el proceso histórico, es necesario retomar la discusión sobre el tema y dejar a un lado las categorías y los rígidos esquemas de Creydt, no solo por estar obsoletos sino porque parten de una premisa y una lectura equivocadas del período colonial. Durante décadas, esa interpretación histórica, construida para justificar en el siglo XX la doctrina de conciliación de clases, educó a buena parte de la izquierda en Paraguay que, como analizaremos, adolecía también de negativas influencias del nacionalismo conservador.

220 Ídem, p. 112. 


\section{CAPÍTULO III - EL CONTENIDO DE LAS INDEPENDENCIAS EN DEBATE}

"Las revoluciones por la independencia de Hispanoamérica fueron repentinas, violentas y universales".

JOHN LYNCH.

Las independencias en América Latina están entre los grandes acontecimientos históricos del siglo XIX. Los elementos fundamentales de este proceso se combinaron en un torrente de acontecimientos arrasadores, en el que la crisis política -en general, devenida en violencia- fue protagonista de sus puntos de inflexión: guerras napoleónicas en Europa; crisis en las metrópolis ibéricas; golpes y contragolpes políticos por doquier; una guerra de liberación que, paralelamente, englobó guerras civiles, con diversa intensidad y duración, entre facciones criollas. El caso de Hispanoamérica es, en este sentido, el más revelador.

En este capítulo no se intentará reseñar la totalidad de este proceso poliédrico sino problematizar algunas de las interpretaciones que, según sugiere la bibliografía consultada, fueron o son más influyentes. A partir de ese repaso, plantearemos propuestas de caracterización de este movimiento general.

El énfasis de nuestra atención estará puesto en el proceso hispanoamericano, debido a su imbricación más directa con la cuestión paraguaya. La experiencia del Brasil, antigua colonia portuguesa en América, supone un caso importante, pero con marcadas diferencias con el devenir político-social de la América hispánica ${ }^{221}$. Al respecto, parece adecuado asumir las palabras de Lincoln Secco:

O Brasil sempre foi um tema complexo. Sua independência foi singular, mas desprovida de radicalismo; a proclamação da República não gerou um regime

\footnotetext{
${ }^{221}$ Para el caso brasileño, entre otros, consultar: RICUPERO, Rodrigo. O exclusivo metropolitano no Brasil e os Tratados diplomáticos de Portugal como a Inglaterra (1642-1661). Revista de História, São Paulo, n. 176, 2017. Disponible en: <http://www.scielo.br/scielo.php?script=sci arttext\&pid=S003483092017000100307\&lng=en\&nrm=iso $>, \quad$ consultado el 15/01/2020; RICUPERO, Rodrigo. O estabelecimento do exclusivo comercial metropolitano e a conformação do Antigo Sistema Colonial no Brasil. História, Franca, v. 35, e100, $2016 . \quad$ Disponible $<$ http://www.scielo.br/scielo.php?script=sci arttext\&pid=S0101-90742016000100509\&lng=en\&nrm=iso $>$, consultado el 09/02/2020; CARDOSO, Ciro. A crise do colonialismo luso na América portuguesa. In: LINHARES, Maria (Org.): História geral do Brasil..., op. cit., pp. 89-110; CHIARAMONTE, José. Metamorfoses do conceito de nação durante os séculos XVII e XVIII. In: JANCSÓ, István (Org.). Brasil: formação do Estado e da nação. São Paulo: Hucitec/Fapesp/Editora Unijuí, 2003, pp. 61-91; COSTA, Wilma. A economia mercantil escravista nacional e o processo de construção do Estado no Brasil (1808-1850). In: SZMRECSÁNYI, Tamas; AMARAL LAPA, José Roberto do (Org.): História econômica da independência e do império. São Paulo: Hucitec, 1996, pp. 147-159.
} 
republicano; a revolução burguesa não se completou; seu desenvolvimento reproduziu o subdesenvolvimento $[\ldots]^{222}$.

Por lo tanto, escapa a nuestro propósito y recursos encarar con rigor la tarea de ahondar en los problemas que plantea esa materia, a no ser aquellos estrictamente necesarios o relacionados con el objeto de este trabajo.

Delimitado lo anterior, subrayamos algunos hechos a modo de contexto.

La invasión napoleónica de 1808 actuó como detonador de una crisis estructural, casi terminal, de la monarquía española, que agudizó su curso de decadencia en el último tercio del siglo XVIII. Como habíamos anticipado en un apartado anterior, la crisis radicó en su atraso industrial con relación a otras potencias europeas. Los sucesos de Bayona dejaron acéfalo el trono español y se abrió una crisis de poder en todo el Imperio. Las Juntas de gobierno surgieron en las principales ciudades de América como respuesta al vacatio regis en Europa. Esas instancias, al tiempo que buscaron asegurar una cuota mayor de autonomía en relación con la metrópoli, en una primera fase proclamaron ejercer soberanía en nombre de la autoridad de Fernando VII, el rey cautivo. Este es el período de la "máscara de Fernando VII", signado por la indefinición y confusión políticas. Sin embargo, aunque muchos de sus protagonistas criollos -que al comienzo no pretendían ir más allá de una posible negociación con los Borbones- no lo supiesen, aquella coyuntura crítica había desatado las fuerzas necesarias para inaugurar una dinámica de ruptura definitiva con Madrid en un plazo relativamente corto.

Si bien la tendencia centrífuga preexistía, esta llegó a un punto de no retorno, no por la decisión independentista -o "separatista", desde la óptica metropolitana- de los dirigentes criollos sino por la intransigencia de España a la hora de conceder algo más de autonomía y por su empeño, desde 1814, en recuperar por la fuerza lo que consideraba sus dominios. El hispanista británico John Lynch reforzó esta idea en cierta ocasión: "España arruinó su oportunidad de mantener buenas relaciones con América Latina negándose a aceptar la independencia de las colonias, acusándolas de rebeldía y tratando de movilizar a las fuerzas europeas en su contra" 223 .

La posición de la Corona forzó a las facciones más poderosas de las clases propietarias americanas no solo a dejar de reconocer cualquier autoridad metropolitana sino

\footnotetext{
222 SECCO, Lincoln. Caio Prado Júnior..., op. cit., p. 229.

${ }^{223}$ LYNCH, John. El caudillismo en Latinoamérica no se debe a la herencia española. El País, 22/09/2007. Disponible en: <https://elpais.com/diario/2007/09/22/cultura/1190412012_850215.html>, consultado el 28/01/2020.
} 
a organizar ejércitos patriotas o libertadores para resistir las expediciones de pacificación enviadas desde la Península. Entre los ejércitos independentistas se destacan el dirigido por los padres católicos Miguel Hidalgo y José María Morelos en el actual México; el sometido a las órdenes del venezolano Simón Bolívar que actuó desde el norte de Sudamérica libertador de los territorios actuales de Bolivia, Colombia, Ecuador, Panamá, Perú y Venezuela-; y el comandado por el general José de San Martín que tuvo el grueso de sus operaciones en el Río de la Plata -libertador de lo que hoy es Argentina, Chile y Perú-. Desde la perspectiva de los sectores sociales explotados de la antigua sociedad colonial, sobre todo indígenas y negros esclavizados, puede afirmarse que la guerra de liberación representó el auge de su participación. La intervención de los sectores oprimidos, aunque indispensable para ganar la guerra, siempre estuvo controlada por las elites locales, que buscaron equilibrar sus temores divididos entre la poderosa reacción de la metrópoli y una posible "haitianización" del proceso. Huelga decir que la guerra tuvo dimensiones continentales, no solo por su dilatado escenario de operaciones sino porque su desenlace tuvo impacto en todos los territorios hispanoamericanos. Otra de las características más interesantes es la simultaneidad con la cual se manifestó la empresa emancipadora en distintas regiones. Una reacción en cadena.

En el terreno militar, por ejemplo, la independencia del Perú -el virreinato que actuaba como base de la reacción españolista en el Alto Perú, Quito, Chile y el Río de la Plata-, se conquistó por medio de la acción coordinada, aunque en momentos distintos, de los ejércitos comandados por San Martín y Bolívar, que derrotaron a los realistas entre 1821 y $1824^{224}$. Este último comprendió que debía ensanchar las alianzas y estableció relaciones con la República de Haití y con los llaneros venezolanos en 1815. A su vez, prometió la libertad de los esclavos que se enrolasen en los ejércitos libertadores y realizó esfuerzos sistemáticos para atraer a sectores indígenas a la causa americanista.

El lento y tempestuoso proceso de consolidación-institucionalización de la independencia de los nuevos Estados nacionales comenzó en la década de 1820, con la caída de los dos virreinatos más importantes: Nueva España y Perú, ambos en 1821. Dos hitos de esta fase: el Trienio Liberal en España entre 1820-1823, que creó condiciones para la creación del Ejército Trigarante -religión católica, independencia y unidad- que entró

\footnotetext{
${ }^{224}$ Sobre el proceso general, consultar: PRADO, Maria. A formação das nações latino-americanas. 3. ed. São Paulo: Atual; Campinas: Editora da Universidade Estadual de Campinas, 1987; BARBOSA, Alexandre de Freitas. A independência dos países da América Latina. 2. ed. São Paulo: Saraiva, 1999.
} 
triunfante en la ciudad de México en 1821; en Sudamérica, la victoria independentista que derrotó el último ejército españolista en la batalla de Ayacucho, librada en 1824. Aunque, si se prefiere, la derrota definitiva de la metrópoli española puede sellarse con la capitulación de sus tropas en enero de 1826, ante el asedio marítimo y terrestre de las fuerzas anticoloniales en el segundo sitio del Callao, Perú.

La última tentativa por parte de la Corona española para reconquistar América se produjo sobre sus antiguas posesiones mexicanas, con la expedición de Isidro Barradas que en 1829 llegó a Tampico. Casi sin posibilidades de éxito desde el principio, también fue derrotada. Con todo, guerrillas realistas residuales continuaron hostilizando a los frágiles gobiernos independientes, por ejemplo, entre 1823 y 1827 en Venezuela; entre 1822 y 1826 en Pasto, Colombia; hasta 1832 en el sur de Chile; y entre 1825 y 1828 por medio de la guerrilla de Iquicha en el Perú.

El colofón del conflicto estuvo marcado, primero, por la Revolución de 1830 que liquidó definitivamente el absolutismo en Francia. Para el rey Fernando VII esto implicó la pérdida de uno de sus principales apoyos. En efecto, puede decirse que todos los proyectos militares de España para reconquistar Hispanoamérica finalizaron en 1833, con la muerte del monarca. Las Cortes de España, sin más remedio, renunciaron a las ex colonias americanas en 1836 y autorizaron al gobierno a concertar tratados de paz y reconocimiento con los nuevos Estados surgidos en el continente. Aunque, en el caso de países como Paraguay, el reconocimiento de su soberanía por parte de Madrid debió esperar hasta 1880.

Al final, la guerra de independencia hispanoamericana creó siete unidades políticas independientes: el Imperio mexicano, que sería reemplazado por una República en 1823; la Gran Colombia; las Provincias Unidas del Río de la Plata; Chile; Perú; Bolivia; y Paraguay.

De esta suerte, si en 1810, aunque con muchas contradicciones y una debilidad inocultable, la Corona española dominaba un extenso imperio, dividido en cuatro virreinatos en los cuales habitaban alrededor de diecisiete millones de personas, tres lustros después los Borbones solo señoreaban Puerto Rico y $\mathrm{Cuba}^{225}$.

Algunos interrogantes: ¿cómo esto fue posible? ¿Se trató de un rayo en cielo sereno o es posible establecer los antecedentes económicos-sociales-culturales que incubaron

\footnotetext{
${ }^{225}$ En 1898, los Estados Unidos ganaron la Guerra Hispano-estadounidense y ocuparon Cuba y Puerto Rico, terminando con el dominio español en América. Cuba obtuvo la independencia en 1902. Por su parte, Puerto Rico es considerado un Estado Libre Asociado dependiente de los EEUU desde 1952.
} 
semejante conflicto? ¿Cuál fue el carácter, el contenido esencial, de ese proceso multifacético?

¿Fueron revoluciones o no? Si se acepta calificarlas como revoluciones: ¿fueron sociales o se limitaron a la arena política?, ¿cuál fue la clase social dirigente? Formulado de la manera que más inquieta a la historiografía especializada actual: ¿primaron los elementos de ruptura o de continuidad con el antiguo sistema colonial?; ¿existían elementos incipientes de nacionalidad en las regiones que lucharon por su independencia, o bien el proceso de conformación de las nacionalidades comenzó únicamente después de la derrota española y a raíz de la descolonización efectiva?; ¿hubo participación real de las clases explotadas?, ¿en qué medida?, ¿qué cambió en la vida de los indígenas encomendados o reducidos, de los negros esclavizados o "libres", de los jornaleros o pequeños campesinos con el fin de la Colonia? En suma: ¿el nuevo orden que surgió de las entrañas de un sistema colonial que duró más de tres siglos fue progresivo o retrógrado?

Tales son las cuestiones dudosas que esta investigación pretende indagar y, en la medida de lo posible, problematizar, proponer hipótesis y conclusiones más meditadas. Pero sin perder de vista que nuestro desafío teórico consiste en traducir cómo ese proceso continental y estos interrogantes se ajustan a las complejas particularidades del caso paraguayo.

El estudio de las independencias, como es sabido, es por demás intrincado y a menudo está cruzado por la emotividad identitaria, cuando no nacionalista y hasta chovinista. Por otro lado, no puede afirmarse que la literatura historiográfica liberal respondió a esas presiones de manera convincente. Esto, en realidad, no debe sorprender. El relato histórico, cuya elevación a estatus oficial alterna entre diferentes narrativas según circunstancias políticas y sociales, siempre fue un recurso ideológico utilizado para incidir políticamente en el presente.

Sin embargo, en las últimas décadas, a veces de modo acertado, y otras veces desacertado, la historiografía especializada intenta contraponer una lectura de la historia menos apasionada y más anclada en el estudio de fuentes primarias. Existe un esfuerzo en buscar base documental para hechos o proposiciones que antes se daban por sentado, sin más. Propone un enfoque multidisciplinario que hace que la ciencia histórica sea permeada por otras áreas humanísticas, proceso que debe tomarse como saludable.

Como hemos adelantado, este capítulo pretende contextualizar el proceso general de las independencias para, en las siguientes partes, analizar con más atención el caso 
paraguayo. Por consiguiente, excede el límite de esta sección una reflexión teórica exhaustiva sobre las distintas interpretaciones y matices que existen sobre las independencias hispanoamericanas y el impacto de sus consecuencias. Igual de pretensioso sería apuntar, con el rigor que esto demanda, cuáles son los temas pendientes de investigación o aquellas lagunas teóricas inexploradas. En las siguientes páginas haremos el intento de entrar en materia, y delimitar presupuestos que serán desarrollados más adelante.

La primera premisa que establecemos para orientarnos en el estudio de este "laberinto" histórico está relacionada con el carácter del proceso como un todo. Estamos entre quienes sostienen que fueron revoluciones -lo cual, como veremos, no significa que no existieron continuidades con el antiguo sistema colonial-.

Ahora bien, su carácter está determinado por su período histórico -la época de las revoluciones democrático-burguesas inaugurada con la Revolución Francesa que se inició en $1789^{226}$ o, si se quiere, con la Revolución de Independencia de las trece colonias británicas que dio origen a los Estados Unidos entre 1775 y 1783-, contexto internacional que planteó las bases materiales, las tareas esenciales y las limitaciones del proceso en ambas orillas del Atlántico. Desde luego, el alcance de la materialización de esas tareas generales fue distinto en cada país o región.

La ubicación del proceso de autodeterminación de las antiguas colonias americanas en ese ciclo de revoluciones burguesas, como acuñaron Eric Hobsbawm, Manfred Kossok ${ }^{227}$, entre otros, nos parece fundamental para delimitar los rasgos generales que incidirán desigualmente en las particularidades. Simón Bolívar llevaba razón cuando cierta vez escribió que: "para entender las revoluciones y a sus participantes debemos observarlos de cerca y juzgarlos de lejos" 228 .

\footnotetext{
226 La Revolución Francesa asestó un golpe mortal tanto al imperio colonial francés, con consecuencias inmediatas en Haití -la primera revolución negra triunfante y el proceso anticolonial más radical-, como -a través de la invasión napoleónica de 1808, que derrocó a los Borbones e inició un proceso de crisis irreversible en sus posesiones americanas- al colonialismo español. Entre las muchas obras sobre el tema, destacamos la trilogía Albert Matthiez: MATTHIEZ, Albert. La Revolución Francesa. La caída de la realeza. Tomo I. Barcelona: Editorial Labor, 1935; MATTHIEZ, Albert. La Revolución Francesa. La Gironda y la Montaña. Tomo II. Barcelona: Editorial Labor, 1935; MATTHIEZ, Albert. La Revolución Francesa. El Terror. Tomo III. Barcelona: Editorial Labor, 1935. Consultar también: SOBOUL, Albert. A revolução francesa. São Paulo: DIFEL, 1985.

${ }^{227}$ HOBSBAWM, Eric [1977]. A era das revoluções [1789-1848]. 33. ed. Rio de Janeiro: Paz e Terra, 2015; KOSSOK, Manfred. El contenido burgués de las independencias de América Latina. Secuencia-Revista de historia y ciencias sociales, México D.F., n. 13, pp. 144-162, 1989; KOSSOK, Manfred. El Virreinato del Río de la Plata. Su estructura económica-social. Buenos Aires: Editorial Futuro, 1959; CHUST, Manuel; SERRANO, José Antonio. Debates sobre las independencias. Madrid-Frankfurt: Vervuert-Iberoamericana, 2007.

228 Simón Bolívar a Pedro Gual, Mompós, 09/02/1815. In: O’LEARY, Daniel F. Memorias del General O'Leary. v. XIV. Caracas: Ministerio de la Defensa, 1981, pp. 67-69.
} 
Otra proposición básica es que, en el caso americano, el proceso de crisis y desintegración del sistema colonial europeo -sobre todo de los antiguos imperios ibéricosfue por partida doble y combinada: de un lado, significó una lucha continental para emancipar las colonias de las metrópolis; de otro, una disputa paralela y no menos violenta para conformar los nuevos Estados nacionales independientes ${ }^{229}$. Tal es la importancia histórica del siglo XIX para nuestro continente.

En general, los estudios contemporáneos no cuestionan la comprensión de que la independencia americana fue parte de la era revolucionaria liberal-burguesa que, a su vez, fue condición clave para la posterior formación-institucionalización de los Estados nacionales modernos, con sus respectivos regímenes políticos, tanto republicanos como monárquicos, en el caso del Brasil y, más brevemente, de México ${ }^{230}$.

Nidia Areces, por ejemplo, resalta la importancia del concepto de "era de las revoluciones, puesto que da lugar a incluir las independencias latinoamericanas, un proceso regional, en el amplio contexto de cambios sustanciales que suceden en el mundo atlántico y que, en definitiva, conformaron los Estados nacionales modernos"231.

Esa primera delimitación analítica cuestiona, entre otras, las interpretaciones que separan los movimientos de independencia de las revoluciones producidas en Europa o en las ex colonias inglesas de Norteamérica.

Como anotamos en la introducción a nuestra tesis, en los últimos años los historiadores especializados tendieron a situar las independencias no en el clásico espacio temporal de 1810 a 1826 sino en un contexto más extenso, por ejemplo, entre 1750 y 1850 , para así abordar desde un mejor ángulo la complejidad que significó la transformación de las colonias en Estados independientes y cómo esas nuevas entidades conservaban mucho de la Colonia. El interés, por otro lado, pasó a enfocarse en el balance entre continuidad y cambios en el terreno económico, social, cultural, abarcando el estudio específico de sectores sociales comúnmente relegados por las lecturas oficiales.

Sobre el carácter de las revoluciones independentistas, se sostendrá aquí que, tanto en la ex provincia del Paraguay como en el resto de la región, no se desarrolló una revolución

\footnotetext{
${ }^{229}$ Sobre las disputas en el Río de la Plata, recomendamos: POMER, León. Os conflitos na Bacia do Prata. São Paulo: Brasiliense, 1979.

230 CHUST, Manuel; FRASQUET, Ivana. Las independencias en América. Madrid: Catarata, 2009; FRASQUET, Ivana; SLEMIAN, Andréa (Org.). De las independencias iberoamericanas a los estados nacionales (1810-1850). 200 años de historia. Madrid: Ahila- Vervuert Iberoamericana, 2009; FRASQUET, Ivana (Coord.). Bastillas, cetros y blasones: la independencia en Iberoamérica. Madrid: Mapfre, 2006.

${ }^{231}$ CHUST, Manuel (Org.). Las independencias iberoamericanas en su laberinto: controversias, cuestiones, interpretaciones. Valencia: Publicacions de la Universitat de Valencia, 2010, p. 49.
} 
económico-social sino político-institucional. Una definición que tendremos oportunidad de profundizar más detalladamente en otros apartados, a la luz del análisis de los antecedentes y de las medidas de los primeros gobiernos nacionales del Paraguay. Baste aquí, siempre a manera introductoria, con mencionar algunos elementos que componen la esencia de esta interpretación.

$\mathrm{Si}$, como examinamos y discutimos en los capítulos anteriores, en América no hubo feudalismo -que no necesariamente es lo mismo que relaciones de tipo servil o alta concentración de tierras- sino un capital comercial y usurario que succionaba el excedente social de la economía local de manera insaciable y valiéndose de todo tipo de violencias, no es coherente afirmar que el proceso de las independencias latinoamericanas haya sido un ciclo de revoluciones sociales - precisamente, burguesas "antifeudales"-.

Dicho de otra forma, si el contenido de la colonización estuvo dictado desde el comienzo por las leyes de acumulación originaria de capital -es decir, en medio de la coexistencia de relaciones sociales capitalistas en imparable ascenso y un feudalismo decadente en la misma Europa-, la liberación de las colonias no podía tener como objetivo liquidar socialmente un feudalismo estructuralmente inexistente. Es más, está comprobado que ni siquiera se propuso acabar con esa convivencia de modos de producción precapitalistas con embriones de trabajo "libre" en las sociedades surgidas del período colonial. Aquello fue resultado, en el mejor de los casos, de una combinación entre presión social de "los de abajo" con las nuevas exigencias que imponía el mundo industrializado, bien entrado el siglo XIX.

Sostener que el proceso se trató esencialmente de una secuencia de revoluciones políticas no supone negar que hubo cambios sociales sino entender que estos se dieron, por norma, de manera gradual y controlados “desde arriba”. Es decir, si bien no se planteó acabar de cuajo con las relaciones no capitalistas de producción, es cierto que, de manera dialéctica, la autodeterminación política posibilitó, en un período más o menos prolongado, las condiciones materiales para el desarrollo de un capitalismo nacional, aunque siempre periférico.

Así pues, proponemos calificar el proceso como revoluciones democráticoburguesas anticoloniales, una variante de las revoluciones democrático-burguesas clásicas que se dieron en Europa.

Esta definición es controvertida. Para el reconocido académico Jaime Rodríguez, entre otros, si bien el proceso consistió en una revolución política y no social, no se trató de 
un movimiento anticolonial. Según ese enfoque, las revoluciones hispanoamericanas formaron parte de un proceso que se dio en un contexto más amplio: la crisis en el "mundo hispánico", que tiene como elemento central la disolución de la monarquía española ${ }^{232}$. Esta ubicación parte de la noción, que comparte con el reconocido historiador F. Guerra y otros, que configura la llamada visión atlántica del período.

Rodríguez, en el afán de cuestionar las interpretaciones de corte nacionalista, en nuestra opinión acaba cometiendo el error de menospreciar el peso decisivo de la relación colonial y, por consiguiente, el carácter de liberación nacional del enfrentamiento entre patriotas y realistas. Esto es más nítido en las premisas que propone dejar de lado:

Por lo general [la historiografía tradicional, nda.], sostiene que España había sido una potencia colonial retrógrada y represiva y que la independencia era el único medio para liberar a los americanos de la opresión. También mantienen que las naciones ya existían antes que el Estado y que la emancipación simplemente reconoció la existencia de tales entidades políticas independientes ${ }^{233}$.

Por otra parte, la noción de un mismo proceso a ambos lados del Atlántico, puede resultar engañosa. No porque no haya existido una relación indisoluble de acontecimientos en la Península ibérica y en América, sino porque ese concepto distorsiona el carácter del proceso y diluye el papel de los actores. En cierta medida, retoma la idea, convenientemente difundida por el nacionalismo español nostálgico de sus tiempos imperiales, de que España y las colonias americanas constituían un único reino, como si fuesen partes con igualdad de condiciones y derechos dentro del "mundo hispánico". Un único reino en el que España era una entidad más. Y eso no se ajusta a la realidad.

Las propuestas más extremas de la llamada visión o revolución Atlántica -un concepto atractivo por ser "euroamericano" pero que no deja de ser geográfico- pasan por alto un hecho inocultable: en una orilla, sí existía una potencia colonial "retrógrada y represiva"; en la otra, colonias oprimidas y explotadas por esa metrópoli. Esto se comprueba en que el liberalismo gaditano, que encontró su auge en el movimiento doceañista, nunca pretendió ir más allá de reformar la monarquía hispánica ${ }^{234}$ por medios constitucionales y, mucho menos, renunciar al dominio sobre las colonias americanas. La participación americana en el proceso de reformas liberales en España, como veremos en otros pasajes de nuestro trabajo, fue siempre marginal ${ }^{235}$. La explicación de este hecho es que España sí era

${ }^{232}$ RODRÍGUEZ, Jaime. La independencia de la América española. 2. ed. México D.F: FCE, 2005, p. 1.

${ }^{233}$ CHUST, Manuel (Org.). Las independencias iberoamericanas en su laberinto..., op. cit., p. 329.

${ }^{234}$ En el sentido de su profundidad programática, nos parece imposible comparar el liberalismo español con el movimiento democrático-burgués que promovió, por ejemplo, la Revolución Francesa.

${ }^{235}$ Sobre ese proceso, consultar: BREÑA, Roberto (Org.). Cádiz a debate: actualidad, contexto y legado. México D.F.: El Colegio de México-Centro de Estudios Internacionales, 2014. 
una potencia colonial. Por lo tanto, incluso para el liberalismo peninsular más avanzado, siempre estuvo claro que renunciar a sus posesiones ultramarinas equivaldría a un suicidio material, algo imposible cuando de privilegios se trata. Ni hablar de los sectores absolutistas. Y no fue por otro motivo que -incluso a pesar de que amplios sectores propietarios criollos agotaron todas las vías de negociación para obtener un poco más de autonomía- la crisis derivó en una escalada que desembocó en una guerra por el control de las Américas.

Cabe insistir, para cerrar el paso a cualquier romantización de los "padres de la Patria", que la embrionaria burguesía criolla, propietaria de importantes medios de producción durante el período colonial, decidió enfrentar (militarmente) a la Corona española solo cuando comprendió que esta no negociaría ninguna concesión de autonomía real. El objetivo de esta cruzada emancipadora no era el bienestar de la plebe ${ }^{236}$ sino sacarse la intermediación colonial de encima para comerciar directamente en el mercado internacional, principalmente con el pujante Imperio británico. Esta definición es importante para entender el carácter del proceso.

John Lynch, que escribió una biografía política del Libertador, escribe al respecto: "Bolívar nunca pretendió ser un revolucionario social. Fue un reformista, que aceptó la situación internacional y que actuó con deferencia ante el superpoder de su tiempo, Gran Bretaña" ${ }^{237}$. El hispanista inglés, de hecho, presenta al icónico venezolano como un "aristócrata por cuna y formación" $" 238$.

No se trató de revoluciones sociales porque, en definitiva, los sectores más fuertes de la burguesía criolla nunca pretendieron cambiar las relaciones de producción ni ampliar derechos democráticos para los oprimidos, sino arrebatar a los españoles el control de las instituciones políticas. En la jerga marxista, no querían un cambio en la estructura social sino superestructural.

En el plano estructural - quizá con la sola excepción del caso haitiano [1791-1804] y la corta experiencia de la insurgencia mexicana liderada por el padre Miguel Hidalgo en 1810-, las independencias no buscaron cambiar sustancialmente las relaciones de producción entre las clases sociales. Siguieron coexistiendo y combinándose desigualmente relaciones de producción precapitalistas y capitalistas (incipientes) como en el período

\footnotetext{
${ }^{236}$ IRUROZQUI, Marta. La justicia del pueblo. Ciudadanía armada y movilización social. In: IRUROZQUI, Marta; GALANTE, Mirian (Ed.). Sangre de Ley. Violencia y justicia en la institucionalización del Estado: América Latina, siglo XIX. Madrid: Ed. Polifemo-GEA, 2010, pp. 235-276.

${ }^{237}$ LYNCH, John. El caudillismo en Latinoamérica no se debe..., op. cit.

${ }^{238}$ LYNCH, John. Simón Bolívar. Barcelona: Editorial Crítica, 2010, p. 213.
} 
colonial. La posición de las naciones latinoamericanas -incluido el Paraguay, mal que le pese a los autores nacionalistas- en el sistema mundial de Estados y en la división internacional del trabajo tampoco cambió -básicamente, continuaron siendo proveedoras de productos primarios-.

En esto sí acierta Jaime Rodríguez: “la revolución hispánica fue en esencia una transformación política. En general, las estructuras sociales, económicas y legales cambiaron con mayor lentitud"239.

En esa misma dirección, apunta Lynch:

Esencialmente, yo creo que hay que hablar de una independencia política. Fueron movimientos políticos dirigidos y organizados por un sector de la sociedad, sin gran participación masiva. En algunos países hubo cierta presencia popular, pero en general fue un movimiento dirigido por la elite criolla, destinado a reemplazar a la elite española al frente del poder ${ }^{240}$.

Las revoluciones independentistas en América son una expresión en estas tierras de la época histórica en que la burguesía estaba dispuesta a destruir cualquier obstáculo al desarrollo del modo de producción capitalista. Una expresión distorsionada por el pasado colonial, evidentemente. Y aquí cabe entender los aspectos progresivos y las contradicciones de esa época histórica. Aquella tarea, en los siglos XVIII y XIX, significaba un avance económico y, en ciertos casos, progresos democráticos. Pero entre todas las libertades individuales y derechos políticos que el joven liberalismo proclamó, la que realmente importaba era la sacrosanta libertad de empresa, fundamentada en el "derecho natural" a la propiedad privada. Por esta razón, ninguna revolución burguesa, ni siquiera las más radicales, resolvieron todas las demandas de democratización. Ni la francesa en Europa ni la haitiana en América. Y no podrían haberlo hecho, puesto que eran revoluciones al servicio de imponer la dominación de facciones de una clase explotadora.

Por lo general, con la mirada puesta en la Revolución Francesa y en los casos europeos, se niega que las revoluciones de independencia del siglo XIX constituyan revoluciones democrático-burguesas. A menudo las contradicciones nublan la esencia y el contexto histórico de esos procesos.

Se argumenta, por ejemplo, que no existía burguesía local en las Américas. Esta es una premisa errónea. Por nuestra parte, juzgamos acertada esta descripción de John Lynch:

[...] en muchas partes de América, los criollos se habían convertido en poderosas elites de terratenientes, altos cargos y miembros del Cabildo que aprovechaban la

${ }^{239}$ CHUST, Manuel (Org.). Las independencias iberoamericanas en su laberinto..., op. cit., p. 335.

${ }^{240} \mathrm{LYNCH}$, John. América latina no necesita ahora una nueva independencia. La Nación. Buenos Aires, 16/06/2010. Disponible en: <https://www.lanacion.com.ar/cultura/america-latina-no-necesita-ahora-unanueva-independencia-nid1275576>, consultado el 29/01/2020. 
expansión comercial bajo el régimen borbónico para mejorar su producción y su porvenir [... a la larga, los criollos ricos exigieron...] libertad para comerciar con todos los países ${ }^{241}$.

La historiadora Xiomara Avendaño Rojas, a su vez, plantea que, por parte de las elites criollas, las independencias se dieron para mantener y aumentar sus privilegios sociales, además de constituir una "medida preventiva para no caer en otra Francia y en otro Haití, en donde la muchedumbre cortó muchas cabezas"242.

Dicho de otra manera: existió, casi desde el mismo inicio de la colonización, un sector criollo propietario de tierras, minas, dueño de esclavos y agraciado con encomiendas, o dedicado a una parte del comercio y la usura. Obviamente, no existía una clase burguesa industrial o con las características del siglo XX o XXI. Esta visión sería anacrónica. Pero sí existió una facción de la clase dominante, más o menos incipiente dependiendo de la región, que mantuvo buenas relaciones con los burócratas coloniales y acaparaba una parte de los negocios locales hasta la crisis terminal en la Península. Lo que esa facción propietaria local no poseía -y ese fue el problema que se dirimió con las armas- era el control del aparato estatal, esto es, el manejo del comercio exterior, el sistema fiscal y las fuerzas armadas. Y llegó un momento en que ese problema político se convirtió en una traba económica para una acumulación más acelerada por parte de esas burguesías criollas.

La exposición de Mario Pastore acerca de la relación entre peninsulares y criollos pudientes en el Paraguay de finales del siglo XVIII, sirve para comprender la dinámica del problema:

Las familias terratenientes se dedicaban a la producción ganadera mientras que los inmigrantes [españoles, nda.] se especializaban en las actividades comerciales [Sin embargo...] la influencia de los inmigrantes en el Cabildo de Asunción tendió a aumentar a expensas de los terratenientes, que lo habían dominado anteriormente, razón por la cual surgieron algunos conflictos entre ellos ${ }^{243}$.

Retomemos el concepto. Si la principal misión de toda revolución democráticoburguesa es eliminar cualquier traba al florecimiento del capitalismo nacional, en las colonias esto se traducía en que la principal tarea para desarrollar plenamente una burguesía y un mercado interno nacionales consistía en liquidar la relación colonial. En términos marxistas, la autodeterminación nacional era una precondición para el desarrollo de las fuerzas productivas locales.

${ }^{241}$ CHUST, Manuel (Org.). Las independencias iberoamericanas en su laberinto..., op. cit., p. 241.

242 Ídem, p. 65; AVENDAÑO, Xiomara R. Pueblos indígenas y la formación de la República. In: ESCOBAR, Antonio (Coord.). Indios, comunidad y nación en América. México D.F.: CIESAS, 1994.

243 PASTORE, Mario. Crisis de la Hacienda pública, regresión institucional y contracción económica: consecuencias de la independencia en Paraguay, 1810-1840. In: PRADOS, Leandro; AMARAL, Samuel. La independencia americana: consecuencias económicas. Madrid: Alianza, 1994, p. 171. 
Desde esta perspectiva, sí fueron revoluciones burguesas. Aunque, obviamente, no siguieron ni podían seguir el esquema de las revoluciones liberales "clásicas" de las naciones europeas, por el simple motivo de que estas eran metrópolis, y las americanas, colonias. El caso en las Américas, permítasenos la insistencia, fue la variante: revoluciones democrático burguesas anticoloniales. Esto significa que, de todas las tareas democráticas planteadas por las revoluciones burguesas clásicas, en este continente -que, no lo olvidemos, en ese entonces estaba sometido a una condición colonial- primó la tarea política de autodeterminación nacional que, solo en una fase posterior, permitiría transformaciones económico-sociales progresivas más o menos retaceadas.

Esto último nos lleva a otro debate. En las elaboraciones más recientes, muchos historiadores son reticentes a reconocer indicios de nacionalidad en el período colonial. Entre tantos ejemplos, podemos citar la perspectiva de Areces, que sostiene:

La nación no existía ni tampoco la respectiva nacionalidad, estas fructificarán con el proceso que se inicia. En virtud de la acefalía del trono y de la retroversión de la soberanía, se abre el debate del sujeto portador de la soberanía ${ }^{244}$.

A menudo, en medio de lo que nos parece una confusión entre los conceptos de nacionalidad y Estado nacional, formulaciones más extremas de esa lectura pasan la idea de que la autopercepción o identidad nacional comienza con la consolidación de las nuevas superestructuras estatales no coloniales. Nos preguntamos: ¿cómo fue posible movilizar tamañas fuerzas sociales en un sentido político y militar que pretendió la autodeterminación, primer paso para la construcción de cualquier Estado moderno, sin que haya mediado algún grado de identificación cultural-territorial, componente básico de la noción de nacionalidad, preexistente al estallido de esa contienda? ${ }^{245}$. La historia ha demostrado que pueden existir Estados artificiales, sin una nacionalidad que les sirva de base, como también existen nacionalidades que no disponen de aparato de Estado. Pero no nos parece que ese haya sido el caso de las Américas en el siglo XIX.

Dicho de otra forma, sin la existencia de una identidad propia, que al comienzo fue regional para después transformarse en sentimiento de pertenencia nacional -aunque sea en estado incipiente-, no es posible explicar ni comprender la lucha por las independencias en la escala política y geográfica que esta adquirió. No existen procesos objetivos de esa

${ }^{244}$ CHUST, Manuel (Org.). Las independencias iberoamericanas en su laberinto..., op. cit., p. 52.

${ }^{245}$ Sobre la progresiva adquisición de conciencias americanistas previas a la independencia, ver también: BRADING, David. Los orígenes del nacionalismo mexicano. México D.F.: Era, 1980; PAGDEN, Anthony. Identity formation in Spanish America. In: CANNY, Nicolas; PAGDEN, Anthony. Colonial Identity in the Atlantic World, 1500-1800. Princeton: Princeton University Press, 1989. 
magnitud que estallen sin un período de maduración subjetiva, por más que sus elementos no hayan germinado plenamente. Lo nuevo necesariamente comienza gestándose en las entrañas de lo viejo. En términos concretos: en algún momento, los americanos se sintieron americanos y no súbditos del reino de España; en algún punto comprendieron que no solo era necesario sino posible independizarse de sus antiguos conquistadores.

De hecho, esto explica la participación popular en el proceso, que tuvo su auge en el enrolamiento que nutrió los ejércitos patriotas. Si bien el alto mando y los oficiales fueron en su mayor parte criollos ricos y blancos, la tropa estuvo compuesta por una acuarela de pieles y culturas salidas de los sótanos de la sociedad colonial: indígenas, mestizos, negros, zambos, gauchos o llaneros, camiluchos...

Estos, si bien no heredaron el poder arrebatado a los españoles, entendieron que la causa de la independencia merecía el sacrificio ${ }^{246}$. Así, siguieron a Toussaint L'Ouverture, Dessalines, Hidalgo o a un Simón Bolívar en su declaración de Guerra a Muerte contra los godos, gachupines o chapetones ${ }^{247}$. Enfatizamos este elemento sin dejar de reconocer el hecho de que los ejércitos realistas también contaron con elementos salidos de los sectores oprimidos. La intención aquí no es alimentar una visión simplificada acerca de "insurgentes" (americanos) versus "realistas" (europeos peninsulares) ${ }^{248}$, sino resaltar que la embrionaria identidad nacional fue, entre otros, uno de los factores que movilizó a un sector de las clases trabajadoras americanas contra la Corona española.

Las nacionalidades americanas -según el relato de Lynch-se nutrieron del propio sistema colonial: las divisiones administrativas españolas, las economías regionales y sus rivalidades, la lucha por el acceso a los cargos públicos, el sentimiento de orgullo por los recursos propios, todos fueron elementos que confluyeron en un primitivo sentimiento de identidad colectiva, distinta de la de los europeos. Alexander von Humboldt, por ejemplo,

\footnotetext{
246 Sobre el relegamiento social y jurídico de los sectores populares, ver: GARCÍA, Manuel. Pensamiento ilustrado y discriminación política en los primeros estados latinoamericanos. In: GONZÁLEZ, Jesús (Ed.). Barbarie y civilización. Madrid: Editorial UCA, 2014, pp. 197-212.

247 "Españoles y canarios, contad con la muerte, aun siendo indiferentes, si no obráis activamente en obsequio de la libertad de la América. Americanos, contad con la vida, aun cuando seáis culpables", rezaba el final del decreto firmado por Bolívar en junio de 1813. In: BOLÍVAR, Simón. Decreto de Guerra a Muerte. 1813. Disponible en: $<$ https://es. wikisource.org/wiki/Decreto de guerra a muerte $>$, consultado el 09/01/2020.

248 Por ejemplo, entre 1810 y $1825,65 \%$ de los oficiales y $80 \%$ de las tropas realistas de los Ejércitos del Perú habían nacido en América. Las expediciones enviadas desde la Península después de 1815 -compuestas por 12.000 hombres, de los cuales 7.000 fueron enviados al Virreinato del Perú y 5.000 a Montevideo- no cambiaron la composición abrumadoramente americana y multiétnica de los ejércitos en lisa. Ambos lados militares consiguieron movilizar sectores populares y eran semejantes en cuanto a organización, reglamentos y modos de hacer la guerra. Por lo tanto, el alineamiento de cada sector social o región en el campo militar "realista" o "patriota" no tenía que ver necesariamente con el lugar de origen sino con preferencias políticas, asentadas en intereses económicos.
} 
observó: "los criollos prefieren que se les llame americanos; y desde la Paz de Versalles, y especialmente de 1789, se les oye decir muchas veces con orgullo: 'Yo no soy español, soy americano', palabras que descubren los síntomas de un antiguo resentimiento" 249 .

En suma: puede afirmarse que hacia finales del siglo XVIII existían, en ciertas regiones, componentes básicos de cualquier nación "en desarrollo": idioma, religión, territorio, costumbres y tradiciones comunes, aunque esas naciones careciesen de Estados propios. El acertado afán de refutar el relato tradicional, que absolutiza esos elementos en detrimento de otros de acuerdo con sus objetivos políticos, no autoriza a negar el proceso de maduración, durante la propia Colonia, de la identidad nacional americana. A nuestro juicio, es necesario equilibrar este aspecto de la interpretación de los hechos.

Por otra parte, hay quienes niegan que hayan sido revoluciones $-\mathrm{o}$ al menos procesos progresivos- porque, expulsados los europeos del poder, primaron demasiados elementos de continuidad con el período colonial. Dos comentarios al respecto: el primero es que el verdadero debate subyacente en esa afirmación es si la ruptura con las metrópolis, al menos en la forma como ocurrió en la vida real, fue progresiva o reaccionaria. El segundo, que un razonamiento de ese tipo implica no entender el proceso: no existen revoluciones "puras". Existe una relación dialéctica, no lineal, entre continuidad y discontinuidad. El paso de un Estado colonial a Estados burgueses nacionales no significa que en esos nuevos Estados independientes no permanecieran resquicios jurídicos o institucionales del viejo orden español. En el Paraguay y otras antiguas provincias, por ejemplo, sobrevivieron la esclavitud negra, las reducciones de indígenas, y el cuerpo normativo de Las Siete Partidas. Eso es tan cierto como la afirmación de que no podía haber sido de otra manera. En la medida que lo nuevo siempre emerge de y se entrelaza con lo viejo, en todos los casos hubo elementos de continuidad. Pero este aspecto formal, sin carecer de importancia, no define el proceso, no es cualitativo. Lo determinante es que el Estado metropolitano perdió el control político de las colonias. Los resquicios pueden ser más o menos duraderos, pero son y serán eso, resquicios. Son restos de un todo que no existe más.

La independencia hispanoamericana no significó el afianzamiento de los componentes propios de la Colonia sino el principio de su fin.

No es lo mismo, por más que permanezca la dependencia económica de las potencias mundiales, que un Estado sea jurídicamente soberano o una colonia sometida al gobierno de

${ }^{249}$ LYNCH, John. Las revoluciones hispanoamericanas [1808-1826]. Barcelona: Ariel, 1976, p. 9. 
otro Estado. No es lo mismo el carácter del Estado brasileño, argentino, uruguayo, boliviano, etc., que el de Aruba, Islas Malvinas, Guayana Francesa o Martinica.

Sin embargo, estamos conscientes de que el debate sobre si primaron las rupturas o las continuidades es intrincado. Una muestra de ello es que un historiador de la talla de Tulio Halperin Donghi afirma que "es difícil no concluir que cualquier respuesta definitiva a esa pregunta es sencillamente inalcanzable" ${ }^{250}$. O bien el caso del británico John Elliot, que se debate en sopesar los grandes cambios "algunos positivos y otros negativos" y en "saber quiénes fueron los ganadores y quiénes los perdedores" de la principal crisis que agitó las Américas en el siglo XIX ${ }^{251}$.

Sin embargo, la razón asiste al historiador brasileño João Paulo Pimenta cuando sostiene que los niveles de ruptura y continuidades ocasionados por las independencias de las sociedades latinoamericanas no deben opacar "el obvio carácter revolucionario" que las atraviesa:

Las independencias iberoamericanas fueron movimientos revolucionarios, básicamente, ya que crearon (o contribuyeron de manera directa en la creación de) condiciones para el advenimiento de un estado de cosas fundamentalmente nuevo, de implicaciones (desiguales) en todos los niveles de la vida social (político, económico, cultural, mental) en escalas y ritmos asimétricos de ambos lados, pero de un modo abarcador en todo el continente. Frente a este cuadro, la cuestión de lo que cambia y de lo que permanece (o cambia poco) se subordina a la apreciación del conjunto de cambios ${ }^{252}$.

Manuel Chust, por su parte, resume de manera convincente el contenido de la controversia:

\begin{abstract}
La cuestión sobre si o bien fue un proceso revolucionario o bien primaron las continuidades está en debate [...] Sin embargo, planteamos su cariz revolucionario en cuanto a antagonista del Antiguo Régimen metropolitano. Tras 1830, la monarquía absoluta desaparecerá como Estado en América. Y a ello nos referimos con lo de revolucionario. Sabemos que también hubo bastantes continuidades, pero subsistieron como pervivencias coloniales en un mundo que ya no era tal y que se adentraba, si bien lentamente, en otros caminos estatales como la república, el parlamentarismo y el constitucionalismo. Lo cual no quiere decir que la revolución supusiera el ascenso al poder de las capas populares o un estado del bienestar para estas. Eso también lo sabemos ${ }^{253}$.
\end{abstract}

En las condiciones de una colonia, si bien los que más se beneficiaron con la independencia fueron los criollos propietarios $-\mathrm{y}$ sus socios comerciales de las potencias industrializadas de Europa-, el fin del dominio metropolitano permitió una conquista más

${ }^{250}$ CHUST, Manuel (Org.). Las independencias iberoamericanas en su laberinto..., op. cit., p. 136. Ver también: HALPERIN DONGHI, Túlio. Reforma y disolución de los imperios ibéricos, 1750-1850. Madrid: Alianza, 1985.

${ }^{251}$ CHUST, Manuel (Org.). Las independencias iberoamericanas en su laberinto..., op. cit., p. 141.

252 Ídem, pp. 307-308.

253 Ídem, p. 23. 
amplia y duradera: la emancipación de naciones oprimidas, como un todo, de la dominación extranjera. Este es el hecho determinante que nos permite otra definición: el proceso, tomado en su conjunto y en escala histórica, fue progresivo.

Por descontado está que cada clase o sector de clase entró en esa lucha de autodeterminación nacional con intereses sociales contrapuestos. Los intereses de la alta burguesía nativa no fueron ni podían ser conciliados con los intereses de los llamados sectores populares ${ }^{254}$. Este fue el telón de fondo de las divisiones de clase dentro de las fuerzas patriotas, que por más que en diversos momentos hayan concretado amplios frentes de acción policlasistas contra el colonizador, no dejaron de chocar entre sí.

Acerca de la población indígena, el historiador Antonio Escobar Ohmstede hizo aportes importantes con relación a las estrategias que utilizaron los pueblos originarios para incorporar o rechazar modelos nacionales devenidos de la derrota de España, o moverse dentro de los parámetros que el blanco nativo estableció para la consolidación de los diversos Estados-nación en cuanto a la imposición de la igualdad legal, la colonización de territorios inhóspitos, la educación, los cambios en las estructuras políticas indias y "no indias", las contribuciones fiscales, el reparto de terrenos considerados comunales, la expansión de las fronteras internas y la consolidación de las externas ${ }^{255}$.

Lo mismo puede decirse de los mestizos, negros, mujeres o blancos pobres: cada sector étnico-social tuvo después que luchar para hacer valer sus derechos y mejorar su posición en las emergentes sociedades nacionales, puesto que, como ya resaltamos, la revolución no había sido hecha en su nombre.

En el caso paraguayo, otro argumento común entre los autores liberales y que discutiremos más largamente en su momento, es que la crisis de la independencia provocó un retroceso en el comercio exterior -que siempre estuvo restricto a las "provincias de abajo", fundamentalmente a Buenos Aires-, y que con ello se esfumó la prosperidad de las últimas décadas de la Colonia. Un período que muchos manuales de historia asocian a un

\footnotetext{
254 Sobre el caso de la población indígena, consultar: JONG, Ingrid; OHMSTEDE, Antonio (Org.). Las poblaciones indígenas en la conformación de las naciones y los Estados de la América Latina decimonónica. Ciudad de México: El Colegio de México/CIESAS/El Colegio de Michoacán, 2016; SANZ JARA, Eva. Los indios de la nación. Los indígenas en los escritos de intelectuales y politicos del México independiente. Madrid: Universidad de Alcalá, Iberoamericana-Vervuert, Bonilla Artigas, 2011, pp. 21-10; BAUD, Michiel. Indigenismo y los movimientos indígenas en la historia andina, siglos XIX y XX. In: OHMSTEDE, Antonio; FALCÓN, Romana; BUVE, Raymond (Coord.). La arquitectura histórica del poder. Naciones, nacionalismos y estados en América Latina. Siglos XVIII, XIX y XX. México: CEDLA-El Colegio de México, 2010, pp. $95-$ 110.

${ }^{255}$ OHMSTEDE, Antonio. Las sociedades indigenas y su papel en la conformación de las naciones y Estados en la América Latina poscolonial. Buenos Aires: UBA, 2016.
} 
tiempo de "bonanza económica" que en cierta medida rompió con la histórica marginalidad de la provincia. Este razonamiento plantea dos problemas. El primero: ¿prosperidad para quiénes? El segundo: si el criterio es el volumen del comercio, entendido como sinónimo de progreso, ¿era preferible seguir siendo una colonia regida por las tenues reformas de los Borbones en el siglo XVIII?

El propio dictador Francia, aborrecido por la narrativa liberal, respondió este problema en 1818, cuando amonestó a uno de sus comandantes de frontera diciéndole: "nunca se llama, ni puede llamarse causa común al tráfico mercantil. Prescindiendo de esto, los americanos en el día llamamos y entendemos por nuestra causa común la libertad e independencia de nuestros países de todo poder extranjero o extraño [... ${ }^{256}$.

La negación de las revoluciones del pasado tiene como objetivo político en el presente instalar la idea de que todo cambio radical es nocivo. Lo cierto es que la burguesía, ni bien pudo consolidarse como clase dominante, pasó a temer su propia época de oro, renegando de sus propias revoluciones. Su conservadorismo es proporcional al poder que concentra.

En suma: las naciones americanas se autodeterminaron políticamente. De colonias pasaron -no sin crisis-a ser Estados burgueses nacionales “en formación”. Y esto representó un hecho progresivo en una escala histórica.

Este cambio político, por más que sus principales dirigentes consideraron la experiencia haitiana o la inspirada en el Grito de Dolores como el modelo que debía ser evitado a cualquier costo, terminó allanando el camino para cambios económicos-sociales que se fueron concretando, de forma más o menos tardía, en cada ex territorio colonial. Pero el proceso de extinción de formas de producción precapitalistas fue, en general, controlado por las elites.

Para tener una idea más clara, en Paraguay la abolición formal, esto es, jurídica de las encomiendas ocurrió en 1812; la de las reducciones o pueblos de indígenas, en 1848, y la de la esclavitud negra recién en $1869^{257}$.

El caso de la Argentina no fue diferente. A contramano de la idea de que el país fue forjado por hijos de inmigrantes blancos europeos, un mito que está siendo derribado, la presencia de esclavos africanos en Buenos Aires está comprobada desde 1585. Entre 1777 y 1812 atracaron en el puerto de Buenos Aires y Montevideo más de 700 barcos, con 72.000

${ }^{256}$ Oficio al comandante de Concepción, 23/06/1818, ANA-SH, v. 228, n. 2.

${ }^{257}$ NÚÑ̃Z, Ronald León. Apuntes sobre el carácter de las independencias..., op. cit. 
esclavos africanos, principalmente destinados a Lima o Potosí. Hacia 1810, según datos del ministerio argentino de la Cultura, la capital porteña tenía alrededor de 40.000 habitantes y se estima que un tercio poseía origen africano. En el momento de la Revolución de Mayo, puede decirse que Buenos Aires no tenía una mayoría de población blanca. La libertad de vientres en las Provincias Unidas del Río de la Plata se declaró en 1813, pero no garantizó la libertad plena a los esclavos, que debió esperar no solo la proclamación de la Constitución Nacional de 1853, que abolió formalmente la esclavitud, sino una reforma de esa legislación en 1860, que estableció la libertad de esclavos pertenecientes a extranjeros e introducidos por sus amos al territorio argentino ${ }^{258}$.

Esta relación entre lo político y lo económico-social, esferas que se complementan pero que tienen ritmos diferentes, es fundamental para discutir, como haremos en un próximo capítulo, el mito del Paraguay-potencia en la preguerra, tan arraigado a través de la propaganda nacionalista y también por sectores del liberalismo.

Hay que decir de entrada que el Paraguay no fue una isla durante el siglo XIX, como predica el nacionalismo. Su suerte siempre estuvo ligada a la resolución de la lucha independentista general. En la práctica, esto significa que sin la victoria de la revolución continental de independencia, simplemente no existiría el Paraguay independiente.

En el terreno metodológico, el estudio de las independencias demostró ser terreno fértil para ciertos desequilibrios. El primero es el estudio exhaustivo de casos considerados emblemáticos, que de hecho marcaron tendencias, pero al costo de marginar las particularidades de otras áreas que tuvieron dinámicas diferentes. En ese sentido, el caso del Paraguay puede considerarse poco estudiado. El segundo consiste en sumergirse en las particularidades, casi en las nimiedades o hechos anecdóticos de un caso determinado, sin tomar en cuenta la totalidad de un fenómeno que tuvo escala continental.

El anacronismo es otro peligro permanente en casos tan enmarañados como el que nos ocupa. Con frecuencia se analizan los hechos desde una perspectiva presentista, tomando como base las actuales fronteras nacionales -conformadas con posteridad a las independencias--. Esto sesga el análisis de los hechos, que no son estáticos sino dinámicos, además de exponer al historiador a resbalones contrafactuales. Dicho de otro modo, existe una falsa disyuntiva entre explicaciones exógenas o endógenas, cuando en realidad ocurrió una combinación dialéctica de factores que incidieron desigualmente en la realidad.

${ }^{258}$ MINISTERIO DE CULTURA-ARGENTINA. Historia de la esclavitud en Argentina. 2017. Disponible en:

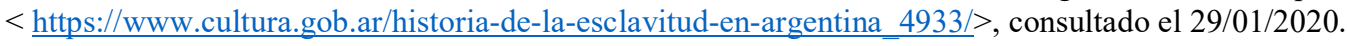


Con esto en mente, pasamos revista a las interpretaciones más relevantes en el mundo académico. Para ello, nos guiamos principalmente por un recuento hilvanado por Manuel Chust, un especialista en este tema ${ }^{259}$.

Partimos de la década de 1950, cuando adquiere relevancia el concepto de “revoluciones atlánticas" de Robert Roswell Palmer ${ }^{260}$, al que después adhirió Jacques Godechot ${ }^{261}$, y que tendrá luego otras acepciones. Lo central que sostiene esta tesis es que el motor de las independencias en el mundo hispano y luso fue la revolución de ideas surgidas de -0 que motivaron- las revoluciones francesa y estadounidense. Además de la evidente preponderancia que esta lectura otorgaba al influjo ideológico anglosajón y francés, no es difícil advertir su naturaleza idealista, que deja en segundo plano el peso de las razones materiales a la hora explicar el fenómeno.

Por otro lado, el Primer Congreso Hispanoamericano de Historia se congregó en Madrid en 1949 para debatir las “causas y caracteres de las independencias americanas". La iniciativa buscaba, en realidad, impulsar una narrativa negacionista del colonialismo español. El intelectual argentino Ricardo Levene pronunció un discurso inaugural con el sugestivo título de "Las Indias no eran colonias". El mensaje básico fue el siguiente: las Américas nunca fueron territorios colonizados sino reinos de un mismo imperio y con igualdad de derechos que los peninsulares. Luego, no es posible hablar de independencia sino de "emancipación", como la de un "hijo con respecto a la tutela de sus padres". Los historiadores que apuntalaron esta perspectiva estuvieron asociados, en su mayoría, a sectores conservadores, clericales e hispanófilos en Argentina, México y España.

Los trabajos del historiador británico John Lynch ganaron relevancia en el marco de un proceso de innovación en el estudio de la materia, en la década de 1970. Según su perspectiva, el estallido del proceso de las independencias se debió al "neoimperialismo" que los Borbones impusieron en las colonias luego de su triunfo en la guerra de sucesión española en 1701. Según Lynch, esto se opuso a la relativa autonomía que las colonias y sus elites locales habrían experimentado bajo el domino de los Austrias. Este autor lleva esta

${ }^{259}$ CHUST, Manuel (Org.). Las independencias iberoamericanas en su laberinto..., op. cit., pp. 15-20. Ver también: GARAVAGLIA, Juan. Os primórdios do processo de independência hispano-americano. In: JANCSÓ, István (Org.). Independência: história e historiografia. São Paulo: Hucitec/Fapesp, 2005, pp. 207234.

${ }^{260}$ PALMER, Robert. The age of the democratic revolution. A political history of Europe and America [17601800]. Princeton: Princeton University Press, 1959.

${ }^{261}$ GODECHOT, Jacques; PALMER, Robert. Le problème de l'Atlantique du XVIII ${ }^{e}$ au XX $X^{e}$ siècle. Congresso internationale di Scienze storiche. Florencia: Relazioni, 1955. 
caracterización al extremo de afirmar que: "a finales del siglo XVII, Hispanoamérica se había emancipado de su inicial dependencia de España"262.

En el contexto de lo que Lynch identifica como "la segunda conquista de América", los Borbones no hicieron otra cosa que exaltar los ánimos de los criollos pudientes con una serie de afrentas políticas y económicas que, con el pasar del tiempo, sería el caldo de cultivo de sus ansias autonomistas:

[...] la reforma imperial plantaba las semillas de su propia destrucción: su reformismo despertó apetitos que no podía satisfacer, mientras que su imperialismo realizaba un ataque directo a los intereses locales y perturbaba el frágil equilibrio de poder dentro de la sociedad colonial ${ }^{263}$.

Lynch, además de admitir la existencia de una burguesía rural y comercial criolla, otorga mucha importancia al inestable equilibrio de poderes entre la metrópoli y los colonos propietarios:

Desde el siglo XVI se desarrolló una elite criolla de terratenientes, cuyos intereses no siempre coincidían con los de la metrópoli. Si bien nunca adquirió un poder político formal, era una fuerza social que los burócratas coloniales no podían ignorar. Así, el gobierno colonial se sostenía en un compromiso entre la soberanía imperial y los intereses inmediatos de los colonos ${ }^{264}$.

Las conocidas reformas borbónicas, siempre de acuerdo con este relato, habrían modificado ese equilibrio, si es que alguna vez existió.

Areces, sin asumir el andamiaje de las obras de Lynch, también achaca a las reformas borbónicas el mismo papel desintegrador:

[...] una idea imperial reformada que distanciaba aún más a España de los territorios coloniales, que se fueron conformando en campos propicios para el discurso patriótico criollo interesado en indagar los antiguos orígenes de las civilizaciones americanas ${ }^{265}$

El conjunto de la obra de Lynch es una referencia obligada para el estudio de ese periodo histórico ${ }^{266}$. Si algo amerita una crítica es la reducción inherente a la idea de que la crisis de las independencias radica en un problema de relación más o menos gravosa, más o menos molesta, entre las Américas y la administración colonial de una casa real u otra. Sin la debida precaución, se corre el riesgo de perder de vista lo más importante: la relación colonial en sí misma, sea bajo la égida de los Austrias o los Borbones.

\footnotetext{
${ }^{262}$ LYNCH, John. Las revoluciones hispanoamericanas..., op. cit., p. 10.

${ }^{263}$ Ibídem.

264 Ibídem.

${ }^{265}$ CHUST, Manuel (Org.). Las independencias iberoamericanas en su laberinto..., op. cit., p. 50.

266 Ver también: LYNCH, John. España bajo los Austrias. Barcelona: Ediciones Península, 1970; LYNCH, John. San Martin soldado argentino, héroe americano. Buenos Aires: Editorial Critica, 2009.
} 
Desde el materialismo histórico, además de las obras de los autores que discutimos en la primera parte de esta tesis, podemos agregar los trabajos de Manfred Kossok ${ }^{267}$ y Pierre $\operatorname{Vilar}^{268}$. Ambos calificaron las independencias como revoluciones burguesas, aunque incompletas.

La comunidad académica, sin embargo, no acogió de buen grado los postulados de la historiografía considerada marxista, usualmente tildada demasiado "ideológica". No pocas veces se incurre en la falsa idea de que el ambiente erudito es inmune a ideas políticas. El propio Chust, al mencionar la obra de autores de corte marxista, remarca que en los ámbitos especializados se "aisló y encasilló buena parte de sus escritos sin ni siquiera en muchas ocasiones un merecido debate, salvo algunas excepciones" ${ }^{\text {"269. }}$. Merece la pena reflexionar más sobre esto último.

De cualquier manera, nos parece importante resaltar que, desde el punto de vista del materialismo histórico, en general se propuso caracterizar las independencias como revoluciones -aunque la controversia se dio alrededor de calificarlas como sociales o políticas, completas o incompletas, etc.-, en contraste con el enfoque unilateral de los teóricos de la Dependencia, que no identificaron más que continuidades con el antiguo colonialismo, un simple "cambio de amos"270.

En los años noventa la propuesta de François-Xavier Guerra se hizo casi hegemónica en el mundo académico. Elías Palti llegó a afirmar que sus trabajos equivalían a una "revolución historiográfica"271. Este historiador franco-español había introducido, en la década anterior, el concepto de "revoluciones hispánicas"272. Según esa visión, tanto en la Península como en América, componentes ambas del "mundo hispánico", se dieron fenómenos tan semejantes que justificarían la categoría de un único proceso revolucionario:

[...] La imbricación constante y la mutua causalidad -escribe Guerra- entre los acontecimientos españoles y los americanos y, por otro [lado], la concordancia de las coyunturas políticas en regiones totalmente diferentes por su estructura económica y social. Todo remite de hecho a una revolución única que comienza

\footnotetext{
${ }^{267}$ ROURA, Lluís; CHUST, Manuel (Ed.). La ilusión heroica. Colonialismo, revoluciones, independencias en la obra de Manfred Kossok. Castellón: Universitat Jaume I, 2010.

${ }^{268}$ VILAR, Pierre; CASTRO, Fidel. Independencia y revolución en América Latina. Barcelona: Anagrama, 1976.

${ }^{269}$ CHUST, Manuel (Org.). Las independencias iberoamericanas en su laberinto..., op. cit., p. 18.

${ }^{270}$ CHUST, Manuel. Insurgencia y revolución en Hispanoamérica. Sin castillas hubo bastillas. Historia Social 20. Valencia: Uned, 1994, pp. 67-96.

${ }^{271}$ PALTI, Elías. El tiempo de la política. El siglo XIX reconsiderado. Buenos Aires: Siglo XXI, 2007.

${ }^{272}$ GUERRA, François-Xavier (Org.). Revoluciones Hispánicas. Independencias americanas y liberalismo español. Madrid: Editorial Complutense, 1995.
} 
con la gran crisis de la Monarquía provocada por las abdicaciones regias de 1808, y acaba con la consumación de las independencias americanas ${ }^{273}$.

Guerra desarrolló distintos conceptos en su relato, tales como modernidad, actores políticos, republicanismo, soberanía, liberalismo, sociabilidad, y otros. Por muchos es tenido como un renovador del debate sobre las independencias y sobre los regímenes surgidos del cisma hispánico ${ }^{274}$.

Destacamos como positivos varios elementos: la noción de que fueron revoluciones; la propuesta de dejar de lado el relato cronológico de la "historia patria" y asumir el desafío de entender la lógica profunda de un proceso complejo en el cual "lo político ocupa un lugar central"; el enfoque que considera el fenómeno como una secuencia de actos indivisibles:

El proceso revolucionario que nos ocupa y que podemos designar como la "revolución Hispánica" tiene, pues, como dos caras complementarias: la primera es la ruptura con el antiguo régimen, el tránsito a la Modernidad; la segunda, la desintegración de ese vasto conjunto político que era la Monarquía hispánica, es decir, las revoluciones de independencia. Dos caras, que corresponden en parte, pero solo en parte, a dos fases cronológicas ${ }^{275}$.

Este enfoque global es un acierto metodológico. Como también es correcta la opción que asume F. Guerra de "dar prioridad al conjunto sobre las partes"276. Sin embargo, como advertimos, el concepto de "revolución hispánica" es problemático porque entraña la supuesta existencia de "españoles en ambos hemisferios" como si se tratase de una única nación ${ }^{277}$. De hecho, cuando compara la metrópoli con las colonias, este autor subraya "una comunidad extraordinariamente homogénea" ${ }^{278}$ • ¿Es posible tal grado de "homogeneidad" en el contexto de una relación colonial, es decir, la más asimétrica que se conoce?

Una de las derivaciones posibles de este presupuesto, por ejemplo, incumbe a la definición de la guerra que enfrentó a españoles y americanos en el siglo XIX. Dependiendo de la lupa, para unos se trató de una guerra anticolonial o de liberación nacional, un embate entre colonizados y colonizadores; para otros, de una "guerra civil" como si los antagonistas fuesen compatriotas.

\footnotetext{
${ }^{273}$ GUERRA, François-Xavier. La desintegración de la monarquía hispánica: revolución de independencia. In: ANNINO, Antonio; CASTRO, Luis; GUERRA, François-Xavier. De los imperios a las naciones: Iberoamérica. Zaragoza: Ibercaja, 1994, p. 195.

274 Entre sus obras más destacadas, citamos: GUERRA, François-Xavier [1992]. Modernidad e independencias: ensayos sobre las revoluciones hispánicas. México D.F.: FCE, 2010; GUERRA, FrançoisXavier [1985]. México: del Antiguo Régimen a la Revolución. México D.F.: FCE, 2014.

275 GUERRA, François-Xavier. La desintegración de la monarquía hispánica..., op. cit., p. 196.

${ }^{276}$ GUERRA, François-Xavier [1992]. Modernidad e independencias..., op. cit., p. 116.

277 Sobre este asunto, conviene consultar también: PORTILLO, José. Crisis atlántica: autonomía e independencia en la crisis de la monarquía hispana. Madrid: Marcial Pons, 2006.

${ }^{278}$ GUERRA, François-Xavier [1992]. Modernidad e independencias..., op. cit., p. 119.
} 
El problema está en que, como diría el propio Bolívar, la cosa fue más complicada. A ambos lados del Atlántico no existían compatriotas sino enemigos, divididos entre opresores y oprimidos, y estos últimos habían adquirido suficiente conciencia de que su posición era opuesta a la de los españoles:

[...] no somos europeos -afirmó Bolívar en Angostura-, no somos indios, sino una especie media entre los aborígenes y los españoles. Americanos por nacimiento y europeos por derechos, nos hallamos en el conflicto de disputar a los naturales los títulos de posesión y de mantenernos en el país que nos vio nacer, contra la oposición de los invasores; así nuestro caso es el más extraordinario y complicado. Todavía hay más; nuestra suerte ha sido siempre puramente pasiva, nuestra existencia política ha sido siempre nula y nos hallamos en tanta más dificultad para alcanzar la Libertad, cuanto que estábamos colocados en un grado inferior al de la servidumbre $[\ldots]^{279}$.

La definición de los americanos como "oprimidos" es válida no solo para las clases subalternas de las sociedades coloniales -eso es evidente-, sino también para los burgueses criollos, entre los cuales se encontraban Bolívar y la mayoría de los dirigentes independentistas. La diferencia estriba en la respuesta a la delimitación de "oprimido" con relación a qué. Puesto que, si bien las elites criollas eran explotadoras y opresoras en relación con las clases trabajadoras en el continente, eran al mismo tiempo oprimidas -política, social, culturalmente- por el yugo del sistema colonial español. Y, si se admite alargar esa espiral de succión, por los verdaderos beneficiarios de las riquezas extraídas de las Américas por los reinos ibéricos, las naciones más avanzadas de Europa.

El contexto de la llamada renovación historiográfica fue el de los llamados procesos del Este europeo - con la caída del Muro de Berlín como evento emblemático de la posterior desaparición de la antigua Unión Soviética -y, en Latinoamérica, el paso de las dictaduras militares hacia un proceso de democratización marcado por el auge del neoliberalismo económico.

Guerra se transformó en referencia puesto que contrapuso conceptos como historia cultural o modernidad, todos en un amplio sentido sociológico, a los esquemas interpretativos clásicos de la historia económica. Cuestionó no solo el relato marxista, sino también los presupuestos cepalinos y dependentistas de los años sesenta y setenta, una crítica muy bien acogida en el contexto antes descripto. La cultura, la política, los discursos, la presencia o ausencia de modernidad, ocupan el lugar de las relaciones sociales entre las clases y las divisiones en el sistema internacional de Estados. En una de sus principales obras

279 BOLÍVAR, Simón. Discurso de Simón Bolívar ante el Congreso de Angostura. 1819. Disponible en: $<$ https://es.wikisource.org/wiki/Discurso_de_Sim\%C3\%B3n_Bol\%C3\%ADvar_ante_el_Congreso_de_Ango stura $>$, consultado el 11/01/2020. 
afirma, por ejemplo, que "los principales actores de la Revolución Francesa primero, y de la hispánica después, son más una 'clase cultural' que una clase social”280.

Como se sabe, muchas de sus conclusiones no son necesariamente originales. François Furet y otros ya habían planteado que el motor de las revoluciones hispánicas era esencialmente cultural. A finales de la década de 1970, F. Furet salió al paso de las interpretaciones, sobre todo marxistas, que asociaban la Revolución Francesa con fenómenos económico-sociales, como la consagración de la burguesía como clase dominante y el modo de producción capitalista como hegemónico. De este modo, cuestionó la tesis de la Revolución Francesa como revolución burguesa clásica, entendiéndola no en su dimensión económico-social sino como el momento de creación de lo que él denominó cultura democrática:

[...] ni el capitalismo ni la burguesía necesitaban de revoluciones para aparecer y dominar la historia de los principales países europeos en el siglo XIX. Pero Francia es el país que inventa, gracias a la Revolución, la cultura democrática y que presenta al mundo una de sus principales conciencias de acción histórica ${ }^{281}$.

Nótese el pedestal reservado a la categoría "cultura", orientada a la exaltación de la democracia liberal clásica. Otro autor clave que influenció la obra de F. Furet y F. Guerra, Auguste Cochin, entendió la Revolución Francesa más como ruptura que como continuidad con el Antiguo Régimen, pero no en el terreno de la economía y de la sociedad sino en la arena político-ideológica, al crear una nueva forma de legitimidad política ${ }^{282}$.

A pesar de la autoridad que adquirió la obra de F. Guerra, algunos de sus conceptos remiten a nociones calificadas por algunos como conservadoras y hasta clericales, como su idea de que la base ideológica de las independencias debía buscarse en la escolástica hispana del siglo XVI y en la neoescolástica del siglo XVII.

Según la opinión de Chust, en cierta medida este autor rehabilitó estudios y a académicos del derecho, que dejaron de ser vistos como conservadores a partir de su enfoque y sus textos. Roberto Breña, más cauteloso, advirtió que la obra de F. Guerra "pocas veces fue objeto de una discusión concienzuda en el mundo académico latinoamericano" 283 . Por otra parte, si François Guerra se transformó en una autoridad en Hispanoamérica, en países

\footnotetext{
${ }^{280}$ GUERRA, François-Xavier [1992]. Modernidad e independencias ..., op. cit., p. 101.

${ }^{281}$ FURET, François. Penser la Révolution Française. París: Gallimard, 1978, p. 44.

${ }^{282}$ Acerca de la relación de Guerra con Cochin, ver: PALTI, Elías. Guerra y Habermas: ilusiones y realidad de la esfera pública latinoamericana. In: PANI, Érika; SALMERÓN, Alicia. Conceptualizar lo que se ve: François-Xavier Guerra historiador. México D.F.: Instituto José Luis Mora, 2004.

${ }^{283}$ BREÑA, Roberto. Diferendos y coincidencias en torno a la obra de François-Xavier Guerra (una réplica a Medófilo Medina Pineda). Anuario Colombiano de Historia Social y de la Cultura, Bogotá, n. 38, p. 283, 2011.
} 
europeos como la propia España el "manual" sobre este tema continúa siendo la obra de Lynch $^{284}$.

En un artículo publicado en 2015, el politólogo brasileño Bernardo Ricupero, realiza una valoración suficientemente equilibrada de las principales obras de Guerra:

\begin{abstract}
Sustento, em particular, que a principal contribuição dela está em, a partir do estudo sobre as revoluções hispânicas, abrir caminho para uma análise mais global de fenômenos históricos. Desconfio, porém, da possibilidade de se fazer história político e cultural que prescindam das histórias econômico e social. Mais importante, indico que está subjacente à obra do historiador franco-espanhol uma visão dualista a respeito da relação entre o Estado, pretensamente moderno, e a sociedade, supostamente tradicional. Por outro lado, acredito que os momentos mais interessantes dos seus estudos são aqueles em que trata de combinações "impuras" do moderno com o tradicional ${ }^{285}$.
\end{abstract}

Para François Guerra, las independencias se dieron, en definitiva, por el choque entre ideas asociadas a la modernidad y una sociedad tradicional; un choque entre "dos mundos". Un embate entre dos dimensiones: "la modernidad ideológica que sirve como base a la revuelta se suma al anacronismo de las relaciones sociales"286; la contradicción entre un Estado pretendidamente moderno y una sociedad anclada en el pasado y en tradiciones caducas.

A partir de ese razonamiento, es posible suponer que el modelo de sociedad "moderna" está ligado al andamiaje ideológico liberal, inaugurado con la Revolución Francesa en el mundo atlántico, cuando lo "tradicional", atrasado y fundado en vínculos clientelistas -encarnado, de manera dual, en el caciquismo $^{287}$, el caudillismo, o el coronelismo, un residuo arcaico que articularía Estado y sociedad- está asociado al llamado "tercer mundo".

Por otra parte, Charles Hale asegura que el historiador franco-español, a pesar de su preocupación con la cultura política no otorga el peso suficiente a analizar el papel de las ideas en la política ${ }^{288}$.

La atracción que provocan las tesis de Guerra en cierta medida proviene de la simplicidad de un modelo basado en la oposición Estado versus sociedad. El primero,

\footnotetext{
${ }^{284}$ CHUST, Manuel (Org.). Las independencias iberoamericanas en su laberinto..., op. cit., p. 18. Sobre la nueva historiografía política de América Latina, ver: PALACIOS, Guillermo. Entre una 'nueva historia' y una 'nueva historiografía' para la historia política de América Latina en el siglo XIX. In: PALACIOS, Guillermo (Org.). Ensayos sobre la nueva historia política. México: El Colegio del México, 2007.

${ }^{285}$ RICUPERO, Bernardo. O que há de novo na nova história política de François-Xavier Guerra?. Almanack, Guarulhos, n.11, pp.841-852, 2015.

${ }^{286}$ GUERRA, François-Xavier [1985]. México: del Antiguo Régimen a la Revolución..., op. cit., p. 324.

${ }^{287}$ El cacique sería parte de los dos mundos, el moderno y el tradicional.

${ }^{288}$ HALE, Charles. El renacimiento de la historia política y la Revolución Francesa en México. In: HALE, Charles. El pensamiento político en México y Latinoamérica. México D.F.: El Colegio de México, 2010.
} 
identificado con lo moderno, la segunda, con lo tradicional y en cierta medida estático. El esquema se completa al sopesar la combinación híbrida e impura entre ambos polos. La pregunta es hasta qué punto es útil el intento de encuadrar -de la manera sofisticada como el autor encara ese desafío, por supuesto- una inmensa cantidad de realidades económicas, sociales, culturares, y de riquezas históricas en tipologías demasiado generales ${ }^{289}$. Sin pretender hacer un análisis exhaustivo del aporte intelectual de F. Guerra, meritorio en muchos aspectos, se puede afirmar que su visión solapa las causas materiales de las independencias para privilegiar elementos idealistas, conceptos polisémicos, tales como cultura, política, discursos, modernidad y tradición, etc.

Aplicados al caso hispanoamericano, la explicación central que ofrece François Guerra sobre el estallido de las revoluciones de independencia y sus derivaciones concretas, descansa en un problema de "legitimidad política" (histórica o moderna), que sin duda fue un elemento importante pero que no consideramos determinante:

\begin{abstract}
Hispanoamérica ocupa un lugar singular, y en cierta manera paradójico, en el área latina. En efecto, cuando toda Europa había vuelto a regímenes monárquicos e incluso absolutistas, solo los países hispanoamericanos continuaban siendo repúblicas y poseyendo constituciones y libertades modernas. Hay que buscar su explicación en el hecho mismo de la Independencia. Al romper el vínculo con la Península, también se rompía el vínculo con el rey, es decir, con la legitimidad histórica. No quedaba entonces más vía para legitimar el poder que la moderna soberanía del pueblo. Por eso, toda instauración de una Monarquía fracasará en América, aun cuando una buena parte de las elites estuviese tentada en algunas épocas por esta solución. Porque: ¿Qué legitimidad podía tener un rey que no fuera el «señor natural» del reino? El problema no tenía solución, sea cual fuera el tradicionalismo de la sociedad y el caso de Brasil, con un imperio que dura hasta 1889, ofrece un perfecto ejemplo contrario de lo que ocurre en Hispanoamérica ${ }^{290}$.
\end{abstract}

Es difícil sostener que, en la actualidad, existe una lectura prevalente en el mundo académico. Aunque, por lo menos en el caso del Paraguay nos parece difícil negar una inclinación a interpretaciones con raíces liberales, que fueron ganando terreno a la todopoderosa tradición nacionalista desde la década de $1980^{291}$.

\footnotetext{
${ }^{289}$ RICUPERO, Bernardo. O que há de novo na nova história..., op. cit., p. 850.

${ }^{290}$ GUERRA, François-Xavier [1992]. Modernidad e independências ..., op. cit., p. 101. En el caso del Brasil, la independencia a partir de un traspaso de poder entre miembros de la misma casa real a ambos lados del Atlántico, habría garantizado el delicado hilo de continuidad de la legitimidad histórica de la monarquía portuguesa.

${ }^{291}$ Sobre lo que se denomina "Nueva Historiografía" en el campo de estudio del Paraguay del siglo XIX hasta la Guerra contra la Triple Alianza, consultar, entre otros: BREZZO, Liliana. La guerra de la Triple Alianza en los límites de la ortodoxia: mitos y tabúes. Universum, Talca, v. 19, n. 1, pp. 10-27, 2004; BREZZO, Liliana. E1 Paraguay en cinco momentos historiográficos: ritos y perspectivas. In: CASAL, Juan; WHIGHAM, Thomas (Org.). Paraguay: el nacionalismo y la guerra. Actas de las Primeras Jornadas Internacionales de Historia del Paraguay en la Universidad de Montevideo. Asunción: Tiempo de Historia-Universidad de Montevideo, 2009, pp. 61-78; DORATIOTO, Francisco. Maldita Guerra: Nova história da Guerra do Paraguai. São Paulo: Companhia das Letras, 2002; DORATIOTO, Francisco. História e Ideologia: a produção brasileira sobre a Guerra do Paraguai. 2009. Disponible en: < https://journals.openedition.org/nuevomundo/49012>, consultado
} 
No obstante, puede decirse que más bien se entrelaza una selección de lecturas de las grandes tesis: las propuestas de Lynch conviven con las de F. Guerra; los menos rescatan la visión de autores que se basan en el materialismo histórico, o bien se referencian en las obras de Jaime E. Rodríguez ${ }^{292}$. Según Areces, la historiografía de nuestros días representa una perspectiva renovada sobre la cuestión americana, en la medida en que no "trata ya de una narración de acontecimientos políticos [...] Sus focos preferenciales están dirigidos a lo institucional, cultural y a la cultura política [... $]^{\prime 293}$.

Ana Ribeiro, en su turno, también se refiere a una reinvención de la disciplina, ahora más interesada en:

[...] historia de las mentalidades, microhistoria, género, historia desde abajo, antropología histórica e historia conceptual, entre otros, desembarcaron en las universidades y librerías. De [la] mano de estos enfoques se descubren nuevos protagonismos, se plantean nuevas preguntas y problemas y se remontan los compartimentos estancos de las historias nacionales $[\ldots]^{294}$.

Por nuestra parte, sostenemos que criticar las bases de la historiografía nacionalista es correcto y necesario. Problematizar los presupuestos basados en el tridente gran héroecronología-relatos políticos, que supone un alto riesgo de incurrir en anacronismos y exageraciones sin fundamento empírico, es una tarea justa. Pero esto no puede esconder que algunas de las propuestas presentadas como nuevas, a menudo variantes de las obras clásicas, no pocas veces pecan de eclecticismo, escepticismo, o sucumben a la tentación que supone la microhistoria.

En ese sentido, el norteamericano David Bushnell afirma justificadamente que se hizo común que los estudiosos cometan "excesos propios al huir de la historia política como si consistiera solo en anécdotas irrelevantes en comparación con la realmente importante social y económica"295, cuando, en realidad, en los acontecimientos políticos subyace siempre un contexto y una problemática económica, social, cultural ${ }^{296}$.

Por otro lado, no es nuestra intención ignorar que las condiciones en las que se desarrolló la ciencia histórica en los últimos treinta años permitieron, además de una

el 12/07/2018; BREZZO, Liliana; DORATIOTO, Francisco. Ojos en la guerra del Paraguay. Archivos, enfoques, lecturas. Anuario IEHS, Tandil, v. 34, n. 2, pp. 123-139, 2019; BARATTA, María. Ciento cincuenta años después. La historiografía reciente sobre la guerra del Paraguay en Argentina. Anuario IEHS, Tandil, v. 34, n. 2, pp. 221-233, 2019.

292 RODRÍGUEZ, Jaime E. La independencia de la América española..., op. cit.

${ }^{293}$ CHUST, Manuel (Org.). Las independencias iberoamericanas en su laberinto..., op. cit., p. 57.

294 Ídem, pp. 323-324.

295 Ídem, p. 95.

${ }^{296}$ BUSHNELL, David: Colombia: una nación a pesar de si misma: de los tiempos precolombinos a nuestros dias. Bogotá: Planeta, 1996. 
pluralidad ampliada de miradas, un alto grado de profesionalización, que se expresa en una exploración más exhaustiva de fuentes primarias y un nivel de producción pocas veces visto. Y esto sin considerar el aporte inestimable de la tecnología, que permite digitalizar y poner a disposición en línea todo tipo de fuentes documentales. Este contexto ciertamente facilita enormemente las investigaciones actuales.

En el terreno metodológico, para no extendernos más, no podemos sino suscribir la recomendación hecha por João Paulo Pimenta:

[...] las independencias son un único y exclusivo proceso, formado por tiempos y espacios variados y específicos, pero que solo pueden ser debidamente comprendidas si las tomamos como parte de una totalidad histórica ${ }^{297}$. Si el conocimiento de esa totalidad está fragmentado, eso no justifica negar la existencia de totalidad sino "de hacer con que cada tema, espacio y momento específico del proceso general de las independencias iberoamericanas surja de un modo menos aislado, menos sujeto a las contingencias impuestas por las persistentes y tradicionales historiografías nacionales, cuyas marcas se ven reforzadas, además, por nuestra hiperespecialización ${ }^{298}$.

En este marco, nos parece posible y seguro avanzar y aplicar la comprensión general de estos problemas al caso de la Cuenca del Plata y, específicamente, a la ex Provincia del Paraguay.

${ }^{297}$ CHUST, Manuel (Org.). Las independencias iberoamericanas en su laberinto..., op. cit., p. 305.

298 Ídem, p. 309. 


\section{CAPÍTULO IV - INDEPENDENCIA Y REPÚBLICA}

"Las revoluciones son las locomotoras de la historia".

KARL MARX, Las luchas de clases en Francia de 1848 a 1850

\section{EL PUERTO Y LAS PROVINCIAS}

\subsection{Crisis del colonialismo ibérico}

No es posible comprender el proceso de desintegración de los antiguos imperios ibéricos ni el proceso de independencia de ningún Estado americano sin considerar los profundos cambios económicos y políticos inaugurados por la época de las revoluciones burguesas en todo el mundo. En el caso del Imperio español se suma a ese fenómeno su crónico atraso industrial, principalmente en la rama naviera, indispensable para el monopolio comercial y para mantener la unidad de sus dominios ultramarinos. Esto, a su vez, no fue sino una expresión de su carácter dependiente y de su papel de intermediario respecto de las manufacturas de las naciones capitalistas más avanzadas de Europa. Madrid terminaría pagando un alto precio por su escasa tradición tecnológica y manufacturera. Ana Ribeiro señala que:

[...] El Imperio español manifestó ya con las reformas borbónicas los problemas que tenía para preservar la vastedad de sus dominios, en un mundo en el que las transformaciones económicas lanzaban a miles de comerciantes a los océanos, impelidos por la fuerza de una nueva productividad manufacturera ${ }^{299}$.

La brecha creciente que separaba a España de las demás naciones europeas competidoras fue producto de las limitaciones que tuvo el proceso de transformaciones democrático-burguesas en la Península: a pesar de las -tardías- medidas modernizadoras de los Borbones, realizadas hacia finales del siglo XVIII, el Imperio hispánico no consiguió desprenderse de la inmensa traba que representaba el poder de una nobleza y un clero a esa altura completamente parasitarios; de la concentración de tierras al servicio de la mera exportación de materias primas; de su industria raquítica; además de una unificación nacional incompleta. En suma, una revolución democrático-burguesa retaceada.

Marx señaló en 1854 que:

[...] en los otros grandes Estados de Europa la monarquía absoluta se presenta como un centro civilizador, como la iniciadora de la unidad social. Allí era la monarquía absoluta el laboratorio en que se mezclaban y amasaban los varios elementos de la sociedad, hasta permitir a las ciudades cambiar la independencia local y la soberanía medieval por el dominio general de las clases medias y la

${ }^{299}$ Ídem, p. 317. 
común preponderancia de la sociedad civil. En España, por el contrario, mientras la aristocracia se hundió en la decadencia sin perder sus privilegios más nocivos, las ciudades perdieron su poder medieval sin ganar en importancia moderna $[\ldots]^{300}$.

Asimismo, la aristocracia española:

[...] hizo todo lo que estaba en su poder para impedir el crecimiento de intereses comunes derivados de la división nacional del trabajo y de la multiplicidad de los intercambios internos, única base sobre la que se puede crear un sistema uniforme de administración y de aplicación de leyes generales $[\ldots]^{301}$.

En consecuencia, la unidad nacional, una de las tareas básicas de cualquier revolución democrático-burguesa, nunca fue completamente resuelta, al menos no en el grado de otras naciones europeas. En relación con esto, el marxista catalán Andreu Nin escribió en 1932:

La unidad española ha sido una unidad artificiosa y despótica, cimentada en la dominación de los elementos semifeudales, los terratenientes y la Iglesia [...] Si España hubiera sido un gran país industrial, sin ningún género de duda el capitalismo habría realizado su unidad y los problemas nacionales no surgirían con la acuidad con que se han producido ${ }^{302}$.

En ese contexto, el conjunto de medidas proteccionistas propiciadas por los Borbones, que intentaron un tímido impulso capitalista hacia finales del siglo XVIII, solo profundizó la tendencia desintegradora.

Al despuntar el siglo XIX, la capacidad de la Corona hispánica para controlar sus colonias había disminuido drásticamente. Durante la mayor parte del siglo anterior, Madrid sostuvo una alianza con Francia, que generó conflictos con Gran Bretaña y su aliado Portugal. La Revolución Francesa cambiaría este esquema de alianzas. En 1793, España adhirió a las coaliciones que intentaron liquidar la experiencia revolucionaria francesa. Pero la incursión de tropas francesa en la Península en 1794 obligó, nuevamente, a un cambio brusco: el absolutismo español volvió a sellar alianza con la Francia revolucionaria, que duraría hasta 1808. Para enfrentar la expansión francesa, la flota británica bloqueó los puertos españoles y provocó un colapso en el comercio entre la metrópoli y sus colonias americanas, donde se intensificó el comercio clandestino. En 1805, la situación empeoró todavía más con la derrota de la armada franco-española en la batalla de Trafalgar, que selló el dominio británico sobre el Atlántico.

\footnotetext{
${ }^{300}$ MARX, Karl. La España revolucionaria..., op. cit.

${ }^{301}$ Ibídem.

302 NIN, Andreu. Consideraciones sobre el problema de las nacionalidades. 1932. Disponible en: $<$ https://www.marxists.org/espanol/nin/1932/consideraciones_nacionalidades.htm>, $\quad$ consultado el $23 / 10 / 2017$.
} 
En medio de ese proceso centrífugo, la “espada” de la Revolución Francesa irrumpirá de manera avasallante.

Entre 1807 y 1808, Napoleón ocupa la Península Ibérica. Este hecho es fundamental en la suerte de España y sus colonias. Lo mismo para la Corona lusitana. Presos Fernando VII y toda la familia real, la metrópoli hispánica quedó acéfala y se abrió una dramática crisis de poder a ambas orillas del Atlántico. Por su parte, el príncipe regente Don João y toda la Corte portuguesa abandonaron Portugal, escoltados por una flota inglesa, para establecerse en el Brasil ${ }^{303}$. Los años desde 1808 a 1810 marcarán el "bienio transcendental”, el momento axial de la crisis.

El vacío en el trono desencadenó una serie de sucesos políticos que aceleraron la desagregación del Imperio español en las siguientes décadas. El 2 de mayo de 1808 el pueblo madrileño inició, de manera espontánea, un levantamiento armado contra la ocupación francesa, que rápidamente se extendió a las demás ciudades ibéricas. Los sublevados formaron Juntas de Gobierno en distintas localidades, las que se centralizaron en la Junta Suprema Central Gubernativa ${ }^{304}$. Este órgano, que estableció su sede en Sevilla y que aseguraba representar los intereses de Fernando VII, el "rey cautivo", en setiembre de 1808 proclamó ser un gobierno paralelo a la ocupación francesa.

En enero de 1809, para contrarrestar los posibles efectos del envío de emisarios a América por parte de José Bonaparte, la Junta Central decidió incluir en su seno a diputados electos en las colonias. El objetivo era reunir una Asamblea que redactase una Constitución para todo el reino, que se convertiría en monarquía constitucional ${ }^{305}$, aunque esas Cortes, “en relación con las colonias, mantuvieron restricciones a la libertad de comercio y la desigualdad de derechos en la representación política" ${ }^{306}$. En el mismo sentido, el historiador João Pimenta señala que las Cortes “insistían en una notoria desigualdad numérica entre

\footnotetext{
${ }^{303}$ ARRUDA, José Jobson de Andrade. Uma colônia entre dois impérios: a abertura dos portos brasileiros, 1800-1808. Bauru: EDUSC, 2008. Sobre la relación entre Portugal y su colonia americana, consultar: ARRUDA, José Jobson de Andrade. O Brasil no comércio colonial. São Paulo: Ática, 1980.

${ }^{304}$ Las Juntas, según la tradición hispánica, eran gobiernos provisorios creados como consecuencia de la desaparición o ausencia de la autoridad suprema.

${ }^{305}$ En efecto, una Asamblea reunida en Cádiz promulgó una Constitución de corte liberal en 1812, que no impidió la independencia de América y fue dejada sin efecto por Fernando VII en 1814, cuando retornó como monarca absoluto. Sobre este proceso histórico, ver: BERBEL, Márcia; OLIVEIRA, Cecília (Org.). $A$ experiência constitucional de Cádis: Espanha, Portugal e Brasil. São Paulo: Alameda, 2012.

${ }^{306}$ PRADO, Maria; PELLEGRINO, Gabriela. História da América Latina..., op. cit., p. 26.
} 
representantes provenientes de América y de Europa: mientras estos ocupaban más de 250 asientos, a aquellos les cabían solo 30"307.

Con todo, lo que quedó conocido como reformas borbónicas -ideadas con el afán de centralizar el Imperio de manera más eficaz- tuvo el efecto opuesto: estas reformas agudizaron las contradicciones entre las incipientes burguesías hispanoamericanas y la metrópoli. Los sectores más dinámicos de las clases propietarias locales, comerciantes y estancieros, aspiraban poder relacionarse de modo más directo con el mercado mundial. La relativa liberación del comercio solo agigantó ese propósito, que implicaba, cuanto menos, atenuar la cada vez más molesta intermediación colonial. Los sucesos de Bayona fueron el detonante del desequilibrio de intereses previo a 1808 .

El historiador Jorge Gelman enfatiza la necesidad de volver la mirada hacia las transformaciones experimentadas por los países en vías de industrialización, convertidos en poderosos polos de atracción, y cómo los cambios en la división internacional del trabajo afectaron el papel de Hispanoamérica:

\begin{abstract}
En este contexto, el rol de las metrópolis imperiales que estaban lejos de la vanguardia del proceso de industrialización era cada vez más superfluo, inclusive podía ser percibido como un estorbo para las posibilidades de algunas regiones americanas de aprovechar ese nuevo escenario ${ }^{308}$.
\end{abstract}

En ese marco, el virreinato del Río de la Plata -actuales Argentina, Uruguay, Paraguay y Bolivia- se estructuró en 1776 como uno de los polos capitalistas dinámicos, sosteniéndose sobre un eje económico completamente ligado al mercado mundial: la minería del Alto Perú. Los metales preciosos se embarcaban en Buenos Aires, que desde mediados del siglo XVIII se había transformado en el principal polo de atracción y redistribución comercial en la región, erigiéndose después en capital virreinal. Del valor de las exportaciones del Plata, entre 1779 y 1784, 81\% correspondió al metálico ${ }^{309}$. Así, hasta mediados del siglo XVIII, la región más pujante y poblada era el Alto Perú -con sus minas en Potosí, Oruro, Chocaya, San Antonio, etc.- y el Interior, no Buenos Aires y el Litoral. Pero esa situación comenzó a cambiar con el paulatino agotamiento de las minas de Potosí, que hasta entonces había sido el polo económico ordenador. Este hecho quebró la economía del Interior. Además, creó una enorme crisis fiscal en el Virreinato: si en 1790 las remesas

${ }^{307}$ PIMENTA, João Paulo. A independência do Brasil e a experiência hispano-americana..., op. cit., p. 96. Sobre la cuestión americana en las Cortes españolas, ver también: CHUST, Manuel. La cuestión nacional americana en las Cortes de Cádiz. Valencia: Centro Francisco Tomás y Valiente Uned Alzira, 1999.

${ }^{308}$ CHUST, Manuel (org.). Las independencias latinoamericanas en su laberinto ..., op. cit., p. 176.

${ }^{309}$ RATH, Christian. El carácter de la Revolución de Mayo. En defensa del marxismo, Buenos Aires, n. 38, p. $8,2010$. 
altoperuanas cubrían $60 \%$ del gasto fiscal de la capital, en 1805 solventaban solo 6\%. Por otra parte, la decadencia minera coincidió con el auge de la ganadería de Buenos Aires y el Litoral. A inicios del siglo XIX, la demanda mundial de cueros había aumentado notablemente. Si entre 1750 y 1778 la región platense exportó un promedio anual de 150.000 unidades de cueros, luego de las reformas borbónicas esa cifra saltó a 800.000. A finales de siglo se llegó a 1.400 .000 cueros $^{310}$. Entre 1810 y 1815 fueron 3.100 .000 unidades de cueros vendidos a Inglaterra ${ }^{311}$. Desde la década de 1780 se pudo aprovechar la carne, salándola.

Los principales compradores -Inglaterra y Francia- pagaban mucho mejor que los comerciantes españoles, a quienes los hacendados locales estaban formalmente obligados a vender. Puesto así, no es difícil entender por qué la demanda de libre comercio fue creciendo entre las clases propietarias platenses.

En ese contexto, el motor de la inestabilidad y de las divisiones de clase radicará en "la crisis de una fuerza productiva superada por el surgimiento y perfeccionamiento de otra, constituida por los saladeros, la lana y los cueros salados"312. La producción minera, si bien estaba orientada a la exportación, estableció una cadena económica que interrelacionaba las regiones a partir de un mercado interno colonial más dinámico de lo que se supone. Su decadencia cedió paso, en palabras del historiador Milcíades Peña, a la "civilización del cuero", con centro en la provincia de Buenos Aires, y que tuvo como principal contraparte a Su Majestad británica. A inicios del siglo XIX, anota Nahuel Moreno: "Buenos Aires, de puerto único se transformó también, incluida su región de influencia, en el aparato productivo más importante del país" ${ }^{313}$.

En medio de esas transformaciones económicas, la crisis europea y de la metrópoli sacudirá a la capital virreinal. Peña resalta el peso de la coyuntura de 1808-1810 en Europa:

[La independencia] fue decidida por las necesidades del desarrollo de la sociedad capitalista europea, creada por las revoluciones democrático-burguesas de Inglaterra y Francia, y porque fue el avance de la revolución democrático-burguesa de Francia sobre España lo que permitió la eclosión de la independencia americana $^{314}$.

En ese sentido, François-Xavier Guerra reflexiona sobre la influencia de la Revolución Francesa en el proceso americano y el mundo occidental:

La Revolución Francesa no tiene precedentes y por eso su capacidad inventiva es incomparablemente superior a las que le suceden. Las revoluciones hispánicas

\footnotetext{
310 Ídem, p. 6.

311 MORENO, Nahuel [1975]. Método de interpretación ..., op. cit.

312 Ibídem.

${ }^{313}$ Ibídem.

${ }^{314}$ PEÑA, Milcíades. Historia del pueblo argentino..., op. cit., p. 89.
} 
dispondrán, al contrario, de todo un acervo de nuevas referencias -ideas, imaginarios, símbolos, experiencias constitucionales-que podrán utilizar, a veces de manera diferente o combinarlas con otras aportaciones, pero que no tendrán que crear necesariamente ${ }^{315}$.

Al "vacío en el trono" peninsular debe sumarse, en las colonias, el influjo de la Revolución de Independencia de los EEUU; de la heroica Revolución negra en Haití316; además de la Rebelión de Túpac Amaru. Todos estos procesos revolucionarios democráticoburgueses anticoloniales, como señalamos, no fueron sino variantes de las revoluciones burguesas clásicas expresadas en las áreas colonizadas.

La crisis de las monarquías ibéricas y la necesidad de abrir nuevos mercados -debido al bloqueo napoleónico en Europa-motivaron dos invasiones inglesas en el Río de la Plata. En 1806 atacaron y tomaron Buenos Aires. En 1807 le tocó el turno a Montevideo. Las dos invasiones fueron derrotadas por la acción de los nacidos en América, ante la huida del virrey Sobremonte. El régimen colonial español quedó herido de muerte. En 1807, un Cabildo Abierto depuso a Sobremonte e invistió como nuevo virrey al francés Santiago de Liniers, héroe de la "Reconquista".

Los ingleses no demoraron en asimilar la derrota. El 1 de mayo de 1807, el lúcido ministro de Guerra, Lord Castlereagh, informaba que no tenía “esperanzas de conquistar este inmenso territorio [Sudamérica] oponiéndose por las armas a su población”. Si lo que se pretendía era "abrir a nuestros productos sus mercados”, convenía más “aproximarse como mercaderes y no como enemigos”; y si se producía la independencia de España, sugería Castlereagh, Inglaterra "debería favorecerla solamente como auxiliar y protectora de los nativos para evitar recelos" 317 .

Pero mencionemos algo sobre la participación paraguaya en el enfrentamiento a las invasiones inglesas en el Plata, puesto que tendrá impacto en los sucesos posteriores. El 12 de setiembre de 1805 había asumido el mando quien sería el último gobernador español de la provincia del Paraguay: Bernardo de Velasco y Huidobro ${ }^{318}$. En enero de 1807, Velasco

315 GUERRA, François-Xavier. Modernidad e independencias..., op. cit., p. 35. Ver también: COGGIOLA, Osvaldo (Org.). A revolução francesa e seu impacto na América Latina. São Paulo: Nova Stella/EDUSP, 1990; PIMENTA, João Paulo. A independência do Brasil e a experiência hispano-americana..., op. cit., p. 31. 316 GORENDER, Jacob. O épico e o trágico na história do Haiti. In: JAMES, C. R. L. [1938]. Os jacobinos negros: Toussaint L'Ouverture e a revolução de São Domingos. São Paulo: Boitempo, 2000; MEZLLAS, Glodel. La revolución haitiana de 1804 y sus impactos políticos sobre América Latina. Estudios de Filosofía Práctica e Historia de las Ideas, Mendoza, v. 11, n. 2, 2009.

317 ROSA, José. Rivadavia y el imperialismo financiero. 1969. Disponible en: $<$ http://www.labaldrich.com.ar/wp-content/uploads/2016/07/Rosa-Jose-Maria-Rivadavia-y-el-imperialismofinanciero.pdf> $>$, consultado el 27/03/2019.

${ }^{318}$ El título encomendado fue el de Gobernador Militar y Político e Intendente de la Provincia del Paraguay y de los treinta pueblos de las Misiones de los indios guaraníes y tapés del Uruguay y del Paraná. 
debió ausentarse temporalmente para contribuir con la defensa de Montevideo contra el ataque de las tropas inglesas ${ }^{319}$.

La noticia de la conquista de Buenos Aires había llegado a Asunción el 20 de julio de 1806. El coronel paraguayo José de Espínola y Peña realizó una leva despiadada en el campo y partió, en agosto de 1806, al frente de un contingente de 534 milicianos $^{320}$. Un segundo contingente de 450 hombres salió a mediados de diciembre. La provincia se hizo cargo de todos los gastos de la expedición y envió, además, dos remesas de colectas realizadas entre los vecinos con destino a Buenos Aires. En enero de 1807, el contingente paraguayo, que combatía al lado de las tropas de otras provincias, sufrió serias bajas contra los ingleses en la batalla del Buceo. Entre muertos y heridos, los expedicionarios salidos de Asunción perdieron la mitad de sus efectivos ${ }^{321}$. Los sobrevivientes del desastre cruzaron el estuario para unirse a una segunda fuerza expedicionaria, comandada por Velasco. En julio de 1807, las milicias paraguayas fueron partícipes de la segunda defensa de Buenos Aires, atacada por más de diez mil soldados británicos al mando de John Whitelocke.

Los restos de la expedición paraguaya fueron repatriados inmediatamente. Signos de descontento y desmoralización se evidenciaron a su retorno. Los milicianos culpaban a Espínola por el desastre de Buceo. Igualmente, desconfiaban de los porteños, que en ese episodio no acudieron a reforzar a quienes defendían Montevideo. El impacto político de aquella derrota militar fue profundo. En palabras del historiador Cooney: "Si había dos cuestiones en las que los oficiales, las tropas y la mayoría de los paraguayos estaban de acuerdo, eran el odio a Espínola y el deseo de no enviar nuevamente la milicia fuera de la Provincia" 322 .

Sin embargo, la campaña contra Inglaterra daría sus frutos. Entre los oficiales paraguayos que fueron a guerrear al estuario y estrecharon lazos con otros combatientes platenses, muchos tendrían una actuación importante en el posterior proceso independentista: el teniente Fulgencio Yegros, los capitanes Juan Manuel Gamarra y José

\footnotetext{
${ }^{319}$ Expediente sobre la marcha del gobernador del Paraguay, Bernardo de Velasco, a Buenos Aires para auxiliar en la defensa de la plaza de Montevideo contra las armas inglesas. ANA-SH, v. 204, n. 5; ANA-SH, v. 204, n. 4. Ver también: GONZÁLEZ DE BOSIO, Beatriz. Las invasiones inglesas en el Río de la Plata 1806-1807: precursoras de la independencia de Hispanoamérica. s/f. Disponible en: $<$ http://www.corredordelasideas.org/docs/bicentenario/invasiones inglesas.pdf>, consultado el 18/05/2015.

${ }^{320}$ CABALLERO CAMPOS, Herib. Proceso de la Independencia paraguaya ..., op. cit., pp. 60-62.

${ }^{321}$ CHAVES, Julio. Compendio de historia paraguaya..., op. cit., p. 107.

322 COONEY, Jerry. Milicia, Estado y Sociedad en Paraguay: El camino a 1813. In: TELESCA, Ignacio; BREZZO, Liliana; CABALLERO CAMPOS, Herib (Org.). Paraguay 1813..., op. cit., p. 84.
} 
Fernández Montiel, el alférez Fernando de la Mora, y el entonces cadete Antonio Tomás Yegros $^{323}$.

\subsection{Alboroto en la capital: la revolución de Mayo en Buenos Aires}

Antes de adentrarnos en el caso del Río de la Plata, es importante retomar la idea de que, cuando estudiamos el período independentista en América, estamos frente a un fenómeno en el que se interrelacionan desigualmente dos cuestiones centrales: 1) la lucha contra la metrópoli en sí; 2) el proceso de conformación de Estados nacionales, con toda su complejidad y contradicciones; un fenómeno que se incubó durante la Colonia y siguió desarrollándose durante la lucha contra España y después de la derrota de la antigua metrópoli.

A inicios de 1810, la victoria de Napoleón en España parecía definitiva. Debido al avance francés, la Junta Central de Sevilla se desarticuló y surgió el Consejo de Regencia. La crisis de poder o de legitimidad en la metrópoli, diría F. Guerra, agudizó inevitablemente la inestabilidad en las colonias ¿A quién jurar obediencia? ¿Al “usurpador” José Bonaparte, al prisionero Fernando VII, al Consejo de Regencia, a la princesa Carlota Joaquina ${ }^{324}$ ?

Como señalamos, los sectores más fuertes y tradicionales de las burguesías latinoamericanas, en un primer período no se plantearon liquidar sino atenuar el dominio colonial. Es decir, no consideraban la independencia ni mucho menos pretendían una guerra contra España. Buscaron un acuerdo que mejorase su posición política y económica, concretamente una abertura en escala superior para el comercio atlántico, sin que esto implicase, necesariamente, cuestionar la relación colonial.

En 1810 surgieron conmociones políticas y Juntas criollas en Caracas, Buenos Aires, Santa Fe de Bogotá, Santiago de Chile, Quito, y Nueva España (actual México). Con sus matices, todas juraron fidelidad a Fernando VII. Esto expresaba nítidamente la vacilación de las clases propietarias criollas en el momento más crítico de la metrópoli. Ese conservadorismo tenía fundamento: históricamente habían actuado como socias menores de los colonizadores. Algunos autores nos dicen que la “máscara de Fernando VII” nunca pasó

\footnotetext{
${ }^{323}$ CABAllero CAMPOS, Herib. Proceso de la Independencia paraguaya..., op. cit., pp. 60-62.

${ }^{324}$ Esposa de Don João, príncipe regente de Portugal, residente en el Brasil, y hermana de Fernando VII. Era la única representante de la familia real española que no estaba presa y reclamaba para sí el dominio de las colonias americanas.
} 
de una suerte de "maniobra" que retrasaría la reacción del realismo ${ }^{325}$. Esta tesis no es consistente porque: 1) si desde la primera hora hubiera existido la decisión firme de avanzar hacia la independencia absoluta, difícilmente los patriotas hubieran proclamado una revolución contra el rey en nombre del rey; 2) si la "máscara" fue una maniobra distractora sin duda esta fue ingenua y no funcionó, puesto que el españolismo nunca dudó acerca de la necesidad de aplastar un movimiento que juzgó separatista desde su inicio.

En ese contexto, el 25 de mayo de 1810 representantes de la pujante burguesía comercial y estanciera de Buenos Aires depusieron en un Cabildo Abierto ${ }^{326}$ al virrey Baltasar Hidalgo de Cisneros y conformaron una Junta Provisional Gubernativa ${ }^{327}$. El cambio de mando fue incruento, hecho que puede explicarse, en parte, a que, desde las invasiones inglesas, el poder militar efectivo en la región estaba en manos de la élite criolla, que se asentaba en regimientos de milicias, como la de Patricios y Arribeños, que en 1807 llegaron a contar con 7.800 hombres a sueldo. En 1810, las reducidas fuerzas veteranas peninsulares no estaban en condiciones de resistir. En el mismo acto, la Junta porteña se arrogó el gobierno del recientemente extinto Virreinato en nombre de Fernando VII, con la promesa de:

[...] proveer por todos los medios posibles la conservación de nuestra Religión Santa, la observancia de las Leyes que nos rigen, la común prosperidad, y el sostén de estas Posesiones en la más constante fidelidad y adhesión a nuestro muy amado Rey y Señor D. Fernando VII y sus legítimos sucesores en la Corona de España $[\ldots]^{328}$.

A pesar de su carácter "pacífico", el cambio de gobierno fue identificado por ambos bandos como una revolución.

Como acertadamente señalan Pellegrino y Prado, Buenos Aires: “[...] projetava manter sua hegemonia sobre os mesmos territórios que haviam composto o antigo Vice-

\footnotetext{
325 Sobre este tema, ver: LANDAVAZO, Marco. La máscara de Fernando VII. Discurso e imaginario monárquico en una época de crisis. Nueva España, 1808-1822. México: El Colegio de México/Universidad Michoacana de San Nicolás de Hidalgo/El Colegio de Michoacán, 2001.

${ }^{326}$ Un Cabildo Abierto era una reunión convocada de manera excepcional, en la que participaban, además de los miembros ordinarios del Cabildo, las personas más destacadas de la provincia, "la parte mejor y más principal del vecindario", según la expresión de la época.

${ }^{327}$ Bando del Cabildo de Buenos Aires y Proclama de la Junta Provisional Gubernativa de la capital del Río de la Plata a los habitantes de ella y de las provincias de su superior mando, del 26/05/1810. ANA-SH, v. 211, n. 2. Ver también: CORBELLINI, Enrique. La revolución de Mayo y sus antecedentes desde las invasiones inglesas al Río de la Plata. Buenos Aires: Lajouane, 1950. La Primera Junta de Gobierno de Buenos Aires estuvo presidida por el coronel Cornelio Saavedra (jefe hasta entonces del Regimiento de Patricios), siendo secretarios Mariano Moreno y Juan José Paso, y vocales Manuel Belgrano, Juan José Castelli, el comandante Miguel de Azcuénaga, el presbítero Manuel Alberti, Domingo Matheu y Juan Larrea.

${ }^{328}$ Bando del Cabildo de Buenos Aires y Proclama... ANA-SH, v. 211, n. 2.
} 
reinado do Rio da Prata. Deste modo, tanto a Banda Oriental, quanto o Paraguai 'deveriam' fazer parte da nascente Províncias Unidas do Rio da Prata" 329.

En aquellos días agitados, el periódico Gazeta de Buenos Aires fue lanzado como vocero oficial de la Junta, que [se] "constituirá não somente no principal instrumento de propaganda do movimento, mas também no suporte mais eficiente de transmissão de notícias da América espanhola para o vizinho Brasil"330, según relata Pimenta.

El 20 de junio, el ministro inglés en Rio de Janeiro, Lord Strangford, informó acerca del 25 de mayo a su gobierno y vaticinó con sagacidad: "pasará mucho antes de que este gobierno rompa toda alianza con Fernando VII y establezca un sistema enteramente independiente" 331 .

La Junta envió una circular a todas las provincias del Interior, en la que exigía que fuera reconocida su autoridad hasta que cada región enviara sus delegados para incorporarse a un gobierno central que debería residir en Buenos Aires ${ }^{332}$.

Aquí aparece límpidamente el problema no solo de la presión centrífuga en las relaciones España-América sino también dentro del propio espacio americano, un proceso concomitante. Si Buenos Aires o Santa Fe de Bogotá rechazaron la autoridad del Consejo de Regencia de Cádiz y reivindicaron soberanía sobre un territorio -en este caso los correspondientes a los virreinatos de la Plata y de Nueva Granada ${ }^{333}$-, Asunción y Cartagena de Indias pretendieron hacer valer el mismo derecho ante sus antiguas capitales. Para los asuncenos y cartageneros, ¿por qué razón el proceso de reversión de soberanía debe detenerse necesariamente en las capitales, en este caso, Buenos Aires y Bogotá? Más todavía cuando la invocación de ese principio y de ese derecho estaba fundamentado en históricas rencillas y reivindicaciones no satisfechas por las "ciudades principales". Si el pacto entre el rey y sus súbditos estaba roto, ¿por qué sí debía mantenerse la preeminencia de unas jurisdicciones americanas sobre otras? La caja de Pandora estaba abierta.

En ese contexto, se erigieron cuatro zonas de oposición a la Junta bonaerense: Montevideo, principal plaza y sede de la flota española; Córdoba, liderada por el ex virrey

\footnotetext{
${ }^{329}$ PRADO, Maria; PELLEGRINO, Gabriela. História da América Latina..., op. cit., p. 48.

${ }^{330}$ PIMENTA, João Paulo. A independência do Brasil e a experiência hispano-americana..., op. cit., p. 99.

${ }^{331}$ MOLINA, Raúl A. Lord Strangford y la Revolución de Mayo. Revista Historia - Colección Mayo, Buenos Aires, n. 19, pp. 174-182, 1960.

332 Bando del Cabildo de Buenos Aires y Proclama..., ANA-SH, v. 211, n. 2.

${ }^{333}$ Sobre el proceso en Nueva Granada (actuales Colombia, Venezuela, Ecuador y Panamá), ver: MÚNERA, Alfonso. El fracaso de la Nación. Región, clase y raza en el Caribe colombiano (1717-1821). Bogotá: Banco de la República-El Áncora, 1998; URIBE, Jaime. La economía del virreinato, 1740-1810. In: OCAMPO, José. (Ed.). Historia económica de Colombia. 2. ed. Bogotá: Planeta, 1988.
} 
Liniers; el Alto Perú; y el Paraguay, entonces liderado por Bernardo de Velasco. Pero la resistencia a la Junta no cupo únicamente a los realistas. Fue más compleja: abarcó también sectores burgueses y pequeñoburgueses de criollos que no solo aspiraban a la independencia de España sino también de la ex capital virreinal.

Es más, es fundamental diferenciar los focos de resistencia a la Junta porteña. Liniers se insubordinó rechazando cualquier cuestionamiento o ruptura con el Consejo de Regencia peninsular. En Montevideo, quien organizó la resistencia fue el futuro virrey Francisco Javier de Elío, furioso realista - a punto de haber sido ejecutado en España durante el Trienio Liberal-, que además contó con el apoyo de poderosos comerciantes ávidos de ganar supremacía ante sus pares de la Banda Occidental ${ }^{334}$. Entonces, es notable que tal resistencia provino de ciudades con posiciones leales a la monarquía española -como fue el caso de Popayán o Santa Marta, en Nueva Granada-. El caso de Paraguay es más complejo. No solo por su sentimiento autonomista alimentado durante siglos por la marginalidad geográfica y comercial, sino porque el peso del españolismo en Asunción no podía ser comparado ni al de Córdoba ni mucho menos al de Montevideo. La dinámica de la oposición paraguaya a la propuesta centralizadora de Buenos Aires, que llegó a intentar controlar la provincia por la fuerza, como veremos más adelante, fue producto más de una reacción contra la opresión histórica de la antigua capital virreinal que una lealtad a la Corona hispánica.

Entre las primeras resoluciones de Buenos Aires estuvo el enviar "en el término de quince días una Expedición de quinientos hombres para [auxiliar a] las Provincias interiores"335. El coronel Francisco A. Ocampo recibió instrucciones precisas: eliminar cualquier interferencia a las votaciones de los diputados locales que irían a la capital; la fuerza armada de cada provincia deberá ser agregada a la fuerza del ejército auxiliador; la tropa auxiliadora se mantendrá en cada ciudad hasta el reconocimiento de la Junta y la partida del diputado correspondiente ${ }^{336}$. La documentación muestra claramente que las expediciones auxiliadoras -luego veremos cómo se dio esto en el caso del Paraguay- no debían limitarse a liberar a las provincias de España garantizando el derecho a la libre autodeterminación. Debían, al mismo tiempo, "hacer reconocer la Junta"337.

\footnotetext{
${ }^{334}$ La Banda Oriental se ubicaba al este del río Uruguay y al norte del Río de la Plata, sobre la costa atlántica de Sudamérica. Abarcaba una zona que corresponde, aproximadamente, con la actual República Oriental del Uruguay y el Estado brasileño de Río Grande del Sur.

335 CHAVES, Julio [1938]. Historia de las relaciones entre Buenos-Ayres y el Paraguay: 1810-1813. 2. ed. Buenos Aires: Ediciones Niza, 1959, p. 22.

${ }^{336}$ Ibídem.

337 Ibídem.
} 
Cabe aquí una primera definición fundamental, que corresponde a Milcíades Peña y que compartimos plenamente: "La Revolución de Mayo tenía dos objetivos: emancipar al país de España y someter todo el Virreinato a Buenos Aires"338. El primero, indudablemente progresivo. El segundo, reaccionario, en la medida en que pisoteaba el derecho a la libre autodeterminación de las naciones oprimidas que emergían o trataban de emerger a la vida independiente en medio de la desintegración del régimen colonial.

Esta primera definición es un punto de partida, pero no agota otros problemas: ¿cuál fue el carácter de la Revolución de Mayo? ¿Fue social o político? ¿Cuál clase o sector de clase fue su protagonista? ¿Cuál fue su programa?

En primer término, sobre la relación entre las clases, Moreno apunta: "En principio, no existían clases nacionales sino regionales. Había zonas económicas, pero no un mercado

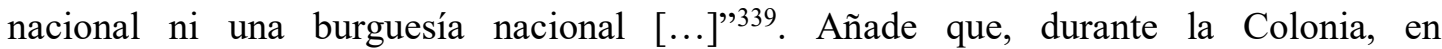
Latinoamérica:

[...] surgió una fuerte clase capitalista productora a la que podemos llamar terrateniente, estanciera, minera, etcétera, pero totalmente diferente a la compradora en cuanto a la composición individual del grupo y a sus intereses sectoriales $^{340}$.

Asentado en estas premisas, plantea un elemento central:

Es imposible comprender la historia argentina o latinoamericana en general si no
se advierte que hay una división tajante, una tremenda lucha, entre los
importadores o compradores y los productores, lucha que tiene lugar,
fundamentalmente, en torno a los impuestos de aduana. En efecto, ¿qué se ha
de gravar para solventar los gastos del Estado, las importaciones o las
exportaciones ${ }^{341}$ ?

A su vez: "los productores estaban claramente divididos entre los que producían para el mercado interno o regional [...] y los productores para la exportación"342.

En este contexto, siempre según Moreno, la preponderancia política la tenía la burguesía comercial: "De estos sectores [...] el que surgió como más unido en escala nacional fue la burguesía comercial, el gran importador de Buenos Aires [...] Era la clase minoritaria, pero, insistimos, más cohesionada, más sólidamente integrada en todo el país". Por su parte, "la burguesía productora [...] actuaba en frente único y no como partido político, siendo ese frente sumamente débil, ya que se fracturaba en cualquier

\footnotetext{
${ }^{338}$ PEÑA, Milcíades. Historia del pueblo argentino..., op. cit., p. 226.

${ }^{339}$ MORENO, Nahuel. Método de interpretación..., op.cit.

340 Ibídem.

${ }^{341}$ Ibídem.

${ }^{342}$ Ibídem.
} 
momento en función de los intereses regionales que lo componían"343. En otras palabras, a lo que sería el federalismo le faltó una dirección y un programa político unificado.

A su vez, la burguesía comercial estaba íntimamente ligada al capital británico, que apoyó la caída de Cisneros. Esta facción, insistimos, será determinante y crecerá por dos vías: como compradora de los cueros que vendían los estancieros, y como revendedora de los productos manufacturados de la industria británica ${ }^{344}$.

En su análisis estructural, Moreno hace una referencia a los pequeños propietarios y trabajadores: pequeño campesinado, peones, esclavos domésticos, artesanos, y el "tipo de vago" que representaba el gaucho ${ }^{345}$. Pero advierte que "los mismos no son aún sujetos del proceso histórico, es decir, no se elevan a la formulación de una política y una actividad propias y adhieren a distintos sectores burgueses y productores nacionales" ${ }^{246}$.

Cuando comienza el proceso independentista, en síntesis, “distintos sectores, pues, confluirán en Mayo. Productores para el mercado interno o el internacional, burgueses comerciales e intelectuales revolucionarios se aliarán para obtener la independencia" 347 .

Así, el punto en común de este primer frente único policlasista fue desalojar del poder estatal a los españoles. En ese sentido, no se trató de una revolución social sino esencialmente política. En otros términos, la revolución no se hizo para cambiar radicalmente la estructura social sino la superestructura política.

Y, como veremos, aún en ese terreno el programa fue vacilante -por decir lo mínimodurante todo un período, pues se expresó más como autonomismo que como independentismo. Pero esto no equivale a decir que ese cambio político no tuvo importancia. Tampoco significa que no existieron cambios sociales o económicos, solo significa que:

\footnotetext{
El movimiento que independizó a las colonias latinoamericanas -anota Peña- no traía consigo un nuevo régimen de producción ni modificó la estructura de clases de la sociedad colonial [...] Solo la alta burocracia enviada desde España por la Corona fue expropiada de su control por el Estado ${ }^{348}$.

Y añade: “esa burocracia importada fue el único grupo social dominante en la Colonia a que la Independencia vino a liquidar"349. Pero, cuando lo hizo, ese proceso

${ }^{343}$ Ibídem.

${ }^{344}$ RATH, Christian. El carácter de la Revolución de Mayo..., op. cit. p.10.

345 Sobre ese sector social, recomendamos la consulta de: POMER, León. Historias de gauchos y gauchisoldados. Buenos Aires: Colihue, 2007.

${ }^{346}$ MORENO, Nahuel. Método de interpretación ..., op. cit.

${ }^{347}$ Ibídem.

${ }^{348}$ PEÑA, Milcíades. Historia del pueblo argentino..., op. cit., p. 83.

349 Ibídem.
} 
revolucionario cumplió un cometido político de enorme magnitud: rompió las cadenas con la explotación y la opresión que la metrópoli ejerció durante tres siglos. Y ese fue un hecho muy progresivo, aun cuando no alteró el orden social existente, el "de los estancieros, de los comerciantes, de un lado, y del otro los gauchos, peones, artesanos y [trabajadores] domésticos"350.

Dicho esto, hay que señalar que uno de los principales obstáculos para que el proceso rioplatense no avanzase radicaba en la clase dirigente del amplio frente anticolonial, que era "casi exclusivamente comercial e intermediaria en el comercio extranjero, eminentemente portuaria y antinacional" 351 :

Su interés más claro [de las burguesías latinoamericanas y de la burguesía porteña] era el comercio libre con el mundo y en especial con Inglaterra, lo que significaba ahogar cualquier desarrollo autónomo industrial, que es la esencia de la revolución democrático-burguesa ${ }^{352}$.

Este fue el problema principal. Los sectores burgueses nativos más poderosos -sobre todo comerciales-, no aspiraban a cambiar la ubicación de los nuevos Estados en la división internacional del trabajo; no aspiraban a dejar de ser exportadores de materias primas y consumidores de manufacturas extranjeras. Al contrario, querían potenciar ese modelo y ser ellos -no los españoles- los que acaparasen el grueso de sus rentas. Su proyecto era capitalista, sin duda, pero no el de un capitalismo independiente o soberano, proteccionista, $\mathrm{y}$ en ese sentido potencialmente industrial, sino periférico y abastecedor de productos primarios.

La Junta porteña, en ese contexto, no tardó en autorizar la permanencia indefinida de los ingleses -que ahora venían como mercaderes y no como enemigos-, antes sometida a plazos. A las dos semanas redujo los impuestos de exportación sobre los cueros y el sebo de 50 a 7,5\%. En seis semanas se anuló la prohibición de exportar metálico. El librecambio produjo una avalancha de productos ingleses que comenzó a corroer las producciones locales y a copar el mercado interno. Los ponchos ingleses invadieron Buenos Aires a tres pesos, cuando los del Interior costaban $\operatorname{siete}^{353}$. En 1814, los productos de consumo popular representaron 51,3\% del total de la exportación británica al Río de la Plata, proporción que se mantuvo arriba de $50 \%$ hasta finales de la década ${ }^{354}$. El aumento del costo de vida azotó

\footnotetext{
350 Ídem, p. 102. Ver también: FRADKIN, Raúl. ¿Qué tuvo de revolucionaria la revolución de independencia? Nuevo Topo. Revista de historia y pensamiento crítico, Buenos Aires, n. 5, pp. 15-43, 2008.

${ }^{351}$ PEÑA, Milcíades. Historia del pueblo argentino..., op. cit., p. 91.

352 Ídem, p. 92.

${ }^{353}$ RATH, Christian. El carácter de la Revolución de Mayo..., op. cit., p. 12.

${ }^{354}$ HISTORIA GENERAL DE LAS RR.EE. DE LA REPÚBLICA ARGENTINA. El cuadro de situación fiscal en el Río de la Plata, 1815-1820: la creciente importancia del comercio exterior en los ingresos del
} 
a los sectores sociales más pobres ${ }^{355}$. A pesar del alto costo de la guerra contra España, los gobiernos porteños casi siempre eximieron a los comerciantes británicos de las cargas contribuciones, empréstitos y eventuales confiscaciones- que recayeron sobre comerciantes locales $\mathrm{y}$, en última instancia, sobre los consumidores finales. Inglaterra conquistaría por medio del laissez faire aquello que no conquistó con las armas.

Destacamos la síntesis del historiador Luis Vitale:

El pensamiento liberal del siglo XVIII que en Europa sirvió para realizar la revolución democrático-burguesa, en América Latina fue utilizado para cumplir solamente una de sus tareas: la independencia política [...] Mientras en Europa el liberalismo servía como instrumento de la burguesía industrial contra los terratenientes, aquí era utilizado por los latifundistas y mineros contra el monopolio español. Allá servía para el proteccionismo industrial, acá para el libre comercio $^{356}$.

¿Cuál fue la participación de las masas populares en 1810? Peña advierte que:

Los hacendados y comerciantes junto a abogados y militares se movieron por sus intereses cuando la ocasión se les presentó propicia, sin necesitar ni buscar ni obtener el respaldo de las grandes masas. Estas se agitaban durante la Colonia y con la independencia se agitarían más todavía, pero por razones y objetivos distintos a los de los cabildantes del 22 y 25 de Mayo $[\ldots]^{357}$.

Además, según su visión, la jura de fidelidad a Fernando VII y "los objetivos puramente políticos [de Mayo] no tenían por qué arrebatar de pasión a las masas" 358 .

Garavaglia refuerza esta idea, explicando que la historiografía tradicional argentina intentó presentar como "pueblo" la ruidosa presencia de jóvenes de familias tradicionales en mayo de 1810, pero "parece evidente que los sectores populares no participaron sino muy secundariamente en esta primerísima etapa de los acontecimientos en Buenos Aires" 359.

La actuación política más clara y decisiva de las masas populares vendría después de 1810, principalmente por medio de su participación en la guerra continental de independencia. Garavaglia anota que, una vez que la soberanía retornó “al pueblo", las disputas entre los diversos sectores de las elites blancas difícilmente pudieron prescindir de las clases trabajadoras urbanas y rurales. La necesidad creciente del concurso de "hombres en armas", tanto para los conflictos regionales como para la guerra de independencia contra la Madre Patria, obligó a los nuevos detentores del poder a apelar a la plebe, sea como votantes, es decir protociudadanos, sea como soldados milicianos. El Ejército de los Andes,

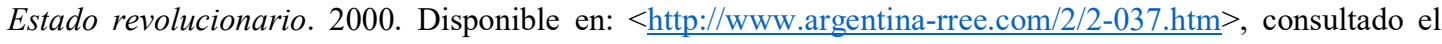
23/06/2017.

${ }^{355}$ RATH, Christian. El carácter de la Revolución de Mayo..., op. cit., p.18.

${ }^{356}$ VITALE, Luis. Interpretación marxista de la historia de Chile..., op. cit.

${ }^{357}$ PEÑA, Milcíades. Historia del pueblo argentino..., op. cit., p. 98.

358 Ídem, p. 97.

${ }^{359}$ GARAVAGLIA, Juan. Os primórdios do processo de independência..., op. cit., p. 231. 
comandado por San Martín, estuvo compuesto mayoritariamente por negros y mulatos, más de la mitad esclavos libertos. El general Martín Miguel de Güemes, gobernador de la provincia de Salta entre 1815 y 1821, detuvo seis invasiones españolistas en el noroeste del actual territorio argentino apelando a una guerra de guerrillas -la Guerra Gaucha- que contó con escasos recursos y una tropa compuesta por campesinos pobres y gauchos, sólidamente apoyada por la población local. Sin la cobertura de Güemes y sus gauchos "infernales", es dudoso que San Martín pudiera dedicarse con todo a organizar y ejecutar el icónico Cruce de los Andes en 1817.

Así, la inestabilidad, las más de las veces surgida de guerras o querellas intestinas, obligó a considerar opiniones y hasta demandas de los sectores populares, anteriormente impensables ${ }^{360}$.

\subsection{Unitarios y federales}

El amplio frente único que depuso al virrey Cisneros no tardó en dar paso a la formación de las dos grandes facciones que disputarían la hegemonía política y económica en el Río de la Plata durante más de medio siglo, protagonizando, en palabras de Chiaramonte, "uno de los conflictos más hondos y duraderos de la historia iberoamericana del siglo XIX" ${ }^{361}$ : el partido unitario y el federal.

Nahuel Moreno anota que esos partidos, en el sentido que este término podía tener en el siglo XIX, expresarán: "la disputa entre los importadores -comerciantes- y los productores (principalmente exportadores)"362. Así, ambos bandos representaban los intereses de distintas facciones burguesas:

Para los federales de la provincia de Buenos Aires el principal interés es pacificar el campo, asediado por los indios, y conquistarles sus tierras para desarrollar su producción ganadera. Los federales del Litoral tenían una política parecida, aunque chocaban con los de Buenos Aires por el monopolio del puerto, que estos ejercían. Los del Interior defendían con uñas y dientes su producción artesanal de la invasión de las mercaderías extranjeras. La burguesía comercial [de Buenos Aires] tenía un solo objetivo: unificar férreamente el país, liquidar las aduanas interiores para facilitar el comercio, eliminando toda rémora o impedimento a la libre circulación de las mercaderías ${ }^{363}$.

\footnotetext{
360 Ídem, p. 213.

361 CHIARAMONTE, José. Nación y Estado en Iberoamérica. El lenguaje político en tiempos de las independencias. Buenos Aires: Sudamericana, 2004, p. 104.

${ }^{362}$ MORENO, Nahuel [1975]. Método de interpretación..., op. cit.

${ }^{363}$ Ibídem.
} 
En la capital y la provincia de Buenos Aires, pese a los conflictos, la burguesía comercial unitaria y los estancieros federales coincidían en lo fundamental: el monopolio del puerto y la aduana. De ahí que el dictador “federal” Juan Manuel de Rosas, por ejemplo, haya sido un férreo "centralista"364.

Ambas facciones bonaerenses, nos dice Peña, “coincidían también en afianzar la acumulación capitalista, proletarizando al gaucho y consolidando la propiedad de la tierra. Ambas coincidían, también, en mantener excelentes relaciones con Inglaterra" ${ }^{365}$.

La cuestión del puerto fue decisiva. El drama geográfico rioplatense, que implicaba una sola puerta al mundo para una enorme región, se haría sentir impiadosamente en el terreno político-militar. Buenos Aires no era un puerto "nacional". No. El meollo de la lucha estribaba en que el sector burgués que lo controlara simplemente atesoraría el grueso de las rentas del comercio. La burguesía bonaerense tenía indiscutiblemente un proyecto de acumulación capitalista, pero "a espaldas e incluso contra la nación", hecho que la presionaba para ligarse más y más a las potencias europeas, sobre todo a Gran Bretaña ${ }^{366}$.

Peña señala, con razón, que la burguesía comercial porteña pretendía: “unificar el país [...] para hacer de toda la nación un solo mercado donde comprar y vender en beneficio de la burguesía porteña y sus socios ingleses" ${ }^{367}$. Su mezquindad y estrechez de miras radicaba en que sus negocios no se basaban en la producción nacional sino en el comercio exterior, principalmente el de importación. Este hecho, con el tiempo, consolidaría un nuevo tipo de dependencia: el de la industria y las finanzas foráneas. Por lo tanto, el unitarismo "no podía aspirar a industrializar el país, porque de ello hubiera resultado su liquidación, puesto que su prosperidad dependía de la introducción de mercancías extranjeras. Y a esto se reducía lo esencial de su política" ${ }^{368}$.

Por su parte, el partido federal era "un gran frente que reflejaba los intereses de los productores del país"369. Estaba integrado por sectores burgueses y pequeñoburgueses de distintas regiones. Por eso, poseía varias alas. La más fuerte era la de los estancieros de

\footnotetext{
364 Sobre este asunto, consultar: MIERS, Jorge. Las formas complejas del poder: la problemática del caudillismo a la luz del régimen rosista. In: GOLDMAN, Noemí; SALVATORE, Ricardo. Caudillismos rioplatenses: nuevas miradas a un viejo problema. Buenos Aires: Editorial Universitaria de Buenos Aires, 1998, pp. 83-100.

365 PEÑA, Milcíades. Historia del pueblo argentino..., op. cit., p. 138.

366 Ídem, p. 118.

367 Ídem, p. 134.

368 Ídem, p. 142.

${ }^{369}$ MORENO, Nahuel [1975]. Método de interpretación..., op. cit.
} 
Buenos Aires, que “en la cuestión decisiva de quién dominaría el país -Buenos Aires o toda la nación- coincidía más con sus enemigos unitarios que con sus aliados federales" ${ }^{370}$.

Dentro del frente federal, tanto los estancieros de Buenos Aires como los del Litoral eran librecambistas, interesados en exportar los productos de la ganadería. El conflicto, en campamento federalista, se dará a raíz de que los estancieros bonaerenses poseían puerto propio, los del Litoral, no: "La nacionalización del puerto de Buenos Aires y [la] apertura de los puertos ultramarinos sobre el río Paraná anularía ciertamente las ventajas que los productores porteños de carne y cueros tenían sobre sus competidores de Santa Fe, Córdoba, Entre Ríos"371.

El Interior, por su parte, no poseía productos exportables, pero sí una manufactura rudimentaria que deseaba proteger de la inundación de mercaderías extranjeras. Tanto los estancieros del Litoral como los productores del Interior coincidían, entonces, en luchar contra el monopolio de la aduana porteña.

Moreno señala un elemento importante que diferenció el federalismo del unitarismo:

[...] todos los trabajadores apoyan -en líneas generales- el federalismo. En realidad, no podía ser de otra manera, pues los pequeños productores estaban ligados a la producción nacional y, por ende, al movimiento político que los representaba, aunque estaba dirigido por la gran burguesía ${ }^{372}$.

Peña reafirma que "confluían al Partido Federal las masas trabajadoras de Buenos Aires y del Interior" 373 .

Cabe ahora otra definición. En ese choque interburgués que arrastró al Río de la Plata a una prolongada guerra civil, ¿existía un sector que expresara un proyecto progresivo? Por lo menos para Nahuel Moreno ese sector fue el federalismo.

Apresurémonos a decir que ninguna persona con criterio científico, y para emplear un término popularizado por una corriente de izquierda, progresista, que se pronuncie por el desarrollo del país, puede dejar de apoyar categóricamente el federalismo como corriente histórica ${ }^{374}$.

Y enfatiza: "el pueblo apoyó el federalismo por su carácter progresivo" 375.

Moreno es categórico en esa cuestión, sin por eso dejar de identificar a los estancieros "federales" de Buenos Aires como el "federalismo oficial", el "ala más reaccionaria dentro

370 PEÑA, Milcíades. Historia del pueblo argentino..., op. cit., p. 140. Sobre el federalismo, ver también: BURGIN, Miron. Aspectos económicos del federalismo argentino. Buenos Aires: Librería Hachette, 1960; CELESIA, Ernesto. Federalismo argentino: apuntes históricos, 1815-1821. Buenos Aires: Librería Cervantes de J. Suárez, 1932.

371 Ídem, p. 137.

372 MORENO, Nahuel [1975]. Método de interpretación..., op. cit.

373 PEÑA, Milcíades. Historia del pueblo argentino..., op. cit., p. 141

${ }^{374}$ MORENO, Nahuel [1975]. Método de interpretación..., op. cit.

375 Ibídem. 
del federalismo argentino"376. Esa facción, que será representada principalmente por Rosas y Mariano Anchorena, luchará por la "defensa de su propia industria y por la conquista de nuevas tierras para ampliar su zona de producción, manteniendo el monopolio del puerto de Buenos Aires y, como consecuencia, se despreocupará del conjunto de la producción nacional" 377 . Eran librecambistas, y eso explica las "excelentes relaciones que mantuvieron con Inglaterra" ${ }^{378}$, de la misma forma que lo hicieron Bernardino Rivadavia y los unitarios.

\subsection{Limitaciones y contradicciones de Mayo}

La revolución política de Mayo nació, inevitablemente, con fuertes contradicciones. El sector de clase que dirigía, la burguesía comercial porteña, imprimió al proceso un carácter mezquino, estrecho, vacilante, centralista, “a espaldas de la nación”, y con la mirada puesta en el comercio "libre" con Inglaterra.

Su objetivo inicial, como en otras partes de Sudamérica, no fue la independencia sino más autonomía. De ahí el reconocimiento de Fernando VII y la declaración de independencia solo en 1816. Peña acierta cuando expone que hasta cierto momento "la forma de ese Estado -monarquía o república- no les preocupaba demasiado, ni tampoco su relación con España,

siempre que esta concediera suficiente autonomía a sus colonias [...]"379. Señala que la independencia se debió más a la dinámica impuesta por la reacción que a la intención inicial de los patriotas: "fue la violenta resistencia opuesta por la burocracia y los militares dependientes de Madrid lo que acentuó la lucha hasta el punto en que solo podía terminarse con la independencia" 380 . Es decir, el punto de no retorno fue impuesto por la intransigencia de la metrópoli, no por el independentismo de la nueva clase dirigente.

Así, muchas contradicciones son comúnmente omitidas por las lecturas nacionalistas y sus variantes. Durante todo un período, por ejemplo, patriotas de la talla de Manuel Belgrano y Juan José Castelli defendieron un proyecto de monarquía constitucional y asumieron las pretensiones de la princesa Carlota Joaquina, esposa del regente portugués en Rio de Janeiro. El propio San Martín en cierto momento defendió un régimen monárquico, como única forma de mantener el orden político y la cohesión social ${ }^{381}$.

\footnotetext{
376 Ibídem.

377 Ibídem.

${ }^{378}$ Ibídem.

379 PEÑA, Milcíades. Historia del pueblo argentino..., op. cit., p. 84.

380 Ídem, p. 87.

${ }^{381}$ PRADO, Maria; PELLEGRINO, Gabriela. História da América Latina ..., op. cit., p. 43.
} 
Las distintas tentativas de negociaciones con España y otras potencias, antes de declarar la independencia, no fueron simples vacilaciones sino una política consciente. En 1814, cuando Fernando VII volvió al trono y se temió el envío de una expedición reconquistadora al Río de la Plata, el gobierno porteño de Gervasio Posadas despachó a Bernardino Rivadavia, Manuel de Sarratea y al propio Belgrano rumbo a Europa para felicitar al Rey por su reincorporación y negociar posibles condiciones de paz.

Esto incluyó la propuesta a Carlos IV, padre de Fernando VII, de coronar al príncipe Infante Francisco de Paula de Borbón, estableciendo una monarquía constitucional en el pretendido Reino Unido del Río de la Plata, que detentaría “el dominio y señorío de los territorios que formaban el virreinato de Buenos Aires, la presidencia de Chile y las provincias de Puno, Arequipa y Cuzco con sus costas e islas adyacentes"382.

Por su parte, en 1815 el Director Supremo Carlos de Alvear, de la Logia Lautaro, envió una carta escandalosa al representante británico ante la Corte del Brasil, en la que ofrecía expresamente la entrega del país al Imperio británico a cambio de protección ${ }^{383}$ :

\begin{abstract}
En estas circunstancias solamente la generosa nación británica puede poner un remedio eficaz a tantos males, acogiendo en sus brazos estas provincias que obedecerán a su gobierno y recibirán sus leyes con el mayor placer... Estas provincias desean a Gran Bretaña, recibir sus leyes, obedecer su gobierno y vivir bajo su influjo poderoso. Ellas se abandonan sin condición alguna a la generosidad y la buena fe del pueblo inglés y yo estoy dispuesto a sostener tan justa solicitud para librarla de los males que la afligen. Es necesario que se aprovechen los momentos, que vengan tropas que [se] impongan a los genios díscolos y un jefe autorizado que empiece a dar al país las formas que sean del beneplácito del rey y de la Nación ${ }^{384}$.
\end{abstract}

En 1816, el Congreso de Tucumán declaró la independencia de las provincias, pero sin condenar la monarquía ni proclamar la República. En una sesión secreta, Belgrano insistió en imponer una monarquía constitucional bajo la égida de un inca ${ }^{385}$. La primera

382 HISTORIA GENERAL DE LAS RR.EE. DE LA REPÚBLICA ARGENTINA. Las misiones de Sarratea, Belgrano y Rivadavia y su fracaso en obtener el reconocimiento español. 2000. Disponible en: $<$ http://www.argentina-rree.com/2/2-022.htm>, consultado el 22/06/2017.

${ }^{383}$ Desde su surgimiento, el gobierno porteño buscó afanosamente el apoyo de Inglaterra. Tres días después de haberse instalado, la Primera Junta escribió a Lord Strangford, ministro británico en Rio de Janeiro, asegurándole su propósito de conservar las posesiones para Fernando VII contra las ambiciones de Napoleón. Dado que España se había transformado en aliada de los ingleses, Strangford contestó el 16 de junio saludando la declaración de fidelidad a Fernando VII. El 20 de febrero de 1811, el Cabildo y la Junta de Buenos Aires confieren a Strangford el título de ciudadano ilustre, que no será aceptado por el diplomático inglés.

${ }^{384}$ PARRA, José. San Martín: debates en torno a su origen e ideología. Margen, n. 75, p. 16, 2014. Disponible en: < http://www.margen.org/suscri/margen75/parra75.pdf> consultado el 22/06/2017.

${ }^{385}$ La declaración de Belgrano, decía: "He sido testigo de las sesiones en que la misma soberanía ha discutido acerca de la forma de gobierno con que se ha de regir la nación, y he oído discurrir sabiamente en favor de la monarquía constitucional, reconociendo la legitimidad de la representación soberana en la casa de los Incas, y situando el asiento del trono en el Cuzco, tanto, que me parece se realizará este pensamiento tan racional, tan noble y justo, con que aseguraremos la loza del sepulcro de los tiranos", citado en: CHIARAMONTE, José. 
Constitución que habló de República fue la unitaria de 1826, dieciséis años después de la Revolución de $\mathrm{Mayo}^{386}$. Incluso después de declarada la independencia, Pueyrredón entonces Director Supremo y también miembro de la Logia Lautaro- inició gestiones entre 1818-1819 para entronar a un miembro de la Casa de Orleans ${ }^{387}$.

Los documentos y las medidas prueban no solo las indecisiones sino el grado de entreguismo al que algunos "próceres" estaban dispuestos a llegar. A duras penas, el proceso iniciado en mayo de 1810 había alcanzado la independencia en 1816, pero sin ser explícitamente republicano ni democrático.

Esto no significa que no existió un sector “jacobino" o, al menos, más radical dentro de los hombres de Mayo. Peña destaca:

[...] la intransigencia apasionada de todo un estrato social de la Colonia abogados, intelectuales, aspirantes a políticos-a quienes los estrechos marcos de la sociedad colonial no ofrecían ninguna ocupación o en todo caso ninguna ocupación a nivel de sus ambiciones de concesionarios de la intelligentsia ${ }^{388}$.

Estos sectores sociales estaban "enteramente dispuestos a llegar hasta el fin con toda energía para apoderarse del Estado, mucho más consecuentemente que los hacendados o comerciantes cuya urgencia no era tan grande por cuanto de todos modos contaban con el poder económico" 389 .

Mariano Moreno fue el principal representante de este sector que, desigualmente y sin que existieran conexiones demasiado concretas, incluyó a Belgrano, Castelli, Bernardo de Monteagudo, José de San Martín, entre otros. Nahuel Moreno escribió sobre el papel del primer secretario de la Junta:

Quien resumió las aspiraciones de todos ellos [los sectores que confluyeron en
Mayo], convirtiéndose en verdadero árbitro entre los mismos, fue Mariano
Moreno, ilustrado abogado jacobino. Muchas de las posiciones contradictorias que
le apuntaban algunos autores fueron producto, precisamente, de la necesidad de
reflejar los intereses casi siempre contrapuestos de importadores y exportadores
productores $^{390}$.

Peña tampoco se priva de resaltar el "indiscutible talento político que fue Mariano Moreno. Inevitablemente, la lucidez de este repúblico impone respeto"391.

Ciudades, provincias, Estados: Orígenes de la Nación Argentina (1800-1846). Documentos. Buenos Aires: Emecé, 2007, p. 172.

${ }^{386}$ PEÑA, Milcíades. Historia del pueblo argentino..., op. cit., p. 102.

${ }^{387}$ HISTORIA GENERAL DE LAS RR.EE. DE LA REPÚBLICA ARGENTINA. Los proyectos de algunos sectores por establecer un príncipe o monarca Borbón francés en el Río de la Plata. 2000. Disponible en: $<$ http://www.argentina-rree.com/2/2-053.htm>, consultado el 01/07/2017.

${ }^{388}$ PEÑA, Milcíades. Historia del pueblo argentino..., op. cit., p. 100.

389 Ídem, p. 101.

${ }^{390}$ MORENO, Nahuel [1975]. Método de interpretación..., op. cit.

${ }^{391}$ PEÑA, Milcíades. Historia del pueblo argentino..., op. cit., p. 100. 
Mariano Moreno ya se había destacado con su texto Representación de los Hacendados, una prédica incisiva sobre el libre comercio en 1809. El Plan de Operaciones, escrito en 1810, muestra su lúcida comprensión de la necesidad de la violencia para apoderarse de la maquinaria estatal: "Los cimientos de una nueva República nunca se han cimentado sino con el rigor y el castigo" ${ }^{392}$. Es progresivo también su interés en la “fomentación de las fábricas, artes, ingenios y demás establecimientos en favor del Estado y de los individuos que las ocupan en sus trabajos" a través de la confiscación de "cinco o seis mil mineros"393. O cuando propone que: "se prohíba absolutamente que ningún particular trabaje minas de plata u oro, quedando el arbitrio de beneficiarla y sacar sus tesoros por cuenta de la Nación, y esto por el término de diez años (más o menos) imponiendo pena capital y confiscación de bienes" 394 .

Sin embargo, así como el propio Mariano Moreno, el Plan contenía una serie de graves errores y contradicciones: 1) Proponía recoger actas de los Cabildos del Interior en que "dichos pueblos [expresan que] se desvelan para conservar los dominios de esta América para el señor don Fernando VII y sus sucesores, a quienes reconocen y reconocerán fiel y verdaderamente en vista de la peligrosa lucha" ${ }^{395}$; 2) La conducta hacia Inglaterra debía ser "benéfica, debemos proteger su comercio, aminorarles los derechos, tolerarlos y preferirlos, aunque suframos algunas extorsiones; debemos [proporcionar] ventajas que su comercio puede sacar de estos preciosos países"396. Mariano Moreno proseguía: "asimismo los bienes de la Inglaterra y Portugal que giran en nuestras provincias deben ser sagrados [...] pagando los derechos como nacionales [...] debemos atraernos y ganar las voluntades de los ministros de las cortes, aunque sea a costa del oro y de la plata, que es quien todo lo facilita" ${ }^{\text {397; }}$; en cuanto a la esclavitud -en el Brasil -, el Plan se mostraba conservador: "no tocar todavía, hasta su debido tiempo, la libertad de los esclavos en aquellos destinos, sino de manera disfrazada ir protegiendo a aquellos que sean de sujetos contrarios a aquella causa" ${ }^{298}$.

Por último, el Plan proponía hacer de Inglaterra:

[...] señor de la isla de Martín García, cuyo plano debe mandarse sacar con todas las circunstancias de su magnitud interior, extensiones, aguas, frutos $\mathrm{y}$

\footnotetext{
392 MORENO, Mariano. Plan de Operaciones. 1810. Disponible en: <http://lahaine.org/amauta/b2img/Mariano\%20Moreno\%201810.pdf>, consultado el 25/05/2017.

393 Ibídem.

394 Ibídem.

395 Ibídem.

${ }^{396}$ Ibídem.

${ }^{397}$ Ibídem. Para un análisis del Plan enfocado en sus implicaciones para el Brasil, ver: PIMENTA, João Paulo. A independência do Brasil e a experiência hispano-americana..., op. cit., pp. 115-121.

${ }^{398}$ MORENO, Mariano. Plan de Operaciones..., op. cit.
} 
calidad de su temperamento y puerto; para que, poblándola como una pequeña colonia y puerto franco a su comercio, disfrute de ella como reconocimiento de gratitud a la alianza y protección que nos hubiese dispensado en los apuros de nuestras necesidades y conflictos ${ }^{399}$.

Esto, sin duda, era inaceptable desde una perspectiva realmente independentista. Con Martín García en sus manos, Inglaterra tendría la llave de todo el Río de la Plata.

Evidentemente, como escribe Peña, esto no demuestra que Mariano Moreno era un "agente británico" sino simplemente "que los hacendados y los comerciantes de Buenos Aires a quienes él representaba tenían una visión muy moderada del interés nacional y, en todo caso, lo concebían atado de por vida a los intereses británicos" 400 .

En otras palabras, ni siquiera el proyecto del "jacobino” Mariano Moreno poseía un carácter nacionalista, o al menos proteccionista de los intereses extranjeros, sobre todo británicos.

En oposición a Mariano Moreno se organizó el sector representado por Cornelio Saavedra, jefe de las milicias y presidente de la Junta. Nahuel Moreno explica que los "roces con [Mariano] Moreno eran consecuencia de la contradicción entre los viejos sectores productores para el mercado virreinal y los nuevos sectores ligados al comercio exterior" ${ }^{\prime 01}$.

De cualquier manera, la derrota del ala "jacobina” de Mayo no demoró mucho.

Mariano Moreno se retiró de la Junta a finales de 1810, oponiéndose férreamente a la incorporación de diputados del Interior a lo que sería la Junta Grande ${ }^{402}$. Es decir, su visión simpatizaba con un régimen más centralizado desde Buenos Aires. Murió en circunstancias dudosas en alta mar el 4 de marzo de 1811, rumbo a una misión diplomática ante las Cortes del Brasil y Gran Bretaña. En abril de ese año, Saavedra impulsó un golpe militar y tomó el control de la Junta Grande. En setiembre, la Junta Grande fue derrocada por el sector más reaccionario y entreguista de la burguesía comercial, liderado por Bernardino Rivadavia, secretario del Triunvirato, que "derogó todas las restricciones que pesaban sobre las importaciones de manufactura inglesa. Y se inició el nuevo período, que culminaría a finales de la década de 1820 con el ascenso al gobierno del ala derecha del federalismo"403. En menos de un año y medio, el ala más antinacional de la burguesía comercial porteña había

\footnotetext{
399 Ibídem.

${ }^{400}$ PEÑA, Milcíades. Historia del pueblo argentino..., op. cit., p. 104.

${ }^{401}$ MORENO, Nahuel [1975]. Método de interpretación..., op. cit.

402 La Junta Grande se conformó en diciembre de 1810, con 22 miembros. Fue derrocada y reemplazada por un Triunvirato en setiembre de 1811.

${ }^{403}$ MORENO, Nahuel [1975]. Método de interpretación..., op. cit.
} 
eliminado a los principales elementos anormales o contradictorios que hicieron parte de los sucesos de mayo de 1810.

Castelli -autor de la proclama a favor de la expropiación de los realistas y de la liberación jurídica de los indígenas en el Alto Perú- fue enjuiciado en 1812 por el gobierno de Buenos Aires, que le reprochó duramente esos actos ${ }^{404}$. Murió a raíz de un cáncer de lengua cuando el juicio aún estaba abierto. Monteagudo, lúcido autor del revolucionario Ensayo sobre la necesidad de una federación general entre los estados hispanoamericanos y plan de su organización, fue asesinado en 1825. Belgrano, aunque más moderado que Castelli en el Norte, murió olvidado y pobre en 1820.

\section{5. ¿Un único Estado latinoamericano?}

La expulsión de los españoles estuvo aparejada de un proceso de formación territorial marcado por el desgajamiento de unidades anteriores: lo cierto es que, en tiempos coloniales, existían cuatro virreinatos y cuatro capitanías generales. De ellos surgieron más de veinte países independientes. Esto abona el debate sobre el proyecto de crear un único Estado latinoamericano o "Patria Grande" presente en las ideas de algunos patriotas. La aplicación de ese proyecto, a pesar de hipotéticamente muy progresivo y avanzado, era prácticamente imposible en las condiciones históricas, económicas y políticas de Sudamérica.

Peña apunta, con razón, que es un mito "que el movimiento de la independencia se proponía crear la gran nación latinoamericana" ${ }^{" 405}$. El primer problema para dilucidar es: ¿acaso existía una única nación sudamericana? Suponiendo que admitamos -al costo de excluir a las regiones donde los idiomas nativos tenían mucho peso, como el Alto Perú y el Paraguay- que existía un idioma y cultura más o menos comunes, no es posible afirmar que existiera la necesaria unidad económica ni política entre las clases dominantes para acometer semejante unificación.

\footnotetext{
${ }^{404}$ Castelli protagonizó la fase que, quizás, pueda ser realmente caracterizada como "jacobina" en el proceso que emanó desde Buenos Aires. Tras la victoria en la batalla de Suipacha (7/11/1810), Castelli ordenó el fusilamiento de los líderes realistas Nieto y Paula Sanz. Sus discursos no solo fueron antiespañoles, sino que proclamaban la completa igualdad entre indígenas y americanos, estableciendo la supresión de las obligaciones serviles y el tributo. Cuando la Junta porteña instruyó que cada Cabildo convocara un "congreso", Castelli exigió que en La Paz el escogido fuera un "secular", además de un representante de los indios "de su misma calidad y nombrado por ellos mismos". Por otra parte, propuso que todos los caciques surgirán de elecciones. No es casual que la burguesía altoperuana rechazara sus medidas y restara apoyo al Ejército a su mando. 405 PEÑA, Milcíades. Historia del pueblo argentino..., op. cit., p. 111.
} 
Ya el propio virreinato del Río de la Plata se impuso arbitrariamente desde la metrópoli como forma de contener poderosas tendencias centrífugas. El Virreinato no contribuyó al fortalecimiento de una nación sino que reforzó el peso de Buenos Aires como submetrópoli, en detrimento de todo el Interior. Como se trataba de revoluciones burguesas, la realidad demostró que, incluso antes de eliminar al “enemigo común” español, los unitarios de Buenos Aires -así como los federales bonaerenses- lucharon para someter a las provincias interiores al dominio del monopolio del puerto. Los intereses capitalistas más fuertes no tendían a una "Patria Grande", no se orientaban hacia un único Estado de una única nación. La tendencia más poderosa fue hacia una disputa mortal entre sectores burgueses, con fisonomía e intereses engendrados dentro del propio período colonial, para conformar un mercado interno propio tras las independencias. En ese marco, las ideas de Monteagudo, Simón Bolívar o San Martín no pasaron de enunciaciones, sin duda muy avanzadas, pero de difícil concreción ${ }^{406}$.

Sobre este problema, John Lynch argumenta:

\begin{abstract}
América era un continente demasiado vasto y heterogéneo como para aspirar a una lealtad individual. Es cierto que algunos libertadores tenían la visión de una América más grande, de una única comunidad que trascendía naciones concretas, pero la mayoría de sus seguidores eran principalmente venezolanos, mexicanos, chilenos y porteños, y era su propio país, y no América, el que consideraban su tierra nacional, por lo que desarrollaron un mayor grado de comunicación entre ellos que con sus vecinos o con los extranjeros ${ }^{407}$.
\end{abstract}

De hecho, puede decirse que experiencias como la de una Colombia más grande y fuerte, presente en las ideas de Bolívar, partieron de una búsqueda de mayor seguridad, de un plan de defensa militar en medio de una guerra contra los españoles. Solo después se creó, alrededor de ciertos postulados, una ideología de corte nacionalista. Antes de cualquier idealización del pensamiento de Bolívar sobre la unidad hispanoamericana, se debe tener presente, ante todo, que su mirada estaba puesta en la estabilidad política: "El sistema de gobierno más perfecto es aquel que produce mayor suma de felicidad posible, mayor suma de seguridad social y mayor suma de estabilidad política"408, decía en 1819.

\footnotetext{
406 Para una discusión sobre el Panamericanismo de Simón Bolívar, ver: CHIARAMONTE, José. Nación y Estado en Iberoamérica..., op. cit., pp. 165-173.

${ }^{407}$ CHUST, Manuel (Org.). Las independencias latinoamericanas en su laberinto..., op. cit., p. 244.

${ }^{408}$ BOLÍVAR, Simón. Discurso de Simón Bolívar ante el Congreso de Angostura..., op. cit.
} 
Por su parte, Mariano Moreno escribía: "Es una quimera pretender que todas las Américas españolas formen un solo Estado" ${ }^{409}$. Monteagudo, que en rigor defendía una federación de Estados para la defensa común, reconocía que:

[...] la inmensa distancia que separa las secciones que hoy son independientes y las dificultades de todo género que se presentan para entablar comunicaciones y combinar planes importantes entre nuestros gobiernos provisorios, alejan cada día más la esperanza de realizar el proyecto de la federación general ${ }^{410}$.

Volviendo a Bolívar, en 1815 escribió:

Yo deseo más que otro alguno ver formar en América la más grande nación del mundo, menos por su extensión y riquezas que por su libertad y gloria. Aunque aspiro a la perfección del gobierno de mi patria, no puedo persuadirme de que el Nuevo Mundo sea por el momento regido por una gran república; como es imposible, no me atrevo a desearlo [...] Los Estados Americanos, han [de ser] menester de los cuidados de gobiernos paternales, que curen las plagas y las heridas del despotismo y la guerra [...] una gran monarquía no será fácil de consolidar, una gran república, imposible $[\ldots]^{411}$.

En la misma carta, proseguía:

Es una idea grandiosa pretender formar de todo el nuevo mundo una sola nación con un solo vínculo que ligue sus partes entre sí y con el todo. Ya que tiene un origen, una lengua, unas costumbres y una religión, debería por consiguiente tener un solo Gobierno, que confederase los diferentes estados que hayan de formarse; mas no es posible, porque climas remotos, situaciones diversas, intereses opuestos, caracteres de semejantes dividen a la América $[\ldots]^{412}$.

Estas son algunas muestras de que incluso los protagonistas más lúcidos de la independencia estaban conscientes de la dificultad de un único Estado y hasta de una "federación general".

No se puede dudar de que una federación de Estados independientes hubiera representado la forma más avanzada y progresiva de gobierno. Pero esto, en el caso de la Cuenca del Plata, solo podría haberse concretado aplastando a los sectores burgueses más fuertes y mezquinos que dominaban el puerto de Buenos Aires y no estaban interesados en respetar ningún derecho nacional de los demás pueblos.

Así, no se puede sino coincidir con Peña cuando afirma que:

El drama de América Latina residía en que, aunque para sus pensadores más lúcidos era evidente la necesidad de unirse [...] tanto la historia como la economía - a diferencia de la del Norte- no empujaban hacia la unidad sino hacia la

\footnotetext{
409 MORENO, Mariano. Sobre el congreso convocado y Constitución del Estado. 1810. Disponible en: $<$ http://hum.unne.edu.ar/academica/departamentos/historia/catedras/hist argen indep/otros/criterios constitu cionales m \%20moreno.pdf>, consultado el 25/05/2017.

${ }_{410}$ MONTEAGUDO, Bernardo. Ensayo sobre la necesidad de una Federación General entre los Estados Hispanoamericanos. México: UNAM, s/f, p. 5.

${ }^{411}$ BOLÍVAR, Simón [1815]. Carta de Jamaica. Caracas: Comisión Presidencial para la Conmemoración del Bicentenario de la Carta de Jamaica, 2015.

412 Ibídem.
} 
dispersión [...] Las fuerzas hacia la dispersión eran mucho más fuertes y apremiantes que las fuerzas hacia la unidad ${ }^{413}$.

A diferencia de los Estados Unidos, no existía un mercado interno común ni sectores burgueses dispuestos a soldarlo con la unidad política, sin aduanas interiores, etc. Los intereses capitalistas más sólidos no se orientaban hacia el mercado interno sino hacia el mercado mundial ${ }^{414}$. Por eso fracasaron todos los intentos de unificación, fueran republicanos o monárquicos. En América Latina - prosigue Peña- "se pasó de la unidad ficticia a la desunión real" 415 y esto fue, categóricamente, una "traba formidable al desarrollo nacional de los países latinoamericanos" $" 416$.

No fue por otro motivo que el célebre Congreso de Panamá, convocado en 1826, resultó en un fracaso: "Como convidados especiais foram chamados os Estados Unidos (o representante morreu a caminho) e a Inglaterra (mandou um simples observador). A reunião fracassou e notáveis ausências foram registradas, como as de Brasil, Argentina, e Chile"417. Para finalizar, una reflexión de Chiaramonte sobre el caso rioplatense:

[...] entre 1810 y 1820 , lejos de encontrarnos ante un Estado rioplatense estamos ante gobiernos transitorios que se suceden en virtud de una proyectada organización constitucional de un nuevo Estado que, o se posterga incesantemente, o fracasa al concretar su definición constitucional. Una situación, por lo tanto, de provisionalidad permanente, que une débilmente a los pueblos soberanos, y no siempre a todos ellos ${ }^{418}$.

\section{La Revolución de Mayo y el Paraguay}

Sin perder de vista los dos objetivos de la revolución en Buenos Aires, que señala Peña, haremos una revisión sucinta de las medidas que la Junta porteña adoptó para relacionarse con el Paraguay entre 1810 y 1813, año en que un Congreso paraguayo instauró una República completamente independiente como forma de gobierno. Desde el punto de vista del primer objetivo -la lucha contra el colonialismo de España-, se trató de un encadenamiento de "errores" que, en realidad, derivaron del segundo objetivo de la burguesía comercial porteña: someter a las provincias a su dominio.

\footnotetext{
413 PEÑA, Milcíades. Historia del pueblo argentino..., op. cit., p. 114.

414 Ídem, p. 115.

415 Ibídem.

${ }^{416}$ Ibídem.

${ }^{417}$ PRADO, Maria; PELLEGRINO, Gabriela. História da América Latina ..., op. cit., p. 33.

${ }^{418}$ CHIARAMONTE, José. Nación y Estado en Iberoamérica..., op. cit., p. 62.
} 


\subsection{Un nuevo poder en la capital}

Para comunicar la nueva situación política al Paraguay, la Junta envió al coronel José de Espínola. Grave error. Espínola era odiado entre el pueblo, pues había sido "el instrumento principal de las violencias del gobernador Lázaro de Rivera" ${ }^{419}$. Llegó diciendo que asumiría el gobierno de la provincia y que organizaría una expedición en auxilio de la ciudad-puerto. El campesino paraguayo, harto de la carga colonial del servicio militar obligatorio y gratuito, no podía simpatizar con tal perspectiva. El pueblo tampoco podía entusiasmarse con la idea de solidarizarse con el nuevo gobierno de la antigua submetrópoli si la diferencia, a sus ojos, era cambiar a Velasco por Espínola.

El gobernador Velasco convocó a una Junta General para definir la relación con Buenos Aires $^{420}$. La Junta se realizó el 24 de julio de 1810, con la presencia de los más altos funcionarios reales, eclesiásticos, militares, comerciantes y estancieros. A la sazón, actuaban tres "partidos": el españolista, que defendía la fidelidad a la metrópoli; el porteñista, que proponía la ruptura con España y la unión inmediata con Buenos Aires; el nacionalista, que, aún minoritario, proponía la independencia absoluta del Paraguay, tanto de España como de Buenos Aires y de Portugal. Su posición -aunque, como comprobaremos más adelante no descartará en un principio una fórmula federativa con Buenos Aires-, de contenido se sintetizaba en la fórmula "no mudar de amos” y tenía como principal dirigente al doctor José Gaspar Rodríguez de Francia ${ }^{421}$, que no era ni comerciante ni ganadero ni militar sino un abogado "ilustrado" y con buena reputación general.

El Paraguay, según Francia, al igual que Buenos Aires y el resto de las provincias, tenía todo el derecho a ser soberano y no depender de un nuevo centro político y comercial. Si el relato de un testigo es verdadero, en aquella Junta convocada por el gobernador español, declaró:

Esta Asamblea no perderá su tiempo debatiendo si el cobarde padre o el apocado
hijo es rey de España. Los dos han demostrado su débil espíritu y su desleal
corazón. Ni el uno ni el otro puede ser ya rey en ninguna parte. Más sea o no rey
de España el uno o el otro, ¿qué nos importa a nosotros? Ninguno de ellos es ya
rey del Paraguay. El Paraguay no es el patrimonio de España, ni provincia de
Buenos Aires. El Paraguay es Independiente y es República, [...] la única cuestión
que debe discutirse en esta asamblea y decidirse por mayoría de votos es: cómo
debemos defender y mantener nuestra independencia contra España, contra Lima,

419 CHAVES, Julio [1942]. El Supremo Dictador. 5. ed. Asunción: Carlos Schauman Editor, 1985, p. 92. Lázaro de Rivera fue Gobernador-Intendente de la provincia entre 1796-1806. Defensor acérrimo de la monarquía absoluta, su gobierno se caracterizó por el despotismo y la represión contra el pueblo.

${ }^{420}$ Manifiesto del gobernador Bernardo de Velasco que convoca a una Junta General de la provincia, del 28/06/1806. ANA-SH, v. 211, n. 6.

${ }^{421}$ CREYDT, Oscar [1963]. Formación histórica de la nación paraguaya..., op. cit., p. 81. 
contra Buenos Aires y contra Brasil; cómo debemos fomentar la pública prosperidad y el bienestar de todos los habitantes del Paraguay; en suma, qué forma de gobierno debemos adoptar para el Paraguay [... $]^{422}$.

Pero las resoluciones de la Junta General fueron una victoria momentánea del españolismo: 1) Jurar fidelidad al Consejo de Regencia; 2) No reconocer la superioridad de la Junta porteña, pero mantener correspondencia y cordiales relaciones con ella; 3) Organizar la defensa de la provincia, alegando el peligro inminente de una invasión portuguesa ${ }^{423}$. En apariencia, Velasco podría repetir lo que escribió en 1807 acerca de la "obediencia ciega y particular estima y respeto que todas las clases de ese pueblo [el del Paraguay, nda.] me manifiestan" 424 .

La Junta porteña reaccionó prohibiendo la entrada y salida "de persona, carta o papeles, buques de todo porte con carga o sin ella, dineros o efectos" 425 al Paraguay. En setiembre de 1810, seis embarcaciones fueron apresadas en Corrientes. El bloqueo, que fue completo, tampoco podía despertar ningún apoyo popular hacia los porteños. Más medidas: el 16 de setiembre, Buenos Aires decretó la separación de las Misiones de la jurisdicción paraguaya ${ }^{426}$. Tres días después, ordenó a la Dirección General de Tabacos que no se cubriese ninguna libranza girada del Paraguay ${ }^{427}$. El españolismo aprovechaba hábilmente estas medidas para explotar el sentimiento contra la opresión porteña existente entre los paraguayos.

El 30 de setiembre, Velasco ordenó una expedición naval de 300 hombres a Corrientes y rescató los buques que habían sido detenidos. Un agente porteño informó luego que los soldados europeos se mostraron "sumamente electrizados", no así los otros, que al parecer actuaron por la fuerza ${ }^{428}$. Los europeos intentaron forzar el juramento de Corrientes al Consejo de Regencia, pero fueron contenidos por algunos oficiales paraguayos, que se mostraron "medio alzados" contra el jefe de la expedición ${ }^{429}$. Eran los primeros indicios de fracturas internas en el bando colonialista.

\footnotetext{
${ }^{422}$ BÁEZ, Cecilio. Historia colonial del Paraguay y el Río de la Plata. Asunción: Zamphirópolos, 1926, p. 173.

423 Acta de la Junta General de la Provincia que expresa el reconocimiento del Consejo de Regencia español, del 27/07/1810. ANA-SH, v. 211, n. 13.

424 COONEY, Jerry. El proceso de la independencia del Paraguay: 1807-1814. Asunción: Editora Intercontinental, 2012, p. 18. En esa asamblea, 87\% de los participantes eran representantes de Asunción.

${ }^{425}$ CHAVES, Julio [1938]. Historia de las relaciones entre Buenos-Ayres y el Paraguay..., op. cit., p. 45.

${ }^{426}$ COONEY, Jerry. El proceso de la independencia del Paraguay..., op. cit., p. 51.

427 CHAVES, Julio [1938]. Historia de las relaciones entre Buenos-Ayres y el Paraguay..., op. cit., p. 59.

428 Ídem, p. 49.

429 Ídem, p. 53.
} 
La acción militar del españolismo en Corrientes, a su vez, integraba un plan contrarrevolucionario más vasto: encerrar a Buenos Aires en un semicírculo formado por el Alto Perú, el Paraguay y Montevideo.

Luego del bloqueo del río, Buenos Aires destacó dos misiones secretas para promover una conspiración contra Velasco y a favor de la autoridad porteña en Asunción. La primera data de agosto de 1810 y fue confiada al capitán Juan Francisco Arias. La segunda, encomendada al abogado paraguayo Juan Francisco de Agüero, fue despachada a finales de setiembre. Como la expedición militar de Belgrano fue autorizada el 24 de setiembre y Agüero fue nombrado el 27 de ese mismo mes, es evidente que la misión del agente era preparar el terreno para el ejército porteño. El nombramiento de Agüero ilustra las intenciones de la Junta, que seguía actuando en nombre de Fernando VII:

[...] instruya a sus paisanos del origen, motivos y objeto de la instalación de esta Junta; les manifieste ser su establecimiento enteramente conforme a los principios de fidelidad a nuestro augusto monarca Señor Don Fernando VII y el único medio de conservar su amable dominación en estos dominios [...] Que les recomienda las ventajas de la unión y los males a que el Paraguay quedará expuesto si continúa dividido, pues aislado y sin comercio sufrirá una ruina $[\ldots]^{430}$.

Ambas misiones fracasaron. En 1810, Buenos Aires contaba con la adhesión de comerciantes y otros "vecinos importantes" en Asunción, pero nunca logró ganarse la simpatía del campesinado paraguayo, mucho menos de otros sectores más explotados ${ }^{431}$.

Para setiembre de 1810, ni el bloqueo ni los ultimatos ni los emisarios secretos le habían rendido frutos a la Junta porteña. El destino del Paraguay sería sellado con las armas.

El españolismo comenzó los preparativos militares de una campaña que, como veremos enseguida, resultaría un tiro por la culata. Era claro que el "peligro inminente" no eran los portugueses sino los porteños. El 30 de julio, Velasco ordenó la formación de un ejército ${ }^{432}$. No demoró en reunir a más de seis mil hombres. Diestro, el jefe español aseguró que nadie prestaría servicio militar fuera de la provincia y manifestó que, en caso de guerra, él moriría por el Paraguay. Se recogieron y repararon armas de toda la provincia. Los preparativos costaron a las arcas públicas alrededor de 100.000 pesos $^{433}$. Sin embargo, la mayoría de los más de 10.000 paraguayos que se movilizaron se armó con machetes, cuchillos y lanzas.

430 Ídem, p. 60.

${ }^{431}$ COONEY, Jerry. El proceso de la independencia del Paraguay..., op. cit., p. 57.

${ }^{432}$ Bando del Gobernador Bernardo de Velasco sobre la conformación del Cuerpo de Urbanos, del 30 /07/1810. ANA-SH, v. 211, n. 14.

${ }^{433}$ Carta de la Junta paraguaya al embajador de España en Rio de Janeiro, donde se explican las razones de la Revolución de Mayo, del 26/09/1811. ANA-SH, v. 214. 


\subsection{La invasión de Belgrano}

En julio de 1810, Buenos Aires envió un ejército para sofocar un levantamiento realista en Córdoba. La revuelta estaba comandada por el prestigioso Santiago de Liniers, que terminó ejecutado el 26 de agosto. Con Córdoba controlada, y otro contingente enviado al Alto Perú, la Junta concentró su atención en el Paraguay y en la Banda Oriental.

Así, el 24 de setiembre de 1810 la Junta porteña decidió enviar una “expedición libertadora" al Paraguay. Este tema es complejo y polémico: ¿Cuál fue el carácter de esta expedición? ¿Liberar al Paraguay del dominio español? ¿Someterlo a Buenos Aires? ¿Las dos cosas?

Es indudable que la Junta porteña, al enviar a Belgrano pretendía derrocar el poder de Velasco y el Cabildo realista. La cuestión, casi siempre omitida, es que, en el mismo acto, el Paraguay debía quedar "en completo arreglo" a los intereses del gobierno porteño. Por lo tanto, si retomamos el concepto de Peña, el objetivo político, ahora expresado en el terreno militar, no era único sino doble.

El decreto de la Junta al respecto es claro: "[...] sujetar a la obediencia a los territorios y colocarlos a cubierto de todo insulto y vejamen de parte de los enemigos de los derechos de los pueblos y de la justa causa en que se hallan empeñadas las provincias" ${ }^{434}$.

El propio Mariano Moreno escribió las instrucciones de Belgrano: “[Pasar al Paraguay] poniendo la provincia en completo arreglo, removiendo el Cabildo y funcionarios públicos, colocando hombres de su entera confianza en los empleos [...]"435.

En ninguna de las proclamas y correspondencia de Belgrano se omite el concepto de libertad, pero tampoco faltan -como notaremos- referencias a la "conquista", "sujeción", o “reducción” del Paraguay. La política era esa y, como bien se sabe, la guerra no es sino la continuación de la política por otros medios.

Posteriormente, Belgrano escribió en su autobiografía que aceptó la misión a pesar de que sus "conocimientos militares eran muy cortos", pues se dio crédito a Espínola, que "regresó diciendo que con doscientos hombres era suficiente para proteger el partido de la revolución”. Basado en esta premisa, el jefe porteño marchó “persuadido [de] que el partido

\footnotetext{
${ }^{434}$ CHAVES, Julio [1938]. Historia de las relaciones entre Buenos-Ayres y el Paraguay..., op. cit., p. 63. 435 INSTITUTO BELGRANIANO CENTRAL. Documentos para la Historia del General don Manuel Belgrano, 1792-1811. Tomo III, v. 1. Buenos Aires: Instituto Nacional Belgraniano, 1982, pp. 258-259.
} 
de la revolución sería grande, muy en ello de que los americanos al solo oír libertad aspirarían a conseguirla" ${ }^{436}$.

Por su parte, el español Velasco difundió una proclama en la que exaltaba el "desprecio" porteño hacia la identidad paraguaya, y estimulaba el rechazo popular a la perspectiva de luchar en el extranjero:

[...] Si obedeciéramos a la Junta de Buenos Aires, tendríais que ir a combatir en su guerra [...] si es preciso morir, moriremos en nuestra Patria, en su defensa de los Dominios de Nuestro Amado Rey y no de la Junta de Buenos Aires, que no sabiendo lo que son los paraguayos, su valor y fidelidad, los desprecia ${ }^{437}$.

Paralelamente, el obispo español Pedro García de Panés exhortaba a todos los sacerdotes a apoyar el Consejo de Regencia de España y predicar a sus feligreses la lealtad hacia la monarquía metropolitana, comparando la lucha contra Buenos Aires con la defensa misma de los valores cristianos ${ }^{438}$.

Exaltando el recelo histórico hacia la que había sido la capital virreinal, el gobernador español prontamente puso en pie un ejército compuesto por miles de campesinos que se alistaron viajando por su cuenta, con sus propias armas y montados. Aquellos que no podían combatir ofrecieron sus ganados y cosechas. La movilización fue ciertamente entusiasta, frenética. Puesto que casi no existía un ejército profesional, la amenaza porteña hizo brotar de todas partes una fuerza un tanto improvisada de "campesinos-soldados", las llamadas milicias urbanas que eran comandadas por vecinos destacados de los pueblos y villas ${ }^{439}$. Era un contingente importante, pero pobremente armado, sin disciplina ni instrucción militar.

¿Cuál fue el motivo principal de esa disposición de combate? ¿Fidelidad al dominio español? ¿Adicción a la Corona? ¿Acaso era el pueblo paraguayo un agente de la contrarrevolución que merecía ser ilustrado o bien castigado por la espada revolucionaria de aquellos venidos desde Buenos Aires?

Nada de eso. Existen elementos para suponer que el pueblo no se levantó en armas por lealtad al poder de la Corona, que como en toda América estaba en crisis y, como veremos, terminaría depuesta unos meses después en Asunción. Se levantó porque vio en la

\footnotetext{
436 BELGRANO, Manuel. Autobiografia: 1770-1820. Disponible en: $<$ https://www.elhistoriador.com.ar/manuel-belgrano-autobiografia-1770-1820/>, consultado el 27/03/2019.

${ }^{437}$ Proclama del Gobierno y Cabildo de Asunción sobre la Junta de Buenos Aires, del 11/09/1810. ANA-SH, v. 211, n. 18 .

${ }^{438}$ COONEY, Jerry. El proceso de la independencia del Paraguay..., op. cit., pp. 46-51.

${ }^{439}$ Muchos de los oficiales de bajo rango que derrocarían a Velasco el 15 de mayo de 1811 actuaron como comandantes de urbanos en el enfrentamiento a Belgrano. El rico hacendado Pedro Juan Caballero [17861821] lideró a los de Tobatí, su pueblo natal. Vicente Ignacio Iturbe [1786-1836] dirigió a los vecinos de San Pedro.
} 
expedición de Belgrano una amenaza a su soberanía, una invasión a su tierra. No fue fidelidad a España sino un acto de afirmación nacionalista -como mínimo de defensa de su terruño- y de desconfianza hacia el puerto. En cualquier discusión sobre este tema, no se puede soslayar que, para los paraguayos, la opresión colonial se concretaba, se expresaba más directamente, a través de Buenos Aires, la capital virreinal que actuaba como una submetrópoli de España. El recelo hacia "la capital" era enorme y venía de mucho antes de la invasión porteña. Nadie había pedido una expedición auxiliadora, precedida por bloqueos y en nombre de una Junta que se decía representante de Fernando VII. Las masas paraguayas sintieron, con razón, que el triunfo de Belgrano significaría simplemente cambiar de amos. Y por eso salieron a enfrentarlo.

Con acierto, el general argentino José María Paz anotaría tiempo después: “Antes dije y repito ahora, que esa unanimidad no provino de [la] adhesión al sistema español sino de un instinto ciego de localidad, al que puede añadirse mucho de amor propio" 440 .

¿Puede decirse que el Paraguay constituía una "nación” en 1810? Es un tema complejo. Según Andreu Nin, una nación...

\begin{abstract}
es un producto directo de la sociedad capitalista. La historia antigua y medieval no ha conocido en realidad la nación, sino únicamente gérmenes de la misma. El fundamento de la nación es el desarrollo del intercambio sobre la base económica del capitalismo. La nación se desarrolla en la medida en que se desarrolla el capitalismo, porque es la forma que corresponde a los intereses de clase de la burguesía. La nación es, pues, una resultante de la aparición y el desarrollo del capitalismo y se caracteriza por la existencia de relaciones económicas determinadas, la comunidad de territorio, idioma y cultura ${ }^{441}$.
\end{abstract}

Si nos guiamos por estos criterios, habría que dejar sentados ciertos elementos. El primero: es claro que en el Paraguay decimonónico aún no se habían desarrollado plenamente las relaciones de producción capitalistas. Pero esto no es un proceso que surge acabado súbitamente. Lo segundo: si bien no puede hablarse de una nación plenamente conformada, existía un proceso histórico, económico y social, que tendía a esa integración. Existía, sin duda, una idiosincrasia propia, una "comunidad de territorio, idioma y cultura", relaciones sociales y culturales desarrolladas en un territorio más o menos homogéneo y soldadas por el uso generalizado del guaraní.

Así, no se pueden confundir los motivos del pueblo con los intereses reaccionarios del realismo, que hasta determinado momento cumplió un papel dirigente. Es verdad que Velasco denunciaba a la "Junta insurreccional" de Buenos Aires y exigía fidelidad a

${ }^{440}$ CHAVES, Julio [1938]. Historia de las relaciones entre Buenos-Ayres y el Paraguay..., op. cit., p. 73.

${ }^{441}$ NIN, Andreu. Consideraciones sobre el problema de las nacionalidades..., op. cit. 
Fernando VII -aunque en esto, en rigor, no se diferenciaba de la retórica de la Junta bonaerense-, pero el centro de su llamado fue insuflar el valor de los paraguayos y el desprecio histórico de los porteños hacia ellos. Velasco, en medio de los aprestos, apeló más a sentimientos nacionalistas o localistas que a la lealtad hacia la metrópoli.

Belgrano, por su parte, no descartó atraer a la dependencia al Paraguay por medios pacíficos. Confiaba en que sus agentes lograrían conspirar contra Velasco evitando la necesidad de cruzar el Paraná y así poder encaminar sus tropas directamente a Montevideo: “Acaso por el medio que se pueda adoptar, de acuerdo con el expresado Cálcena Don José Alberto, evitaríamos perder tiempo para nuestro segundo objeto, y atraeríamos a la dependencia a la nominada Provincia" ${ }^{442}$.

E1 9 de octubre de 1810 la Junta le responde: "mientras toda la Provincia del Paraguay no se halle completamente reducida, ni debe fiarse su conformidad a otros medios, que al respeto debido a la fuerza que está a las órdenes de V.E. Así quiere la Junta que V.E. convierta toda su atención a la Provincia del Paraguay..."443.

El 15 de octubre, la Junta le advierte que no contase más con un partido de la revolución en la provincia, porque en el pueblo paraguayo "había echado raíces la seducción de sus jefes" $" 44$.

Belgrano, entonces, aclara que en ningún momento había pensado distraerse del plan de ocuparse primero del Paraguay, y que solo acabaría su misión...

cuando adhiriendo toda ella [el Paraguay] a las miras de V.E. la Junta [de Buenos Aires] y apoderándome de los autores de la desunión me bastase remitir un piquete con quien pudiera organizar todo, sin necesidad de mi presencia, ni la del ejército, que en tal caso podría volver sus tiros contra los insurgentes mencionados [los de Montevideo] ${ }^{445}$.

Basado en las informaciones de que disponía, Belgrano marchó realizando una serie de proclamas políticas con la intención de ganar a los criollos paraguayos a la causa de Buenos Aires. Hizo promesas, envió emisarios, y desparramó tras su paso diversos números del periódico oficial Gazeta de Buenos Aires.

Así, el 29 de noviembre dirigió desde Candelaria una proclama a los naturales, intentando atraerlos hacia su ejército:

[...] La excelentísima Junta Provisional gubernativa, que a nombre de su Majestad el Señor Don Fernando VII rige las Provincias del Río de la Plata, me manda a restituiros vuestros derechos de libertad, propiedad y seguridad de

\footnotetext{
${ }^{442}$ CHAVES, Julio [1938]. Historia de las relaciones entre Buenos-Ayres y el Paraguay..., op. cit., p. 65.

${ }^{443}$ Ídem, p. 66.

${ }^{444}$ Ídem, p. 67.

${ }^{445}$ Ídem, p. 66.
} 
que habéis estado privados por tantas generaciones sirviendo como esclavos a los que han tratado únicamente de enriquecerse a costa de vuestros sudores y aun de vuestra propia sangre $[\ldots]^{446}$.

Así, luego de algunos ultimatos en los que alertó que traía consigo la "persuasión y la fuerza”, Belgrano cruzó el Paraná el 18 de diciembre de 1810. Antes, alertó que a fusilaría a todo aquel que hostilizase a "las armas de Fernando VII" o "armas españolas" como solía nombrar a su ejército. La suerte estaba echada.

El 30 de diciembre, hizo públicas 29 disposiciones que redactó en el campamento de Tacuarí. Entre esas promesas se destacaban la liberación de tributos, libertad para poseer propiedades, libertad de comercio, igualdad con los españoles, acceso irrestricto a los empleos civiles, políticos, militares y eclesiásticos ${ }^{447}$. No existen evidencias de que estas promesas hayan sido recibidas por la población indígena. Lo cierto es que, durante toda su campaña militar, Belgrano no recibió refuerzo significativo de las Misiones. Solo se le sumaron algunos destacamentos desde Corrientes y Entre Ríos.

Realizó nuevas proclamas. En una de ellas, dirigida "a los nobles, fieles y leales paraguayos", aseguró que su finalidad consistía en:

Liberaros de la opresión en que os tienen y restituiros a vuestros derechos [...] que no han querido que obtengáis, a pesar de la buena voluntad del Rey, los que han estado encargados de vuestro gobierno, por haber disfrutado de vuestros sudores con sus comercios y monopolios y con las intrigas de que se han valido aún sus parientes, amigos y comensales [...] Venid, venid a mí valerosos paraguayos que vuestra causa es la de la patria y esta solo quiere vuestra felicidad ${ }^{448}$.

Pero la situación sobre el terreno no se mostraba como Belgrano esperaba. Conforme avanzaba, por ningún lado aparecían los partidarios de la Junta porteña ni encontraba el caluroso recibimiento popular a su "ejército auxiliador". Se movía, por el contrario, en medio de un vacío desolador. Entre el Paraná y el Tebicuary solo había "tierra arrasada".

Esta situación fue descrita por Bartolomé Mitre, uno de sus principales historiadores.

Desde el Tacuarí, río que se derrama en el Paraná entre San Cosme e Itapúa, había empezado a comprender que se hallaba en un país enemigo, y que no debía contar con más recursos que los que llevaba. Los pueblos estaban desiertos, las casas de campo abandonadas y los ganados habían sido retirados: las poblaciones habían emigrado en masa barriendo el terreno que iban pisando los invasores ${ }^{449}$.

\footnotetext{
${ }^{446}$ MITRE, Bartolomé. Historia de Belgrano y de la Independencia Argentina. Tomo I. 3. ed. Buenos Aires: Imprenta de Mayo, 1876, p. 301.

${ }^{447}$ BELGRANO, Manuel. Reglamento para el Régimen Político y Administrativo y Reforma de los 30 Pueblos de las Misiones. 1810. Disponible en: < https://www.educ.ar/recursos/128513/reglamento-de-belgrano-sobrelas-misiones $>$, consultado el 27/03/2019.

${ }_{448}$ BREZZO, Liliana. ¡Viva la unión!: las relaciones entre Paraguay y Buenos Aires. In: TELESCA, Ignacio; BREZZO, Liliana; CABALlERO CAMPOS, Herib (Org.). Paraguay 1813..., op. cit., p. 143.

${ }^{449}$ MITRE, Bartolomé. Historia de Belgrano..., op. cit., p. 310.
} 
El 16 de enero, Belgrano escribe a su gobierno y reconoce que el carácter de su ejército no sería más el de "auxiliador" sino el de "conquistador" del Paraguay:

He llegado a este punto con poco más de quinientos hombres y me hallo al frente del enemigo, que está situado en la banda norte del Yuquery; según unos con cinco mil hombres, y según otros con nueve mil. Desde que atravesé el Tebicuary no se me ha presentado ni un paraguayo, ni menos los he hallado en sus casas; esto, unido al ningún movimiento hecho, hasta ahora, a nuestro favor, $\mathrm{y}$ antes por el contrario presentarse en tanto número para oponérsenos, le obliga al ejército de mi mando a decir que su título no debe ser de auxiliador, sino de conquistador del Paraguay ${ }^{450}$.

En ese contexto, Velasco había salido de Asunción el 29 de diciembre, no sin antes asegurar: "Moriré con gusto en medio de vosotros, y tendré la gloria de acabar mis cansados días al frente de una Provincia heroica [...]"451.

\subsubsection{Paraguarí}

El gobernador español esperó a Belgrano en Paraguarí. Solo existían 500 fusiles para seis mil hombres y otros 200 sables para 3.600 jinetes. La mayoría de la tropa disponía de lanzas, chuzas, garrotes y otras armas blancas ${ }^{452}$. El jefe español cubrió sus flancos con los dos regimientos de caballería, cada uno con 1.800 hombres. A la izquierda, mandaba el sargento mayor Juan Manuel Gamarra; a la derecha, lideraba el teniente coronel Manuel Atanasio Cabañas. En el centro, se dispuso a las tropas de reserva al mando del coronel paraguayo Pedro Gracia ${ }^{453}$. Tanto Cabañas como Gamarra, entonces simples capitanes de milicias, también eran paraguayos y dos de los terratenientes más ricos de la provincia.

Belgrano, mejor armado, disponía de 1.200 soldados con más experiencia, apoyados por seis piezas de artillería ligera ${ }^{454}$.

Los dos ejércitos chocaron en las primeras horas del 19 de enero de 1811. En un primer momento, la caballería porteña consiguió romper las defensas centrales y alcanzó el cuartel general de Velasco. Este, sintiéndose perdido, huyó del campo de batalla con toda la alta oficialidad española. Pero, pasada la confusión, Cabañas y Gamarra pudieron reorganizar la caballería y lanzar un contraataque por los flancos a las tropas de Belgrano, que se habían dedicado al saqueo de Paraguarí. Con un movimiento envolvente, los oficiales

\footnotetext{
450 Ídem, p. 314.

${ }^{451}$ CABALLERO CAMPOS, Herib. Proceso de la Independencia paraguaya ..., op. cit., p. 80.

${ }^{452}$ CHAVES, Julio [1961]. La revolución paraguaya de la independencia: Biografía de los próceres. Asunción: Editora Intercontinental, 2010, p. 56.

${ }^{453}$ CABALlERO CAMPOS, Herib. Proceso de la Independencia paraguaya..., op. cit., p. 81.

${ }^{454}$ Ibídem.
} 
y campesinos paraguayos ocasionaron la desbandada del ejército porteño. Los muertos y heridos de ambos bandos fueron pocos, pero los paraguayos hicieron 123 prisioneros porteños.

Cuando la noticia de la victoria porteña llegó a Asunción, sobre todo por medio del teniente coronel español Juan de la Cuesta, el pánico se apoderó de las autoridades y de los comerciantes europeos. Sin demora, prepararon su huida hacia Montevideo, cargando diecisiete buques con sus bienes, estimados en un millón de pesos. Si no zarparon fue porque más tarde llegó otro emisario anunciando el giro que había dado la batalla y la victoria criolla.

La batalla de Paraguarí es un hito en el proceso independentista paraguayo. Fue una victoria neta de los naturales de la provincia. Tuvo en el medio paraguayo el mismo impacto político que tuvo la reconquista de Buenos Aires contra los ingleses. Dos fueron los derrotados: el ejército porteño y los jefes realistas, que en la hora decisiva demostraron completa cobardía. La fuga precipitada de Velasco lo desprestigió en toda la provincia. Asimismo, la prisa de los comerciantes españoles para evacuar sus fortunas y huir río abajo dejó irremediablemente desacreditado al partido realista en el Paraguay. Si bien continuó existiendo formalmente hasta mediados de mayo de 1811, las relaciones de poder en la provincia habían cambiado drásticamente: el régimen español había sido herido de muerte en Paraguarí.

Si hasta allí podía argumentarse que el conflicto se daba entre un ejército "realista" -absolutizando el elemento de la dirección de Velasco-y otro "patriota”, luego del desbande español en Paraguarí el enfrentamiento militar quedó caracterizado plenamente por el choque entre dos ejércitos de americanos.

La derrota forzó al ejército porteño a emprender una retirada ordenada rumbo al sur. En el transcurso, Belgrano recibió reiteradas intimaciones de rendición, rechazándolas todas.

En esos días, el jefe porteño expresó toda su desazón. De un lado, con los suyos: "cada vez observaba más la tropa acobardada y fue preciso seguir la marcha [retirada]" Por otro, en su pensamiento, la resistencia paraguaya solo podía representar que "este país no quiere perder los grillos". Escribió varias cartas a su gobierno impregnadas de frustración y hasta desprecio: "Todo me confirma en la idea que tengo de que esta gente será eternamente esclava”. Así, “era de precisión decretar la conquista del Paraguay”, pues

455 InSTITUTO BELGRANIANO CENTRAL. Documentos para la Historia del General don Manuel Belgrano, 1811-1812. Tomo IV. Buenos Aires: Instituto Nacional Belgraniano, 1982, p. 377. 
"no hay uno solo que esté por la causa sagrada y se nos hace la guerra por todos los medios". En otra carta: “[cuando] me informo más, es preciso conquistar al Paraguay: no es posible pintar la rusticidad de estos hombres y cómo están entusiasmados para conservarse esclavos" $" 456$.

El 24 de enero de 1811, insiste: "V.E. se convencerá, en vista de cuanto le he referido, que es de precisión decretar la conquista del Paraguay, para que S.M. el Señor D. Fernando VII no lo pierda" ${ }^{457}$. El 31 del mismo mes escribió una misiva personal a Cornelio Saavedra, entonces presidente de la Junta, quejándose de los "salvajes paraguayos":

Mi querido amigo: [...] solo me ha consolado el aviso que me da Rodríguez de hallarse en la Bajada y que esperaba que pasasen los pardos para ir a atacar a los del Arroyo de la China: quiera Dios que sea feliz, para que pueda venirse con todos y entrar a la conquista de los salvajes paraguayos, que solo se pueden convencer a fuerza de balas ${ }^{458}$.

En la misma carta, reiterando su pedido de refuerzos, Belgrano enfatizó su objetivo militar: "Cuanto menos necesito mil quinientos infantes y quinientos de caballería para la empresa de la conquista del Paraguay"459.

\subsubsection{Tacuarí}

El 21 de febrero de 1811, el oficial Antonio Tomás Yegros se presentó en el campamento porteño con una carta del teniente coronel Manuel Cabañas, que increpaba: “¿por qué razón ha traído armas y se ha hecho nuestro agresor? Talando los derechos de esta Provincia, sin haber pecado siquiera venialmente contra el Rey, Religión ni nuestra reconocida natural hermandad, hasta llegar a experimentar el rigor de nuestras armas" $\$ 60$.

Belgrano, consciente de que estaba en una situación militar desventajosa, retomó su campaña de persuasión política. Contestó que no había venido a talar los derechos de la provincia sino a liberarla de los "mandones que la gobiernan". Alegó que no era tarde para que los paraguayos "reconociesen su error" y entendieran que había venido a "quitarles el inicuo servicio de las milicias, libertarlo de gabelas, desterrar el estanco de tabaco y darle un comercio libre con todas las provincias" ${ }^{\prime 61}$.

\footnotetext{
${ }^{456}$ CARDOZO, Efraím. La diplomacia de Belgrano en el Paraguay. Sociedad de Historia Argentina, 1940, p. 15.

457 NAVARRO VIOLA, Miguel; QUESADA, Vicente. La revista de Buenos Aires: Historia americana, literatura y derecho. Tomo XII. Buenos Aires: 1867, p. 84.

${ }^{458}$ MITRE, Bartolomé. Historia de Belgrano. Tomo I. Buenos Aires: Imprenta de Mayo, 1859, p. 570.

459 Ídem, p. 572.

${ }^{460}$ BREZZO, Liliana. ¡Viva la unión!...., op. cit., p. 144.

${ }^{461}$ CHAVES, Julio [1942]. El Supremo Dictador..., op. cit., p. 99.
} 
A pesar de la correspondencia, porteños y paraguayos no detuvieron sus planes. Belgrano detuvo su retirada después de atravesar el río Tacuarí. En los primeros días de marzo de 1811, ambos contingentes estaban nuevamente frente a frente, separados solamente por el río.

Cabañas intimó al jefe porteño para que se rindiera, amenazándolo con pasarlo a cuchillo junto con sus hombres. Belgrano respondió enfático que las armas de Fernando VII no se rendían ${ }^{462}$.

La batalla comenzó el 9 de marzo de 1811. Después de seis horas de combate, las fuerzas porteñas sufrieron un nuevo descalabro y, rodeadas, se vieron perdidas. Belgrano, entendiendo su desesperada posición, ordenó la destrucción del archivo y solicitó un armisticio prometiendo que "abandonaría inmediatamente el territorio de la provincia y [...] nunca regresaría para empuñar las armas contra ellos [los paraguayos]" ${ }^{463}$. Nueva victoria de los nativos paraguayos.

Ocurrió entonces algo inesperado. En lugar de aniquilar el ejército porteño, que estaba completamente derrotado, los oficiales paraguayos retomaron la correspondencia con Belgrano. Cabañas, Fulgencio Yegros y otros exponentes de la baja oficialidad se reunieron con el vocal de la Junta dispuestos a alcanzar un acuerdo. De un lado, Belgrano comprendió que en ese momento carecía de condiciones para conquistar el Paraguay por las armas. Del otro, los conceptos de paz, unidad, derechos de los americanos, libre comercio - propugnados por Belgrano- despertaron interés y simpatía entre los jóvenes oficiales paraguayos, muchos de ellos estancieros y yerbateros ${ }^{464}$.

Finalmente, se alcanzó un acuerdo de ocho puntos: 1) Paz, unión, entera confianza, franco y liberal comercio de todos los frutos de la provincia, incluso el tabaco, con las provincias del Río de la Plata y particularmente con Buenos Aires; 2) El Paraguay nombraría un diputado para el Congreso de las Provincias Unidas del Río de la Plata; 3) Formación de una Junta en Asunción, que incluiría al gobernador Velasco como presidente; 4) Pago de la caballada y ganados usados y consumidos por el ejército porteño; 5) Amnistía para las familias que se unieron a Belgrano; 6) Libertad para los prisioneros de Paraguarí y Tacuarí; 7) Libertad para el mensajero porteño Ignacio Warnes; 8) Libertad a quienes estaban presos en el Fuerte Borbón, acusados de ser adictos a la causa de Buenos Aires ${ }^{465}$.

\footnotetext{
${ }^{462}$ CABAllero CAMPOS, Herib. Proceso de la Independencia paraguaya ..., op. cit., p. 84.

${ }^{463}$ COONEY, Jerry. El proceso de la independencia del Paraguay..., op. cit., p. 79.

${ }^{464}$ BREZZO, Liliana. ¡Viva la unión!..., op. cit., p. 145.

${ }^{465}$ CHAVES, Julio [1961]. La revolución paraguaya de la independencia ..., op. cit., p. 56.
} 
Luego de las negociaciones, Cabañas y la oficialidad local aceptaron la retirada de Belgrano y sus hombres con honores, permitiéndoles llevarse consigo sus armas y pertrechos. El habilidoso jefe porteño había pasado de general derrotado a diplomático exitoso.

Las victorias en Paraguarí y Tacuarí representaron el comienzo del fin del régimen colonial. Su impacto aceleró la dinámica independentista del Paraguay. Al final de la campaña, miles de campesinos-soldados se sintieron victoriosos tras defender "su tierra". Los oficiales criollos, provenientes de poderosas familias terratenientes, crecieron en autoconfianza y simpatizaron con las promesas de libre comercio que había traído el invasor.

Un hecho no siempre reconocido: al conceder a Belgrano una retirada segura y completa, a pesar de que estaba completamente perdido, los oficiales paraguayos, en la práctica, habían salvado al ejército de Buenos Aires, puesto que el plan del españolismo era aplastarlo con la ayuda de mil soldados portugueses, según el acuerdo entre Velasco y el general riograndense Diogo de Souza ${ }^{466}$.

Pese a la confraternización en Tacuarí, las relaciones entre Asunción y Buenos Aires continuarían tensas. Al anunciar su rendición ante los paraguayos, Belgrano insistió en el carácter "auxiliador" de su ejército:

Las armas de Buenos Aires han venido únicamente con miras a auxiliar a los habitantes naturales de la provincia, que por informes dados al gobierno de Buenos Aires sabían que estaban oprimidos por su gobernador y que por su interés particular impedía el que se estableciera en ella un sistema patrio a ejemplo de la capital $[\ldots]^{467}$.

Sin embargo, pese a esta retórica, pocos días después, en una carta a su gobierno escrita el 14 de marzo en Candelaria, el mismo Belgrano hizo un balance de la expedición y propuso a Buenos Aires nuevas medidas para "reducir a los paraguayos a la Unión":

Por consiguiente, recuerdo únicamente que V.E. [...] dejaba a mi elección la
conquista del Paraguay: nada más tengo presente, porque mi imaginación ha
estado ocupada con viveza en cosas de guerra, y después, en suplir la falta de
fuerzas con la política, para reducir a los paraguayos a la Unión [...]
V.E. no puede formar una idea bastante del grado de ceguedad en que se halla la
Provincia: igual es la ignorancia de los primeros hombres de ella, que
arrastran [a] la multitud, siempre más ignorantes que aquellos, como en todas
partes, y a qué grado de entusiasmo han llegado, bajo el concepto de que,
oponiéndose a las miras de V.E. defienden la patria, y lo que hay de más
sagrado. Así que han trabajado para venir a atacarme de un modo increíble,
venciendo imposibles que solo viéndolos pueden creerse: pantanos formidables,
el arroyo a nado, bosque inmenso e impenetrable, todo ha sido nada para ellos;

${ }^{466}$ Bando de la Junta que informa sobre una carta al embajador de España en Río de Janeiro con órdenes de no consentir el ingreso de tropas portuguesas a la provincia ni su uso para cortar la retirada de Belgrano, del 03/07/1811. ANA-SH, v. 213.

${ }^{467}$ BREZZO, Liliana. ¡Viva la unión!..., op. cit., p. 145. 
pues su entusiasmo todo les ha allanado. ¡Qué mucho! ¡Si las mujeres, niños, viejos, clérigos y cuantos se dicen hijos del Paraguay están entusiasmados por su patria, y adoran a Velasco, tanto que, aun conociendo que es gobernado por el sobrino y Elizalde, a quienes detestan, los disculpan!

[...] si no nos queda el arbitrio de ir a ellos a fuerza de armas, nos queda el interceptarles la entrada de ganados y caballos [...] Con este motivo he conferenciado largamente con Rocamora y convinimos en que la conquista del Paraguay, si acaso no entran por los partidos que he hecho a Cabañas es obra muy larga $[\ldots]^{468}$.

Al mismo tiempo, Belgrano expresaba optimismo: "acábese con Montevideo y el Paraguay de suyo se unirá con nosotros". Confiaba en que los paraguayos no atacarían a Buenos Aires: "Estoy casi persuadido que no sale un paraguayo de la provincia". Y como conclusión, una reflexión crítica: "Es preciso conocer a los países; si yo hubiera conocido el Paraguay, no se habría derramado una sola gota de sangre" 469 .

Por el momento, la vía militar de dominio del Paraguay había fracasado para la arrogante Junta porteña. El propio Belgrano, que fue procesado en Buenos Aires por la derrota de su expedición, reconoció años después: “[La expedición al Paraguay] solo pudo caber en unas cabezas acaloradas que solo veían su objeto y a quienes nada era difícil, porque no reflexionaban ni tenían conocimientos" 470 .

\subsection{Consideraciones para el estudio y el debate}

I. La invasión militar de la Junta porteña plantea la enorme complejidad de un único proceso general que combinó la lucha contra el dominio colonial en medio de candentes problemas nacionales o localistas -incubados históricamente durante la Colonia-, que se expresarían en el proceso de conformación de los Estados nacionales.

II. En ese marco, la expedición de Belgrano no tuvo carácter "libertador" pues, aunque las tropas de Buenos Aires hubiesen derrocado el poder español, la nación paraguaya habría caído en otra opresión: la de la burguesía comercial porteña. Esto es así porque la "liberación” de España estaba intrínsecamente ligada a la "conquista del Paraguay". Esto es un hecho que consta en la documentación. Para reforzar la autoridad de esta afirmación, que puede ser polémica, hemos apelado a la correspondencia entre el propio

\footnotetext{
${ }^{468}$ Oficio de Belgrano a la Junta Gubernativa, Candelaria, 14/03/1811, citado en: MITRE, Bartolomé. Historia de Belgrano..., op. cit., pp. 584-590.

${ }^{469}$ CHAVES, Julio [1938]. Historia de las relaciones entre Buenos-Ayres y el Paraguay..., op. cit., 96.

${ }^{470}$ BELGRANO, Manuel. Autobiografia ..., op. cit.
} 
Belgrano y la Junta de Buenos Aires. La lectura de ese material nos parece ser inequívoca en el sentido que señalamos. Lo no quiere decir que Mariano Moreno o Manuel Belgrano, con sus contradicciones, no hayan sido revolucionarios. Solamente demuestra que la Junta porteña nació con un proyecto centralista que pretendía abarcar todo el antiguo territorio virreinal, y que estaba dispuesta a ejecutar ese proyecto a cualquier costo.

III. Es necesario, al analizar e interpretar la historia, considerar la óptica de las naciones oprimidas, comúnmente invisibles y sin voz. En este caso, el Paraguay era una nación oprimida; su dependencia de la metrópoli se instrumentaba -y por eso era más sentida y visible- a partir de las políticas emanadas de la submetrópoli, Buenos Aires. Debido a ello, la expedición de Belgrano fue interpretada por el pueblo, correctamente, como una amenaza a su soberanía y a su "patria", como una tentativa de "cambiar de amos". Así, salió a enfrentarla. En ese marco, la dirección realista inicial pasa a ser un elemento secundario. El pueblo paraguayo, como quedaría demostrado poco después, no era adicto a España. La lucha contra Belgrano se debió, esencialmente, a un hecho muy sencillo: el pueblo no quería depender de Buenos Aires. Y demostró esa voluntad en el campo de batalla y, luego, en representativos congresos nacionales.

IV. El propio Mitre, refiriéndose a la expedición de Belgrano y a las raíces históricas del Paraguay, confirmará con su desprecio tanto que la ex provincia podía ser considerada una nación, aunque "atrofiada", como que era oprimida por Buenos Aires:

\begin{abstract}
La expedición militar sobre el Paraguay bajo la bandera redentora fue recibida por su población con las armas en la mano, y aunque aceptó más tarde la insurrección por su propia cuenta, rechazó la unión nacional. El Paraguay obraba lógicamente, y obedecía por instinto a su naturaleza. Miembro atrofiado del virreinato, aunque ligado geográficamente a él por el gran estuario del Plata; producto de una civilización embrionaria injertada en el tronco de una raza indígena, apenas modificada por el espíritu jesuítico, el Paraguay no tenía puntos de contacto con la sociabilidad argentina bosquejada en la cuenca del Río de la Plata. No formaba, por lo tanto, parte de su organismo rudimentario. $\mathrm{Su}$ resistencia, que revelaba una solución de continuidad política, determinó en el hecho una nueva nacionalidad por generación seccional. Obedeciendo siempre a la ley de la inercia, se aisló dentro de sus bosques y pantanos, se sustrajo al movimiento general y a los sacrificios comunes, y segregóse de hecho, sin encontrar dentro de sí mismo los gérmenes fecundos de la vida orgánica ${ }^{471}$.
\end{abstract}

${ }^{471}$ MITRE, Bartolomé. Historia de San Martín y de la emancipación sudamericana. Tomo I. Buenos Aires: Editorial Juventud Argentina, s/f, p. 120. 
V. No está en discusión el gran papel progresivo de Buenos Aires en la lucha contra España. Pero debe admitirse también que, a pesar de su retórica, la burguesía porteña no pretendía la unión justa de los pueblos emancipados. No quería, como el propio Belgrano reflexionó, “conocer a los países”, sino “conquistarlos”. La única unión que le interesaba era aquella en la cual-como en tiempos de la Colonia- el puerto dominase al Interior por medio de monopolios aduaneros. Eso no era progresivo sino reaccionario; iba en contra de cualquier proyecto de unidad voluntaria de los pueblos.

Pero, aun suponiendo que el objetivo fuera una unión justa entre naciones libres o incluso concretar una mera alianza militar, el bloqueo del río, la suspensión del comercio, y el envío de un ejército al Paraguay solo podían aumentar la desconfianza y alejar a una nación oprimida de tales objetivos. La invasión del Paraguay no fue un mero "error de cálculo". Devino irrefrenablemente del carácter centralista de la Junta controlada por la burguesía comercial. Si hubiese sido un error circunstancial, las relaciones hubieran tendido a normalizarse. Pero, como analizaremos, el derecho a la independencia nacional expresado por los paraguayos será rechazado y hostilizado sistemáticamente por todos los gobiernos unitarios $-\mathrm{y}$ en varias ocasiones incluso por caudillos federales- hasta 1852, cuarenta años después de la expedición de Belgrano. El ataque final será en 1864, de la mano de Bartolomé Mitre, aliado al Imperio esclavista del Brasil y al Uruguay de Venancio Flores. Existe, por lo tanto, un hilo de continuidad política entre Paraguarí y Cerro Corá.

\section{LA REVOLUCión PARAgUaya, BUENOS AIRES Y LA IDEA DE LA CONFEDERACión}

Hemos visto que la derrota del ejército porteño fue una doble victoria de los patriotas paraguayos: contra Buenos Aires y contra el realismo. Después de Tacuarí, el régimen español entró en una profunda crisis, que se ahondaría con las medidas de Velasco: 1) desarme y desmovilización de las tropas, sin pago; 2) privación de mando efectivo a los oficiales nativos que vencieron a Belgrano. Esto indispuso considerablemente a la joven oficialidad, puesto que los jefes españoles que habían huido recibieron mejor trato. La falta 
de pago, por su parte, causó insatisfacción en miles de campesinos que habían costeado su propia movilización para defender la provincia.

No solo Velasco tomó represalias por el armisticio de los paraguayos con Belgrano. El Cabildo, realista hasta la médula, hizo lo propio el 28 de marzo de 1811, y criticó duramente la confraternización con los porteños ${ }^{472}$.

\subsection{El plan contrarrevolucionario hispano-portugués}

Enumeramos algunas medidas del realismo en sus horas más críticas:

Los prisioneros porteños fueron maltratados y enviados a Montevideo en una expedición que costó más de 1.300 pesos, exactamente cuando el españolismo alegaba no tener dinero para pagar a las tropas desmovilizadas.

El 17 de abril de 1811, Velasco ordenó una expedición naval que ocupó Corrientes y obligó a sus autoridades a jurar fidelidad al Consejo de Regencia.

En el marco de su política general hacia la crisis política abierta en el Río de la Plata, los intereses y las medidas de la Corte portuguesa en Rio de Janeiro, amparadas evidentemente por sus protectores británicos, incidieron en el proceso independentista paraguayo. No es el caso exponer aquí un análisis del impacto que causó el proceso independentista hispano en el Brasil. Limitémonos a coincidir con Pimenta sobre que: “[...] el constitucionalismo español y la abertura del proceso revolucionario en la América española [...] representarán un agravamiento de los temores y recelos relativos a las condiciones mismas de sobrevivencia del orden dinástico en el interior de la unidad imperial portuguesa" ${ }^{473}$, que estaba atenta al desarrollo de los acontecimientos. Esto fue así porque: "la desintegración hispano-americana definitivamente no interesaba a los círculos políticos dominantes portugueses, y por ellos era incluso muy recelada" ${ }^{474}$.

Lo que interesaba y motivaba la política del régimen monárquico portugués era:

[...] un sincero interés en preservar en toda la América ibérica el principio de legitimidad dinástica -y evitar con eso la interrupción de flujos mercantiles y la desestructuración de la producción. En suma, hay un empeño en alcanzar objetivos específicos de política nacional, como la expansión territorial al Plata y la consolidación de la alianza luso-británica, pero siempre en plena observancia de esos principios generales ${ }^{475}$.

\footnotetext{
472 COONEY, Jerry. El proceso de la independencia del Paraguay..., op. cit., p. 89.

473 PIMENTA, João Paulo. A independência do Brasil e a experiência hispano-americana..., op. cit., p. 97.

474 Ídem, p.133. Ver también: PIMENTA, João Paulo. A independência do Brasil como uma revolução: história e atualidade de um tema clássico. História da historiografia, Ouro preto, n. 3, 2009.

475 Ídem, p. 134.
} 
La Corte portuguesa, en efecto, estaba dispuesta a ofrecer auxilio a la causa monárquica en Sudamérica. Esto se planteó para Perú o Chile, como también para el Paraguay. El diplomático Rodrigo de Sousa Coutinho ${ }^{476}$, por ejemplo, opinaba que la Junta de Buenos Aires se esforzaba por "revolucionar las Fronteras de los Países limítrofes de Vuestra Alteza Real, y sin duda con la intención de atacar los Estados de Vuestra Alteza Real de aquel lado"; tal peligro exigía medidas urgentes para "impedir que los Revolucionarios viniesen a dominar sobre su Frontera"477. Coutinho acompañaba los acontecimientos de manera expectante, deseando algún pedido de auxilio por parte de los realistas españoles ${ }^{478}$, pedido que llegaría desde el gobernador del Paraguay.

En efecto, consciente de que había perdido el control de las fuerzas armadas, Velasco solicitó una intervención portuguesa de doscientos hombres. El general portugués Diogo de Souza respondió que gustoso enviaría hasta mil soldados con artillería ${ }^{479}$.

El 9 de mayo llegó a Asunción el teniente Diego de Abreu, emisario del general de Souza. Ofreció una fuerza de 1.500 portugueses para impedir cualquier futura invasión porteña ${ }^{480}$. Velasco y el Cabildo realista lo recibieron con honores y sin esconder su alivio.

Las tratativas con los jefes portugueses hacían parte de un plan contrarrevolucionario más vasto: a) las tropas portuguesas penetrarían en las Misiones, aplastarían a las fuerzas de Belgrano y avanzarían sobre la Banda Oriental; b) El virrey Javier de Elío, instalado en Montevideo, enviaría tropas a Corrientes, que se unirían a los europeos que había sido enviados por Velasco. Así, la alianza Elío-Velasco-Souza estaba llamada, según el primero, a ostentar el "glorioso título de reconquistadores de la América del Sur"481.

La revolución paraguaya se dará en medio de este difícil contexto para la causa americana.

\footnotetext{
${ }^{476}$ Rodrigo de Sousa Coutinho, conde de Linhares, fue un diplomático de mucha influencia en Lisboa y, después, en el Brasil. Fue él quien aceptó el plan de traslado de la Corte portuguesa al Brasil y defendió los acuerdos posteriores con Gran Bretaña.

477 Oficio de D. Rodrigo a D. João del 16/01/1811, citado en: PIMENTA, João Paulo. A independência do Brasil e a experiência hispano-americana..., op. cit., p. 134.

${ }^{478}$ En oficio a D. João del 24/02/1811, Coutinho afirmaba: "Quiera el Cielo que el Virrey y Gobernador Español recurran a Vuestra Alteza sin pérdida de tiempo”, citado en: Ibídem.

${ }^{479}$ Carta de la Junta paraguaya al embajador de España en Rio de Janeiro donde se explican las razones de la Revolución de Mayo, del 26/09/1811. ANA-SH, v. 214.

${ }^{480}$ COONEY, Jerry. El proceso de la independencia del Paraguay..., op. cit., p. 102.

${ }^{481}$ CHAVES, Julio [1938]. Historia de las relaciones entre Buenos-Ayres y el Paraguay..., op. cit., p. 103.
} 


\subsection{El Mayo paraguayo: carácter y límites}

El plan original de los patriotas dictaba que Fulgencio Yegros debía sublevarse en Itapúa y marchar hacia la capital. En las Cordilleras debía unírsele Cabañas con otro ejército de campesinos-soldados ${ }^{482}$. Blas Rojas haría lo propio en Corrientes. Esa "marcha nacional" debía tomar Asunción el 25 de mayo, a ejemplo de Buenos Aires. Pero la llegada de Abreu y el peligro de una invasión portuguesa inminente precipitaron los acontecimientos.

El 14 de mayo, los revolucionarios supieron que la conspiración había sido descubierta. De tal suerte que, ante la ausencia en la capital de los jefes militares del movimiento - Yegros y Cabañas-, oficiales de menor escalón, como los capitanes Pedro Juan Caballero y Juan Bautista Rivarola, y el alférez Vicente Ignacio Iturbe, todos ellos estancieros, se vieron súbitamente al mando del levantamiento.

Dada su inexperiencia política, consultaron al doctor Francia sobre un plan de emergencia. Esa misma noche, los oficiales tomaron el cuartel principal. Liberaron a los presos políticos, y a ellos se les unieron los soldados. Entre todos, no alcanzaban un centenar. Desde el cuartel, imputaron a Velasco -que se había refugiado junto a los miembros del Cabildo y el emisario Abreu en la Casa de los Gobernadores- que estaba dispuesto a entregar la provincia a "una potencia extranjera que no la defendió con el más pequeño auxilio, que es la Potencia Portuguesa" ${ }^{483}$. Exigieron que entregue todas las armas, municiones, el archivo, y acepte la incorporación al gobierno de dos diputados nombrados por el cuartel hasta que una Junta General resolviese la cuestión del poder ${ }^{484}$. Velasco, mientras quemaba los archivos principales, respondió con evasivas. Al clarear el 15 de mayo, los oficiales y soldados salieron del cuartel arrastrando seis piezas de artillería, y rodearon la sede del gobierno con sus bocas. El gobernador europeo, sin posibilidad de resistir, entregó el poder.

Todavía sin noticias de la capital, Yegros y Rojas se sublevaron y apresaron a los españoles en Itapúa y Corrientes. En Asunción, los comerciantes españoles que intentaron huir a Montevideo fueron multados con $60.000 \operatorname{pesos}^{485}$. Así, por medio de un cuartelazo de oficiales subalternos, se abrió el proceso independentista en el Paraguay.

\footnotetext{
${ }^{482}$ Cabañas poseía estancias entre Barrero Grande y el Tebicuary. Gozaba de gran prestigio y ciertamente sería capaz de movilizar fuertes contingentes de paisanos.

${ }^{483}$ VELILLA, Margarita (Org.). Autos de la Revolución del Paraguay..., op. cit., p. 65.

${ }^{484}$ Nota de Caballero al Gobernador Velasco del 15/05/1811. ANA-SH, v. 213A, n. 1.

${ }^{485}$ COONEY, Jerry. Milicia, Estado y Sociedad en Paraguay..., op. cit., p. 91.
} 
¿Cuál es la relación e importancia de este hecho para la causa americana? Primero, alejó el peligro de que el ejército porteño fuera atacado por los portugueses. Segundo, desbarató el plan realista de unificar el Alto Perú, Paraguay y Montevideo en contra de Buenos Aires. Esto hubiera sido dramático, más aún cuando, semanas después, sus ejércitos sufrieron una dura derrota en Huaqui.

Meses después, la Junta paraguaya escribía que Velasco se atrajo "el común desprecio y aún la abominación de la provincia” cuando tramó con los portugueses y con el virrey Elío “el plan que proponía emplear sus fuerzas unidas a las de esta provincia y Montevideo para ocupar y separar de la dominación de Buenos Aires todo el país del Uruguay y Paraná $[\ldots]^{3486}$.

Este aporte paraguayo a la "causa común" americana raramente es reconocido por los historiadores tradicionales.

Así, el primer paso independentista en el Paraguay se dio -y debido a su ubicación histórica no podría haber ocurrido de otra manera-, no solo contra la corona de España sino contra los designios centralistas de Buenos Aires y las miras monarquistas de Portugal. Los porteños habían invadido la provincia, y los lusitanos, con la connivencia de las desesperadas autoridades hispanas, estaban prestos a hacer lo mismo.

Sobre el carácter del proceso. La revolución de mayo de 1811 también fue esencialmente política y no social. Su objetivo principal fue consagrar en el poder político a la incipiente burguesía nativa y desplazar a la burocracia colonial proveniente de la metrópoli. No puede decirse que existiera, en el momento del derrocamiento de Velasco, acción directa de los sectores populares. Tampoco, como veremos, las medidas tomadas después de ese hecho tuvieron como objetivo aliviar o mejorar la calidad de vida del común, o bien abolir relaciones sociales arcaicas, como las reducciones de indios o la esclavitud negra. El primer acto de la revolución anticolonial no se hizo en nombre de la plebe sino de la autonomía y el libre comercio de los frutos de la provincia. Pero esto no resta importancia a los sucesos de mayo de 1811. Fueron el punto de partida de lo que podríamos calificar como un proceso político que, con distintas fases y altibajos, tendría su epílogo en 1870.

¿Quiénes fueron sus protagonistas? ¿Cuál fue el sujeto social del proceso? El régimen español fue derrocado por una especie de "frente único" anticolonial que abarcó desde los ricos militares-estancieros, los comerciantes porteñistas, hasta elementos oriundos de

\footnotetext{
${ }^{486}$ Carta de la Junta paraguaya al embajador de España en Rio de Janeiro donde se explican las razones de la Revolución de Mayo, del 26/09/1811. ANA-SH, v. 214.
} 
sectores medios urbanos como el doctor Francia. Es decir, se unieron en la acción clases y sectores de clase con intereses más o menos ligados al comercio exterior que, en esa coyuntura, tenían en común su voluntad de deshacerse del dominio político de los europeos. Vale insistir: nada prueba una participación popular activa o relevante.

Pero las diferencias no tardarían en aflorar. El partido porteñista, al principio dirigido por el doctor Somellera, abogaba por la unión sin más con Buenos Aires desde antes de la caída de Velasco. Cuando esto se concreta, la primera medida que propone Somellera fue la remisión de un parte a la Junta porteña. Cuando el doctor Francia llegó al cuartel ordenó suspender el envío de la nota. Argumentó que a duras penas se había salido de un despotismo y existía el peligro concreto de caer en otro. En lugar de un parte, sugirió que el capitán Antonio Tomás Yegros viajase a Buenos Aires en calidad de enviado oficial. Esta anécdota es una simple muestra de desacuerdos políticos más profundos. Mientras Somellera proponía despachar un simple parte entre el subordinado y el superior, el doctor Francia orienta una misión especial entre iguales ${ }^{487}$. Son los primeros pasos en la dura lucha por el programa basado en "no mudar de amo", que tendrá en el doctor Francia a su principal representante.

La heterogeneidad de ese frente anticolonial, con preponderancia sociopolítica de los sectores terratenientes y comerciantes, impregnó el proceso con una serie de vacilaciones políticas. La toma del poder se hizo, como en el puerto, "reconociendo siempre al desgraciado soberano bajo cuyos auspicios vivimos" 488 . El exgobernador Velasco no fue fusilado ni arrestado, sino que continuó formalmente en el gobierno, asociado con otros dos diputados: el doctor José Gaspar Rodríguez de Francia y el capitán Juan Valeriano Zevallos, peninsular que había adherido a la causa patriota ${ }^{489}$.

Así que triunfó el alzamiento, ese triunvirato instaló un toque de queda desde las nueve de la noche, prohibiéndose cualquier reunión de "tres personas juntas, y ni una de ellas de las clases de Negros y Pardos [...]"490. Otro edicto ordenó "a todos los vecinos y habitantes" la entrega de todas las armas en 24 horas, bajo pena de riguroso castigo ${ }^{491}$. La revolución, realizada en nombre de las clases propietarias criollas, desde el comienzo se

${ }^{487}$ CHAVES, Julio [1938]. Historia de las relaciones entre Buenos-Ayres y el Paraguay..., op. cit., p. 130.

${ }^{488}$ Bando del triunvirato que comunica la instauración del nuevo gobierno, del 17/05/1811. ANA-SH, v. 213A, n. 1.

${ }^{489}$ Designación y juramento de Francia y Zevallos como diputados de gobierno, del 16/05/1811. ANA-SH, v. 213A, n. 1; Bando del triunvirato que comunica la instauración del nuevo gobierno, del 17/05/1811. ANA-SH, v. $213 \mathrm{~A}$, n. 1.

${ }^{490}$ VELILLA, Margarita (Org.). Autos de la Revolución del Paraguay..., op. cit., p. 28.

${ }^{491}$ Bando del triunvirato que comunica la instauración del nuevo gobierno, del 17/05/1811. ANA-SH, v. 213A, n. 1. 
mostró preocupada con una posible participación popular. Todos los sectores -incluido el doctor Francia- coincidían en que cualquier tipo de transición debía ser ordenada y controlada por arriba. Si bien existen autores que presentan el caso paraguayo como una revolución "radical”, el hilo de los acontecimientos es incomparable, por ejemplo, con Haití o con el movimiento liderado por el padre Hidalgo en México, para citar dos procesos realmente surgidos desde abajo.

Como anota Pellegrino, esta actitud hacia las clases populares fue común en toda América:

Em nome da ordem como valor absoluto, fundamentavam a permanência do poder limitado nas mãos das elites por serem elas consideradas o único grupo social com "preparo" político para exercê-lo. Tal proposta de exclusão das classes populares do universo decisório da política foi a vitoriosa não apenas na Argentina e no México, mas também em toda América Latina ${ }^{492}$.

En 1819, en el conocido discurso de Angostura, Bolívar se refiere a la forma democrática y al grado de participación popular en la conducción de los nuevos Estados:

\begin{abstract}
Por lo mismo que ninguna forma de gobierno es tan débil como la democrática, su estructura debe ser de la mayor solidez; y sus instituciones consultarse para la estabilidad. Si no es así, contemos con que se establece un ensayo de gobierno, y no un sistema permanente; contemos con una sociedad díscola, tumultuaria y anárquica y no con un establecimiento social, donde tengan su imperio la felicidad, la paz y la justicia.

No seamos presuntuosos, Legisladores; seamos moderados en nuestras pretensiones. No es probable conseguir lo que no ha logrado el género humano; lo que no han alcanzado las más grandes y sabias naciones. La libertad indefinida, la democracia absoluta, son los escollos adonde han ido a estrellarse todas las esperanzas republicanas. Echad una mirada sobre las repúblicas antiguas, sobre las repúblicas modernas, sobre las repúblicas nacientes; casi todas han pretendido establecerse absolutamente democráticas y a casi todas se les han frustrado sus justas aspiraciones ${ }^{493}$.
\end{abstract}

Por lo tanto, lo que se inició el 15 de mayo de 1811 fue una revolución política anticolonial, que tendrá consecuencias económico-sociales, pero sin tener esto como objetivo central. Es más, incluso en el sentido de un enfrentamiento anticolonial, no estaba dicho que el proceso terminaría en una ruptura definitiva ni con España ni con Buenos Aires. El proceso se fue desarrollando de manera contradictoria y sinuosa. Ahora bien, la marginalidad del Paraguay en el sistema colonial - con su doble dependencia-, sumada al peligro portugués, desde el comienzo impondría a la dirección criolla del Paraguay menos margen de maniobra que a sus pares de Buenos Aires.

Restaba saber, ahora que el poder colonial español había caído tanto en Buenos Aires como en Asunción, cuál sería la relación entre ambas provincias igualmente "libres".

492 PRADO, Maria; PELLEGRINO, Gabriela. História da América Latina..., op. cit., p. 56.

${ }^{493}$ BOLÍVAR, Simón. Discurso de Simón Bolívar ante el Congreso de Angostura..., op. cit. 
Al mismo tiempo que el bando del 17 de mayo declara que la revolución se hizo para evitar "entregar o dejar esta Provincia al mando o autoridad o disposición de la de Buenos Aires ni de otra alguna y mucho menos el sujetarla a ninguna potencia extraña"494, formula, por primera vez, la idea de la confederación con la capital y las demás provincias hermanas: “uniendo y confederándose [el Paraguay] con la misma ciudad de Buenos Aires para la defensa común y para procurar la felicidad de ambas provincias y las demás del continente bajo un sistema de mutua unión, amistad y conformidad, cuya base sea la igualdad de Derechos" ${ }^{495}$.

A la hora de despachar al portugués Abreu, los patriotas intentan calmar los ánimos y le dicen que la revolución no había tenido otro fin que acabar con la guerra civil y construir un sistema de buena armonía con Buenos Aires "sin subyugarse una a otra"496. Diogo de Souza respondió a Abreu diciendo que cualquier relación o auxilio solo sería realizado después de que el Paraguay adhiera sin cortapisas a Fernando VII y reinstituyera en el poder a Velasco 497

Sobre la posible intervención en el Paraguay, Pimenta escribe:

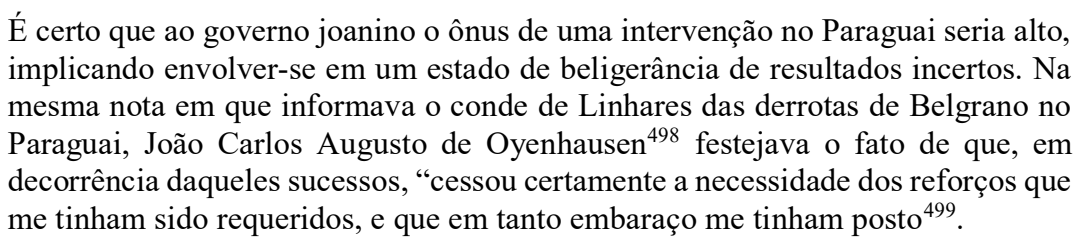

Tocaba ahora saber cuál sería la reacción de la ex capital del Virreinato frente al llamado a adoptar "un sistema de mutua unión, amistad y conformidad, cuya base sea la igualdad de Derechos" entre todas las provincias del continente, que emanaba desde Asunción.

\subsection{El primer Congreso y gobierno nacionales}

El objetivo primordial del "triunvirato" -como quedó conocido aquel gobierno provisorio- era convocar a una Junta o Congreso General, a la cual debían acudir "no solo los diputados de las villas y poblaciones, mas también muchos vecinos principales

\footnotetext{
494 Ibídem.

495 Ibídem.

${ }^{496}$ CHAVES, Julio [1938]. Historia de las relaciones entre Buenos-Ayres y el Paraguay..., op. cit., p. 123.

${ }^{497}$ PIMENTA, João Paulo. A independência do Brasil e a experiência hispano-americana..., op. cit., p. 135.

${ }^{498}$ Entonces gobernador de Mato Grosso.

499 Carta de João Carlos Augusto de Oyenhausen al conde de Linhares, Cuiabá, 14 de mayo de 1811, citado por: Ídem, p. 136.
} 
moradores en campaña que viven a largas distancias"500, para determinar el "régimen y gobierno que deba observarse en adelante y cimentar la forma de unión y relaciones que esta provincia haya de tener con la de Buenos Aires"501.

En ese sentido, anunció el retiro de las tropas paraguayas de Corrientes y su devolución al control de Buenos Aires, deshaciendo una medida que había sido tomada por el españolismo. El motivo alegado fue, otra vez, "conservar la tranquilidad anterior y la paz, unión y buena armonía con la ciudad de Buenos Aires y las demás del continente"502.

Se informó también al comandante portugués del fuerte de Coimbra que se habían resuelto las diferencias con Buenos Aires: "[Por] medios pacíficos [...] adoptando un sistema de confederación de ambas provincias con las demás del continente, para sostener la causa común de [roto] derechos augustos y para procurar la prosperidad general de todas $[\ldots]^{\prime \prime 503}$.

El 9 de junio, Velasco es destituido del gobierno tras descubrirse correspondencia conspirativa con Montevideo. Fue acusado de aliarse con los "tiranos opresores de nuestra patria y de nuestros derechos" 504 . Así, hasta el 17 de junio, el gobierno recayó en el doctor Francia y en Zevallos.

En esa fecha comenzó el primer Congreso nacional. Sin alterar la tradición, la convocatoria se limitó a los "vecinos principales". La diferencia estuvo en que, de los 264 diputados, solo cuatro eran españoles peninsulares.

El doctor Francia realizó el discurso inaugural en clave liberal:

La Provincia del Paraguay, volviendo del letargo de la esclavitud, ha reconocido y recobrado sus derechos y se halla hoy en plena libertad, para cuidar y disponer

\footnotetext{
${ }^{500}$ Convocatoria a un Congreso General para establecer el régimen de Gobierno en la Provincia del Paraguay y sus relaciones con la de Buenos Aires, del 28/05/1811. ANA-SH, v. 213A, n. 1; Modelo de esquela de citación para el Congreso General de 1811. ANA-SH, v. 213A. Las asambleas locales para el Congreso de junio de 1811 se realizaron en San Pedro del Ycuamandiyú, Concepción (conocida entonces como Villa Real), Curuguaty, Rosario de Cuarepotí, Villa del Pilar del Neembucú y Villa Rica. El vecino era definido como el varón padre de familia, con un domicilio determinado que lo vinculaba con la comunidad o ciudad de residencia. Los "vecinos principales" o beneméritos en Paraguay eran aquellos que provenían de familias importantes, generalmente descendientes de los primeros conquistadores o que habían prestado algún servicio importante para la Corona. Los negros e indígenas no eran ni vecinos, citado en: CABALLERO CAMPOS, Herib. Los Congresos de 1811 y 1813: representación política y ciudadana. In: TELESCA, Ignacio; BREZZO, Liliana; CABALLERO CAMPOS, Herib (Org.). Paraguay 1813 ..., op. cit., p. 118.

${ }^{501}$ Convocatoria a un Congreso General para establecer el régimen de Gobierno en la Provincia del Paraguay y sus relaciones con la de Buenos Aires, del 28/05/1811. ANA-SH, v. 213A, n. 1.

502 Bando del Gobierno interino que anuncia el retiro de tropas paraguayas en Corrientes, del 30/05/1811. ANA-SH, v. 213A, n. 1.

${ }^{503}$ Oficio al comandante del fuerte portugués de Coimbra, Don Jerónimo Joaquín Núñez, del 7/06/1811. ANASH, v. 214, publicado en: RODRÍGUEZ ALCALÁ, Guido; DURÁN ESTRAGÓ, Margarita; ROMANO GARCÍA, Martín (Org.). FRANCIA: [1762-1816]..., op. cit., p. 77.

${ }^{504}$ Bando que suspende "sus oficios y en un lugar de seguridad a Don Bernardo Velasco e individuos del Cabildo hasta la resolución de la Junta General”, del 9/06/1811. ANA-SH, v. 213A, n. 1.
} 
de sí misma y de su propia felicidad [pues] La naturaleza no ha creado a los hombres esencialmente sujetos al yugo perpetuo de ninguna autoridad civil; antes bien hizo a todos iguales y libres $[\ldots]^{505}$.

El Congreso negó toda legitimidad a las "Cortes, Consejo de Regencia y toda representación de la autoridad suprema" ${ }^{506}$. Sin embargo, se aprobó "no reconocer otro Soberano que al Señor Don Fernando VII [...]"507.

Sobre la relación con Buenos Aires, se resolvió que la provincia "no solo tenga amistad, buena armonía y correspondencia con la ciudad de Buenos Aires y demás provincias confederadas, sino que también se una con ellas para el efecto de formar una sociedad fundada en principios de justicia y equidad y de igualdad"508.

Según el Congreso paraguayo, para que tal unión sea justa debían darse estas condiciones: 1) el Paraguay se gobernaría a sí mismo, sin intromisión de Buenos Aires, hasta la concertación de un nuevo pacto en un Congreso General; 2) restablecido el comercio, se dejaría de cobrar el peso de plata [sisa y arbitrio] exigido por cada tercio de yerba; 3 ) librecambio de todos los productos, especialmente del tabaco; 4) la eventual Constitución dictada en el Congreso General sería ad-referendum de una "Junta plena, y general de sus habitantes y moradores" 509 .

El Congreso privó a los españoles de ocupar cargos públicos y finalizó instaurando una "Junta Superior de Gobierno". Esta Junta fue el primer gobierno netamente nativo. Su composición expresó, de manera contradictoria, el frente común entre las distintas facciones de las clases propietarias que promovió la Revolución de Mayo: Fulgencio Yegros nombrado presidente de la Junta y Comandante General de Armas-y Pedro Juan Caballero, representaban a los estancieros-militares; el sacerdote Francisco Javier Bogarín, en nombre del clero no españolista; Fernando de la Mora, intelectual y comerciante asociado a los intereses "unitarios" de Buenos Aires; y el doctor Francia - renombrado por sus méritos personales e intervención en los sucesos de Mayo-, que expresaba el ala más radical basada en el programa de "no mudar de amo".

En síntesis, las resoluciones del Congreso de junio de 1811 aún expresaban muchas vacilaciones de la embrionaria burguesía y sectores medios locales. Aunque se conformó un gobierno de nativos, no se rompió explícitamente con España. En el nivel regional, quedó

\footnotetext{
${ }^{505}$ Discurso inaugural del Congreso General de la Provincia del 17/06/1811. ANA- SH, v. 213A, n. 1.

${ }^{506}$ Ibídem. Sobre las resoluciones del Congreso, ver también: ANA-SH, v. $213 \mathrm{~B}$.

${ }^{507}$ Acta de votación del Congreso General de la provincia, del 18/06/1811. ANA-SH, v. 213A, n. 1.

508 Ibídem.

509 Ibídem.
} 
patente el interés de la dirección paraguaya no solo de mantener amistad y comercio sino de unirse con Buenos Aires y las demás provincias del continente, aunque preservando su propio gobierno y planteando el fin de antiguas imposiciones coloniales en sentido librecambista.

\subsection{La nota del 20 de julio: el primer llamado a la Confederación}

La primera Junta paraguaya, a través del doctor Francia, redactó una nota oficial para comunicar las resoluciones del Congreso de junio al gobierno de Buenos Aires. Este documento fundamenta:

No es dudable que abolida o deshecha la representación del Poder Supremo recae este o queda refundido naturalmente en toda la Nación. Cada pueblo se considera entonces en cierto modo participante del atributo de soberanía [...] De este principio [...] se deduce ciertamente que reasumiendo los pueblos sus derechos primitivos, se hallan todos en igual caso y que igualmente corresponde a todos velar sobre su propia conservación $[\ldots]^{510}$.

A partir de ese razonamiento, la Junta paraguaya expuso, considerándola una fórmula posible de unión, la propuesta de una confederación de las ex provincias del Río de la Plata:

La confederación de esta provincia con las demás de nuestra América y principalmente con las que comprendía la demarcación del antiguo Virreinato, debía ser de un interés más inmediato, más accesible y por lo mismo más natural, como de pueblos no solo de un mismo origen, sino que, por el enlace de particulares y recíprocos intereses, parecen destinados por la naturaleza misma a vivir y conservarse unidos ${ }^{511}$.

Al mismo tiempo en que la nota insiste sobre que "su voluntad decidida es unirse con esta ciudad y demás confederadas, no solo para conservar una recíproca amistad, comercio y correspondencia, sino también para formar una sociedad fundada en los principios de justicia, de equidad y de igualdad", la Junta aclara que "[...] se engañaría cualquiera que llegase a imaginar que su intención había sido entregarse al arbitrio ajeno, y hacer dependiente su suerte de otra voluntad. En tal caso nada más habría adelantado, ni reportado otro fruto de sus sacrificios que el cambiar unas cadenas por otras y mudar de $\operatorname{amos}[\ldots]^{\prime 512}$.

Así, la nota del 20 de julio es la primera manifestación de federalismo en el Río de la Plata. La propuesta de una confederación entre naciones se basaba en anteriores documentos oficiales: el bando del 17 de mayo; el manifiesto del 9 de junio; el acta del

${ }^{510}$ Oficio de la Junta de Gobierno del Paraguay a la de Buenos Aires, del 20 de julio de 1811. ANA-SH, v. 214, n. 7.

511 Ibídem.

512 Ibídem. 
Congreso del 17 de junio y, como veremos, se insistirá en ella en el tratado del 12 de octubre de 1811. La nota del 20 de julio inspirará en parte las célebres Instrucciones del Año XIII, dictadas por Gervasio Artigas a los delegados orientales a la Asamblea General celebrada en Buenos Aires ${ }^{513}$. El propio Artigas reconocerá el impulso paraguayo a la idea federativa en una nota a Asunción del 17 de abril de 1813, en la que resaltaba la importancia de "6 diputados nuestros, 7 de esa Provincia grande, y 2 del Tucumán decididos al sistema de confederación que manifiesta V.S. tan constantemente [...]"514.

La confederación no implicaba un único Estado, pero emergía como una fórmula americanista que, al mismo tiempo, preservaría el derecho de autodeterminación nacional de todos los pueblos rioplatenses. Nótese que la confederación propuesta por Asunción no sería solo con Buenos Aires sino "con las demás de nuestra América". Un hecho que cuestiona la frecuente visión de “aislamiento" sobre el Paraguay de preguerra. El propio Bartolomé Mitre reconocerá, décadas más tarde, que la "primera acta de confederación levantada en el Río de la Plata" fue de autoría de Rodríguez de Francia ${ }^{515}$.

Chiaramonte confirma este hecho:

\begin{abstract}
La idea de confederación caracterizó y complicó desde el inicio las relaciones entre la provincia del Paraguay y la Buenos Aires revolucionaria. El recurso al principio de retroversión de la soberanía a los pueblos y la consiguiente igualdad de derechos entre las ciudades del ex Virreinato se encuentran ya en el bando del 17 de mayo de 1811 -lanzado por la flamante Junta paraguaya- y todavía con mayor claridad en el oficio del 20 de julio del mismo año, documentos en cuya redacción intervino decisivamente el Dr. Francia ${ }^{516}$.
\end{abstract}

\title{
3.5. El Tratado del 12 de octubre de 1811
}

El doctor Francia se retira de la Junta el 1 de agosto, debido a desacuerdos con los estancieros-militares. Hacia finales de ese mes llegó la noticia de que Buenos Aires había despachado una misión diplomática compuesta por Manuel Belgrano y el doctor Vicente Anastasio de Echevarría. El Cabildo, oficiales y otros miembros del gobierno urgen la reincorporación del "miembro más útil de la Junta" ${ }^{17}$. Francia retorna el 3 de setiembre.

\footnotetext{
${ }^{513}$ Instrucciones orientales del Año XIII. In: CHIARAMONTE, José. Ciudades, provincias, Estados..., op. cit., pp. 142-143.

514 CHAVES, Julio [1938]. Historia de las relaciones entre Buenos-Ayres y el Paraguay..., op. cit., p. 146. Ver también: BRUSCHERA, Oscar H. José Artigas: documentos. Montevideo: Casa de las Américas, 1971.

${ }^{515}$ MITRE, Bartolomé [1859]. Historia de Belgrano..., op. cit., pp. 27-28.

${ }^{516}$ CHIARAMONTE, José. Nación y Estado en Iberoamérica ..., op. cit., p. 75.

${ }^{517}$ Carta del comandante del Cuartel General, Antonio Tomás Yegros, al Cabildo de Asunción, del 02/09/1811, ANA-SH, v. 214, n. 5.
} 
Las instrucciones de los enviados porteños eran claras: "la provincia del Paraguay debe quedar sujeta al gobierno de Buenos Aires como lo están las Provincias Unidas, por exigirlo así el interés común de todos [...]"518.

Sobre la propuesta de confederación, se alertaba:

[...] el ejemplo de la del Paraguay pudiera ser un estímulo de las que tentase a su separación $[\ldots]$ que el vínculo solo de federación no basta en una urgente necesidad en que nos hallamos de obrar con unidad y energía [...] La Provincia del Paraguay, mantenida por solo el vínculo federativo, no contribuye por su parte de un modo condigno a satisfacer los grandes esfuerzos y sacrificios que las demás van a hacer por sus derechos y libertad; que una vez que el interés es uno e indivisible, la voluntad general de todas las provincias debe ser la ley superior que obligue al Paraguay a prestarse a una subordinación sin la cual el sistema y los movimientos pudieran desconcertarse $\mathrm{s}^{519}$.

Si esto no es posible: "se tratará $[\ldots]$ de unir ambos gobiernos bajo un sistema ofensivo y defensivo contra todo enemigo que intentase atacar sus respectivos territorios" $" 520$.

Las diferencias estaban claras. El Paraguay sostenía: unidad en la forma de una confederación de todas las provincias sin subordinación entre ellas. Buenos Aires contestaba: unidad, pero con subordinación de las provincias al gobierno central ${ }^{521}$.

El 9 de setiembre, la Junta asuncena condicionó la entrada al país de los diplomáticos “[...] entre tanto la Excelentísima Junta por sí misma no reconozca expresa y formalmente nuestra independencia de ella en los términos propuestos y acordados por nuestra provincia $[\ldots]^{\prime, 522}$.

Belgrano y Echevarría debieron aguardar la contestación de su gobierno en Corrientes, que llegó con fecha del 28 de agosto. En esa nota, Buenos Aires reconocía el autogobierno del Paraguay, aunque subordinaba el asunto a lo que resolviese la Asamblea General. La Junta paraguaya, entendiéndola como un avance diplomático importante, celebró esa respuesta efusivamente. El 14 de setiembre publicó un bando en el que expresaba:

[La Junta de Buenos Aires] nos protesta igualmente que nada ha distado tanto de las intenciones de aquella ciudad y de su Junta Provisional como la ambición de dominar a los demás pueblos si era voluntad de la provincia el gobernarse por sí misma y con independencia de la Junta Provisional de Buenos Aires, no se opondría a ello con tal que estuviésemos unidos y obrásemos de conformidad para defendernos de cualquier agresión exterior, contribuyendo nuestras fuerzas según lo exijan la necesidad y la conveniencia general [....]

Así queda ya decidida nuestra suerte, y afianzada nuestra libertad $e$ independencia [...] Ciudadanos del Paraguay, sois todos libres, y la Junta,

\footnotetext{
518 CHAVES, Julio [1938]. Historia de las relaciones entre Buenos-Ayres y el Paraguay..., op. cit., p. 159.

519 Ídem, p. 160.

520 Ibídem.

521 Ídem, p. 162.

${ }^{522}$ Carta de la Junta paraguaya a los emisarios de Buenos Aires, del 09/09/1811. ANA-SH, v. 214, n. 7.
} 
participando al público esta lisonjera noticia, os congratula por este suceso, a que era acreedor vuestro esfuerzo y vuestro valor. No se escuche de hoy [en] adelante entre nosotros otra voz que la unión y la libertad. No se reconozcan otras relaciones que las que se dirigen a afirmar nuestros comunes derechos $[\ldots]^{523}$.

Así, la Junta autorizó la entrada al país de los dos emisarios porteños para tratar las espinosas cuestiones comerciales y militares pendientes ${ }^{524}$. El gobierno paraguayo designó al doctor Francia como su principal negociador.

A fin de cuentas, las cláusulas del Tratado representaron un progreso para las reivindicaciones paraguayas: 1) se reconoció implícitamente "la independencia en que queda esta Provincia del Paraguay de la de Buenos Aires conforme a lo convenido en la citada contestación oficial del 28 de agosto último [...]”. 2) Ambas provincias debían unirse en una "federación y alianza indisoluble", quedando obligadas a cooperar con cualquier clase de auxilio "toda vez que lo demande el sagrado fin de aniquilar y destruir cualquier enemigo que intente oponerse a los progresos de nuestra justa causa y común libertad"; 3) se abolió el estanco del tabaco y se liberó su comercio; 4) el derecho de alcabala se realizaría solamente "en el lugar de la venta"; 5) la sisa y el arbitrio por cada tercio de yerba se abonaría en Asunción, no en Buenos Aires; 6) No obstante, se autorizó a Buenos Aires a fijar un moderado impuesto a la introducción de frutos del Paraguay siempre que "una urgente necesidad lo exija"; 7) Para evitar desavenencias, se firmó un artículo adicional en el que se estableció que esa eventual imposición no pasaría de un real y medio por tercio de yerba y otro real y medio por arroba de tabaco ${ }^{525}$.

La principal resolución política del tratado de 1811 fue que ambas provincias debían unirse en una "federación y alianza indisoluble"526, estando cada parte obligada a cooperar con cualquier clase de auxilio "toda vez que las demande el sagrado fin de aniquilar y destruir cualquier enemigo que intente oponerse a los progresos de nuestra justa causa y común libertad" 527 .

El gobierno en Asunción anunció la firma del acuerdo y la "feliz unión” con Buenos Aires en este tenor:

\footnotetext{
${ }^{523}$ Bando de la Junta paraguaya que anuncia la respuesta de la de Buenos Aires, que reconoce el autogobierno del Paraguay, del 14/09/1811. ANA-SH, v. 214, n. 7.

${ }^{524}$ Carta de la Junta a los enviados de Buenos Aires, del 18/09/1811. ANA-SH, v. 214, n. 7; Carta de la Junta al comandante de Neembucú, del 18/09/1811. ANA-SH, v. 214, n. 7.

525 Tratado entre la Junta de Gobierno del Paraguay y los representantes enviados por Buenos Aires, del 12/10/1811. ANA-SH, v. 214, n. 8.

526 Ibídem.

${ }^{527}$ VIOLA, Alfredo. Dr. José Gaspar Rodríguez de Francia: Defensor de la Independencia del Paraguay. Asunción: Editor Carlos Schauman, 1992, p. 46.
} 
[...] ya no hay ni debe haber división entre una y otra Provincia. Los hijos de Buenos Aires son y deben reputarse del Paraguay y los hijos de esta Provincia son y deben también mirarse como patricios de Buenos Aires. Serán nuestros enemigos todos los que se declaren contra aquel pueblo amigo y aliado; y Buenos Aires se sacrificará también a fin de perseguir y exterminar a los que se declaren enemigos nuestros.

Unidos con esta alianza indisoluble y proveídos ya de nuestros recursos, debemos considerarnos más fuertes y con más poder para sostener la causa común [...que] sea el grito general de todos: Morir por la Patria y por la común libertad ${ }^{528}$.

Lamentablemente, no pasaría mucho tiempo para que esa euforia se transformase en decepción. Mientras se negociaba el tratado subía al poder el Triunvirato. El 1 de diciembre de 1811, cuando ya se había celebrado el acuerdo, Bernardino Rivadavia alertó a los comisionados:

[...] El gobierno del Paraguay no penetrado aún de los verdaderos intereses que deben dar impulso a sus resoluciones, nos estrecha a la concesión de ventajas que después de no estar a los alcances de nuestras facultades, son puramente egoístas e interesadas, aprovechándose aún de las que reportó anteriormente. [Pido que] se manejen en este asunto de un modo diestro, y con toda política, teniendo presente los intereses de nuestro territorio $[\ldots]^{529}$.

\subsection{Ruptura definitiva con Buenos Aires}

El tratado de octubre de 1811 abrió la posibilidad de concretar una fórmula de unidad basada en el respeto a los derechos nacionales entre el Paraguay y la ciudad-puerto. Sin embargo, en la práctica, las autoridades porteñas no aceptaron las condiciones del documento. En el transcurso de 1812, el gobierno porteño tomó medidas contrarias al acuerdo y, con ello, no hizo sino "empujar" al Paraguay por el camino de su "separación". Veamos los hechos.

En abril de 1812, en San Nicolás fue cobrado el derecho de sisa y arbitrio a dos comerciantes paraguayos por 130 tercios de yerba mate. Según el Tratado, esos derechos debían exigirse en Asunción.

El 1 de setiembre de 1812, el Triunvirato publicó un Reglamento Provisional sobre los derechos comerciales de los ramos de la extinta renta del tabaco. El artículo $3^{\circ}$ dice:

[...] los tabacos extranjeros o de las Provincias separadas de la jurisdicción de este Superior Gobierno pagarán a su introducción y según las clases referidas en el artículo anterior, duplicados derechos que los impuestos a los nacionales ${ }^{530}$.

\footnotetext{
${ }^{528}$ Bando de la Junta paraguaya que informa el Tratado con Buenos Aires, del 14/10/1811. ANA-SH, v. 214, n. 8.

${ }^{529}$ CHAVES, Julio [1938]. Historia de las relaciones entre Buenos-Ayres y el Paraguay..., op. cit., p 168.

530 Ídem, p. 192.
} 
A raíz de esta disposición, el Paraguay debía pagar por la introducción de su tabaco un impuesto de tres pesos por arroba. Este aumento no solo violaba el Tratado -que establecía "un real y medio por tercio de yerba y otro real y medio por arroba de tabaco, y no más"-, sino que era usado como elemento de extorsión para forzar el reconocimiento de la superioridad de Buenos Aires. Al mismo tiempo, el Triunvirato creó una aduana intermediaria en la ciudad de Corrientes como "punto de frontera" 531.

La Junta paraguaya reclamó el "exorbitante impuesto de tres pesos por arroba con que se ha gravado el tabaco exportado de esta provincia por su entrada en Santa Fe”. La nota objetó también la "extraña distinción que se hace entre esta y las demás provincias", puesto que se imponían "derechos dobles al tabaco del Paraguay". Este procedimiento, según Asunción, tenía "por objeto el hacer decaer el comercio de los frutos de esta provincia" 532.

Casi sin recursos debido a la paralización del comercio exterior y asumiendo el riesgo de enfrentar a la flota española que dominaba el Paraná, la Junta paraguaya despachó una flotilla con frutos del país para ser vendidos en Buenos Aires. A su regreso, la flotilla fue atacada y capturada por corsarios realistas. Una sumaca de Buenos Aires logró rescatarla, pero, en lugar de devolverla, confiscó una goleta junto al producto de la venta de la carga, que alcanzaba 53.000 pesos. Asunción reclamó airadamente a sus pares de Buenos Aires la retención de una "goleta con la ingente cantidad de numerario efectivo represado en Santa Fe y que pertenece a los fondos públicos de esta provincia" ${ }^{533}$.

Las relaciones entre el Paraguay y la Banda Oriental también fueron motivo de discordia. El 20 de octubre de 1811, el Triunvirato firmó el vergonzoso Tratado de Pacificación con el virrey Elío. Las bases habían sido negociadas en Rio de Janeiro bajo la intervención directa del ministro inglés lord Strangford. De acuerdo con el pacto, el Triunvirato porteño reconocía la unidad de la nación española y a Fernando VII como Rey. También se comprometía a auxiliar a España en la guerra contra Napoleón. Las tropas de Buenos Aires debían abandonar totalmente la Banda Oriental y las zonas de Gualeguay y Gualeguaychú, que quedarían sujetas a Elío. Por su parte, el virrey se comprometía a garantizar el retiro de las tropas portuguesas y a finalizar el bloqueo de las comunicaciones y el comercio entre Buenos Aires y Montevideo ${ }^{534}$. Esto fue una traición a la "causa común”, aquella que el gobierno porteño no dudaba en esgrimir para justificar su política de

\footnotetext{
531 Ibídem.

${ }^{532}$ Oficio de la Junta del Paraguay a la de Buenos Aires, del 25/11/1812. ANA-SH, v. 218, n. 1.

533 Ibídem.

${ }^{534}$ CHAVES, Julio [1938]. Historia de las relaciones entre Buenos-Ayres y el Paraguay..., op. cit., p. 170.
} 
sometimiento de las provincias. ¿Con qué autoridad el gobierno porteño entregaba la Banda Oriental y Entre Ríos a los principales enemigos de la independencia americana? La motivación era eminentemente económica. El fin del bloqueo español interesaba a los comerciantes porteños y a los ingleses.

Artigas se opuso férreamente. El pueblo, abandonado por Buenos Aires a su suerte, siguió a su caudillo en lo que quedó conocido como el Éxodo Oriental. Artigas buscó entonces el apoyo de las provincias interiores. En diciembre, envió un representante a Asunción para solicitar cooperación militar en contra de los portugueses. El gobierno paraguayo respondió que carecía de armas y de un ejército regular, y que por esa razón mal conseguía defender sus propias fronteras de los mismos portugueses. Se comprometió, no obstante, a enviar yerba mate y tabaco para las tropas orientales. También envió un emisario ante Artigas, el capitán Laguardia ${ }^{535}$. En señal de buena fe, toda la correspondencia con Artigas fue remitida a Buenos Aires, que respondió cuestionando el derecho paraguayo de recibir y acreditar representantes diplomáticos de otras provincias. El 9 de julio de 1812, Chiclana, Pueyrredón y Rivadavia repudiaron "las sugestiones escandalosas con que vuestro diputado [Laguardia] trató de seducir al general Artigas para que se substrajese de la dependencia de este Gobierno [...]"536. Asunción defendió su derecho a enviar y recibir emisarios, pero trató de apaciguar los ánimos con Buenos Aires: “[...] estamos tan distantes de romper en lo más mínimo el pacto federativo de nuestra alianza" 537.

El doctor Francia se retiró de la Junta por segunda vez en diciembre de 1811, por nuevos roces con los estancieros-militares. No retornaría sino hasta noviembre de 1812 , exigiendo la mitad de los batallones y armas de la provincia, y el llamado a un Congreso nacional con amplia convocatoria.

En el transcurso de 1812, el Tratado de 1811 se había transformado en letra muerta. La cuestión de fondo radicaba en que la política centralista, que había triunfado el 25 de mayo de 1810, no podía aceptar que el Paraguay ni ninguna de las provincias del Interior se gobernaran por sí mismas.

Aceptar aquello sería un "ejemplo" y un "estímulo" peligroso para el dominio del puerto. Así, el unitarismo de Buenos Aires se erigía en un obstáculo para cualquier fórmula

\footnotetext{
535 Ídem, p. 174.

536 Ídem, p. 176.

537 Ídem, p. 177.
} 
de unidad o federación capaz de respetar los derechos de las naciones que se emancipaban de España.

El Triunvirato acentuó la política centralista, es verdad. Pero ella estuvo presente desde la Primera Junta. Recordemos la circular del 27 de mayo de 1810, que exhortaba a considerar a la Junta porteña como "centro de unidad".

En las instrucciones de la expedición militar que marchó sobre Córdoba se autorizó la conformación de Juntas locales que subrogasen la autoridad de los gobernadores pero que, al mismo tiempo, reconociesen la dependencia de la de Buenos Aires ${ }^{538}$. La Primera Junta porteña también aceptó la elección e "incorporación” de diputados provinciales al gobierno central. Esto podría parecer una concesión al Interior. Pero ¿cuál era, según Buenos Aires, el carácter de esas Juntas locales? En el decreto del 10 de febrero de 1811 se ordena:

[...] que en toda capital de provincia se forme una junta de cinco miembros presidida por el gobernador en la que residirá in-solidum la autoridad, pero con entera subordinación a la Junta Superior. Que en las ciudades o villas, que deban nombrar diputado al Congreso, se formarán juntas de tres miembros presididas por el comandante de armas. Que estas juntas reconocerán a las respectivas capitales la subordinación en que han estado; estas juntas son llamadas subalternas ${ }^{539}$.

La fórmula era clara: subordinación de las Juntas subalternas a las provinciales; subordinación de las Juntas provinciales a la Junta Superior. Por si faltase algo, Buenos Aires podía remover a los presidentes de las provincias, decidir los empates en la elección de vocales, y hasta señalar los días de despacho. Las atribuciones de esas Juntas locales en nada se diferenciaban de las que tenían los antiguos intendentes y subdelegados del régimen colonial. De hecho, la base de ese decreto fue la Ordenanza de Intendentes de $1782^{540}$.

Así, en diciembre de 1810 arribaron a Buenos Aires los diputados de Corrientes, Salta, Córdoba, Tucumán, Mendoza, Tarija, Catamarca, Jujuy, y Santa Fe ${ }^{541}$. Un sector de los miembros de la Primera Junta porteña -Saavedra, Azcuénaga, Alberti, Matheuargumentó que los diputados provincianos no tenían derecho alguno a incorporarse al gobierno, pero que era políticamente conveniente aceptarlos. En la sesión del 18 de diciembre, Mariano Moreno se opuso completamente a la incorporación de los representantes del Interior, por contraria al derecho y al bien general del Estado ${ }^{542}$. El tema se llevó a votación y se aceptó incorporar a los diputados de las provincias, creándose la

\footnotetext{
538 Ídem, p. 131.

539 Ídem, p. 134.

540 Ídem, p. 135.

541 Ídem, p. 150.

542 Ídem, p. 152.
} 
llamada Junta Grande ${ }^{543}$. Moreno renunció al cargo de Secretario y nunca más retornaría al gobierno.

A la Junta Grande le sucedió, el 23 de setiembre, el Triunvirato de Feliciano Chiclana, Manuel de Sarratea, y Juan José Paso ${ }^{544}$. En realidad, este órgano estaba orquestado por unos de sus secretarios, Bernardino Rivadavia, representante de la burguesía comercial y agente inglés ${ }^{545}$. La primera consigna del Triunvirato fue defender a la capital de todo agravio ${ }^{546}$. Una de sus primeras proclamas, reza: "Donde no hay subordinación no hay gobierno; y sin gobierno viene a ser una nación como una tabla en medio del océano" ${ }^{547}$. Los diputados del Interior formaron la Junta Conservadora de la Soberanía del señor Fernando VII y de las leyes nacionales, una especie de "poder legislativo". El Triunvirato lo disolvió en noviembre de 1811, asumió plenos poderes titulándose Gobierno Superior Provisional de las Provincias Unidas del Río de la Plata, y emitió el Estatuto Provisional del Gobierno Superior de las Provincias Unidas del Río de la Plata, a nombre de Fernando VII, que regiría hasta que un Congreso General dictase una Constitución ${ }^{548}$.

El 8 de octubre de 1812 fue derrocado el Triunvirato y asumió un Segundo Triunvirato: Juan José Paso, Nicolás Rodríguez Peña, y Antonio Álvarez Jonte. El nuevo gobierno surgió con la condición expresa de convocar una Asamblea General ${ }^{549}$. Aparentemente, se fortalecía la tendencia independentista, puesto que el nuevo gobierno fue promovido por José de San Martín y Carlos María de Alvear, organizados en la Logia Lautaro, que actuó junto a la Sociedad Patriótica fundada por los seguidores de Mariano Moreno.

Pero no fue así. La tendencia de Alvear, centralista, terminó imponiéndose. Así, en la convocatoria de la Asamblea del Año XIII se exigió que los delegados del Interior no vinieran con mandatos de sus pueblos pues serían diputados “de la Nación”. Puesto que no existía tal "nación", aquella convocatoria no pasaba de un eufemismo para justificar la preponderancia de la capital. Todas las instrucciones de los provincianos debían ser examinadas en una sesión preliminar. Los diputados orientales -que concurrieron con la instrucción de declarar inmediatamente la independencia, instaurar una Confederación con

\footnotetext{
${ }^{543}$ Ibídem.

${ }^{544}$ Desde abril de 1812, Paso es reemplazado por Juan Martín de Pueyrredón, también de la célebre Logia Lautaro.

545 Ídem, p. 154.

546 Ídem, p. 155.

547 Ídem, p. 156.

548 Ídem, p. 155.

549 Ídem, p. 198.
} 
autonomía para las provincias, y fijar una capital fuera de Buenos Aires-, simplemente no fueron acreditados. En la sesión de la Asamblea del 8 de marzo de 1813, Alvear mocionó que los diputados de las provincias tampoco pudieran "de ningún modo obrar en comisión" ${ }^{550}$. La Asamblea del Año XIII terminaría sin declarar la independencia de España ni repudiar formas monárquicas de gobierno.

En medio de ese proceso, el Segundo Triunvirato envió en noviembre de 1812 una nota invitando al gobierno paraguayo a nombrar diputados a la Asamblea General del Año XIII. En Asunción, el doctor Francia retornaba a la Junta. Como medida de presión, Buenos Aires utilizaba el aumento del impuesto al tabaco y la entrega de la goleta con los fondos retenidos en Santa Fe. Ante cada reclamo paraguayo, el Gobierno Superior respondía que esas cuestiones serían examinadas en la Asamblea General. Así, la posibilidad de alcanzar una “confederación” se hacía más distante.

Buenos Aires argumentaba que eran los paraguayos quienes no cumplían con lo acordado, especialmente en lo que referente a la ayuda militar. El gobierno porteño solicitaba hombres para combatir en la Banda Oriental, una vez que había quedado claro que el españolismo no cumpliría con su parte del escandaloso Tratado de Pacificación. Los portugueses no se habían retirado y se retomó el Sitio a Montevideo. En un oficio firmado en diciembre de 1812, la Junta porteña escribió que el Paraguay "ha mirado con helada indiferencia nuestros peligros, y no solo no ha tratado de cooperar activamente a la defensa de todos, sino que abandonó a Buenos Aires a la suerte de sus recursos y sus fuerzas" ${ }^{251}$.

La Junta paraguaya alegaba que carecía de fondos, armas, y que la provincia estaba amenazada por los portugueses por el Norte y el Este. En efecto, en mayo de 1812 los indios mbayás, alentados por militares portugueses, saquearon el Fuerte Borbón, en el norte, que fue inmediatamente ocupado por las armas lusitanas ${ }^{552}$. Ante esa emergencia, la Junta destinó todos sus recursos para costear una expedición de 200 soldados. En setiembre de 1811 había sido desbaratada una conspiración realista que pretendía reponer a Velasco en el poder.

El 27 de diciembre de 1812, la Junta asuncena remite otra nota a Buenos Aires. En esa misiva respondió a la acusación sobre ser indiferente a la "causa común" americana:

Nunca podíamos imaginar que mereciese tan poca o más bien ninguna consideración el Gobierno de un pueblo aliado, cuya revolución redundó en tanto beneficio para Buenos Aires. Pero esta no es la primera vez que se rompen los

\footnotetext{
550 Ídem, p. 202.

${ }^{551}$ CABALLERO CAMPOS, Herib. Proceso de la independencia paraguaya..., op. cit., p. 108.

${ }^{552}$ COONEY, Jerry. Milicia, Estado y Sociedad en Paraguay..., op. cit., p. 95.
} 
lazos de nuestra unión, ni el primer golpe con que se conmueven los cimientos de nuestra armonía [...] Buenos Aires no debe olvidar que a la generosa y favorable revolución del Paraguay debe las ventajas consiguientes a su separación de la confederación enemiga, el desconcierto de una triple alianza que podía haberle sido funesta y reducirlo a otros conflictos, la restitución de la ciudad de Corrientes, la posesión de toda la Banda Oriental ${ }^{553},[\ldots]$ y lo que importa e influye en el sistema y aspecto general de los negocios políticos, la declaración de esta provincia por la sagrada causa de la libertad de América $^{554}$.

Al mismo tiempo, enfatizó:

[...] Deseche Vuestra Excelencia cualquier recelo, que debe ser vano e infundado [...] Es necesario que Buenos Aires reforme y modere sus procedimientos ofensivos a tan fiel aliado [...] Nada más fácil, nada más santo y justo que indemnizar a esta provincia con la pronta restitución de sus caudales públicos y moderar el excesivo recargo a sus frutos que la tienen escandalizada. Este es el modo de reafirmar nuestra confederación, restablecer la amistad, echar nuevos nudos a los lazos de nuestra feliz alianza y coadyuvar los esfuerzos generosos del Paraguay a sostener por su parte la causa común ${ }^{555}$.

Buenos Aires pedía mil hombres para la Banda Oriental. Era evidente que la situación militar en ese frente, deteriorada por el pacto con Elío, era dramática. Enviar hombres a la Banda Oriental interesaba a la propia supervivencia de la Junta en Asunción. Ahora, ¿existían condiciones para ello? La Junta juzgó que no, que si el Paraguay enviaba esas tropas con las pocas armas de que disponía, el país quedaría indefenso ante Portugal.

En otra carta, enviada en enero de 1813, la Junta paraguaya argumentó:

[...] Esta provincia en mucha parte arruinada por resulta de la pasada guerra civil, sin fondo alguno efectivo, se hallaba como hasta aqui se halla también sin sobrante de armas y municiones y sin más que las muy precisas para la custodia $y$ defensa de un dilatado territorio, más expuesto a nuevos riesgos y acaecimientos por consecuencia de su misma revolución y del sistema de la libertad de América que había abrazado. Con todo, Vuestra Excelencia se empeñó en que este Gobierno equipase y enviase un Ejército armado a doscientas o trescientas leguas [...] ¿Con qué fundamento, o en cuya virtud podía suponer Vuestra Excelencia que [en] una provincia como esta, que jamás había sido formalmente abastecida de armamento, municiones y auxilios militares, quedase todavía más abundante de estos recursos para costear y enviar a países remotos fuera de su territorio un Ejército armado y bien equipado aún después de sus consumos y pérdidas y destrucción ocasionada con la antecedente guerra civil, cuando Buenos Aires no ha querido proveernos un solo fusil, reteniendo más bien algunos pocos pertenecientes a esta provincia ${ }^{556}$.

\footnotetext{
${ }^{553}$ Se refiere a la orilla oriental del Paraná, incluyendo Entre Ríos y Corrientes, que los realistas querían ocupar para aislar al gobierno de Buenos Aires.

${ }_{554}$ Oficio de la Junta del Paraguay a la de Buenos Aires, del 27/12/1812. ANA-SH, v. 218, n. 1.

555 Ibídem.

${ }^{556}$ Sobre el pedido de armas a Buenos Aires para la defensa del peligro realista portugués, ver: Oficio de la Junta al Primer Triunvirato de Buenos Aires, del 27/10/1811. ANA-SH, v. 214, n. 8; Oficio de la Junta del Paraguay a la de Buenos Aires del 27/01/1813. ANA-SH, v. 222, n. 1. La Junta paraguaya reclamaba a Buenos Aires la devolución de armamento retenido en esa ciudad: "[...] tres cañones de a seis, cuatro cañones de a cuatro, tres cajones regulares con cartuchos de estas piezas, doscientas balas sueltas de cañón, tres esmeriles grandes de abordar, diez fusiles y un cajón con mil doscientos cartuchos para ellos. Además, existen allí el cañón de a cuatro y nueve fusiles que llevó de aquí Don José de Espínola y según exposición de su propio hijo, que lo acompañó, se pusieron en la fortaleza de esa ciudad”, según el oficio de la Junta del Paraguay a la de Buenos Aires, del 24/02/1813. ANA-SH, v. 222, n. 4.
} 
La misma nota se refería a las condiciones para una Confederación y para la participación de la provincia en el Congreso General platense:

[...] se ha llegado también al extremo de manifestar cierta aversión o encono por la independencia y verdadera libertad de esta provincia, cuando se le distingue con un odioso recargo duplicado de impuesto sobre sus haciendas y frutos. Y esto sí que deja más comprometida y equívoca la opinión y conducta de Buenos Aires en la proclamación que hace de los derechos sagrados de los pueblos.

Por último, ¿quiere Vuestra Excelencia que este negocio se remita al juicio del Congreso que propone, es decir de una asamblea de súbditos y dependientes del mismo gobierno de Buenos Aires en cuya comparación la representación de la odiosa Provincia del Paraguay sería nula y de mera formalidad? Pero dejando esto y mucho más que se podría deducir, si en el concepto de Vuestra Excelencia ya no subsisten los tratados, ya no hay unión, alianza ni confederación, ¿cómo o con qué intento o idea se invita al Paraguay a este Congreso? Es preciso satisfacer antes esta pregunta y resolver estas dificultades ${ }^{557}$.

Algo más sobre la cooperación militar en aras de la "causa común”. En febrero de 1813, buques realistas llegaron a la zona de San Pedro. La Junta paraguaya escribió a Buenos Aires alertando que "es creíble que sus empresas no se limiten a la piratería, o a impedir la consumación con la Banda Oriental y que se dirijan también al saqueo de los pueblos y poblaciones de una y otra costa". Cupo entonces a los paraguayos la invocación de la cooperación militar entre patriotas para "proteger el comercio de una y otra provincia". Asunción no pidió hombres sino, simplemente, que sean devueltos "los quince cañones propuestos" o al menos "los ocho cañones y diecinueve fusiles que existen en esa, pertenecientes a esta provincia”. Buenos Aires se negó a devolver las armas. Este hecho, escribió la Junta paraguaya "ministra la más decisiva evidencia de que las obras [de Buenos Aires] no concuerdan con las palabras ni con las grandes promesas" ${ }^{558}$.

La suma de estas tensiones fue alejando a las autoridades paraguayas, principalmente al doctor Francia, de la propuesta inicial de una Confederación. El 24 de febrero de 1813, la Junta escribe a la de Buenos Aires en tono de claro distanciamiento:

[...] el Gobierno de Buenos Aires [...] ha dado y continúa dando pruebas de que sus miras no se limitan a exterminar a los enemigos, sino también a conquistar y subyugar los pueblos al mismo tiempo de proclamar sus derechos sacrosantos [...] Ciertamente que esta conducta no anuncia la prosperidad de la causa, sino [que] ha sido ya un obstáculo a su progreso [...]

¿En qué estado se hallaría Buenos Aires si según iban las cosas, el Paraguay con su revolución no las hubiese puesto y reducido a otro orden? A cuya cooperación activa debe Buenos Aires la reconquista de la ciudad de Corrientes, mucho más valuable que la represa de la goleta y su cargamento que Vuestra Excelencia se niega a restituir. A cuya cooperación activa debe Buenos Aires la conservación de todos los pueblos y territorios de la inmensa Banda Oriental y el haber podido salvar las tropas que tenía en esa banda. A cuya cooperación activa debe Buenos Aires el restablecimiento de su comercio con esta provincia, cuyos frutos sin atención a la buena fe de los tratados se han regravado por no haberse sometido a

${ }^{557}$ Oficio de la Junta del Paraguay a la de Buenos Aires del 27/01/1813. ANA-SH, v. 222, n. 1.

${ }^{558}$ Oficio de la Junta del Paraguay a la de Buenos Aires del 05/02/1813. ANA-SH, v. 222, n. 4. 
Buenos Aires, manifestando con esta odiosa distinción un proceder que está en contradicción con los mismos principios que se proclaman [...] Por último concluimos que con Buenos Aires nada se adelanta y nada hay que esperar aún tratándose de la justicia y buena fe que deben observarse en los tratados $[\ldots]^{559}$.

Es interesante, también, el intercambio de cartas entre la Junta paraguaya y Artigas.

Sobre la Asamblea convocada en la ciudad-puerto, la Junta escribió el 19 de enero al caudillo federal:

\begin{abstract}
No es menos singular el pretender que la llamada asamblea [convocada en Buenos Aires] sea juez de esta discusión [cooperación militar], y de las demás relaciones, que hay de fijar destino de los pueblos, cuando esa congregación no ha de ser compuesta sino de súbditos y dependientes del mismo gobierno de Buenos Aires [...] Pues Buenos Aires, con todos sus pueblos dependientes (incluso los de la antigua provincia de Córdoba), no puede considerarse sino como una sola provincia, por consecuencia, incapaz e insuficiente para terminar negocios de otra provincia igualmente soberana e independiente ${ }^{560}$.
\end{abstract}

El 15 de marzo de 1813, la Junta responde a otra carta de Artigas, en la cual el jefe oriental también criticaba la política porteña:

\begin{abstract}
Si desde el principio se hubiesen respetado suficientemente los derechos sagrados de los pueblos, y si las operaciones hubiesen ido en consonancia y armonía con la moderación debida y con la justicia y liberalidad de principios que se anunciaban, no ocurrían tales disensiones domésticas; no se verían los pueblos precisados a su vez a un nuevo particular esfuerzo para redimirse del despotismo de los mismos pretendidos libertadores y, tomando todos un interés más inmediato, la causa común habría hecho progresos verdaderamente asombrosos $[\ldots]^{561}$.
\end{abstract}

La ruptura con el puerto estaba planteada de manera concreta.

\title{
4. LA REPÚBLICA
}

\subsection{La Misión Herrera}

En abril de 1813 llegó a Asunción un nuevo comisionado de Buenos Aires: Nicolás de Herrera. La ciudad-puerto había convocado una Asamblea General Constituyente de las Provincias Unidas del Río de la Plata y, según su reglamento, Asunción debía enviar dos diputados dada su condición de "capital de provincia". La misión de Herrera consistía en garantizar la presencia paraguaya en la Asamblea ${ }^{562}$.

\footnotetext{
${ }^{559}$ Oficio de la Junta del Paraguay a la de Buenos Aires del 24/02/1813. ANA-SH, v. 222, n. 4.

560 RODRÍGUEZ ALCALÁ, Guido (Org.). Artigas y la independencia del Paraguay: correspondencia. Asunción: Servilibro, 2003, p. 115.

561 Ídem, p. 120.

${ }^{562} \mathrm{La}$ Asamblea General comenzó a sesionar en enero de 1813 y se disolvió oficialmente en enero de 1815 . El propósito fue declarar formalmente la independencia de España y promulgar una Constitución. Ninguno de estos objetivos fundamentales se cumplió. La Asamblea, no obstante, declaró la libertad de vientres, el fin de la mita y los tributos indígenas, y la supresión de títulos de nobleza. Con el paso de los meses, la Asamblea que supuestamente era "de la Nación" y superior al gobierno-, fue cediendo poder al Ejecutivo: primero al Segundo Triunvirato y, desde 1814, al Directorio, órgano de poder unipersonal. Tanto Gervasio Posadas como
} 
Para ello, Herrera iba con instrucciones precisas: exponer "las ventajas del vínculo de anexión, objeto preferente de la misión..."563.

En el caso de que se plantease la discusión sobre el nuevo impuesto al tabaco, Herrera debía usar de esta arma de acuerdo con la marcha de la negociación ${ }^{564}$.

De esta suerte, la misión Herrera proponía: a) anexión como vínculo político; b) impuesto al tabaco y hasta el uso de la fuerza como medio de coacción.

El gobierno recibió a Herrera diciendo: “esta Junta tendrá particular satisfacción en afirmar las relaciones de unión que se deben conservar entre pueblos confederados por un interés común" ${ }^{\circ 65}$. Herrera urgió que se nombrasen los diputados de la provincia. La Junta, orientada por el doctor Francia, condicionó tal medida a la decisión de un "Congreso General de toda la provincia y tal que sea mucho más completo que el anterior para que delibere lo que guste conveniente" 566 .

El 5 de junio, el enviado escribió a su gobierno. Opinó que la Asamblea General en Buenos Aires no podía suspender sus sesiones por ningún congreso provincial. Propuso dos medidas para atraer al Paraguay: imponer a sus frutos el derecho de extranjería; declarar que las provincias que no concurran a la Asamblea en un plazo determinado deberán aceptar la Constitución allí sancionada ${ }^{567}$.

El 13 de julio consultó cuál debía ser la actitud si el Congreso paraguayo se negaba a nombrar diputados. Si debía considerar al Paraguay como neutral o como enemigo. En el primer caso, proponía retirar inmediatamente la misión, prohibir el comercio, cerrar los puertos a sus frutos y su ganado. En el segundo caso, había que forzarle con las armas a cumplir el Tratado del 12 de octubre ${ }^{568}$.

Los informes secretos son aún más reveladores:

Artigas ha escrito a estos que no se dejen engañar: que sostengan su federalismo
y que cuenten con él. Tienen correspondencia directa [...] Los porteños son más
odiados que los sarracenos [...] El partido de la incorporación es numeroso pero
débil. Las tropas no llegan a trescientos hombres; indisciplinadas, sin oficiales y
con malas armas ${ }^{569}$. Tienen una fábrica de pólvora, otra de balas en peor estado.
En ocho meses han hecho un barril de pólvora [...] Si se niegan a enviar
Diputados, y se les declara la guerra, media Provincia se une con nosotros: tal es su sobrino, Carlos María de Alvear, primeros Directores Supremos, gobernaron casi sin consultar a la Asamblea.

${ }^{563}$ CHAVES, Julio [1938]. Historia de las relaciones entre Buenos-Ayres y el Paraguay..., op. cit., p. 205.

564 Ídem, p. 206.

565 Oficio de la Junta a Nicolás de Herrera del 21/04/1813. ANA-SH, v. 222, n. 4.

566 Oficio de la Junta al Cabildo, del 14/06/1813. ANA-SH, v. 222, n. 4.

${ }^{567}$ CHAVES, Julio [1938]. Historia de las relaciones entre Buenos-Ayres y el Paraguay..., op. cit., p. 207.

568 Ídem, p. 208.

${ }^{569}$ Nótese que Buenos Aires exigía el envío de mil hombres a la Banda Oriental y el Paraguay decía, como confirma plenamente Herrera en este informe, que carecía de condiciones materiales para ello. 
el efecto de la tiranía con que los tratan. Si este arbitrio no se adopta es necesario cerrar enteramente el comercio: arrojarlos de Candelaria y prohibir la introducción de ganados. Al mismo tiempo es preciso mandar a Corrientes 500 a 600 hombres y levantar todas las milicias mandando alli un nuevo gobernador ${ }^{570}$.

El 19 de julio, alarmado, informa sobre la posibilidad de que el Congreso paraguayo declare la independencia:

Se demora el Congreso porque se espera [...] una contestación de Artigas y de las Provincias interiores y sus Diputados. El Gobierno cada vez más tirano y el Pueblo más esclavo. Se habla ya públicamente de erigir aqui una República independiente de los porteños y hasta los frailes piensan ya en los prelados supremos que ha[n] de elegir. Ellos creen que no podemos vivir sin yerba y tabaco [...] Ellos tienen [...] trescientos hombres sin disciplina y doscientos y tantos mil pesos en caja. Tienen fábricas de pólvora y balas que no sirven ${ }^{571}$.

En medio de tal situación, tocará apelar a la fuerza para "reducir" al Paraguay:

Los mandones son absolutamente ignorantes, los aborrecen pero les temen [...] se necesita mandar quinientos hombres a Santa Fe, que bastan. Los patriotas solo esperan este auxilio, para abandonar este lugar mil veces más tiranizado que en el antiguo régimen. Tengan V.V. energía que es el único modo de reducirlos porque estos labradores se estremecen al oír que se cerrará el comercio $[\ldots]^{572}$.

Con la misma postura arrogante y virreinal, Herrera informa sobre la resistencia hacia los porteños:

El odio a Buenos Aires es implacable [...] En mi vida he visto mayor ignorancia y barbarie. Los hombres ilustrados unos piensan salir del país y otros vivir retirados esperando su redención del Pueblo de Buenos Aires. No me escriba V. con esta tinta ${ }^{573}$ porque no tengo ni hay aquí vitriolo, pues esto es una aldea y no lo que [ilegible] se precisa. Están muy engañados los que piensan que esto puede ofendernos ${ }^{574}$.

Lo mismo le escribe a su esposa: "aquí nada quieren saber de los porteños"575.

\subsection{El Congreso de 1813: los mil diputados y la proclamación de la República}

Habían pasado más dos años desde la caída de Velasco. La hostilidad de la política centralista de Buenos Aires había detonado los posibles puentes hacia la Confederación que el Paraguay propuso oficialmente en julio de 1811. El Tratado de octubre de 1811 era letra muerta y cualquier protesta paraguaya había caído en saco roto. El nuevo emisario no traía nada nuevo. Con la habitual pedantería y el desprecio del porteño "ilustrado", expuso las mismas amenazas y exigió enviar diputados a una Asamblea que ya estaba en curso y en

\footnotetext{
570 Ibídem.

571 Ídem, p. 209.

572 Ibídem.

573 Tinta simpática.

574 Ibídem.

575 Ibídem.
} 
donde las posiciones independentistas y/o federalistas -si nos basamos en el veto a los delegados orientales- no tenían ni tendrían ningún espacio.

En ese marco, se celebró en Asunción el congreso nacional de 1813. Este hecho debe ser considerado el hito principal de la independencia paraguaya. La amplia convocatoria fue insólita para la provincia y para la región. Fueron llamados mil diputados surgidos de "elecciones populares y libres en cada uno de dichos lugares por todos, o la mayor parte de sus respectivos habitantes". El número de representantes debía ser proporcional a la población de cada pueblo o villa. El número de congresistas aumentó $400 \%$ con relación a junio de 1811.

La convocatoria expresaba que:

[... el] número de sufragantes no baje de mil individuos de votos enteramente libres y sean naturales de esta provincia [...] siendo este Congreso soberano como debe serlo [... que] sean convocados dichos mil sufragantes de todas las villas, poblaciones, partidos y departamentos de su comprensión a proporción de sus respectivas populaciones y que sus nombramientos sean no por señalamiento o citación de determinadas personas, sino por elecciones populares y libres en cada uno de dichos lugares por todos, o la mayor parte de sus respectivos habitantes; que estas diligencias y convocatorias para el efecto [sean] como de asunto puramente civil y dirigido al libre uso y ejercicio de los derechos naturales y libres, inherentes a todos los ciudadanos de cualquier estado, clase o condición que sean $[\ldots]^{576}$.

Si estos criterios se comparan con el reglamento electoral dictado por el Triunvirato porteño para la Asamblea General Legislativa de abril de 1812, en el que los compromisarios porteños y el Cabildo de Buenos Aires “sorteaban” los diputados atendiendo una proporción de 49 representantes para la capital y siete para el resto de las provincias -Córdoba, Corrientes, Catamarca, Salta, Tucumán, San Luis, San Juan-, la diferencia en cuanto a participación democrática es categórica ${ }^{577}$.

Evidentemente, no existía el sufragio femenino y nada se dice sobre el voto de los indios de los pueblos, mucho menos de los negros libres o esclavos. Podían ser electos únicamente los varones casados, o los solteros con más de 23 años. Además, quedaban excluidos "aquellos que hayan sido [en]causados o sindicados de opuesto[s] o desafectos al sistema de la libertad [...]"578.

Tal amplitud en la convocatoria, sobre todo el hecho de que no existía un criterio explícitamente censitario, mereció aclaraciones de la Junta a algunos comisionados de los pueblos del Interior.

\footnotetext{
${ }^{576}$ Oficio de la Junta al Cabildo, del 30/06/1813. ANA-SH, v. 222, n. 4.

577 CHAVES, Julio [1938]. Historia de las relaciones entre Buenos-Ayres y el Paraguay..., op. cit., p. 157.

${ }^{578}$ Oficio de la Junta al Cabildo, del 30/06/1813. ANA-SH, v. 222, n. 4.
} 
[...] Las cualidades que se requieren en los sufragantes del Congreso General de que se trata el oficio convocatorio que cita Vuestra Merced en el suyo de nueve del corriente, no penden del calzado ni de otros adornos exteriores que no teniendo la menor conexión con las circunstancias que constituyen el carácter de un hombre de bien y honrado patriota, nada influyen en lo formal del objeto que se ha propuesto esta Superioridad en su citada convocatoria ${ }^{579}$.

A modo de comparación, podemos citar la idea que Bernardo de Monteagudo tenía sobre "ciudadanía" en 1812:

Nuestra futura constitución debe ser obra del voto general de los que tengan derecho de ciudadanía [...] ¿Quién gozará pues los derechos de ciudadanía? Olvidemos las preocupaciones de nuestros mayores, hagamos un paréntesis a los errores de la educación, y consultemos la justicia. Todo hombre mayor de veinte años que no esté bajo el dominio de otro, ni se halle infamado por un crimen público plenamente probado, y acredite que sabe leer y escribir, y se ejercita en alguna profesión, sea de la clase que fuere con tal que se haga inscribir en el registro cívico de su respectivo cantón, después de haber vivido más de un año en el territorio de las Provincias Unidas, obligando su persona y bienes al cumplimiento de los deberes que se imponga, gozará los derechos de ciudadanía. El que reúna estas cualidades debe ser admitido a la lista nacional [... ${ }^{580}$.

El 30 de setiembre comenzaron las sesiones en Asunción. La primera medida de los delegados fue rechazar las propuestas de Nicolás de Herrera, que había escrito un desafiante alegato sobre la conveniencia de enviar diputados a Buenos Aires.

La incorporación reportará gran utilidad al Paraguay. Si el Paraguay niega su incorporación quedará como aliado, neutral o enemigo; en los dos primeros casos tendrá que mantener su administración y ejército, sus frutos sufrirán fuerte gravamen y perderá sus mercados. En el tercer caso, no resistirá a las fuerzas de las Provincias Unidas $[\ldots]^{581}$.

El emisario porteño planteaba la misma disyuntiva: anexión u hostilidad comercial y militar. Las expectativas de una unión justa con Buenos Aires casi se habían disipado. Los delegados paraguayos, en su mayoría provenientes del campo, resolvieron "no enviar ahora diputados de esta provincia a la Asamblea formada en Buenos Aires", al tiempo que declararon oficialmente el nacimiento de la "República del Paraguay". Durante muchos años, en los documentos oficiales figuró la máxima: La Primera República del Sur, en el Paraguay, una e indivisible ${ }^{582}$.

${ }^{579}$ Oficio de la Junta al Juez Comisionado Don Bartolomé José Galiano, del 10/09/1813. Archivo Nacional de Asunción - Nueva Encuadernación (ANA-NE), v. 3409, publicado en: RODRÍGUEZ ALCALÁ, Guido; DURÁN ESTRAGÓ, Margarita; ROMANO GARCÍA, Martín (Org.). FRANCIA: [1762-1816]..., op. cit. p. 258.

${ }^{580}$ MONTEAGUDO, Bernardo. Clasificación de los ciudadanos. Artículo publicado en Gazeta Extraordinaria, n. 26, del 15 de febrero de 1812. In: CHIARAMONTE, José. Ciudades, provincias, Estados..., op. cit., p. 113. ${ }^{581}$ CHAVES, Julio [1938]. Historia de las relaciones entre Buenos-Ayres y el Paraguay..., op. cit., p. 211.

582 Decreto del doctor Francia del 22/11/1815. ANA-NE, v. 3411. En realidad, la primera República independiente de Sudamérica fue la venezolana de 1811. Aunque efímera, fue la primera que rompió explícita y definitivamente con Fernando VII. Comenzó el 5 de julio de 1811 y fue derrotada por las fuerzas realistas el 25 de julio de 1812. Consultar el Acta de la Declaración de la Independencia de Venezuela. 1811. Disponible en: 
Como forma de gobierno, se estableció el Consulado -una alusión al antiguo derecho y a la República romanas- conformado por el doctor Francia y Fulgencio Yegros. También se resolvió la obligatoriedad de celebrar congresos anuales:

[...] con la misma formalidad, número y circunstancias, señalándose a este efecto el día quince de cada mes de octubre [...] con el justo fin de que la provincia oportunamente y al menos una vez al año pueda congregarse a tratar como pueblo libre y soberano $[\ldots]^{583}$.

El Congreso de 1813 fue sin duda un "punto de inflexión" en el proceso independentista paraguayo. Hasta ese momento, formalmente o no, con o sin "máscara", se había reconocido la soberanía de Fernando VII. La propuesta de la Confederación perdió perspectiva concreta debido a la hostilidad porteña. Así, la proclamación de la República independiente implicó una ruptura política definitiva tanto con la metrópoli española como con la ex capital virreinal platense.

En el plano interno, representó una victoria de la política del doctor Francia como representante del programa de "no mudar de amo", que allanó el camino hacia su poder unipersonal y supremo. El abogado jacobino había maniobrado hábilmente durante el proceso previo a la Asamblea. El comerciante británico John P. Robertson, comenta que durante su alejamiento del gobierno en 1812:

[Francia] recibía visitas secretas de la mayoría de los granjeros y propietarios de peso del campo; él alentaba las aspiraciones de hombres que jamás habían soñado con adquirir el poder anteriormente; él era solo dulzura y condescendencia con las clases más bajas de la sociedad y solo altivez con las más altas. Su plan era imprimir en los hombres del campo la idea de que estaban mal gobernados por unos pocos ignorantes carentes de mérito [los miembros de la Junta], e insinuarles que, si él volviera al poder, todo sería muy diferente $[\ldots]^{584}$.

En las horas decisivas, el doctor Francia había comprendido mejor que nadie el sentimiento del olvidado pero mayoritario "mundo rural", sobre el cual se apoyó para alcanzar el poder total. El propio Robertson escribió sobre el papel del futuro Dictador en el Congreso de 1813:

[Francia] imbuyó a las clases más bajas (de las que siete octavos de los diputados al congreso estaba compuesto) con una sospecha, profunda y fuerte, de que el único objetivo de Buenos Aires al enviar un Embajador al Paraguay, era el sujetarlo a sus propias visiones ambiciosas, y de envolverlo en sus propios principios revolucionarios para la promoción de sus propias traicioneras finalidades ${ }^{585}$.

\footnotetext{
$<$ https://es.wikisource.org/wiki/Firma_del_Acta_de_la_Declaraci\%C3\%B3n_de_Independencia_de_Venezu

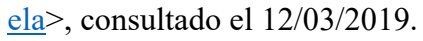

$\overline{583}$ Acta del Congreso General y Reglamento de Gobierno de la República, del 12/10/1813. ANA-SH, v. 222, n. 3.

${ }^{584}$ COONEY, Jerry. El proceso de la independencia del Paraguay..., op. cit., p. 198.

${ }^{585}$ CABALlERO CAMPOS, Herib. Proceso de la independencia paraguaya..., op. cit., p. 114.
} 
Desarrollemos más sobre cuál fue la dinámica interna. Frente al cierre de los ríos y la irregularidad, cuando no suspensión del comercio externo, los exponentes más tradicionales de la burguesía nativa -los estancieros militares y los comerciantes- quedaron desorientados y se mostraron cada vez más vacilantes en sus relaciones con la ex capital. La negativa de Buenos Aires a conceder incluso "más autonomía”, un reclamo que en un primer momento unificaba el frente patriota paraguayo, fue colocando a los sectores burgueses más ligados al comercio exterior frente a una encrucijada de hierro: seguir la lucha por la independencia, o aceptar la subordinación a la burguesía comercial porteña y actuar como su socia menor.

El período de 1811 a 1813 fue un interregno de pujas y definiciones. Al mismo tiempo en que tenían roces con Francia, los "ganaderos uniformados" tampoco optaban por prescindir de su concurso. Lo consideraban, con razón, el "más capaz” de la Junta. Había una coexistencia entre los sectores más dependientes del comercio exterior con el ala liderada por el doctor Francia, que de manera más o menos abierta fue hilando el apoyo en "la campaña" -medianos chacareros e incluso grandes ganaderos sin el poder ni el prestigio de los apellidos más tradicionales-. El Congreso de 1813 cierra ese período de coexistencia entre las facciones antiespañolistas, en el contexto de un agravamiento de la situación regional. Al mismo tiempo, inaugura la fase de ascenso político definitivo de El Supremo.

Así, el mismo hombre que en forma pionera propuso la fórmula de la Confederación justa y voluntaria entre provincias, no dudó en transformarse en el inspirador de la República independiente.

Herrera, escribía en noviembre de 1813:

Las proposiciones de Francia no tienen otro objetivo que ganar tiempo y gozar sin pesadumbre las ventajas de la independencia [...] Este hombre [...] me ha dado muchas pruebas de su ignorancia, de su odio a Buenos Aires, y de la inconsistencia de sus principios. Él ha persuadido a los paraguayos que la provincia sola es un imperio sin igual, que Buenos Aires la adula y lisonjea porque la necesita: que con el pretexto de la unión [Buenos Aires] trata de esclavizar al continente; que los pueblos han sido violentados por el envío de sus representantes; que todas nuestras ventajas son supuestas; y hasta en su contestación manifiesta su rivalidad pues jamás se me ha reconocido como enviado del Supremo Poder Ejecutivo de las Provincias del Río de la Plata, sino como a un diputado de Buenos Aires; ni a V.E. se le atribuye otra autoridad ${ }^{586}$.

El emisario porteño emprendió su retorno en los primeros días de noviembre. Al enterarse de la declaración de independencia del Paraguay, el gobierno porteño escribió a Herrera el 19 de noviembre que "la declaración pública exacerbará a los españoles quienes

${ }^{586}$ CHAVES, Julio [1942]. El Supremo Dictador..., op. cit., p. 165. 
iniciarán una guerra sangrienta al Paraguay"587. Antes que celebrar ese paso adelante hacia la victoria sobre los españoles, los gobernantes de Buenos Aires estaban más preocupados con no "exacerbar" a los antiguos colonizadores y principales enemigos de la "causa común".

El desarrollo desigual del proceso hizo que el pequeño y periférico Paraguay diera un paso político que Buenos Aires, por la cobardía de su clase dirigente, no daría sino tres años después.

La cuestión, en esa coyuntura, era: ¿qué actitud tomaría el gobierno de Buenos Aires, adalid de la "causa común", frente la primera República independiente en el Cono Sur? Pues bien, en un mes creó un nuevo impuesto de guerra sobre los productos paraguayos: un peso por cada arroba de yerba mate y dos pesos por cada arroba de tabaco ${ }^{588}$.

Herrera confirmó al comerciante británico Guillermo Robertson que tal medida no pasaba de una represalia:

Los nuevos derechos son fuertes; pero, créame Ud., las circunstancias lo exigen de un modo imperioso. Si el Congreso del Paraguay del 1 de octubre hubiera comprendido mejor sus intereses habrían evitado la imposición de tan fuertes derechos. Pero cada uno comprende mejor sus propios negocios ${ }^{589}$.

En 1817, el Director Supremo de Buenos Aires y miembro de la Logia Lautaro, Juan Martín de Pueyrredón, ordenó el bloqueo de todo comercio y comunicaciones con la "provincia rebelde". La independencia paraguaya no sería reconocida por Buenos Aires hasta 1852.

El Congreso de 1813 marcó el ápice de un proceso político tan vertiginoso que, en menos de tres años desde la revolución en Buenos Aires, hizo que una nación pobre, ubicada en la periferia de la periferia del antiguo régimen colonial español, se transformara en la primera República soberana de la región platense.

La doble dependencia histórica del Paraguay impuso una dinámica tan acelerada que, a galope de la desintegración del régimen colonial, la lucha por más autonomía política y comercial fue "empujando" a la burguesía rural criolla y a sectores medios urbanos hacia una ruta de colisión tanto con España como con Buenos Aires.

Sin embargo, en 1810, la emergencia de la República del Paraguay no aparecía como un fin inexorable. Hasta finales de 1812, existió una tendencia real hacia una unión política con Buenos Aires, que era defendida categóricamente por el gobierno paraguayo. Pero esa

\footnotetext{
${ }^{587}$ CHAVES, Julio [1938]. Historia de las relaciones entre Buenos-Ayres y el Paraguay..., op. cit., p. 214.

${ }^{588}$ Ibídem.

589 Ibídem.
} 
tendencia fue perdiendo fuerza con cada golpe de la política centralista de la burguesía comercial porteña, principal responsable por debilitar la unidad en la causa común.

Es evidente que en 1810 existían "tendencias separatistas" en el Paraguay, como existían en todo el ex Virreinato, que nunca pasó de una estructura colonial arbitraria, una cárcel de los pueblos. En ese marco, ¿era posible un único Estado como expresión de una única nación o "patria grande”? No. Pero sí era progresiva -y hasta posible- una unidad federativa de los pueblos. Fue la política nacionalista de Buenos Aires, es decir, de la nación opresora, la que avivó y exacerbó las tendencias centrífugas en el Interior, al negarse a impulsar una federación democrática y voluntaria de los pueblos libres.

Más tarde, el doctor Francia dirá:

[...] ha sido tal el desvanecimiento y deslumbramiento de los infatuados porteños, que han intentado sobreponerse y dominar al Paraguay y demás pueblos, queriendo alucinar y señorear haciendo las veces de españoles y establecerse en lugar de ellos al frívolo pretexto de haber sido algún tiempo capital en el antiguo régimen extinguido, lo que era impertinente y sin importancia alguna, porque entonces la autoridad venida de España, que residía en Buenos Aires, era la que dominaba a los pueblos y solo por eso se figuraba capital, pero desde la revolución [... han] avanzado a querer disponer de esta y demás provincias porque los de Buenos Aires no hicieron su revolución por pura inclinación y adhesión sincera a la independencia y libertad de los pueblos de esta América, sino por el insensato deseo y con la presuntuosa quijotesca idea de tener los pueblos dominados, avasallados y dependientes $[\ldots]^{590}$.

En los años venideros, la ruptura con Buenos Aires será sentida con más peso por los miembros de burguesía comercial y demás sectores propietarios dependientes del comercio exterior. Esos sectores, que en un principio llegaron a plantear un programa de negociar "más autonomía" con el puerto, abandonaron cualquier pose o posición soberanista ni bien Buenos Aires se mostró intransigente. Esto fue así porque, desde el período colonial, aquella oligarquía tradicional defendía un modelo librecambista y, en ese sentido, poseía una ligazón umbilical con los comerciantes y financistas porteños. De tal suerte que, llegada la hora de la verdad, no tuvo el coraje de romper con la antigua capital virreinal. Luego, ese sector burgués librecambista y dependiente, derrotado en 1813-1814, conspirará contra el doctor Francia.

La ruptura con el puerto afectaría también a quienes trabajaban en las actividades que florecieron durante la relativa abertura borbónica: los yerbales, el cultivo del tabaco, y el tráfico fluvial. Con el comercio exterior disminuido, una masa de trabajadores "libres" se

590 Fragmento sin fecha, relativo a la situación del Paraguay. ANA-SH, v. 228, n. 1, publicado en: RODRÍGUEZ ALCALÁ, Guido; DURÁN ESTRAGÓ, Margarita; ROMANO GARCÍA, Martín (Org.). FRANCIA: [1817-1830]..., op. cit., pp. 599-600. 
reorientaría al trabajo en el campo -que, en realidad, nunca había abandonado completamente- y revitalizaría los cultivos de subsistencia. El aislamiento -forzado, y en cierta medida también por decisión del doctor Francia- terminará reforzando un lento proceso de desarrollo capitalista con marcados rasgos endógenos, apoyado en una clase de medianos y pequeños labradores y/o criadores de ganado, que producirá para su subsistencia en sus propias parcelas o en lotes arrendados del Estado. Ese sector, a su vez, conseguirá colocar algún excedente en el mercado interno y, en proporción mucho menor, en el externo -vía los "puertos terrestres" de Itapúa y Pilar-. Ese proceso hará que el campesinado mestizo libre se robustezca socialmente, atenuando el impacto del "aislamiento".

Insistimos: el factor interno que más debilitó los lazos de unidad entre las naciones del Plata fue la política centralista de la dirección porteña. El caso paraguayo es emblemático en ese sentido. El Paraguay no solo nunca atacó a Buenos Aires, sino que propuso una unión justa; a diferencia de los porteños, no solo nunca pactó con los españoles ni coqueteó con proyectos monárquicos, sino que constituyó una República independiente... Pero el puerto siguió atacándolo y cortándole todo vínculo vital con el mundo. Nada ni nadie podía cuestionar el monopolio del puerto y la aduana. Y si había que impulsar la segregación de la Banda Oriental para acabar con la "anarquía" de Artigas -que nunca propuso crear un Estado independiente-, entregando esa provincia a la invasión luso-brasileña y negociando luego su separación de acuerdo con los ingleses, Buenos Aires tampoco dudaría en tomar ese camino, concretando así "una de las más grandes infamias políticas perpetradas por la burguesía comercial porteña" 591 . El temor que generó entre los gobernantes porteños la posibilidad de una "guerra social" impulsada por Artigas, el "Protector de los Pueblos Libres", fue quizás superior al peligro realista. Para describirlo, bastan las palabras del mismo Nicolás de Herrera: "El dogma de la igualdad agita a la multitud contra todo gobierno y ha establecido una guerra entre el pobre y el rico, el amo y el Señor, el que manda y el que obedece"592.

Esto solo podrá entenderse si se comprende que no existió una sola guerra, la de la independencia americana contra España. Desde 1810 existió, al mismo tiempo, una guerra civil entre burguesías americanas "patriotas" por la hegemonía en el proceso de conformación de Estados nacionales y la definición de los mercados internos.

Era la lucha entre "productores" e "importadores" que señalaba Nahuel Moreno. En esa guerra, el unitarismo porteño - desinteresado de la producción nacional a raíz de su

\footnotetext{
${ }^{591}$ MORENO, Nahuel [1975]. Método de interpretación..., op. cit.

${ }^{592}$ FRADKIN, Raúl; GARAVAGLIA, Juan. La Argentina Colonial...op. cit., p. 246.
} 
íntima ligazón con los intereses británicos- expresó el campo reaccionario, mezquino y antidemocrático. En la lucha contra sus "hermanos" del Interior, la burguesía porteña no se valdría solo de bocas de fuego sino también de la capacidad de asfixiar económicamente que le otorgaba el control del puerto. Paraguarí y Tacuarí fueron los primeros capítulos de esa guerra civil fratricida entre el puerto y las provincias. Cerro Corá será el último. 


\section{CAPÍTULO V - El CARÁCTER HISTÓRICO Y LOS LÍMITES DEL RÉGIMEN DE EL SUPREMO [1814-1840]}

[[...] nunca se llama, ni puede llamarse causa común al tráfico mercantil. Prescindiendo de esto, los americanos en el día llamamos y entendemos por nuestra causa común la libertad e independencia de nuestros paises de todo poder extranjero o extraño [...]".

DOCTOR FRANCIA, 1818.

La enigmática y controvertida figura de José Gaspar Rodríguez de Francia, Supremo Dictador Perpetuo de la República del Paraguay entre 1814 y 1840, es indisociable del derrotero de la revolución paraguaya de independencia.

Si bien su obra es casi desconocida y su nombre descansa a la sombra de otros grandes próceres latinoamericanos como Simón Bolívar o José de San Martín, en el Paraguay y entre los estudiosos de la Guerra contra la Triple Alianza, es difícil encontrar otro personaje que despierte tanta pasión en la polémica historiográfica.

Así, la interpretación de su legado político y económico divide aguas entre férreos apologistas y detractores, entre francistas y antifrancistas.

La historiografía liberal, que impuso su interpretación de los hechos con el fin de la Guerra contra el Paraguay y representa esencialmente la "historia de los vencedores", pinta todo el período entre 1814 y 1870 como una era obscurantista, signada por el aislamiento comercial, el atraso económico, el terror político, y la ignorancia. En suma, un período retrógrado en el que predominó la "barbarie".

El relato liberal, en efecto, tejió una "leyenda sombría” alrededor del doctor Francia. En ella, este no pasaría de un tirano desequilibrado y sanguinario que, por mero capricho y arrogancia, "aisló" al Paraguay del "progreso" material y cultural que supuestamente traía aparejado el modelo basado en el libre comercio durante el siglo XIX. El dictador Francia y luego, los dos López-, según este relato, representan la barbarie que resistió a la civilización propiciada por el laissez faire. De ahí la conclusión, con más o menos paliativos, de que la Guerra contra el Paraguay encerraba un carácter progresivo y civilizatorio. Tal es la construcción histórica que predominó al terminar la Guerra Grande, en medio de un Paraguay arrasado.

A inicios del siglo XX surgió la historiografía nacionalista, que para contraponerse a la interpretación liberal se hizo llamar revisionista. Apelando a una narrativa de estilo 
épico, que no se priva de enaltecer la "raza paraguaya", el nacionalismo burgués creó alrededor de las figuras del dictador Francia y de los López un verdadero culto a la "personalidad del héroe". Francia es presentado como el "padre de la patria", el "creador de la nacionalidad", que a su vez sería producto de un proceso esencialmente endógeno, único, divorciado del contexto histórico internacional. De esta suerte, el Supremo es retratado como un gobernante infalible, intachable, y siempre "justo"; un político sin contradicciones, que ejecutó un programa que había sido concebido mucho antes del proceso independentista. Es más, ese plan, según sus apologistas, no solo perseguía la independencia del país, sino instaurar una "sociedad igualitaria". En suma, Francia no sería solamente el dirigente más importante de la independencia -que lo fue-, sino también una especie de patriarca que “aniquiló" a la "oligarquía” y actuó como benefactor de los más pobres.

La corriente patriotera encontró su apogeo a partir del golpe militar de 1936, que acabó con la sucesión de gobiernos liberales -ciertamente oligárquicos y antinacionalesque venía desde 1870 y entregó el poder al coronel Rafael Franco. Conviene recordar que, en su embate contra la "democracia" liberal, Franco no dudó en expresar su simpatía hacia el fascismo italiano.

Ese nacionalismo rehabilitó las figuras del doctor Francia y de los López. En especial la de Francisco Solano, que de "asesino de su Patria y enemigo del género humano"-como fue declarado en 1870- se transformó oficialmente en "héroe máximo de la Nación sin ejemplar".

Siguiendo esa línea, la propaganda oficial de la dictadura militar-colorada del general Stroessner [1954-1989], a pesar de ser profundamente servil a intereses extranjeros, también presentó a su régimen como el genuino "sucesor" de la obra de Solano López y, de modo más general, de aquella edad de oro perdida en el siglo XIX ${ }^{593}$.

Basamos este trabajo en que tanto la del liberalismo como la del nacionalismo representan dos interpretaciones burguesas de la historia paraguaya, es decir, intrínsecamente conservadoras. Esto plantea un problema poco estudiado y no resuelto: ¿cuál fue la interpretación general que expuso el amplio espectro que se reclama de izquierda, especialmente aquella que reivindica el marxismo?

\footnotetext{
593 Sobre esta discusión, entre otros trabajos, consultar: MAKARAN, Gaya. Paraguay: el nacionalismo y sus mitos. México D.F.: Universidad Nacional Autónoma de México-Centro de investigación sobre América Latina y el Caribe, 2014.
} 
Es desde la perspectiva metodológica del materialismo histórico que examinamos el proceso de independencia hispanoamericana y, en particular, el caso paraguayo. A nuestro juicio, ese proceso no acabó en 1813 con la proclamación de la República, sino que continuó hasta el fin de la Guerra contra el Paraguay. Por ello, sin llegar al período de la Guerra -un laberinto que merece un estudio propio-, sí nos pareció relevante analizar y debatir las medidas y ciertas interpretaciones tanto de derechas como de izquierdas sobre los gobiernos que consolidaron el Estado nacional paraguayo: José Gaspar Rodríguez de Francia [18141840]; Carlos Antonio López [1842-1862]; y Francisco Solano López [1862-1870], aunque en el caso del Mariscal nos detengamos en los prolegómenos de la contienda. Esto contribuirá a ampliar la visión del proceso, sobre todo de los avances, o no, en el sentido económico-social.

En ese contexto, comencemos por plantear algunos problemas en el ámbito de la llamada izquierda. En el justo afán de polemizar con el relato liberal, que reproduce con más o menos matices el discurso que justificó la Triple Alianza, un amplio mosaico "crítico" y "social", que abarca desde el PCP y pasa por las variantes del castro-guevarismo-chavismo contemporáneo, hasta los sectores "sociales" de la Iglesia católica, no evitó caer en el culto a la personalidad del doctor Francia y de los López que propone la literatura nacionalista de derechas.

En el caso de Francia, esa facción de la izquierda no dudó en asumir el mito del “igualitarismo". Algunos, como veremos más adelante, fueron más allá y le atribuyeron un carácter precursor y "protosocialista". El propósito político de esa lectura, durante el siglo XX y hasta la actualidad, es justificar una permanente búsqueda de algún sector patronal "patriótico" que pudiera dirigir el "campo democrático y popular" en contra del "reaccionario y oligárquico", en aras de la revolución "antifeudal” y "antiimperialista”. En síntesis, una visión campista y etapista del proceso histórico ${ }^{594}$.

El método de análisis marxista todavía tiene mucho que aportar al estudio de ese proceso. En primer término, sostenemos que una lectura marxista debe polemizar con las dos principales corrientes de pensamiento que apuntamos. Ambas construcciones teóricas, además de su énfasis en el papel de los individuos, cometen el error metodológico de considerar solo algunos elementos de la realidad, aquellos más ajustados a su versión de los

\footnotetext{
594 NÚÑEZ, Ronald León. La izquierda y la tentación nacionalista. ABC Color. Asunción, 24/11/2019. Disponible en: <https://www.abc.com.py/edicion-impresa/suplementos/cultural/2019/11/24/la-izquierda-y-latentacion-nacionalista/>, consultado el 16/01/2020.
} 
hechos, para después aislarlos de la totalidad. Así, con facilidad, las contradicciones se transforman en esencia, o bien se construye una "narrativa global" que diluye esas contradicciones.

El marxismo, advirtámoslo desde ya, en general asume la defensa del derecho a la autodeterminación de las naciones coloniales y oprimidas. Este será el punto de partida para interpretar y tomar posición sobre el proceso de independencia latinoamericano y, específicamente, sobre el caso paraguayo, donde la revolución de independencia cristalizó conquistas importantes, hasta su destrucción final a manos de la Triple Alianza.

Pero el marxismo no es "nacionalista". Esto se traduce, en el caso paraguayo, en que no es "francista" ni "lopista" ni nada parecido. El método marxista estudia e interpreta la historia a partir de la lucha de clases o entre facciones de clase. En ese marco, evidentemente, incorpora a su análisis el papel del individuo, pero es contrario a cualquier culto a la personalidad.

Una cosa es, bajo determinadas condiciones, defender la causa nacional de un país oprimido de la agresión de una nación opresora, y otra, muy distinta, es ser nacionalista. En esto no puede existir confusión teórica. León Trotsky, entre otros, dejó clara la posición general del marxismo ante el nacionalismo:

El patriotismo es el ingrediente principal de la ideología con que la burguesía envenena la conciencia de clase de los oprimidos y paraliza su voluntad revolucionaria, dado que "patriotismo" significa sumisión del proletariado a la “nación”, en cuya cumbre está la burguesía ${ }^{595}$.

Comprender esta cuestión no significa negar el papel individual de figuras como el doctor Francia o los López en la consolidación y en la defensa de la independencia del Paraguay. Significa que los individuos responden a intereses de clase y son producto de procesos estructurales, profundos, y no lo contrario.

Es más, el individuo cumple un papel subjetivo que puede llegar a ser crucial, pero que nunca estará disociado, ni en su surgimiento ni en su dinámica posterior, de un contexto histórico objetivo. Esto se debe, según Marx, a que "los hombres hacen su propia historia, pero no la hacen a su libre arbitrio, bajo circunstancias elegidas por ellos mismos, sino bajo aquellas circunstancias con que se encuentran directamente, que existen y les han sido legadas por el pasado [...]" 596 .

595 TROTSKY, León. Lecciones de Octubre. 1935. Disponible en: $<$ https://www.marxists.org/espanol/////trotsky/ceip/escritos/libro4/T07V133.htm>, consultado el 16/01/2020. ${ }^{596}$ MARX, Karl [1852]. El Dieciocho Brumario de Luis Bonaparte. Buenos Aires: Ediciones Libertador, 1998, p. 17. 
Es fundamental, entonces, analizar cada proceso tomándolo en su conjunto, contextualizar su época histórica, interpretar el papel de las clases y sus sectores, identificar sus aspectos progresivos, pero también apuntar sus límites y contradicciones.

Así, antes de abordar la independencia paraguaya y las medidas del dictador Francia, se hace indispensable comprender el proceso histórico general que lo encuadra.

\section{EL MARCO HISTÓRICO: LA REVOLUCIÓN DEMOCRÁTICO-BURGUESA ANTICOLONIAL}

Si convenimos que el dictador Francia es producto del proceso revolucionario de independencia, y no al revés, se hace necesario partir de la definición del carácter de esa revolución. Como analizamos en otros capítulos, la revolución paraguaya de independencia, como las demás del continente, fue una revolución democrático-burguesa, no solo por situarse en la época de ascenso mundial de la burguesía sino, esencialmente, por sus tareas. La diferencia con los procesos "clásicos" europeos estribaba en la jerarquización del programa a ser implementado: por tratarse de naciones colonizadas, oprimidas, la principal tarea democrática consistía en conquistar la independencia nacional, y esto solo podía lograrse rompiendo con cualquier tipo de dominación de la metrópoli. Por lo tanto, nos parece más acertado trabajar con la definición de revolución política democrático-burguesa anticolonial.

Por tratarse de un proceso anticolonialista, fue esencialmente político, no social. Aunque siempre conviene insistir en que esto no significa que no existieron cambios económico-sociales.

El concepto de revolución política que utilizamos está basado, principalmente, en los análisis y la formulación acuñados por León Trotsky sobre la sociedad y las tareas planteadas en la ex URSS:

La revolución que la burocracia [estalinista, $n d a$.] prepara en contra de sí misma no será social como la de octubre de 1917, pues no tratará de cambiar las bases económicas de la sociedad ni de reemplazar una forma de propiedad por otra. La historia ha conocido, además de las revoluciones sociales que sustituyeron al régimen feudal por el burgués, revoluciones políticas que, sin tocar los fundamentos económicos de la sociedad, derriban las viejas formaciones dirigentes (1830 y 1848 en Francia; febrero de 1917, en Rusia). La subversión de la casta bonapartista tendrá, naturalmente, profundas consecuencias sociales; pero no saldrá del marco de una revolución política ${ }^{597}$.

\footnotetext{
597 TROTSKY, León. La revolución traicionada. 1936. Disponible en: $<$ https://www.marxists.org/espanol/trotsky/1936/rt/11.htm\#seg\%203>, consultado el 11/02/2019.
} 
El trotskista argentino Nahuel Moreno resumirá esta definición en 1980: "Es que la revolución política es una verdadera revolución porque refleja la lucha encarnizada, mortal, entre distintos sectores sociales, no clases, pero sí sectores sociales" ${ }^{" 598}$.

Si apelamos a ejemplos del siglo XX y en países capitalistas, podemos citar la Revolución de los Claveles en Portugal, en 1974, que sin cambiar las bases económicas de la sociedad -que siguieron siendo capitalistas y colonialistas- derrocó un régimen político dictatorial y lo substituyó por otro parlamentarista. Lo mismo puede decirse de muchos otros procesos revolucionarios, como el que derrocó a la dictadura militar argentina en 1982, en el que se desplazó a las fuerzas armadas como institución principal del poder para abrir el paso a un sistema basado en elecciones regulares y el parlamentarismo liberal, sin trastocar el sistema social basado en la propiedad privada de los medios de producción. $\mathrm{O}$ el caso de la revolución nicaragüense que en 1979 derrocó el régimen dictatorial de Somoza, incluso por medio de una insurrección armada, pero no avanzó hacia una revolución social, en ese caso, de tipo socialista. En síntesis, la estructura queda intacta, pero ocurre un cambio más o menos abrupto en el régimen político-institucional.

En ese marco, lo que ocurrió en el siglo XIX puede interpretarse como una disputa feroz por el poder político entre dos facciones burguesas: la española-colonialista y la de los criollos. Y el Imperio español fue derrotado.

El carácter esencialmente político del proceso se manifiesta en que se destruyó la superestructura controlada por la metrópoli española, dando origen a otra de carácter nacional-independiente, ahora controlada por la naciente burguesía nacional. En otras palabras, de un Estado colonial se pasó a Estados burgueses nacionales; algo extremadamente progresivo en el contexto del siglo XIX, independientemente del grado de resquicios jurídicos y/o institucionales del viejo orden español que pudieran haber sobrevivido. Porque eran eso, resquicios de un sistema de subordinación colonial que dejó de existir como tal.

¿Esto significa que esas burguesías y esos Estados nacionales eran como son actualmente? Obviamente, no. Eran incipientes, embrionarios. La máquina estatal burguesa -sobre todo en el caso paraguayo-, en los tiempos del dictador Francia era extremadamente rústica. Su construcción partió de muy atrás, incluso comparándola con otras naciones de la región. No existían cuadros políticos, diplomáticos, militares, y otros especialistas que el

598 MORENO, Nahuel. Actualización del Programa de Transición. 1980. Disponible en: $<$ https://www.marxists.org/espanol/moreno/actual/apt 3.htm\#t23 >, consultado el 28/03/2019. 
momento demandaba. Todo estaba por hacerse o “en formación”. En más de una oportunidad, el propio doctor Francia expresó en su correspondencia su frustración ante la falta de personal calificado que pudiera dar cuenta de las tareas que exigía erguir el aparato estatal. En una nota de 1823, en la que se refiere a las sucesivas incursiones de indios "hostiles", ordena al comandante local que haga "lo que se pueda".

[...] porque yo en medio de las infinitas atenciones y ocupaciones que me rodean, sin que el Estado costee al Gobierno los operarios auxiliares precisos, no he de hacer milagros para evitar esos continuos asaltos que dice su carta, estando en el Paraguay y entre paraguayos, donde no hay hombres para cosas de importancia ni gente apta para todo lo que se quiere ${ }^{599}$.

En otra misiva, de diciembre de 1828, el dictador paraguayo expresó con más claridad, además de su obsesión de intervenir directamente en cada detalle de los asuntos públicos, la precariedad en que debió gobernar, incluso lamentando estar en "un país de pura gente idiota":

Aquí cuando recibí este desdichado Gobierno, no encontré de cuenta de la Tesorería ni dinero, ni una vara de género, ni armas, ni municiones, ni ninguna clase de auxilios y no obstante he estado y estoy sosteniendo los crecidos gastos, la provisión y apresto de artículos de guerra que demanda el resguardo general a más de las costosas obras y faenas a fuerza de arbitrios, de maña, de diligencias aun con otros países y de un incesante trabajo y desvelo supliendo por oficios y ministerios que otros debían desempeñar en lo civil, en lo militar y hasta en lo mecánico [sic]. Recargado por esto aun de ocupaciones que no me corresponden, ni me eran decentes, todo esto por hallarme en un país de pura gente idiota, donde el Gobierno no tiene a quien volver los ojos, siendo preciso que yo lo haga, lo industrie y lo amaestre, todo por sacar al Paraguay de la infelicidad y abatimiento en que ha [estado] sumido por tres siglos. Por esto después de la revolución todos se atrevieron a robarlo y lo robaron a satisfacción porteños, artigueños y portugueses $^{600}$.

Si está claro, o al menos es muy difícil negar, el carácter embrionario del Estado nacional paraguayo -así como el de los demás Estados nacionales latinoamericanos, que a duras penas trataban de consolidarse luego de tres siglos de colonialismo-, hecho que evidenciaba todavía la coexistencia de lo "nuevo" con lo "viejo", etc., la pregunta clave es: ¿de qué tipo de Estado era aquel “embrión”? ¿De un Estado nacional-burgués, "protosocialista", de algún "híbrido" sui géneris...? Para nosotros, no existe duda de que lo que el doctor Francia y los demás dirigentes de los distintos procesos independentistas intentaron construir eran Estados nacionales burgueses, es decir, superestructuras que, en dinámica, expresarían el avance del modo de producción capitalista que, aunque aún no era

${ }^{599}$ Oficio al comandante de Concepción del 20/01/1823. ANA-SH, v. 237, n. 2.

${ }^{600}$ Oficio al subdelegado de Itapúa, del 10/12/1828. ANA-SH, v. 239, n. 11. Este era un reclamo habitual, ver: Oficio al comandante de Concepción, del 20/01/1823. ANA-SH, v. 237, n. 2; Decreto que ordena despoblar Tevegó del 12/10/1823. ANA-SH, v. 237, n. 2; Oficio al delegado de Itapúa, del 12/04/1831. ANA-SH, v. 241, n. 7. 
hegemónico ni mucho menos en la estructura social, avanzaba desigualmente en el continente y el mundo.

Esta definición tiene importancia porque, o se niega el carácter burgués de los cambios inaugurados con las independencias, o bien, en el caso paraguayo, se alimenta el mito de un Estado igualitario moldeado por el dictador Francia. Dos polos igualmente equivocados.

En suma, el cambio político, con el tiempo allanaría el camino para algunas conquistas económicas y democráticas para los pueblos americanos. Es decir, una revolución política anticolonial, aunque con efectos más o menos tardíos y retaceados en la base económico-social.

Es fundamental, para poder estudiar con propiedad las particularidades de cada caso, comprender la esencia de todo el proceso. Si bien toda revolución social, por su alcance, es al mismo tiempo política, no toda revolución política es social.

\section{El CASO PARAGUAYO}

$\mathrm{Si}$, como examinamos, la independencia paraguaya es inseparable del proceso de liberación continental, que tuvo alcance desigual, cabe ahora señalar sus particularidades: su contexto regional específico; el papel de las clases y sectores de clase; y el alcance de sus realizaciones.

Dada la histórica marginalidad geográfica y económica de la antigua provincia paraguaya, para poder defender su independencia política - declarada en octubre de 1813-y generar condiciones mínimas para su desarrollo material, la nación debió enfrentar no solo el poder español sino también la política anexionista de la burguesía comercial de Buenos Aires, que monopolizaba el principal puerto y aduana de la región. El centralismo porteño, en el contexto de su guerra contra todo el Interior, mostró una hostilidad tan férrea que no reconoció la independencia de la nueva República sino hasta 1852.

Como ocurrió en otros casos latinoamericanos, entre 1811 y 1813 existió un amplio frente anticolonial, que en un primer período estuvo liderado por la alta burguesía rural y comercial criolla, pero que necesitó incorporar a representantes políticos de las clases medias urbanas, como fue el caso del doctor Francia, futuro principal dirigente del proceso.

Por la importancia individual de este personaje en todo el proceso, permítasenos un paréntesis para describir algunos aspectos de la trayectoria política que, en menos de tres 
años de la ruptura con España, lo erigiría como el guía indiscutible de la revolución de independencia y del proceso de consolidación del Estado nacional paraguayo como un todo.

\subsection{José Gaspar en el período prerrevolucionario}

Lo primero digno de nota es que ya en 1808 el doctor Francia era una personalidad con alguna importancia dentro del medio asunceno ${ }^{601}$. Hijo de José Engracia García Rodríguez de Francia y de María Josefa Fabiana Velasco y Yegros, José Gaspar nació en Asunción el 6 de enero de 1766. Su padre fue uno de los luso-brasileños ${ }^{602}$ que llegó a la provincia a mediados del siglo XVIII para dedicarse a la fabricación de tabaco torcido. Durante 34 años había servido a España como militar, alcanzando al grado de capitán de artillería, de acuerdo con su foja de servicios de $1806^{603}$.

En 1787 fue designado administrador de temporalidades del pueblo de Yaguarón, cargo que ejerció durante una década ${ }^{604}$. Además de esas funciones públicas, José Engracia se dedicaba al comercio. Por su parte, la madre del futuro dictador, María Josefa, nació de la unión de don Mateo Félix de Velasco y doña María Josefa de Yegros y Ledesma, sobrina de un antiguo gobernador, don Fulgencio Yegros y Ledesma ${ }^{605}$. También es digno de señalar que, en esos años, los Velasco y, principalmente, los Yegros estaban entre las familias más ricas y distinguidas dentro de la provincia.

Entre 1781 y 1785, el joven José Gaspar estudió en el Real Colegio Convictorio de Nuestra Señora de Monserrat en Córdoba, una de las principales casas de estudios superiores

\footnotetext{
${ }^{601}$ Existen muchas biografías escritas sobre el doctor Francia. Las más destacadas son: CHAVES, Julio [1942]. El Supremo Dictador..., op. cit.; WISNER DE MORGENSTERN, Francisco. El Dictador del Paraguay José Gaspar de Francia. Asunción: Instituto Cultural Paraguayo-Alemán, 1996; BÁEZ, Cecilio [1910]. Ensayo sobre el Dr. Francia y la dictadura en Sudamérica. Asunción: Editorial Cromos, 1985; PASTOR BENÍTEZ, Justo. La vida solitaria del Dr. José Gaspar de Francia, dictador del Paraguay. Asunción: Servilibro, 2010; DEMERSAY, Alfred [1856]. El doctor Francia, dictador del Paraguay. Asunción: El Lector, 2011; CARLYLE, Thomas [1842]. El dictador Francia. Asunción: El Lector, 2011; CABANELLAS, Guillermo. El dictador del Paraguay: Dr. Francia. Asunción: Editorial Claridad, 1946.

${ }^{602}$ Existe, sin embargo, incertidumbre acerca del origen de García Rodríguez de Francia. El gobernador Lázaro de Ribera escribió: “Como Francia es extranjero, que aún no sabemos si es portugués o francés”, citado en: CHAVES, Julio [1942]. El Supremo Dictador..., op. cit., p. 32.

${ }^{603}$ Solicitud de un certificado de servicios militares presentado por García Rodríguez de Francia, del 03/07/1806, ANA-SH, v. 438, n. 7, publicado en: RODRÍGUEZ ALCALÁ, Guido; DURÁN ESTRAGÓ, Margarita; ROMANO GARCÍA, Martín (org.). FRANCIA: [1762-1816]..., op. cit., p. 54.

${ }^{604}$ Designación de García Rodríguez de Francia como administrador del pueblo de Yaguarón, del 18/08/1787, ANA-SH, v. 439, n. 8, publicada en: Ídem, pp. 15-16.

605 José Gaspar Rodríguez de Francia era primo del teniente coronel Fulgencio Yegros, renombrado prócer de la independencia paraguaya, que en 1821 fue fusilado por sus órdenes.
} 
del virreinato ${ }^{606}$. Allí obtuvo el título de "bachiller licenciado y maestro en Filosofía, y el de bachiller licenciado y doctor en Sagrada Teología" ${ }^{07}$. Había ingresado en Córdoba a través de dos tíos, los frailes Fernando Caballero y Mariano Velasco, por entonces profesores de la institución. Su permanencia como alumno interno sin duda ocasionó gastos importantes, pero su padre gozaba de una holgada situación económica y, además, el joven era el predilecto de Martín José de Aramburu, rico español y, por entonces, ministro de la Real Hacienda ${ }^{608}$.

A su regreso, José Gaspar enseñó latinidad y filosofía en el Real Seminario de San Carlos ${ }^{609}$. Posteriormente se consagró a la profesión de letrado, en la cual, según los suizos Rengger y Longchamp ${ }^{610}$ :

[...] Nunca mancilló su ministerio encargándose de la defensa de una causa injusta; jamás trepidó en defender al débil contra el fuerte; al pobre contra el rico: exigía considerables honorarios de los que podían pagarlos, de aquellos, sobre todo, en que distinguía pasión por los pleitos; pero se manejaba con un raro desprendimiento respecto de los litigantes que carecían de comodidades [y] era muy desinteresado con los litigantes menesterosos, o a quienes las pretensiones injustas de los otros llevaban ante los tribunales $[\ldots]^{611}$.

Un relato ilustrativo sobre los atributos y funciones públicas ejercidas por el doctor Francia dos años antes de iniciarse la revolución de independencia puede leerse en la notificación que el propio Cabildo asunceno escribió al virrey Cisneros después de la elección de José Gaspar como diputado provincial:

[...] Es natural de esta ciudad, hijo legítimo de padres notoriamente nobles, que lo fueron Don García Rodríguez de Francia, antiguo Capitán Comandante de

${ }^{606}$ Por Real Cédula, en 1800 pasó a denominarse Real Universidad de San Carlos y de Nuestra Señora de Monserrat. El Colegio Monserrat fue casa de estudios de muchos hombres decisivos para la historia argentina: Juan José Castelli, Juan José Paso, el deán Gregorio Funes, Nicolás Avellaneda, y José Figueroa Alcorta, entre otros.

${ }^{607}$ CHAVES, Julio [1942] El Supremo Dictador..., op. cit., p. 64.

${ }^{608}$ Ídem, pp. 36-37.

${ }^{609}$ Certificación de los servicios de José Gaspar de Francia como catedrático de Latinidad del Real Colegio Seminario de San Carlos, del 01/02/1789, ANA-SH, v. 439, n. 8, publicada en: RODRÍGUEZ ALCALÁ, Guido; DURÁN ESTRAGÓ, Margarita; ROMANO GARCÍA, Martín (org.). FRANCIA: [1762-1816]..., op. cit., p. 17; Acta de la toma de posesión de la Cátedra de Teología de Vísperas del Real Colegio Seminario de San Carlos, del 27/03/1789, ANA-SH, v. 439, n. 8, publicada en: Ídem, pp. 18-19.

${ }^{610}$ Los médicos y naturalistas suizos Johann Rengger y Marcelin Longchamp llegaron al Paraguay en julio de 1819 y permanecieron en el país hasta 1826. Fueron de los pocos extranjeros que vivenciaron y escribieron sobre los hechos ocurridos durante los primeros años de la independencia y sobre el gobierno del doctor Francia. En 1827 publicaron en Europa su obra más conocida: Ensayo histórico sobre la Revolución del Paraguay. En su relato describen la situación política y social durante la estadía, así como aspectos personales sobre el dictador Francia, que recibió la obra con profundo encono. En 1835, Rengger publicó otra obra de mucha importancia, donde describe aspectos zoológicos, botánicos, etnográficos y sociológicos sobre el Paraguay de la época, ver: RENGGER, Johann [1835]. Viaje al Paraguay en los años 1818 a 1826. Asunción: Tiempo de Historia, 2010.

${ }^{611}$ RENGGER, Johann; LONGCHAMP, Marcelin [1827]. Ensayo histórico sobre la Revolución del Paraguay: precedido de la biografía del tirano Francia, y continuado con algunos documentos y observaciones históricas. Buenos Aires: Imprenta y Librería de Mayo, 1883, p. 49. 
Milicias de Artillería de esta provincia y Doña María Josefa de Velasco, habiendo sido su tío abuelo materno Don Fulgencio de Yegros y Ledesma, que fue Gobernador y Capitán General de esta misma provincia. Su edad es de cuarenta y tres años, de estado soltero, persona de conocido talento y de una instrucción bastante general, al paso de ser de un carácter pacífico, prudente y moderado y de bien acreditada honradez e integridad y de arreglada conducta. Hizo sus estudios en la Universidad de Córdoba del Tucumán con manifiestas ventajas y obtuvo los grados de Maestro en Filosofía y Doctor en Sagrada Teología.

En este Real Colegio Seminario, después de haber enseñado Latinidad, regentó la Cátedra de Vísperas de Teología que se le confirió en rigurosa oposición. Ha tenido particular aplicación al estudio del Derecho, en cuyas materias ha manifestado a satisfacción del público y de los magistrados suficiente capacidad y extensión de conocimientos en los varios encargos del foro que se le han confiado, como han sido los de Defensor de Capellanías y Obras Públicas y de Promotor Fiscal de Real Hacienda, así como en las Causas de Pobres que se han encomendado, conduciéndose siempre con honor y rectitud.

Por su reputación y buen nombre fue electo el año mil ochocientos ocho Alcalde ordinario de primer voto de esta ciudad, cuyo cargo desempeñó cumplidamente, así como el de diputado interino del Real Consulado que ejerció por la mitad de su año a falta del propietario y finalmente en el presente que corre fue electo Síndico Procurador General, que es el oficio en que actualmente se halla $[\ldots]^{612}$.

La documentación muestra que el doctor Francia, al igual que muchos otros líderes independentistas, antes de la crisis del sistema colonial no solo expresaba fidelidad a la Corona sino que incluso había ocupado cargos importantes en la política provincial, aunque siempre dentro de los límites establecidos para los criollos.

Si bien no podía ser considerado rico, el doctor Francia no sufría apremios financieros. Entre sus bienes más importantes se encontraba una quinta en Ibiray, situada en la periferia de la capital, que había adquirido con sus honorarios como abogado. En 1810 recibió una herencia paterna valuada en 1.858 pesos plata, integrada por dos lances de casas de teja en la plazuela de la Merced, la mulata Rafaela, el mulatillo Pío, 438 pesos dos reales plata sellada, muebles y otros objetos sin importancia ${ }^{613}$. Sobre sus posesiones personales, Rengger y Longchamp observan:

Heredero de un patrimonio moderado jamás procuró aumentarlo: la mitad de una casa en la ciudad, y una pequeña chacra constituían toda su fortuna, y satisfacían todos sus deseos. De modo que viéndose un día poseedor de 800 pesos, creyó que esta cantidad era excesiva para un hombre solo y la jugó $[\ldots]^{614}$.

Siendo así, ¿es posible considerar al doctor Francia, poco antes de estallar la crisis de la independencia, parte de la "elite" provincial? La respuesta es sí y no. El solitario abogado no era comerciante ni estanciero; tampoco integraba el cuadro de oficiales de la

\footnotetext{
${ }^{612}$ Oficio del Cabildo de Asunción al virrey Baltasar Hidalgo de Cisneros del 18/08/1809. ANA-NE, v. 3405, publicado en: RODRÍGUEZ ALCALÁ, Guido; DURÁN ESTRAGÓ, Margarita; ROMANO GARCÍA, Martín (Org.). FRANCIA: [1762-1816] ..., op. cit., pp. 57-58.

${ }^{613}$ Expediente sucesorio de los herederos de García Rodríguez de Francia, del 31/05/1810, Archivo Nacional de Asunción - Testamentos y Propiedades (ANA-TP), v. 847, n. 5, publicado en: Ídem, p. 63.

${ }^{614}$ RENGGER, Johann; LONGCHAMP, Marcelin. Ensayo histórico sobre la Revolución del Paraguay..., op. cit., p. 49.
} 
milicia o el cuerpo eclesiástico. Era más bien parte de los llamados "sectores medios" de una sociedad en la que, como se sabe, no resultaba fácil traspasar las rígidas fronteras sociales. En 1804, por ejemplo, cuando Francia solicitó la mano de la joven Petrona de Zavala, hija del respetable teniente coronel José Antonio Zavala y Delgadillo, fue rechazado tildándosele de "mulato". A pesar de sus logros académicos y su reputación como abogado, a los ojos de las familias asuncenas más distinguidas no era más que el hijo de un "mameluco paulista". Un mote que imponía una barrera entre él y los principales apellidos de la provincia ${ }^{615}$. No obstante, debido a su formación intelectual y a sus capacidades personales, que difícilmente podrían pasar desapercibidas, Francia no podía dejar de ser reconocido, al menos como parte de la reducidísima "elite letrada" asuncena, como certifica la carta del Cabildo que citamos anteriormente. Un hombre "ilustrado". Ya Domingo Faustino Sarmiento percibió que no podía encasillar a Francia en su conocido esquema de "civilización o barbarie" y notó que: "no es un bárbaro creado en las estancias, en los suburbios de la civilización como su imitador Rosas; es un hombre educado, es un hombre de letras"616.

Crónicas de observadores europeos también corroboran esta última cuestión. Al registrar su primer encuentro personal con el doctor Francia, en 1812, el comerciante escocés John P. Robertson ponderó sus atributos intelectuales, sus referencias ideológicas, y el influjo de su figura en el medio asunceno:

Para brindar la primitiva hospitalidad, común en el país, me invitó a sentarme en el corredor para tomar un mate y fumar un cigarro. Un globo astronómico, un gran telescopio y un teodolito estaban bajo el pequeño pórtico [...] Me hizo entrar en su biblioteca, un cuarto cerrado con una pequeñísima ventana y tan sombreado por el techo del corredor que apenas penetraba la luz necesaria para estudiar. La biblioteca estaba dispuesta en tres filas de estantes extendidos a través del cuarto y se compondría de trescientos volúmenes. Había muchos libros voluminosos de derecho; pocos de ciencias experimentales; algunos en francés y en latín sobre literatura general, con los Elementos de geometría de Euclides y algunos textos escolares de álgebra [...] Le complacía que se supiese de su conocimiento del francés, un conocimiento muy poco común en el Paraguay. Hacía alguna ostentación de su familiaridad con Voltaire, Rousseau y Volney, y adhería completamente a las teorías del último. Pero, más que todo, se enorgullecía de ser reputado algebrista y astrónomo [...] En el Paraguay, con el conocimiento del francés, los Elementos de geometría de Euclides, las ecuaciones, las maneras de servirse del teodolito, y con libros prohibidos por el Vaticano, él era-en lo relativo al saber- la total excepción a la regla general, hasta el punto de que el hombre en posesión de esos atributos (Francia era el único en ese sentido) podía ser considerado tanto un mago como un semidiós ${ }^{617}$.

${ }^{615}$ CHAVES, Julio [1942]. El Supremo Dictador..., op. cit., pp. 74-75.

${ }^{616}$ RAMA, Ángel; SONOWSKI, Saúl; MARTÍNEZ, Tomaz Eloy. La crítica de la cultura en América Latina. Madrid: Biblioteca Ayacucho, 1972, p. 320.

617 ROBERTSON, John P; ROBERTSON, William P. [1843]. Cartas del Paraguay. Asunción: Editora Intercontinental, 2010, pp. 48-51. 


\subsection{El proceso social y político}

Como referíamos, el frente amplio anticolonial de los primeros meses del proceso incorporaba representantes de distintos sectores de clase. El hegemónico, en 1811, era el sector más "tradicional" de la "elite" criolla -que se había fortalecido y enriquecido como clase propietaria ya durante el período colonial, haciendo negocios con empresarios españoles y porteños-. Esta facción de grandes propietarios, que centraba su acumulación en la producción y el comercio de exportación, era la más conservadora y menos democrática: su programa político, a lo sumo, aspiraba a negociar con Buenos Aires "más autonomía" comercial y política en las mejores condiciones posibles. No significa que, al principio, no estuviera dispuesta a presionar, pero ello siempre estaría al servicio de alcanzar algún tipo de acuerdo. Si la autonomía podía lograrse "por las buenas", sin llegar a una ruptura definitiva con la ciudad-puerto, tanto mejor.

Pero la doble presión externa, que a su vez era producto de la doble dependencia histórica de la metrópoli y de la submetrópoli, Buenos Aires, en la práctica fue inviabilizando cualquier compromiso autonomista, cualquier fórmula federalista. El propio Rodríguez de Francia abrazó la propuesta federalista en 1811. Pero la intransigencia de Buenos Aires fue tal que para 1813 las únicas dos alternativas para la embrionaria burguesía nacional eran someterse al control de la burguesía comercial porteña, actuando como su socia menor; o bien emprender el camino de la independencia. Esta disyuntiva rompió el "frente patriota" inicial. Atenazada, la alta burguesía criolla, si bien había derrocado el poder español y hasta cierto punto presionado a Buenos Aires, demostró los límites de su carácter vacilante. Ante la extorsión comercial de Buenos Aires, se mostró incapaz de avanzar por el camino de la independencia absoluta y la construcción del nuevo Estado nacional.

El sector de los militares estancieros -Yegros, Cabañas, Caballero, Iturbe, etc.-, así como el sector comerciante -Fernando de la Mora, Gregorio de la Cerda, etc.--, estaban ligados al comercio exterior; no tenían mucho interés en desarrollar la producción para fortalecer el mercado interno. Desde antes de romper con el españolismo, Buenos Aires había sido el centro principal de sus financiamientos y mercado -consumidor y redistribuidor-casi exclusivo de la producción de yerba mate y tabaco. Existían relaciones comerciales y hasta familiares entre grupos de empresarios de ambas capitales. Hubo también, aunque con mucho menos peso político, civiles y militares que mostraron simpatía por el federalismo de Artigas, que se oponía al "centralismo" de Buenos Aires, pero sin 
necesariamente aspirar a constituir Estados nacionales independientes. De cualquier manera, la influencia de la corriente liderada por Artigas fue mínima. Posiblemente debido a muchas de sus medidas contra los ganaderos y otros propietarios en la Banda Oriental, que despertaron la desconfianza de los oficiales paraguayos, que a su vez eran estancieros y empresarios en otros ramos.

Esta dinámica llevó a que, tanto la tarea de garantizar la independencia nacional consolidación de un Estado nacional [ejército y finanzas propias] y de un mercado interno, como la resolución del histórico problema de la ligazón directa con el mercado mundial defensa de la libre navegación de los ríos y rechazo al monopolio aduanero porteño-, fueran asumidas por sectores propietarios "no tradicionales" -compuestos por estancieros ricos pero relegados del poder, medianos chacreros, pequeños comerciantes de las villas, etc.-. En suma, por segmentos rurales menos dependientes del comercio exterior y más interesados en el mercado interno, sobre todo dedicados a la ganadería y a la pequeña producción mercantil. Por esa razón, estos sectores sufrían menos el impacto de la interrupción del comercio regional, provocada por las vicisitudes políticas en el Plata.

El doctor Francia emergió como el principal representante de estos propietarios rurales, que no integraban ni tenían el poder y el prestigio de las "cien familias" principales de la ex provincia pero estaban deseosos de ascender socialmente.

Francia, que no era comerciante ni estanciero ni caudillo militar, sino un abogado "ilustrado", supo maniobrar en medio de la inestabilidad política y social de 1812, capitalizándola a su favor, para lo que hábilmente se apoyó en ese sector social hasta alcanzar el poder absoluto, a partir de dos congresos nacionales, en 1813 y 1814, basados en la inédita convocatoria de "mil diputados". La llegada al poder de Francia responde a un momento crítico para la independencia y, al mismo tiempo, marca el ápice de la participación democrática en el proceso que se había iniciado en 1811.

Algo más sobre la "base social" de Francia. Las convocatorias de los congresos de 1813 y 1814 sin duda obedecieron a un criterio democrático muy avanzado para la época y la región: diputados electos por el voto "enteramente libre" de todos los varones con más de 23 años “de cualquier estado, clase, o condición” -es decir, voto no censitario-, y en número proporcional a la población de cada villa ${ }^{618}$. Esta singularidad es muy relevante y debe ser

${ }^{618}$ Oficio de la Junta al Cabildo, del 30/06/1813. ANA-SH, v. 222, n. 4. 
señalada, aunque no resuelve el problema de la definición de la base social de Rodríguez de Francia.

Es un lugar común, especialmente en la literatura nacionalista "de izquierda", sostener que Francia alcanzó el poder a través de los “delegados rurales”, o bien afirmar que en 1813 "la campaña" se impuso "a la ciudad". Esto es una verdad a medias. El problema para una definición que pretende ser marxista se presenta cuando en la formulación "el campo" se engloba a los pequeños propietarios pobres, a los campesinos sin tierra que vivían como "tolerados" en lotes ajenos, al peón agrícola "libre", a los esclavos negros, etc., junto con grandes terratenientes, como era el caso de José Miguel Ibáñez, un militar que en 1816 fue el diputado que defendió la propuesta de declarar a Francia "dictador perpetuo con calidad de ser sin ejemplar"619. Ibáñez, junto con Manuel Gamarra, era el latifundista más rico de Concepción.

Ignacio Telesca refirió que, en las actas de Pilar y Pedro González, todos los delegados electos estaban antecedidos por el título de don ${ }^{620}$. ¿Cuántos "medianos y pequeños campesinos" participaron como delegados en esos congresos? ¿Hubo representantes indígenas? ¿Algún negro o “mulato”? No es posible saber, aunque es probable que ninguno. $\mathrm{Y}$ esto no es menor, puesto que esos sectores de las clases explotadas representaban, aproximadamente, $40 \%$ de la población en ese entonces. En el acta del congreso de 1813 no constan las firmas de los mil diputados, solo las de unos veinte, posiblemente designados para refrendar el documento, todos "miembros de la elite, muchos de ellos ex cabildantes, incluso de la época colonial, y tres eclesiásticos"621.

Así, la base social del doctor Francia no puede definirse a la ligera como "popular" o "plebeya". Mucho menos puede decirse que El Supremo representaba a los sectores históricamente más explotados, los indígenas segregados en las reducciones, y los esclavos negros. De ninguna manera. Su ascenso se apoyó, principalmente, en una facción de propietarios rurales, compuesta no solo por "pequeños y medios campesinos", como comúnmente enfatiza la historiografía tradicional, sino también por algunos grandes latifundistas, aunque sin fuertes conexiones con el mercado externo.

\footnotetext{
${ }^{619}$ Acta del Congreso General del 01/06/1816. ANA-SH, v. 226, n. 1.

${ }^{620}$ La anteposición de "don" o "doña" al nombre de una persona, sin ser un título, consistía en un tratamiento de deferencia que expresaba respeto y distinción social, generalmente aplicado a "ciudadanos propietarios".

621 TELESCA, Ignacio. Revolución, república y pueblo. In: TELESCA, Ignacio; BREZZO, Liliana; CABALLERO CAMPOS, Herib (Org.). Paraguay 1813..., op. cit., p. 55. Ver también: Acta del Congreso General y Reglamento de Gobierno de la República del 12/10/1813. ANA-SH, v. 222, n. 3.
} 
De hecho, los “delegados de gobierno" y comandantes militares que Francia nombró en el interior eran propietarios de tierras y ganado ${ }^{622}$. El propio Policarpo Patiño, que se desempeñó como secretario personal y "mano derecha" del Dictador, era un empresario productor-comerciante de yerba de San Pedro de Ycuamandiyú. El inventario de bienes de Patiño, que cayó en desgracia y se suicidó tras la muerte de Francia, incluía cuantiosas tierras, casas, y esclavos ${ }^{623}$.

Esta precisión, si bien es fundamental para entender el período de Francia, en sí misma no resta importancia a la convocatoria democrática de los congresos nacionales de 1813 y 1814. Tampoco disminuye el significado de la derrota política de la "oligarquía tradicional" a manos de otra facción de la incipiente burguesía y pequeña burguesía rural, más interesada en la producción nacional y en el mercado interno, liderada por una figura oriunda de la pequeña burguesía urbana. Esto, a la larga, se reveló como un hecho progresivo que garantizó la independencia en su momento más crítico. Y aquí reside otra singularidad: mientras que en Buenos Aires y otras regiones aquellos sectores medios de la sociedad que podrían ser identificados como alas “jacobinas” del proceso - por ejemplo, Mariano Moreno y Juan José Castelli- fueron derrotados, en el Paraguay -debido fundamentalmente a la debilidad y a la cobardía de la burguesía más tradicional frente a la amenaza exterior-, alcanzaron y, sobre todo, lograron mantener el poder.

Pero la analogía con los "jacobinos" también debe tomarse con pinzas y en su contexto. No se trató de un fenómeno político surgido ni montado en la movilización activa y radicalizada de las masas empobrecidas de la ciudad y del campo, como ocurrió en el caso de los jacobinos y enragés franceses, apoyados -y presionados- por los sans-culottes; una analogía que, aplicada con todas sus salvedades al caso del Paraguay de 1811-1813, equivaldría a un movimiento pequeñoburgués radicalizado por el empuje de los campesinos pobres, los sin tierra, los peones rurales, los indios reducidos y los negros esclavizados. Ni esos sectores realmente "plebeyos" y "populares" participaron de manera directa de los acontecimientos ni la revolución fue hecha en su nombre de sus intereses.

En este aspecto, el proceso que se dio en el Paraguay no puede ser comparado con el levantamiento de campesinos e indígenas de 1810 en México, dirigido por el padre Miguel

\footnotetext{
${ }^{622}$ Ver informe del vicecónsul francés Aimé Roger, en: PASTOR BENÍTEZ, Justo. La vida solitaria del Dr. José Gaspar de Francia..., op. cit. p. 266.

623 VERÓN, Carlos. Polí, el malquerido. ABC Color. Asunción, 16/10/2011. Disponible en: $<$ http://www.abc.com.py/edicion-impresa/suplementos/abc-revista/poli-el-malquerido-320768.html>, consultado el 01/02/2018.
} 
Hidalgo, que en su auge llegó a comandar 80.000 indígenas y mestizos que mataron a 15.000 españoles en pocos meses de insurrección. Su programa, además, exigía reforma agraria y el fin de cualquier tipo de servidumbre y esclavitud.

Mucho menos puede compararse el caso paraguayo -ni el de ninguno en toda América- con el del Haitín ${ }^{24}$ de los “jacobinos negros", que movilizando a más de 100.000 negros armados ${ }^{625}$ conquistaron su independencia y abolieron la esclavitud luego de derrotar a los ejércitos de España, Gran Bretaña y, sobre todo, a la fuerza expedicionaria mandada por el propio Napoleón Bonaparte en 1801; además de exterminar físicamente a casi todos los blancos esclavistas de la isla. De los 33.000 soldados, marineros y personal civil de la expedición francesa contra Haití, contando incluso los refuerzos, murieron $29.000^{626}$. No, definitivamente el proceso haitiano no tiene paralelo en América.

Así, es evidente que el proceso guiado por el doctor Francia no tiene nada que ver, en cuanto a la participación directa del pueblo, con estos ejemplos históricos. En el Paraguay, el mismo día que fue derrocado el poder español, un edicto impuso un toque de queda que prohibía cualquier reunión de "tres personas juntas, y ni una de ellas de las clases de Negros y Pardos [...]"627.

La incipiente burguesía paraguaya, intrínsecamente conservadora, por más que en algunos momentos supo "apoyarse" en sectores más "plebeyos" o ampliar algunos criterios democráticos de participación indirecta, no quería una insurrección popular ni nada parecido. Como a toda clase dominante, esa perspectiva le causaba espanto. Buscaba cambios políticos y sociales, evidentemente, pero enteramente "controlados" y a su medida. En definitiva: lo que se impone con el doctor Francia es un sector social nacionalista y mercantilista, y esto era progresivo en términos del desarrollo de las fuerzas productivas en clave capitalista -la única objetivamente planteada en el siglo XIX-, pero nunca debe perderse de vista que sus representantes eran burgueses o aspirantes a burgueses.

\footnotetext{
${ }^{624}$ Sobre la revolución haitiana, según nuestro criterio, no existe mejor referencia que el libro de JAMES, C. R. L. [1938]. Os jacobinos negros..., op. cit. Ver también: PONS, Frank. La independencia de Haití y Santo Domingo. In: BETHELL, Leslie (Org.). Historia de América Latina. La independencia. Tomo V. Barcelona: Editorial Crítica, 1991, pp. 124-153.

${ }^{625}$ LOCKARD, Craig. Societies, Networks, and Transitions: A Global History: Since 1450. Boston: Cengage Learning, 2010, p. 524.

${ }^{626}$ WILSON, Samuel. [1999]. The Emperor's Giraffe and other stories of cultures in contact. Boulder/Oxford: Westview Press, 2007, p. 79.

${ }^{627}$ VELILLA, Margarita (org.). Autos de la Revolución del Paraguay..., op. cit., p. 28.
} 


\section{LAS MEDIDAS DE LA REVOLUCIÓN}

La combinación entre el peligro externo y la dinámica interna de la lucha entre las clases y sectores de clase hizo que el proceso revolucionario democrático-burguésanticolonial paraguayo concretase y consolidase tareas importantes de manera muy avanzada, al menos si lo analizamos en el contexto del Cono Sur latinoamericano. Por razones de espacio, nos limitaremos a enumerarlas y comentarlas someramente para, a partir de ahí, profundizar sobre el papel histórico del gobierno de Francia.

\subsection{La independencia nacional}

Como señalamos, este fue el objetivo político fundamental de la revolución y el hilo conductor de toda la obra de gobierno del doctor Francia. En efecto, su gobierno y su régimen, aunque dictatoriales y policiacos, fueron intransigentemente nacionalistas y económicamente proteccionistas.

Sostener que la figura histórica de Rodríguez de Francia está, sobre todo, firmemente ligada a la consolidación de la independencia nacional no significa caer en ningún tipo de "apología". Significa, simplemente, reconocer el importante papel que este individuo cumplió en el marco de ese proceso sociopolítico específico. Y eso es un hecho.

Y esa independencia nacional, en el caso de la aislada República del Paraguay -que comenzaba su proceso soberanista luego de tres siglos de haber sido una de las provincias más pobres de la colonización española-, tuvo que ser defendida no solo de los españolistas sino también del centralismo porteño y sus agentes internos; del "federalismo" del dictador Rosas; y hasta de la hostilidad portuguesa en el norte.

El doctor Francia expresó su convicción y confianza en la independencia del Paraguay en muchas ocasiones. En una de ellas, cuando tomó conocimiento de que la "expedición pacificadora" enviada por Fernando VII para reconquistar sus antiguos dominios americanos zarpó de Cádiz, escribió una de sus máximas más citadas:

\footnotetext{
Ya habrá Vuestra Merced oído de esa expedición que atraviesa los mares para inquietar e invadir países extraños y pacíficos. Yo antes quiero morir que volver a ver mi Patria oprimida y en la esclavitud, tengo la satisfacción de creer que lo general de toda la República está en lo mismo, y así, anime Vuestra Merced a nuestros compatriotas de ese territorio exhortándolos incesantemente a sostener la causa de la Patria ${ }^{628}$.
}

\footnotetext{
${ }^{628}$ Oficio al comandante de Pilar, del 14/06/1815. ANA-NE, v. 3410, publicado en: RODRÍGUEZ ALCALÁ, Guido; DURÁN ESTRAGÓ, Margarita; ROMANO GARCÍA, Martín (Org.). FRANCIA: [1762-1816]..., op. cit., p. 356.
} 
Así, la revolución política anticolonial y la osada declaración de la República en 1813 liberó fuerzas económicas y sociales para comenzar a construir y consolidar un embrionario Estado burgués nacional, basado en la estructuración de un ejército nacional profesional que liberó a buena parte del campesinado mestizo pobre del servicio militar obligatorio y no remunerado, común durante el período colonial ${ }^{629}$ - y al que Francia, que ejercía las funciones de ministro de Guerra, comandante en jefe y auditor de guerra, destinaría, en promedio, $64 \%$ de las recaudaciones durante todo su gobierno ${ }^{630}$. Hubo años, como 1837 , en que los gastos militares consumieron $91 \%$ de los ingresos estatales, aumentando a $94 \%$ un año después, cuando el ejército consumió 120.594 de los 127.624 pesos desembolsados por la tesorería nacional ${ }^{631}$.

Evidentemente, ese incipiente ejército nacional, considerado como institución, no era, como romantiza un autor, una fuerza "plebeya" ${ }^{632}$, sino un aparato represivo burgués, en primer lugar al servicio de garantizar la paz social interna y, en segundo lugar, de proteger las fronteras del incipiente mercado interno nacional.

Durante el siglo XIX era común la idea de que el Paraguay poseía una gran fuerza militar. Existen autores que cifran las fuerzas armadas del Paraguay gobernado por Francia en 5.000 hombres de tropa regular y una reserva activa de $20.000^{633}$. Pero, tratándose de un país pobre, esos números parecen exagerados. Otros estudiosos señalan que, excepto en los períodos de mayor crisis, como 1815, 1821 y 1833, el ejército paraguayo no superaba los 3.000 hombres bajo las armas ${ }^{634}$, cifra más razonable y que, al mismo tiempo, demuestra la naturaleza incipiente de ese aparato. Por otro lado, se sabe que el grueso de las tropas se encontraba en Asunción, facilitando el control del Dictador sobre las ellas. En 1830, esa guarnición contaba con 1.416 soldados, es decir, aproximadamente la mitad de los efectivos. Cabe apuntar que estas tropas debieron ser muy perceptibles en una ciudad con no más de 12.000 personas $^{635}$. Esa cifra, según White, aumentó a 1.760 efectivos en 1837,

${ }^{629}$ El sueldo promedio de un soldado era de 6 pesos, aunque se le descontaba el valor del uniforme y otras provisiones.

${ }^{630}$ WHITE, Richard Alan [1984]. La Primera Revolución Popular en América..., op. cit., p. 122.

${ }^{631}$ Ídem, pp. 238-240.

${ }^{632}$ MAESTRI, Mário. Paraguai: a República camponesa [1810-1865]. Porto Alegre: FCM Editora, 2015, p. 134.

${ }^{633}$ HORTON BOX, Pelham [1930]. Orígenes de la Guerra de la Triple Alianza. Asunción: El Lector, 1996, p. 17; THOMPSON, George. La guerra del Paraguay. Asunción: Servilibro, 2010, p. 87.

${ }^{634}$ CHAVES, Julio [1942] El Supremo Dictador..., op. cit., p. 227.

${ }^{635}$ WILLIAMS, John Hoyt. Desde la mira del fusil: algunas observaciones acerca del Dr. Francia y el militarismo paraguayo. In: WHIGHAM, Thomas; COONEY, Jerry (Org.). El Paraguay bajo el Dr. Francia: Ensayos sobre la sociedad patrimonial. Asunción: Editorial El Lector, 1996, pp. 55-57. 
disminuyendo en 1839 a 1.345 militares regulares en la capital ${ }^{636}$. Esto indica que, además de la tarea de "defender las fronteras" del "enemigo exterior", el régimen estaba bien consciente de la necesidad de protegerse de cualquier amenaza interna.

En el contexto más general de la tarea independentista, la defensa permanente de la libre navegación de los rios interiores "sin sujeción a ninguna traba arbitraria de impuesto, registro, puerto preciso, derecho de tránsito u otra cualquier invención semejante [...]”637, que se concretaba básicamente en la oposición del Dictador a los afanes anexionistas de Buenos Aires, indica el interés histórico de la embrionaria burguesía nacional por ligarse al mercado internacional, aunque de manera independiente.

Rodríguez de Francia sabía que no habría independencia política sin independencia financiera. En distintas ocasiones, el dictador Francia expresó su interés en que el Paraguay pudiera gozar de las ventajas de un comercio libre y constante como el que se realizaba en Buenos Aires, pero nunca en detrimento de la independencia nacional. En este sentido, en una carta al comandante político-militar de Concepción, escrita en agosto de 1816, expuso varios aspectos de su pensamiento sobre el comercio internacional, desde el período colonial hasta el control de los criollos porteños imperante en ese entonces, que nos permitimos citar excusándonos por su extensión.

Cuando la América toda estaba bajo la servidumbre y yugo de España, le era absolutamente prohibido el comerciar con otras naciones, a fin de que los españoles gozasen todas las utilidades de un comercio exclusivo de la extracción de metales, en el despacho de sus propios efectos a la estimación que querían darles, en las utilidades y ganancias que reportaban de la reventa de los géneros extranjeros que tomaban y daban a los americanos con nuevo encarecimiento, y finalmente en la baratez o menos estimación con que obtenían los frutos de los mismos americanos, no pudiendo estos venderlos a otras naciones aunque fuese a menor precio.

Este monopolio y restricción ha sido una de las quejas constantes de los americanos, que realmente eran perjudicados; porque pudiendo proveerse de lo preciso para las necesidades, y comodidades de la vida con menos dinero o con menor porción de sus frutos, eran privados de estas ventajas por aquella prohibición general. No solo por eso sino también por una consecuencia inevitable de la revolución de América, todas las provincias revolucionarias abrieron luego sus puertos y comercios a todo negociante extranjero de cualquier nación que fuese, porque cesando ya el comercio y tráfico con España, les era forzoso hacerlo con otras naciones así para expender frutos y producciones como para abastecerse de los géneros y efectos necesarios, lo que de otra suerte no podrían conseguir aún con el dinero en mano.

Así se ve frecuentemente que [a] Buenos Aires vienen muchos comerciantes, buques ingleses, portugueses, de los colonos del Norte, y de otras naciones de Europa. Lo propio sucede en las demás provincias puestas en revolución así en esta parte del sur como en la del norte, y por este medio Buenos Aires como aquellas otras provincias han tenido la proporción de proveerse suficientemente

${ }^{636}$ WHITE, Richard Alan [1984]. La Primera Revolución Popular en América ..., op. cit., pp. 282-283.

${ }^{637}$ Decreto del doctor Francia, del 04/11/1825. ANA-SH, v. 237, n. 10. 
de armas y municiones porque entre tantos comerciantes extranjeros no faltan quienes por interés de dinero, o de los frutos o producciones de América traigan bastantes artículos de guerra que vender; y ojalá nosotros pudiésemos lograr igual facilidad, bien que yo espero que poco a poco, y con el tiempo también lo conseguiremos, a cuyo fin para animar a los que puedan hacer esta especie de negocio, he dado a saber y publicado que el producto de armas útiles y municiones permitiré aquí que se extraiga en dinero ${ }^{638}$. Buenos Aires aún ha [hecho] más; ha permitido y franqueado generalmente la extracción del dinero y metales en todo tráfico a todos los comerciantes extranjeros, que de resultas ha sacado y se están llevando cantidades inmensas ${ }^{639}$.

Al mismo tiempo, reiteró su criterio acerca del libre comercio con otras naciones:

[...] en cuanto sea posible, y compatible con la dignidad, decoro, bienestar y conveniencia de nuestra República, toda política y buena razón dicta que conservemos la paz, la buena armonía y cualquier tráfico que nos importe con todas las naciones extranjeras y con todos los países, pueblos y provincias, siempre que no atente contra nuestra sagrada libertad, independencia y derechos ni se nos causen perjuicios $^{640}$.

En contraposición con la imagen del Dictador como un sujeto que "encerró" al Paraguay siguiendo sus caprichos, la documentación muestra intentos por romper el bloqueo comercial y ligar a la joven República directamente con el mercado internacional.

En 1824, por ejemplo, el dictador Francia estaba persuadido de que debía concretar un acuerdo comercial con la propia Inglaterra. Según comenta el comerciante y cronista británico John P. Robertson, el doctor Francia le habría manifestado:

[...] Mi deseo es vincularme estrechamente con Inglaterra, sin que puedan perjudicar al Paraguay los feudos de los países vecinos ni los obstáculos que opongan al comercio y a la navegación; los buques de la Gran Bretaña cruzarán el Atlántico y vendrán a este país, y en unión de nuestras flotillas facilitarán el tráfico desde la desembocadura del Plata hasta el lago Xarayes. Vuestro gobierno acreditará su ministro aquí y yo, a mi vez, en la Corte de St. James. Vuestros connacionales nos traerán sus mercaderías y pertrechos de guerra y recibirán en cambio los nobles productos de este país ${ }^{641}$.

En efecto, el cónsul británico residente en Buenos Aires, Woodbine Parish escribió al Dictador paraguayo en 1824 diciéndole que deseaba una negociación para alcanzar "la expresión de recíprocos y uniformes sentimientos de reconocimiento y amistad" entre ambas naciones. El gobierno paraguayo contestó expresando su deseo de "mantener una sincera amistad, armonía y mucha correspondencia entre la generosa nación inglesa y el Estado del Paraguay" ${ }^{642}$, al tiempo en que solicitó el nombramiento de un cónsul de Comercio. Parish respondió que haría tal solicitud a su gobierno.

\footnotetext{
${ }^{638}$ Generalmente, el dictador Francia solo pagaba "en dinero" o "en metálico" las importaciones de armas y municiones.

${ }^{639}$ Oficio al comandante de Concepción, del 31/08/1816. ANA-SH, v. 226, n. 1.

${ }^{640}$ Ibídem.

${ }^{641}$ RIBEIRO, Ana. Gaspar Rodríguez de Francia ..., op. cit., p. 41.

${ }^{642}$ WHITE, Richard Alan [1984]. La Primera Revolución Popular en América ..., op. cit., p. 178; PARISH, Woodbine. Buenos Aires y las provincias del Río de la Plata. Buenos Aires: Editorial Hachette, 1958.
} 
En enero de 1825, en una de sus cartas a Parish, el Dictador hizo saber que la navegación comercial que interesaba a su país debía ser "sin limitación alguna":

Que en esta conformidad cuando se halle libre la navegación, [la] cual debe ser enteramente franca y libre para todos sin exceptuar los del Paraguay desde sus puertos a los de fuera sin limitación alguna, y de igual forma, y de igual modo también de estos al Paraguay, porque un comercio en otra forma en ninguna manera es admisible por perjudicial y ruinoso ${ }^{643}$.

Finalmente, el acuerdo de amistad y comercio con Inglaterra no se concretó. El problema radicó en que Parish decidió subordinar cualquier tratado a un entendimiento previo entre el Paraguay y Buenos Aires:

Pero con el fin de promover dichas relaciones es preciso que el que suscribe advierta que la posición geográfica del Paraguay hace absolutamente necesario que en primer lugar se verifique algún acuerdo preliminar ente el gobierno de dicho Estado y las Provincias Unidas del Río de la Plata, por medio de cuyos territorios tiene que pasar todo comercio extranjero ${ }^{644}$.

Gran Bretaña no estaba dispuesta a concretar acuerdos con el doctor Francia en detrimento de sus relaciones con Buenos Aires, uno de sus principales aliados en la región. Pero esto no significaba que despreciaba la posibilidad de explotar los recursos del Paraguay.

En 1828, Parish reiteró su interés en “asegurar una vez más una intercomunicación con aquel rico país y el resto del mundo" ${ }^{445}$. Posiblemente, lo hizo basado en un informe confidencial que el agente inglés presente en Corrientes, Mr. Hope, había remitido el año anterior: "Supongo, si el tráfico se abriera, cerca de un millón y medio de dólares (es decir, pesos) serían el valor de las manufacturas británicas que podrían introducirse allí anualmente" $" 646$.

El Dictador estaba dispuesto a comerciar, pero siempre que eso no amenazase la independencia política del nuevo Estado que estaba en desarrollo. Mantuvo este concepto durante todo su mandato.

En suma: el doctor Francia, controlando el poder con mano de hierro y en medio de una situación crítica en nivel regional, consiguió imponer y, hasta cierto punto, consolidar la independencia nacional, principal tarea política de la revolución democrático-burguesa en curso. Y, a raíz de una combinación de circunstancias externas e internas, debió hacerlo a partir de un modelo nacionalista y proteccionista -que muchos autores liberales tildan de

${ }^{643}$ Villamayor a Parish, 26/01/1825, citado en: WILLIAMS, John Hoyt. Woodbine Parish and the "opening" of Paraguay. Proceedings of the American Philosophical Society, Philadelphia, v. 116, n. 4, p. 348, 1972.

${ }^{644}$ WHITE, Richard Alan [1984]. La Primera Revolución Popular en América..., op. cit., pp. 177-179.

${ }^{645}$ WILLIAMS, John Hoyt. Woodbine Parish and the "opening" of Paraguay..., op. cit., p. 348.

${ }^{646}$ Ibídem. 
"aislado" o "cerrado-; un modelo basado en la intervención y el control estatal, y no en el laissez faire, que se expresó en otras medidas de carácter económico.

\subsection{La expropiación y el terror del nuevo régimen contra las fuerzas contrarrevolucionarias}

La inestabilidad del comercio regional generó una gravísima crisis financiera. A esto se sumó una oposición creciente al gobierno, que no cedía a la extorsión porteña y del propio Litoral. Falto de recursos, el dictador Francia se vio forzado a confiscar propiedades y otro tipo de bienes, además de aplicar fuertes multas a todo aquel que él juzgase enemigo, real o potencial, de la independencia: la Iglesia católica, los españolistas, porteñistas, artiguistas, etc. En sí, esto no sería algo novedoso; en otros procesos independentistas también se dieron confiscaciones y multas contra individuos o sectores sociales reaccionarios, realistas o locales. Lo singular del caso paraguayo es que las propiedades confiscadas prácticamente no se vendieron o se "repartieron", sino que fueron mayormente nacionalizadas.

El 20 de setiembre de 1824, el doctor Francia suprimió todas las órdenes religiosas por entonces franciscanos, dominicos y mercedarios- y expropió sus bienes en favor del patrimonio del Estado:

[...] todas las propiedades o pertenencias de cualquier clase de los conventos suprimidos son y se reputarán en adelante propiedades del Estado [entendiéndose por esto] todos los bienes raíces o muebles de cualquier especie o clase pertenecientes a su convento o iglesias, como también las acciones, créditos, censos, memorias pías, capellanías u otras fundaciones o derechos que tengan de cualquier modo [y] que correspondan a sus conventos o iglesias, entendiéndose lo mismo con sus libros, documentos o papeles sean los que fuesen ${ }^{647}$.

El clero paraguayo, entonces, debió sujetarse al Estado nacional, no más a Roma. Al final de su mandato, la República se había apropiado, solo "en dinero", de 37.580 pesos de 39 iglesias y de dos fondos religiosos ${ }^{648}$.

Lo importante de esta medida radica en que la Iglesia, una de las instituciones más poderosas materialmente y fuente de legitimidad del españolismo, fue descabezada. De ese modo, Rodríguez de Francia imprimió a la revolución paraguaya de independencia un corte anticlerical sumamente avanzado y progresivo. No se puede perder de vista el poder del clero y su posición durante el proceso independentista. Vale citar la síntesis que John Lynch ensaya en relación con esto último: “en 1808 todos los obispos fueron realistas y, en el curso

\footnotetext{
${ }^{647}$ Decreto de supresión de los conventos de regulares en toda la República, 20/09/1824. ANA-SH, v. 237, n. 7. ${ }^{648}$ WHITE, Richard Alan [1984]. La Primera Revolución Popular en América..., op. cit., p. 96.
} 
de la guerra, proespañoles; la Iglesia fue muy importante para hacer carrera, los obispos y las órdenes religiosas constituyeron un gran conjunto de influencias" ${ }^{249}$.

En 1814, el gobierno dispuso que los españoles no pudieran casarse con mujeres blancas, sino únicamente "con indias de los pueblos, mulatas conocidas y reputadas públicamente por tales y las negras" ${ }^{650}$. Complementando esa medida, el Estado se adjudicaría sin trámite la herencia de todo español o extranjero que muriera sin hijos nacidos en el Paraguay. Así, esta resolución, además de contribuir a generar un clima de persecución entre los europeos, pretendía limitar el número de españoles que pudieran dejar herederos legales, de tal suerte que sus bienes pasaran a engrosar el patrimonio público.

Según estimaciones de White, las multas y "contribuciones" forzosas contra los antiguos sectores hegemónicos de la clase dominante alcanzaron, por lo menos, 825.794 pesos hasta 1840. Para hacerse una idea de la magnitud de esa forma de represión, la suma equivalía a los gastos para mantener todo el aparato de gobierno, incluyendo el ejército, por un período de seis o siete años ${ }^{651}$. En la siguiente tabla, podemos apreciar la evolución y magnitud de estas medidas.

Tabla 3. Apropiaciones del Estado [1816-1840].

\begin{tabular}{lrc}
\hline \multicolumn{1}{c}{ Concepto } & Monto & Porcentaje \\
\hline Herencias del Estado & 156.632 & $18,97 \%$ \\
\hline Confiscaciones a la Iglesia católica & 60.971 & $7,38 \%$ \\
\hline Colecta de deudas & 68.937 & $8,35 \%$ \\
\hline Multas y confiscaciones & 294.690 & $35,69 \%$ \\
\hline Contribuciones forzosas & 244.564 & $29,62 \%$ \\
\hline Total en pesos & 825.794 & $100 \%$ \\
\hline
\end{tabular}

Fuente: WHITE, Richard Alan. La Primera Revolución Popular en América ..., op. cit., pp. 111-112.

En 1816, el Congreso de Tucumán designó Director Supremo de las Provincias Unidas del Río de la Plata al general Juan Martín de Pueyrredón ${ }^{652}$. El doctor Francia

649 LYNCH, John. El trono y el altar, soportes del imperio. El País, 13/05/1988. Disponible en: $<$ https://elpais.com/diario/1988/05/13/cultura/579477603 850215.html >, consultado el 27/01/2020.

${ }^{650}$ Decreto de los Cónsules del 1 de julio de 1814. Archivo de la Curia Metropolitana de Asunción, Sección Histórica, publicada en: RODRÍGUEZ ALCALÁ, Guido; DURÁN ESTRAGÓ, Margarita; ROMANO GARCÍA, Martín (Org.). FRANCIA: [1762-1816]..., op. cit., pp. 480-481.

${ }^{651}$ WHITE, Richard Alan [1984]. La Primera Revolución Popular en América ..., op. cit., p. 113.

${ }^{652}$ Juan Martín de Pueyrredón y O'Dogan [1777-1850]: militar y político argentino que se desempeñó como Director Supremo de las Provincias Unidas del Río de la Plata entre el 9 de julio de 1816 y el 9 de junio de 1819. 
aumentó el estado de alerta: "ahora hay que tenerles más cuidado a los porteños porque han sometido a sus miras a esas pobres provincias y ahora han de intentar reducir al Paraguay"653.

En efecto, Pueyrredón se propuso "pacificar" Santa Fe, Entre Ríos, Corrientes, y dominar el Paraguay:

El término de la expedición en el Entre Ríos por su situación aparece que debe ser Corrientes, incorporadas las tropas de esta provincia del modo que dejo referido, cuando menos el ejército se compondrá de cinco mil hombres con armas sobradas. Aquí, pues, es donde se presenta el campo más hermoso y fácil de recoger el mejor fruto de todo el trabajo, subyugando a la rebelde provincia del Paraguay [...] Prescindiendo de todas las ventajas que resultaría de reunir esta numerosa provincia y de salir de la zozobra en que nos tiene la equívoca conducta de su déspota en punto a patriotismo. Le sigue la principal en el escarmiento de los demás pueblos dando al través con la piedra del escándalo, o el plantel de la disidencia como ha sido y es este. Mientras no se ponga en el orden debido al Paraguay, no cesará el clamoreo de los mal intencionados, de los ignorantes y principalmente de Entre Ríos, de que los paraguayos son los que entienden ${ }^{654}$.

La renovada idea de una incursión militar contra el Paraguay, en verdad, entusiasmaba al jefe de las Provincias Unidas:

Lejos de desagradar a nuestra gente la internación a aquel país, toda ella iría gustosísima, como que es el destino más rico hoy de toda la América, así en las cajas de gobierno, donde debe haber un millón a millón y medio de pesos ${ }^{655}$.

En función de estos planes, a través del decreto del 8 de enero de 1817, el gobierno de Buenos Aires prohibió la introducción de cualquier tipo de tabacos del Paraguay “... hasta la incorporación del Paraguay" ${ }^{656}$. Pueyrredón dispuso además el bloqueo de todo comercio y comunicación, así como la confiscación de propiedades pertenecientes a residentes paraguayos en la jurisdicción bajo su gobierno ${ }^{657}$.

Así, la crisis regional, combinada con la hostilidad de porteños y artiguistas, hizo que las exportaciones cayeran de 391.233 pesos en 1816 a 57.498 pesos en $1820^{658}$. Fue en medio de ese descalabro comercial que el sector burgués "tradicional", exportador e importador, que había sido duramente golpeado pero no derrotado en 1814, conspiró para asesinar al Dictador. La "gran conspiración" de 1820 fue resultado de una creciente disconformidad de aquellos sectores de la sociedad que lo habían perdido casi todo con el ascenso político del doctor Francia: los cuerpos de jóvenes oficiales-terratenientes criollos y la anteriormente

\footnotetext{
${ }^{653}$ RIBEIRO, Ana. Gaspar Rodríguez de Francia..., op. cit., p. 45.

${ }^{654}$ ARECES, Nidia; GONZALEZ DE BOSIO, Beatriz. El Paraguay durante los gobiernos de Francia y de los López..., op. cit., pp. 28-29.

${ }^{655}$ RIBEIRO, Ana. Gaspar Rodríguez de Francia..., op. cit., p. 47.

${ }^{656}$ WHITE, Richard Alan [1984]. La Primera Revolución Popular en América ..., op. cit., p. 82.

${ }^{657}$ Ibídem.

658 Ídem, p. 83.
} 
poderosa corporación comerciante, mayormente compuesta por españoles ${ }^{659}$. La caída del comercio, producto de la inestabilidad en el Plata, en general y de la hostilidad hacia el Paraguay, en particular, convulsionaba el ambiente político en Asunción.

Como explicamos anteriormente, la defección de la burguesía paraguaya tradicional frente al problema de la independencia absoluta y la construcción de un Estado nacional, fue el motivo principal de que la resolución de estos dos problemas fundamentales recayera en manos de un sector de propietarios rurales menos vinculados al mercado externo, que encontró en el doctor Francia su principal exponente político, y que, para imponerse, debió derrotar y después aplastar a la facción más conservadora de la burguesía nativa. En esas circunstancias "anormales", la dinámica de clases del proceso hizo que "el Estado, en muchos terrenos, cumpliera el papel que debía cumplir una clase capitalista comercial" 660 .

Por este motivo, opinamos que el historiador White se equivoca cuando afirma que "la Gran Conspiración no fue un conflicto intraclases sino más bien una confrontación de clases, que confrontó los intereses de la elite -el 5\% de la población- contra el bienestar del 95\% restante de los paraguayos $[\ldots]^{\prime \prime 661}$.

El problema de la interpretación de White, incuestionablemente uno de los más rigurosos investigadores -y defensores- de la obra de Francia, parte de la premisa falsa de que la revolución fue "social", es decir, "entre clases". Para nosotros, como aseguramos anteriormente, se trató de una revolución política, es decir, de una lucha entre sectores de las clases propietarias.

El plan contrarrevolucionario de 1820 fue descubierto y el Dictador respondió con una dura represión. Las mazmorras se llenaron de presos y torturados. A partir de cartas interceptadas en 1821, Francia se convenció de que los conspiradores estaban de acuerdo con el caudillo entrerriano Francisco Ramírez, que amenazó abiertamente con invadir el Paraguay $^{662}$. A inicios de ese año, el Dictador ordenó a los aproximadamente trescientos peninsulares de la capital y sus alrededores que comparecieran en la plaza central, donde fueron todos arrestados. La mayoría de estos españoles solo fue liberada año y medio

\footnotetext{
${ }^{659}$ WILLIAMS, John Hoyt. The 'Conspiracy of 1820' and the Destruction of the Paraguayan Aristocracy. Revista de Historia de América, México, n. 75-76, p. 142, 1973.

${ }^{660}$ NÚÑEZ, Ronald León. Revolución y Genocidio: El mal ejemplo de la independencia paraguaya y su destrucción. Asunción: Arandurã, 2011, p. 93.

${ }^{661}$ WHITE, Richard Alan [1984]. La Primera Revolución Popular en América ..., op. cit., p. 115.

${ }^{662}$ Francisco Ramírez, antiguo lugarteniente de Artigas. Se rebeló contra su jefe, provocando la huida de Artigas y su asilo en el Paraguay, en setiembre de 1820. En 1821, Ramírez amenazó invadir el Paraguay, reclamando la entrega de Artigas. Ramírez tuvo que abandonar sus planes, obligado por las luchas civiles en la Argentina, y poco después moriría en el campo de batalla.
} 
después, tras pagar una "contribución" colectiva de 150.000 pesos para financiar una expedición paraguaya con la finalidad de "aliviar" el bloqueo del comercio internacional ${ }^{663}$.

Finalmente, los principales conspiradores fueron fusilados, entre ellos próceres de la talla de Fulgencio Yegros, ex cónsul de la República. Pedro Juan Caballero se suicidó en su celda. Las propiedades de los acusados fueron confiscadas, engrosando aún más el patrimonio estatal ${ }^{664}$. La "gran conspiración" de 1820, al tiempo que marcó el auge del terror y de las confiscaciones del Dictador, posibilitó la consolidación definitiva de su régimen político.

\subsection{La política mercantilista: prohibición de la exportación de metales preciosos y control del comercio exterior}

Otra particularidad del proceso independentista paraguayo es que el aparato estatal, férreamente controlado por el poder unipersonal de Francia, pasó a regular el comercio, tanto externo como interno, de los principales rubros de la economía rural del país: la yerba mate, el tabaco, los cueros. Los primeros dos productos siguieron representando más de $90 \%$ de las exportaciones ${ }^{665}$. La venta de maderas duras, con alta demanda para construcciones, directamente se declaró un monopolio estatal.

La fuerte intervención del Estado en la economía obedece principalmente, como explicamos, a que tras el derrocamiento del poder español la clase comerciante y terrateniente nacional era muy débil y dependiente. Se había conformado en las entrañas del régimen colonial como socia menor de los españoles, incluso se había fortalecido en las últimas tres décadas con las reformas borbónicas, pero seguía siendo frágil e inexperta; estaba "en formación”. Este problema se agravó aún más cuando ese sector volcado al comercio exterior, el que poseía más acumulación en todos los terrenos, desertó de la causa independentista y debió ser duramente reprimido. El poder, como analizamos, pasó a manos de la facción ligada a la producción nacional para el mercado interno y la pequeña economía

${ }^{663}$ WILLIAMS, John Hoyt. The 'Conspiracy of 1820 '..., op. cit., p. 148.

${ }^{664}$ Sobre la conspiración de 1820, ver: Proceso de conspiración contra el Gobierno en 1820. ANA-TP, v. 542, n. 1, publicado en: RODRÍGUEZ ALCALÁ, Guido; DURÁN ESTRAGÓ, Margarita; ROMANO GARCÍA, Martín (org.). FRANCIA: [1831-1840]..., op. cit., pp. 1683-1688; CHAVES, Julio [1942]. El Supremo Dictador..., op. cit., pp. 271-287; WHITE, Richard Alan [1984]. La Primera Revolución Popular en América..., op. cit., pp. 94-115; VIOLA, Alfredo. Dr. José Gaspar Rodríguez de Francia..., op. cit., pp. 115171.

${ }^{665}$ ANDRADA E SILVA, Raul de. Ensaio sobre a ditadura do Paraguai: 1814-1840. São Paulo: Coleção Museu Paulista, 1978, pp. 212-213. 
mercantil, que evidentemente poseía menos acumulación y experiencia en los asuntos públicos que aquellos sectores tradicionales. La debilidad de la burguesía nacional, todavía "en formación", hizo que la máquina estatal [burguesa], para compensar esa fragilidad estructural, cumpliera un papel que, normalmente, cabría a una clase dominante consolidada.

Por otro lado, con la irregularidad, cuando no la suspensión completa del comercio exterior, escaseaban los recursos para costear el aparato del Estado, sobre todo para sostener a las fuerzas armadas.

El Estado, entonces, nacionalizó tierras y bienes y prohibió la exportación de los escasos metales preciosos ${ }^{666}$. Se llegó al punto en que solo las armas y las municiones podían ser pagadas "en dinero" 667 ; todo lo demás debía negociarse mediante el trueque con productos primarios nacionales ${ }^{668}$. En 1829, el Dictador insistía en esa orden: "a nadie se permite vender el valor ni de medio real a dinero y todo se hace a puro cambio" ${ }^{069}$.

Sin embargo, la medida económica más importante en este terreno consistió en que el gobierno controló el comercio exterior.

Con los ríos cerrados, el Dictador abrió dos “válvulas de escape”, en Itapúa y Pilar, por donde fluyó un mínimo comercio externo. Pero la situación era tan precaria que el propio Francia establecía, personalmente, la equivalencia para el intercambio de productos nacionales por extranjeros. Él mismo examinaba y hacía el "aforo" (tasación) de las muestras de las mercaderías que enviaban sus funcionarios desde esos centros de comercio con el exterior. Luego remitía una orden con la determinación sobre qué productos interesaban al Estado, qué impuestos debían pagar, además de establecer los precios -a partir de su equivalencia con los frutos del país-y las condiciones de la transacción ${ }^{670}$.

El derecho de introducción fue de 15\% hasta 1835, cuando disminuyó a 13\% ${ }^{671}$; el de exportación, 9\%. El Estado participaba con producción propia en el comercio exterior: en 1837 sus exportaciones alcanzaron $35 \%$ del total de las ventas nacionales y, un año después, llegaron a $65 \%{ }^{672}$. Sin embargo, el comercio privado no se extinguió, como comúnmente se

\footnotetext{
${ }^{666}$ Decreto del 13/11/1814. ANA-SH, v. 223, n. 4. El castigo a los infractores consistía en una multa equivalente al valor extraído, pudiendo implicar incluso la prisión.

${ }^{667}$ Decreto del 08/12/1816. ANA-SH, v. 226, n. 1.

${ }^{668}$ Oficio al comandante de Pilar, del 04/10/1825. ANA-NE, v. 3107, publicado en: RODRÍGUEZ ALCALÁ, Guido; DURÁN ESTRAGÓ, Margarita; ROMANO GARCÍA, Martín (Org.). FRANCIA: [1817-1830]..., op. cit., p. 887.

669 Oficio al delegado de Itapúa, del 13/03/1829. ANA-SH, v. 240, n. 2.

${ }^{670}$ Oficio al delegado de Itapúa, del 05/06/1829. ANA-SH, v. 240, n. 2.

${ }^{671}$ Decreto del doctor Francia del 26/10/1835. Archivo Nacional de Asunción - Sección Civil y Judicial (ANASC), v. 68, n. 108 .

${ }^{672}$ WHITE, Richard Alan [1984]. La Primera Revolución Popular en América ..., op. cit., p. 168.
} 
afirma. En 1816, el comercio particular, aunque controlado, representó 38\% del total. En 1829 se elevó a $83 \%$, proporción que se mantendría en 1832 y $1835^{673}$. Los comerciantes privados solo podían realizar transacciones, externas o internas, con licencias expedidas por el gobierno. Los yerbales públicos, por ejemplo, podían ser explotados por empresarios particulares mediante una licencia y con la obligación de pagar 3\% de lo producido en concepto de alquiler.

La principal condición para el otorgamiento de licencias comerciales consistía en que los productos a ser intercambiados debían ser ganado o frutos de las propias cosechas de los solicitantes. El Dictador pensaba que, de esta manera, estimularía la producción interna, además de disminuir la participación de intermediarios.

Para evitar dudas sobre la introducción de negociantes del distrito de la Subdelegación a Itapúa, advierto que la permisión para concederles licencia debe entenderse llevando a expender sus ganados o los frutos de sus propias cosechas, pero no con haciendas acopiadas y mercadas de otros ${ }^{674}$.

En 1823 dispuso que un tercio de toda la yerba comercializada en Itapúa por aquellos que habían obtenido licencias, debía ser comprada de los almacenes del Estado en Asunción ${ }^{675}$. Es decir, el Estado se concedía licencias a sí mismo y, así, se aseguraba una porción del comercio exterior.

En el mercado interno, las llamadas tiendas o almacenes del Estado comerciaban una parte de los bienes importados. Esas ventas, por ejemplo, representaron 38\% de los ingresos públicos en 1834. Nótese que los militares constituían una porción importante del mercado consumidor de bienes importados y de la producción del Estado. En 1832, las ventas del Estado a las tropas representaron 36\% de las recaudaciones totales, aumentado a $41 \%$ el año siguiente ${ }^{676}$. A medida que la situación financiera mejoró, el Estado disminuyó impuestos a los productores rurales. Entre 1816 y 1823, los impuestos alcanzaron un promedio de 54,9\% de todo lo recaudado, mientras que las ventas públicas eran responsables por $12,4 \%$. Sin embargo, en los últimos 12 años del gobierno del doctor Francia, los impuestos cayeron a 19,4\%, mientras que las ventas del Estado crecieron a 50,2\% de todas las rentas públicas ${ }^{677}$.

En apretada síntesis: la frágil burguesía nacional, por su extrema debilidad, debió apoyarse en un Estado "fuerte", intervencionista y proteccionista que, ante la escasez de

\footnotetext{
673 Ídem, p. 170.

${ }^{674}$ Orden de Francia, del 13/03/1825. ANA-NE, vol. 3107, publicado en: RODRÍGUEZ ALCALÁ, Guido; DURÁN ESTRAGÓ, Margarita; ROMANO GARCÍA, Martín (Org.). FRANCIA: [1817-1830]..., op. cit., p. 875.

${ }^{675}$ Decreto de Francia, del 12/09/1823. ANA-SH, v. 237, n. 1.

676 WHITE, Richard Alan [1984]. La Primera Revolución Popular en América ..., op. cit., pp. 229-232.

677 Ídem, p. 134.
} 
recursos y el peligro externo, aplicó una política básicamente mercantilista: acaparamiento del metálico disponible; control de los principales rubros del comercio exterior; regulación y participación directa en el mercado interno. Este modelo, como veremos, distaba mucho de la política de librecambio y abertura aduanera que imperaba en el Imperio del Brasil y en el resto del Río de la Plata ${ }^{678}$.

\subsection{El problema de la tierra: nacionalización y arrendamientos}

La cuestión agraria, como se sabe, es un problema fundamental en cualquier revolución burguesa. Para socavar el poder económico de los opositores a la independencia -o a su gobierno, que para Francia era la misma cosa-, y al mismo tiempo hacerse de rentas indispensables para mantener el funcionamiento del Estado nacional, sobre todo el mantenimiento del ejército regular, el gobierno confiscó grandes superficies de tierra.

A finales de la década de 1820 -a partir de la expropiación de los conspiradores (1821), de la Iglesia católica (1824), y de las tierras cuyos dueños no presentaron títulos de propiedad (1825)-, el Estado concentró más de la mitad de las tierras de la región central del país. Hacia 1840, con la incorporación de la región chaqueña al patrimonio estatal, alrededor de $80 \%$ de la tierra había sido nacionalizada.

Si bien las tierras áridas del Chaco siguieron básicamente inexploradas, en la región oriental el Dictador fortaleció un sistema de empresas estatales agropecuarias que denominó Estancias de la República, que comprendían campos de pastoreo, montes ricos en madera de construcción, yerbales, y tierras cultivables. Hacia 1818, el gobierno había construido una red de cincuenta estancias estatales -tres de ellas eran conjunto de varias- y veintidós pequeños puestos ganaderos ${ }^{679}$. Las estancias debían, principalmente, proveer lo necesario para sostener el ejército: caballos, ganado en pie, charque, además de mandioca y yerba. El mismo ejército proveía el grueso de la fuerza de trabajo en las estancias públicas. El excedente era comercializado luego en el mercado interno, a través de los almacenes del Estado, y en el externo vía Itapúa y Pilar. Se estima que a finales de la década de 1840 existían en las estancias públicas más de 270.000 cabezas de ganado ${ }^{680}$.

\footnotetext{
${ }^{678}$ Para el caso brasileño, consultar: MANCHESTER, Alan K [1933]. Preeminência inglesa no Brasil. São Paulo: Brasiliense, 1973.

${ }^{679}$ Durante la Colonia existieron las llamadas "estancias del Rey”, con objetivos similares, pero que no habrían pasado de dos. Sobre este dato, consultar: PASTORE, Mario. Crisis de la Hacienda pública..., op. cit., p. 170. ${ }^{680}$ Oficio al delegado de Itapúa, del 03/09/1830. ANA-SH, v. 240, n. 2, publicado en: RODRÍGUEZ ALCALÁ, Guido; DURÁN ESTRAGÓ, Margarita; ROMANO GARCÍA, Martín (Org.). FRANCIA: [1817-1830]..., op. cit., p. 1083.
} 
Otra parte de las tierras nacionalizadas se destinó a familias campesinas, que accedieron a la tierra básicamente a través de un sistema de arrendamientos que generó rentas al Estado y contribuyó a la producción agrícola y a la colonización de regiones menos pobladas. Los arrendamientos se hicieron a precios moderados y sin término fijo. El pago al Estado era anual ${ }^{681}$. La condición básica consistía en ocupar efectivamente las parcelas, cultivarlas, o destinarlas a la cría de ganado ${ }^{682}$.

En este sentido, para el Dictador, las "mercedes de tierra" no representaban una adjudicación "puramente gratuita":

[...] fueron adjudicadas a efecto de que los mercedarios pasasen con sus familias a establecerse formalmente en ellas, a fin de que las poblaciones de las villas en donde respectivamente debían domiciliarse como vecinos de ellas, tomasen incremento y se fuesen aumentando con gente suficiente para su resguardo y demás servicios necesarios ${ }^{683}$.

El no cumplimiento de la condición de poblarlas era motivo suficiente para la anulación de la concesión ${ }^{684}$. Si bien esta política facilitó el acceso a la tierra para quien quisiera trabajarla, Mário Maestri incurre en una exageración cuando afirma que: "a população camponesa hispano-guarani [chacareros], que conheceria então por décadas situação de literal acesso livre a pequenas explorações agrícolas [chácaras]" ${ }^{685}$. El acceso no era libre sino sujeto, en primer lugar, al pago del arriendo.

Los beneficiados, según explicó el propio Francia en 1828, debían pagar una "moderada composición", que era anual y que debía efectuarse "en dinero" ${ }^{686}$. Los lotes más pequeños costaban poco más de dos pesos anuales y los más grandes cerca de cuatro pesos anuales $^{687}$, mientras que las parcelas mayores, que muchas veces eran parte de las Estancias de la República, en promedio costaban veinte pesos por año.

${ }^{681}$ Orden de Francia, del 25/08/1835. ANA-SC, v. 1369, n. 1, publicado en: RODRÍGUEZ ALCALÁ, Guido; DURÁN ESTRAGÓ, Margarita; ROMANO GARCÍA, Martín (Org.). FRANCIA: [1831-1840]..., op. cit., p. 1474.

${ }^{682}$ Decreto del 14/02/1816. ANA-SC, v. 465, n. 8, publicado en: RODRÍGUEZ ALCALÁ, Guido; DURÁN ESTRAGÓ, Margarita; ROMANO GARCÍA, Martín (Org.). FRANCIA: [1762-1816]..., op. cit., p. 407. Ver también el otorgamiento de la merced de un terreno a José Céspedes. ANA-SC, v. 371, publicado en: Ídem, p. 435. Otro ejemplo: Orden del Dr. Francia, del 10/06/1816. ANA-SC, v. 71, publicado en: Ídem, p. 427.

${ }^{682}$ Decreto del 03/11/1828. ANA-SC, v. 71, publicado en: Ídem, p. 973.

683 Ibídem.

${ }^{684}$ Decreto del 01/07/1816. ANA-SC, v. 1380, n. 14, publicado en: Ídem, p. 432.

685 MAESTRI, Mário. 150 anos da destruição do Estado-nação paraguaio pelo exército brasileiro. s/f. Disponible en: $<$ https://www.curitibasuburbana.com/noticias/150-anos-da-destruicao-do-estado-nacaoparaguaio-pelo-exercito-brasileiro/>, consultado el 27/01/2020.

${ }_{686}$ Orden de Francia, del 22/05/1837. ANA-SH, v. 71, n. 18.

${ }^{687}$ Oficio al comandante de Pilar, del 11/10/1826. ANA-NE, v. 637, publicado en: RODRÍGUEZ ALCALÁ, Guido; DURÁN ESTRAGÓ, Margarita; ROMANO GARCÍA, Martín (org.). FRANCIA: [1817-1830]..., op. cit., p. 926. 
Para tener una referencia acerca de los precios de los arrendamientos, el sueldo de un capataz, según un decreto de marzo de 1816, era de "cincuenta pesos anuales" ${ }^{688}$. El de un peón oscilaba entre los dos pesos fuertes ${ }^{689}$ y un peso y medio mensuales ${ }^{690}$, el de un soldado raso, seis pesos; el costo de una res estaba entre dos y cuatro pesos en 1826.

El historiador estadounidense Richard A. White estimó, a partir de la documentación disponible, que en 1839 existían 6.484 lotes de entre cinco y diez hectáreas arrendados por el Estado, que beneficiarían a aproximadamente 49.278 personas $^{691}$. Si tomamos como base el censo de 1846, que arrojó 238.862 habitantes $^{692}$, y suponemos que se mantuvo esa estimación de beneficiarios, el sector arrendatario representaría al menos 20\% de la población.

La política de arrendamientos, a su vez, respondía a una realidad que impuso la interrupción del comercio exterior. Este hecho, además de arruinar al sector burgués dedicado a la exportación de yerba mate y tabaco, hizo que una masa de antiguos peones y marineros de los ríos retornara a las chacras, fortaleciéndose con ello la economía de subsistencia y, paulatinamente, la pequeña producción mercantil.

Pero no solo se fortaleció la economía de subsistencia sino que la reorientación hacia el mercado interno, con el tiempo favoreció incipientes iniciativas manufactureras. Los médicos suizos Rengger y Longchamp, que escribieron sobre su estadía en el país, afirmaron:

\begin{abstract}
La interrupción del comercio produjo otro resultado feliz, que fue el acrecentamiento de la industria manufacturera. Hasta entonces solo se había servido del algodón para fabricar una sola especie de tela delgada que servía para hacer camisas, pero la necesidad precisó a los fabricantes a labrar tejidos para toda suerte de ropajes. Los ponchos y las mantas para los caballos, que eran de lana, y costaban crecidas sumas que salían anualmente del Paraguay, se fabricaron entonces en el país: hasta los telares se perfeccionaron [El aislamiento y el terror hicieron que] los herreros se hicieran cerrajeros, armeros y espaderos; los zapateros, silleros, guarnicioneros; los plateros, fundidores; y los albañiles, arquitectos $[\ldots]^{693}$.
\end{abstract}

\footnotetext{
${ }^{688}$ Decreto que nombra capataz de la estancia de la República de Surubí a Juan José Ruidias, del 27/03/1816. ANA-SH, v. 226, n. 2.

${ }^{689}$ Orden de pago emitida por el Dr. Francia del 19/06/1816. ANA-NE, v. 2555, publicada en: RODRÍGUEZ ALCALÁ, Guido; DURÁN ESTRAGÓ, Margarita; ROMANO GARCÍA, Martín (Org.). FRANCIA: [17621816]..., op. cit., p. 434.

${ }^{690}$ Orden de pago del 17/02/1816. ANA-NE, v. 1823, publicado en: Ídem, p. 407. Para otros ejemplos de salarios rurales ver también: ANA-NE, v. 739.

${ }^{691}$ WHITE, Richard Alan [1984]. La Primera Revolución Popular en América ..., op. cit., p. 141.

${ }^{692}$ Según datos corregidos por John Hoyt Williams.

${ }^{693}$ RENGGER, Johann; LONGCHAMP, Marcelin. Ensayo histórico sobre la Revolución del Paraguay..., op. cit., p. 72-74.
} 
En suma, podemos afirmar que el arriendo de las tierras nacionalizadas facilitó el acceso a la tierra de una parcela importante de la población rural, que reforzó la base social de la dictadura y, aunque con peso distinto, la de los dos López.

De manera esquemática, las formas de utilización de la tierra durante el régimen del doctor Francia fueron:

I. Las tierras arrendadas directamente por el Estado (bajo el régimen enfitéutico) para unidades agrícolas (chacras) que beneficiaron a una parte de la población rural;

II. La explotación ganadera directamente estatal, principalmente a través del sistema de Estancias de la República;

III. Las tierras bajo el régimen especial correspondientes a los Pueblos de Indios de las antiguas Misiones jesuitas;

IV. Las tierras comunales o municipales, pertenecientes a los distintos pueblos de la República.

V. Las grandes estancias ganaderas privadas;

VI. Las pequeñas y medianas explotaciones (chacras) que pertenecían a campesinos "libres" de tributos (a partir del proceso de desaparición de las encomiendas).

Ahora bien, si los propios historiadores liberales reconocen que entre 80 y $90 \%$ de las tierras fueron nacionalizadas y una buena parte de ellas fue arrendada a un sector del campesinado, es curioso que Ignacio Telesca opine que:

No hubo reforma agraria durante el gobierno de Francia, tampoco durante el de López. Un caso testigo como el de Paraguarí, donde casi el 100\% de las tierras eran arrendadas y de un tamaño inferior a dos hectáreas en su mayoría, nos pone en alerta sobre el control de las mismas que el Estado poseía ${ }^{694}$.

Por supuesto, podemos discutir qué significa "reforma agraria". Es posible que, para Telesca, la nacionalización no represente una solución efectiva del problema agrario, y tal vez se incline a concebir ese concepto como el reparto o cesión en propiedad de parcelas de tierras a los campesinos pobres u otras variantes. Pero el hecho que el propio Telesca revela con las cifras de Paraguarí no hace sino confirmar el impresionante grado de nacionalización de las tierras en el Paraguay, previo a la Guerra Grande. Y, como analizaremos más adelante,

\footnotetext{
${ }^{694}$ TELESCA, Ignacio. Antes y después. Del amor al espanto. Construcciones históricas e historiográficas del Paraguay del siglo XIX. In: GARAVAGLIA, Juan; FRADKIN, Raúl. A 150 años de la Guerra de la Triple Alianza contra el Paraguay. Buenos Aires: Prometeo Libros, 2016, p. 186.
} 
desde la perspectiva marxista, la nacionalización es la vía más avanzada de resolver, a la manera burguesa y en la época histórica de ascenso del capitalismo, el problema agrario.

Sin embargo, tampoco debe incurrirse en la falsa afirmación de algunos autores que sostienen que se "erradicó" el latifundio y se "aniquiló a la oligarquía"695. Eso no fue así. Las confiscaciones y el "terror" -independientemente de los "excesos"-, fueron medidas necesarias contra la resistencia de un sector burgués reaccionario, enemigo de la independencia, es decir, de la principal tarea planteada. Pero la represión de Francia fue selectiva, enfocada en individuos o familias de "conspiradores", que sin duda eran poderosos económicamente, pero no fue -ni podía ser- una represión contra las clases propietarias como un todo.

Los propietarios, rurales o urbanos, que no cuestionaron el régimen, nunca fueron molestados por el Dictador. Lázaro Rojas Aranda ${ }^{696}$, uno de los hombres más ricos del Paraguay, por ejemplo, nunca fue incomodado ${ }^{697}$. Don Carlos Antonio López, otro hacendado que se retiró al interior, tampoco. O bien el caso de José Mauricio Casal, rico estanciero de Caapucú, del que un observador extranjero anotó:

\begin{abstract}
El padre de don Mauricio había sido uno de los estancieros más ricos del país durante el antiguo régimen colonial, pues poseía ocho estancias muy grandes. Esas estancias tenían de tres a ocho leguas cuadradas de extensión y millares de cabezas de ganado [...] En aquella casa, la vajilla de plata debía pesar centenares de libras, sino toneladas; en ella se guardaban las compras de las sedas, brocados y damascos más finos y bordados con hilos de plata y oro [...] Don Mauricio se convirtió en el heredero de ese gran patrimonio en los primeros tiempos del régimen de Francia [...] Durante la larga estadía de Francia en el poder, don Mauricio pudo sustraerse al destino de casi todos los de su clase en el país, y sobrevivió al Dictador. Nunca provocó la enemistad ni las sospechas de Francia sino que, por el contrario (...) se congració con él mediante sus liberales donaciones de vacas y caballos al Estado $^{698}$.
\end{abstract}

Está claro que no solo no se "aniquiló a la oligarquía" sino que un sector de estancieros sostenía el régimen de Francia, porque, al fin y al cabo, se transformó en garantía de estabilidad política y "paz" social.

\footnotetext{
${ }^{695}$ FOGEL, Ramón. La reforma agraria encarada por el gobierno de Rodríguez de Francia [1814-1840]. In: CORONEL, Jorge (Org.). La república francista del Paraguay. Escritos en homenaje a Richard Alan White. Asunción: Arandurã, 2017, p. 12.

${ }^{696}$ Lázaro Rojas Aranda fue el padrino de Francisco Solano López, al que designó luego como principal heredero.

697 RODRÍGUEZ ALCALÁ, Guido. Francia y López. In: SOLER, Lorena, et al. (Org.). Antología del pensamiento crítico paraguayo contemporáneo. Buenos Aires: CLACSO, 2015, p. 526.

${ }^{698}$ WASHBURN, Charles. The history of Paraguay: with notes of personal observations, and reminiscences of diplomacy under difficulties. Boston: Lee and Shepard, 1871, citado en: WHIGHAM, Thomas. La economía de la independencia..., op. cit., p. 116.
} 
Ese sector de propietarios accedía a licencias para comerciar, podía alquilar tierras estatales para sus rebaños, o bien dedicarse a la extracción de yerba mate, que evidentemente mantuvo alta demanda en el mercado interno y, en menor medida, siguió siendo exportada principalmente por la ruta Itapúa-São Borja. Esa dinámica de enriquecimiento a partir del control de la máquina estatal, como veremos después, se agudizará en el régimen de los dos López.

\subsection{El debate sobre la nacionalización de las tierras: ¿medida burguesa o socialista?}

Es común abonar la idea de que el dictador Francia fue una especie de precursor de medidas "protosocialistas", con argumentos que parten del hecho de que su régimen confiscó a sectores reaccionarios y nacionalizó gran parte de las tierras de la República.

Esto nos lleva a una discusión muy interesante y útil, principalmente en medios de izquierdas, sobre cuál es el carácter de esas medidas. Concretamente, la nacionalización de las tierras ¿es una tarea democrático-burguesa o de transición al socialismo?

En primer término, para dilucidar esta cuestión sin caer en anacronismos, es fundamental precisar a qué época histórica nos referimos.

Según el marxismo, en la época del ascenso del capitalismo, marcada por el auge de las revoluciones burguesas, es decir, cuando este modo de producción todavía desarrollaba las fuerzas productivas de la sociedad en general -que es la época histórica en la que se enmarcan los gobiernos de Francia y de los dos López-, la nacionalización de la tierra era una medida de progreso burgués.

Para explicar mejor esta cuestión tan importante, presentamos algunas citas de los escritos de Lenin, uno de los que más elaboró sobre el programa agrario del marxismo. Lenin, evidentemente, escribió centrado en el caso de la revolución rusa y polemizando con otras corrientes de ese país a inicios del siglo XX, pero creemos que en sus planteos hay ciertos criterios que poseen valor general y sirven a la compresión del problema.

Primero, analicemos la definición de la medida en su aspecto económico.

[...] El concepto de nacionalización de la tierra, reducido a la esfera de la realidad económica, es una categoría de la sociedad mercantil y capitalista [...] Bajo las relaciones capitalistas, la nacionalización de la tierra es la entrega de la renta al Estado, ni más ni menos. [...] La nacionalización (en su aspecto puro) presupone 
que el Estado recibe la renta de los empresarios agrícolas, los cuales abonan un salario a los obreros y obtienen el beneficio medio de su capital $[\ldots]^{699}$.

Para Lenin, este problema estaba estrechamente ligado a la teoría de la renta de Marx.

El problema de la nacionalización de la tierra en la sociedad capitalista se divide, pues, en dos partes esencialmente distintas: en el problema de la renta diferencial y de la absoluta. La nacionalización sustituye al poseedor de la primera y socava la existencia misma de la segunda. Consiguientemente, la nacionalización es, por un lado, una reforma parcial dentro del marco del capitalismo (sustitución del poseedor de una parte de la plusvalía) y, por otro, es la abolición de un monopolio que obstaculiza todo el desarrollo capitalista en general $^{700}$.

E insiste:

[...] La nacionalización es la entrega de toda la tierra en propiedad al Estado. La propiedad significa el derecho a la renta y la fijación por el poder estatal de las normas comunes a todo el Estado, de posesión y usufructo de la tierra. En caso de nacionalización, se incluye indefectiblemente en estas normas comunes la prohibición de todo intermediario, es decir, se prohíbe el traspaso de tierras a los subarrendatarios, se prohíbe la cesión de tierras a quienes no sean agricultores $^{701}$.

Esta descripción, aunque evidentemente no en el sentido estricto que señala el texto, resulta muy similar a las medidas que tomó el dictador Francia -nacionalización y arrendamientos con la obligación de ocupar y trabajar directamente las tierras otorgadas por el Estado-y que fueron mantenidas, en lo esencial, hasta el fin de la guerra en 1870.

Sigamos. Si nacionalización significa básicamente una reforma capitalista que transfiere la propiedad y la renta de la tierra al Estado, Lenin se pregunta en otro texto:

¿Es posible semejante reforma en el marco del capitalismo? No solo es posible, sino que supone el capitalismo más puro, el capitalismo más consecuente, un capitalismo de una perfección ideal. Marx lo enseñó en la Miseria de la Filosofia, lo demostró con pormenores en el tomo III de El Capital y lo desarrolló con singular evidencia en la polémica con Rodbertus en Teorías de la plusvalía ${ }^{702}$.

Ahora bien, ¿esto era así únicamente en aquellos países con desarrollo capitalista más avanzado? No, para Lenin el fenómeno ocurría más bien al contrario. Es decir, la medida progresiva burguesa de nacionalizar la tierra tenía más condiciones de efectuarse en sociedades burguesas "jóvenes" que en aquellos países que ya habían alcanzado un elevado desarrollo capitalista.

Desde el punto de vista teórico, la nacionalización representa el desarrollo puro "ideal" del capitalismo en la agricultura. Otra cosa es la cuestión de si son posibles con frecuencia en la historia una concurrencia tal de condiciones y de una correlación tal de fuerzas que permitan la nacionalización en la sociedad capitalista. Pero no solo es una consecuencia, sino también una condición del desarrollo rápido del capitalismo. Pensar que la nacionalización es solo posible

${ }^{699}$ LENIN, V. I. [1907]. La cuestión agraria. Madrid: Editorial Ayuso, 1975, p. 90. Destacado en el original.

700 Ídem, p. 93.

701 Ídem, p. 133.

${ }^{702}$ LENIN, V. I. [1912]. La democracia y el populismo en China. In: LENIN, V. I. Obras Completas. Tomo 21. Moscú: Progreso, 1974, pp. 400-406. 
dado un desarrollo muy alto del capitalismo en la agricultura, equivale, puede decirse, a negar la nacionalización como una medida de progreso burgués, pues [...] una medida de progreso burgués, como medida burguesa, es inconcebible cuando se ha agudizado mucho la lucha de clases entre el proletariado y la burguesía. Una medida tal es verosímil más bien en una sociedad burguesa "joven", que todavía no ha desplegado sus fuerzas, todavía no ha desarrollado sus contradicciones hasta el fin, que todavía no ha creado un proletariado tan pujante que tienda directamente hacia la transformación socialista. Y Marx admitía, y en parte defendía de un modo abierto, la nacionalización no solo en la época de la revolución burguesa de 1848 en Alemania, sino en 1846 para los EEUU, respecto de los cuales señalaba ya entonces con entera exactitud que no hacian más que comenzar el desarrollo "industrial" $[\ldots]^{703}$.

Así, queda claro que, en países con desarrollo capitalista más avanzado, las trabas para que se concrete la nacionalización de la tierra, incluso siendo una medida "de progreso burgués", eran superiores. Lenin explicaba:

Cuando la burguesía, como clase, en proporciones vastas y predominantes, se ha ligado ya a la posesión de la tierra, "se ha territorializado" ya, "se ha asentado en la tierra" y ha sometido por entero a su poder el régimen de la propiedad agraria, es cuando no puede haber un verdadero movimiento social de la burguesía en favor de la nacionalización. Y no puede haberlo por la sencilla razón de que ninguna clase irá jamás contra sus propios intereses ${ }^{704}$.

De esto se desprende que, para Lenin, la nacionalización de la tierra era una medida propia de la época de la revolución burguesa, pero que dependía de la congruencia de ciertas condiciones históricas previas y de una correlación de fuerzas particulares. Por eso insistía en eso de que allí donde "[...] la burguesía no se ha territorializado aún...",

[...] se hace posible el fenómeno de que la masa de agricultores burgueses, de granjeros, luche contra las formas principales de propiedad agraria, y llegue, por tanto, a realizar en la práctica la plena "emancipación de la tierra" al modo burgués, es decir, la nacionalización ${ }^{705}$.

Hay que reflexionar si no fue este el fenómeno por el cual fue posible concretarla en el Paraguay del siglo XIX, una región que tenía fuerzas productivas más atrasadas y una burguesía muy incipiente, que todavía no se había "territorializado" completamente; una realidad diferente de la del Imperio del Brasil y de la de Buenos Aires, donde la burguesía agraria ya se había "territorializado", ya había expandido y estaba consolidando sus latifundios privados. En el Paraguay, por decirlo de alguna manera, si bien partía de mucho más atrás, el capitalismo tenía ese "obstáculo" menos para poder desarrollarse de una manera más "libre". Contradictoriamente, una ventaja del atraso.

\footnotetext{
${ }^{703}$ LENIN, V. I. [1907]. La cuestión agraria..., op. cit., pp. 114-115.

704 Ídem, pp. 115-116.

705 Ídem, p. 116.
} 
En síntesis, en sus polémicas con aquellos que defendían el reparto o la "municipalización" de la propiedad terrateniente, Lenin siempre insistió en que la nacionalización de la tierra es una medida burguesa y que negar esto correspondía a una:

[...] deformación teórica del marxismo, el cual ha dejado sentado con toda precisión que la nacionalización de la tierra es posible y concebible también en la sociedad burguesa, que no retendrá, sino que intensificará el desarrollo del capitalismo y que constituye el máximo de las reformas democráticas burguesas en la esfera de las relaciones agrarias ${ }^{706}$.

Por este mismo motivo, también sostenía que:

No hay nada más erróneo que la nacionalización de la tierra tiene algo de común con el socialismo o inclusive con la tenencia igualitaria de la tierra. El socialismo, como sabemos, significa la abolición de la economía mercantil. La nacionalización significa transformar la tierra en propiedad del Estado, y semejante transformación no afecta en nada la explotación privada de la tierra. El sistema de explotación de la tierra no cambia por el hecho de que esta sea propiedad o "patrimonio" de todo el país, de todo el pueblo $[\ldots]^{707}$.

Sostenía esta posición, entre otras cosas, apoyado en una determinada concepción del campesinado, que era contraria a la defendida por los populistas rusos y sus variantes. A estos, Lenin les respondía:

[...] Para el populista, en suma, el movimiento campesino es un movimiento verdaderamente socialista, auténtica y directamente socialista [...] Para el marxista, el movimiento campesino es precisamente un movimiento no socialista, sino democrático burgués ${ }^{708}$.

El dirigente de la Revolución Rusa argumentaba que "[...] la victoria completa de este movimiento campesino no eliminará el capitalismo, antes bien creará una base más amplia para su desenvolvimiento, acelerará y agudizará el desarrollo puramente capitalista"709.

Enseguida, cuestionaba:

La libertad más completa y la expropiación más completa de los terratenientes (confiscación de sus tierras), ¿acabarán con la economía mercantil? No, no acabarán con ella [...] ¿acabarán con el profundo abismo existente entre el campesino rico, propietario de muchos caballos y vacas, y el bracero, el jornalero, es decir, entre la burguesía rural y el proletariado agrícola? No, no acabarán con él $[\ldots]$ no acabará con el régimen burgués de economía, no acabará con el capitalismo, con la división de la sociedad en clases, en ricos y pobres, en burguesía y proletariado ${ }^{710}$.

\footnotetext{
${ }^{706}$ LENIN, V. I. [1906]. Revisión del programa agrario del partido obrero. In: LENIN, V. I. Obras Escogidas. Moscú: Editorial Progreso, 1973, p. 93.

${ }^{707}$ LENIN, V. I. [1908]. El problema agrario en Rusia a fines del siglo XIX. In: LENIN, V. I. Obras Completas. Tomo 15. Madrid: Akal Editor, 1977, p. 137.

708 LENIN, V. I. [1905]. Socialismo pequeñoburgués y socialismo proletario. In: LENIN, V. I. Obras completas. Tomo 12. Moscú: Editorial Progreso, 1982, pp. 39-48.

${ }^{709}$ Ibídem.

${ }^{710}$ Ibídem.
} 
Planteada así la cuestión, al no representar la abolición de la economía mercantil ni siquiera de la propiedad privada como un todo, incluso en los casos más avanzados, Lenin remataba: "No puede haber igualitarismo en la producción mercantil"711.

El propio Lenin, en medio del proceso revolucionario de 1917, releyendo sus escritos de 1905-1907 sobre el problema agrario y la nacionalización de la tierra, apuntó el problema en ese sentido: "[...] la nacionalización de la tierra no solo es 'la última palabra' de la revolución burguesa, sino también un paso hacia el socialismo"712.

Pero la cuestión de ser "también un paso hacia el socialismo" no se aplica al período 1813-1870 en el Paraguay del doctor Francia y de los López, pues en ese tiempo el capitalismo no estaba en decadencia sino en su época de desarrollo más o menos acelerado.

De hecho, cuando Lenin discutía el desarrollo del capitalismo en Rusia, planteaba dos vías de evolución: la "junker-burguesa" y la "campesino-burguesa"713. Ante esa disyuntiva, el dirigente bolchevique insistía:

En aras del desarrollo de las fuerzas productivas (este criterio supremo del progreso social) debemos apoyar, no la evolución burguesa de tipo terrateniente, sino la evolución burguesa de tipo campesino [...pues esta, $n d a$.] entraña el más rápido desarrollo de las fuerzas productivas y las mejores condiciones de existencia de la masa campesina (las mejores en cuanto esto es posible en general bajo la producción mercantil) $[\ldots]^{714}$.

¿Es posible afirmar que entre 1813 y 1870 se dio en el Paraguay un proceso similar a la vía de evolución capitalista “campesino-burguesa”? Sin duda, toda analogía es siempre incompleta y encierra peligros de unilateralidad, pero nos arriesgamos a sostener la hipótesis de que se engendró un proceso de características similares.

De todas maneras, si coincidimos con Lenin cuando sostiene que la nacionalización de la tierra, junto con la república, constituye el "máximo posible de la revolución democrático burguesa" ${ }^{\text {15 }}$, no es difícil hacerse una idea de la dimensión de este proceso. Y también podemos extraer conclusiones si aplicamos ese planteamiento a la inversa: nada de esto se había realizado en el Imperio del Brasil, la posterior Argentina, u otra región del Río de la Plata, regiones que presentaron una evolución capitalista más cercana a la vía "terrateniente" y, por lo tanto, mucho más conservadora.

${ }^{711}$ LENIN, V. I. [1907]. La cuestión agraria..., op. cit., p. 75. Destacado en el original.

712 Ídem, pp. 232-233.

713 Ídem, p. 140.

714 Ídem, p. 33.

${ }^{715}$ LENIN, V. I. [1906]. Revisión del programa agrario del partido obrero. In. LENIN, V. I. Obras completas. Tomo 12..., op. cit., p. 267. 


\section{LEGADO}

El Dictador murió en 1840. Su principal papel y legado histórico fue haber defendido la independencia paraguaya. El incipiente Estado nacional, en medio de la constante amenaza externa y a pesar del histórico atraso de las fuerzas productivas, se había fortalecido. No existían acuerdos políticos ni deuda externa que sujetara la nación a ningún poder extranjero. A la muerte de Francia, el Paraguay prácticamente había desaparecido de las rutas comerciales y de la política regional, pero era independiente.

Además de esa enorme conquista política y de los adelantos materiales -todavía tímidos-, existieron también avances en el terreno de la cultura. En 1834 mencionó el pago regular de 140 maestros rurales que atendían a cinco mil jóvenes ${ }^{716}$. Siendo que los ingresos totales del Estado en 1834 fueron de $78.777 \operatorname{pesos}^{717}$, los aproximadamente 10.000 pesos fuertes destinados a la educación primaria en el campo que señala el Dictador representarían algo en torno a 12\% de total de recaudaciones. En 1836 se inauguró la primera biblioteca pública con más de 5.000 volúmenes en distintos idiomas, muchos de ellos "heredados" o confiscados de los opositores políticos ${ }^{718}$.

La dictadura nunca se propuso promover ningún tipo de educación superior, pero el alcance de la educación elemental fue notable. El naturalista francés Jean Richard de Grandsire, que pasó durante breve período por Itapúa en 1825, en carta a Alexander von Humboldt anotó que "casi todos los habitantes sabían leer y escribir"719. Más adelante escribió que "los nativos pueden dirigirse al Dictador para educar a sus hijos a expensas del Estado"720. En el mismo sentido, el suizo Rengger señaló que en las escuelas del Estado "los jóvenes de ambos sexos recibían una tolerablemente regular educación"721.

Sin embargo, a la muerte de El Supremo, ningún otro Estado había reconocido oficialmente la independencia. Para sus vecinos, el Paraguay continuaba siendo una "provincia". Tampoco se había sido resuelto el problema de la libre navegación de los ríos ni se habían definido las fronteras nacionales.

\footnotetext{
${ }^{716}$ Decreto del 30/08/1834. ANA-SH, v. 242, n. 9.

${ }^{717}$ WHITE, Richard Alan [1984]. La Primera Revolución Popular en América..., op. cit., p. 234.

718 VÁZQUEZ, José Antonio. El doctor Francia visto y oído por sus contemporáneos. Buenos Aires: Editorial Universitaria de Buenos Aires, 1975, p. 40; WHITE, Richard Alan [1984]. La Primera Revolución Popular en América..., op. cit., p. 139.

719 Ídem, p. 138.

${ }^{720}$ Ibídem.

${ }^{721}$ RENGGER, Johann; LONGCHAMP, Marcelin. Ensayo histórico sobre la Revolución del Paraguay..., op. cit., p. 186.
} 
La economía paraguaya, que durante un cuarto de siglo fue encerrada y al mismo tiempo se encerró, había alcanzado un estadio que, si bien acumulaba un patrimonio estatal considerable y contaba con finanzas equilibradas, demandaba una pronta apertura hacia mercados externos. Todos estos complejos problemas pasarían del Dictador a sus sucesores, los López.

\section{TRES DEBATES SOBRE EL RÉGIMEN DEL DICTADOR FRANCIA}

El gobierno del doctor Francia, junto con el de Francisco Solano López, es uno de los más controversos en la historiografía que estudia el siglo XIX en el Paraguay. Destacamos aquí tres grandes temas: a) el supuesto igualitarismo de Francia; b) el significado y alcance del "terror" durante su mandato; c) las razones y límites de su política de "no intervención", tanto en la guerra continental contra la metrópoli hispánica como en la guerra civil en el Plata.

\section{1. ¿Era "igualitarista" el régimen de Francia?}

Es interesante notar que la caracterización de un régimen "igualitario" durante el gobierno de Francia ha sido funcional tanto a los historiadores liberales como a los autores nacionalistas "de izquierda". Los primeros, para denostarlo; los segundos, para rendirle pleitesía $^{722}$.

Efraím Cardozo y Justo P. Benítez, reconocidos estudiosos liberales, sostienen que "la Dictadura produjo la completa nivelación de la sociedad paraguaya"723, y que Francia "fue un tremendo igualitario. Las diferencias sociales le irritaban"724, respectivamente. Carlos Pastore, otro autor liberal, afirma que: "mitayos, yanaconas y mestizos no asimilados se nivelaron a las clases superiores en ciertos aspectos de la vida"725.

Sobre la misma cuestión, pero posicionándose desde de la "izquierda" y el llamado “pensamiento crítico", el profesor Ramón Fogel escribe que el doctor Francia instauró "una sociedad basada en principios de justicia, igualdad, y equidad", sustentada en la "unidad

\footnotetext{
${ }^{722}$ NÚÑ̃EZ, Ronald León. El mito del igualitarismo del doctor Francia. ABC Color. Asunción, 22/09/2019. Disponible en: <https:/www.abc.com.py/edicion-impresa/suplementos/cultural/2019/09/22/el-mito-deligualitarismo-del-doctor-francia/>, consultado el 16/01/2020.

${ }_{723}$ CARDOZO, Efraím [1949]. El Paraguay independiente. 2. ed. Asunción: Carlos Shauman Editor, 1988.

${ }^{724}$ PASTOR BENÍTEZ, Justo. La vida solitaria del Dr. José Gaspar de Francia..., op. cit. 131.

${ }^{725}$ PASTORE, Carlos. La lucha por la tierra en el Paraguay. 3. ed. Asunción: Editora Intercontinental, 2008, pp. 98-99.
} 
racial y social", puesto que "se había retornado, en medida importante, al tekojoja [igualitarismo] de los guaraníes"726.

El historiador brasileño Mário Maestri, por su parte, propone la existencia de una "dictadura plebeya", en la cual reinaría un "indiscutible consenso social"727.

Este autor, que se reivindica marxista, basa ese supuesto "consenso social" en la premisa de que durante el gobierno del doctor Francia ni siquiera existía burguesía, ni madura ni en formación. Maestri, en realidad, rechaza cualquier definición de los capitalistas criollos, con sus diversos sectores -terratenientes, ganaderos, comerciantes, etc.- como núcleo incipiente de una futura "burguesía nacional", categoría que, según él, "no existía, siquiera en forma embrionaria, en un país como el Paraguay" 728.

Pero Maestri fue más lejos y afirma que: "la encomienda, las aldeas de indios, los obrajes de yerba mate y de madera, las chacras, las estancias, formas específicas de producción y de materialización de la explotación, determinadas fuertemente en el período francista, a favor de los explotados"729.

¿Es aceptable, desde una perspectiva marxista, pasar la idea de que durante el régimen del doctor Francia, la encomienda y los pueblos de indios -concentraciones de indígenas dirigidas por autoridades religiosas o coloniales para facilitar la explotación de la fuerza de trabajo nativa- habrían cambiado de carácter "a favor de los explotados"? ¿Acaso se acabó la explotación en tiempos del doctor Francia?

En oposición a la concepción marxista del Estado, Maestri plantea el concepto del "Estado francista, de claro sentido plebeyo y campesino"730. ¿En algún momento de la historia de las sociedades humanas existió un "Estado plebeyo y campesino"? Nunca, eso es científicamente imposible. En tiempos del doctor Francia, es decir, en la época de las revoluciones burguesas y de decadencia del absolutismo monárquico solo existían dos tipos de Estado: el feudal y el capitalista.

Más adelante, el mismo autor extiende esta definición nada menos que a las fuerzas armadas que El Supremo se esforzó por consolidar, señalando: “el carácter tendencialmente

\footnotetext{
${ }^{726}$ FOGEL, Ramón. La reforma agraria..., op. cit., pp. 48-53.

${ }^{727}$ MAESTRI, Mário. Paraguai: a República camponesa..., op. cit., pp. 114-124.

728 MAESTRI, Mário. Paraguai: Revolução e Genocídio. O Mau Uso da História. 2012. Disponible en: $<\underline{\text { http://socialismo-o- }}$

barbarie.org/webanterior/historias/120330_maestri_paraguay_revolucion_y_genocidio.htm>, consultado el 02/01/17.

${ }^{729}$ Ibídem. Destacado en el original.

${ }^{730}$ MAESTRI, Mário. Paraguai: a República camponesa..., op. cit., p. 102. Destacado en el original.
} 
plebeyo de las fuerzas armadas [...] la conformación social y la orientación ideológica claramente popular de aquel importante aparato de represión del Estado [...]"731.

En suma, de acuerdo con la interpretación de Maestri, durante el régimen de Francia no solo no existía "burguesía", ni siquiera en "estado embrionario", sino que existía un gobierno, un régimen, un Estado y hasta unas fuerzas armadas "plebeyas", "populares" y "progresistas", que se erigían por encima de una sociedad que estaba marcada por un “indiscutible consenso social”. El hilo conductor de estas deducciones es la definición del proceso que propone nuestro autor: una "revolução nacional-popular vitoriosa"732.

¿No son estos planteamientos, además de una interpretación de los hechos históricos poco rigurosa, una apología para con el régimen del doctor Francia?

Evidentemente, no se trata de negar que un sector del campesinado haya accedido al usufructo de la tierra y que naturalmente haya visto ese hecho como "su" conquista. Tampoco se niega que, al descabezar a la antigua oficialidad criolla que se había formado en tiempos de la Colonia, el embrionario ejército nacional tuvo que improvisar nuevos cuadros militares, muchos de ellos salidos de la campaña y que no tenían la alcurnia de los anteriores; ni hablar de la tropa misma, que era reclutada en las villas y distritos. En ese sentido descriptivo -y solo en él-podría decirse que la composición de ese ejército era más "plebeya".

Pero eso no determina el "carácter" de un ejército en ninguna sociedad de clases, ni "tendencial" ni definitivamente. Lo que interesa a una definición de cuño marxista no es la “composición" de la base o de la baja oficialidad -que en un sentido siempre serán más o menos "populares"-, sino qué intereses de clase y al servicio de qué Estado está ese aparato represivo como institución. El ejército napoleónico, como se sabe, tenía una marcada composición campesina y "plebeya”, pero a nadie se le ocurriría pensar que esas tropas no estuvieran al servicio de extender los postulados de la revolución burguesa en Europa, en interés de los capitalistas franceses.

No se puede separar la definición del carácter de clase del Estado -una definición que Maestri se rehúsa a hacer en términos marxistas- de la del carácter de clase de las fuerzas armadas, por la simple razón de que las fuerzas armadas, entendidas como "destacamentos armados" al servicio de la represión de una clase sobre otra, son el pilar fundamental de cualquier Estado.

731 Ídem, p. 134. Destacado en el original.

${ }^{732}$ MAESTRI, Mário. 150 anos da destruição do Estado-nação paraguaio..., op. cit. 
Sigamos. Luis Rojas, sin mucha cautela, sigue esa misma lógica y nos dice que, entre 1813 y 1840 existió un "gobierno popular" que "logró una gran igualdad social...", a punto tal que "las clases sociales se fueron diluyendo en el Paraguay [...]"733.

Y, así, de la mano de Bernardo Coronel, llegamos al extremo de esta escuela de pensamiento basada en mitos y apologías, que caracteriza el período de Francia como "protosocialista", blandiendo como argumento que el Dictador habría "expropiado a los

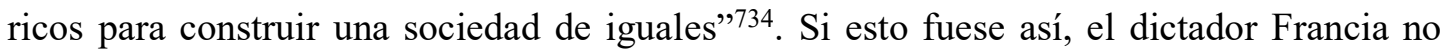
debería ser considerado "solamente" como un "jacobino radical" sino directamente como un comunista, y tan avanzado que se habría adelantado casi un siglo a la Revolución Rusa... ¿Puede tomarse con seriedad una posición como esta?

Ninguna de las afirmaciones que mencionamos hasta ahora corresponde a la realidad. Ni Francia era igualitarista ni las clases sociales se "diluyeron" durante su mandato. No se pueden combatir mitos creando otros mitos.

Las confiscaciones de una parte de la clase propietaria y las nacionalizaciones no eliminaron la sociedad de clases ni la economía mercantil, al contrario, sentaron las bases para una posible dinámica de desarrollo más acelerado del capitalismo. Y, como sostenía Lenin: "No puede haber igualitarismo en la producción mercantil""735.

Ninguna revolución burguesa, debido a su propia naturaleza de clase, aspiró jamás a una completa democratización de la sociedad. Mucho menos pretendió algún tipo de "igualitarismo". Por tratarse de una clase minoritaria, la burguesía tuvo que apelar y apoyarse, en mayor o menor grado, en las masas populares. En algunos casos llegó incluso a hacer -0 le fueron arrancadas- concesiones de libertades formales. Pero su estrategia, intrínseca a su condición de clase opresora, consistió siempre en imponer su dominio para explotar, a través del modo de producción capitalista, al resto de la nación. Cuando los revolucionarios burgueses, incluso los más radicales, luchaban por la libertad, se trataba de libertad para $s u$ clase, no para las clases explotadas.

Hubo episodios, excepcionales y relativamente cortos, en que sectores de la pequeña burguesía dirigieron el proceso, en general con más osadía que la propia burguesía, pero siempre lo hicieron al servicio de un proyecto burgués.

\footnotetext{
${ }^{733}$ ROJAS, Luis. Independencia y economía durante el período de Francia. In: CORONEL, Jorge (org.). La república francista del Paraguay..., op. cit., pp. 117-135.

${ }^{734}$ CORONEL, Bernardo. Breve interpretación marxista de la historia paraguaya [1537-2011]. Asunción: Arandurã, 2011, p. 61.

${ }^{735}$ LENIN, V. I. [1907]. La cuestión agraria..., op. cit., p. 75. Destacado en el original.
} 
El caso de los jacobinos en la Revolución Francesa es el más conocido. Trotsky, en una interesante polémica que sostuvo a finales de la década de 1920 con el dirigente y economista soviético Preobrazhensky sobre tareas objetivas y sujetos sociales, explica cuál fue el papel que cumplieron los seguidores de Robespierre.

El período jacobino de la revolución francesa fue, por supuesto, el período de la dictadura pequeñoburguesa, en el cual, además, la pequeña burguesía en armonía total con su "naturaleza sociológica", abrió el camino para la gran burguesía ${ }^{736}$.

Y Preobrazhenski, en este asunto, le dada la razón: "La revolución de 1789 fue completada por la pequeña burguesía, pero nadie ha caracterizado la gran revolución francesa como una revolución pequeñoburguesa [...]"737.

$\mathrm{Y}$ esto es así porque nunca existió una sociedad pequeñoburguesa $\mathrm{y}$, consecuentemente, un Estado pequeñoburgués. El propio Trotsky, en sus Tesis de la revolución permanente, utilizó el caso del campesinado para explicar que la experiencia histórica...

[...] ha demostrado, y en condiciones que excluyen toda torcida interpretación, que, por grande que sea el papel revolucionario de los campesinos, no puede ser nunca autónomo ni, con mayor motivo, dirigente. El campesino sigue al obrero o al burgués $[\ldots]^{738}$.

En otro texto de 1928, Trotsky mencionó la interpretación sobre el papel del campesinado que desarrolló Engels todavía en la época de ascenso del capitalismo: "Engels, en su libro Las guerras campesinas en Alemania, demostró que las guerras campesinas del siglo XVI siempre fueron dirigidas por alguna fracción urbana, es decir, por una u otra ala de la burguesía"739.

Es decir, incluso admitiendo por un minuto la hipótesis de que el doctor Francia hubiera liderado un movimiento y un proyecto pequeñoburgués "puro", esto tampoco permitiría, desde el punto de vista marxista, atribuirle un carácter "igualitarista" ni mucho menos revolucionario en un sentido "protosocialista". En 1850, Marx explicaba que:

La pequeña burguesía democrática está muy lejos de desear la transformación de toda la sociedad; su finalidad tiende únicamente a producir los cambios en las

\footnotetext{
736 TROSTKY, León. Correspondencia con Preobrazhensky. 1928. Disponible en: $<$ http://www.ceip.org.ar/Correspondencia-entre-Trotsky-y-Preobrazhensky>, consultado el 12/02/2019. ${ }^{737}$ Ibídem.

738 TROTSKY, León. La revolución permanente. Tesis fundamentales. 1929. Disponible en: $<$ https://www.marxists.org/espanol/trotsky/revperm/rp10.htm>, consultado el 12/02/2019.

739 TROTSKY, León. El marxismo y la relación entre revolución proletaria y revolución campesina. 1928. Disponible en: <http:/www.ceip.org.ar/El-marxismo-y-la-relacion-entre-revolucion-proletaria-y-revolucioncampesina $>$, consultado el 13/02/2019.
} 
condiciones sociales que puedan hacer su vida en la sociedad actual más confortable y provechosa ${ }^{740}$.

Esto es así porque, históricamente, el nervio de la cuestión radica en que la pequeña burguesía no tuvo, tiene, ni puede tener un papel independiente, ni económico ni político, en la lucha de clases. No es una clase fundamental en la sociedad burguesa.

$\mathrm{Y}$ esto no significa negar el potencial revolucionario del campesinado pobre o de ciertos sectores medios de la sociedad, ni en la época de las revoluciones burguesas ni en la actual época de la revolución obrera y socialista., según la definición del marxismo. Simplemente, es una constatación de su imposibilidad de cumplir un papel autónomo como clase o sector de clase.

Continuemos. Algunas revoluciones burguesas, ciertamente engendraron sectores igualitaristas, es decir, que no solo reivindicaron la plenitud de derechos políticos sino que también cuestionaron, de manera pionera, la propiedad privada.

En la Revolución Inglesa surgieron los Cavadores [diggers], que se autoproclamaron los "verdaderos Niveladores [levellers]", que fue la facción más democrático-radical de ese proceso. Gerrard Winstanley, el líder de los Cavadores, escribió en 1648: "Mientras los gobiernos sostengan que la tierra les pertenece, manteniendo el principio de la propiedad privada, del 'mío' y del 'tuyo', jamás las gentes sencillas tendrán libertad [...]”. Tanto Niveladores como Cavadores fueron aplastados por Cromwell ${ }^{741}$.

En la Revolución Francesa aparecen los Furiosos [enragés], dirigidos por Jacques Roux, Jean Varlet y Jean Leclerc. Durante el período de la Convención Nacional, se posicionaron a la izquierda de los jacobinos, exigiéndoles más terror y presionando por más medidas contra los ricos y a favor de la masa de sans-culottes. Defendían la "igualdad de goces", esto es, la igualdad social y no solo jurídica. Fueron reprimidos y desarticulados por los propios jacobinos.

El máximo ejemplo de lucha "igualitarista" es el de François Babeuf, que en 1796 organizó la fracasada "Conspiración de los Iguales" contra el Directorio que tomó el poder luego de la reacción termidoriana. Babeuf superó a los diggers, jacobinos, hebertistas y enragés - todos defensores de la igualdad en los marcos de la pequeña propiedad-cuando propuso la abolición de la propiedad privada. El "comunismo" de Babeuf ciertamente no era científico, pues se basaba más en la distribución de bienes que en la producción socializada.

740 MARX, Karl. Circular del Comité Central a la Liga Comunista. 1850. Disponible en: $<$ https://www.marxists.org/espanol/m-e/1850s/50_circ.htm>, consultado el 13/02/2019.

${ }^{741}$ Ver: HILL, Christopher. La revolución inglesa [1640]. Barcelona: ANAGRAMA, 1977. 
Pero esto no le resta mérito a su carácter precursor. Puesto que "todos los estómagos son iguales", propuso abolir la herencia, y declaró: "nuestros dogmas son democracia, igualdad sin mácula y sin reserva”. Babeuf desarrolló ideas igualitaristas muy avanzadas para su tiempo, puesto que las condiciones materiales en Francia no estaban maduras, en 1796, para abolir la propiedad privada. Fue guillotinado, pero su ideario sirvió de inspiración para generaciones futuras.

Independientemente de la discusión sobre si en el Paraguay del siglo XIX -una de las regiones más pobres del antiguo sistema colonial y que conquistó su independencia partiendo de fuerzas productivas muy atrasadas- existían o no bases materiales para el "igualitarismo", podría argumentarse que el doctor Francia, aunque lo hiciera de manera utópica, defendía un programa de ese tipo. Pero esto tampoco es verdadero. Ninguna de las ideas que señalamos está presente en los escritos del Dictador. Tampoco en su obra. La lucha de Francia nunca fue contra la propiedad privada; cuando la atacó, se cuidó de hacerlo en la medida necesaria para debilitar al sector reaccionario que se oponía a la independencia nacional. Nada más.

Oscar Creydt acierta cuando afirma que:

[...] no hay duda de que, bajo la protección de la dictadura perpetua, la naciente burguesía nacional continuó desarrollándose, a pesar de las limitaciones del comercio exterior. La acumulación era realizada principalmente en la forma de ganado, que tenía un precio general estable, aunque bajo, en el mercado interno ${ }^{742}$.

No solo las clases sociales no se fueron "nivelando" sino que los indios reducidos alrededor de $30 \%$ de la población- continuaron segregados en sus pueblos, controlados por “corregidores" blancos y sujetos a la obligación de acudir como fuerza de trabajo, en general gratuita, ante cualquier requerimiento del Estado.

Merced al estudio de su correspondencia, incluso puede decirse que el doctor Francia despreciaba a la población originaria. En agosto de 1839 escribió a su comandante de frontera sobre la relación que debía mantener con tribus locales que, puede suponerse, se presentaron en busca de socorro y, sin saber siquiera a qué nación o parcialidad pertenecían, observó:

Esos indios haraganes y por no querer trabajar, andarán muertos de hambre y vienen a ver si consiguen algo de balde, lo que no se debe hacer porque es mal imponerlos [malacostumbrarlos], pues no quieren vivir sino robando cuando pueden como haraganes salteadores [...] Ya otras veces, en iguales circunstancias que han venido, les he dicho decir claramente que si padecen hambre es porque son haraganes y que así trabajen como se hace por acá y no les faltará qué comer. Pero no les has preguntado lo que correspondía, lo primero, de qué nación eran, lo

${ }^{742}$ CREYDT, Oscar [1963]. Formación histórica de la nación paraguaya..., op. cit., p. 93. 
segundo, a qué fin o para qué querían traer esas mujeres y criaturas, y lo tercero, por qué quieren que se le dé el aguardiente, el toro y la carne. Si es de balde, se les debe decir que por acá nada se pide ni se da de balde y que todo se vende y se compra $[\ldots]^{743}$.

En la misma misiva, Francia termina con una alerta y una orden: “[...] pero se estará con todo cuidado, [por] si acaso se desmandan, para destruir a balazos a los varones, reservando [perdonando] las mujeres y criaturas" $" 74$.

Los negros, que representaban $10 \%$ de la población, continuaron sometidos a la esclavitud. Todos los esclavos confiscados a los españolistas, a los conspiradores, o a la Iglesia católica, no fueron liberados sino que pasaron a ser propiedad del Estado, que los utilizaba en las obras públicas y en las Estancias de la República. El propio Dictador poseía esclavos domésticos ${ }^{745}$, y no dudaba en atacar a sus enemigos acusándolos de "mulatos"746.

En 1813, Francia confinó a centenas de negros y “pardos” en Tevego, una localidad inhóspita del extremo norte del país. El nuevo pueblo de negros debía contribuir a la "pacificación de la frontera", sirviendo de "antemural" frente a las terribles incursiones que los indios guaycurúes, comúnmente alentados por los portugueses, realizaban sobre el poblado de Concepción. Irritado por la necesidad de enviar raciones desde Asunción al nuevo asentamiento de negros, el doctor Francia se quejaba constantemente de la “ ... desidia o pereza natural que los hace indolentes" ${ }^{\text {"747 }}$. Las condiciones de ese alejado lugar eran tan duras que, poco después, el propio Dictador utilizó Tevego como destino de destierro para "pardos" y criminales comunes.

Así, resulta escandalosa la posición de algunos autores de "izquierda", que atenúan la histórica explotación y el racismo contra el negro diciendo que Francia trataba a sus esclavos "con bondad" o que "la segregación de la población negra, que se inició antes del gobierno de Francia, permite conservar la identidad de los negros y mulatos" ${ }^{\text {"748. Esto es }}$ sencillamente inaceptable, por su evidente racismo, pero es revelador del enorme atraso de la izquierda paraguaya en la discusión sobre la opresión racial y cultural en esa sociedad.

Al mismo tiempo, posiciones como esas le hacen un enorme favor a la historiografía liberal, que en general no duda en criticar la supervivencia de la esclavitud negra y de la sujeción del indio después de la independencia. Es evidente que esta crítica, viniendo de

\footnotetext{
${ }^{743}$ Carta al comandante de Olimpo sobre el trato a los indiso, 02/08/1839. ANA-SH, v. 244, n. 2.

${ }^{744}$ Ibídem.

${ }^{745}$ Decreto del 09/08/1834. ANA-SH, v. 242, n. 9; Decreto del 29/11/1835. ANA-SH, v. 242, n. 9.

${ }^{746}$ Oficio al delegado de Itapúa, del 28/10/1838. ANA-SH, v. 243, n. 12; Oficio al comandante del Fuerte Olimpo, del 20/09/1839. ANA-SH, v. 243, n. 12.

747 TELESCA, Ignacio. Revolución, república y pueblo..., op. cit., p. 52.

${ }^{748}$ FOGEL, Ramón. La reforma agraria..., op. cit., p. 45.
} 
intelectuales que consienten o atenúan el genocidio del Paraguay y que defienden el Imperio esclavista del Brasil o el régimen librecambista de Buenos Aires -que realizó otro genocidio y limpieza étnica contra su propia población indígena en la conocida "Conquista del Desierto"- es, por decir lo mínimo, hipócrita. Pero no justifica el silencio o la minimización de la explotación y la opresión de los negros esclavizados y de los indígenas sujetos a variantes de servidumbre en el Paraguay posterior a 1811, por parte de sectores de la izquierda paraguaya que todavía beben de fuentes nacionalistas.

La realidad, reñida con el mito de la "igualdad social", muestra que existía una sociedad de clases donde las relaciones de producción basadas en el trabajo "libre" o asalariado aún eran marginales y coexistían con aquellas basadas en la coerción extraeconómica. Eran comunes las "levas" de "vagos, holgazanes o mal entretenidos" para someterlos a trabajos forzados en las obras públicas ${ }^{749}$. El trabajo gratuito se extendía a los presos comunes y llegaba hasta el ejército.

La cuestión es que Rodríguez de Francia, como otros dirigentes latinoamericanos independentistas, no aspiraba ni al bienestar ni a la participación del pueblo en el proceso político.

En general, el pánico a la "anarquía" y al "desorden" que pudiera surgir de las acciones del "populacho", como bien mostró la experiencia haitiana o el incontenible estallido social de 1810 en México, en muchos "próceres" era más fuerte que el descontento con la propia España. Por ejemplo, uno de los más lúcidos dirigentes independentistas, Francisco Miranda, escribía en 1798:

Le confieso que tanto como deseo la libertad y la independencia del Nuevo
Mundo, otro tanto temo la anarquía y el sistema revolucionario. No quiera Dios
que estos hermanos países tengan la suerte de Saint-Domingue [Haití], teatro de
sangre y crímenes, so pretexto de establecer la libertad; antes valiera que se
quedaran un siglo más bajo la opresión bárbara e imbécil de España ${ }^{750}$.

Es un hecho que el doctor Francia, un abogado acomodado, fue obligado a atacar los intereses de un sector de la "oligarquía". Pero eso no lo transforma en un "gobierno popular". Simplemente demuestra que existió una lucha entre facciones burguesas y que Francia tenía un lado en ese embate. Se puede admitir que el sector burgués nacionalista era "más progresivo" en el sentido capitalista que el antinacional y librecambista, por supuesto que sí; pero esa premisa no le quita el carácter burgués ni a los unos ni a los otros.

\footnotetext{
${ }^{749}$ Decreto del 02/04/1819. ANA-SH, v. 229, n. 9.

750 Miranda a Turnbull, 12/01/1798, citado por: LYNCH, John. Los orígenes de la independencia. In: BETHELL, Leslie (Org.). Historia de América Latina..., op. cit., p. 39.
} 
El Dictador Francia aborrecía "la anarquía", como muestran muchos de sus escritos. Cabe reflexionar si, en la hipótesis de que hubiese existido un proceso de levantamiento popular que cuestionase su régimen, no hubiera reprimido aquella manifestación de "desorden" con ese mismo ejército que algunos juzgan ingenuamente de "plebeyo" e ideológicamente "popular".

Para polemizar con el liberalismo, insistimos, no es necesario recrear ningún paraíso "social". Tampoco se puede plantear un relato en términos de un patriarca que quería "diluir las clases sociales" enfrentando a la "oligarquía".

La discusión de fondo con el liberalismo no es esa. Es sobre si el período de 1813 a 1870 fue progresivo o fue un "retroceso" en un sentido histórico y global.

Lo fundamental es demostrar que el proyecto burgués de independizar la nación, fortalecer el Estado nacional y, por encima de todo, nacionalizar la tierra, en el contexto del siglo XIX, era esencialmente progresivo y, por lo tanto, debía ser defendido.

\subsection{El debate sobre el Terror}

En la interminable polémica entre "francistas" y "antifrancistas", es común que la historiografía liberal reivindique la "democracia" -así en abstracto y en sentido universal-y cargue contra el "terror" del dictador Francia.

Es verdad que el régimen de El Supremo no garantizaba ninguna libertad democrática al pueblo. Pero no es eso lo que disgusta a los (neo)liberales. Lo que no admiten es la represión que sufrió la "elite" de "patricios ilustrados", en el contexto de la derrota del programa librecambista y conciliador con los enemigos de la independencia.

Y esto a pesar de que el auge del "terror" de Francia -21 fusilamientos en 1820- no puede compararse con el terror jacobino y, ni hablar, con la represión ejercida por los revolucionarios negros en Haití.

Sin embargo, si aceptáramos por un minuto la asociación que a menudo se hace del doctor Francia con el "jacobinismo", y quisiésemos formular una respuesta a liberales y nacionalistas de izquierda en esos términos, sería justo plantear lo que expresó Trotsky en 1906:

Jacobinismo es hoy una injuria en boca de los sabelotodo liberales. El odio burgués contra la revolución, contra las masas, contra la violencia y contra la historia que se hace en la calle, se ha concentrado en un grito de indignación y de angustia: ¡Jacobinismo! Nosotros, el ejército mundial del comunismo, históricamente hemos ya arreglado cuentas hace tiempo con el jacobinismo. Todo el movimiento proletario internacional de la actualidad ha nacido $y$ se ha 
fortalecido en disputa con las tradiciones del jacobinismo. Lo hemos sometido a una crítica teórica, hemos mostrado su estrechez, hemos desenmascarado su contradicción social, su utopismo, su fraseología y hemos roto con sus tradiciones que, durante décadas, pasaban por herencia sagrada de la revolución.

Pero defendemos el jacobinismo contra los ataques, las calumnias y los ultrajes insípidos de que le hace objeto el liberalismo flemático y exangüe. La burguesía ha traicionado ignominiosamente todas las tradiciones de su juventud histórica, sus mercenarios actuales profanan las tumbas de sus antepasados y calumnian los vestigios de sus ideales $[\ldots]^{751}$.

No se puede disociar el terror, o como prefiera llamarse a la represión política, del contexto en el que emerge la dictadura: una situación en que la independencia corría un peligro real. Acosada, la embrionaria y debilísima burguesía nacional apeló a una autoridad fuerte, capaz de enfrentar al enemigo externo y, al mismo tiempo, "pacificar" el interior del país. La figura de Francia asciende en ese contexto dramático. Si convenimos en que la independencia nacional era una tarea progresiva, el "terror" ejercido contra el sector burgués que abandonó esa causa era históricamente necesario. En este marco, la discusión sobre si hubo o no "excesos" es válida pero secundaria.

Las críticas "democráticas” que realiza la literatura liberal, las más de las veces utilizando como parámetro las modernas democracias burguesas parlamentarias, están divorciadas del contexto histórico concreto. En realidad, el elemento "democrático" de esa narrativa sirve para endulzar su objetivo fundamental: rechazar globalmente la vía de desarrollo capitalista que el Paraguay tomó hasta 1870. Y esto debe quedar al desnudo con un debate riguroso, fundamentado, no en los moldes del llamado revisionismo histórico populista.

Esa es la razón de fondo. Lo demás es mera envoltura. Lo central para el (neo)liberalismo es el rechazo a las confiscaciones, a los monopolios estatales, a la represión que sufrió la crema y nata de la sociedad, el lamento por los mercados perdidos...

En palabras de un reconocido autor, el problema principal radicó en el militarismo y en la asunción de un gobierno dictatorial-absolutista que favoreció "la secesión y el estatismo económico $[\ldots]^{3752}$.

Este es un camino sin retorno en el que no pocos estudiosos pasan a añorar la "bonanza comercial" del último período del colonialismo borbónico y, por esa vía, inevitablemente, terminan negando el proceso de independencia como un todo. Por ejemplo,

\footnotetext{
751 TROTSKY, León. Resultados y perspectivas. 1906. Disponible en: $<$ https://www.marxists.org/espanol/trotsky/ryp/03.htm>, consultado el 14/02/2019. Destacado en el original. 752 PASTORE, Mario. Crisis de la Hacienda pública..., op. cit., p. 172.
} 
Guido Rodríguez Alcalá embiste contra el gobierno de Francia y pierde totalmente el foco al decir que "en la colonia había mayor libertad"753. Y más claramente:

[...] el dictador adoptaría las políticas mercantilistas que provocaron la ruina económica del país, cuya pretendida autonomía fue la vuelta a la economía de subsistencia de etapas muy anteriores, ya que los últimos años del gobierno español fueron muy prósperos por comparación de la dictadura ${ }^{754}$.

La conclusión está a la vista: la cosa estaba mejor cuando éramos colonia de los españoles. Entre el dictador Francia y los Borbones... ipues los Borbones!

El peligro de esta posición es el de asumir, en nombre de un supuesto librecambio durante el último tercio del siglo XVIII, la perspectiva de la vieja clase capitalista comercial y terrateniente, en buena medida compuesta por españoles colonialistas y sus socios locales, que fue desplazada del poder por el sector liderado por Francia.

Mario Pastore, competente economista e historiador liberal, que mencionamos anteriormente, insiste en lo mismo:

La actividad económica de las tres décadas que siguieron a la independencia cayó muy por debajo de los niveles relativamente altos alcanzados durante el último período colonial. Atribuyo este pobre rendimiento económico fundamentalmente a la incapacidad de innovar a partir de la estructura institucional colonial y a la propia regresión institucional que caracterizó este período $[\ldots]^{755}$.

¿Cuáles son las características de la "regresión institucional" que propone Pastore?: Estado absolutista, dinastías familiares, militarismo, y redistribución de los derechos de propiedad hacia el Estado ${ }^{756}$.

[... El] auge de un ejército permanente, así como del absolutismo y de la regulación estatal de $-\mathrm{y}$ la intervención directa en- la economía, tuvieron definitivamente consecuencias económicas y políticas negativas a corto plazo [...] Esto condujo a una forma de lo que se puede llamar república solo de nombre, con la más completa ausencia de formas de representación popular que hasta las monarquías constitucionales aseguraban. Estas formas institucionales persistieron tras la muerte de Francia en $1840[\ldots]^{757}$.

La ausencia de democracia popular es un hecho innegable. Pero, en el siglo XIX, esta característica no era una exclusividad del Paraguay gobernado por el doctor Francia. La democracia, como forma institucional, no existía como tal en la región. Y es anacrónico exigir de la época algo que solo maduró, a duras penas, en el siglo XX. Por lo tanto, expresiones como "absolutismo" o "dinastía" no pasan, según nuestra comprensión, de recursos retóricos más o menos eficientes, pero científicamente imprecisos, puesto que, a

${ }^{753}$ RODRÍGUEZ ALCALÁ, Guido. Francia y López..., op. cit., p. 534.

${ }^{754}$ RODRÍGUEZ ALCALÁ, Guido (Org.). Artigas y la independencia ..., op. cit., p. 33.

${ }^{755}$ PASTORE, Mario. Crisis de la Hacienda pública..., op. cit., p. 164.

756 Ídem, p. 165.

757 Ídem, p. 194. 
pesar de sus males y defectos, el régimen político no retrocedió a uno de carácter monárquico. Por eso, es incorrecto referirse al periodo haciendo alusión a supuestas medidas "neoborbónicas". A nuestro juicio, lo verdaderamente intolerable para la historiografía de corte liberal no es la falta de democracia popular sino, en palabras de Pastore, la regulación e intervención directa del gobierno en la economía, la negación de laissez faire.

Así, la síntesis del proceso de la independencia, específicamente del período de gobierno de Francia está en el mismo título del artículo que venimos citando: crisis de la Hacienda pública, regresión institucional y contracción económica ${ }^{758}$. Es difícil no inferir de este alegato que la independencia, al final de cuentas, fue un proceso retrógrado. El primer cuestionamiento que deriva de este razonamiento es: ¿qué régimen institucional puede ser más retrógrado que el colonial?

Lo primero que esos autores liberales no comprenden, o sugieren que debía ser evitado de alguna $\mathrm{u}$ otra manera, es que un proceso tan profundo como la independencia americana y su reflejo en el Río de la Plata no podía dejar de desembocar en períodos de inestabilidad, crisis, violencia, bloqueos de los ríos por parte de los realistas o por la rivalidad entre Buenos Aires y las provincias interiores, etc. Todo ello necesariamente impactaría en el comercio regional.

Si se abstraen esos elementos del contexto, los clamores por democracia y laissez faire terminan siendo abstractos, sobre todo porque no comprenden que entre una colonia y un país independiente existe una diferencia cualitativa, pues no existe peor dictadura o absolutismo político, peor opresión para un pueblo, que la tiranía de un colonizador.

Y esto es acertado aun cuando se admita que no pasó demasiado para que los Estados nacionales iberoamericanos cayeran en otro tipo de dependencia, semicolonial o con trazos de "colonias informales" del comercio y las finanzas del Reino Unido y otras naciones europeas industrializadas. Aun así, seguirá existiendo una diferencia entre una colonia -sin derecho a un gobierno propio ni soberanía económica-y una semicolonia-soberanía formal, pero con dependencia económica dictada por las asimetrías del sistema internacional de Estados-.

\footnotetext{
${ }^{758}$ En la página 196 de ese artículo, Mario Pastore opina que, incluso en la década de 1990, un período de auge del neoliberalismo en el mundo, en el Paraguay "las formas pasadas del absolutismo y el mercantilismo económico seguirán resistiéndose rabiosamente a desaparecer”.
} 
La ruptura con la metrópoli, considerando los argumentos anteriores, es un hecho capital. En abono de nuestra posición, citamos las palabras de John Lynch sobre la dimensión de lo que discutimos:

[...] la dependencia económica con España era muy real y concreta. España mantenía un monopolio comercial y de inversiones. Con la abolición de ese monopolio, los latinoamericanos quedaron libres de elegir qué dependencia querían, si querían alguna. Adquirieron cierto poder de elección que antes no tenían ${ }^{759}$.

El razonamiento que está detrás de las conclusiones liberales -con mucho peso en medios académicos- que mencionamos anteriormente es el comercio por el comercio en sí. Si es así, no se puede dejar de indagar: en el caso de que el Imperio español hubiera hecho concesiones mayores a las colonias en materia de autonomía comercial y hasta mejores cargos públicos a los criollos productores o comerciantes, ¿el camino hacia la ruptura con la metrópoli debía ser evitado? Este es el debate de fondo.

Por otro lado, aunque en la actual época de decadencia del capitalismo al liberalismo moderno le sea incómodo reconocer, el "progreso", con todas las contradicciones que podían presentar naciones recién emancipadas, estaba en el proteccionismo y no en el librecambio; estaba en las nacionalizaciones y no en el latifundio privado. El progreso estaba en medidas como la "redistribución de los derechos de propiedad hacia el Estado", no en la libre iniciativa privada extranjera. Todas las naciones capitalistas más avanzadas, en su fase de acumulación de capital, no se basaron en el "libre mercado" sino que aplicaron medidas proteccionistas, regularon la economía desde el Estado y, no raramente, incentivaron empresas estatales para explotar determinados recursos. No se puede confundir el "estatismo" y el "mercantilismo" del período en el que el Paraguay era una colonia, como sugiere la corriente historiográfica liberal, con el de un Estado-nación políticamente independiente ${ }^{760}$.

Por otra parte, no se puede omitir que, en todo este debate, el liberalismo se ceba en las exageraciones de los nacionalistas y populistas "de izquierda", que describen la dictadura como un régimen "popular" que ejercía violencia únicamente contra la "oligarquía".

Ese mito es una cuña para la propaganda liberal. Una cosa es decir que la violencia contra los enemigos de la independencia era históricamente necesaria; otra cosa es sostener que aquello se debía a que el régimen de Francia era una "democracia popular". Esto es

\footnotetext{
${ }^{759}$ LYNCH, John. América latina no necesita ahora una nueva independencia..., op. cit.

${ }^{760}$ Mario Pastore, por ejemplo, sostiene que el absolutismo y el estatismo político y económico colonial persistieron tras la independencia tanto a corto como a largo plazo. Ver: PASTORE, Mario. Crisis de la Hacienda pública..., op. cit., p. 195.
} 
falso. Es un hecho que Francia concentró todo el poder y lo ejerció de manera absoluta, con mano de hierro. Para el pueblo no existían libertades democráticas, ni de derecho ni de hecho.

Luego de los congresos de "mil diputados" en 1813 y 1814, el quórum establecido para el de 1816, que proclamó a Francia Dictador Perpetuo, disminuyó a 250 delegados. El dictador nunca más convocaría otro congreso hasta su muerte, en 1840. Es verdad que el pueblo nunca se levantó contra Francia ni dio su apoyo a los conspiradores en 1820-1821. Pero, de ninguna manera puede decirse que el pueblo participaba de las decisiones del gobierno.

Lo cierto es que la idea de una "democracia popular" tiene la misma consistencia que las críticas liberales que se espejan en la democracia parlamentaria moderna: ninguna. No hubo ninguna revolución burguesa dispuesta a instaurar verdaderos regímenes democráticos. Exceptuando la lucha por la libre empresa y la libertad de disponer de propiedad privada, el resto de las libertades democráticas, especialmente aquellas que interesaban también a los sectores populares, no solo no eran esenciales para la gran burguesía, sino que le resultaban peligrosas. Por eso las retaceó al máximo o, simplemente, las dejó inconclusas.

Tanto es así que ni siquiera las tendencias políticas más avanzadas de las revoluciones burguesas persiguieron una "democracia popular".

Los levellers ingleses, una expresión de los pequeños propietarios rurales y urbanos que originó el primer movimiento democrático radical, al mismo tiempo en que se decían republicanos, parlamentaristas, y reivindicaban la libertad religiosa, negaban el derecho de voto a los trabajadores asalariados y a los pobres que dependían del "socorro" público.

En Francia, posiblemente exceptuando el proceso que originó la Convención Nacional en 1792, el derecho al voto masculino se estableció solo en 1848. En junio de 1791, la famosa Ley Le Chapelier, en el mismo acto en que abolió los "gremios" -que fue un golpe al Antiguo Régimen y, al mismo tiempo, una exigencia del principio de la libre empresa y contrato- prohibió, so pena de muerte, cualquier derecho de asociación y huelgas obreras. El "delito de asociación” permanecería vigente hasta 1864. El auge revolucionario abolió la esclavitud en 1794, pero cuando cambió la correlación de fuerzas fue restaurada por Napoleón, en 1804. La abolición definitiva debió esperar hasta 1848.

La avanzadísima Declaración de Independencia de los Estados Unidos, como se sabe, estableció el voto censitario y hasta mantuvo la esclavitud, que perduró hasta el triunfo de la burguesía industrial en el segundo capítulo de la revolución norteamericana, la Guerra Civil de 1861-1865, cuando fue definitivamente abolida jurídicamente. 
En el caso de las revoluciones anticoloniales, el "poder unipersonal" fue ejercido ampliamente. Jean-Jacques Dessalines, el líder que concretó la independencia de Haití en 1804, se declaró Emperador con el nombre de Jacques I. Henri Christophe; otro dirigente de la revolución haitiana, en 1806 se proclamó Rey de la mitad septentrional del país, que pasó a llamarse Reino de Haití (1811-1820). Alexandre Pétion, en el sur de la Isla, se declaró Presidente Vitalicio en 1816. Ni siquiera en Haití, palco de la más radical revolución anticolonial y de la primera república negra, el pueblo gozó de derechos políticos.

En el Perú, según el propio Bolívar, se le rindieron "honores de Presidente Perpetuo". El propio Libertador, en su mensaje al Congreso Constituyente de Bolivia, en 1826, se refirió a la presidencia vitalicia en estos términos:

El Presidente de la República viene a ser en nuestra Constitución como el Sol que, firme en su centro, da vida al Universo. Esta suprema Autoridad debe ser perpetua, porque en los sistemas sin jerarquías se necesita más que en otros un punto fijo alrededor del cual giren los Magistrados y los ciudadanos: los hombres y las $\operatorname{cosas}^{761}$.

Sucre se transformó de esta manera en "Presidente Vitalicio" de la actual Bolivia. De hecho, la decisión de Bolívar de crear una presidencia vitalicia con derecho a elegir sucesor es una de las más controvertidas de su carrera política. El hecho es que su modelo fue autoritario.

Así, en el caso paraguayo, el centro de la discusión no consiste en negar o atenuar la existencia de una "dictadura"; no consiste en negar la inexistencia de libertades formales; mucho menos en atribuirle a ese régimen un carácter "popular" e "igualitario". Lo que se debe determinar y explicar son las condiciones concretas de su surgimiento y el sentido histórico que poseyó.

\subsection{El principio de "no intervención" y la causa americana}

Existen muchos debates sobre el "aislamiento", no solo económico sino también político, del Paraguay gobernado por el doctor Francia. Una de las aristas de esa discusión hace al involucramiento paraguayo en la guerra de liberación continental. El Paraguay no participó de las campañas militares contra España. Eso es un hecho. Y es un hecho negativo, puesto que la independencia política de ninguna de las ex colonias podía resolverse en la arena nacional, mucho menos en un territorio geográficamente marginal, como era el caso

${ }^{761}$ BOLÍVAR, Simón. Proyecto de Constitución para la República de Bolivia y discurso del Libertador. Buenos Aires: Imprenta de Hallet y Cia, 1826, p. 7. 
del Paraguay. Así, cualquier fractura en el amplio frente militar contra el colonizador debilitaba la causa americana. Eso es así.

Pero la cuestión fundamental no es esa. El problema reside en determinar por qué el Paraguay, a pesar de haber sido una de las primeras naciones que se independizó de España y se declaró República soberana por medio de un congreso muy representativo, no participó militarmente de esa gesta progresiva. Esto no puede ser respondido con generalidades y abstracciones, sino a partir de un análisis del contexto histórico y político concreto. Veamos.

¿Era acaso el Paraguay un "bastión” del realismo españolista? No. En 1811, meses después de derrotar la invasión porteña liderada por Belgrano, ocurre la ruptura con España. En 1813, un congreso proclama la República soberana. Desde la caída del poder colonial, el gobierno paraguayo impulsó el proyecto federalista, mucho más avanzado y progresista que el modelo unitario y centralista que pretendía imponer la burguesía comercial porteña a todo el territorio que comprendía el antiguo virreinato del Río de la Plata. Está demostrado que Francia defendió la "confederación" de los Estados platinos "y demás del continente" desde 1811, antes que Artigas. La cuestión es que defendía una unión libre, voluntaria y “justa”.

En 1813, cuando quedó claro que el centralismo porteño no admitiría siquiera "más autonomía" para el Paraguay, el futuro dictador constató ese hecho, abandonó la idea de la confederación, y adoptó la estrategia de la independencia absoluta. Hay que señalar que los gobiernos porteños, con su política de extorsión comercial y sus amenazas de todo tipo, objetivamente empujaron el proceso hacia la "separación". A partir del congreso paraguayo de 1813, la ruptura con Buenos Aires fue completa. La independencia paraguaya, un derecho democrático elemental de cualquier nación, no solo no será reconocida por la antigua capital virreinal sino que fue constantemente atacada hasta 1852.

El comercio paraguayo fue bloqueado y la nueva República estuvo acosada y en estado de alerta casi permanente frente al peligro de una invasión extranjera. En ese contexto, desde que asumió el poder absoluto, Francia concentró todos los esfuerzos en defender y tratar de consolidar la fragilísima independencia nacional. Así, el no reconocimiento de la independencia y la hostilidad de Buenos Aires, según el criterio de Francia, inviabilizaban cualquier acuerdo militar. De hecho, si no existían relaciones políticas ni comerciales, difícilmente podían existir compromisos militares. El Dictador aplastó al españolismo internamente y nunca entró en acuerdos con ningún "enemigo de la libertad" de los americanos, pero mantuvo al Paraguay al margen de la guerra de liberación continental. 
Se puede discutir si esto fue un "error" únicamente atribuible al capricho o a la mezquindad de Francia. Pero más importante que discutir cuán "provinciano" era $E l$ Supremo es determinar si existían o no condiciones políticas para la participación militar paraguaya en la guerra contra España.

Nuestra opinión es que el "aislamiento" o la "no intervención" del doctor Francia fue, fundamentalmente, una reacción defensiva frente a las agresiones porteñas hacia la autodeterminación nacional y el comercio paraguayos.

La extrema desconfianza del Dictador hacia Buenos Aires poseía bases concretas: los porteños habían invadido el país con un ejército en 1810; no reconocían la independencia; bloqueaban la navegación o imponían tasas exorbitantes al comercio; combatían a Artigas, principal caudillo federalista de la Banda Oriental -en ocasiones tanto o más que a los propios españoles-, etc. La pregunta es: ¿esa política centralista, arrogante y expansionista, fortalecía o debilitaba la necesaria unidad de las naciones alrededor de la "causa común"? ¿Existían condiciones políticas reales para la cooperación militar entre una nación que se había declarado independiente y otra que le negaba ese derecho? ¿Existían condiciones para movilizar a miles de campesinos y enviarlos a luchar al lado de los ejércitos del gobierno de Buenos Aires, el mismo que había invadido su territorio en 1810 y que ahora invocaba la “causa común" pero sin admitir la voluntad que había expresado la nación paraguaya de ser independiente, de tener su propio Estado? Nosotros pensamos que no.

Si la guerra es la continuación de la política por otros medios, Buenos Aires la hacía con la mira puesta en su doble objetivo estratégico: derrotar a España y, en el mismo acto, someter a las provincias del Interior a su dominio. De la misma forma, el acorralado Paraguay utilizaría la guerra para un fin político básico y esencialmente defensivo: mantener su independencia, que no solo era combatida, evidentemente, por el Imperio español, sino también por sectores burgueses del propio "frente patriota".

No se debe idealizar la "lucha contra España" y pensar que el "frente libertador" era homogéneo, un bloque enfocado únicamente en la derrota de la metrópoli. No. El "frente libertador" estaba compuesto de un abanico de sectores burgueses y pequeñoburgueses, en el que las facciones más poderosas - que comandaban militarmente la guerra contra Madrid, en el mismo acto en que luchaban contra los peninsulares hacían lo posible para dominar a las regiones más débiles.

Entonces, ¿es correcto sostener que la no participación paraguaya "debilitaba" el frente militar patriota? En los hechos, sí. 
Lo que decimos es que no se puede simplificar la explicación de ese hecho abstrayendo el análisis de la política previa y posterior en la región.

La guerra contra España se ganó, pero podría no haber sido así. En ese caso, ¿sobre qué sector debería recaer la principal responsabilidad histórica por la "división" de la causa americana? ¿Sobre los “errores” intrínsecos al "histórico aislacionismo" del Paraguay? ¿Sobre el capricho y la necedad personal de un individuo, el doctor Francia? No. No es correcto medir la política de una nación oprimida con el mismo rasero que usamos para una nación opresora. En la lucha común contra España, la política más mezquina y más dañina fue el centralismo y el expansionismo de la burguesía comercial de Buenos Aires. Lo que "dividía" la "causa común" era la opresión nacional, el chantaje y las amenazas económicas y militares del más fuerte, no las reacciones defensivas del oprimido y más débil.

Solo a partir de incorporar en el análisis y entender la perspectiva de la nación oprimida es posible discutir las innegables limitaciones y errores del régimen de Francia en este aspecto.

Por ejemplo, existe un elemento interno que contribuye a explicar la "abstención" paraguaya. La base social de Francia -grandes y medianos propietarios rurales y el campesinado arrendatario- se oponía a cualquier movilización militar fuera de sus fronteras. Sobre todo el campesinado pobre. El peso brutal del antiguo servicio militar obligatorio colonial, que había sido abolido con la revolución, dejó marcas profundas entre el pueblo común. El peso de los sacrificios que implicaban las guardias en lejanos fuertes de frontera o la experiencia desastrosa del contingente paraguayo que, según estimaciones, perdió $70 \%$ de sus hombres en la defensa de Buenos Aires y Montevideo ante las invasiones inglesas, se hizo fuerte en la memoria popular. Así, cualquier iniciativa de enrolamiento masivo para campañas militares externas, como habitualmente ocurría en tiempos de la Colonia, sería mal recibida por el campesinado, reticente a abandonar sus cosechas y alterar su modo de vida. El campesino, asentado en su parcela de tierra, propia o arrendada, anhelaba estabilidad. Su mundo orbitaba la chacra que trabajaba. Su visión del mundo partía de esa parcela. El Dictador le proporcionó "paz interna" y una distancia segura de la "anarquía" que imperaba en las "provincias de abajo". El campesinado le retribuyó no perturbando su régimen y hasta puede decirse que también con simpatía política.

Por otra parte, no se puede negar que una vez que el Dictador se consolidó en el poder, las tendencias conservadoras del proceso político se fortalecieron. Francia no vio motivos para crear él mismo condiciones que pudieran desestabilizar su régimen. Una 
campaña en el exterior, además del problema de las relaciones con Buenos Aires, no solo agitaría al campesinado sino que los pondría en movimiento y en contacto con las tan rechazadas ideas "liberales" que Francia identificaba como "la anarquía".

Este elemento pesó también en su actitud hacia el otro aspecto de la "guerra continental": la guerra civil entre los sectores burgueses latinoamericanos por la conformación de los Estados nacionales. Hemos explicado en otros capítulos que la guerra continental contra España y la guerra civil entre facciones burguesas nativas fueron procesos paralelos e inseparables. En el Río de la Plata, esto último se tradujo en el enfrentamiento armado entre unitarios y federales, que se extendió durante décadas.

En ese enfrentamiento, sí pensamos que Francia cometió un error político: se negó a colaborar, de alguna manera, con los insistentes pedidos de auxilio del caudillo Artigas, que expresaba el otro polo avanzado del proceso revolucionario rioplatense, un proyecto independentista consecuente contra la metrópoli, además de republicano y federalista. Por lo tanto, un proyecto opuesto a los intereses de Buenos Aires, que lo combatió con todas sus fuerzas.

Es cierto que una vez que el Dictador negó cualquier colaboración y hasta cualquier contacto, Artigas pasó a hostilizar la navegación por el Paraná e invadió las Misiones, reivindicadas por el Paraguay, alejando aún más la posibilidad de una alianza militar contra la burguesía comercial porteña. Pero no entender lo que representaba Artigas y su Liga de los Pueblos Libres en lucha contra Buenos Aires y, por ende, no colaborar materialmente con su campaña, fue una equivocación. En la práctica, Francia tuvo la misma política hacia el unitarismo reaccionario y hacia el federalismo progresivo de Artigas: "no intervención". Y esto sí expresa conservadorismo y miopía política. El triunfo final de un federalismo del tipo que defendía Artigas o el del unitarismo porteño no significaba lo mismo para los derechos nacionales del Paraguay ni para el Interior rioplatense. Por otro lado, la posibilidad de colaborar con Artigas no implicaba, necesariamente, un peligro para la independencia paraguaya. La victoria de Buenos Aires, por el contrario, fortalecía a un enemigo declarado de ese derecho. Si no daba igual, una política abstencionista tarde o temprano cobraría su precio.

Finalmente, Artigas fue derrotado y cayó en completa desgracia. En 1820, el caudillo oriental pidió refugio y Francia le concedió asilo en el Paraguay, donde falleció en 1850. Buenos Aires, en las décadas siguientes consolidó su posición y retomó su ofensiva contra el Paraguay. 


\section{Capítulo Vi - El Paraguay de los López [1842-1870]}

“El Estado guaraní era dueño, a mediados del siglo XIX, de casi 90\% del territorio nacional y prácticamente controlaba las actividades económicas, pues cerca de $80 \%$ del comercio interno y externo era

de propiedad estatal”.

FRANCISCO DORATIOTO, Maldita Guerra, 2002.

\section{FUERZAS PRODUCTIVAS Y RELACIONES DE PRODUCCIÓN}

"Hacemos saber a Vmd. que en esta fecha ha muerto de enfermedad natural el Excmo. Señor Dictador de la República"762, rezaba la esquela que recibieron las autoridades civiles y militares el 20 de setiembre de 1840. A pesar de las insistencias de su médico, Francia no dejó indicación alguna para sucederle: no me molesten con esas zonceras, fue su única respuesta.

En Asunción hubo manifestaciones públicas de reivindicación y rechazo hacia el legado del difunto. Cobró fuerza la exigencia de un nuevo Congreso nacional, que no se reunía desde 1816. A toda prisa se constituyó una Junta Provisoria presidida por el alcalde Manuel Ortiz y compuesta por los cuatros comandantes militares de la capital, todos ellos tenientes o subtenientes. Policarpo Patiño, que había sido secretario personal del exdictador, ocupó el mismo cargo en la nueva Junta. Ese improvisado "gobierno de subtenientes" indica el grado todavía muy incipiente de la máquina estatal de la burguesía nacional a la muerte del Supremo.

El 24 de setiembre, la Junta resolvió postergar la discusión sobre "si conviene o no convocar a un Congreso General en esta República"763. Pero pasaron los meses y ninguna convocatoria emanó de las nuevas autoridades. El 23 de enero de 1841, un sargento llamado Romualdo Duré dirigió un golpe militar que derrocó a la Junta y conformó un triunvirato de alcaldes con expreso mandato de convocar el Congreso. El 9 de febrero, un nuevo golpe militar, dirigido por Mariano Roque Alonso -otro oficial de bajo rango-, se hizo con el poder.

\footnotetext{
762 Comunicaciones a los comandantes de varios puntos de la República de la muerte del Dictador Supremo José Gaspar Rodríguez de Francia. ANA-SH, v. 449, n. 1; CHAVES, Julio [1955]. El presidente López. Asunción: El Lector, 2011, p. 22.

763 Ídem, p. 24.
} 
Alonso designó como secretario a Carlos Antonio López, un ex catedrático de teología y abogado, que había regresado a la capital desde su estancia en el interior, adonde se había marchado durante años sin molestar ni ser molestado por el Dictador. López, que era hijo de un sastre, se transformó en acaudalado hacendado al casarse en 1826 con Juana Pabla Carrillo, hijastra de uno de los hombres más ricos del país, don Lázaro Rojas, que había ejercido como recaudador de impuestos de la dictadura. Rojas apadrinó luego a Francisco Solano, primogénito de Carlos Antonio, heredándole parte de su fortuna, incluido el terreno en el que más tarde el joven López construiría su imponente residencia particular, que quedaría conocida como el Palacio de López, sede actual del gobierno paraguayo.

El Congreso se realizó finalmente el 12 de marzo de 1841. Participaron alrededor de 400 delegados. Un sector exigió una Constitución para establecer “un régimen más tolerable después de una larga tiranía". López se opuso, argumentando que el país no estaba preparado, puesto que no existían suficientes personas instruidas. Ante el peligro de la "anarquía", declaraba, era necesario un "poder fuerte" para "mantener el orden y la tranquilidad públicos". La política de López era abrir más el país al comercio, retomando relaciones con otras naciones, pero "sin perjuicio de la independencia y la seguridad de la República". López logró maniobrar para opacar al candidato "francista", Norberto Ortellado, exdelegado en las Misiones. El Congreso finalmente eligió el binomio López-Alonso como “cónsules”, siguiendo las reglas de $1813^{764}$.

Comenzaba así el período de gobierno de la familia López, que regiría el país con mano de hierro hasta 1870 .

La compleja cuestión nacional, ahora en manos del viejo López, residía en cuatro problemas principales: 1) reconocimiento internacional de la independencia nacional; 2) definición de las fronteras; 3) libertad de navegación hasta el océano para el comercio paraguayo; 4) la concesión o no de la libertad de navegación de los ríos comunes para otras banderas, a su paso por el territorio paraguayo.

En este capítulo proponemos abordar principalmente cinco cuestiones: 1) el proyecto de los López como continuidad o ruptura con el de la dictadura de Francia; 2) el grado de desarrollo de las fuerzas productivas alcanzado por el Paraguay; 3) las relaciones de

\footnotetext{
${ }^{764}$ Acta de designación de miembros de la nueva Junta de Gobierno. ANA-SH, v. 245, n. 14; Bando publicado por Carlos Antonio López y Mariano Roque Alonso, nombrados Cónsules de la República, del 14/03/1841. ANA-SH, v. 245, n. 16; CHAVES, Julio [1955]. El presidente López..., op. cit., p. 33.
} 
producción; 4) el régimen político de los López; 5) las relaciones y conflictos políticos internacionales hasta 1864 .

\section{2. ¿CONTINUIDAD O RUPTURA CON EL PROYECTO DEL SUPREMO?}

A menudo se discute si el modelo económico y el régimen político de los López representaron una continuidad o no con el de su antecesor.

No se trata, por supuesto, de señalar si hubo o no cambios - eso es evidente-, sino de precisar si estos fueron cualitativos.

Lo esencial es definir si el proyecto de consolidar una burguesía nacional, lo suficientemente fuerte como para incorporarse de forma independiente al mercado mundial -para lo cual resultaba vital la libre navegación de los ríos hasta el océano y la definición de las fronteras nacionales-, se mantuvo o fue abandonado.

Nosotros opinamos que se mantuvo. La diferencia con el período del doctor Francia fueron las nuevas condiciones políticas regionales en las que intervinieron los López, que ampliaron la base material para desarrollar el proyecto nacionalista burgués.

Hasta 1840, en medio de la marginalidad comercial y la abierta hostilidad porteña hacia la independencia paraguaya, el dictador Francia había conseguido -a partir de la nacionalización de la tierra ${ }^{765}$ y de una política mercantilista en lo comercial y fiscal-asentar los cimientos -aunque todavía endebles- para la estructuración de un aparato estatal y un ejército nacionales.

Sobre esa base, los López irrumpen representando a un sector burgués rural ávido de acumular a través de la producción y el comercio de exportación.

Pero seguía planteado el problema del "aislamiento" y la hostilidad del puerto. En la década de 1840 se recrudeció la lucha contra el entonces gobernador "federal" de Buenos Aires, Juan Manuel de Rosas. El Restaurador Rosas, en realidad, aplicaba una firme política unitaria: mantuvo cerrado el Paraná; monopolizó las rentas de la aduana porteña; no reconoció la independencia paraguaya. En 1850, Rosas fue autorizado a disponer "sin limitación alguna, de todos los fondos" hasta hacer efectiva "la reincorporación de la Provincia del Paraguay a la Confederación Argentina"766.

${ }^{765}$ En un decreto de abril de 1847, por ejemplo, el presidente López exoneró de impuestos a los arrendatarios del Estado y de las comunidades de indios por un año, debido a la sequía y a una plaga de langosta, ver: ANASH, v. 280, n. 8.

${ }^{766}$ CHAVES, Julio [1955]. El presidente López..., op. cit., p. 134. 
El bloqueo anglo-francés de 1845-1848, modificó en parte la situación de marginalidad comercial del Paraguay. Para abastecer el mercado porteño de yerba y tabaco -que Buenos Aires, a pesar de su calidad inferior, importaba del Brasil y de Cuba-, Rosas se vio forzado a disminuir en un tercio los derechos de importación. Los productos paraguayos, transportados por tierra, consiguieron burlar el bloqueo europeo y circularon hacia Buenos Aires y otros puertos del Litoral. Así, entre marzo de 1847 y setiembre de 1848 se descargaron en Pilar, rumbo al exterior, mercaderías por valor de 330.000 pesos $^{767}$, una suma significativa que equivalía aproximadamente a tres años de recaudaciones durante el período de Francia.

Pero el verdadero cambio de situación llegó en febrero de 1852, con la caída de Rosas a manos de una amplia alianza militar liderada por el caudillo entrerriano Justo José de Urquiza, que triunfó en Caseros y se hizo con el poder. A pesar de que López no participó de las acciones militares contra Rosas, la independencia del Paraguay fue por fin reconocida formalmente por el nuevo gobierno argentino, en julio de ese año -39 años después de haberse proclamado la República-, y se decretó la libertad de navegación y comercio a través del Paraná. En ese tratado, López cedió las Misiones a cambio de conservar el Chaco.

El nuevo escenario regional abrió una inmensa perspectiva para el desarrollo comercial y se hizo inevitable el fortalecimiento de un sector burgués paraguayo decidido a hacerse con las ganancias que el "boom exportador" prometía. Y ese sector burgués estaría encabezado por los López y por un reducido círculo de jefes militares y otros burócratas estatales, no pocos de ellos emparentados con la propia familia gobernante.

Los años de enclaustramiento y bloqueo comercial parecían pertenecer a un pasado que ningún rico propietario paraguayo quería revivir. En 1854, López declaró su interés de ser reconocido y de relacionarse "con las primeras potencias del mundo culto"768. El mejor aprovechamiento de las nuevas condiciones será el telón de fondo de las medidas económicas y políticas que tomarán los gobiernos de Carlos Antonio López y de su posterior "heredero", Francisco Solano.

Esas medidas, en lo esencial, mantuvieron el modelo francista, basado en la nacionalización de la tierra; el control estatal del comercio interno y externo; una política fiscal también mercantilista; y la ausencia de deuda externa. En suma, un modelo nacionalista, estatista, y proteccionista. Pero, al mismo tiempo, la perspectiva de una mayor

\footnotetext{
${ }^{767}$ WHIGHAM, Thomas. La economía de la independencia ..., op. cit., p. 123.

${ }^{768}$ LÓPEZ, Carlos A. Mensaje de 1854. In: LÓPEZ, Carlos A. Mensajes..., op. cit., p. 92.
} 
y más rápida acumulación aceleraría una dinámica más elitista y antidemocrática de esa burguesía nacional en formación.

\section{LOS MONOPOLIOS Y EL PROTECCIONISMO ESTATALES}

Sin embargo, la liberación de la navegación comercial no significó, por parte de los López, ni la liberación ni la apertura completa de la economía paraguaya.

El viejo López estableció el monopolio estatal de la producción y comercialización de la yerba mate, de las maderas de construcción y, ocasionalmente, de los cueros y los derivados de la ganadería ${ }^{769}$. Decía don Carlos a los diputados del Congreso de 1854, que "mucho nos falta para ser una nación independiente en todo el rigor de la palabra, [... para ello] es necesario que la Nación se baste a sí misma"770.

Los empresarios particulares, interesados en participar de la explotación y el comercio interno y externo de esos rubros, debían contar con licencias oficiales, como en tiempos de Francia. La yerba mate de origen privado, por ejemplo, debía ser entregada al Estado a precios previamente estipulados por el gobierno, que luego la vendía en Buenos Aires y en el litoral paranaense a través de sus agentes comerciales. El Tesoro nacional actuaba como prestamista local ${ }^{771}$. Un dato de 1854 permite tener una noción de las ganancias a partir de la extracción de sobretrabajo: en los yerbales se pagaba 0,15 libras por arroba, que después se vendía en Buenos Aires por 1,60 libras ${ }^{772}$. En 1857, un periódico porteño opositor a López denunciaba que la yerba paraguaya se vendía en ese mercado a "doce veces su costo" "773.

En el mercado interno, el gobierno mantuvo relativamente bajos los precios de la yerba y de otros productos. Para el mercado exterior, estableció precios muy altos. Por ejemplo, entre 1856 y 1860, el viejo López fijó el precio de la yerba en seis pesos por arroba, sin observar las oscilaciones de la oferta y la demanda.

En 1859, George Morice, un ingeniero naval británico al servicio del gobierno paraguayo, escribía a Solano López sobre ese asunto:

\footnotetext{
${ }^{769}$ Decreto que declara propiedad del Estado la yerba mate y la madera de construcción naval, 02/01/1846. ANA-SH, v. 276, n. 4.

${ }^{770}$ LÓPEZ, Carlos A. Mensaje de 1854. In: LÓPEZ, Carlos A. Mensajes..., op. cit., p. 92.

${ }^{771}$ Lista de personas que tomaron préstamos del Tesoro Nacional. ANA-SH, v. 321, n. 11.

772 SCAVONE, Ricardo. Estudio preliminar. In: SCAVONE, Ricardo (Org.). Polémicas en torno al gobierno de Carlos Antonio López en la prensa de Buenos Aires [1857-1858]. Asunción: Tiempo de Historia, 2010, p. 15 .

${ }^{773}$ Ibídem.
} 
Encuentro que el mercado de la yerba es desastrosamente malo. ¡No se puede vender a más de 40 a 42 reales de plata la arroba! El hecho es que la yerba de Misiones o de Brasil cuenta con el favor del mercado en razón de su precio -en calidad esta yerba es muy inferior a la paraguaya- pero el precio es aproximadamente la mitad [...] lo que tendrá serios efectos sobre el comercio del Paraguay y será bueno que su Gobierno efectúe arreglos para reducir el precio de la yerba ${ }^{774}$.

Esto último era improbable, puesto que el monopolio y la política de precios respondían a la necesidad de asegurar recursos al fisco, siguiendo un modelo proteccionista. Además, la misma familia López se beneficiaba, directa o indirectamente, de buena parte de ese comercio.

En 1842, López tasó en 40\% la importación de artículos que podían ser producidos en el Paraguay. La introducción de relojes, joyas y sedas debía pagar un impuesto de 25\%. El resto de las importaciones pagaba 15\%, con excepción de mapas e instrumentos científicos, que estaban liberados. En cuanto a la exportación, el gobierno decretó un pequeño derecho de dos reales por cada cuero exportado y 5\% de arancel para las demás exportaciones. Los embarques privados de madera eran tasados en $20 \%$. Por otro lado, las exportaciones de "invenciones útiles" o productos manufacturados -bebidas espirituosas, aceite vegetal, jabón, etc.- estaban exentas de derechos. La prohibición de exportar monedas y cualquier metal precioso se mantuvo ${ }^{775}$.

Esta política proteccionista, que gravaba más la importación que la exportación, era uno de los aspectos más criticados del régimen paraguayo en el exterior. El mismo ingeniero inglés que citamos antes, hizo saber a López lo perjudicial que encontraba esa medida: "yo recomendaría encarecidamente la reducción a la mitad de todos los impuestos a las importaciones y exportaciones. No tengo dudas de que el ingreso no disminuirá, porque el comercio se duplicará por la reducción de aranceles"776.

En el campo, las tierras se mantuvieron nacionalizadas. Continuó además la política de arrendamientos a medianos y pequeños productores por parte del Estado. Barbara Potthast anota que don Carlos dispuso, como regla general, que el arriendo exigido no debía exceder $5 \%$ del valor de la tierra ${ }^{777}$. Sin embargo, la situación de los medianos y pequeños chacareros había cambiado desde los tiempos de Francia. López restableció en 1842-1843 el diezmo y la media anata, impuestos sobre las cosechas y el ganado. Los López pertenecían y se

\footnotetext{
774 WHIGHAM, Thomas. La economía de la independencia ..., op. cit., p. 44.

${ }^{775}$ Decreto de Reglamento de Aduanas e impuesto aduanero, 13/01/1842. ANA-SH, v. 251, n. 3.

${ }^{776}$ George F. Morice a Francisco Solano López, 26/12/1859, citado en: WHIGHAM, Thomas. Lo que el río se llevó. Estado y comercio en Paraguay y Corrientes [1776-1870]. Asunción: CEADUC, 2009, p. 286.

${ }^{777}$ POTTHAST, Barbara. Entre lo invisible y lo pintoresco..., op. cit.
} 
apoyaron, principalmente, en los sectores de terratenientes y comerciantes, fracción que pasó a controlar la máquina estatal, aunque sin llegar a una ruptura definitiva con la pequeñoburguesía ni anular completamente las medidas de su antecesor.

Las conocidas Estancias de la República, fundamentales para la provisión del ejército y con importante participación de su producción en el mercado interno, aumentaron a 64, y se incorporaron 300.000 cabezas de ganado bovino y equino. Cuando comenzó la Guerra, en 1864, se estima que el rebaño de ganado -que crecía entre 25 y $27 \%$ por añoalcanzaba al menos 2.000.000 de cabezas ${ }^{778}$.

En 1855, el cónsul británico en Asunción, Charles Henderson, informaba a Londres: "La mayor parte de la propiedad rural es propiedad del Estado. Las mejores casas de la ciudad pertenecen al gobierno y este posee valiosas granjas de cría y agrícolas en todo el país"779.

El historiador brasileño Francisco Doratioto, conocido detractor de Rodríguez de Francia y de los López, confirma lo anterior: "El Estado guaraní era dueño, a mediados del siglo XIX, de casi $90 \%$ del territorio nacional y prácticamente controlaba las actividades económicas, pues cerca de $80 \%$ del comercio interno y externo eran de propiedad estatal" ${ }^{\text {" }} 80$.

\section{EL AUGE COMERCIAL}

En la década de 1850, la independencia paraguaya había sido reconocida por sus dos poderosos vecinos: la Confederación Argentina ${ }^{781}$ y el Imperio del Brasil ${ }^{782}$. Esto permitió el reconocimiento y la firma de tratados comerciales entre 1853 y 1854 con Estados importantes como Gran Bretaña ${ }^{783}$, Francia, Cerdeña, y Estados Unidos ${ }^{784}$. Asunción recuperó su carácter de puerto principal del país, recibiendo varios buques de vapor.

\footnotetext{
${ }^{778}$ WHIGHAM, Thomas. La economía de la independencia..., op. cit., pp. 125-130.

779 POMER, León [1968]. La Guerra del Paraguay: Estado, política y negocios. Buenos Aires: Colihue, 2008, p. 49.

${ }^{780}$ DORATIOTO, Francisco. Maldita Guerra..., op. cit., p. 44.

${ }^{781}$ Acta de reconocimiento de la Independencia y la soberanía del Paraguay, firmada por el Gobierno de la Confederación Argentina, 17/07/1852. ANA-SH, v. 298, n. 10.

${ }^{782}$ Reconocimiento de la Independencia del Paraguay por parte del Brasil, 14/09/1844. ANA-SH, v. 266, n. 26.

783 Tratado de Amistad, Comercio y Navegación entre Inglaterra e Irlanda y la República del Paraguay, 04/03/1853. ANA-SH, v. 306, n. 32.

${ }^{784}$ Copia del reconocimiento de la independencia del Paraguay por los Estados Unidos y Francia. ANA-SH, v. 304, n. 4; Decreto sobre el reconocimiento de la independencia del Paraguay por la Reina de Inglaterra e Irlanda. ANA-SH, v. 306, n. 1; Decreto sobre el reconocimiento de la independencia del Paraguay por el rey de Cerdeña. ANA-SH, v. 306, n. 5.
} 
Según datos de Charles Henderson, las exportaciones aumentaron de 68.000 libras esterlinas en 1851 a casi 440.000 en 1859. Las importaciones, que en 1851 representaron algo más de 46.000 libras esterlinas, en 1859 superaron las $300.000^{785}$. La yerba mate abarcaba entre 40 y 50\% del total de las exportaciones. La exportación de tabaco se triplicó entre 1854 y 1858 , en ocasiones sobrepasando el volumen del de la yerba. Una parte del tabaco paraguayo, que se consumía principalmente en las provincias argentinas, llegaba a Europa $^{786}$.

El conjunto de las exportaciones de yerba, tabaco, maderas, y cueros, en 1857, 1858 y 1860 fue casi dos veces y medio superior al valor de las realizadas entre 1852 y 1854 . Las cifras de importación del mismo período -siempre según informes de Henderson- sugieren un crecimiento de al menos $100 \%{ }^{787}$.

Del total de importaciones, alrededor de la cuarta parte correspondía a compras del Estado, que también era el único importador de armas, municiones, hierro, y materiales de construcción. El resto - perfumes, vinos, tejidos finos, etc.- estaba orientado a la reducida "alta sociedad" asuncena. En general, el consumo popular mantuvo poco contacto con la mercancía extranjera ${ }^{788}$.

Así, entre 1851 y 1861 la balanza de pagos del gobierno paraguayo obtuvo del comercio un saldo positivo de cuatro millones de pesos, cifra importante para el Alto Plata $^{789}$. Las exportaciones, anota el cónsul inglés, saltaron de 341.616 pesos en 1851 a 1.693.904 pesos en 1860, es decir, quintuplicaron ${ }^{790}$.

Si comparamos las 9.084 arrobas de yerba exportadas en 1839, en el ocaso de la dictadura del doctor Francia, con las 254.513 arrobas de yerba exportadas en $1861^{791}$-una cifra 28 veces superior-, el salto es innegable.

Si tomamos como punto de partida el nivel de las fuerzas productivas desde su ruptura con el colonialismo español, no es difícil advertir que, en medio siglo, se produjo un crecimiento impresionante. $\mathrm{Y}$ ese progreso se debe a la política proteccionista y nacionalista. Sin ella, el Paraguay no solo no hubiera llegado a ese grado de acumulación, sino que es probable que ni siquiera hubiese podido sostener su carácter de Estado independiente.

\footnotetext{
${ }^{785}$ SCAVONE, Ricardo. Estudio preliminar..., op. cit., p. 14.

${ }^{786}$ WHIGHAM, Thomas. Lo que el río..., op. cit., p. 134.

${ }^{787}$ Ibídem.

788 Ídem, p. 138.

${ }^{789}$ Ibídem. Aproximadamente, 5 pesos equivalían a $£ 1$.

790 Ídem, p. 139.

791 Ídem, p. 192.
} 
En 1846, el cónsul de los EEUU, Edward A. Hopkins, escribió a Rosas que el Paraguay era "la nación más poderosa del nuevo mundo, después de los Estados Unidos", puesto que "su pueblo es el más unido, y que el gobierno es el más rico que el de cualquiera de los Estados de este continente"792. La impresión de Hopkins, aunque intencionalmente exagerada, no dejaba de apoyarse en un grado de progreso material que era real y que causaba recelos en el exterior.

\section{EL PROCESO DE MODERNIZACIÓN}

Una parte de las rentas que generaba el comercio exterior fue invertida en dos grandes objetivos: 1) aumentar la capacidad exportadora a partir de los monopolios estatales; 2) fortalecer militarmente el país, teniendo presente las ambiciones territoriales de sus vecinos; es decir, definir las fronteras, asegurar el mercado interno.

En la década de 1850, el gobierno contrató a cerca de 200 técnicos extranjeros ingenieros, maquinistas, médicos, etc.-, en su mayoría británicos, para impulsar nuevas empresas estatales. Así se inició un incipiente proceso de modernización e industrialización, que partía de muy atrás y que se basó en la importación de tecnología y conocimientos. Ese programa abarcó importantes obras de infraestructura: fundición de hierro, arsenal, astilleros, ferrocarril, telégrafo. En el terreno militar se destacó la fortificación de Humaitá.

En Asunción se construyó un moderno muelle, además de decenas de nuevos edificios, entre ellos el palacio de Solano López, la estación del ferrocarril, el teatro, el club nacional, el oratorio de la Virgen de la Asunción.

La fundición de hierro de Ybycuí comenzó a operar en 1850 a mando del ingeniero inglés Henry Godwin. Funcionaba con 117 obreros y tenía capacidad para producir, en promedio, una tonelada de hierro por día.

En 1855 se estableció el arsenal de Asunción, con más de 250 obreros y aprendices. Estuvo a cargo del inglés William Whytehead, nombrado "principal ingeniero del Estado", con un salario anual que alcanzó las 1.200 libras.

En 1857, Carlos A. López informaba al Congreso sobre los primeros progresos de la fundición, sobre el arsenal, y sobre el proyecto del ferrocarril:

Se han fundido en la fábrica de fierro catorce cañones de a veinte y cuatro, un gran número de balas de todos calibres, bombas y otros muchos objetos. Los cañones pronto serán taladrados en el Arsenal [...] Se hallan corrientes en el Arsenal dos

${ }^{792}$ CARDOZO, Efraím [1961]. El Imperio del Brasil y el Río de la Plata: Antecedentes y estallido de la Guerra del Paraguay. Asunción: Intercontinental, 2012, pp. 71-72. 
pequeñas máquinas de aserrar maderas a vapor, y se están montando otras dos máquinas grandes que dejarán sin uso en la Capital, el modo primitivo de aserrar maderas. Queda concluido, y en uso corriente un camino de fierro de quinientas varas desde el Arsenal hasta la gran muralla de la ribera, con el fin de facilitar los transportes del muelle y los terraplenes de los muros. En breve se construirá otro ferrocarril desde el muelle hasta la Aduana central. Se han comprado en Inglaterra los materiales necesarios para un ferrocarril de quince leguas desde el muelle hasta Paraguarí [...] También han llegado a este puerto los diez y ocho cañones de a 68, comprado últimamente en Inglaterra [...] La fábrica de fierro proveerá de materiales para continuar el ferrocarril desde Paraguarí hasta el arroyo de Ybycuí y del punto indicado de Paraguarí hasta Villarrica $[\ldots]^{793}$.

En efecto, las primeras locomotoras, vagones y rieles comenzaron a llegar a Asunción en 1858. El primer tramo del ferrocarril, entre Asunción y Trinidad, se inauguró en diciembre de 1861. Unos cinco mil hombres trabajaron en la construcción del camino de hierro. En agosto de 1864, la vía férrea alcanzó 72 kilómetros, uniendo la capital con Paraguarí, asiento del campamento militar de Cerro León, el más importante del país.

En octubre de 1864, se inauguró el telégrafo, instalado por un ingeniero y técnicos alemanes. Su principal misión era militar; consistía en comunicar a Asunción con la fortaleza de Humaitá y con el campamento de Paso de la Patria.

El astillero, construido entre 1856 y 1857, contaba con alrededor de 180 obreros dedicados a la construcción de buques de vapor, con maquinarias y motores importados que eran montados en Asunción, aunque con cascos de madera.

Así, se puso en funcionamiento una importante flota mercante que incluía seis buques de vapor construidos en Asunción: el Yporã, el Salto del Guairá, el Correo, el Río Apa, el Jejuí, y el Ygurey, este último de 250 toneladas. En 1854, además, el Estado adquirió el buque de guerra Tacuarí, construido en Inglaterra por la casa Blyth, que costó 29.850 libras esterlinas. El Tacuarí, dotado de seis cañones y con 448 toneladas de peso, era el único de la flota con casco metálico. Luego fueron incorporados a la Marina, entre otros, el Río Negro, el Río Blanco, el Paraná, el Olimpo, y el Paraguarí, todos vapores de carga. Desde 1856, el gobierno habilitó una línea de vapores a Buenos Aires, que después se extendió a Montevideo. En 1857 arribó el primer cargamento de productos locales al puerto de Londres.

En el mismo mensaje de 1857, el presidente López informó sobre el astillero:

[...] El Vapor Yporã, de 226 toneladas con fuerza de 70 caballos, se ha construido en este puerto con todas las condiciones que exigen los ríos Paraguay y Paraná [...] El Yporã es obra de paraguayos bajo la dirección única del inglés constructor Mister Thomas N. Smith.

Se han construido también en este puerto bajo la dirección del citado Smith otros dos vapores, el uno de setenta caballos de fuerza y 244 toneladas de medida, y el

${ }^{793}$ LÓPEZ, Carlos A. Mensaje de 1857. In: LÓPEZ, Carlos A. Mensajes ..., op. cit., pp. 134-135. Ver también: Memoria de 1857 escrita por el ingeniero inglés Whytehead sobre trabajos del arsenal. ANA-SH, v. 323, n. 2. 
otro de doce caballos de fuerza y de 31 toneladas de medida de casco. Ambos buques en breve serán lanzados al agua ${ }^{794}$.

Aunque muy criticadas, algunas de estas empresas estatales no dejaban de causar impresión en el extranjero. En 1862, el capitán español Joaquín Navarro anotaba, en un informe secreto sobre la situación militar del país, que lo único digno de nota en el Paraguay era el arsenal "sin disputa, el mejor que poseen las Repúblicas Hispanoamericanas"795.

En 1864, el Standard de Buenos Aires publicó un artículo sobre los astilleros dirigidos por Whytehead, hombre que "había convertido el Paraguay en otro Clyde"796.

El Progreso, periódico oficial de Corrientes, expresó en 1863, en tono de reclamo a su gobierno, su simpatía hacia el modelo paraguayo:

\begin{abstract}
¿No sería más útil si el gobierno [nacional], en vez de gastar grandes sumas de dinero en la compra de buques de vapor de fabricación extranjera, comprara solamente las maquinarias (y la pericia) y construyera los buques en esta provincia como lo hacen en la vecina República del Paraguay? ¡Nosotros ciertamente creemos eso! ${ }^{797}$.
\end{abstract}

\title{
6. RELACIONES DE PRODUCCIÓN
}

Indudablemente, el salto en la producción y el programa de modernización solo fue posible y se sostuvo mediante un aumento de la extracción de excedente social de los obreros y esclavos negros al servicio del Estado, de los pueblos nativos, del semiproletariado agrícola $^{798}$-peones yerbateros, braceros de estancias, marineros de los ríos, etc.-, y de la pequeñoburguesía rural, principalmente los medianos y pequeños chacareros.

Durante el período de los López, la estructura social no cambió mucho en comparación con el gobierno del doctor Francia. Se mantuvo una combinación de relaciones

794 Ídem, pp. 136-137.

${ }^{795}$ CARDOZO, Efraím [1961]. El Imperio del Brasil..., op. cit., p. 110.

796 WHIGHAM, Thomas. Lo que el río..., op. cit., p. 297. La referencia alude a la concentración de astilleros sobre el río Clyde, en Glasgow, Escocia.

${ }^{797}$ El Progreso. Un astillero especial en la República, 20/09/1863, citado en: WHIGHAM, Thomas. Lo que el río..., op. cit., p. 298.

798 Tomamos la definición de Lenin de semiproletariado como clase oprimida: “[...] los semiproletarios (los campesinos que no explotan trabajo ajeno y que recurren constantemente a la venta, aunque solo sea en parte, de su fuerza de trabajo) [...]", en: LENIN, V. I. Tesis e informe sobre la democracia burguesa y la dictadura del proletariado. $1919 . \quad$ Disponible en: $<$ https://www.marxists.org/espanol/lenin/obras/1910s/internacional/informe.htm>, consultado el 20/02/2019. Sugerimos también considerar esta cita: "[...] Los campesinos pobres no hacen parte del proletariado, y, actualmente, ni siquiera del semiproletariado, pero son los que están más cercanos del semiproletariado [...]”, en: LENIN, V. I. Sobre as tarefas dos sindicatos. 1919. Disponible en: $<$ https://www.marxists.org/portugues/lenin/1919/01/tarefas.htm>, consultado el 20/02/2019. En el Paraguay del siglo XIX, un sector de peones o jornaleros "asalariados" al mismo tiempo poseía o usufructuaba una parcela de tierra. 
de producción en la que el trabajo jurídicamente "libre", asalariado, todavía coexistía con relaciones de producción precapitalistas, basadas en la coerción extraeconómica, como la esclavitud negra, la mano de obra extraída de los pueblos de indios -formalmente, por lo menos hasta 1848-, y los trabajos forzados de los presos y vagos.

Durante el gobierno de Carlos A. López, la medida más avanzada en cuanto a la liberación jurídica del trabajo se dio en octubre de 1848, cuando el presidente decretó la disolución de los últimos 21 pueblos de indios, declarando a los nativos "ciudadanos" libres $\mathrm{y}$, en el mismo acto, adueñándose de las tierras, el ganado, $\mathrm{y}$ otros bienes de las reducciones ${ }^{799}$.

Antes de ese decreto, un sector de la población indígena continuaba confinada en reducciones. En el Archivo Nacional de Asunción obran pedidos aislados de libertad de los pueblos, como el que realizó la "india libre” María Petrona Yaharí para tres de sus hijos, en abril de $1846^{800}$. O bien un pedido presentado ese mismo año por el indio Evaristo Arce, sobre una copia del documento de su libertad ${ }^{801}$.

Si bien hay coincidencias sobre que en 1848 las reducciones no tenían el mismo peso económico que en los siglos XVII o XVIII, está planteado un debate importante sobre el carácter de esta medida y sobre el destino de los indígenas y de los bienes de aquellos últimos pueblos de indios.

Estamos de acuerdo con Telesca cuando sostiene que "resta mucha materia por investigar para comprender fehacientemente la sociedad del Paraguay tras la muerte de José Gaspar Rodríguez de Francia en 1840"\$02. El estudio documental, sin duda, no está agotado. Pero nos parece que, a partir del decreto, es posible apuntar hipótesis y una caracterización más general de su sentido socioeconómico.

Tomada en su aspecto histórico, esta medida -aunque en sí no estableció inmediatamente el modo de producción capitalista "puro"-, poseía un sentido claramente capitalista: liquidó los resquicios de una forma de explotación precapitalista, entonces en total decadencia y casi obsoleta. Aunque tardío y completamente controlado "por arriba", este fue un paso muy importante para la consolidación del Estado nacional unificado y

\footnotetext{
${ }^{799}$ Decreto de Carlos A. López que declara ciudadanos libres a los indios naturales de toda la República del 07/10/1848. ANA-SH, v. 282, n. 24.

${ }^{800}$ ANA-SH, v. 279, n. 6.

${ }^{801}$ ANA-SH, v. 279, n. 9.

802 TELESCA, Ignacio. Paraguay 1848: pueblos de indios y conformación del Estado. 2016. Disponible en: $<$ http://grupoparaguay.org/L_Telesca2016.pdf> $>$, consultado el 20/02/2019.
} 
"moderno"; por supuesto en términos burgueses y realizado con métodos burgueses, es decir, explotadores y arbitrarios.

Nuestra definición no es original. Expresa una concordancia con lo esencial del planteamiento que hizo Creydt en 1963:

[...] Al transformar una parte de los indios en campesinos libres y otra parte, en proletarios obligados a vender su fuerza de trabajo, la disolución de las comunidades indígenas contribuía a crear las condiciones previas para el desarrollo de las relaciones capitalistas. Por tanto, era una reforma progresista $^{803}$.

Creydt también definió, con razón, que la medida "terminó de unificar a la nación suprimiendo definitivamente la división en castas" ${ }^{804}$. Aunque fuese una supresión tan solo jurídica, no por eso dejaba de significar un paso progresivo. De estar segregados en sus pueblos, al servicio muchas veces gratuito del Estado o de los resquicios de encomenderos o empresarios privados, los naturales pasaron a ser jurídicamente ciudadanos "libres".

Mauricio Schvartzman, un intelectual de orientación gramsciana, escribió que el decreto sentaba "las bases definitivas para la creación de una población asalariada, desbloqueando el proceso de diferenciación social que estuvo contenido durante la colonia y agudizado en la dictadura del Dr. Francia" $" 805$.

Branislava Susnik, por su parte, hizo una descripción del proceso de desagregación de las reducciones desde 1843 y no descartó la idea de una proletarización posterior:

[Las comunidades, $n d a$ ] comenzaron a desintegrarse por la frecuente ausencia de los hombres, sirviendo en los batallones o en las partidas de vaqueros [...y] los guaraníes liberados se convirtieron en simples arrendatarios del Estado [o bien se inició, $n d a$.] la proletarización rural de los naturales ${ }^{806}$.

Aunque el proceso se dio sin reparación real, aparentemente los indígenas no salieron de las reducciones completamente desposeídos. Según señala Ignacio Telesca, el decreto concedía por única vez a los corregidores y empleados de los Cabildos una pensión, y a las familias debería entregárseles algún animal y/o herramienta, además de otorgarles la gracia de no pagar ni diezmo ni derechos parroquiales o arriendo por un lapso de tres años ${ }^{807}$.

\footnotetext{
${ }^{803}$ CREYDT, Oscar [1963]. Formación histórica de la nación paraguaya..., op. cit., p. 84.

804 Ídem, p. 100.

805 SCHVARTZMAN, Mauricio. Contribuciones al estudio de la sociedad paraguaya. Asunción: CIDSEP, 1988, p. 83.

806 SUSNIK, Branislava. Una visión socioantropológica del Paraguay del siglo XIX. Asunción: Museo Etnográfico Andrés Barbero, 1992, pp. 167-168. Consultar también: SUSNIK, Branislava. El rol de los indigenas en la formación y en la vivienda del Paraguay. Asunción: Intercontinental, 2013.

807 TELESCA, Ignacio. Pueblos de Indios y tierra en el Paraguay de Carlos Antonio López. 2018. Disponible en: <http://grupoparaguay.org/2018 Telesca.pdf> , consultado el 20/02/2019.
} 
Según la interpretación de este autor, la "ciudadanización" del ex indígena reducido significó “[...] fundamentalmente, convertirse en sujeto de la leva militar, por un lado, y económicamente dejar de vivir en tierra comunitaria para hacerlo en tierras arrendadas por el Estado, además de comenzar a pagar impuestos" $" 808$.

Pero, sobre todo, la razón del decreto respondía no tanto a la proletarización sino a "la necesidad de aumentar el ejército, además de enviar ganado vacuno para dar de comer a este ejército", dada la creciente amenaza del dictador Rosas en contra del Paraguay ${ }^{809}$.

La hipótesis de la proletarización del indígena es razonable, no como único resultado sino como el más importante, en el sentido de crear un ejército de desposeídos que pudiera servir de mano de obra barata para los estancieros particulares y para el propio Estado.

La cuestión es concreta. De un plumazo, López incorporó a cerca de 25.000 indios al mercado de fuerza de trabajo. Aunque no sea posible cuantificarla con exactitud, se puede afirmar que una parte lo hizo como peones yerbateros, jornaleros de estancias, transportadores de mercaderías por el río. Otra parte engrosó el campesinado mestizo libre, sea como arrendatarios del Estado o no. Los indígenas desempleados fueron considerados "vagos y mal entretenidos", un crimen que la ley punía comúnmente con trabajos forzados para el propio Estado ${ }^{810}$. De esa manera, la liberación jurídica de la mano de obra indígena aseguró al Estado nacional y a los grandes propietarios rurales la suficiente fuerza de trabajo para aumentar la producción y poder aprovechar mejor las oportunidades que la abertura de los ríos ofrecía al comercio exterior ${ }^{811}$.

Dicho lo anterior, no es consistente la tesis del liberalismo que niega cualquier proyecto de desarrollo en clave capitalista o de "industrialización” por parte de los López, expresada, por ejemplo, en las conclusiones de Mario H. Pastore, cuando afirma que:

El “original”, "sui géneris" experimento del período nacional temprano en el Paraguay no fue sino la prolongación del militarismo, absolutismo, y del mercantilismo coloniales al período nacional temprano, que acentuó algunas facetas del mercantilismo colonial y le dio una apariencia particular ${ }^{812}$.

808 TELESCA, Ignacio. Paraguay 1848 ..., op. cit.

${ }^{809}$ TELESCA, Ignacio. Pueblos de Indios y tierra en el Paraguay..., op. cit. Decreto de Carlos A. López que establece juzgados y jefaturas de milicias en los distritos de los pueblos de naturales declarados libres y reglamenta su organización, del 06/11/1848. ANA-SH, v. 282, n. 29.

${ }^{810}$ Por ejemplo, ver el decreto sobre el castigo y azotes a ladrones y vagos del 01/05/1848. ANA-SH, v. 282, n. 12. En agosto de 1856, otro decreto revoca el castigo de azotes a ladrones y establece la pena de confinamiento en la frontera. ANA-SH, v. 319, n. 10.

${ }^{811}$ Incluso existe registro de un pedido de informes a varios pueblos sobre "naturales idóneos para el ejercicio de empleos públicos". ANA-SH, v. 285, n. 8.

812 PASTORE, Mario. Estado e industrialización: dos hipótesis y la evidencia sobre el Paraguay [1852-1870]. 1993. Disponible en: < https://mpra.ub.uni-muenchen.de/27505/1/MPRA_paper_27505.pdf $>$, consultado el 20/02/2019. 
Lo que no alcanzan a comprender ciertos intelectuales asociados al pensamiento liberal, como Carlos Pastore, Mario H. Pastore, Thomas Whigham, o Guido Rodríguez Alcalá, es que, a pesar de las evidentes e inevitables continuidades jurídicas y económicas, entre 1811 y 1813 se dio una ruptura cualitativa con el régimen colonial. Hay un antes y un después de ese proceso.

Este hecho fundamental no resultó en un mero "mercantilismo adaptado" ni fue un cambio "aparente". Como ya debatimos, el período "nacional" no fue una simple y mecánica “prolongación” del período colonial. Fue una ruptura, más o menos drástica o radical, pero una ruptura con todo un sistema específico de explotación que obstaculizaba cualquier progreso económico y cultural para la nación como un todo. Y, desde el punto de vista del progreso general de la nación en escala histórica, la independencia y el modelo estatista nacional representó un paso adelante.

En síntesis: independientemente del destino de los indígenas devenidos "ciudadanos" 813 en 1848; o sea, de que se hayan proletarizado o semiproletarizado; o se hayan mantenido en sus chacras como arrendatarios del Estado; o bien hayan engrosado las filas del ejército, cuando sostenemos que la disolución de los pueblos de indios fue "progresiva" lo hacemos desde una perspectiva histórica, no inmediata o coyuntural. No hacemos esa afirmación porque consideramos que los naturales dejaron de ser explotados u oprimidos al salir de sus antiguas reducciones sino porque, al menos jurídicamente, pasaron a ser libres de aquellos campos de trabajo las más de las veces forzado; libres de una forma de explotación con trazos de servidumbre, esto es, mucho más atrasada que las relaciones capitalistas que trataban de abrirse paso en el siglo XIX.

Es evidente que la riqueza del crecimiento económico, generado por el excedente extraído del sudor y la sangre de los que con su trabajo producían valor, fue acaparada por la familia López y su círculo de “ciudadanos propietarios”, mientras la vida del esclavo negro y del peón yerbatero siguió siendo un infierno en la Tierra.

Por ejemplo, el Estado militarizó Villarrica para defender los yerbales de los ataques de indios no domesticados. Era común utilizar a los soldados como mano de obra para la recolección de la yerba mate. Los jefes militares también reclutaban fuerza de trabajo entre la población local, y pagaban con "vales” a ser canjeados únicamente en los almacenes del

\footnotetext{
${ }^{813}$ Vale remarcar que, en todo caso, se transformaron en ciudadanos de segundo orden. Todavía en 1850 existen documentos relativos al papel sellado, exclusivo para el matrimonio "entre naturales", ver: ANA-SH, v. 291, n. 5 .
} 
Estado, siempre a un valor muy desventajoso para los peones. El viejo sistema de "enganche por deudas" tampoco desapareció ${ }^{814}$. En 1848, Carlos A. López decretó que cualquier trabajador que huyera de los yerbales sería tratado como un "desertor" y sufriría la pena de muerte "como en los combates" 815 . En casos menos extremos, si el peón fugitivo era capturado y no podía resarcir a su patrón, era castigado con azotes ${ }^{816}$.

La esclavitud negra también permaneció, a pesar de que en noviembre de 1842 el gobierno decretó la libertad de vientres de las esclavas ${ }^{817}$. El decreto estableció que, a partir del 1 de enero de 1843, los hijos de esclavos pasarían a ser llamados "libertos". Pero esa ley no liberó a nadie. Los nacidos antes de esa fecha siguieron siendo esclavos. Y los "libertos" fueron obligados servir a "sus señores como patronos": los varones hasta los 25 años y las mujeres hasta los 24. Así, la libertad solo llegaría en 1866-1867, cuando el Paraguay estaba ya en plena guerra ${ }^{818}$. No se abolió la trata ni la vergonzosa institución de la "esclavatura del Estado". El único gesto "humanitario" de la ley de 1842 fue prohibir que se fijara precio a "las crías" en "edad de lactación", es decir, antes de los tres años, y que se los separara de sus padres antes de los seis.

La propia familia López era propietaria de esclavos, muchos de ellos comprados "al Estado". En un recibo de 1853, se lee: "son [...] cuarenta y cinco pesos corrientes metálicos que ha mandado entregar el Excmo. Señor Presidente de la República [Carlos A. López] en pago de un esclavito del Estado llamado Desiderio Cartaman, de diez años de edad"819. Francisco Solano, Venancio, y Benigno, hijos del presidente, también se hacían de "esclavitos".

Según el historiador Cooney, al comienzo de la guerra al menos 20.000 paraguayos eran esclavos y posiblemente otros 25.000 eran negros y de otros grupos ${ }^{820}$. No existe una

\footnotetext{
${ }^{814}$ La comparecencia de peones a los yerbales estaba estrictamente reglamentada. Ver la consulta del Juez de Paz de la Villa de San Pedro sobre órdenes del gobierno al respecto en: ANA-SH, v. 295, n. 28.

${ }^{815}$ Decreto de López sobre castigo a los desertores de los beneficios de yerba, del 16/09/1848. ANA-SH, v. 282, n. 18. Ver también: Decreto de López del 13/05/1848 sobre los trabajos agrícolas en los pueblos de indios. ANA-SH, v. 282, n. 11.

${ }^{816}$ WHIGHAM, Thomas. La economía de la independencia..., op. cit., p. 43.

${ }^{817}$ Decreto de Carlos A. López sobre la libertad de vientres de las esclavas, del 24/11/1842. ANA-SH, v. 252, n. 9.

${ }^{818}$ Una muestra de la existencia de esclavos y libertos enrolados en el Ejército paraguayo se puede encontrar en la Constancia expedida por los vecinos de Villarrica a los esclavos y libertos de la localidad para su enrolamiento. ANA-SH, v. 340, n. 6.

${ }^{819}$ Libro de Caja para el año 1853. 15/06/1852, n. 308, foja 109, citado en: RODRÍGUEZ ALCALÁ, Guido. Francia y López. In: SOLER, Lorena, et al. (Org.). Antología del pensamiento crítico paraguayo..., op. cit., p. 554.

${ }^{820}$ COONEY, Jerry. Abolition in the Republic of Paraguay: 1840-1870. Jahrbuch für Geschichte von Staat, Wirtschaft und Gessellschaft, Köln, n. 11, 1974, p. 154.
} 
cifra cierta sobre cuántos fueron movilizados, pero se estima que no menos de 6.000 esclavos sirvieron en el ejército paraguayo. La abolición definitiva debió esperar hasta el 2 de octubre de 1869, otra medida extremadamente tardía y que cupo a la iniciativa de los Aliados. Pero esta solo habría beneficiado a alrededor de 450 esclavos. El resto de los esclavos y/o negros "libertos" probablemente murió durante la contienda.

El culto a la personalidad de los López, que la mayor parte de la izquierda asumió bebiendo de las fuentes del nacionalismo burgués, es tan nocivo que a menudo atenúa o anula la crítica a la brutal explotación de los indígenas, de los negros y de los demás sectores de la clase trabajadora durante el periodo independiente. En la década de 1850, la reorientación hacia la exportación generó en el campo al menos dos fuertes caídas de los tradicionales cultivos de subsistencia, planteándose incluso el peligro de hambruna ${ }^{821}$.

Como señalamos, si bien las medidas económicas y el programa de desarrollo estaban orientados en sentido capitalista, en la producción sobrevivieron formas de explotación precapitalistas incluso después de 1848. Estas coexistían y se combinaban desigualmente con las formas de trabajo "libre", presentes en las empresas estatales y que tuvieron un impulso con la disolución de los pueblos de indios, relacionado con el incremento de la demanda de fuerza de trabajo que exigía el comercio exterior y con la necesidad de fortalecer el ejército como forma de protección de ese modelo.

\section{7. ¿ERa el Paraguay una gran Potencia?}

Luego de examinar la producción, las relaciones de producción, el comercio y los objetivos del programa de modernización, existen mejores condiciones para retomar el espinoso debate sobre el grado de desarrollo de las fuerzas productivas del Paraguay anterior a la Guerra.

La historiografía liberal, interesada en justificar la guerra "civilizatoria" en contra de un Paraguay "bárbaro" y “opuesto al progreso", minimiza todo el proyecto de modernización de los López apuntando que, como mucho, estaba orientado a fines estrictamente militares $^{822}$. En el otro extremo, la historiografía nacionalista y "revisionista", sobre todo aquella adicta a la teoría de la dependencia, no duda en pintar el Paraguay -con el correcto

${ }^{821}$ WHIGHAM, Thomas. Lo que el río..., op. cit., p. 308.

${ }^{822}$ DORATIOTO, Francisco. Maldita Guerra..., op. cit., p. 44. 
afán de denunciar a la Triple Alianza- como una "gran potencia", no solo superior a sus vecinos sino casi en condiciones de competir con la industria británica.

Ninguno de estos extremos es correcto. La idea del Paraguay-potencia es un mito que fue utilizado tanto por la literatura liberal de corte mitrista como por el nacionalismo de “derecha" y de "izquierda" para justificar sus respectivos relatos.

El Paraguay, en 1864 no era ninguna potencia industrial ni militar. Su ubicación en la división internacional del trabajo nunca dejó de ser la de un productor de materias primas y frutos tropicales, y consumidor de manufacturas y tecnologías foráneas, principalmente británica.

Si bien no es tema de este trabajo, el siguiente cuadro ilustra la verdadera correlación de fuerzas entre los países que se enfrentarían en la Guerra, poco antes de su estallido.

Tabla 4. Poder económico y militar de los países beligerantes hacia 1860.

\begin{tabular}{llllll}
\hline & Paraguay & Argentina & Brasil & Uruguay & $\begin{array}{l}\text { Total } \\
\text { regional }\end{array}$ \\
\hline Comercio exterior en $\mathfrak{£}$ & 560.392 & 8.951 .621 & 23.739 .898 & 3.607 .711 & $\mathbf{3 6 . 8 5 9 . 6 2 2}$ \\
\hline $\boldsymbol{\%}$ & 1,5 & 24,3 & 64,4 & 9,8 & $\mathbf{1 0 0 , 0}$ \\
\hline Ingresos fiscales en $\mathfrak{f}$ & 314.260 & 1.710 .324 & 4.392 .226 & 870.714 & $\mathbf{7 . 2 8 7 . 5 2 4}$ \\
\hline $\boldsymbol{\%}$ & 4,3 & 23,5 & 60,3 & 11,9 & $\mathbf{1 0 0 , 0}$ \\
\hline Fuerzas movilizadas & $57.000^{*}$ & 30.000 & 139.000 & 5.582 & $\mathbf{2 3 1 . 5 8 2}$ \\
\hline \% & 24,6 & 13,0 & 60,0 & 2,4 & $\mathbf{1 0 0 , 0}$ \\
\hline Superficie en $\mathbf{k m}^{\mathbf{2}}$ & 275.000 & 1.388 .328 & 4.255 .983 & 93.463 & $\mathbf{6 . 0 1 2 . 7 7 4}$ \\
\hline \% & 4,6 & 23,1 & 70,8 & 1,6 & $\mathbf{1 0 0 , 0}$ \\
\hline Población & 450.000 & 1.737 .076 & 9.100 .000 & 250.000 & $\mathbf{1 1 . 5 3 7 . 0 7 6}$ \\
\hline \% & 3,9 & 15,1 & 78,9 & 2,2 & $\mathbf{1 0 0 , 0}$ \\
\hline
\end{tabular}

Fuente: BRUN, Diego A. La guerra de la Triple Alianza: tres modelos explicativos. Revista Paraguaya de Sociología, Asunción, v. 26, n. 74, pp. 175-197, 1989; DORATIOTO, Francisco. Maldita Guerra..., op. cit., pp. 91, 458, 461, 462.

*Tropas profesionales movilizadas por el Paraguay al comienzo de la guerra.

El proyecto de los López nunca pretendió cambiar esto. Por el contrario, se esforzaban por aumentar lo más posible la capacidad exportadora de productos primarios locales y para que el comercio de esos productos no fuera obstaculizado.

Esto nos lleva a la discusión de fondo: ¿cuál era el proyecto económico y político de los López? Desarrollar una economía que continuó siendo principalmente primaria, es decir agraria y extractivista, capaz de exportar tanto como les fuera posible.

La diferencia con Buenos Aires, con el Interior argentino, y con Rio de Janeiro no estaba en que la burguesía paraguaya pretendía alcanzar una economía industrial y las otras simplemente querían exportar materias primas e importar bienes manufacturados. 
No. El Paraguay de los López quería exportar la mayor cantidad posible de yerba mate, maderas, tabaco, algodón y otros productos primarios. Cuando estalló la guerra, no aspiraban exportar bienes de capital, máquinas o ferrocarriles, o bien generar tecnología propia, ni podían hacerlo. Al contrario, los importaban, principalmente de Inglaterra. Los López eran exportadores de materias primas. Para eso reivindicaban la apertura de los ríos y el fin de los obstáculos aduaneros, e intentaron llegar con sus productos a Europa.

La diferencia es que los López querían acaparar esa acumulación para ellos mismos y su círculo palaciano, los "200 ciudadanos propietarios". Era una burguesía nueva, que se aferraba al aparato del Estado para acumular; que aspiraba a su propio mercado interno y su espacio económico en la región. El férreo control de la máquina estatal -para hacer negocios y defender sus intereses-representaba, al mismo tiempo, tanto la debilidad o rusticidad como la principal fortaleza de esa facción propietaria.

Esta es la esencia, desde el punto de vista de esa incipiente burguesía nacional, del concepto de "independencia" política. Ese sector social, al menos hasta 1864, no quería intermediarios ni trabas aduaneras ni asumía deuda externa.

En otras palabras, en 1864 existía una burguesía nacional, débil en relación con sus vecinos pero mucho más consolidada y sofisticada que en 1840. Una clase dominante más corrupta y antidemocrática, que se apropiaba de diferentes formas del excedente producido por los campesinos, yerbateros, jornaleros, indígenas, y negros esclavizados. Pero todo al servicio de una acumulación originaria capitalista local.

Entonces, la cuestión determinante es la existencia de un proyecto de consolidar una burguesía nacional independiente política y económicamente, pero no debido a una idea romántica de "patriotismo" sino para poder hacer sus propios negocios. El nacionalismo no era un criterio abstracto y moral sino la forma que los López y esa burguesía embrionaria encontraron para acumular más y mejor: una acumulación centrada en los negocios a través del Estado.

Esa era la diferencia con Buenos Aires y con el Imperio brasileño. En estos Estados y sociedades, la burguesía estaba mucho más desarrollada y, por lo tanto, era mucho menos homogénea que la paraguaya; y el sector preponderante era el exportador-importador, que tenía acuerdos establecidos y hacía décadas que se había conformado con ser "socia menor" de los capitalistas ingleses.

De contenido, existían dos modelos de acumulación, ambos capitalistas, pero con diferencias importantes: uno nacionalista, es decir, basado en fuertes monopolios e 
inversiones estatales, un sistema independiente y proteccionista. El otro, librecambista, basado en la inversión extranjera, en el empréstito externo, y en todo tipo de pactos con Inglaterra y otras naciones europeas "civilizadas".

El Paraguay era una nación que, exactamente por ser oprimida e históricamente marginada, necesitaba de la independencia política para poder liberar fuerzas productivas y desarrollarse.

¿Pero acaso no hubo un avance de las fuerzas productivas en el Paraguay por medio de la revolución anticolonial que rompió con España, Buenos Aires, y cualquier poder extranjero, entre 1811 y 1864 ?

Sin lugar a dudas, sí. Y hasta podríamos decir que fue espectacular. Pero solo si lo comparamos con su propio punto de partida -la excolonia más pobre y marginal- y no con sus poderosos vecinos de la región, ni mucho menos con el Imperio británico, como hacen el nacionalismo paraguayo y el revisionismo histórico argentino.

Hubo un claro crecimiento de las fuerzas productivas. El propio Doratioto debe reconocer que el Paraguay contaba "con avances tecnológicos en relación con otras naciones del continente" 823 .

El crecimiento económico tuvo reflejos y ciertos avances en el terreno de la cultura. En 1857, López informaba que existían 16.755 alumnos distribuidos en 408 escuelas, sin contar las escuelas particulares ${ }^{824}$. Cinco años después, existían 435 escuelas públicas con 25.000 alumnos. Esto significaba que alrededor de $5 \%$ de la población total ${ }^{825}$ estudiaba, una cifra cinco veces superior al número de alumnos declarado por el doctor Francia en $1834^{826}$. Pero, para dimensionar todavía más claramente este avance cultural, baste señalar que, por ese tiempo, el ministro del ramo informaba a Mitre que la Argentina, una nación mucho más populosa y rica, poseía la misma cantidad de alumnos que el "bárbaro" Paraguay ${ }^{827}$.

Y hay que señalar que eso no fue un "milagro". Ese progreso fue producto de una política de desarrollo capitalista independiente -basado en la explotación brutal del pueblo pobre, por supuesto-. El modelo paraguayo no se basó en el librecambio sino en el proteccionismo y la regulación económica; en los monopolios y las empresas estatales, antes

\footnotetext{
823 Ibídem.

${ }^{824}$ LÓPEZ, Carlos A. Mensaje de 1857. In: LÓPEZ, Carlos A. Mensajes..., op. cit., p. 137. En octubre de 1843 se creó la Cátedra de Filosofía en la Academia Literaria y se emitió un decreto ordenando a los Comisionados del Gobierno a exhortar a los padres de familia a recibir enseñanza gratuita. ANA-SH, v. 256, n. 21.

${ }^{825} \mathrm{Si}$ tomamos como base la cifra aproximada de 450.000 habitantes.

${ }^{826}$ Decreto del 30/08/1834. ANA-SH, v. 242, n. 9.

${ }^{827}$ POMER, León [1968]. La Guerra del Paraguay..., op. cit., p. 58.
} 
que en grandes inversiones extranjeras; en la nacionalización de las tierras, antes que en el latifundio privado. Es decir, el progreso se concretó haciendo lo opuesto de lo que aplicaba la futura Triple Alianza y de lo que pregonan los historiadores liberales hasta hoy.

El plan de modernización se concretó a partir de la importación de tecnología, y fue financiado enteramente con recursos del Estado. Hasta 1864 no existían deuda externa ni pactos semicoloniales. En esto reside la "singularidad" del Paraguay del siglo XIX dentro de la región, y no en que el país fuese "la principal potencia" de Sudamérica.

¿Es posible que, si no hubiese existido la guerra, la dinámica de ese modelo nacionalista hiciera posible que el Paraguay dejase de ser una economía primaria y avanzase hacia una economía industrial? Como hipótesis teórica esto no se puede descartar, aunque pensamos que sería altamente improbable. Sin embargo, una discusión de este tipo no podría salir nunca del campo de la especulación, pues la guerra liquidó el modelo nacionalista y, con él, todos los adelantos técnicos que esa política trajo aparejada.

Lo central es no perder de vista que si bien las fuerzas productivas se desarrollaban, estas partían de mucho más atrás que las de sus propios vecinos: no debe olvidarse la ubicación marginal de la nación dentro del sistema colonial ni el bloqueo porteño hasta 1852 . Tener presente este atrasado punto de partida de las fuerzas productivas, que hace más impresionante el progreso que significó la fundición de hierro ${ }^{828}$, los vapores salidos de sus astilleros, el telégrafo, o el ferrocarril, es indispensable para definir el verdadero peso del Paraguay en la región.

Por ejemplo, si nuestro parámetro se restringe a las fronteras paraguayas, es indudable que entre 1811 y 1864 existió un enorme salto material. Pero si analizamos la situación en el contexto internacional no se puede dejar de concluir que el Paraguay, por motivos históricos, seguía siendo no solo un país oprimido sino mucho más débil. En 1860, el comercio exterior paraguayo totalizó 560.392 libras esterlinas. Esto significaba $6 \%$ del argentino y solamente 2,3\% de los intercambios internacionales del Imperio del Brasil, que alcanzaban 23.739.898 de libras $^{829}$.

Por consiguiente, el Paraguay tampoco podía ser una "potencia” en el terreno militar. En vísperas de la guerra, a pesar de todos los esfuerzos, la diferencia en cuanto a poderío militar con sus vecinos era enorme. El Paraguay enfrentaría la guerra con obsoletos fusiles

${ }^{828}$ Desde agosto de 1854, el encargado de la fábrica de hierro de Ybicuí fue el teniente paraguayo Elizardo Aquino. ANA-SH, v. 310, n. 19. Ver también: Apuntes del ingeniero inglés W. K. Wythehead sobre la misma fundición. ANA-SH, v. 312, n. 2.

${ }^{829}$ DORATIOTO, Francisco. Maldita Guerra..., op. cit., p. 91. 
a chispa, cañones de ánima lisa, y una escuadra de buques con casco de madera. La "inexpugnable" fortaleza de Humaitá, en realidad ni siquiera contaba con artillería capaz de causar daño alguno a los modernos acorazados que presentó el Imperio del Brasil. Pero, eso sí, aquellos cañones lisos y aquellos vapores mercantes eran fabricados en el país.

Para denunciar a la Triple Alianza no es necesario incurrir en el error de exagerar el grado de desarrollo de las fuerzas productivas ni alimentar el mito del Paraguay-potencia. Esta exageración no solo no contribuye al debate, sino que abre un flanco innecesario -e imposible de defender seriamente- a los apologistas de la Triple Alianza.

Lo que sí debe ser resaltado es que en el Paraguay existía una burguesía nacional que, debido a su propia debilidad y como reacción eminentemente defensiva, había puesto en marcha una experiencia de acumulación originaria capitalista independiente.

Fue la marginalidad geográfica y la hostilidad de sus vecinos lo que obligó a la clase dominante paraguaya a apoyarse en una "economía defensiva" que, como anota Milcíades Peña, le "permitió, pese a su pobreza en relación con Buenos Aires y pese a los tributos que el puerto único porteño le imponía, capitalizarse aceleradamente" ${ }^{\$ 30}$.

En 1864, ese tipo de desarrollo burgués independiente se oponía al modelo librecambista y dependiente del capital europeo, sobre todo británico, que imperaba en Buenos Aires y en el Imperio del Brasil.

El historiador estadounidense Thomas Whigham, que no pierde ocasión de atacar cualquier intervención del Estado en la economía, apunta que "no existía una contradicción estructural entre la economía del Paraguay y la de los países vecinos que tuviera que resolverse por medio de la guerra" 831 .

Esto es correcto solo en el sentido de que la guerra no consistió en un enfrentamiento entre un proyecto "capitalista" y otro "protosocialista", ni siquiera uno "antiimperialista" un planteamiento igualmente anacrónico, puesto que no existía el imperialismo como tal y que Solano López no tenía ninguna posición en tal sentido-. Pero lo que Whigham y los historiadores liberales no identifican, es que sí existían -y chocaron- dos modelos de acumulación capitalista opuestos: uno estatista e independiente; otro librecambista y semicolonial.

${ }^{830}$ PEÑA, Milcíades. Historia del pueblo argentino..., op. cit., p. 227.

${ }^{831}$ WHIGHAM, Thomas. Lo que el río..., op. cit., p. 154. 
Tanto es así que, incluso Guido Rodríguez Alcalá - un historiador tan liberal como puede llegar a ser Whigham, además de un "lopista" insospechado- está dispuesto a reconocer esa realidad:

[Carlos Antonio] López tuvo una política nacionalista. Contrató técnicos extranjeros para hacer un trabajo estrictamente técnico, dentro de un programa definido por el Gobierno paraguayo. Él no hubiera permitido que ninguno de esos técnicos le escribiera sus discursos (se bastaba solo), ni que le impusiera los programas de educación, ni la política económica, ni los planes de desarrollo. El crecimiento económico de aquellos tiempos se logró sin endeudamiento externo y concesiones a factores de poder internacionales ${ }^{832}$.

Los monopolios estatales no eran dañinos al progreso económico paraguayo; no eran expresión de "barbarie", sino lo opuesto: todas las naciones capitalistas más poderosas aplicaron medidas mercantilistas y proteccionistas para desarrollarse. En ese sentido, Peña señala que:

El monopolio estatal del comercio exterior no perjudicaba, sino que estimulaba el desarrollo del capitalismo paraguayo, pero impedía que ese desarrollo se hiciera ante todo en beneficio de la burguesía europea y de su socia menor rioplatense, la burguesía porteña [y de la del imperio del Brasil, agregamos nosotros, $n d a.]^{833}$.

Este era el problema fundamental.

Así, la guerra significará el enfrentamiento entre una alianza de tres países -entre ellos las dos principales economías de la región, financiadas en parte por el capital inglésy una nación que, si bien había iniciado un proceso de evolución autónomo hacia el desarrollo capitalista, era más pobre, débil, e históricamente oprimida. Ese país fue destruido, desmembrado, y sometido a un atroz genocidio. Esto, por sí solo, debería ser suficiente para definir un campo militar en esa guerra. En esta cuestión, desde nuestra perspectiva, no cabe ninguna clase de neutralidad.

\section{SUPERESTRUCTURA POLÍTICA: LA DICTADURA DE UNA FAMILIA}

Hemos referido la decisiva intervención del Estado en la economía paraguaya hasta el fin de la Guerra. Pusimos de relieve que la razón de este fenómeno residía en que en el Paraguay, que partía de fuerzas productivas mucho más atrasadas dentro la región, no existía una clase dominante tan fuerte en términos de acumulación como lo era la burguesía comercial o estanciera de Buenos Aires, o como la de los terratenientes esclavistas del Brasil.

832 RODRÍGUEZ ALCALÁ, Guido. López y Horacio Cartes. Última Hora, 2016. Disponible en: < https://www.ultimahora.com/lopez-y-horacio-cartes-n1025702.html>, consultado el 15/01/2020.

${ }^{833}$ PEÑA, Milcíades. Historia del pueblo argentino..., op. cit., p. 232. 
Así, la incipiente burguesía nacional debió apoyarse en la máquina estatal para hacer negocios, acumular, y protegerse interna y externamente.

Pero se sabe que "el Estado" no es una abstracción. Según la teoría marxista, es una "fuerza especial de represión” que, a su vez, es "el producto y la manifestación del carácter irreconciliable de las contradicciones de clase" en la sociedad ${ }^{834}$.

Este aparato de coerción de clase, basado en "destacamentos especiales de hombres armados", en el caso que estudiamos estaba al servicio de la dominación de la naciente clase burguesa nacional o, más precisamente, de un sector de esta. Esa facción estaba compuesta por la familia López y un reducido entorno que la orbitaba.

Los López eran, sin duda, los “dueños” del país ${ }^{835}$. Eran los principales terratenientes, además de explotar los yerbales de San Pedro, Concepción y Río Estrella ${ }^{836}$. Participaban ventajosamente del comercio interno y externo. Francisco Solano, por ejemplo, poseía una sociedad con los hermanos Pedro y Buenaventura Decoud para comercializar yerba mate en Buenos Aires y otras plazas ${ }^{837}$.

Vicente Barrios, marido de la hermana de Solano López, explotaba yerbales en San Estanislao. Otros dos hijos de Carlos Antonio, Venancio y Benigno, también vendían yerba al Estado. Saturnino Bedoya, otro yerno de don Carlos y que llegó a ser Tesorero General durante la guerra, además de sus negocios yerbateros con el Estado poseía una de las principales casas comerciales de la capital ${ }^{838}$.

Hacían todo tipo de negocios y especulaciones. Las mujeres de la familia López, por ejemplo, se dedicaban a comprar billetes deteriorados con descuentos de $8 \%$, para después cambiarlos por su valor real en el Ministerio de Hacienda ${ }^{839}$.

${ }^{834}$ LENIN, V. I. [1917]. O Estado e a revolução. São Paulo: Editora Sundermann, 2005, pp. 28-31.

${ }^{835}$ Para hacernos una idea, ya en plena guerra contra la Triple Alianza, el culto a la figura del presidente Solano López era proporcional a las privaciones de la tropa y la población civil, ver: Legajo de correspondencia relativa al obsequio de una espada de oro al Mariscal Francisco Solano López por su cumpleaños en 1867. ANA-SH, v. 353, n. 11; Legajo de adhesiones populares para el obsequio de una guirnalda de oro y gorro triunfal al Mariscal Francisco Solano López. ANA-SH, v. 353, n. 3; Acta de los festejos de cumpleaños y la entrega de un espadín de oro al Mariscal Francisco Solano López en 1868. ANA-SH, v. 355, n. 10; Actas de asambleas celebradas en Luque en 1868, donde se propuso la emisión de monedas de oro con la efigie del Mariscal Francisco Solano López. ANA-SH, v. 355, n. 11. Ya en 1863, por ejemplo, consta un informe de Carlos Calvo en París sobre el costo de una condecoración de brillantes para Solano López. ANA-SH, v. 444, n. 19; Sobre el caso de Carlos Antonio López, ver: Circular sobre el proyecto de creación de un monumento al difunto presidente Carlos Antonio López, de 1863. ANA-SH, v. 334, n. 35.

${ }^{836}$ WHIGHAM, Thomas. Lo que el río..., op. cit., p. 132.

837 RODRÍGUEZ ALCALÁ, Guido. Francia y López..., op. cit., p. 553; SCAVONE, Ricardo. Estudio preliminar..., op. cit., p. 15.

${ }^{838}$ WHIGHAM, Thomas. Lo que el rio..., op. cit., p. 132.

839 Ídem, pp. 132-133. 
Tampoco se puede negar que los López trataban las propiedades del Estado como propias. En 1856, Carlos Antonio López compró un campo estatal en Capiipobo ${ }^{840}$. Benigno López compró tierras y ganado público en San Joaquín ${ }^{841}$. En 1859, Venancio López compró tierras del Estado en Rosario ${ }^{842}$. Nadie podía oponerse a los López en cualquier tipo de subasta o negocio comercial. Hay constancia de una "orden suprema" de abril de 1853 que dispuso la transferencia de ganado de la estancia estatal de Yacarey a la estancia privada del presidente López ${ }^{843}$.

Los reclamos que la irlandesa Elisa Alicia Lynch, que fue pareja del mariscal López, hizo en Asunción al terminar la guerra, dan cuenta de las gigantescas propiedades estatales que el presidente López le transfirió como bienes particulares. Ella exigió en 1875 la devolución de 32 propiedades rurales y urbanas que equivalían a cerca de 9.000 .000 de hectáreas de tierras, una buena parte de estas en territorios que fueron anexados por la Argentina y el Brasil ${ }^{844}$.

Los negocios de los López y de su reducido entorno, lícitos o ilícitos, realizados a partir de esa posición dirigente en el Estado, no solo muestran el carácter burgués de ese gobierno sino la evolución "normal" de una burguesía nacional que a medida que se fortalecía se hacía más reaccionaria, antidemocrática, y corrupta con los bienes públicos.

\subsection{El régimen político dictatorial}

¿El régimen de los López fue una dictadura? ¿Fueron tiranos? Si bien ninguno de los dos López se hizo nombrar formalmente "Dictador", como sí lo hizo el doctor Francia, el poder que ejercieron no fue menos unipersonal $\mathrm{y}$, por ende, dictatorial. El régimen era despótico. Esto es categórico. Una lectura marxista no debe titubear en reconocer este hecho. En la práctica, los López eran "el Estado".

El Congreso de 1844 aprobó una ley fundamental que si bien reconocía tres poderes, concedía poderes casi ilimitados al "Supremo Gobierno", esto es, al Presidente de la República.

\footnotetext{
${ }^{840}$ ANA. Libro de Caja 1855/1857, 06/06/1856, n. 826, citado en: RODRÍGUEZ ALCALÁ, Guido. Francia y López..., op. cit., p. 552.

${ }^{841}$ ANA-CRB, 1259 y 1354, citado en: Ibídem.

${ }^{842}$ Libro Caja 1858/1859, 01/06/1859, n. 434, citado en: Ídem, p. 553.

${ }^{843}$ ANA-NE, vol. 2713, citado en: WHIGHAM, Thomas. La economía de la independencia ..., op. cit., p. 116.

${ }^{844}$ RODRÍGUEZ ALCALÁ, Guido. Francia y López..., op. cit., p. 553.
} 
Si para los congresos generales de 1813 y 1814 fueron convocados "mil diputados", electos en las villas por el sufragio masculino, sin criterios censitarios, para el de 1816 el llamado se restringió a 250 representantes. Luego, el dictador Francia jamás convocó otro Congreso nacional. En el Congreso de 1842 participaron 400 diputados $^{845}$. En el de 1844 ese número se redujo a $300^{846}$, y la denominada "Ley que establece la Administración Política de la República del Paraguay" limitó los próximos congresos a 200 diputados, incorporando por primera vez la condición de ser "propietarios". En 1856, la representación en los congresos se redujo a 100, cerrando todavía más el círculo palaciego, puesto que tanto elegidos como electores debían ser propietarios ${ }^{847}$. Así, lo que se evidencia desde 1816 es un continuo retroceso en cuanto a la participación popular "democrática" formal y a la representación política institucional.

Sin embargo, esta evolución autoritaria era normal en un régimen y un Estado burgués que se habían ido consolidando. La burguesía, o sectores de ella, en su época de ascenso podía "apelar" al pueblo y, sobre la base de determinadas relaciones de fuerza, ampliar cierta participación democrática y hasta conceder libertades formales. Pero, a medida que consolida su poder sobre el resto de la nación, la tendencia inevitable es el ataque a esas libertades y garantías democráticas.

Las justificaciones de la deriva dictatorial fueron varias. En 1854, por ejemplo, Carlos A. López defendió el criterio de propiedad y alertó sobre los peligros que entrañaba el sufragio universal.

La experiencia de todas las Naciones en que rige el sistema representativo, tanto en Europa como en América, ha mostrado los gravísimos males e inconvenientes que trae el sufragio universal. Por eso [...] las condiciones que deben reunir los electores y los elegibles: la condición de propiedad y de una capacidad regular, a más de la probidad, buena fama, conocido patriotismo, y el goce de todos los derechos civiles, deben ser requisitos esenciales en unos y $\operatorname{otros}^{848}$.

Para "el goce de todos los derechos civiles" se exigía "un capital propio de ocho mil pesos". Si consideramos que en tiempos del doctor Francia el sueldo promedio de un soldado raso -normalmente reclutado entre el campesinado mestizo pobre de habla guaraní- era de

\footnotetext{
${ }^{845}$ Convocatoria del Congreso extraordinario de 400 diputados. ANA-SH, v. 252, n. 6.

${ }^{846}$ Convocatoria del Congreso ordinario de 300 diputados para instalar nuevo Gobierno. ANA-SH, v. $266, \mathrm{n}$. 5.

${ }^{847}$ CHAVES, Julio [1955]. El presidente López..., op. cit., p. 221.

${ }^{848}$ LÓPEZ, Carlos A. Mensaje de 1854. In: LÓPEZ, Carlos A. Mensajes..., op. cit., p. 100. Ver también el Manifiesto del presidente López sobre su reelección. ANA-SH, v. 310, n. 13.
} 
seis pesos mensuales, no se puede discutir que las clases trabajadoras no decidían ni podían decidir absolutamente nada. Esto es un hecho.

No es que en el Imperio del Brasil o en Buenos Aires lo hicieran, pero está claro que en el Paraguay todo el poder político se concentraba en ese núcleo duro de 100 diputados “propietarios", ligados a los López y a los negocios del Estado. Era una verdadera "oligarquía". Ese poder, aunque se convocaran congresos, siguió siendo unipersonal y absoluto.

En sus informes, don Carlos reconocía que su régimen nada tenía de representativo y "liberal". El argumento era que el pueblo no estaba preparado para gozar de derechos democráticos. Así, planteaba que el sistema institucional era "provisorio", hasta que "el pueblo se acostumbre al uso regular y moderado de derechos que aún no conoce [...]"849. Mientras eso no ocurra, su sistema era el "único preventivo" contra las "calamidades" y la "anarquía" de los Estados vecinos. El viejo López juzgaba que las constituciones liberales que se aplicaron en la ex América española, "a excepción del Paraguay", habían sido producto de un "inmoderado deseo de libertad":

Todas estas, más o menos, teóricamente perfectas, están basadas sobre los principios más luminosos y encierran las ideas más elevadas, justas y liberales, todas otorgan a sus ciudadanos, amplios e importantes derechos políticos: todas garanten los derechos primordiales del hombre, su libertad, su propiedad, su seguridad, y su igualdad ante la ley; todas están marcadas con el sello de permanencia, e inmutabilidad; todas han debilitado la autoridad y, creyendo hacer difícil el despotismo, no han hecho más que facilitar la anarquía ${ }^{850}$.

Según el mensaje de López de 1854, los pueblos americanos "no estaban preparados ni tenían educación y cualidades necesarias y adecuadas para gozar, sin perturbaciones, de la libertad y derechos a que los empujaron algunas imaginaciones exaltadas e inexpertas", puesto que "en América es imposible un completo sistema representativo, porque las masas no lo comprenden y no saben usar de los instrumentos y resortes que hacen funcionar este hermoso pero complicado mecanismo político. El que no sabe usar una cosa, precisamente abusa de ella" ${ }^{\prime 51}$.

Entre el "despotismo y la tiranía" y la "libertad racional que civiliza", siempre de acuerdo con el pensamiento de López, había un "abismo" que debía ser llenado "poco a poco, y gradualmente" $" 852$.

\footnotetext{
849 Ídem, p. 94.

${ }^{850}$ Ibídem.

851 Ídem, pp. 94-95.

852 Ídem, 95.
} 
Así, planteó a los diputados aplazar una Constitución permanente y la concesión de derechos políticos al pueblo.

Proclamemos y respetemos con la mayor escrupulosidad los derechos civiles esenciales y primordiales de todo hombre, la libertad, la propiedad, seguridad e igualdad ante la ley, pero excusemos por ahora de establecer derechos políticos hasta que se entienda y conozca lo que importan y significan estas palabras. La inteligencia de la cosa debe preceder al uso del derecho de esa $\operatorname{cosa}^{853}$.

Y, finalmente, exhortó a mantener un "poder fuerte".

Mantengamos un poder fuerte: sin un poder fuerte, no hay justicia, no hay orden, no hay libertad civil ni política. Un poder fuerte por la ley, no es ni quiere decir un poder arbitrario y tiránico que nada respete. Un poder fuerte, ilustrado y prudente, es la primera condición, es el primer elemento de organización y constitución de toda República [...] Impliquémonos para que el pueblo se incline ante la Autoridad Suprema y ante todos los que por sus funciones participan de ella, no en una postura humillante y servil sino respetuosamente, como conviene a hombres verdaderamente libres ${ }^{854}$.

El gobierno, en definitiva, alertaba:

[...] dos peligros que amenazan a la República: el mal y el peligro de quedar estacionario en medio de las mejoras y progresos de todo género que hacen las sociedades modernas; y el peligro revolucionario, que quiere precipitar todo, y transformar todo a pretexto de mejoras [...] pues el espíritu precipitado y revolucionario es enemigo del orden público y sin orden público no hay libertad, paz, ni progreso ${ }^{855}$.

En razón de ello, era necesario "empezar por regenerar al pueblo, por ponerlo y guiarlo en el camino por donde debe ir para llegar, sin riesgo de extravíos y caídas [...]"856.

En 1856, el régimen del "poder fuerte” se endureció todavía más. Preocupado con la sucesión, el viejo López propuso reducir la edad mínima que era requerida para las candidaturas presidenciales, de 45 a 30 años. En adelante, los candidatos también podrían ser militares. Los cambios tenían el claro objetivo de allanar el camino del entonces general Solano López hacia la sucesión del poder. Esa misma reforma otorgó al presidente la atribución de designar, a través de un "pliego cerrado", a la persona que en su ausencia ejercería como vicepresidente. Poco antes de su muerte, Carlos Antonio puso en ese pliego el nombre de su primogénito, heredándole el poder en la práctica ${ }^{857}$. El Congreso de los “cien propietarios", reunido el 16 de octubre de 1862, no hizo más que ratificar el contenido del pliego: designó por unanimidad a Solano López como presidente efectivo ${ }^{858}$.

\footnotetext{
853 Ídem, p. 96.

854 Ibídem.

855 Ídem, p. 101.

856 Ídem, p. 93.

${ }^{857}$ Decreto testamentario por el cual el presidente Carlos Antonio López nombre al General Francisco Solano López como vicepresidente y sucesor. ANA-SH, v. 331, n. 5.

${ }^{858}$ Ley del Congreso que designa presidente de la República a Francisco Solano López, 16/10/1862. ANA-SH, v. 331, n. 9 .
} 
Pero la dictadura de los López se degeneraría aún más. En 1861, El Semanario, periódico oficial y único del país, dedicó varios números a una aberrante campaña favorable a una monarquía constitucional.

Tras la liberación de España, argumentaba El Semanario, las naciones pasaron por un "período de fiebre revolucionaria", sin transición, de la monarquía a la república. Esto no podía sino causar trastornos políticos, pues "pueblos educados por la monarquía, no han podido acostumbrarse a las formas republicanas" ${ }^{\text {"59 }}$. Continuaba diciendo que el Brasil había evitado las "convulsiones políticas" gracias a "sus instituciones: el Imperio". La otra excepción en ese sentido era el Paraguay, debido a la limitada concesión de "inmoderadas garantías" y que había "procurado en cuanto le ha sido posible, buscar la armonía entre la república y el antiguo sistema, sin que por eso deje de alimentar el noble deseo de ver a su pueblo en el pleno goce de todas las libertades" $" 860$.

En otra edición, El Seminario se preguntaba:

¿Podrá decirse que hay incompatibilidad entre la libertad y las monarquías? ¿Que solo hay compatibilidad entre ella y las repúblicas? ¿No podrán los reyes dar a los pueblos aquella libertad que estos creen deben tener? ¿No podrán las repúblicas privarlos de la que ellos creen que les corresponde? ${ }^{861}$.

Y concluía afirmando que monarquía y libertad no eran incompatibles: "de consiguiente, lo que se llama república no significa precisamente la completa libertad de los pueblos". En la edición siguiente, el periódico oficial hizo en una defensa categórica del régimen monárquico: "de consiguiente, la monarquía constitucional y la democracia es una misma cosa" $" 862$.

El coqueteo con un posible régimen monárquico continuó y alcanzó extremos inaceptables. En 1863, siendo ya Solano López el presidente, el "Supremo Gobierno" hizo imprimir y difundir el conocido Catecismo de San Alberto $^{863}$, una inequívoca apología no ya de la monarquía constitucional sino de la absoluta, con su consabida fundamentación divina. En el catecismo, que estuvo destinado "a los párrocos, maestros de escuela, padres de familia y demás ciudadanos", puede leerse:

P. ¿Quién es, pues, el origen de los Reyes?

R. Dios mismo, de quien deriva toda potestad.

P. ¿Quién es superior al Rey?

\footnotetext{
${ }^{859}$ CARDOZO, Efraím [1961]. El Imperio del Brasil..., op. cit. p. 123.

860 Ídem, p. 124.

861 Ídem, p. 125.

862 Ibídem.

${ }^{863}$ El Catecismo Real de José Antonio de San Alberto es un texto político editado en 1786. Fue una respuesta de la metrópoli al levantamiento de Túpac Amaru. Su principal objetivo era legitimar y predicar obediencia religiosa a la monarquía hispánica.
} 
R. Solo Dios en lo civil y temporal de su reino.

P. ¿El Rey está sujeto al pueblo?

R. No; que esto sería dejar sujeta la cabeza a los pies.

P. ¿Está obligado el vasallo a aceptar las penas?

R. Si; porque son justas y establecidas por la ley [debiendo, además,] subir la escalera si lo ahorcan o aplicar la garganta si lo degüellan por sus delitos.

En la versión de López constó la aclaración de que el vocablo "Rey” debía entenderse como "Supremo Gobierno, u otra equivalente, para que los niños se acostumbren" 864 .

No se tomó ninguna medida para cambiar formalmente el régimen republicano, aunque completamente bonapartista y policíaco, por otro monárquico. Pero, tanto la campaña de El Semanario - vale decir, del propio López-como la adopción y difusión de un catecismo que inculcaba ideas de servilismo y opresión, muestran el grado de degeneración de un retaceado régimen republicano y firmemente nacionalista, pero despótico y al servicio de un puñado de "propietarios".

Un régimen dictatorial en el que el propio López no solo reconocía que no existían atisbos de las más básicas garantías y libertades democráticas para el pueblo, sino que decía que tal cosa sería sumamente perniciosa para la nación. Un régimen así solo empeoraba las condiciones de explotación para el pueblo trabajador, completamente imposibilitado de poder expresarse políticamente. No existía ningún derecho democrático para el pueblo, ni siquiera para algún burgués que osara desafiar el régimen. Los López querían un pueblo dócil y obediente de sus dictámenes "supremos".

Desde el punto de vista de la burguesía nacional, el régimen dictatorial de los López, así como el de Francia, expresaba su propia debilidad e inmadurez - puesto que la clase dominante no podía prescindir de un régimen de "poder fuerte" para garantizar su propia estabilidad y acumulación-, tanto como el temor a cualquier levantamiento popular contra la camarilla gobernante, la tan aludida "anarquía".

Pero ese régimen de poder unipersonal mostraría todas sus limitaciones cuando comenzó a cerrarse el cerco de las hostilidades internacionales. El Estado burgués, debido al atraso y al temor de los López en promocionar cuadros que pudieran hacerles sombra, mostrará una carencia alarmante de personal especializado, de cuerpo diplomático, y de oficialidad militar competente ${ }^{865}$.

${ }^{864}$ CARDOZO, Efraím [1961]. El Imperio del Brasil..., op. cit., pp. 128-129; CHAVES, Julio [1955]. El presidente López..., op. cit., p. 292.

${ }^{865}$ No existía academia militar ni cuerpo diplomático propiamente dicho. En 1863, el gobierno envió 30 jóvenes para cursar estudios en Europa, principalmente ingeniería civil y mecánica. Solo seis fueron destacados para estudios militares en la Escuela Militar de Saint Cyr. Solo uno terminó el curso, cuando la guerra estaba casi terminada. 
Hacia finales de 1864, cuando comenzó la Guerra, para una fuerza que bien podría alcanzar los 80.000 y hasta los 150.000 soldados si se apelase a la conscripción generalizada -como se terminó haciendo-, la oficialidad paraguaya estaba compuesta por un general -el propio López-, 5 coroneles, 2 tenientes coroneles, 10 mayores, 51 capitanes, y 22 tenientes. Más abajo en la cadena de mando existían algunos centenares de subtenientes ${ }^{866}$, y eso era todo. Ni hablar de la competencia o de la experiencia sobre el terreno de estos oficiales, puesto que el último enfrentamiento real del ejército paraguayo contra fuerzas extranjeras databa de la invasión de Belgrano, 53 años antes.

La forma despótica de gobernar, en la que tanto Francia como los López se ocupaban de los detalles más triviales, inevitablemente abonaba un terreno propicio a la mediocridad general en las esferas de poder.

El doctor Francia ya se quejaba de la falta de "hombres capaces" y de que todo debía resolverlo personalmente. Don Carlos, en su momento, también resaltó que: "la falta de hombre especiales para los diferentes destinos y ramos de la administración (no nos avergoncemos Honorables Representantes de reconocerlo, porque no es culpa nuestra sino de circunstancias que no hemos podido evitar) es completa" ${ }^{867}$. La altísima concentración de poder en una sola persona, necesaria para la burguesía nacional por todo un período, ciertamente no contribuía para dotar a la máquina estatal de ese personal especializado. Y esto cobraría su precio más alto entre 1864 y 1870.

Una advertencia. El régimen político dictatorial de los López es solo parte de una totalidad definida por el modelo económico basado en la nacionalización de la tierra y la acumulación estatal, al servicio de defender la independencia nacional.

\section{Nubes de tormenta en el Plata: la Crisis internacional y el ascenso de SOLANO LóPEZ}

Desde 1810 hasta el estallido de la Guerra Grande en 1864, el Paraguay tuvo enfrentamientos o recibió amenazas de agresión por parte de Buenos Aires, del Imperio brasileño, de los EEUU, de Francia -por complicaciones en un fracasado intento de inmigración francesa-, y de la propia Gran Bretaña.

\footnotetext{
866 WHIGHAM, Thomas. Aspectos clave de la larga resistencia paraguaya: disciplina militar, cohesión burocrática y egomanía indomada del Mariscal López. In: GARAVAGLIA, Juan; FRADKIN, Raúl. A 150 años de la Guerra..., op. cit., p. 26.

${ }^{867}$ LÓPEZ, Carlos A. Mensaje de 1854. In: LÓPEZ, Carlos A. Mensajes...op. cit., p. 99.
} 
La crisis principal, aquella potencialmente explosiva, se daba con el Imperio del Brasil y con la Confederación Argentina. En 1862, cuando Solano López asumió la presidencia, expiraba el plazo de la resolución de límites, que había sido postergado en 1856. Por otro lado, la campaña periodística y diplomática abiertamente a favor de llevar la guerra al Paraguay para "destruir los monopolios" se había puesto en marcha en el Plata por lo menos desde 1857.

Aunque no es posible hacer un examen pormenorizado de cada incidente, intentaremos plantear algunos de los conflictos más importantes, para entender mejor los antecedentes políticos de la guerra.

\subsection{Notas sobre las relaciones con el Imperio del Brasil}

La histórica disputa con Buenos Aires hizo que la diplomacia imperial admitiera la independencia paraguaya en 1844. El Brasil incluso gestionó el reconocimiento de la soberanía paraguaya tanto en América como en Europa. Por su parte, necesitado de apoyo contra la hostilidad de Rosas, que consideraba al Paraguay una provincia argentina ${ }^{868}$, López se avino a la "protección" brasileña. En diciembre de 1850, ambos gobiernos suscribieron un pacto defensivo contra Rosas, el enemigo común, dando largas a las cuestiones de límites $^{869}$.

El cónsul brasileño en Montevideo, Duarte da Ponte Ribeiro, había escrito en 1845:

De la existencia del Paraguay como Estado independiente de la Confederación Argentina depende [...] la conservación del Imperio del Brasil. [... Esto] además de ser una fuerte barrera contra las tentativas argentinas sobre aquellas tres provincias [Mato Grosso, Rio Grande do Sul, y São Paulo], evitará que la población paraguaya vaya a aumentar las fuerzas de la Confederación Argentina ${ }^{870}$.

Esta afirmación, aunque exagerada, es una muestra de que aquella "amistad" brasileña hacia el Paraguay estaba en función de la disputa por la hegemonía regional con Buenos Aires, que por su parte mantenía el viejo anhelo de "reconstruir" el poder perdido como capital del antiguo Virreinato, disuelto en 1810. El Paraguay, mientras tanto, aprovechaba las brechas que abría ese embate.

\footnotetext{
868 El representante de Rosas en Rio de Janeiro, general Tomás Guido, protestó y declaró nulo el reconocimiento brasileño. Guido argumentó explícitamente que, como parte de la antigua capital virreinal, el Paraguay era una provincia subordinada a Buenos Aires.

${ }^{869}$ Tratado de Alianza defensiva entre Paraguay y Brasil, 25/12/1850. ANA-SH, v. 292, n. 1.

${ }^{870}$ RODRÍGUEZ ALCALÁ, Guido; ALCÁZAR, José. Paraguay y Brasil..., op. cit., p. 6.
} 
Caído Rosas, los reclamos y las desconfianzas históricas entre el Paraguay y el Imperio, se hicieron cada vez más tirantes. El conflicto se centraba en la libre navegación de los ríos comunes y en la demarcación de los límites. El Brasil reivindicaba la libre navegación por el río Paraguay como la manera más viable para comunicarse con el Mato Grosso, su más apartada provincia. López lo negaba, convencido de que el Brasil lo utilizaría para fortalecerse militarmente exactamente en el territorio que estaba en disputa entre ambos gobiernos. En el actual Mato Grosso, el Paraguay reconocía como límite con el Brasil el río Blanco; para el Imperio, su frontera llegaba al río Apa. El viejo López condicionaba un acuerdo sobre navegación al arreglo definitivo de los límites. La cosa empeoró cuando el Imperio comenzó a instalar fuertes militares dentro del territorio en litigio: el del Pan de Azúcar [Fecho dos Morros] debió ser desalojado por tropas paraguayas en 1850.

En 1854, López expulsó al cónsul brasileño Felipe Pereira Leal, acusándolo de insultos e intrigas contra su gobierno. La prensa y el senado brasileños se escandalizaron. El emperador Pedro II decidió apelar a la antigua "diplomacia de la cañonera" y envió a Asunción una imponente escuadra de 20 buques, con 130 bocas de fuego y 2.600 soldados al mando del almirante Pedro Ferreira de Oliveira. Esta flota atravesó territorio argentino sin ser cuestionada ${ }^{871}$.

El jefe brasileño tenía instrucciones de forzar la firma de un tratado de navegación y límites. Si eso fracasaba, debía destruir las fortificaciones paraguayas y remontar el río. Al llegar a la boca del río Paraguay, desde las baterías paraguayas se informó a Oliveira que "si su misión era pacífica como decía, remontase en un solo vapor, y que entonces sería recibido como el Representante de un Monarca amigo" ${ }^{872}$. El almirante decidió subir hasta Asunción en el Amazonas, su buque insignia, pero este quedó atascado en el río y tuvo que ser reemplazado por el Ipiranga. La escuadra, en realidad, no estaba lista para forzar el paso. Oliveira, juzgando desventajosa su posición, accedió a firmar un tratado de amistad, comercio y navegación en abril de 1855, postergando la cuestión de límites. La prensa brasileña atacó la misión de Oliveira considerándola un fiasco y exigió una nueva expedición, mucho mayor. Por su parte, el Emperador no ratificó ese tratado.

López, que había ganado tiempo, acreditó a José Berges para negociar con José Maria da Silva Paranhos, en Rio de Janeiro. En abril de 1856 ambos firmaron un nuevo tratado de

${ }^{871}$ Proclama del presidente López a los soldados, sobre la defensa contra la escuadra brasileña, 21/02/1855. ANA-SH, v. 314, n. 15.

${ }^{872}$ LÓPEZ, Carlos A. Mensaje de 1857. In: LÓPEZ, Carlos A. Mensajes..., op. cit., p. 113. 
libre navegación, aplazando la cuestión de límites por seis años. Pero en julio, Carlos A. López reglamentó el tratado de tal forma que en la práctica anulaba la libre navegación. La prensa en Rio de Janeiro denunció un nuevo "vejamen” contra el Brasil. Por su parte, el Imperio habilitó una línea de vapores hasta el Mato Grosso, pasando por territorio paraguayo, no solo para buques brasileños sino para los de todas las banderas. El Paraguay protestó.

El Imperio envió entonces a José Maria de Amaral con la misión de acabar con la reglamentación de López. Amaral llegó con ultimatos, pero no consiguió nada.

En 1857, López escribe:

[...] el tratado del 6 de abril [Berges-Paranhos] no ha sido para que el Brasil lleve por río sus pertrechos y refuerzos. El Imperio piensa oprimir a la República con sus dos brazos [... por el] Paraná y por el Alto Paraguay. Alguna vez he dicho a usted que es cuestión de tiempo la guerra del Brasil al Paraguay ${ }^{873}$.

En efecto, Pedro II de nuevo recurre a Paranhos, que esta vez parte respaldado por otra escuadra y tropas estacionadas en Rio Grande do Sul. Pero lo más importante es que comenzó a instrumentarse una nueva política. Antes de dirigirse a Asunción, Paranhos se detuvo en Paraná ${ }^{874}$ para negociar una alianza con Urquiza contra el Paraguay. Paranhos no solo estaba convencido de la necesidad de una guerra sino de que ella no podría llevarse a cabo sin el concurso del gobierno argentino, país que según él poseía la "llave de acceso" al Paraguay.

En 1858, el diplomático imperial expuso sus razones a Urquiza.

La guerra $[\ldots]$ debe poner término a todas las cuestiones con el Paraguay [...] la cuestión fluvial es de alta importancia para los dos países [...] una guerra que realizase estos fines, y pusiese a cada gobierno en circunstancias de ocupar su territorio contestado, no sería impopular en ninguno de los dos países $[\ldots]$;El golpe, si el Paraguay lo provocase, será muy fuerte para que pueda levantarse tan pronto! ${ }^{875}$.

La alianza efectiva contra el Paraguay no se concretó. No por falta de entusiasmo de Urquiza, sino porque Paranhos encontró exageradas las pretensiones del caudillo entrerriano: todo el Chaco hasta Bahía Negra. Años después, Mitre reconoció que de esa negociación había salido un protocolo que:

[...] en todo caso, sea que se efectuase o no la alianza, la República Argentina se comprometía a dar paso por su territorio a los ejércitos del Brasil contra el Paraguay, por reconocer que la causa era común y que el Brasil iba a combatir a la vez por la navegación de los ríos y los límites de la República Argentina ${ }^{876}$.

${ }^{873}$ C.A. López a Guido, 25/02/1857, citado en: CHAVES, Julio [1955]. El presidente López..., op. cit., p. 230.

${ }^{874}$ Entre 1852 y 1861, Buenos Aires se separó de las restantes trece provincias de la Confederación Argentina, que estableció capital en Paraná y tuvo al general Urquiza como Director.

${ }^{875}$ CARDOZO, Efraím [1961]. El Imperio del Brasil..., op. cit., pp. 75-76.

${ }^{876}$ Mitre a Urquiza, 15/02/1865, citado en: Ídem, p. 76. 
Al salir de Paraná, el siempre generoso Paranhos concedió a la Confederación un empréstito de 3.000 patacones y consiguió que Urquiza escribiera a López pidiendo que considerara las pretensiones imperiales ${ }^{877}$. En su despedida, el brasileño hizo un brindis porque "la gloria de Caseros no sea la única adquirida en común por el Brasil y la Nación Argentina" 878 .

Aunque luego el Imperio abandonaría el cortejo a Urquiza y pasaría a privilegiar la búsqueda de un acuerdo con Mitre, queda claro que siete años antes estaba ya esbozada la política de concretar una alianza que, según el propio Paranhos, debía dar un "golpe muy fuerte" para derrotar completamente al Paraguay.

Paranhos tuvo éxito en Asunción. López otra vez cedió y, en febrero de 1858, firmó una "convención especial” que derogaba las restricciones paraguayas. La cuestión de límites continuó aplazada ${ }^{879}$.

\subsection{El problema de límites con la Confederación Argentina}

Según el tratado Derqui-Varela de 1852, el Paraguay cedió las Misiones a cambio de mantener el Chaco ${ }^{880}$. Sin embargo, ese acuerdo no fue ratificado por el Congreso argentino. Así, tanto la zona misionera como el Chaco permanecieron como territorios disputados.

En 1856, poco antes de la misión Paranhos, el gobierno de Urquiza comisionó al general Guido para negociar un acuerdo en Asunción. La misión no tuvo resultado alguno. La Argentina pretendía la totalidad del Chaco paraguayo y López se opuso, diciendo que eso equivalía a "cortar la mano de un hermano". Las negociaciones se estancaron. Guido informó a su canciller, en mayo: "no tengo la menor esperanza de llegar a un acuerdo" 881 .

Para salir del impasse y, quizá, seguir ganando tiempo, en vista de su inferioridad militar, una vez más López negoció sobre la libre navegación, y aplazó aquello que realmente le preocupaba, la demarcación de límites. El 29 de julio de 1856 se firmó el tratado VázquezGuido, un acuerdo de navegación y comercio con la Confederación, que aplazaba por seis

\footnotetext{
${ }^{877}$ LIMA, Luiz Otavio de. A Guerra do Paraguai. São Paulo: Planeta, 2016.

${ }^{878}$ CHAVES, Julio [1955]. El presidente López..., op. cit., p. 236.

${ }^{879}$ Convención ajustada entre Paraguay y Brasil sobre la inteligencia y práctica del Tratado de amistad, navegación y comercio del 6 de abril de 1856, del 12/02/1858. ANA-SH, v. 324, n. 21.

${ }^{880}$ En 1849, el presidente López había decretado la ocupación definitiva por el gobierno paraguayo del territorio de las Misiones entre los ríos Paraná y Uruguay. ANA-SH, v. 286, n. 11.

${ }^{881}$ Guido a Gutiérrez, 24/05/1856, citado en: CHAVES, Julio [1955]. El presidente López..., op. cit., p. 212.
} 
años el problema de límites. Así, ambos plazos, con el Imperio brasileño y con la Argentina, expirarían en $1862^{882}$.

\section{3. "Destruir los monopolios..."}

Los monopolios estatales y la política comercial de López, además del problema de demarcación de límites, suscitaban polémicas y un fuerte rechazo entre la prensa y los gobernantes de los países vecinos ${ }^{883}$.

Esa posición coincidía con la de varios observadores europeos, que identificaban cualquier política que se opusiera al librecambio como una traba al progreso económico.

Al respecto, citamos algunas opiniones de agentes comerciales o diplomáticos británicos.

En 1843, en un informe a Lord Aberdeen, el agente J. R. Gordon describió el Paraguay como una tierra de grandes pero irrealizables oportunidades: el Paraguay "no vale nada y no tiene posibilidad de nada en su estado actual y bajo el sistema de gobierno actual" 884 .

En 1856, el cónsul británico Henderson, más equilibrado que Gordon, sí identificaba potencial en la economía paraguaya, aunque coincidía con su oposición a la política del gobierno.

El comercio del Paraguay es susceptible de un gran crecimiento. Si el gobierno abandonara el monopolio y la política restrictiva, admitiendo libremente a los extranjeros y las mejoras efectuadas por ellos, estimulando a la población nacional a acostumbrarse a la industria, permitiéndole cosechar los beneficios de sus esfuerzos y alentando la creación de empresas útiles para las cuales el país ofrece un campo espléndido, pronto se haría sentir un cambio beneficioso y la industria y el comercio podrían tener vigor y prosperidad, en lugar de [la] pobreza y la indolencia que ahora son extremas ${ }^{885}$.

Henderson insistía con que bajo un "sistema de comercio de la ilustración" la producción del país se incrementaría diez veces ${ }^{886}$.

\footnotetext{
${ }^{882}$ Copia del Tratado de paz, amistad, límites, comercio y navegación entre Paraguay y Argentina. ANA-SH, v. 322 , n. 18.

${ }^{883}$ Para el caso de los litigios con Argentina, ver: Discusión sobre límites e independencia nacional del Paraguay entre el periódico Paraguayo Independiente y la Gaceta de Buenos Aires. ANA-SH, v. 284, n. 18. ${ }^{884}$ TATE, Edward N. Gran Bretaña y Latinoamérica en el siglo XIX: el caso del Paraguay [1811-1870]. Contribuciones desde Coatepec. Toluca: Universidad Autónoma del Estado de México, n. 5, 2003, p. 70.

${ }^{885}$ Informe comercial de 1855 del cónsul Charles Henderson, 22/07/1856, citado en: WHIGHAM, Thomas. Lo que el río..., op. cit., p. 136.

886 Ídem, p. 138.
} 
Ya en 1842, el British Packet, periódico de la comunidad británica en Buenos Aires, se encargó de desalentar a aquellos que esperaban el fin de la injerencia estatal en los negocios del Paraguay a la muerte de Francia.

\begin{abstract}
Se piensa que ya ocurrió un cambio radical, y que aquel El Dorado de tantos sueños está esperando la llegada de aventureros extranjeros para sacar sus riquezas superabundantes... [Pero] el sistema del Dictador vive aún más que su fundador, y $[\ldots]$ los fundamentos que constituyen su base siguen en vigor. $[\mathrm{No}]$ ha ocurrido ningún cambio de importancia en el modo en que el Dictador imponía y recogía sus derechos, ni en la manera patriarcal de conducir sus negocios ${ }^{887}$.
\end{abstract}

Por su parte, la prensa de Buenos Aires cargaba contra el monopolio estatal de López con el argumento de que encarecía artificialmente el precio de la yerba y que sus ganancias servían al fortalecimiento militar de un régimen "bárbaro" y "tiránico". En 1856, ocho años antes del estallido de la Guerra contra el Paraguay, en la prensa porteña ya aparecían llamados a:

[...] redimir ese pueblo, destruir los monopolios, pulverizar esos castillos y baluartes que se levantan para sostén de los tiranos y esclavitud de la nación, dar completa libertad a los ríos, brindar su suelo a la industria, y explotar francamente sus riquezas ${ }^{888}$.

En 1857, el diario porteño La Prensa, escribía que la Confederación, el Estado de Buenos Aires [entonces separado del resto de las provincias argentinas], el Estado Oriental, y el Imperio del Brasil tenían "un interés positivo en un cambio de administración y de política [en el Paraguay], operado por la separación de López del puesto que ocupa"889.

Domingo F. Sarmiento iba más lejos. En las páginas de El Nacional exponía en 1855, casi diez años antes de la guerra, que no bastaba con derrocar el gobierno paraguayo, puesto que existía toda una "una tradición de servilismo, de obediencia ciega, heredada del guaraní, de la teocracia jesuita, y del terror de cuarenta años del doctor Francia" ${ }^{890}$ que debía ser extirpado. Así, en 1857 Sarmiento sostenía que se haría "un gran bien al Paraguay con hacerle la guerra" $" 891$.

En diciembre de ese año, Bartolomé Mitre, desde Los Debates, si bien en ese momento rechazó una posible alianza con el Brasil -la que estaba siendo promovida por Paranhos en Paraná-, como "un hecho inaudito en la América del Sur y el más inmoral que recuerda la historia moderna" 892 , expresó su coincidencia con que "el gobierno del Paraguay

\footnotetext{
${ }^{887}$ British Packet and Argentine News, 16/07/1842, citado en: Ídem, p. 187.

${ }^{888}$ SCAVONE, Ricardo (Org.). Polémicas..., op. cit., p. 33.

889 Ídem, p. 40.

${ }^{890}$ SARMIENTO, Domingo. Rumores de Guerra en perspectiva. El Nacional, 27/11/1855, citado en: Ídem, p. 45 .

891 Ídem, p. 46.

${ }^{892}$ En 1864, evidentemente Mitre cambiaría de opinión.
} 
es un gobierno de retroceso, cuya administración es inmoral y cuyo sistema es despótico $[\ldots]^{\prime 893}$.

Estas ideas, a finales de la década de 1850 tampoco eran originales. Ya en 1830 el enviado brasileño, Antônio Correia da Câmara, había alertado a su gobierno que el Paraguay es "uno de los más pesados enemigos del Brasil" y que era inevitable una guerra preventiva: "el único medio de acabar con aquel coloso naciente sería una rápida y combinada invasión" $" 894$.

El régimen paraguayo, a su vez, justificaba su política económica argumentando que los monopolios eran necesarios para "crear y organizar un ejército fuerte", toda vez que "la dictadura [de Francia] arruinó las pocas fortunas del país con multas, contribuciones y confiscaciones exorbitantes". Por ello, decía don Carlos en 1849, el gobierno "tomó el expediente de reservar al Estado el comercio exterior de la yerba mate y maderas de construcción naval”, puesto que "todos los minerales de la yerba son producciones naturales en tierras públicas, y por lo mismo pertenecen al Estado" 895 . Nótese que López, aunque en la práctica y esencialmente desarrollaba el mismo modelo estatista, realizaba críticas hacia las medidas más radicales de Francia en contra de la antigua oligarquía.

El gobierno tampoco consideraba incurrir en la contratación de empréstitos extranjeros, más bien se jactaba de no contar con deuda externa. En el mismo mensaje de 1849, López enfatizó:

El único país de la América antes española que hoy puede realizar la operación [la emisión de papel moneda] como corresponde, es la República del Paraguay, porque es el único que tiene capitales existentes, grandes y valiosas propiedades territoriales, garantías sólidas y seguras, y ninguna deuda interior, ni exterior. Así es que en la República corren los billetes a la par del metálico ${ }^{896}$.

Así, insistimos en que el telón de fondo de las polémicas periodísticas y de los informes diplomáticos que citamos era la existencia de dos proyectos de desarrollo capitalista en la región: de un lado, el modelo proteccionista y nacionalista; de otro, el librecambista, basado en las inversiones extranjeras y el endeudamiento externo, y consagrado en pactos semicoloniales.

\footnotetext{
${ }^{893}$ MITRE, Bartolomé. Política Argentina. Los Debates, 12/12/1857, citado en: Ídem, p. 47.

${ }^{894}$ CARDOZO, Efraím [1961]. El Imperio del Brasil..., op. cit., pp. 71-73.

${ }^{895}$ LÓPEZ, Carlos A. Mensaje de 1849. In: LÓPEZ, Carlos A. Mensajes ..., op. cit., p. 62.

896 Ídem, p. 64.
} 


\subsection{Una escuadra norteamericana en el Plata}

En 1858, en medio de aquellas disputas territoriales, el presidente de los EEUU, James Buchanan, envió contra el Paraguay una flota de 20 buques de guerra, con 200 cañones y 2.500 hombres.

El objetivo era exigir disculpas oficiales y forzar exorbitantes reparaciones por la expulsión del cónsul y empresario Hopkins, y por el cañonazo que en 1855 recibió el buque Water Witch cuando quiso adentrarse en el río Paraguay sin permiso oficial.

La decisión se dio después de un largo debate en el Senado norteamericano, en el que también se hicieron críticas a las trabas a la navegación y a los monopolios de los paraguayos $^{897}$.

La escuadra norteamericana pasó por Buenos Aires en noviembre de 1858 y en enero de 1859 fondeó en Corrientes. El Semanario anunció que el país "afrontaría la arrogancia norteamericana" y se defendería sin escatimar esfuerzos. Para repeler el posible ataque, el general Solano López movilizó unos 12.600 soldados hacia la fortaleza de Humaitá. El conflicto casi detona en guerra. Cuando el tiempo se agotaba, una mediación de Urquiza superó el incidente por vías diplomáticas.

López dio satisfacciones sobre el caso Hopkins y se avino a pagar 10.000 pesos a la familia del timonel que murió en el Water Witch. En 1860, un tribunal en Washington determinó que los reclamos de la compañía de Hopkins, que había exigido 5.000.000 de pesos, no tenían "ningún derecho" 898 .

\subsection{El Tacuarí es cañoneado por la escuadra inglesa en Buenos Aires}

En 1859, fue arrestado el súbdito inglés Santiago Canstatt ${ }^{899}$, acusado de participar de un complot para asesinar al presidente López.

El cónsul Henderson exigió su libertad, una indemnización por "sus padecimientos personales y las pérdidas originadas en su fortuna", además de una satisfacción por la "falta de respeto a su Majestad"900. El gobierno respondió devolviéndole su pasaporte.

\footnotetext{
${ }^{897}$ CHAVES, Julio [1955]. El presidente López..., op. cit., p. 240.

898 Ídem, p. 268.

899 Canstatt era uruguayo, pero hijo de ingleses.

${ }^{900}$ Lord Russell a Carlos Calvo, Londres, 23/04/1860, en: Cuestión Canstatt. Documentos oficiales cambiados entre la legación de la República del Paraguay y el Gobierno de Su Majestad británica con motivo de dicha cuestión. París: Besanzon-Imprenta de José Jacquin, 1864, p. 4. Disponible en: $<$ https://babel.hathitrust.org/cgi/pt?id=hvd.32044103254454; view=1 up;seq=111 >, consultado el 08/03/2018.
} 
El 29 de noviembre de 1859, cuando el general López pretendía partir de Buenos Aires en el Tacuarí, luego de la mediación que interpuso entre el general Urquiza y el Estado de Buenos Aires ${ }^{901}$, el Burzard y el Grappler, barcos de guerra ingleses, cañonearon la nave paraguaya. López consideró responder, pero la tripulación inglesa del Tacuarí le hizo saber que, si lo hacía, ellos serían considerados traidores en Gran Bretaña. A esto se sumó la consideración de que las naves inglesas eran superiores a la capacidad de fuego del buque paraguayo. Solano López dejó sus cañones inmóviles. Pero luego protestó ante el gobierno porteño, que no tomó posición a pesar de la ayuda prestada por López. El elogiado mediador tuvo que regresar por tierra.

El almirante inglés Lushington anunció que tenía órdenes de apresar el Tacuarí hasta la liberación de Canstatt. Otro oficial inglés manifestó que existía una orden de atacar el Paraguay con una escuadra de 14 barcos de guerra y 2.000 hombres de desembarco ${ }^{902}$.

La gravedad de la crisis hizo que el gobierno paraguayo comisionase a Carlos Calvo para tratar el asunto en Londres, donde el enviado se deparó con un ambiente hostil. El jefe del Foreign Office, Lord Russell, no aceptó acreditarlo hasta el cumplimiento de las exigencias de Henderson. En la práctica, las relaciones estaban rotas.

Transcribimos una parte del informe firmado por Calvo acerca de una reunión que mantuvo con Lord Wodehouse, "subsecretario de negocios extranjeros y encargado de los asuntos de América". El mismo es revelador del desprecio y de las amenazas británicas hacia el Paraguay.

\begin{abstract}
[...] ya que yo había hecho uso de la palabra civilización, me decía que el Paraguay no estaba en el caso de las naciones que habían alcanzado esas ventajas [... Sus ofensas...] merecían un tratamiento ejemplar, y que con países que proceden así, debía cortarse toda relación política y comercial, como lo había hecho con Bolivia, tratándoles como pueblos salvajes; y que fundado en ese principio, el gobierno de $\mathrm{Su}$ Majestad estaba dispuesto a proceder del mismo modo con el Paraguay; que le tomaría sus vapores y le haría todo el daño posible, sin ocuparse para ello de enviar una escuadra, como lo había hecho el gobierno de los Estados Unidos. Que la prueba de que Inglaterra no buscaba pendencias, era que las mismas dificultades había tenido la República del Paraguay con todas las naciones con quienes había estado en relaciones, y que estas habían tenido que hacer uso de la fuerza para ponerla en razón [...] que en cuanto al suceso ocurrido en la rada de Buenos Aires, aunque el gobierno de Su Majestad no había dado esas instrucciones al almirante Lushington, porque no hubo el tiempo necesario para ello, había aprobado su conducta, y que lo único que había
\end{abstract}

\footnotetext{
${ }^{901}$ En momentos en que el caudillo Urquiza tenía prácticamente rodeada a Buenos Aires, interviene Carlos A. López y envía a su hijo Francisco Solano para mediar en el conflicto. El resultado fue el Pacto de San José de Flores, del 11 de noviembre de 1859. Desde el punto de vista paraguayo la mediación fue un grave error que debilitó su posición en la región y fortaleció al sector porteño, con Mitre a la cabeza, dándole el suficiente tiempo para recomponer su tropa y luego vencer a Urquiza en la batalla de Pavón, en 1861. Cuatro años más tarde, Mitre se asociaba al Imperio para atacar el Paraguay y ocasionar su destrucción total.

902 CHAVES, Julio [1955]. El presidente López..., op. cit., p. 269.
} 
lamentado era que el comandante Peel, que había sido severamente castigado, no hubiese cumplido con su deber, apoderándose de la persona del general López y del vapor que lo conducía; y agregó: "Los 15 vapores que tiene el Paraguay, siendo de construcción inglesa, deben ser buenos para aumentar nuestra marina" $" 903$.

En Buenos Aires, el ministro Thornton reiteró que Calvo no sería recibido en Londres hasta no cumplir con las exigencias inglesas. Don Carlos escribe: "no ha de extrañarse la opinión del gringo Thornton [...] es lo sumo de la insolencia decirnos que no será Vd. recibido mientras no sea indemnizado el oriental Santiago Canstatt [... $]^{\prime 904}$.

El 20 de julio, el viejo López le escribe a Calvo diciéndole incluso que está dispuesto a ir a la guerra con los ingleses.

\begin{abstract}
Repito a Vd. que no hay que entrar en capitulación de cantidad alguna en sentido de indemnización al oriental traidor de Santiago Canstatt [...] ¿Capitular? Ni por el valor de un peso, porque no se trata de la cantidad sino de la dignidad del gobierno. Diga Ud. que estamos dispuestos a aceptar la guerra como único medio de defender la paz de una manera honrosa y sólida, sean cuales sean los sacrificios que llegue a importar ${ }^{905}$.
\end{abstract}

Carlos Calvo, en carta a Russell, protestó por el ataque "sin previa declaración de hostilidades", cosa que juzgaba "una ofensa mucho más grave al derecho de gentes" que los reclamos ingleses sobre Canstatt. En la misma nota decía que, en caso de que no se solucionase el problema diplomáticamente, solo la guerra podría dirimirlo, aunque:

[...] esa palabra expresa mal la situación; no puede haber guerra propiamente dicha entre la Inglaterra y el Paraguay. Llegado a ese triste caso, la Inglaterra tomaría satisfacción del Paraguay por la fuerza ${ }^{906}$. Pues bien, Milord, ese caso ha tenido lugar ya, la Inglaterra se ha servido de la fuerza y se ha satisfecho. En efecto, ¿puede considerarse de otro modo el ataque al Tacuarí? ${ }^{907}$.

Finalmente, el conflicto se resolvió por vía diplomática. Canstatt fue liberado y, en abril de 1862, E. Thornton llegó a Asunción ofreciendo un acuerdo y declarando que su gobierno nunca quiso interferir en la política interna del Paraguay; que el incidente con el Tacuarí solo podía atribuirse a una decisión de Lushington. El gobierno paraguayo, por su parte, expresó que nunca había tenido intención de ofender al gobierno británico ${ }^{908}$.

Pero el incidente no pasó sin revelar el concepto inglés de "civilización”: era justo y necesario hacer "todo el daño posible" para "poner en razón” al gobierno de un "pueblo salvaje" que ofendiese a Su Majestad.

\footnotetext{
903 Carlos Calvo a Nicolás Vázquez, Londres, 08/05/1860, citado en: Cuestión Canstatt..., op. cit., pp. 9-11.

904 C.A. López a Calvo, 19/03/1860, citado en: CHAVES, Julio [1955]. El presidente López..., op. cit., p. 269. 905 Ídem, p. 270.

${ }^{906}$ Destacado en el original.

907 Memorándum de Carlos Calvo a Lord Russell, Londres, 13/09/1860, citado en: Cuestión Canstatt..., op. cit., p. 111.

${ }^{908}$ Copia del Tratado de reanudación de relaciones entre S.M. británica y el Paraguay. ANA-SH, v. 444, n. 7.
} 


\section{FranCisco Solano LóPEZ, PRESIDENTE}

El 10 de setiembre de 1862 muere Carlos Antonio López, pero su familia mantuvo el poder y el régimen no sufrió cambios. Como dictaba el "pliego cerrado", el general Francisco Solano asumió la vicepresidencia y luego la presidencia.

El contexto regional era grave y amenazador. Los plazos de la definición de límites habían acabado. A las ambiciones del Imperio se sumaban ahora las inquietantes declaraciones del gobierno del general Mitre, que desde su victoria en Pavón había tomado el control del país "unificado". Mitre representaba como pocos la esencia del unitarismo y librecambismo porteños; su estandarte no era otro que el de civilización o barbarie. La torpeza del gobierno paraguayo al haberlo salvado de las fuerzas de Urquiza y, por consiguiente, haberlo ayudado a alcanzar el poder, no tardaría en cobrar su precio.

En noviembre de 1862, Mitre escribía que uno de sus propósitos era: "fomentar y consolidar la reconstrucción de las nacionalidades de América que imprudentemente se han dividido y subdividido"909. La Nación Argentina, su vocero oficial, declaraba que "estamos destinados a reconstruir la grande obra que deshicieron las pasiones locales, volviendo así las nacionalidades americanas a las condiciones en que se hallaban antes de los sucesos que las redujeron a su estado actual" "910. De nuevo resonaba el proyecto de "reconstrucción del virreinato" del Plata. Al mismo tiempo, la campaña internacional contra el proteccionismo y los monopolios estatales de la "China de América", se intensificaba.

En medio de esa situación regional, cada vez más enrarecida, el 16 de octubre de 1862 un Congreso extraordinario proclamó presidente a Francisco Solano López, entonces con 36 años. Sus pocos opositores fueron encarcelados, acusados de promover una "revolución social, moral, y política"911.

Solano López había sido preparado para "heredar" el poder. Era relativamente culto y admirador de las cortes europeas que conociera durante su misión en 1854. Había sido nombrado general a los 18 años $\mathrm{y}$, sin haber participado en ninguna batalla, existen elementos que indican que su arrogancia lo llevaba a sobreestimar su capacidad como jefe militar y de las propias fuerzas de su país. En 1864 declaró que había llegado el momento de "hacer oír la voz del Paraguay: es tiempo ya de hacerlo"912. Esa voz, declaró, estaría al

\footnotetext{
${ }^{909}$ CARDOZO, Efraím [1961]. El Imperio del Brasil..., op. cit., pp. 107-108.

${ }^{910}$ La Nación, 10/11/1862, citado en: Ídem, p. 108.

911 Ídem, p. 117.

912 Ídem, p. 450.
} 
servicio de mantener el "equilibrio de los Estados del Plata", una fórmula que en esos años cada nación tuvo ocasión de esgrimir e interpretar de manera diferente. Para el Paraguay, aquello implicaba el respeto a su independencia y a la libre navegación para su comercio.

En el plano interno, Solano López mantuvo lo esencial de la política que ejecutaron sus antecesores. El régimen, cada vez más tiránico y justificado ideológicamente por el Catecismo de San Alberto, siguió sin garantizar al pueblo ningún derecho democrático elemental.

El progreso en la capacidad exportadora del país hacía que Solano López tuviera más celo en mantener y ampliar los mercados para los productos paraguayos. Después de las buenas rentas que había generado el comercio en la última década, ni López ni ningún propietario paraguayo estaba interesado en una situación de aislamiento o en una posición de mera abstención en asuntos regionales. Así, cualquier amenaza al "equilibrio" y a la estabilidad que garantizaban el buen flujo comercial desde 1852, sería tomada por la burguesía paraguaya como un peligro existencial y, por lo tanto, justificaría asumir altos riesgos.

El joven López y su séquito de “cien propietarios” parecían insaciables. Francisco Solano se esforzó para que los productos paraguayos alcanzasen Europa. A través de sus agentes, envió muestras de yerba mate ${ }^{913}$, tabaco, maderas, muebles, etc. En razón de la crisis abierta con la Guerra de Secesión en los EEUU, se preocupó especialmente por aumentar y mejorar los cultivos de algodón, introduciendo semillas norteamericanas y nuevas técnicas. El gobierno estableció premios a los agricultores que cosechasen la fibra, y en 1863 compró 400 copias de un panfleto titulado Manual para el cultivo de algodón, para distribuirlo entre los campesinos ${ }^{914}$. El cultivo no tardó en hacerse obligatorio. Michael Mullhall, comerciante británico, estimó que la producción de algodón paraguayo en 1864 alcanzaba dos millones de arrobas desmotadas ${ }^{915}$.

En 1863, López despachaba a su cónsul en París, Ludovico Tenré, una muestra de 1.500 libras de algodón. El mismo año, enviaba a John Blyth 13 fardos de algodón y otros 14 iban a Amberes, Bélgica, consignados a su agente Du Gratty. Por primera vez, el algodón paraguayo llegaba a Londres, Liverpool y El Havre.

\footnotetext{
${ }^{913}$ López intentó que el ejército prusiano consumiera la yerba mate paraguaya.

914 WHIGHAM, Thomas. Lo que el río..., op. cit., p. 148.

915 HERKEN KRAUER, Juan; GIMÉNEZ DE HERKEN, Isabel. Gran Bretaña y la Guerra de la Triple Alianza. Asunción: Editorial Arte Nuevo, 1982, pp. 41-42.
} 
De Nueva York, Solano López importaba máquinas para que el Estado comenzase la explotación de la fibra. En 1864 llegaban a Asunción una prensa y dos desmotadoras. También llegaban desde Londres dos máquinas de la Cotton Suply Association de Manchester. El cónsul en Francia, satisfecho con las primeras muestras de algodón, solicitó otras, de maderas y tabacos ${ }^{916}$.

En 1863, las primeras partidas de algodón paraguayo introducidas en Gran Bretaña se cotizaron a $24 \mathrm{~d}$. por libra ${ }^{917}$.

En 1864, López encargó al especialista Charles Twite de la Royal School of Mines of Great Britain la confección de un "mapa mineralógico de la República"918.

En el mismo Congreso que lo designó presidente, López hizo un informe nada auspicioso sobre la deficiente situación del armamento y de la oficialidad del ejército y la marina. La conclusión fue que el mejoramiento del material de guerra dependía de urgentes compras en Europa.

Sin embargo, la principal atención siguió enfocada en otros proyectos de modernización. La construcción de la línea férrea hasta Villarrica, zona yerbatera, fue una prioridad: "uno de los acontecimientos más importantes y conducentes a la felicidad de la República -decía Solano López-, aunque al presente una de las cargas más pesadas para el Tesoro, es, sin duda, la introducción del ferrocarril" ${ }^{19}$.

Historiadores liberales como Whigham atacan duramente aquella "molesta interferencia del Estado"920. Efraím Cardozo, también liberal, critica esta inversión estatal diciendo que "en todos los demás países sudamericanos estas empresas eran confiadas al capital privado; solo el Estado paraguayo cargó él solo con la pesada tarea"921. La explicación del problema que ofrecía Solano López en 1862 se basaba en que las “compañías mercantiles” entraban en:

[...] estas especulaciones sobre la base de un agiotaje poco ordenado, [el gobierno] ha tenido que acometer la empresa por cuenta del Estado, distrayendo así una gran suma de los capitales y medios de defensa, ordenando la construcción de un ferrocarril de esta ciudad a Villarrica ${ }^{922}$.

\footnotetext{
916 POMER, León [1968]. La Guerra del Paraguay..., op. cit., p. 58.

${ }^{917}$ HERKEN KRAUER, Juan; GIMÉNEZ DE HERKEN, Isabel. Gran Bretaña y la Guerra..., op. cit., pp. 4142.

918 GARCÍA MELLID, Atilio. Proceso a los falsificadores de la historia del Paraguay. Tomo II. Buenos Aires: Ediciones Theoria, 1964, p. 232.

${ }^{919}$ CARDOZO, Efraím [1961]. El Imperio del Brasil..., op. cit., p. 114.

${ }^{920}$ WHIGHAM, Thomas. Lo que el río..., op. cit., p. 308.

${ }^{921}$ CARDOZO, Efraím [1961]. El Imperio del Brasil..., op. cit., p. 113.

922 Memoria de 1862, citado en: Ídem, p.114.
} 
Hasta 1864, Solano López envió más jóvenes becados a Europa; amplió los préstamos del Estado a comerciantes; adquirió nuevos vapores para aumentar la flota mercante; ensanchó los arsenales y la fundición de hierro; inició el tendido del telégrafo; planteó un plan de transformación edilicia de Asunción a través de arquitectos europeos...

Todo esto en medio de una colosal crisis política en el Plata, que se agravó en abril de 1863 a partir de la rebelión liderada por el caudillo oriental Venancio Flores para derrocar el gobierno del Partido Blanco en Montevideo, apoyada por el gobierno de Mitre y por el Imperio brasileño. Esta crisis alcanzó un punto de no retorno en octubre de 1864 con la agresión militar brasileño-porteña en el Uruguay, hecho fundamental que desencadenaría el inicio de la "cruzada civilizadora" contra el Paraguay.

Permítasenos algunas reflexiones más. La destrucción del Paraguay luego de la guerra contra la Triple Alianza es difícil de cuestionar, incluso para la literatura liberal. El desastre paraguayo en la guerra adquirió proporciones colosales y significó el fin de las conquistas de su revolución de independencia, el período que hemos tratado de profundizar en esta tesis. Una derrota histórica de la nación como un todo.

El censo de 1870 reveló que de una población inicial de 420.000 a 450.000 habitantes -que es la cifra más aceptada entre los especialistas-, sobrevivieron 116.351 personas, de las cuales $71 \%$ fueron mujeres. Los historiadores Whigham y Potthast, que trabajaron los datos de ese censo, hicieron algunas correcciones y establecieron esa cifra entre $141.351 \mathrm{y}$ 166.351 habitantes al finalizar la guerra ${ }^{923}$. En suma, en un lapso de cinco años, desapareció entre 60 y $69 \%$ de la población total del país: “un porcentaje enorme, prácticamente sin precedentes en la historia de una nación moderna"924.

Mientras el Paraguay perdió 69\% de sus habitantes, la Triple Alianza en su conjunto perdió $0,64 \%$. Desde otra perspectiva, $80 \%$ de la mortandad total de la guerra cupo a la población paraguaya. Si aplicáramos la proporción de la hecatombe demográfica paraguaya después de 1870 a cifras actuales, simplemente para hacernos una idea más nítida de su magnitud, sería como si el Brasil perdiera cerca de 145 millones de habitantes y la actual Argentina otros 30,3 millones en una guerra.

923 WHIGHAM, Thomas; POTTHAST, Barbara. The Paraguayan Rosetta Stone: New Insights into the Demographics of the Paraguayan War, 1864-1870. Latin American Research Review, v. 34, n. 1, pp. 174-186, 1999.

924 RIVAROLA, Armando. Holocausto paraguayo en la Guerra del 70. ABC Color. Asunción, 26/09/2009. Disponible en: <http://www.abc.com.py/articulos/holocausto-paraguayo-en-guerra-del-70-24852.html>, consultado el 01/04/2019. 
Tabla 5. Mortalidad de las naciones aliadas.

\begin{tabular}{lccc}
\hline País & Población inicial & $\begin{array}{c}\text { Mortalidad en la } \\
\text { Guerra }\end{array}$ & $\begin{array}{c}\text { \% sobre la población } \\
\text { total }\end{array}$ \\
\hline Imperio del Brasil & 9.100 .000 & 50.000 & $0,55 \%$ \\
Argentina & 1.737 .076 & 18.000 & $1,04 \%$ \\
Uruguay & 250.000 & 3.120 & $1,25 \%$ \\
Totales & 11.087 .076 & 71.120 & $0,64 \%$ \\
\hline
\end{tabular}

Fuente: DORATIOTO, Francisco. Maldita Guerra..., op. cit., pp. 91, 458, 461, 462.

Por otro lado, luego de la guerra el Paraguay perdió casi $40 \%$ de su territorio y quedó reducido a una semicolonia, a una especie de protectorado de las clases poseedoras del Brasil y la Argentina. El país vencido soportó la ocupación militar de las tropas aliadas hasta mayo de 1879 y quedó sujeto al pago de una deuda de guerra con los países que lo destruyeron hasta inicios de la década de 1940.

De ser una nación con cerca de $90 \%$ de sus tierras nacionalizadas hasta 1870 , actualmente el Paraguay es el país más desigual del mundo en cuanto a la tenencia de la tierra $^{925}$. La guerra implicó un retroceso histórico, que pone a la orden de día la tarea de resolver el problema agrario. Según estudios de la organización no gubernamental OXFAM, $2 \%$ de los propietarios acapara $85 \%$ de las tierras. Las organizaciones campesinas estiman que existen al menos 300.000 familias de labradores sin tierra. Mientras tanto, además de los latifundios "legales", se estima que existen ocho millones de hectáreas "mal habidas", es decir, propiedades concedidas, principalmente por la corrupta dictadura militar-colorada de Stroessner [1954-1989], de manera discrecional ${ }^{926}$. En el siglo XX, Paraguay se transformó en un enclave sojero: es actualmente el cuarto exportador mundial de esta commodity, a la que destina $60 \%$ de su suelo cultivable. Se calcula que en cada ciclo productivo se utilizan alrededor de 30 millones de litros de agrotóxicos en todo el país. Por otro lado, solo 8\% de la tierra fértil se dedica a la producción familiar de alimentos para el consumo interno ${ }^{927}$. Su industria es raquítica.

Pero esto...es otra historia.

${ }^{925}$ ARANTXA, Guereña; ROJAS, Luis. Yvy Jára: Los dueños de la tierra en Paraguay. Asunción: OxfamParaguay, 2016, p. 14.

926 OXFAM. Paraguay: El país donde la soja mata. 2014. Disponible en: $<$ https://www.oxfam.org/es/paraguay-el-pais-donde-la-soja-mata $>$, consultado el 06/03/2019.

${ }^{927}$ ARANTXA, Guereña; ROJAS, Luis. Yvy Jára..., op. cit., pp. 19-21. Según la FAO, en el 2019, 24,2\% de la población se encuentra en situación de pobreza y $4,8 \%$ en extrema pobreza. La pobreza afecta $34,6 \%$ de la población rural y 17,8\% de la urbana. Ver: EFE. FAO admite un "estancamiento" en la reducción de la pobreza en Paraguay. 2019. Disponible en: <http://www.nanduti.com.py/2019/03/28/fao-admiteestancamiento-la-reduccion-la-pobreza-paraguay/>, consultado el 01/04/2019. 


\section{CONCLUSIONES}

La hipótesis principal de este trabajo consistió en que el proceso de independencia de la ex Provincia del Paraguay de la metrópoli española debe caracterizarse -por el programa y la praxis de su clase dirigente- como una revolución política y no de carácter social.

Si bien el proceso iniciado en el Cono Sur americano en 1810 fue identificado por sus contemporáneos -en uno y otro lado del Atlántico y cualquiera fuera el bando político que asumieran- como una "revolución", estamos conscientes de la dificultad y de las controversias que sigue y seguirá suscitando este problema. En primer lugar, porque existen pocas categorías que se discutan tanto como la de revolución. No solo porque esa noción siempre provocó hostilidad a los intereses y construcciones ideológicas dominantes en distintas épocas históricas sino por su evidente multiplicidad de acepciones.

Desde la perspectiva marxista, que asumimos en este trabajo, el carácter de una revolución está determinado por las tareas que pretende realizar, por las contradicciones que pretende resolver. Y esto está en comunión con su época histórica. Contradicciones que, por su parte, se acumulan gradualmente entre lo viejo y lo nuevo. Dicho de otra manera, los elementos de lo nuevo se engendran y maduran en el seno de lo viejo, de todo aquello que está caduco y mohoso.

Lenin sostenía que la revolución social implica una transformación tal que destroza lo viejo en lo más fundamental y básico. En 1917 explicó el asunto con más precisión: “el paso del poder del Estado de manos de una clase a manos de otra, es el primer rasgo, el principal, el fundamental de la revolución, tanto en el sentido rigurosamente científico, como en el sentido político-práctico de ese concepto" ${ }^{928}$.

En otras palabras, se trata de una lucha entre dos clases con intereses opuestos, entre explotados y explotadores. Es más, según el marxismo, un proceso así constituye la expresión más álgida de la lucha de clases, puesto que aspira conscientemente a instaurar nuevas y superiores formas de organización de la sociedad humana; pretende ser el puente de una formación económico-social hacia otra.

Otra definición de Lenin, escrita en octubre de 1917, sostiene

Una revolución, una revolución verdadera, profunda, "popular", según expresión de Marx, es un proceso increíblemente complicado y doloroso, de muerte del viejo

${ }^{928}$ LENIN, V. I. Cartas sobre táctica. In: LENIN, V. I. Obras Completas. Tomo 31. Moscú: Editorial Progreso, 1961, p. 133. 
orden social y nacimiento del nuevo orden social, del estilo de vida de decenas de millones de hombres. La revolución es la lucha de clase y la guerra civil más agudas, más furiosas, más encarnizadas ${ }^{929}$.

Por su parte, Karl Kautsky, el conocido dirigente marxista alemán, sostenía que "una revolución social pertenece a la categoría de las eventualidades más complejas de todas, dicho de otro modo: un completo trastorno de las formas que hasta ese momento revisten las relaciones individuales" $\$ 30$.

Si nos guiamos por los conceptos que aporta el marxismo: máxima expresión de la lucha entre clases con intereses antagónicos; paso del poder político de una clase a manos de otra; duelo entre lo viejo y lo nuevo, entendiendo lo nuevo como una completa transformación del orden social que destruye las condiciones de producción prexistentes y sus expresiones jurídicas, las relaciones de propiedad; si estos son los elementos que caracterizan una revolución social, ¿podemos calificar las revoluciones de independencia iberoamericanas como tales?

Nuestra conclusión fundamental es que no.

El proceso que nos ocupa se trató, esencialmente, de un movimiento anticolonialista que modificó la superestructura política controlada por la metrópoli española, para abrir paso a otra de carácter nacional-independiente, sin modificar sustancialmente las relaciones de producción ni de propiedad entre las distintas clases sociales ni alterar los cimientos de la economía continental y paraguaya -un modelo centrado en la exportación de yerba mate, tabaco y maderas utilizables para la construcción para el mercado regional platense, con algunos intentos de alcanzar un intercambio con algunos países europeos desde la década de 1850, que se combinaba en el plano interno con una economía de subsistencia sostenida por un campesinado pobre o arrendatario de tierras públicas-.

La independencia tampoco modificó - ni fue el proyecto de sus dirigentes- el papel del Paraguay en la división internacional del trabajo en medio del auge de la Revolución Industrial, que siguió restricto al de proveedor de productos primarios y consumidor de bienes manufacturados. El modelo estatista, proteccionista y, sobre todo, basado en la nacionalización de la tierra y el control del comercio exterior, al que el débil Estado nacional debió apelar como medio de acumulación de la incipiente burguesía local y mejor defensa de la soberanía nacional, no cambia en nada nuestra definición del proceso general. Esto

\footnotetext{
${ }_{929}$ LENIN, V. I. ¿Podrán los bolcheviques retener el poder? In: LENIN, V. I. Obras Completas. Tomo 27. Madrid: Akal Editor, 1976, p. 229.

${ }^{930}$ KAUTSKY, Karl [1903]. La revolución social. Valencia: Alejandría Proletaria, 2018, p. 5.
} 
último, sin detrimento de considerar ese modelo progresivo con relación al del librecambio, siempre desde la perspectiva democrático-burguesa en el contexto del siglo XIX.

Pero profundicemos más en aquello de por qué no fue social y sí política. En la época de las revoluciones burguesas, la revolución política es una lucha por el poder el Estado -y esto es un rasgo común con las revoluciones de tipo social-, pero no entre clases antagónicas sino entre facciones de la clase propietaria. Por lo tanto, su propósito no es modificar la estructura social sino la superestructura, acometiendo cambios institucionales o jurídicos en la medida estrictamente necesaria para acelerar la acumulación de la facción triunfante.

Frecuentemente, las revoluciones de 1830 y 1848 en Europa son mencionadas como ejemplos de revoluciones políticas ${ }^{931}$.

En su primera fase, la propia Revolución Francesa también fue política, puesto que su propósito se limitaba a atenuar los poderes absolutos de la monarquía, es decir, reformarla y no necesariamente liquidarla como institución. Pero ese mismo caso muestra que una revolución política, bajo determinadas circunstancias, puede derivar en una revolución social. La dinámica de la más clásica de las revoluciones burguesas, en un lapso relativamente corto, no solo acabó con la monarquía sino que barrió con todos los obstáculos que impedían el dominio absoluto de la burguesía en el terreno económico-social-cultural. Inauguró una nueva época histórica.

En el terreno de las revoluciones socialistas ocurridas durante el siglo XX puede decirse lo mismo. La Revolución de febrero de 1917 en Rusia se restringió a derrocar el poder del Zar y allanar el camino hacia un régimen democrático-parlamentario - una tarea que enfrentó la contradicción que implicaba la coexistencia de instituciones clásicas de la democracia burguesa con los soviets o consejos, instituciones obreras y populares-, un cambio político de gran porte. Pero, como se sabe, una combinación de condiciones objetivas y subjetivas hicieron que, en octubre, triunfase una revolución de tipo socialista, que trastocó no solo el régimen político sino que en el medio plazo liquidó la propiedad privada de los medios de producción y las relaciones sociales capitalistas.

Para entender la dinámica de la transición de lo político a lo social, conviene apelar a otra cita de Kautsky:

[...] una revolución política no deviene una revolución social más que si es realizada por una clase hasta entonces oprimida y obligada a asegurar mediante su emancipación social su liberación política, porque su condición social ha llegado a convertirse, irreductiblemente, en obstáculo para su dominación política. De

${ }^{931}$ ZARPELON, Sandra. O novo socialismo utópico e a importância da revolução política para o socialismo marxista. Cadernos Cemarx, v. 1, n. 2, pp. 94-100, 2005. 
suerte que un conflicto en el seno de las clases dirigentes no será por nada del mundo una revolución social por más que presente los más violentos caracteres de guerra civil ${ }^{932}$.

Con el criterio anterior, las revoluciones de independencia no podrían llegar a ser sociales, puesto que las clases explotadas y oprimidas de la sociedad no solo no participaron de la dirección del proceso, sino que este ni siquiera se llevó a cabo en su nombre. La única excepción a esta regla es el caso de Haití, donde la revolución anticolonial fue dirigida no por representantes de las clases dominantes sino de las clases explotadas, los esclavos negros. Esto resultó no solo en la independencia sino en la abolición de la esclavitud, modo de producción fundamental de la antigua colonia francesa.

Pero en el caso de Iberoamérica, las facciones de la incipiente -insistimos, incipiente- burguesía nativa, sector social dirigente, no pueden ser consideradas parte de las clases explotadas, oprimidas y subalternas, dentro de la sociedad colonial sino lo contrario: eran integrantes, con más o menos poder político, de las clases propietarias. Es decir, cuando comenzó el enfrentamiento con la otra facción propietaria, la españolista, que era la dominante y se empeñaba en mantener estas tierras como dominio de la monarquía, una facción de los criollos contaba con poder económico importante. Su lucha, por lo tanto, consistió en adueñarse del poder político para eliminar las trabas que la metrópoli imponía a su propia acumulación como sector de clase. Si bien nos parece correcto enfatizar que la lucha fundamental se dio entre colonialistas y anticolonialistas, puede decirse que la literatura tradicional, tanto liberal como nacionalista, simplifica esa disputa, presentándola en términos de europeos versus americanos, metrópolis versus colonias, sin distinguir que entre "los nacidos en América" existían clases y sectores de clase.

Por descontado está que nuestra interpretación no pretende restar mérito ni deja de reconocer el inmenso avance que representó para Iberoamérica el hecho de haberse emancipado del yugo colonialista europeo. Esto fue extremadamente progresivo, en el sentido de que, a la postre, liberó fuerzas productivas de las naciones emancipadas como un todo. Solo pretendemos definir el carácter y los límites de esa emancipación.

Como hemos dicho en otro apartado de esta tesis, si bien toda revolución social es al mismo tiempo política, no toda revolución política llega a ser social, en la acepción que nos pareció más rigurosa y precisa.

${ }^{932}$ KAUTSKY, Karl [1903]. La revolución social..., op. cit., p. 7. 
Si bien las definiciones son indispensables como instrumentos para entender la realidad, no se puede olvidar que no pasan de abstracciones que constituyen la parte más pobre de cualquier análisis, puesto que pretenden condensar una infinidad de elementos contradictorios y, por eso mismo, siempre poseen carácter relativo. Por ejemplo, los conceptos de revolución y reforma, como cualquier noción de las ciencias sociales, son relativos al objeto de estudio. Si nuestro objeto de estudio se restringe a la superestructura política, la independencia fue una revolución; pero si nuestra delimitación se extiende a la estructura social, ese hecho no pasó de una reforma, si bien importante y con fuertes implicancias dependiendo del caso, pero una reforma, a fin de cuentas. Depende de lo que tengamos en la mira de nuestro "microscopio" histórico.

Estamos suficientemente convencidos de que la lectura crítica de los hechos, fundada en el análisis de fuentes primarias y en la consulta de obras de otros autores y autoras ineludibles para el estudio de este período histórico -marxistas y no marxistas-, confirman nuestras afirmaciones anteriores.

La segunda conclusión fundamental, pero no menos importante, es que la independencia paraguaya fue parte inseparable del proceso anticolonialista continental. Es decir, su suerte siempre dependió del desenlace del embate global con la metrópoli, que permeó todas las regiones latinoamericanas; un fenómeno poliédrico que discutimos como complemento al objeto de nuestro estudio. Esta premisa, además de contribuir a la justa comprensión de la ubicación del proceso paraguayo y sus particularidades con relación a otras regiones hispanoamericanas, evita incurrir en el error conceptual -propiciado principalmente por la historiografía nacionalista y dependentista- de imaginar el Paraguay del siglo XIX como una especie de "isla", desde los albores de la colonización hasta el comienzo de la guerra contra la Triple Alianza en 1864.

Por otra parte, el conjunto de argumentos que hemos expuesto pueden fundamentar la afirmación de que la independencia paraguaya no contó con la participación ni se hizo en nombre de las clases trabajadoras o sectores populares: indígenas encomendados o confinados en reducciones; afrodescendientes esclavizados o "libertos"; pequeño campesinado pobre y mestizo, que trabajaba con técnicas rudimentarias una pequeña parcela de tierra o bien era "tolerado" en tierras ajenas a cambio de que una parte del excedente producido fuera entregado al propietario; jornaleros de estancias particulares o estatales; marineros transportadores de yerba mate y otros productos exportables a través de los ríos; peones que se internaban durante meses en inhóspitos montes para ocuparse en el beneficio 
de la yerba mate, que conformaron el núcleo embrionario del trabajo libre, aunque las más de las veces no recibieran pago en metálico -que solo comenzó a circular hacia finales del siglo XVIII- sino en mercaderías sobrevaluadas, un mecanismo que los "enganchaba" y dejaba a merced de los empresarios beneficiadores por medio de un ciclo de deudas impagables. La cotidianeidad de estas clases o sectores de clase de la sociedad, marcada por la explotación de su fuerza de trabajo, siguió básicamente la misma con el advenimiento de la República independiente. Ni Edén ni igualitarismo social, explotación. La historia paraguaya posterior a 1811 es la de un capitalismo "en formación”. La diferencia, en el terreno económico-social, radicó en que los componentes de la clase dominante, principal explotadora de la mano de obra local, pasaron a ser "compatriotas" y no burócratas y empresarios amparados por los monopolios otrora detentados por la metrópoli. Y esto fue posible porque el poder del Estado, en el terreno político, pasó a manos de los criollos entre 1811 y 1813.

No existió transformación radical en la esfera de las relaciones de producción porque, al contrario de lo que afirma la historiografía liberal, nacionalista, y hasta algunos autores que dicen reivindicar el materialismo histórico, no existió feudalismo en Iberoamérica entendido como un modo de producción, no como manifestaciones ideológicas, tradiciones, maneras, terminología, o referencias a estamentos sociales en el contexto de un régimen monárquico en la metrópoli que poseía ramificaciones en las colonias-.

La colonización ibérica, protagonista del primer capítulo de este trabajo, si bien no estableció ni podía establecer un sistema de producción capitalista, puesto que no existía un mercado de fuerza de trabajo libre, estuvo regida por los dictámenes del proceso de acumulación originaria de capital, elemental en la transición que aseguró el triunfo del capitalismo moderno.

Por consiguiente, la tesis de que la independencia significó una revolución social antifeudal que instauró el modo de producción capitalista en estas tierras debe ser objetada. En primer lugar, porque, como hemos dicho, no se puede liquidar algo que no existía. En segundo lugar, porque el período independiente no instauró el modo de producción capitalista ni en Iberoamérica ni en Paraguay ${ }^{933}$. Como hemos argumentado, durante décadas

933 Modo de producción capitalista entendido como un sistema de explotación basado en el trabajo jurídicamente libre o asalariado, previo proceso de expropiación de los medios de trabajo a los productores directos de valor. Este era el único cambio radical posible en las relaciones de producción en la época histórica que nos ocupa, puesto que cualquier alternativa no capitalista o socialista simplemente no estaba planteada objetivamente en la primera mitad del siglo XIX, mucho menos en regiones que partían de fuerzas productivas poco desarrolladas, como es el caso de las colonias. 
perduró una coexistencia de modos de producción precapitalistas -basados en el trabajo no asalariado- con bolsones, embriones marginales, de trabajo jurídicamente libre.

Si lo anterior es correcto, retomemos nuestra definición central: lo que sí ocurrió fue una revolución política democrático-burguesa anticolonial.

Revolución, porque la derrota de los colonizadores sí produjo un cambio radical de la superestructura estatal en las antiguas regiones colonizadas, que pasaron -con sus altibajos y crisis- a ser Estados soberanos. Hubo, entonces, un cambio cualitativo en ese terreno. En el caso paraguayo existe un antes y un después de 1813.

Política, porque no se trató de una lucha entre clases sino entre facciones de una misma clase, en este caso, clases propietarias: de un lado, la facción española o españolista, que luchó para mantener Hispanoamérica bajo el control de los Borbones; de otro, la facción de la incipiente burguesía criolla, que después de una dilatada vacilación comprendió que el reino de España no estaba abierto a compromisos y luchó por su independencia.

La autodeterminación nacional, despojada de la aureola romántica impuesta por la ideología nacionalista, poseía para la embrionaria burguesía nativa un significado concreto: el poder político del aparato estatal, esto es, el dominio del sistema de recaudación fiscal, del comercio exterior, de las fuerzas armadas, en suma, el inicio del proceso de conformación-consolidación de Estados nacionales modernos y de las clases dominantes y dominadas en su forma contemporánea.

Democrático-burguesa-anticolonial, porque, en primer lugar, el período de las independencias iberoamericanas corresponde a la época histórica de las revoluciones burguesas. En el caso de las colonias, el sujeto social y el programa fueron burgueses. La diferencia en relación con las revoluciones democrático-burguesas clásicas que se dieron en Europa reside en que para las nacientes burguesías americanas lo más importante del ideario liberal fue la autodeterminación nacional, indispensable para poner en práctica, sin intermediarios coloniales, la doctrina del librecambio.

Caracterizarlas como revoluciones políticas no significa que el proceso careció de importancia fundamental o estuvo ausente de impactos en el terreno económico-social. Un razonamiento de ese tipo es objetable por muchos motivos. Principalmente, porque parte de una extrapolación de ciertos elementos y la omisión o menosprecio de otros igualmente relevantes. Ningún proceso colectivo es lineal. Existe una relación dialéctica entre lo político y lo económico; en la jerga marxista, entre superestructura y estructura social. 
En el caso de las ex colonias americanas, la conquista de la autodeterminación nacional suponía una precondición para liberar fuerzas productivas y, con ello, generar las condiciones materiales para allanar el camino a cambios en las relaciones sociales de producción -que en contexto del siglo XIX no podían ser otras que aquellas que sirvieran de puntal para la sociedad burguesa-. Si bien no es posible establecer una regla general, en países donde la independencia se dio de manera tardía o sin sobresaltos político-militares realmente profundos, las relaciones de producción arcaicas resistieron más tiempo: en Puerto Rico y Cuba, las dos colonias que España pudo mantener bajo su dominio hasta finales del siglo XIX, la esclavitud negra se abolió en 1873 y 1886, respectivamente. En el caso del Brasil, como es conocido, la esclavitud fue formalmente abolida en 1888. Fue el último en realizar esta tarea en las Américas.

Otra cosa es que el proceso de acumulación originaria de capital en el continente, tomando prestada y con las precauciones necesarias una categoría marxista, es decir, el proceso de separación de los productores directos de sus medios de trabajo y subsistencia hasta el punto en que estos se vean obligados a vender su fuerza de trabajo para sobrevivir condición, para hablar con propiedad, de un modo de producción capitalista hegemónico-, haya sido lento y tortuoso.

Por ejemplo, el conocido proceso de modernización del Paraguay de preguerra, al mismo tiempo que representó un salto en el desarrollo de las fuerzas productivas, no solo partió de una base material muy atrasada, sino que siguió apoyándose en la combinación desigual de relaciones de producción no capitalistas y capitalistas, un duelo entre lo viejo que no terminaba de morir y lo nuevo que no terminaba de nacer. El orden surgido entre 1811 y 1813, en cierta medida, fue heredero tanto de la revolución como de la Colonia. El nuevo régimen no dudó en mantener determinadas tradiciones arcaicas para legitimar nuevos fines. No olvidemos que la abolición jurídica de la encomienda de los indígenas se llevó a cabo en 1812; la de los últimos pueblos de indios en 1848; y la de la esclavitud negra en 1869, es decir, casi seis décadas después del primer paso en dirección hacia la independencia. Y esas medidas no fueron producto directo de rebeliones de los explotados sino controladas "desde arriba".

Esto significa que en el pujante Paraguay de preguerra convivía un sector asalariado -que abarcaba a la propia burocracia estatal, militar, el clero, los técnicos europeos, en general bien remunerados, además de obreros que trabajaban en la fundición de hierro, el arsenal, el ferrocarril, etc.- con el sector no capitalista que abarcaba a los "esclavos del 
Estado"; negros confinados a lugares remotos para servir de "antemural" ante el peligro que suponían los "indígenas indomados"; o bien indígenas segregados en pueblos, sin ningún derecho "ciudadano" hasta 1848.

No es difícil concluir que lo que sucedió en la realidad es opuesto a lo que sugiere la historiografía que rinde culto a la personalidad del doctor Francia y de los López, interesada en reforzar el mito de que el Paraguay se transformó en una "potencia industrial" en el siglo XIX.

Es más, a pesar de su abolición formal, las relaciones no capitalistas dejaron resquicios hasta finales del siglo XIX, y algo más. Los yerbales, por ejemplo, continuaron siendo sinónimo de explotación de mano de obra semiesclava en pleno siglo XX. La terrible experiencia del mensú está allí como muestra de un pasado que no termina de desaparecer hasta hoy ${ }^{934}$. En pleno siglo XXI, para mencionar un drama actual, existen más de 47.000 niños y adolescentes que en el Paraguay sobreviven en situación de criadazgo, un tipo de explotación semiesclava del trabajo infantil, en el cual las familias pobres, principalmente del interior rural, entregan sus hijos como criados a familias pudientes, a cambio de techo, comida y, con algo de suerte, educación.

Pero si la resistencia a la desaparición de las relaciones sociales no capitalistas representa la contradicción, en forma de resquicios o excrecencias, la esencia del proceso está en que la revolución democrático-burguesa anticolonial del siglo XIX, si bien fue política, en una escala de tiempo más o menos extensa posibilitó cambios sociales que en el período colonial eran impensables. En pocas palabras: la esfera política y la económicosocial no son en la realidad compartimentos estancos, sino que están interrelacionados, si bien poseen leyes y ritmos diferentes.

Tres últimas reflexiones. La primera es que, como la historia de las revoluciones de independencia es parte indisoluble de la historia de la conformación de los Estados nacionales, en sí misma encierra una multiplicidad de factores económicos, sociales, demográficos, étnicos, culturales en el que, aun con el panorama global bien comprendido, todavía hay mucho para escudriñar. Un repaso de la cuestión indica que lo anterior cabría dentro de un proyecto de estudio mucho más ambicioso: la historia de la génesis y el

\footnotetext{
${ }^{934}$ Se denominó Mensú al trabajador rural que extraía yerba mate de los montes en la zona del Paraguay y las provincias argentinas de Corrientes y Misiones. El término proviene de la palabra "mensual", referida a la frecuencia del pago del salario. Sobre la situación social de Paraguay a inicios del siglo XX, consultar: BARRETT, Rafael [1911]. El dolor paraguayo. Caracas: Ayacucho, 1978. El notable escritor paraguayo Augusto Roa Bastos caracterizó a Barrett, un periodista español anarquista que vivió en Paraguay, como "el descubridor de la realidad social paraguaya".
} 
desarrollo del capitalismo en Iberoamérica o, por lo menos, en el Paraguay. El proceso de conformación de las clases sociales fundamentales: sus bases materiales, su fisonomía, sus tradiciones, su cultura política.

Si existiesen condiciones propicias, no dudaríamos en avanzar por ese camino apoyándonos en este y otros trabajos. Mientras estas no existan, valga el apunte como indicación de una pesquisa que merece ser acometida por alguien más aventajado en algún momento.

La segunda está relacionada con el enfoque teórico que atravesó esta tesis de doctorado. Una lectura de la historia iberoamericana y paraguaya que utilice las herramientas conceptuales y adopte el método del materialismo histórico no puede debatir casi exclusivamente con la narrativa liberal conservadora. En el Paraguay, un énfasis en la polémica historiográfica con esa corriente es comprensible, puesto que con justicia está asociada a la facción político-ideológica que impulsó una guerra con consecuencias desastrosas para el país ${ }^{935}$. Pero detenerse en ello es unilateral. Consciente o inconscientemente, la interpretación que surja de semejante mutilación del análisis será sesgada. Es común que muchos historiadores paraguayos identifiquen el relato liberal con la historiografía "oficial" a ser combatida. El problema es que no existe una única corriente que se consagró como oficial sino dos: la liberal y la nacional-patriótica, las más de las veces degenerada en chovinismo fanático.

Desde 1936, la lectura nacionalista se elevó al rango de doctrina de Estado. Fue pieza clave del arsenal ideológico de la última dictadura militar, la del general Stroessner, entre 1954 y 1989.

Por lo tanto, estamos convencidos de que el materialismo histórico debe debatir con ambas corrientes tradicionales y que en períodos diferentes fueron elevadas a estatus oficial. El problema es que hace décadas que el justo duelo ideológico con el liberalismo engendró, en los medios que se reivindican del "campo democrático y progresista", una distorsión no menos dañina: el nacionalismo de izquierdas.

El punto es que, independientemente de su ropaje, si de derechas o de izquierdas, el nacionalismo será siempre nacionalismo. La estrategia política que su relato histórico

\footnotetext{
${ }^{935}$ La guerra contra la Triple Alianza representó una derrota histórica de la nación paraguaya: perdió 69\% de su población total y aproximadamente $40 \%$ de su territorio, anexados por el entonces Imperio del Brasil y Argentina. Las deudas impuestas por los vencedores ejercieron un papel de dominación político-financiera hasta la década de 1940. Sobre el grado de mortandad, asumimos las conclusiones consignadas en: WHIGHAM, Thomas; POTTHAST, Barbara. The Paraguayan Rosetta Stone..., op. cit.
} 
pretende justificar nunca podrá ser otra que supeditar los intereses de las clases subalternas de la sociedad a la "nación" dominada por la burguesía. Por su parte, el marxismo, aunque en determinadas circunstancias pueda apoyar causas nacionales de países oprimidos, no es nacionalista. Su naturaleza es internacionalista. Por eso, ninguna concesión teórica al nacionalismo, aun en su faceta más radical, puede estar asociada con el marxismo.

La tercera reflexión es que cualquier falsificación de la realidad, pasada o presente, resulta perniciosa para la clase trabajadora y los sectores oprimidos de esta sociedad en su lucha por mejorar sus condiciones de existencia materiales y culturales. Por eso, el estudio de la historia debe basarse en hechos comprobados. No admite deformaciones y requiere rigor científico. Presentar el Paraguay de preguerra como un paraíso terrenal es nocivo, en primer lugar, porque es falso. Ni el doctor Francia fue un igualitarista o nivelador social ni los dos López fueron hombres incorruptibles y modernizadores, que se basaron en una doctrina no solo nacionalista sino antiimperialista. Estas son premisas anacrónicas que mientras más rápidamente sean desechadas por los estudiosos que aspiran a alcanzar una compresión materialista de la historia, en mejores condiciones estaremos para comprender el pasado y sus implicaciones en el presente. No se pueden combatir mitos creando otros mitos.

Este estudio, en el marco de sus limitaciones, intentó poner en tela de juicio una determinada construcción histórica, común a las corrientes historiográficas consagradas. Un relato que atañe a la propia percepción identitaria en el Paraguay, que históricamente invisibiliza al indígena y al negro bajo la cobertura de categorías como la "raza paraguaya" o el concepto de "amplio mestizaje". Esto hace que partes significativas de la sociedad todavía se indignen cuando se les recuerda su ascendencia indígena, africana, o cuando alguien se atreve a señalar y criticar la esclavitud que sufrieron los pueblos originarios y los afrodescendientes ${ }^{936}$.

Puede afirmarse que si la historiografía que se reivindica marxista, o de la llamada izquierda en su sentido más amplio, insiste en la propaganda sobre el supuesto Paraguay “sin pobres ni analfabetos" del siglo XIX y no reconoce ni explica cómo se construyó económica, política, social y culturalmente el capitalismo en el Paraguay, una nación multiétnica y

\footnotetext{
${ }^{936}$ Basta observar el revuelo que causó un estudio de la Dirección de Memoria Histórica y Reparación del Ministerio de Justicia y el Equipo Argentino de Antropología Forense (EAFF), que reveló que 85\% del perfil genético de la población paraguaya es de origen nativo americano; 7\% africano; 7\% europeo; y el último 1\% de distintas zonas del Medio Oriente. Ver: Paraguay, el segundo país con más "sangre nativa". ABC Color. Asunción, 05/12/2018. Disponible en: <https://www.abc.com.py/nacionales/adn-paraguayo-es-7-europeo1766399.html>, consultado el 20/01/2019.
} 
multicultural como todos los países latinoamericanos, simplemente estará siendo connivente con los brutales tipos de explotación ocurridos durante el siglo XIX. Y más: seguirá abriendo un flanco completamente indefendible en la necesaria polémica entablada con la narrativa liberal, que de vez en cuando critica la esclavitud negra y hasta la explotación del indígena y del peón endeudado, pero como instrumento de un objetivo más amplio: la impugnación global del período "sombrío" comprendido entre 1813 y 1870.

Esperamos que este estudio pueda aportar en el sentido de revertir este y otros problemas teóricos y consiga contribuir para una aproximación marxista más acabada de uno de los procesos que, junto con la guerra contra la Triple Alianza, marcó el derrotero del Paraguay: la independencia nacional. 


\section{FUENTES}

\section{Fuentes MaNuscritas}

\section{Archivo Nacional de Asunción - Sección Histórica}

Volúmenes: $60 ; 62 ; 71 ; 149 ; 172 ; 198 ; 200 ; 204 ; 211 ; 213 ; 213 \mathrm{~A} ; 213 \mathrm{~B} ; 214 ; 218 ; 222 ; 223$; $226 ; 228 ; 229 ; 237 ; 239 ; 241 ; 242 ; 243 ; 244 ; 245 ; 251 ; 252 ; 256 ; 266 ; 276 ; 279 ; 280 ; 282$; $284 ; 285 ; 286 ; 291 ; 292 ; 295 ; 298 ; 304 ; 306 ; 310 ; 312 ; 314 ; 319 ; 321 ; 322 ; 323 ; 324 ; 331$; $334 ; 340 ; 353 ; 355 ; 444 ; 449$.

\section{Archivo Nacional de Asunción - Nueva Encuadernación}

Volúmenes: 739; 3411.

\section{Archivo Nacional de Asunción - Sección Civil y Judicial}

Volumen: 68.

\section{Fuentes Publicadas}

Acta de la Declaración de la Independencia de Venezuela [1811]. Disponible en: $<$ https://es.wikisource.org/wiki/Firma_del_Acta_de_la_Declaraci\%C3\%B3n_de_I ndependencia de Venezuela>, consultado el 12/03/2019.

BELGRANO, Manuel. Autobiografia: 1770-1820. Disponible en: $<$ https://www.elhistoriador.com.ar/manuel-belgrano-autobiografia-1770-1820/>, consultado el 27/03/2019.

Reglamento para el Régimen Político y Administrativo y Reforma de los 30 Pueblos de las Misiones. 1810. Disponible en: < https://www.educ.ar/recursos/128513/reglamento-de-belgrano-sobre-lasmisiones $>$, consultado el 27/03/2019.

BOLÍVAR, Simón [1815]. Carta de Jamaica. Caracas: Comisión Presidencial para la Conmemoración del Bicentenario de la Carta de Jamaica, 2015.

\section{Decreto de Guerra a Muerte. 1813. Disponible en:} $<\underline{\mathrm{https}}$ ://es.wikisource.org/wiki/Decreto_de_guerra_a_muerte $>$, consultado el 09/01/2020. 
- Discurso de Simón Bolívar ante el Congreso de Angostura. 1819.

Disponible

$<$ https://es.wikisource.org/wiki/Discurso de Sim\%C3\%B3n Bol\%C3\%ADvar a

nte el Congreso de Angostura $>$, consultado el 11/01/2020.

- Proyecto de Constitución para la República de Bolivia y discurso del Libertador. Buenos Aires: Imprenta de Hallet y Cia, 1826.

BURTON, Richard F. Cartas desde los campos de batalla del Paraguay. Buenos Aires: Editorial El Foro, 1998.

Cuestión Canstatt. Documentos oficiales cambiados entre la Legación de la República del Paraguay y el Gobierno de Su Majestad Británica con motivo de dicha cuestión. París: Besanzon-Imprenta de José Jacquin, 1864. Disponible en: $<$ https://babel.hathitrust.org/cgi/pt?id=hvd.32044103254454; view=1 up;seq=111>, consultado el 08/03/2018.

DEMERSAY, Alfred [1856]. El doctor Francia, dictador del Paraguay. Asunción: El Lector, 2011.

. Historia Geral do Paraguay: desde a sua descoberta até nossos dias. Rio de Janeiro: Typographia Perseverança, 1865.

INSTITUTO BELGRANIANO CENTRAL. Documentos para la Historia del General don Manuel Belgrano [1811-1812]. Tomo IV. Buenos Aires: Instituto Nacional Belgraniano, 1982.

. Documentos para la Historia del General don Manuel Belgrano [1792-

1811]. Tomo III, v. 1. Buenos Aires: Instituto Nacional Belgraniano, 1982.

LÓPEZ, Carlos A. Mensajes de Carlos Antonio López. Asunción: Imprenta Nacional, 1931.

MITRE, Bartolomé. Guerra del Paraguay. Buenos Aires: La Nación, 1911.

. Historia de Belgrano y de la Independencia Argentina. Tomo I. 3. ed. Buenos Aires: Imprenta de Mayo, 1876.

. Historia de Belgrano. Tomo I. Buenos Aires: Imprenta de Mayo, 1859.

. Historia de San Martín y de la emancipación sudamericana. Tomo I. Buenos Aires: Editorial Juventud Argentina, s/f.

MOLAS, Mariano [1840]. Descripción histórica de la antigua provincia del Paraguay. Asunción: Ediciones Nizza, 1957.

MORENO, Mariano. Plan de Operaciones. 1810. Disponible en: $<$ http://lahaine.org/amauta/b2-img/Mariano\%20Moreno\%201810.pdf $>$, consultado el 25/05/2017.

. Sobre el congreso convocado y Constitución del Estado. 1810. Disponible en: 
$<$ http:/hum.unne.edu.ar/academica/departamentos/historia/catedras/hist argen in

dep/otros/criterios constitucionales m \%20moreno.pdf>, consultado el 25/05/2017.

Ordenanzas de Alfaro. 1612. Disponible en: <http://www.enciclopediajuridica.biz14.com/d/ordenanzas-de-alfaro/ordenanzas-de-alfaro.htm>, consultado el 24/12/2018.

RENGGER, Johann. Viaje al Paraguay en los años 1818 a 1826. 1835. Asunción: Tiempo de Historia, 2010.

RENGGER, Johann; LONGCHAMP, Marcelin [1827]. Ensayo histórico sobre la Revolución del Paraguay: precedida de la biografía del tirano Francia, y continuada con algunos documentos y observaciones históricas. Buenos Aires: Imprenta y Librería de Mayo, 1883.

ROBERTSON, John P; ROBERTSON, William P. [1843]. Cartas del Paraguay. Asunción: Editora Intercontinental, 2010.

RODRÍGUEZ ALCALÁ, Guido (Org.). Artigas y la independencia del Paraguay: correspondencia. Asunción: Servilibro, 2003.

RODRÍGUEZ ALCALÁ, Guido; ALCÁZAR, José. Paraguay y Brasil: documentos sobre las relaciones binacionales [1844-1864]. Asunción: Tiempo de Historia, 2007.

RODRÍGUEZ ALCALÁ, Guido; DURÁN ESTRAGÓ, Margarita; ROMANO GARCÍA, Martín (Org.). FRANCIA: [1762-1816] Edición comentada, aumentada y corregida de la Colección Doroteo Bareiro del Archivo Nacional de Asunción. vol. 1. Asunción: Editorial Tiempo de Historia, 2009.

. FRANCIA: [1817-1830] Edición comentada, aumentada y corregida de la Colección Doroteo Bareiro del Archivo Nacional de Asunción. vol. 2. Asunción: Editorial Tiempo de Historia, 2009.

. FRANCIA: [1831-1840]. Edición comentada, aumentada y corregida de la Colección Doroteo Bareiro del Archivo Nacional de Asunción. vol. 3. Asunción: Editorial Tiempo de Historia, 2010.

SCAVONE, Ricardo (Org.). Polémicas en torno al gobierno de Carlos Antonio López en la prensa de Buenos Aires [1857-1858]. Asunción: Tiempo de Historia, 2010.

TUTTÉ, Andrea; IBÁÑEZ DE YEGROS, Norma. Catálogo Sección Historia del Archivo Nacional de Asunción: síntesis revisada de los catálogos elaborados durante el siglo XX. Asunción: Editorial Tiempo de Historia, 2008.

VELILLA, Margarita (Org.). Autos de la Revolución del Paraguay del 15 de mayo de 1811: Archivo Nacional de Asunción, Sección Historia, vols. 213 A y B. Asunción: Servilibro, 2011.

VIOLA, Alfredo (Org.). Cartas y decretos del Dictador Francia. Tomo I. Asunción: Biblioteca de Estudios Paraguayos Universidad Católica, 1989. 
. Cartas y decretos del Dictador Francia. Tomo II. Asunción: Biblioteca de Estudios Paraguayos Universidad Católica, 1990.

Cartas y decretos del Dictador Francia. Tomo III. Asunción: Biblioteca de Estudios Paraguayos Universidad Católica, 1990. 


\section{REFERENCIAS}

ABELARDO, Jorge. La historia de la nación latinoamericana. Tomo I. Buenos Aires: Editorial Peña y Lillo, 1973.

ACEVEDO, Edberto Oscar. La Intendencia del Paraguay en el Virreinato del Río de la Plata. Buenos Aires: Ediciones Ciudad Argentina, 1996.

ANDERSON, Perry. Tras las huellas del materialismo histórico. México D.F.: Siglo XXI Editores, 1986.

ANDRADA E SILVA, Raul de. Ensaio sobre a ditadura do Paraguai: 1814-1840. São Paulo: Coleção Museu Paulista, 1978.

ANNINO, Antonio; CASTRO, Luis; GUERRA, François-Xavier. De los imperios a las naciones: Iberoamérica. Zaragoza: Ibercaja, 1994.

ARANTXA, Guereña; ROJAS, Luis. Yvy Jára: Los dueños de la tierra en Paraguay. Asunción: Oxfam-Paraguay, 2016.

ARECES, Nidia. Concepción "peligrosa" y "descubierta" de la frontera norte paraguaya: Espacio étnico y sociopolítico. Revista de História, São Paulo, n. 133, pp. 59-74, 1995.

. La economía paraguaya en los primeros años revolucionarios. In: TELESCA, Ignacio; BREZZO, Liliana; CABALLERO CAMPOS, Herib (Org.). Paraguay 1813: La proclamación de la República. Asunción: Taurus, 2013.

. La expansión criolla en la frontera norte del Paraguay: Estancieros y chacreros en Concepción (1773-1840). Revista Europea de Estudios Latinoamericanos y del Caribe, Ámsterdam, n. 62, pp. 54-69, 1997. Disponible en: $<$ https://www.jstor.org/stable/25675731? seq $=1$ \#page scan tab contents $>$, consultado el 14/03/2019.

ARECES, Nidia; GONZALEZ DE BOSIO, Beatriz. El Paraguay durante los gobiernos de Francia y de los López. Asunción: El Lector, 2010.

ARICÓ, José. Marx e a América Latina. Rio de Janeiro: Paz e Terra, 1982.

ARRUDA, José Jobson de Andrade. O Brasil no comércio colonial. São Paulo: Ática, 1980.

. Uma colonia entre dois impérios: a abertura dos portos brasileiros, 18001808. Bauru: EDUSC, 2008.

ASSADOURIAN, Carlos; BEATO, Guillermo; CHIARAMONTE, José. Argentina, de la conquista a la independencia. Buenos Aires: Editorial Paidós, 1972.

ASSADOURIAN, Carlos; CARDOSO, Ciro; CIAFARDINI, Horacio, et al. Modos de producción en América Latina. 2. ed. Córdoba: Cuadernos Pasado y Presente, 1974. 
AVENDAÑO, Xiomara R. Pueblos indígenas y la formación de la República. In: ESCOBAR, Antonio (Coord.). Indios, comunidad y nación en América. México D.F.: CIESAS, 1994.

BÁEZ, Cecilio [1910]. Ensayo sobre el Dr. Francia y la dictadura en Sudamérica. Asunción: Editorial Cromos, 1985.

. Historia colonial del Paraguay y el Río de la Plata. Asunción: Zamphirópolos, 1926.

BAGÚ, Sergio. Economía de la sociedad colonial: Ensayo de Historia comparada de América Latina. Buenos Aires: El Ateneo, 1949.

BANDEIRA, Luiz Alberto M. [1985]. O expansionismo brasileiro e a formação dos Estados na Bacia do Prata: Argentina, Uruguai e Paraguai, da colonização à Guerra da Tríplice Aliança. 3. ed. Rio de Janeiro: Revan, 1998.

BARATTA, María. Ciento cincuenta años después. La historiografía reciente sobre la guerra del Paraguay en Argentina. Anuario IEHS, Tandil, v. 34, n. 2, pp. 221-233, 2019.

BARBOSA, Alexandre de Freitas. A independência dos paises da América Latina. 2. ed. São Paulo: Saraiva, 1999.

BARRETT, Rafael [1911]. El dolor paraguayo. Caracas: Ayacucho, 1978.

BAUD, Michiel. Indigenismo y los movimientos indígenas en la historia andina, siglos XIX y XX. In: OHMSTEDE, Antonio E.; FALCÓN, Romana; BUVE, Raymond (Coord.). La arquitectura histórica del poder. Naciones, nacionalismos y estados en América Latina. Siglos XVIII, XIX y XX. México: CEDLA-El Colegio de México, 2010.

BERBEL, Márcia; OLIVEIRA, Cecília (Org.). A experiência constitucional de Cádis: Espanha, Portugal e Brasil. São Paulo: Alameda, 2012.

BETHELL, Leslie (Org.). Historia de América Latina. La independencia. Tomo V. Barcelona: Editorial Crítica, 1991.

BOCCIA ROMAÑACH, Alfredo. Paraguay y Brasil, crónica de sus conflictos. Asunción: El Lector, 2000.

BOSCH ALESSIO, Constanza. El debate marxista sobre los modos de producción coloniales latinoamericanos en el seno de la intelectualidad argentina [18901973]. 2016. Disponible en: <http://www.aacademica.org/constanza.bosch/27>, consultado el 23/11/2016.

BRADING, David. Los orígenes del nacionalismo mexicano. México D.F.: Era, 1980.

BREÑA, Roberto (Org.). Cádiz a debate: actualidad, contexto y legado. México D.F.: El Colegio de México-Centro de Estudios Internacionales, 2014. 
. Diferendos y coincidencias en torno a la obra de François-Xavier Guerra (una réplica a Medófilo Medina Pineda). Anuario Colombiano de Historia Social y de la Cultura, Bogotá, n. 38, 2011.

BREZZO, Liliana. ¡Viva la unión!: las relaciones entre Paraguay y Buenos Aires. In: TELESCA, Ignacio; BREZZO, Liliana; CABALLERO CAMPOS, Herib (Org.). Paraguay 1813: La proclamación de la República. Asunción: Taurus, 2013.

. El Paraguay en cinco momentos historiográficos: ritos y perspectivas. In: CASAL, Juan; WHIGHAM, Thomas (Org.). Paraguay: el nacionalismo y la guerra. Actas de las Primeras Jornadas Internacionales de Historia del Paraguay en la Universidad de Montevideo. Asunción: Tiempo de Historia-Universidad de Montevideo, 2009.

. La guerra de la Triple Alianza en los límites de la ortodoxia: mitos y tabúes. Universum, Talca, v. 19, n. 1, pp. 10-27, 2004.

BREZZO, Liliana; DORATIOTO, Francisco. Ojos en la guerra del Paraguay. Archivos, enfoques, lecturas. Anuario IEHS, Tandil, v. 34, n. 2, pp. 123-139, 2019.

BRUN, Diego A. La guerra de la Triple Alianza: tres modelos explicativos. Revista Paraguaya de Sociología, Asunción, v. 26, n. 74, pp. 175-197, 1989.

BRUSCHERA, Oscar H. José Artigas: documentos. Montevideo: Casa de las Américas, 1971.

BURGIN, Miron. Aspectos económicos del federalismo argentino. Buenos Aires: Librería Hachette, 1960.

BUSHNELL, David: Colombia: una nación a pesar de si misma: de los tiempos precolombinos a nuestros días. Bogotá: Planeta, 1996.

CABALlERO CAMPOS, Herib. El Virreinato del Río de la Plata [1776-1810]. In: TELESCA, Ignacio (Org.). Historia del Paraguay. 4. ed. Asunción: Taurus, 2014.

. Los Bandos del Buen Gobierno de la Provincia del Paraguay, 1778-1811. Asunción: FONDEC/Arandurã, 2007.

. Los Congresos de 1811 y 1813: representación política y ciudadana. In: TELESCA, Ignacio; BREZZO, Liliana; CABALLERO CAMPOS, Herib (Org.). Paraguay 1813 La proclamación de la República. Asunción: Taurus, 2013. 2010 .

. Proceso de la Independencia paraguaya [1780-1813]. Asunción: El Lector,

CABANELLAS, Guillermo. El dictador del Paraguay: Dr. Francia. Asunción: Editorial Claridad, 1946.

CAMARERO, Hernán. El período formativo de un intelectual: Milcíades Peña y el trotskismo en las décadas de 1940-1950. Archivos de historia del movimiento obrero y la izquierda, Buenos Aires, n. 3, pp. 9-33, 2013. 
CANNY, Nicolas; PAGDEN, Anthony. Colonial Identity in the Atlantic World, 1500-1800. Princeton: Princeton University Press, 1989.

CARDOSO, Ciro. A crise do colonialismo luso na América portuguesa. In: LINHARES, Maria (Org.): História geral do Brasil. Rio de Janeiro: Campus, 1990.

. El modo de producción esclavista colonial en América. In: ASSADOURIAN, Carlos et al. Modos de producción en América Latina. Córdoba: Cuadernos Pasado y Presente, 1974.

Escravo ou camponês? O protocampesinato negro nas Américas. São Paulo: Brasiliense, 1987.

O trabalho na colônia. In: LINHARES, Maria (Org.). História geral do Brasil. 5. ed. Rio de Janeiro: Campus, 1990.

- Severo Martínez Peláez y carácter del régimen colonial. In: ASSADOURIAN, Carlos, et al. Modos de producción en América Latina. Córdoba: Cuadernos Pasado y Presente, 1974.

CARDOSO, Ciro; PÉREZ, Héctor. História econômica da América Latina. 3. ed. Rio de Janeiro: Edições Graal, 1983.

CARDOZO, Efraím [1949]. El Paraguay independiente. 2. ed. Asunción: Carlos Shauman Editor, 1988.

[1955]. El Paraguay Colonial. Asunción: El Lector, 1996.

[1961]. El Imperio del Brasil y el Río de la Plata: Antecedentes y estallido de la Guerra del Paraguay. Asunción: Intercontinental, 2012.

[1965]. Breve historia del Paraguay. Asunción: El Lector, 1996. 1940.

. La diplomacia de Belgrano en el Paraguay. Sociedad de Historia Argentina,

CARLYLE, Thomas [1842]. El dictador Francia. Asunción: El Lector, 2011.

CASAL, Juan; WHIGHAM, Thomas (Org.). Paraguay: el nacionalismo y la guerra. Actas de las Primeras Jornadas Internacionales de Historia del Paraguay en la Universidad de Montevideo. Asunción: Tiempo de Historia-Universidad de Montevideo, 2009.

CASTRO, Antonio Barros de. A economia política, o capitalismo e a escravidão. In: AMARAL LAPA, José Roberto do (Org.). Modos de produção e realidade brasileira. Petrópolis: Vozes, 1980.

CELESIA, Ernesto. Federalismo argentino: apuntes históricos, 1815-1821. Buenos Aires: Librería Cervantes de J. Suárez, 1932.

CHAVES, Julio [1938]. Historia de las relaciones entre Buenos-Ayres y el Paraguay: 18101813. 2. ed. Buenos Aires: Ediciones Niza, 1959. 

1985.

[1942]. El Supremo Dictador. 5. ed. Asunción: Carlos Schauman Editor, [1955]. El presidente López. Asunción: El Lector, 2011.

[1958]. Compendio de historia paraguaya. Asunción: Carlos Schauman Editor, 1991.

[1961]. La revolución paraguaya de la independencia: Biografía de los próceres. Asunción: Editora Intercontinental, 2010.

CHIARAMONTE, José. Ciudades, provincias, Estados: Orígenes de la Nación Argentina (1800-1846). Documentos. Buenos Aires: Emecé, 2007.

. Metamorfoses do conceito de nação durante os séculos XVII e XVIII. In: JANCSÓ, István (Org.). Brasil: formação do Estado e da nação. São Paulo: Hucitec/Fapesp/Editora Unijuí, 2003.

. Nación y Estado en Iberoamérica. El lenguaje político en tiempos de las independencias. Buenos Aires: Sudamericana, 2004.

CHUST, Manuel (Org.). Las independencias iberoamericanas en su laberinto: controversias, cuestiones, interpretaciones. Valencia: Publicacions de la Universitat de Valencia, 2010.

. Insurgencia y revolución en Hispanoamérica. Sin castillas hubo bastillas. Historia Social 20. Valencia: Uned, 1994.

. La cuestión nacional americana en las Cortes de Cádiz. Valencia: Centro Francisco Tomás y Valiente Uned Alzira, 1999.

CHUST, Manuel; FRASQUET, Ivana. Las independencias en América. Madrid: Catarata, 2009.

CHUST, Manuel; SERRANO, José Antonio. Debates sobre las independencias. MadridFrankfurt: Vervuert-Iberoamericana, 2007.

COGGIOLA, Osvaldo (Org.). A revolução francesa e seu impacto na América Latina. São Paulo: Nova Stella/EDUSP, 1990.

COMINTERN. Programa y estatutos de la Internacional Comunista: Adoptados por el VI Congreso Mundial en Moscú el 1 de setiembre de 1928. Bruselas: Ediciones Adelante, $\mathrm{s} / \mathrm{f}$.

COONEY, Jerry. Abolition in the Republic of Paraguay: 1840-1870. Jahrbuch für Geschichte von Staat, Wirtschaft und Gessellschaft, Köln, n. 11, 1974. 1990. . Economía y sociedad en la Intendencia del Paraguay. Asunción: CEPES, 
. El fin de la colonia en el Paraguay: 1810-1811. Asunción: Editora Intercontinental, 2010.

. El proceso de la independencia del Paraguay: 1807-1814. Asunción: Editora Intercontinental, 2012.

. Milicia, Estado y Sociedad en Paraguay: El camino a 1813. In: TELESCA, Ignacio; BREZZO, Liliana; CABALLERO CAMPOS, Herib (Org.). Paraguay 1813: La proclamación de la República. Asunción: Taurus, 2013.

CORBELLINI, Enrique. La revolución de Mayo y sus antecedentes desde las invasiones inglesas al Río de la Plata. Buenos Aires: Lajouane, 1950.

CORONEL, Bernardo. Breve interpretación marxista de la historia paraguaya [1537-2011]. Asunción: Arandurã, 2011.

CORONEL, Jorge (Org.). La república francista del Paraguay. Escritos en homenaje a Richard Alan White. Asunción: Arandurã, 2017.

COSTA NETO, Pedro. Forças produtivas, progresso e expansão colonial em Marx e Engels (1845-1853). Disponible en: $<$ https://www.unicamp.br/cemarx/ANAIS\%20IV\%20COLOQUIO/comunica\%e7 \%f5es/GT4/gt4m4c4.PDF $>$, consultado el 03/01/2020.

. Notas preliminares sobre o conceito de progresso em Karl Marx e Friedrich Engels. Germinal: Marxismo e educação em debate, Salvador, v. 10, n. 1, pp. 43$52,2018$.

COSTA, Iraci del Nero da. Repensando o modelo interpretativo de Caio Prado Júnior. Cadernos NEHD, São Paulo, v.3, 1995.

COSTA, Wilma. A economia mercantil escravista nacional e o processo de construção do Estado no Brasil (1808-1850). In: SZMRECSÁNYI, Tamas; AMARAL LAPA, José Roberto do (Org.): História econômica da independência e do império. São Paulo: Hucitec, 1996.

CREYDT, Oscar [1963]. Formación histórica de la nación paraguaya. 2. ed. Asunción: Servilibro, 2004.

DORATIOTO, Francisco. História e Ideologia: a produção brasileira sobre a Guerra do Paraguai. 2009. Disponible en: $<$ https://journals.openedition.org/nuevomundo/49012>, consultado el 12/07/2018.

- Maldita Guerra: Nova história da Guerra do Paraguai. São Paulo: Companhia das Letras, 2002.

EFE. FAO admite un "estancamiento" en la reducción de la pobreza en Paraguay. 2019. Disponible en: <http://www.nanduti.com.py/2019/03/28/fao-admiteestancamiento-la-reduccion-la-pobreza-paraguay/>, consultado el 01/04/2019. 
ENGELS, Friedrich [1884]. El origen de la familia, la propiedad privada y el Estado. In: MARX, Karl; ENGELS, Friedrich. Materiales para la historia de América. Córdoba: Cuadernos Pasado y Presente, 1972.

. Carta a Marx del 22 de diciembre de 1882. Disponible en: $<$ https://www.marxists.org/espanol/m-e/cartas/e1882-12-22.htm>, consultado el 19/03/2019.

ESCOBAR, Antonio (Coord.). Indios, comunidad y nación en América. México D.F.: CIESAS, 1994.

FOGEL, Ramón. La reforma agraria encarada por el gobierno de Rodríguez de Francia [1814-1840]. In: CORONEL, Jorge (Org.). La república francista del Paraguay. Escritos en homenaje a Richard Alan White. Asunción: Arandurã, 2017.

FRADKIN, Raúl. ¿Qué tuvo de revolucionaria la revolución de independencia? Nuevo Topo. Revista de historia y pensamiento crítico, Buenos Aires, n. 5, pp. 15-43, 2008.

FRADKIN, Raúl; GARAVAGLIA, Juan. La Argentina Colonial: el Río de la Plata entre los siglos XVI y XIX. Buenos Aires: Siglo XXI Editores, 2009.

FRAGOSO, João Luís. Novas perspectivas acerca da escravidão no Brasil. In: CARDOSO, Ciro (Org.), Escravidão e abolição no Brasil: novas perspectivas. Rio de Janeiro: Jorge Zahar, 1988.

FRASQUET, Ivana (Coord.). Bastillas, cetros y blasones: la independencia en Iberoamérica. Madrid: Mapfre, 2006.

FRASQUET, Ivana; SLEMIAN, Andréa (Org.). De las independencias iberoamericanas a los estados nacionales (1810-1850). 200 años de historia. Madrid: Ahila- Vervuert Iberoamericana, 2009.

FURET, François. Penser la Révolution Française. París: Gallimard, 1978.

GARAVAGLIA, Juan [1983]. Mercado interno y economía colonial: tres siglos de historia de la yerba mate. 2. ed. Rosario: Prohistoria ediciones, 2008.

. Economía, sociedad y regiones. Buenos Aires: Ediciones de la Flor, 1987.

La demografía paraguaya: aspectos sociales y cuantitativos (siglos XVIXVIII). Suplementos Antropológico, v. 19, n. 2, pp. 19-85, 1984.

Os primórdios do processo de independência hispano-americano. In: JANCSÓ, István (Org.). Independência: história e historiografía. São Paulo: Hucitec/Fapesp, 2005.

. Un modo de producción subsidiario: la organización económica de las comunidades guaranizadas en la formación regional altoperuana-rioplatense. In: ASSADOURIAN, Carlos et al. Modos de producción en América Latina. 2. ed. Córdoba: Cuadernos Pasado y Presente, 1974. 
GARAVAGLIA, Juan; FRADKIN, Raúl. A 150 años de la Guerra de la Triple Alianza contra el Paraguay. Buenos Aires: Prometeo Libros, 2016.

GARCÍA MELLID, Atilio. Proceso a los falsificadores de la historia del Paraguay. Tomo II. Buenos Aires: Ediciones Theoria, 1964.

GARCÍA, Manuel. Pensamiento ilustrado y discriminación política en los primeros estados latinoamericanos. In: GONZÁLEZ, Jesús (Ed.). Barbarie y civilización. Madrid: Editorial UCA, 2014.

GEBRAN, Philomena (Org.). Conceito de modo de produção. Rio de Janeiro: Paz e Terra, 1978.

GODECHOT, Jacques; PALMER, Robert. Le problème de l'Atlantique du XVIII ${ }^{e}$ au XX siècle. Congresso internationale di Scienze storiche. Florencia: Relazioni, 1955.

GODEIRO, Nazareno. O marxismo e a questão nacional e colonial. 2017. Disponible en: < https://teoriaerevolucao.pstu.org.br/o-marxismo-e-a-questao-nacional-ecolonial/>, consultado el 03/02/2020.

GOLDMAN, Noemí; SALVATORE, Ricardo. Caudillismos rioplatenses: nuevas miradas a un viejo problema. Buenos Aires: Editorial Universitaria de Buenos Aires, 1998.

GOLDMANN, Lucien. Sciences Humaines et Philosophie. París: Gontier, 1966.

GONZÁLEZ DE BOSIO, Beatriz. Las invasiones inglesas en el Río de la Plata 1806-1807: precursoras de la independencia de Hispanoamérica. s/f. Disponible en:

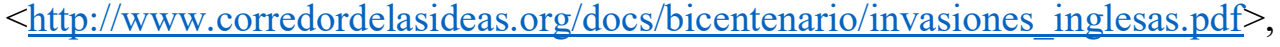
consultado el 18/05/2015.

GONZÁLEZ, Jesús (Ed.). Barbarie y civilización. Madrid: Editorial UCA, 2014.

GORENDER, Jacob [1978]. O escravismo colonial. 3. ed. São Paulo: Ática, 1980.

[1981]. A burguesia brasileira. 3. ed. 2. reimp. São Paulo: Brasiliense, 2004.

. O épico e o trágico na história do Haiti. In: JAMES, C. R. L. [1938]. Os jacobinos negros: Toussaint L'Ouverture e a revolução de São Domingos. São Paulo: Boitempo, 2000.

GUERRA, François-Xavier (Org.). Revoluciones Hispánicas. Independencias americanas y liberalismo español. Madrid: Editorial Complutense, 1995. 2014.

[1985]. México: del Antiguo Régimen a la Revolución. México D.F.: FCE,

[1992]. Modernidad e independencias: ensayos sobre las revoluciones hispánicas. México D.F.: FCE, 2010. 
. La desintegración de la monarquía hispánica: revolución de independencia. In: ANNINO, Antonio; CASTRO, Luis; GUERRA, François-Xavier. De los imperios a las naciones: Iberoamérica. Zaragoza: Ibercaja, 1994.

GUNDER FRANK, André. ¿Con qué modos de producción convierte la gallina maíz en huevos de oro?. 1965. Disponible en: <https://amauta.lahaine.org/debate-rodolfopuiggros-andre-gunder-frank-sobre-los-modos-de-produccion-en-americalatina/>, consultado el 19/03/2019.

. Capitalismo y subdesarrollo en América Latina. 1965. Disponible en: $<$ http://www.eumed.net/cursecon/textos/Frank/index.htm $>$, consultado el $19 / 11 / 2016$.

HALE, Charles. El pensamiento político en México y Latinoamérica. México D.F.: El Colegio de México, 2010.

. El renacimiento de la historia política y la Revolución Francesa en México. In: HALE, Charles. El pensamiento politico en México y Latinoamérica. México D.F.: El Colegio de México, 2010.

HALPERIN DONGHI, Túlio H. Reforma y disolución de los imperios ibéricos, 1750-1850. Madrid: Alianza, 1985.

. História da América Latina. São Paulo: Editora Paz e Terra, 2001.

. Revolución y guerra. Formación de una élite dirigente en la Argentina criolla. 2. ed. Buenos Aires: Siglo XXI Editores Argentina, 2005.

HERKEN KRAUER, Juan; GIMÉNEZ DE HERKEN, Isabel. Gran Bretaña y la Guerra de la Triple Alianza. Asunción: Editorial Arte Nuevo, 1982.

HIIL, Christopher. Comentário. In: SWEEZY, Paul; DOOB, Maurice, et al. Do feudalismo ao capitalismo. Lisboa: Publicações Dom Quixote, 1971.

. La revolución inglesa [1640]. Barcelona: ANAGRAMA, 1977.

HINDESS, Barry; HIRST, Paul. Modo de produção e formação social. Rio de Janeiro: Zahar Editores, 1978.

HISTORIA GENERAL DE LAS RR.EE. DE LA REPÚBLICA ARGENTINA. El cuadro de situación fiscal en el Río de la Plata, 1815-1820: la creciente importancia del comercio exterior en los ingresos del Estado revolucionario. 2000. Disponible en: $<$ http://www.argentina-rree.com/2/2-037.htm>, consultado el 23/06/2017.

. Las misiones de Sarratea, Belgrano y Rivadavia y su fracaso en obtener el reconocimiento español. 2000. Disponible en: <http://www.argentinarree.com/2/2-022.htm>, consultado el 22/06/2017.

. Los proyectos de algunos sectores por establecer un príncipe o monarca Borbón francés en el Río de la Plata. 2000. Disponible en: $<\underline{\text { http://www.argentina- }}$ rree.com/2/2-053.htm>, consultado el 01/07/2017. 
HOBSBAWM, Eric [1977]. A era das revoluções [1789-1848]. 33. ed. Rio de Janeiro: Paz e Terra, 2015.

HORTON BOX, Pelham [1930]. Orígenes de la Guerra de la Triple Alianza. Asunción: El Lector, 1996.

IRUROZQUI, Marta. La justicia del pueblo. Ciudadanía armada y movilización social. In: IRUROZQUI, Marta; GALANTE, Mirian (Ed.). Sangre de Ley. Violencia y justicia en la institucionalización del Estado: América Latina, siglo XIX. Madrid: Ed. Polifemo-GEA, 2010.

IRUROZQUI, Marta; GALANTE, Mirian (Ed.). Sangre de Ley. Violencia y justicia en la institucionalización del Estado: América Latina, siglo XIX. Madrid: Ed. PolifemoGEA, 2010.

JAMES, C. R. L. [1938]. Os jacobinos negros: Toussaint L'Ouverture e a revolução de São Domingos. São Paulo: Boitempo, 2000.

JANCSÓ, István (Org.). Brasil: formação do Estado e da nação. São Paulo: Hucitec/Fapesp/Editora Unijuí, 2003. 2005 .

(Org.). Independência: história e historiografia. São Paulo: Hucitec/Fapesp,

JONG, Ingrid; OHMSTEDE, Antonio (Org.). Las poblaciones indígenas en la conformación de las naciones y los Estados de la América Latina decimonónica. Ciudad de México: El Colegio de México/CIESAS/El Colegio de Michoacán, 2016.

KAUTSKY, Karl [1903]. La revolución social. Valencia: Alejandría Proletaria, 2018.

KOSSOK, Manfred. El contenido burgués de las independencias de América Latina. Secuencia-Revista de historia y ciencias sociales, México D.F., n. 13, pp. 144-162, 1989.

. El Virreinato del Río de la Plata. Su estructura económica-social. Buenos Aires: Editorial Futuro, 1959.

LACLAU, Ernesto. Feudalismo y capitalismo en América Latina. In: ASSADOURIAN, Carlos, et al. Modos de producción en América Latina. Córdoba: Cuadernos Pasado y Presente, 1974.

LANDAVAZO, Marco. La máscara de Fernando VII. Discurso e imaginario monárquico en una época de crisis. Nueva España, 1808-1822. México: El Colegio de México/Universidad Michoacana de San Nicolás de Hidalgo/El Colegio de Michoacán, 2001.

LENIN, V. I. [1899]. El desarrollo del capitalismo en Rusia: El proceso de la formación del mercado interior para la gran industria. Moscú: Editorial Progreso, 1974.

[1905]. Socialismo pequeñoburgués y socialismo proletario. In: LENIN, V. I. Obras completas. Tomo 12. Moscú: Editorial Progreso, 1982. 
[1906]. Revisión del programa agrario del partido obrero. In: LENIN, V. I. Obras Escogidas. Moscú: Editorial Progreso, 1973.

[1906]. Revisión del programa agrario del partido obrero. In. LENIN, V. I. Obras completas. Tomo 12. Moscú: Editorial Progreso, 1982.

[1907]. La cuestión agraria. Madrid: Editorial Ayuso, 1975.

[1908]. El problema agrario en Rusia a fines del siglo XIX. In: LENIN, V. I. Obras Completas. Tomo 15. Madrid: Akal Editor, 1977.

[1912]. La democracia y el populismo en China. In: LENIN, V. I. Obras Completas. Tomo 21. Moscú: Progreso, 1974.

[1917]. O Estado e a revolução. São Paulo: Editora Sundermann, 2005.

. ¿Podrán los bolcheviques retener el poder? In: LENIN, V. I. Obras Completas. Tomo 27. Madrid: Akal Editor, 1976.

. Cartas sobre táctica. In: LENIN, V. I. Obras Completas. Tomo 31. Moscú: Editorial Progreso, 1961.

. El derecho de las naciones a la autodeterminación. 1914. Disponible en:

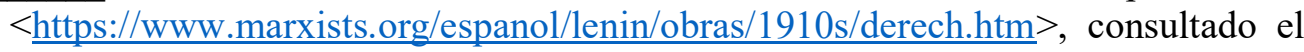
$04 / 12 / 2020$.

. Obras completas. Tomo 12. Moscú: Editorial Progreso, 1982.

. Obras Completas. Tomo 15. Madrid: Akal Editor, 1977.

. Obras Completas. Tomo 21. Moscú: Progreso, 1974.

. Obras Escogidas. Moscú: Editorial Progreso, 1973.

- Sobre as tarefas dos sindicatos. 1919. Disponible en: $<$ https://www.marxists.org/portugues/lenin/1919/01/tarefas.htm>, consultado el 20/02/2019.

- Tesis e informe sobre la democracia burguesa y la dictadura del proletariado. $1919 . \quad$ Disponible en: $<$ https://www.marxists.org/espanol/lenin/obras/1910s/internacional/informe.htm>, consultado el 20/02/2019.

. Obras escogidas. Tomo 2. Moscú: Editorial Progreso, 1966.

LIMA, Luiz Otavio de. A Guerra do Paraguai. São Paulo: Planeta, 2016.

LINHARES, Maria. (Org.): História geral do Brasil. Rio de Janeiro: Campus, 1990.

LOCKARD, Craig. Societies, Networks, and Transitions: A Global History: Since 1450. Boston: Cengage Learning, 2010. 
LOWY, Michael. Método dialético e teoria política. 2. ed. Rio de Janeiro: Paz e Terra, 1978.

LYNCH, John. América latina no necesita ahora una nueva independencia. La Nación. Buenos Aires, 16/06/2010. Disponible en: $<$ https://www.lanacion.com.ar/cultura/america-latina-no-necesita-ahora-unanueva-independencia-nid1275576>, consultado el 29/01/2020.

. El caudillismo en Latinoamérica no se debe a la herencia española. El País, 22/09/2007.

Disponible

en:

$<$ https://elpais.com/diario/2007/09/22/cultura/1190412012 850215.html $>$, consultado el 28/01/2020.

. El trono y el altar, soportes del imperio. El País, 13/05/1988. Disponible en: $<$ https://elpais.com/diario/1988/05/13/cultura/579477603 850215.html $>$, consultado el 27/01/2020.

. España bajo los Austrias. Barcelona: Ediciones Península, 1970.

. Las revoluciones hispanoamericanas [1808-1826]. Barcelona: Ariel, 1976.

. Los orígenes de la independencia. In: BETHELL, Leslie (Org.). Historia de América Latina: La independencia. Tomo V. Barcelona: Editorial Crítica, 1991.

. San Martin soldado argentino, héroe americano. Buenos Aires: Editorial Critica, 2009.

. Simón Bolívar. Barcelona: Editorial Crítica, 2010.

MAEDER, Ernesto. La población en el Paraguay en 1799: el censo del gobernador Lázaro de Ribera. Estudios Paraguayos, Asunción, v. 3, n. 1, pp. 63-86, 1975.

. Las Misiones jesuíticas. In: TELESCA, Ignacio (Org.). Historia del Paraguay. 4. ed. Asunción: Taurus, 2014.

MAESTRI, Mário. 150 anos da destruição do Estado-nação paraguaio pelo exército brasileiro. s/f. Disponible en: < https://www.curitibasuburbana.com/noticias/150anos-da-destruicao-do-estado-nacao-paraguaio-pelo-exercito-brasileiro/>, consultado el 27/01/2020.

. Paraguai: a República camponesa [1810-1865]. Porto Alegre: FCM Editora, 2015.

. Paraguai: Revolução e Genocídio. O Mau Uso da História. 2012. Disponible en: <http://socialismo-obarbarie.org/webanterior/historias/120330 maestri paraguay revolucion_y geno cidio.htm>, consultado el 02/01/17.

MAKARAN, Gaya. Paraguay: el nacionalismo y sus mitos. México D.F.: Universidad Nacional Autónoma de México-Centro de investigación sobre América Latina y el Caribe, 2014. 
MANCHESTER, Alan K [1933]. Preeminência inglesa no Brasil. São Paulo: Brasiliense, 1973.

MARX, Karl [1852]. El Dieciocho Brumario de Luis Bonaparte. Buenos Aires: Ediciones Libertador, 1998.

[1859]. Contribución a la crítica de la economía política. Buenos Aires: Estudio, 1970.

. Carta a Sigfrid Meyer y August Vogt. 1870. Disponible en: $<$ https://www.marxists.org/espanol/m-e/1870/abril/09.htm>, consultado el $04 / 02 / 2020$.

. Circular del Comité Central a la Liga Comunista. 1850. Disponible en: $<$ https://www.marxists.org/espanol/m-e/1850s/50 circ.htm>, consultado el $13 / 02 / 2019$.

. El Capital. Tomo I, v. 3. 8ª reimp. México: Siglo XXI, 2009.

. El Capital. Tomo I, vol. 1. 28 . reimp. México: Siglo XXI, 2008.

. El Capital. Tomo I. Buenos Aires: Editorial Cartago, 1956.

. El Capital. Tomo II. Buenos Aires: Editorial Cartago, 1956.

. El Capital. Tomo III. In: MARX, Karl; ENGELS, Friedrich. Materiales para la historia de América. Córdoba: Cuadernos Pasado y Presente, 1972.

. Elementos fundamentales para la crítica de la economía política: Grundrisse [1857-1858]. In: MARX, Karl; ENGELS, Friedrich. Materiales para la historia de América. Córdoba: Cuadernos Pasado y Presente, 1972.

. Historia crítica de la teoría de la plusvalía. Tomo II. México: Fondo de Cultura Económica, 1944.

. La acumulación originaria de capital. México D.F.: Editorial Grijalbo, 1969.

\begin{tabular}{llllr}
\hline & La España revolucionaria. 1854. & Disponible & en: \\
\hline$<\mathrm{https}: / /$ www.marxists.org/espanol/m-e/1850s/9-ix-54.htm $>$, & consultado & el
\end{tabular} $15 / 01 / 2020$.

MARX, Karl; ENGELS, Friedrich. Acerca del colonialismo. Artículos y cartas. Moscú: Editorial Progreso, 1981.

. Correspondencia. Buenos Aires: Editorial Cartago, 1957.

. La ideología alemana. In: MARX, Karl; ENGELS, Friedrich. Materiales para la historia de América. Córdoba: Cuadernos Pasado y Presente, 1972. 
. Manifiesto del Partido Comunista. 1848. Disponible en: $<$ https://www.marxists.org/espanol/m-e/1840s/48-manif.htm>, consultado el $18 / 11 / 2016$.

MATTHIEZ, Albert. La Revolución Francesa. El Terror. Tomo III. Barcelona: Editorial Labor, 1935.

. La Revolución Francesa. La caída de la realeza. Tomo I. Barcelona: Editorial Labor, 1935.

. La Revolución Francesa. La Gironda y la Montaña. Tomo II. Barcelona: Editorial Labor, 1935.

MAZZEO, Antonio Carlos. Estado e burguesia no Brasil: origens da autocracia brasileira. 2. ed. São Paulo: Cortez Editora, 1997.

MEZLLAS, Glodel. La revolución haitiana de 1804 y sus impactos políticos sobre América Latina. Estudios de Filosofía Práctica e Historia de las Ideas, Mendoza, v. 11, n. 2, 2009.

MIERS, Jorge. Las formas complejas del poder: la problemática del caudillismo a la luz del régimen rosista. In: GOLDMAN, Noemí; SALVATORE, Ricardo. Caudillismos rioplatenses: nuevas miradas a un viejo problema. Buenos Aires: Editorial Universitaria de Buenos Aires, 1998.

MINISTERIO DE CULTURA-ARGENTINA. Historia de la esclavitud en Argentina. 2017. Disponible en: < https://www.cultura.gob.ar/historia-de-la-esclavitud-enargentina 4933/>, consultado el 29/01/2020.

MOLINA, Raúl A. Lord Strangford y la Revolución de Mayo. Revista Historia-Colección Mayo, Buenos Aires, n. 19, pp. 174-182, 1960.

MONTE DE LÓPEZ MOREIRA, Mary. Ocaso del colonialismo español: El gobierno de Bernardo de Velasco y Huidobro, su influencia en la formación de Estado paraguayo [1803-1811]. Asunción: Fondec, 2006.

MONTEAGUDO, Bernardo. Ensayo sobre la necesidad de una Federación General entre los Estados Hispanoamericanos. México: UNAM, s/f.

MONTEIRO, John Manuel. Negros da terra: índios e bandeirantes nas origens de São Paulo. São Paulo: Companhia das Letras, 1994.

MORENO, Fulgencio [1912]. Causas de la independencia del Paraguay. Asunción: Editora Intercontinental, 2011.

MORENO, Nahuel. Actualización del Programa de Transición. 1980. Disponible en: $<$ https://www.marxists.org/espanol/moreno/actual/apt 3.htm\#t23>, consultado el 28/03/2019. 
. Cuatro tesis sobre la colonización española y portuguesa en América. 1948. Disponible en: <https://www.marxists.org/espanol/moreno/obras/01 nm.htm>, consultado el 18/11/2016.

. Método de interpretación de la historia argentina. 1975. Disponible en: $<$ http://www.litci.org/es/wpcontent/uploads/14 metodo_historia_argentina_1.pdf>, consultado el 17/11/2016.

MÚNERA, Alfonso. El fracaso de la Nación. Región, clase y raza en el Caribe colombiano (1717-1821). Bogotá: Banco de la República-El Áncora, 1998.

NAVARRO VIOLA, Miguel; QUESADA, Vicente. La revista de Buenos Aires: Historia americana, literatura y derecho. Tomo XII. Buenos Aires: 1867.

NIN, Andreu. Consideraciones sobre el problema de las nacionalidades. 1932. Disponible en:

$<$ https://www.marxists.org/espanol/nin/1932/consideraciones nacionalidades.htm $>$, consultado el 23/10/2017.

NOVACK, George. Los orígenes del materialismo. Buenos Aires: Ediciones Pluma, 1975.

. O desenvolvimento desigual e combinado na história. São Paulo: Editora Sundermann, 2008.

. Para comprender la historia. Buenos Aires: Ediciones Pluma, 1975.

NOVAIS, Fernando. Portugal e Brasil na crise do Antigo Sistema Colonial [1777-1808]. São Paulo: Hucitec, 1979.

NÚÑEZ, Ronald León. Apuntes sobre el carácter de las independencias americanas. $A B C$ Color. Asunción, 15/12/2019. Disponible en: $<$ https://www.abc.com.py/edicionimpresa/suplementos/cultural/2019/12/15/apuntes-sobre-el-caracter-de-lasindependencias-americanas/>, consultado el 02/01/2020.

. El mito del igualitarismo del doctor Francia. ABC Color. Asunción, 22/09/2019. Disponible en: $\quad<$ https://www.abc.com.py/edicionimpresa/suplementos/cultural/2019/09/22/el-mito-del-igualitarismo-del-doctorfrancia/>, consultado el 16/01/2020.

- El pensamiento político y económico de José Gaspar Rodríguez de Francia: 1814-1840. 248 f. Dissertação (Mestrado) - Curso de História Econômica, Faculdade de Filosofia, Letras e Ciências Humanas, Universidade de São Paulo, São Paulo, 2015. Disponible en: < doi:10.11606/D.8.2015.tde-05112015-144136>. Consultado el: 22/01/2020.

. La izquierda y la tentación nacionalista. ABC Color. Asunción, 24/11/2019. Disponible en: <https://www.abc.com.py/edicionimpresa/suplementos/cultural/2019/11/24/la-izquierda-y-la-tentacionnacionalista/>, consultado el 16/01/2020. 
Revolución y Genocidio: El mal ejemplo de la independencia paraguaya y su destrucción. Asunción: Arandurã, 2011.

O’LEARY, Daniel F. Memorias del General O'Leary. v. XIV. Caracas: Ministerio de la Defensa, 1981.

OCAMPO, José. (Ed.). Historia económica de Colombia. 2. ed. Bogotá: Planeta, 1988.

OHMSTEDE, Antonio. Las sociedades indígenas y su papel en la conformación de las naciones y Estados en la América Latina poscolonial. Buenos Aires: UBA, 2016.

OHMSTEDE, Antonio.; FALCÓN, Romana; BUVE, Raymond (Coord.). La arquitectura histórica del poder. Naciones, nacionalismos y estados en América Latina. Siglos XVIII, XIX y XX. México: CEDLA-El Colegio de México, 2010.

OXFAM. Paraguay: El país donde la soja mata. 2014. Disponible en: $<$ https://www.oxfam.org/es/paraguay-el-pais-donde-la-soja-mata $>$, consultado el $06 / 03 / 2019$.

PAGDEN, Anthony. Identity formation in Spanish America. In: CANNY, Nicolas; PAGDEN, Anthony. Colonial Identity in the Atlantic World, 1500-1800. Princeton: Princeton University Press, 1989.

PALACIOS, Guillermo (Org.). Ensayos sobre la nueva historia política. México: El Colegio del México, 2007.

. Entre una 'nueva historia' y una 'nueva historiografía' para la historia política de América Latina en el siglo XIX. In: PALACIOS, Guillermo (Org.). Ensayos sobre la nueva historia política. México: El Colegio del México, 2007.

PALMER, Robert. The age of the democratic revolution. A political history of Europe and America [1760-1800]. Princeton: Princeton University Press, 1959.

PALTI, Elías. El tiempo de la política. El siglo XIX reconsiderado. Buenos Aires: Siglo XXI, 2007.

- Guerra y Habermas: ilusiones y realidad de la esfera pública latinoamericana. In: PANI, Érika; SALMERÓN, Alicia. Conceptualizar lo que se ve: François-Xavier Guerra historiador. México D.F.: Instituto José Luis Mora, 2004.

PANI, Érika; SALMERÓN, Alicia. Conceptualizar lo que se ve: François-Xavier Guerra historiador. México D.F.: Instituto José Luis Mora, 2004.

Paraguay, el segundo país con más "sangre nativa". ABC Color. Asunción, 05/12/2018. Disponible en: $<$ https://www.abc.com.py/nacionales/adn-paraguayo-es-7-europeo1766399.html>, consultado el 20/01/2019.

PARISH, Woodbine. Buenos Aires y las provincias del Río de la Plata. Buenos Aires: Editorial Hachette, 1958. 
PARRA, José. San Martín: debates en torno a su origen e ideología. Margen, n. 75, p. 16, 2014. Disponible en: <http://www.margen.org/suscri/margen75/parra75.pdf $>$, consultado el 22/06/2017.

PASTOR BENÍTEZ, Justo. La vida solitaria del Dr. José Gaspar de Francia, dictador del Paraguay. Asunción: Servilibro, 2010.

PASTORE, Carlos. La lucha por la tierra en el Paraguay. 3. ed. Asunción: Editora Intercontinental, 2008.

PASTORE, Mario. Crisis de la Hacienda pública, regresión institucional y contracción económica: consecuencias de la independencia en Paraguay, 1810-1840. In: PRADOS, Leandro; AMARAL, Samuel. La independencia americana: consecuencias económicas. Madrid: Alianza, 1994.

. Estado e industrialización: dos hipótesis y la evidencia sobre el Paraguay [1852-1870]. 1993. Disponible en: <https://mpra.ub.unimuenchen.de/27505/1/MPRA_paper_27505.pdf>, consultado el 20/02/2019.

. La hipótesis de Domar sobre las causas de la servidumbre o la esclavitud en una colonia hispanoamericana: contraste y reformulación. Revista de Historia Económica, Madrid, v. 8, n. 3, pp. 577-578, 1990.

. Trabalho forçado indígena e campesinato mestiço livre no Paraguai: uma visão de suas causas baseada na teoria da procura de rendas econômicas. Revista brasileira de história, São Paulo, v. 11, n. 21, p. 152, set.1990-fev.1991.

PCB. Resolução política do $V$ Congresso do PCB. 1960. Disponible en: $<$ https://pcb.org.br/fdr/index.php?option=com content\&view=article\&id=149:res olucao-politica-do-v-congresso-do-pcb\&catid=1:historia-do-pcb $>$, consultado el $02 / 12 / 2016$.

PEÑA, Milcíades. Historia del pueblo argentino. Buenos Aires: Emecé, 2012.

PERICÁS, Luiz. Caio Prado Júnior. Uma biografia política. São Paulo: Boitempo, 2016.

PERUSSET, Macarena. Conductas y procedimientos fuera de la ley: comercio ilícito, líderes $\quad y \quad$ prácticas. 2017. Disponible en: $<$ http://www.scielo.org.co/pdf/unih/n63/n63a11.pdf>, consultado el 13/02/2015.

PIMENTA, João Paulo. A independência do Brasil como uma revolução: história e atualidade de um tema clássico. História da historiografia, Ouro preto, n. 3, 2009.

. A independência do Brasil e a experiência hispano-americana (1808-1822). São Paulo: Hucitec/Fapesp, 2015.

PIRES, Júlio Manuel; COSTA, Iraci del Nero da. O capital escravista-mercantil. Cadernos NEHD, São Paulo, v.3., n.1., 1995.

PLÁ, Josefina. La esclavitud en el Paraguay. Asunción: Editora Intercontinental, 2010. 
POMER, León [1968]. La Guerra del Paraguay: Estado, política y negocios. Buenos Aires: Colihue, 2008.

. Historias de gauchos y gauchisoldados. Buenos Aires: Colihue, 2007. . Os conflitos na Bacia do Prata. São Paulo: Brasiliense, 1979.

PONS, Frank. La independencia de Haití y Santo Domingo. In: Bethell, Leslie (Org.). Historia de América Latina. La independencia. Tomo V. Barcelona: Editorial Crítica, 1991.

PORTILLO, José. Crisis atlántica: autonomía e independencia en la crisis de la monarquía hispana. Madrid: Marcial Pons, 2006.

POTTHAST, Barbara. Entre lo invisible y lo pintoresco: las mujeres paraguayas en la economía campesina [siglo XIX]. Jahrbuch für Geschichte Lateinamerikas, Köln, n. 40, pp. 203-220, 2003.

PRADO Jr., Caio [1933]. Evolução política do Brasil. 15. ed. São Paulo: Brasiliense, 1986. 1972. [1942]. Formação do Brasil contemporâneo. 12. ed. São Paulo: Brasiliense, [1945]. História econômica do Brasil. 43. ed. São Paulo: Brasiliense, 2012. [1957]. Esboço dos fundamentos da teoria econômica. 3. ed. São Paulo: Brasiliense, 1961.

[1966]. A revolução brasileira. 3. ed. São Paulo: Brasiliense, 1968.

. Diretrizes para uma política econômica brasileira. São Paulo: Gráfica Urupềs, 1954.

PRADO, Maria. A formação das nações latino-americanas. 3. ed. São Paulo: Atual; Campinas: Editora da Universidade Estadual de Campinas, 1987.

PRADO, Maria; PELLEGRINO, Gabriela. História da América Latina. 1. ed. 2. reimp. São Paulo: Contexto, 2016.

PRADOS, Leandro; AMARAL, Samuel. La independencia americana: consecuencias económicas. Madrid: Alianza, 1994.

PUIGGRÓS, Rodolfo. ¿Diálogo entre sordos?. 1965. Disponible en: $<$ https://amauta.lahaine.org/debate-rodolfo-puiggros-andre-gunder-frank-sobrelos-modos-de-produccion-en-america-latina/>, consultado el 19/03/2019.

. Historia económica del Río de la Plata. Buenos Aires: Siglo XX, 1948.

. Los modos de producción en Iberoamérica. 1965. Disponible en: $<$ https://amauta.lahaine.org/debate-rodolfo-puiggros-andre-gunder-frank-sobrelos-modos-de-produccion-en-america-latina/>, consultado el 19/03/2019. 
RAMA, Ángel; SONOWSKI, Saúl; MARTÍNEZ, Tomaz Eloy. La crítica de la cultura en América Latina. Madrid: Biblioteca Ayacucho, 1972.

RATH, Christian. El carácter de la Revolución de Mayo. En defensa del marxismo, Buenos Aires, n. 38, 2010.

RIBEIRO, Ana. Gaspar Rodríguez de Francia: El hombre de la independencia y el aislamiento paraguayo. Asunción: El Lector, 2011.

RICUPERO, Bernardo. O que há de novo na nova história política de François-Xavier Guerra?. Almanack, Guarulhos, n.11, pp.841-852, 2015.

RICUPERO, Rodrigo. O estabelecimento do exclusivo comercial metropolitano e a conformação do Antigo Sistema Colonial no Brasil. História, Franca, v. 35, e100, 2016. Disponible

en: $<$ http://www.scielo.br/scielo.php?script=sci arttext\&pid=S010190742016000100509\&lng=en\&nrm=iso $>$, consultado el 09/02/2020.

. O exclusivo metropolitano no Brasil e os Tratados diplomáticos de Portugal como a Inglaterra (1642-1661). Revista de História, São Paulo, n. 176, 2017. Disponible en: <http://www.scielo.br/scielo.php?script=sci arttext\&pid=S0034-

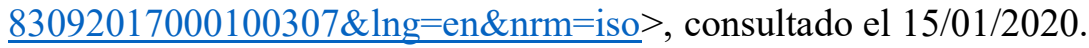

RIVAROLA, Armando. Holocausto paraguayo en la Guerra del 70. ABC Color. Asunción, 26/09/2009. Disponible en: <http://www.abc.com.py/articulos/holocaustoparaguayo-en-guerra-del-70-24852.html $>$, consultado el 01/04/2019.

RODRÍGUEZ ALCALÁ, Guido. Francia y López. In: SOLER, Lorena, et al. (Org.). Antología del pensamiento crítico paraguayo contemporáneo. Buenos Aires: CLACSO, 2015.

. López y Horacio Cartes. Última Hora. Asunción, 21/09/2016. Disponible en: < https://www.ultimahora.com/lopez-y-horacio-cartes-n1025702.html>, consultado el 15/01/2020.

RODRÍGUEZ, Jaime. La independencia de la América española. 2. ed. México D.F: FCE, 2005.

ROJAS, Luis. Independencia y economía durante el período de Francia. In: CORONEL, Jorge (org.). La república francista del Paraguay. Escritos en homenaje a Richard Alan White. Asunción: Arandurã, 2017.

ROMERO DE VIOLA, Blanca Rosa. Paraguay siglo dieciocho: Período de transición. Asunción: Ediciones Comuneros, 1987.

ROSA, José. Rivadavia y el imperialismo financiero. 1969. Disponible en: $<$ http://www.labaldrich.com.ar/wp-content/uploads/2016/07/Rosa-Jose-MariaRivadavia-y-el-imperialismo-financiero.pdf $>$, consultado el 27/03/2019. 
ROURA, Lluís; CHUST, Manuel (Ed.). La ilusión heroica. Colonialismo, revoluciones, independencias en la obra de Manfred Kossok. Castellón: Universitat Jaume I, 2010.

SANZ JARA, Eva. Los indios de la nación. Los indígenas en los escritos de intelectuales y políticos del México independiente. Madrid: Universidad de Alcalá, Iberoamericana-Vervuert, Bonilla Artigas, 2011.

SCAVONE, Ricardo; SCAVONE, Sebastián (Org.). Cecilio Báez-Juan E. O’Leary. Polémica sobre la historia del Paraguay. Estudio preliminar de Liliana Brezzo. Asunción: Editorial Tiempo de Historia, 2012.

SCHVARTZMAN, Mauricio. Contribuciones al estudio de la sociedad paraguaya. Asunción: CIDSEP, 1988.

SECCO, Lincoln. Caio Prado Júnior: o sentido da revolução. São Paulo: Boitempo, 2008.

SOBOUL, Albert. A revolução francesa. São Paulo: DIFEL, 1985.

SOFRI, Giani. O modo de produção asiático: História de uma controvérsia marxista. Rio de Janeiro: Paz e Terra, 1977.

SOLER, Lorena, et al. (Org.). Antología del pensamiento crítico paraguayo contemporáneo. Buenos Aires: CLACSO, 2015.

SOUZA, João Paulo de. Entre o Sentido da Colonização e o Arcaísmo como Projeto: A Superação de um Dilema através do Conceito de Capital Escravista-Mercantil. Revista Estudos Econômicos, São Paulo, v. 1., n. 38, 2008, pp. 173-203.

STALIN, Iósif. Materialismo dialéctico y el materialismo histórico. 1938. Disponible en: $<$ http://www.marx2mao.com/M2M(SP)/Stalin(SP)/DHM38s.html $>$, consultado el $08 / 02 / 2020$.

STERN, Steve. Feudalism, Capitalism, and the World-System in the Perspective of Latin America and the Caribbean. The American Historical Review, v. 93, n. 4, pp. 829$872,1988$.

SUSNIK, Branislava. El rol de los indígenas en la formación y en la vivienda del Paraguay. Asunción: Intercontinental, 2013.

. Una visión socioantropológica del Paraguay del siglo XIX. Asunción: Museo Etnográfico Andrés Barbero, 1992.

SWEEZY, Paul. Uma crítica. In: SWEEZY, Paul; DOOB, Maurice, et al. Do feudalismo ao capitalismo. Lisboa: Publicações Dom Quixote, 1971.

SWEEZY, Paul; DOOB, Maurice, et al. Do feudalismo ao capitalismo. Lisboa: Publicações Dom Quixote, 1971.

SZMRECSÁNYI, Tamas; AMARAL LAPA, José Roberto do (Org.): História econômica da independência e do império. São Paulo: Hucitec, 1996. 
TATE, Edward N. Gran Bretaña y Latinoamérica en el siglo XIX: el caso del Paraguay [1811-1870]. Contribuciones desde Coatepec. Toluca: Universidad Autónoma del Estado de México, n. 5, 2003.

TEIXEIRA, Fabiano. A Primeira Guerra do Paraguai: A expedição do Império do Brasil a Assunção [1854-1855]. Passo Fundo: Editora Méritos, 2012.

TEIXEIRA, Rodrigo. Capital e Colonização: A Constituição da Periferia do Sistema Capitalista Mundial. Revista Estudos Econômicos, São Paulo, v. 3, n. 36, 2006, pp. 539-591.

TELESCA, Ignacio (Org.). Historia del Paraguay. 4. ed. Asunción: Taurus, 2014.

Antes y después. Del amor al espanto. Construcciones históricas e historiográficas del Paraguay del siglo XIX. In: GARAVAGLIA, Juan; FRADKIN, Raúl. A 150 años de la Guerra de la Triple Alianza contra el Paraguay. Buenos Aires: Prometeo Libros, 2016.

. La historiografía paraguaya y los afrodescendientes. 2008. Disponible en: $<$ http://bibliotecavirtual.clacso.org.ar/ar/libros/sursur/AFRICAN/10tele.pdf $>$, consultado el 27/03/2019.

La Provincia del Paraguay: revolución y transformación [1680-1780]. Asunción: El Lector, 2010.

- Paraguay 1848: pueblos de indios y conformación del Estado. 2016. Disponible en: <http://grupoparaguay.org/L Telesca2016.pdf> 20/02/2019.

. Pueblos de Indios y tierra en el Paraguay de Carlos Antonio López. 2018. Disponible en: <http://grupoparaguay.org/2018 Telesca.pdf>, consultado el 20/02/2019.

. Revolución, república y pueblo. In: TELESCA, Ignacio; BREZZO, Liliana; CABALLERO CAMPOS, Herib (Org.). Paraguay 1813: La proclamación de la República. Asunción: Taurus, 2013.

- Tras los expulsos: cambios demográficos y territoriales después de la expulsión de los jesuitas. Asunción: CEADUC, 2009.

TELESCA, Ignacio; BREZZO, Liliana; CABALLERO CAMPOS, Herib (Org.). Paraguay 1813: La proclamación de la República. Asunción: Taurus, 2013.

THOMPSON, George. La guerra del Paraguay. Asunción: Servilibro, 2010.

TROSTKY, León. Correspondencia con Preobrazhensky. 1928. Disponible en: $<$ http://www.ceip.org.ar/Correspondencia-entre-Trotsky-y-Preobrazhensky>, consultado el 12/02/2019.

- El marxismo y la relación entre revolución proletaria y revolución campesina. 1928. Disponible en: <http://www.ceip.org.ar/El-marxismo-y-la- 
$\underline{\text { relacion-entre-revolucion-proletaria-y-revolucion-campesina }>}, \quad$ consultado el $13 / 02 / 2019$.

. La revolución española y la táctica de los comunistas. 1931. Disponible en: $<$ http://www.ceip.org.ar/La-revolucion-espanola-y-la-tactica-de-los-comunistas $>$, consultado el 17/11/2016.

. La revolución permanente. Tesis fundamentales. 1929. Disponible en: $<$ https://www.marxists.org/espanol/trotsky/revperm/rp10.htm $>$, consultado el $12 / 02 / 2019$.

La revolución traicionada. 1936. Disponible en: $<$ https://www.marxists.org/espanol/trotsky/1936/rt/11.htm\#seg\%203>, consultado el 11/02/2019.

Lecciones de Octubre. 1935. Disponible en: $<$ https://www.marxists.org/espanol/////trotsky/ceip/escritos/libro4/T07V133.htm> , consultado el 16/01/2020.

Resultados $y$ perspectivas. 1906. Disponible en: $<$ https://www.marxists.org/espanol/trotsky/ryp/03.htm>, consultado el 14/02/2019.

URIBE, Jaime. La economía del virreinato, 1740-1810. In: OCAMPO, José A. (Ed.). Historia económica de Colombia. 2. ed. Bogotá: Planeta, 1988.

VÁZQUEZ, José Antonio. El doctor Francia visto y oído por sus contemporáneos. Buenos Aires: Editorial Universitaria de Buenos Aires, 1975.

VERÓN, Carlos. Polí, el malquerido. ABC Color. Asunción, 16/10/2011. Disponible en: $<\underline{\text { http://www.abc.com.py/edicion-impresa/suplementos/abc-revista/poli-el- }}$ malquerido-320768.html>, consultado el 01/02/2018.

VILAR, Pierre [1947]. Historia de España. Barcelona: Crítica, 2014.

VILAR, Pierre; CASTRO, Fidel. Independencia y revolución en América Latina. Barcelona: Anagrama, 1976.

VIOLA, Alfredo. Dr. José Gaspar Rodríguez de Francia: Defensor de la Independencia del Paraguay. Asunción: Editor Carlos Schauman, 1992.

VITALE, Luis. Interpretación marxista de la historia de Chile: La Colonia y la Revolución por la independencia [1540-1810]. Tomo II. 1967. Disponible en: $<\underline{\text { http://www.archivochile.com/Historia_de_Chile/trab_gen/HCHtrabgen0005.pdf }}$ $>$, consultado el 06/01/2017.

WHIGHAM, Thomas. Aspectos clave de la larga resistencia paraguaya: disciplina militar, cohesión burocrática y egomanía indomada del Mariscal López. In: GARAVAGLIA, Juan; FRADKIN, Raúl. A 150 años de la Guerra de la Triple Alianza contra el Paraguay. Buenos Aires: Prometeo Libros, 2016.

. La economía de la independencia. Asunción: Intercontinental, 2010. 
Lo que el río se llevó. Estado y comercio en Paraguay y Corrientes [17761870]. Asunción: CEADUC, 2009.

WHIGHAM, Thomas; COONEY, Jerry (Org.). El Paraguay bajo el Dr. Francia: Ensayos sobre la sociedad patrimonial. Asunción: Editorial El Lector, 1996.

WHIGHAM, Thomas; POTTHAST, Barbara. The Paraguayan Rosetta Stone: New Insights into the Demographics of the Paraguayan War, 1864-1870. Latin American Research Review, v. 34, n. 1, pp. 174-186, 1999.

WHITE, Richard Alan [1984]. La Primera Revolución Popular en América: Paraguay 18101840. 2. ed. Asunción: Carlos Schauman Editor, 1989.

WILLIAMS, John Hoyt. Desde la mira del fusil: algunas observaciones acerca del Dr. Francia y el militarismo paraguayo. In: WHIGHAM, Thomas; COONEY, Jerry (Org.). El Paraguay bajo el Dr. Francia: Ensayos sobre la sociedad patrimonial. Asunción: Editorial El Lector, 1996.

. The 'Conspiracy of 1820' and the Destruction of the Paraguayan Aristocracy. Revista de Historia de América, México, n. 75-76, 1973.

. The Rise and Fall of the Paraguayan Republic: 1800-1870. Texas: University of Texas, 1979.

. Woodbine Parish and the "opening" of Paraguay. Proceedings of the American Philosophical Society, Philadelphia, v. 116, n. 4, 1972.

WILSON, Samuel. [1999]. The Emperor's Giraffe and other stories of cultures in contact. Boulder/Oxford: Westview Press, 2007.

WISNER DE MORGENSTERN, Francisco. El Dictador del Paraguay José Gaspar de Francia. Asunción: Instituto Cultural Paraguayo-Alemán, 1996.

ZARPELON, Sandra. O novo socialismo utópico e a importância da revolução política para o socialismo marxista. Cadernos Cemarx, v. 1, n. 2, pp. 94-100, 2005. 